\title{
The Archaeology and Paleoecology of the Aubrey Clovis Site (41DN479) Denton County, Texas
}

C. Reid Ferring

Center for Environmental Archaeology

Follow this and additional works at: https://scholarworks.sfasu.edu/ita

Part of the American Material Culture Commons, Archaeological Anthropology Commons, Environmental Studies Commons, Other American Studies Commons, Other Arts and Humanities Commons, Other History of Art, Architecture, and Archaeology Commons, and the United States History Commons

Tell us how this article helped you.

This Article is brought to you for free and open access by the Center for Regional Heritage Research at SFA ScholarWorks. It has been accepted for inclusion in Index of Texas Archaeology: Open Access Gray Literature from the Lone Star State by an authorized editor of SFA ScholarWorks. For more information, please contact cdsscholarworks@sfasu.edu. 


\section{The Archaeology and Paleoecology of the Aubrey Clovis Site (41DN479) Denton}

County, Texas

\section{Creative Commons License}

\section{(c) (1) $\Theta(9$}

This work is licensed under a Creative Commons Attribution-NonCommercial-No Derivative Works 4.0 International License. 


\title{
THE ARCHAEOLOGY AND PALEOECOLOGY OF THE AUBREY CLOVIS SITE (41DN479) DENTON COUNTY, TEXAS
}

\author{
C. REID FERRING \\ with contributions by
Scott A. Elias
Stephen A. Hall
Herbert Haas
John D. Humphrey
Raymond W. Neck
Bonnie C. Yates \\ Ernest L. Lundelius, Jr. \\ Center for Environmental Archaeology \\ Department of Geography \\ University of North Texas \\ Report Submitted in Partial Fulfilment of \\ Contract No. \\ U.S. Army Corps of Engineers, \\ Fort Worth District
}





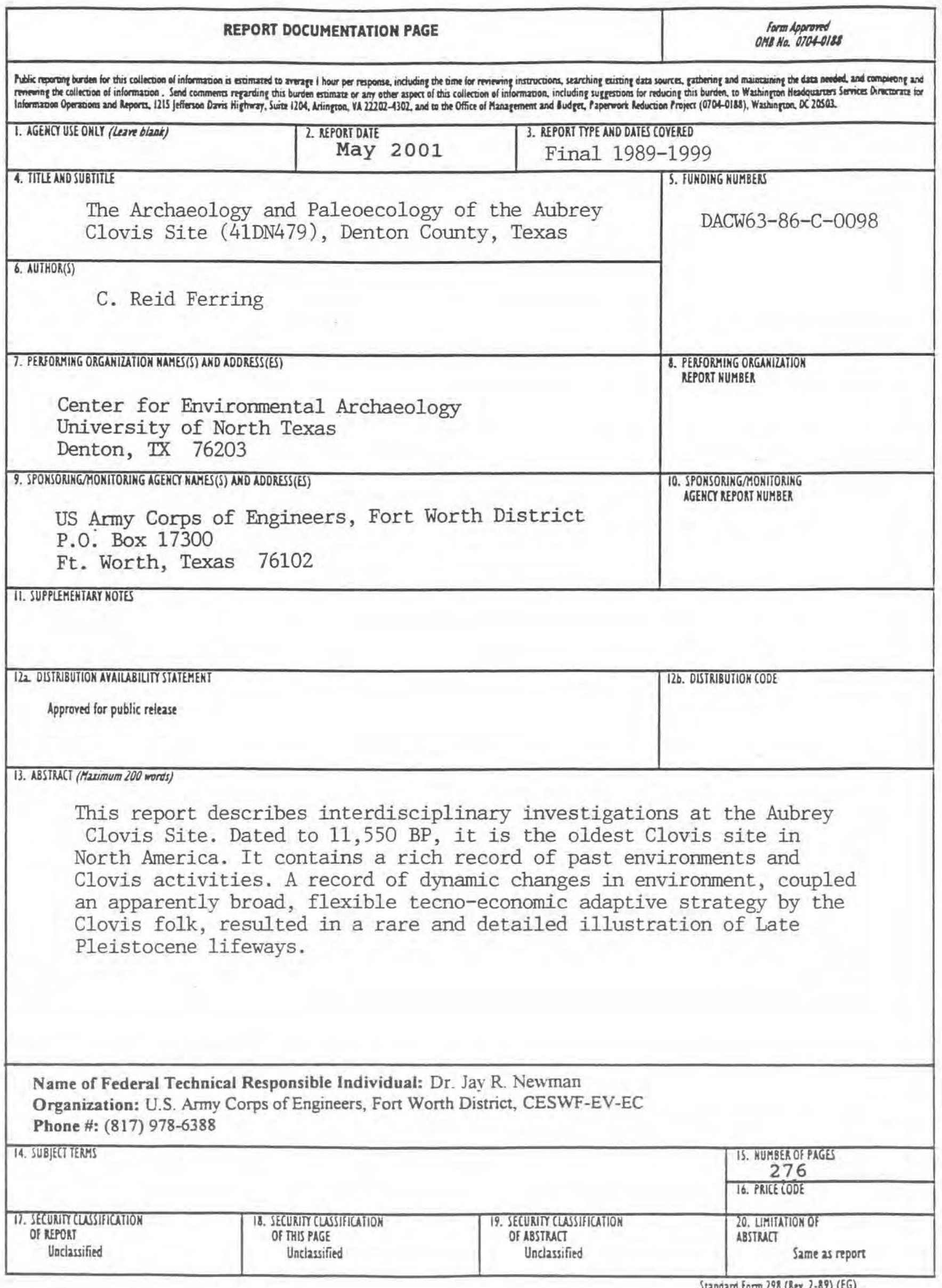





\section{MANAGEMENT SUMMARY}

This report contains the results of interdisciplinary investigations of the Aubrey Clovis Site (41DN479), located at Lake Ray Roberts, Denton County, Texas, and conducted by the Center for Environmental Archaeology, University of North Texas for the U.S. Army Corps of Engineers, Fort Worth District. Exposed by construction of the artificial outlet channel for the reservoir, the site is a multi-cluster complex of archaeological features and artifact-faunal concentrations buried 7-9 meters below the flood plain of the Elm Fork Trinity River. The Clovis-age materials are geologically situated on a paleosurface within a $14 \mathrm{~m}$ thick sequence of late Quaternary deposits, associated with spring, lacustrine, alluvial and colluvial sedimentary environments. A stratigraphically consistent set of 23 radiocarbon ages establishes a sound chronometric frame for these deposits between $1.6 \mathrm{Ka}$ and $14.2 \mathrm{Ka}$. The Clovis occupations are directly dated by two radiocarbon ages of ca. $11,550 \mathrm{Ka}$ determined on charcoal from a hearth. These ages are securely bracketed by stratigraphically and numerically consistent ages above and below, within the period of ca. 12,300 to 10,940 Ka. Paleoenvironmental reconstructions for the periods before, during and after Clovis occupations have been afforded by pollen, insects, mollusks, vertebrate faunas as well as sedimentary and geochemical data. In the early post-glacial period, the site environs was a cool grassland with moderate effective precipitation, that evolved towards significantly warmer and drier conditions prior to Clovis occupations. The environment ameliorated at about the time of occupations, but exhibited a maximum of Late Quaternary mammalian biodiversity. Clovis artifacts and faunas occur in multiple clusters, including "Camps B and $F^{n}$ that contain ca. 9,800 lithic artifacts, over 4,000 faunal remains and features including hearths, lithic concentrations and a pit considered to be a well. These concentrations were adjacent to a Clovis-age pond and river. Bison bones and associated artifacts indicate a butchering (and "kill"?) locus on the pond shore opposite Camp B. Subsistence data from the camps indicate exploitation of a broad set of animals, ranging from megamammals (Bison and possibly Mammoth) down to small game, fish and birds. Lithic artifacts show procurement from a minimum of almost $200 \mathrm{~km}$ from the site, with materials dominated by Tecovas quartzite, white Novachert and Edwards chert, and including chalcedony, Alibates chert, and Morrison or Dakota sandstone. The assemblage is dominated by repair and maintenance debris associated with bifacial and unifacial tools. Latest stage manufacture is indicated for a biface(s), while all other activities were apparently performed with only resharpening/ repair of other stone tools. Detailed spatial patterning indicates quite well differentiated activities within and between these occupation clusters. Overall, the uniquely detailed record of Clovis occupations at Aubrey registers an adaptive strategy characterized by high mobility, broad exploitation of dispersed, variable resources, long-distance raw material procurement coupled with efficient blank and tool depletion, and a probable combination of functional flexibility and strong withingroup task differentiation and integration. 



\section{TABLE OF CONTENTS}

\section{PAGE}

Management Summary

Table of Contents

Acknowledgements

List of Figures

List of Tables

1 INTRODUCTION

C. Reid Ferring

2 OVERVIEW OF THE AUBREY SITE SETTING AND EXCAVATIONS

C. Reid Ferring

3 GEOLOGY OF THE AUBREY CLOVIS SITE

C. Reid Ferring

4 LATE QUATERNARY STABLE ISOTOPES OF THE AUBREY CLOVIS SITE John D. Humphrey and C. Reid Ferring

5 PALEOENVIRONMENTAL SIGNIFICANCE OF LATE GLACIAL INSECT FOSSIL ASSEMBLAGES FROM THE AUBREY SITE Scott A. Elias

6 PALYNOLOGY OF THE AUBREY CLOVIS SITE Stephen A. Hall

7 MOLLUSCAN REMAINS FROM THE AUBREY SITE Raymond W. Neck

8 VERTEBRATE FAUNAS FROM THE AUBREY CLOVIS SITE Bonnie C. Yates and Ernest L. Lundelius Jr.

9 ARCHEOLOGY OF THE AUBREY CLOVIS SITE

APPENDICES

Appendices B-E are on disc, in the envelope attached to the inside back cover of this report.. These may be opened in Microsoft Word, EXCEL or ASCII.
A. Faunal Coding Data
B. Lithic Tool Attributes
C. Unit Coding Data
D. Detailed profile descriptions and sediment lab data
E. Borehole descriptions 



\section{Acknowledgements}

Many people participated in the Aubrey Project- and all are due hearty thanks. I hope that none are overlooked here- and apologize to any that I have omitted by mistake. Ms. Karen Scott and Dr. Jay Newman of the Corps of Engineers provided long and solid support for the work at Aubrey. Mr. Ron Rufinack and Ms. Sally Werst of the Corps of Engineers public affairs office were supportive and congenial throughout our project. All the Corps staff at Lake Ray Roberts provided constant patience and help during our year of fieldwork.

The administration at the University of North Texas has consistently enhanced our research capabilities and graciously provided assistance with the Aubrey Project. I am especially grateful to Dr. Rollie Shaffer for his consistent encouragement and assistance.

Bonnie Yates- zooarchaeologist, friend and advisor kept this project, and many others, going many times when all should have and nearly did grind or crash to a halt. It is fair to say that she deserves full credit for all things that kept going and did get completed. I can never repay all of her selfless and critical efforts. And I will always hold dear the gifts of happiness she lavished on so many others and me.

Two people were absolutely superb leaders on this project. These are lab director Karen Horn and crew chief Bobby Skiles. They are undoubtedly the most competent, reliable and dedicated people we could have had in these key positions. On a daily basis they maintained the highest standards of research and are responsible for the quality of data recovery and analysis we worked hard to maintain. I will always be in their debt for their professionalism, and will long remember their camaraderie.

My sincere thanks go to the colleagues who joined the team and also made their own contributions to this project, to Paleoindian archaeology and to Quaternary research. These are: Scott Elias (entomology), Herb Haas (radiocarbon dating), Steve Hall (palynology), Earnest Lundelius Jr. (vertebrate paleontology), Raymond Neck (malacology), and Bonnie Yates (vertebrate paleontology and taphonomy). I also extend special thanks to John Humphrey for his generous (literally) and valuable research on stable isotopes.

Special thanks go to all of the people in the Institute of Applied Sciences- Dr. Ken Dickson, Ms. Wanda Cast, Ms.Denise Shaw and many others gave constant help in many ways. Tom Nelson worked diligently to develop and maintain databases and coordinate constantly among the laboratory staff, the bone people and the archaeologists. Robert Cast and Jim Morris did outstanding work in the soils-sediment lab.

Ms. Kathryn Monigal of SMU drew all of the lithic illustrations save the chopper. I want to thank her for her fine and careful work.

Jo Clark, Johnny Byers and Debra Mcllvain have provided much support and help in the last phase of report preparation

I am grateful to the friends and colleagues helped the project immeasurably by their visits, conversations, information or advice. These include: Larry Banks, Bruce Bradley, Chris Caran, Mike Collins, Tim Dalby, Brooks Ellwood, George Frison, Vance Haynes, Jr., Vance Holliday, Bruce Huckell, Jack Hughes, Pegi Jodry, Eileen Johnson, Lee Kruetzer, Rolfe Mandel, David Meltzer, Bob Slaughter (deceased), Christian Soegaard, Dennis Stanford and Dale Winkler. Following long-established protocol, I absolve each of these folks from any errors of fact or interpretation contained in this report and all other products of this research. 
Among a number of volunteers, special thanks go to Johnny Byers, Lisa Huckell, Debra McIlvain, Robert Merrill, Brian Schaffer, Mike Shannon and Dennis Stanford.

I also want to thank an anonymous friend and donor who contributed substantially to our research.

And, last, I want to thank all of the fine people who worked as crew members on the Aubrey project- either in the field or the lab. Each of these folks joined in the sense of importance of our work, and made their own contributions to the quality of our research. With sincere apologies to anyone I overlook, the crew members are:

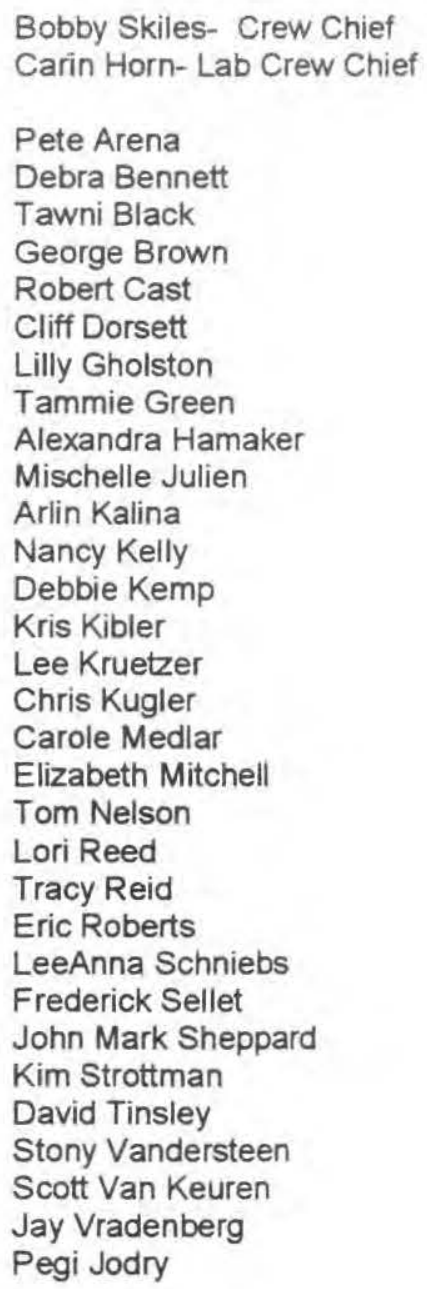


1.1 Map of the Southern Plains with location of Aubrey Site 1

1.2 Map of outlet channel and Aubrey site at Lake Ray Roberts

1.3 Map of the Southern High Plains showing Paleoindian localities 6

1.4 Map of the Rolling Plains showing Paleoindian localities 7

2.1 Climatic parameters for northcentral Texas 13

$\begin{array}{lll}2.2 & \text { Biotic provinces of Texas } & 14\end{array}$

2.3 Photographs of vegetation communities in North Texas 15

2.4 Photograph of the outlet channel at Ray Roberts Lake 18

2.5 Photograph of overburden removal at Aubrey 19

2.6 Map of excavations at Aubrey 20

3.1 Geologic map of northcentral Texas 24

3.2 Geologic cross-section of northcentral Texas 24

3.3 Drainage networks in northcentral Texas 26

3.4 Diagrammatic Cross-Section of the Upper Trinity Basin 28

3.5 Topographic map showing terraces in vicinity of the Aubrey site 29

3.6 Geologic history of the Upper Trinity River Basin 30

3.7 Borehole cross-section at the Ray Roberts Dam 32

3.8 Map of site area with USACE borehole locations 33

3.9 USACE borehole logs from outlet channel $\quad 34$

3.10 Geomorphic history of the Aubrey site area 35

3.11 Photographs of south slope of outlet channel at Aubrey Site. 36

3.12 Geologic cross-section of the Aubrey locality 37

3.13 Geologic profile of Trench 14, Area B 38

3.14 Geologic profile of Trench 25, Area B 39

3.15 Geologic profile of Trench 3, Area B 40

3.16 Geologic cross-section of Area A, with profile locations 41

3.17 Geologic cross-section of Trench 1, Area A 42

3.18 Geologic profile of Trench 1C, Area A 43

3.19 Geologic profile of Trench 13, Area A 43

3.20 Geologic profiles of Trenches 2 and 15, Area A 44

3.21 Photograph of south wall of Trench 2

3.22 Aubrey site stratigraphic columns with radiocarbon ages 46

3.23 Ternary textural diagrams for alluvium at the Aubrey locality 47

3.24 Age-depth relationships in Trench 25, Aubrey site 48

3.25 Floor of excavation unit in pond area, showing crayfish burrows 54

4.1 Cross-section of Aubrey site with trench locations 56

4.2 Carbon-oxygen isotopes cross-plot 59

4.3 Composite oxygen isotope record from Aubrey 59

4.4 Gulf of Mexico oxygen isotope record from G. rubra 62

4.5 Carbon isotope record for pedogenic and organic carbon 65

4.6 Pedogenic carbon isotope data and inferred climate history 67

5.1 Stratigraphic occurrence of selected insect taxa at Aubrey 70

5.3 Known modern North American distribution of beetle species

6.1 Summary pollen diagram of the Aubrey Clovis site 83

8.1 Map of ground sloth dermal ossicles, Area A 113

$\begin{array}{ll}\text { 8.2 Map of large mammals, deer and bison, Area A } & 114\end{array}$

$\begin{array}{lll}\text { 8.3 Burned bone from pond sediments by stratum } & 115\end{array}$

8.4 Map of small mammals, rabbits and rodents, Area A 116

$\begin{array}{ll}\text { 8.5 Map of reptiles and amphibians, Area A } & 116\end{array}$

8.6 Habitats represented by faunas at the Aubrey site 119

$\begin{array}{ll}9.1 & \text { Photograph of the Aubrey site with excavation areas }\end{array}$ 
$\begin{array}{ll}9.2 & \text { Photograph excavations in Camp F } \\ \end{array}$

$\begin{array}{ll}\text { 9.3 Map of features in Camp B } & 124\end{array}$

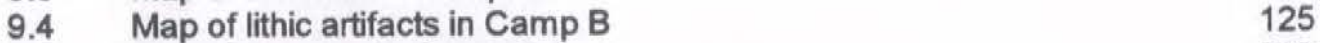

9.5 Map of features in Camp F 126

9.6 Photograph and cross-section of the western pond margin 127

9.7 Photographs of the well at the red wedge (Area A) 128

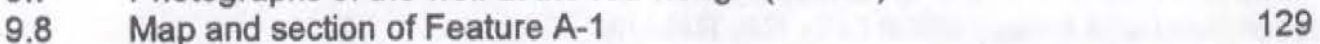

\begin{tabular}{ll}
9.9 & Debitage class frequencies \\
\hline
\end{tabular}

9.10 Raw material by debitage class $\quad 136$

9.11 Sources of lithic raw materials from Aubrey 140

9.12 Blade core tablet from Camp B 146

9.13 Refitted core trimming elements from Camp B $\quad 148$

9.14 Refitted flakes of radial core from Camp B 149

9.15 Discoidal cores from the Crockett Gardens site $\quad 150$

9.16 Refitted biface thinning flakes from Camp B 151

9.17 Abrader from Camp B 152

9.18 Raw materials of biface thinning flakes in Camp B and Camp F 153

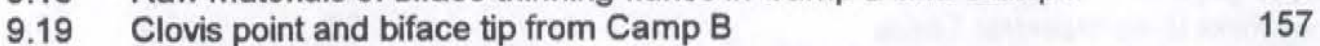

9.20 End scrapers from Camp B $\quad 159$

9.21 Unifacial tools from Camp B $\quad 162$

9.22 Lithic tools from Camps B and F 164

\begin{tabular}{ll}
9.23 & Retouched piece from Area C \\
\hline
\end{tabular}

9.24 Tools and core from Camp F 166

9.25 Tools from upper red wedge, Area A $\quad 168$

9.26 Photographs of bison scapula and utilized blade from red wedge 169

$\begin{array}{ll}9.27 & \text { Limestone chopper from Area G } \\ & 171\end{array}$

9.28 Vertical patterning of artifacts and bone, Camps B and F 174

9.29 Plotted tool elevations in Camps B and F 175

9.30 Biface thinning flakes and point quartzite in Camp B 178

9.31 Distribution of white Edwards chert in Camp B 179

9.32 Photographs of end scrapers and URCs from Camp B 180

9.33 Spatial distribution of chalcedony URCs and white novachert in Camp B 181

9.34 Distribution of other quartzites in Camp B 182

9.35 Other Edwards and Alibates distributions in Camp B 185

9.36 Patchiness and packing of bone fragments in Camp B 187

9.37 Large mammal bone in Camp B 188

9.38 Large mammal bone and URC clusters in Camp B 190

9.39 Distribution of small and medium mammal bone in Camp B 191

9.40 Distribution of small mammal taxa and reptiles in Camp B 192

9.41 Distribution of total bone in Camp F 194

9.42 Total artifacts, tools and URCs in Camp F 195

9.43 Bladelets and Edwards chert artifacts in Camp F 196

9.44 Identifiable bone and mammoth rib from Camp F 197

9.45 Frequency of uniface resharpening flakes by square meter units, Camp B 200

9.46 Map of refitted, bend break and radial break tools from Camp B 201

10.1 Radiocarbon ages defining the Clovis occupation at Aubrey 205

10.2 Summary of pollen from the Aubrey Site 209

10.3 Late Quaternary Faunal Localities in the Southern Plains 220

10.4 Radiocarbon dated mammoths from North America 222

10.5 Clovis sites in the southern mid-continent 225

$\begin{array}{lll}10.6 & \text { Intrasite cluster patterns at Paleoindian sites } & 228\end{array}$

$\begin{array}{lll}10.7 & \text { Eastern fluted point site locations } & 230\end{array}$

10.8 LogNISP-LogTAXA diagram for Aubrey faunas 239

10.9 Frequencies of burned unidentifiable bone from Aubrey 240 
3.1 Cretaceous Stratigraphy of Northcentral Texas 25

3.2 Radiocarbon Ages from the Aubrey Site 49

3.3 Summarized Geologic History of the Aubrey Clovis Site 53

4.1 Stratigraphic Summary for the Aubrey Site 57

4.2 Radiocarbon Ages from the Aubrey Site 58

4.3 Aubrey Site Carbon and Oxygen Isotope Data 60

4.4 Carbon Isotopes from Organic and Carbonate Carbon 64

5.1 Fossil Insect Faunal List for the Aubrey Site 71

6.1 Pollen Counts, Aubrey Clovis Site 81

6.2 Late-Glacial Pollen Percentages vs. Modern Grassland Percentages 85

7.1 Molluscan Remains from Carrollton Alluvium 90

7.2 Molluscan Remains Recovered from Pond Margin of Aubrey Site 91

7.3 Molluscan Remains Recovered from Pond Axis of Aubrey Site 92

7.4 Summary of Ambient Conditions Surrounding Aubrey Pond Margin 9 96

7.5 Summary of Ambient Conditions Surrounding Aubrey Pond Axis 98

7.6 Summary of Ambient Environmental Change at Aubrey Pond 101

8.1 Identified Fauna from the Aubrey Site 106

8.2 Bone from Area A, Pond Sediments by Stratum 111

8.3 NISP from Area A, Pond Sediments by Stratum 112

9.1 Assemblage Composition, Aubrey Site 131

$\begin{array}{lll}9.2 & \text { Artifacts from Area A, Red Wedge } & 132\end{array}$

9.3 Artifacts from Area A-Pond Axis 133

9.4 Artifacts from Area C 133

9.5 Artifacts from Area G 133

$\begin{array}{lll}\text { 9.6 Cortical Pieces from the Aubrey Site } & 135\end{array}$

$\begin{array}{lll}\text { 9.7 Raw Material for Debitage and Tools } & 137\end{array}$

9.8 UV Flourescense for Some Southern Plains Lithic Materials 138

$\begin{array}{lll}9.9 & \text { Debitage Class by Raw Material, Camp B } & 142\end{array}$

9.10 Debitage Class by Raw Material, Camp F 142

9.11 Tool Typology, Aubrey Site 156

9.12 Artifact and Bone Densities in Camps B and F 173

$\begin{array}{lll}9.13 & \text { Cluster Characteristics of Aubrey and Eastern Paleoindian Sites } & 175\end{array}$

9.14 Comparison of the ADebitage Piles $\cong$ in Camps B and F 177

9.15 Point Quartzite and White Edwards Debitage from Camp B 177

9.16 Distribution Statistics for Bone in Camp B 186

9.17 Comparison of Faunal Assemblages from Camps B and F 193

10.1 Aubrey pollen data 208

10.2 Late Quaternary Mammalian Faunas from the Southern Plains 211

10.3 Late Quaternary Mammalian Faunas from Southern New Mexico 216

10.4 Faunal Similarity Matrices for Southern Plains Localities 219

10.5 Patterns of Flux in Late Quaternary Faunas 221

10.6 Distance from Aubrey to Sources of Lithic Raw Materials 224

10.7 Cluster Data from Fluted Point Sites 232

10.8 Vertebrate Faunas from the Lewisville Site 240 



\section{CHAPTER 1 INTRODUCTION}

by

C. Reid Ferring

This report describes the archaeological and paleoenvironmental investigations conducted at the Aubrey Clovis Site (41DN479) by an interdisciplinary team lead by the Center for Environmental Archaeology, University of North Texas. This work was performed as part of Contract No. Dacw63-86-C0098 with the Fort Worth District, U.S. Army Corps of Engineers. That contract originally covered investigations within the reservoir area of Lake Ray Roberts, located in north central Texas (Figure 1.1). Discovery of the Aubrey Site in the outlet channel of the reservoir led to contract modifications and an intensive mitigation effort.

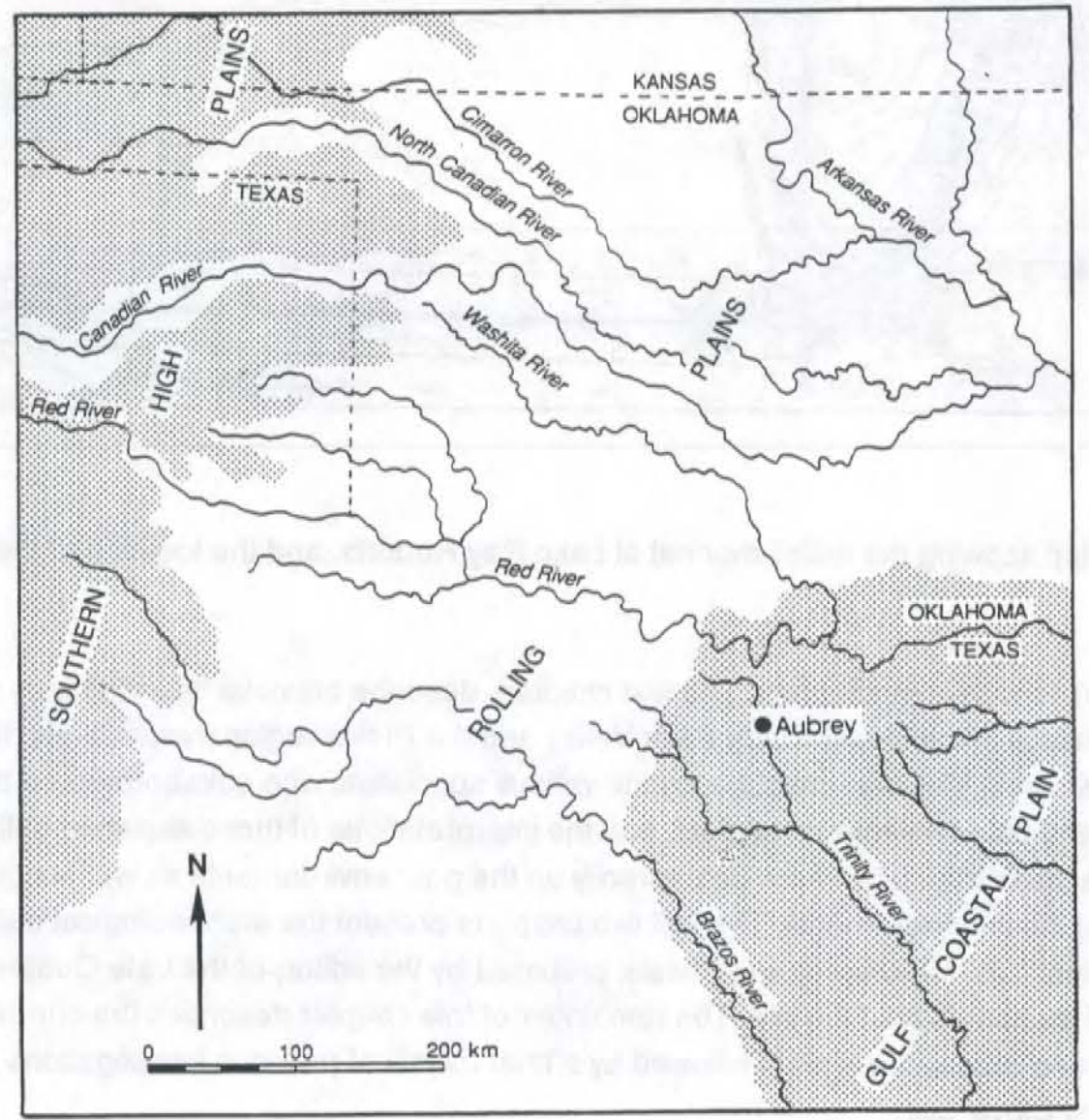

Figure 1.1 Map of the Southern Plains with location of Aubrey Site. 


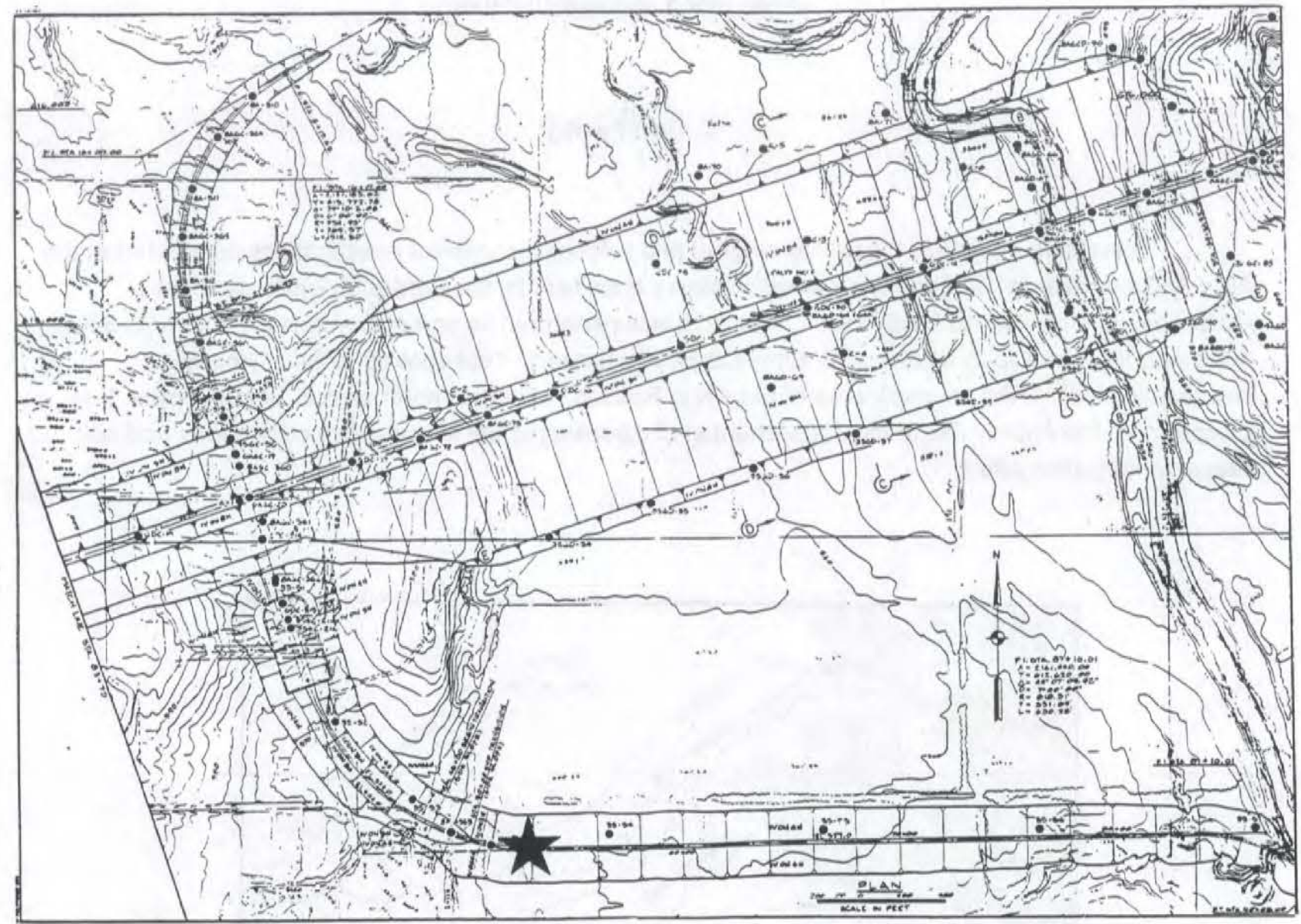

Figure 1.2 Map showing the outlet channel at Lake Ray Roberts, and the location of the Aubrey site

The report contains ten chapters. The first chapters describe previous investigations of the geology and Clovis archaeology in the Upper Trinity River Valley and the Plains region, respectively; the setting of the site is then described. The next chapters, by the various specialists who collaborated on the research, present geologic and paleoenvironmental data, and the interpretations of those separate authors of their data. Included are the faunal data, which bear directly on the past environments as well as evidence for Clovis utilization of those environments. The last two chapters present the archaeological data from the excavations and analyzes, followed by a synthesis, prepared by the editor, of the Late Quaternary paleoecology and archaeology of the site. The remainder of this chapter describes the chronicle of site discovery, testing and excavation. This is followed by a brief review of previous investigations pertinent to the study of the Aubrey Clovis Site.

Discovery, Evaluation and Investigations

Friday, December 2, 1988, was the last day of a two-year field program of Cultural Resources 
investigations at Lake Ray Roberts and Lake Lewisville. The next afternoon, the Aubrey site was discovered during an informal visit to the outlet channel of the Ray Roberts Dam by the author and his eight year-old son, Taylor. The outing was in part to collect fossils for Taylor's third grade teacher. The other aim was to see what kinds of deposits had been exposed by excavation of the outlet channel trench. The outlet channel is 10-11 m deep and $800 \mathrm{~m}$ long. It connects the outlet works at the dam with the natural channel of the Elm Fork Trinity River, and was necessary because the natural channel is located at the eastern abutment of the dam (an unsuitable location for outlet works).

The interest in the deeply exposed sediments was not entirely passing, since the author had constructed a stratigraphic cross-section of the alluvium in 1985, using borehole data from the Ray Roberts Dam pre-construction plans (Ferring, 1986). That cross-section was part of a data base on the late Quaternary geology of the upper Trinity River basin compiled in order to develop a geoarchaeological managment plan for cultural resources by the Corps. One conclusion of that study was the proposal that the Pleistocene-Holocene stratigraphic boundary was buried deeply below the floodplain, at the contact with sandy basal deposits and overlying silt and clay. The outlet channel was the only prospect for actually seeing that contact, but it was also outside the scope of services for the CRM work at Ray Roberts. The entire construction area had been surveyed almost a decade earlier, at which time the Aubrey site was buried 7.5-9 $\mathrm{m}$ below the floodplain.

We walked down to the bottom of the channel, taking an oblique descent route, crossing the readily visible contact between Cretaceous bedrock and the deep alluvium. Near the base ofthe channel slope were reddish sands overlain by thick dark clays that extended to the floodplain. Near the (buried) vertical contact between bedrock and alluvium were pale gray (almost white) lacustrine marls, overlain by dark gray clay. Several bison bones and one deer carpal were found eroding from the dark clay. In the same clay, as well as the sediments below snail shells were abundant, especially the very distinctive Pomateopsis lapidaria, which is extirpated from the region today (Cheatum and Allen 1966).

P. lapidaria is one of the few snails known to me by species. Shells of P. lapidaria were abundant in and just above the stratum containing the mammoth at the Domebo Clovis site. I was introduced to this snail (and its stratigraphic importance) by Dr. Richard Fullington, during our visit to Domebo in 1979, following our excavations at nearby Delaware Canyon (Ferring 1982, 1986). All of these things- the depth, the prominent stratigraphic change, the lacutrine marls, the bison bones and the hundreds of $P$. lapidariacreated an immediate excitement, for at the least a rich record of past environments was preserved here. And, given the possible terminal Pleistocene age for the deepest deposits, the possibility that archaeology was also there loomed. On the basis of these findings, the author notified Corps officials the following Monday and a visit to the locality by Corps archaeologists was arranged.

On December 8, 1988, the author led Corps archaeologists Ms. Karen Scott and Dr. Jay Newman and Dr. Ken Brown (UNT) to the locality. About $100 \mathrm{~m}$ east of the bison bones, the author found the first artifact: a Tecovas quartzite flake, located in the bottom of one of the many deep, short gullies that had formed by erosional removal of the construction spoil from the slopes of the outlet channel. These gullies, we later learned, were prominent at the level of the soil containing the Clovis artifacts. Below that horizon there was a sharp reduction in the channel slope, corresponding with the less resistent Pleistocene sand.

Following up the gully in search of the flake's origin, the base of a gray quartzite biface was found 
protruding from undisturbed deposits. Careful removal of the biface was followed quickly by the revelation that terminations of flutes were present on both faces. The exact position of the point was marked with a flagged nail. Three more flakes were found after all parties carefully scrutinized the slope of the outlet channel near and below the point location. The next day the author and Bob Skiles (crew chief on the RRLL project) reurned to the site, set up a datum and mapped the location of the spearpoint. This began their collaboration on the excavations at the site, which were completed a year and one week later, when we supervised the last of the backfilling of our excavation blocks.

These discoveries led to initial, limited test excavations, which included the following goals:

a. documentation of in situ archaeological materials

b. definition of the geologic context of the archaeological materials

c. definition of cultural affiliations of faunal materials located at the site

d. determination of the potential for paleoecological investigations

e. collection of data permitting recommendations for possible continuing archaeological and geological studies at the site

Artifacts and faunal materials had been located on both the north and south side of the outlet channel. Test excavations during this phase were only conducted on the south side of the channel. Investigations on the north side included limited geologic observations, mapping and collection of an artifact and faunal materials.

Exposure of the archaeological materials, between seven and eight meters below the surface, was accomplished during construction of the outlet channel. It was clear that some of the archaeological deposits were lost during exposure of the site; this unfortunate loss was offset by discovery of the site and by the preservation of in situ materials amenable to continued testing.

The activities conducted during test excavations included:

1. establishment of site grid system, including temporary datum

2. intensive surface survey, followed by three-dimensional mapping of all surface artifacts and bone

3. location on the site (with generous help from Corps personnel) of a stake tied to the embankment centerline and to a degradation benchmark.

4. limited topographic mapping

5. preliminary geologic mapping and stratigraphy

6. Excavation and/or partial excavation of eight $1 \times 1 \mathrm{~m}$ test pits

7. inspection of site by paleontologists (Dr. Steve Hall and Dr. Ernest Lundelius, Jr.), including preliminary sampling for pollen, molluscs, and microfaunal assessment.

8. partial laboratory processing and analysis of materials recovered through test excavations

Three areas of the site were initially incorporated into the grid system, because the site was so large (these are described in detail in Chapters 2 and 9). Area A included spring and pond deposits; Area B included sediments with Clovis lithic artifacts. Areas $A$ and $B$ are on the south side of the outlet channel. Area $C$ is on the north side of the outlet channel, across from Areas $A$ and $B$. Results of testing in these areas were:

In Area $A$, all bones found on the surface were mapped and removed. Six 1 square meter test pits, 
and two stratigraphic trench pits (test units 1755,1855 ) were excavated. Pit 1258 was excavated into a gray marl, and was essentially sterile except for molluscs and microfauna. The three central test units (1555, 1556,1655 ) yielded many bones of an apparent single Bison sp. Quartzite resharpening chips and large bones (bison and deer) were recovered from a very dark gray clay, rich in molluscs and organic material.

Several deer elements were also mapped in place, and large numbers of bone fragments were recovered in the fine screens. No features were found in Area A; these sediments appeared to be pond deposits, unsuitable for habitation, yet rich in paleoenvironmental data.

Because of extremely clayey deposits only two test pits were excavated in Area B. Both yielded lithic artifacts in a definite occupation horizon. In these two test pits, 56 lithic artifacts and bone fragments were mapped in situ. The vast majority of these occurred within a horizon that is ca. $5 \mathrm{~cm}$ thick. No evidence of features was detected in these test units. A few bone fragments (large mammal and turtle) were found in situ.

The concentration of lithic materials in a very thin zone, on a paleosurface that was above the pond yet below $7 \mathrm{~m}$ of alluvium indicated clearly that this was an intact archaeological deposit.

As a result of test excavations, mitigation was recommended. The Corps supported a year-long field season that involved concurrent field and lab studies. This work was conducted throughout 1989 , ending in mid-December of that year. Those efforts focused on three areas with in situ Clovis artifacts, including two camp areas and a bison butchering/procurement area. The mitigation efforts resulted in systematic recovery of over 10,000 lithic artifacts and 15,000 faunal elements from excellent stratigraphic contexts. The resulting analyzes of those materials, coupled with ancillary studies of paleoecological data, have documented a rare and important record of Clovis occupations.

\section{Previous Investigations}

Paleoindian cultures including Clovis, Folsom, Midland, Plainview and Firstview, are known from only a few in situ sites in the Southern Plains (Johnson, 1987; Wormington, 1957; Sellards, 1952). Paleoindian artifacts have been found on the surface throughout the region, yet in situ sites are concentrated on the Llano Estacado (Meltzer 1987; Meltzer and Bever 1995). The few sites with faunal remains indicate exploitation of extinct megafauna including mammoth and bison, although broader patterns of animal and plant procurement are presumed (Johnson 1987, 1995). Artifact assemblages include spearpoints, scrapers, burins and bone tools. Most in situ sites have one or more large mammal kills, but camp sites are very rare.

In 1927 the association between artifacts and extinct bison was demonstrated at the Folsom locality (Figgins, 1927). Since then interdisciplinary study of late Quaternary geology and archaeological sites on the Southern High Plains has been intensive compared to most other regions of North America. As part of the history of archaeological geology, the research on the Southern High Plains is important in that it demonstrated the efficacy of interdisciplinary teamwork in defining the character and context of late Quaternary archaeological records. This conclusion will be illustrated by reviewing work at several key 


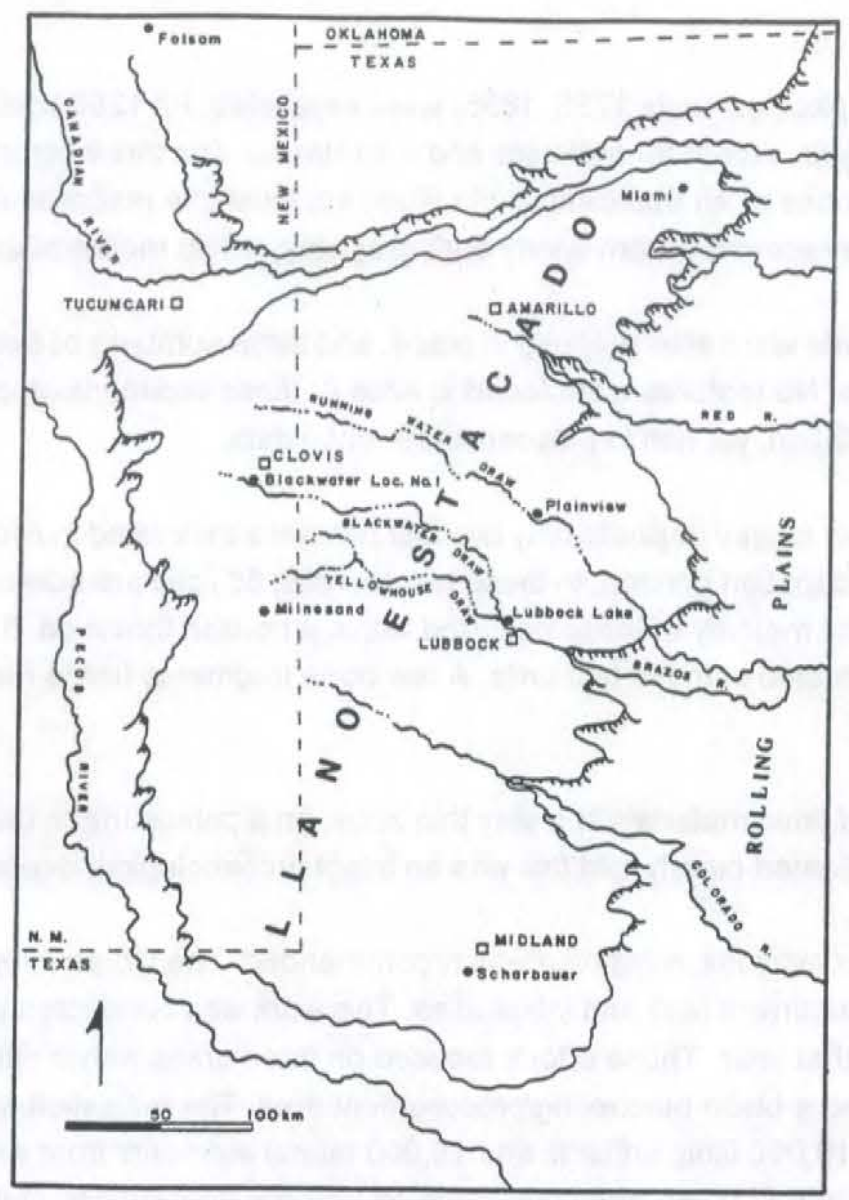

Figure 1.3 Map of the Southern High Plains showing Paleoindian localities

demonstrated the efficacy of interdisciplinary teamwork in defining the character and context of late Quaternary archaeological records. This conclusion will be illustrated by reviewing work at several key localities on the Southern High Plains (Figure 1.2).

Brief reference must be made to several localities, at which comparatively limited research was conducted in the 1940's and 1950's. Notable among these, and other researches, is the effort of E.H. Sellards. Sellards' remarkably long and influential career of archaeological work in Texas began with excavations at the Miami site, a Clovis locality in Roberts County, Texas (Sellards 1938, 1952: 18-29; Holliday et al 1994). There, Sellards documented remains of at least five mammoths, with associated Clovis artifacts, in the sedimentary fill of an ancient playa lake. His cautious appraisal of the cause of death of the mammoths predicted much of the hunting-scavenging debate in today's literature on big game procurement.

Later, Sellards collaborated with Evans and Meade (Sellards et al 1947; Sellards 1952: 60-68) at the Plainview site, located along Running Water Draw. Their work defined the Plainview culture, a postFolsom Paleoindian manifestation, in association with extinct bison. While work has continued at this site 


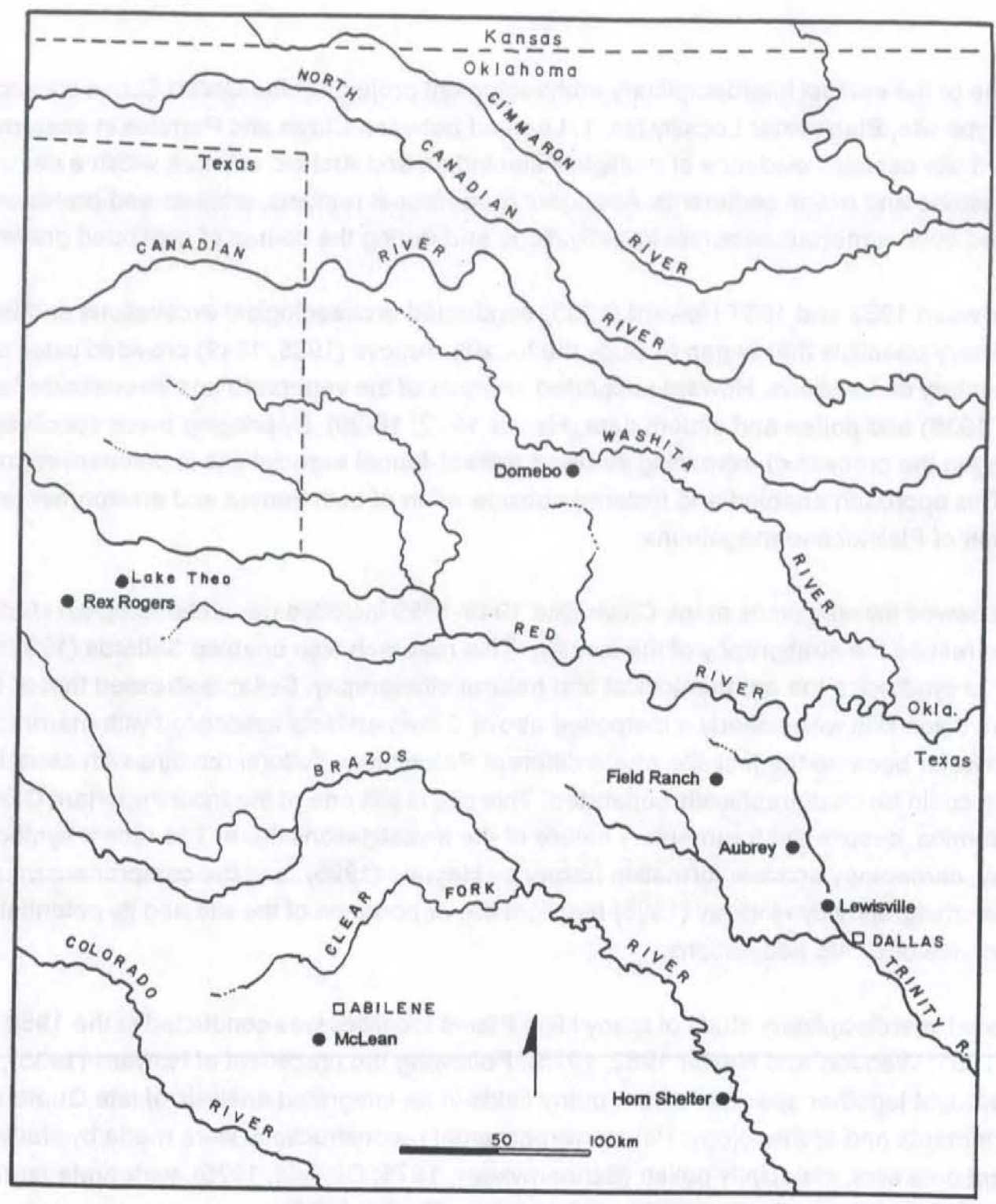

Figure 1.4 Map of the Rolling Plains showing Paleoindian localities.

more recently (Holliday, 1985b), much more data on the Plainview culture has been recovered at Lubbock Lake (see below). At the Milnesand site Sellards (1955) also found unfluted Paleoindian spear points, other artifacts and bison bones in eolian sands.

In the same year of the Milnesand publication, the first (and only) human remains from a Southern Plains Paleoindian locality were reported from the Scharbauer (Midland) site, located near Midland, Texas (Wendorf et al 1955; Wendorf and Krieger 1959). This site has several eolian and possibly lacustrine sand units, from which numerous Paleoindian artifacts and late Pleistocene-early Holocene vertebrate remains were recovered. 
One of the earliest interdisciplinary archaeological projects in the United States was conducted at the Clovis type site, Blackwater Locality No. 1. Located between Clovis and Portales in eastern New Mexico, this stratified site contains evidence of multiple Paleoindian and Archaic activities within a sequence of spring, lacustrine and eolian sediments. Abundant megafaunal remains, artifacts and prehistoric wells have been studied over numerous separate investigations and during the course of continued gravel quarrying.

Between 1933 and 1937 Howard (1935) conducted archaeological excavations and led a team of interdisciplinary scientists that began to study the locality. Antevs $(1935,1949)$ provided initial stratigraphic and sedimentary descriptions. Howard supported analysis of the vertebrate and invertebrate faunas (Stock and Bode, 1936) and pollen and diatom data (Hester 1972: 18-29). By bringing these specialists together, Howard began the process of examining stratified artifact-faunal associations in paleoenvironmental contexts. This approach enabled and fostered consideration of both human and environmental factors in the extinction of Pleistocene megafauna.

Renewed investigations at the Clovis Site 1949-1950 included geoarchaeological studies by Evans (1951) who refined the stratigraphy of the locality. This research also enabled Sellards (1952: 28-31, 54$58,72-74)$ to synthesize the archaeological and natural stratigraphy. Sellards stressed that at the Clovis Site Folsom bison kills were clearly superposed above Clovis artifacts associated with mammoth bones. Thus Blackwater became the first site where different $P$ aleoindian cultural remains with associated extinct megafauna could be stratigraphically separated. This site is still one of the most important Clovis localities in North America, despite the fragmentary nature of the investigations there. The recent synthesis of the stratigraphy, chronology and site formation history by Haynes (1995), and the comprehensive review of High Plains stratigraphy by Holliday (1995) highlight the importance of the site and its potential to yield further evidence of Clovis adaptations.

Serial interdisciplinary study of many High Plains localities was conducted in the 1950's and 1960's (Wendorf 1961; Wendorf and Hester 1962, 1975). Following the precedent of Howard (1935), Fred Wendorf brought together specialists from many fields in an integrated analysis of late Quaternary geology, past environments and archaeology. Paleoenvironmental reconstructions were made by study of multiple independent data sets, especially pollen (Schoenwetter, 1975; Oldfield, 1975), vertebrate faunas (Slaughter, 1975), diatoms (Hohn, 1975), and molluscs (Drake, 1975).

The framework for the paleoenvironmental and archaeological data was established through the stratigraphic analyzes of Harbour (1975) and especially Haynes (1975). These studies contributed directly to paleoenvironmental reconstruction in that emphasis was given to sedimentary environments. The geologic data also were used to establish archaeological stratigraphy, the contexts of artifacts and faunal remains, and the paleotopographic-habitat settings of archaeological sites. Stratigraphic correlation of High Plains localities was a framework for syntheses of archaeological-paleoenvironmental data (Hester 1975; Wendorf 1975; Wendorf and Hester 1962, 1975). On a larger regional scale, the late Quaternary stratigraphic framework developed by Haynes $(1967,1970,1984,1995)$ and Holliday $(1995)$ is essential for site comparisons and as a basis for archaeological site prediction.

Research at the Lubbock Lake site, a deeply stratified locality on Yellowhouse Draw near Lubbock (Figure 1.2), has proceeded almost as long as the work at Blackwater Draw. Initial investigations supported by the W.P.A. began shortly after its discovery during quarrying operations in 1939. Although not published 
until much later (Wheat, 1974), the initial work demonstrated the presence of Clovis, Folsom, Archaic and Late Prehistoric artifacts and features, and also recorded substantial information on the geology of the site. Work by Glen Evans and Grayson Meade for the Texas Memorial Museum resulted in the first Folsom radiocarbon age (Sellards 1952: 53).

The Lubbock Lake site contains stratified Clovis, Folsom, Plainview and Firstview Paleoindian occupations as well as younger Archaic and late Prehistoric artifacts and features (Johnson and Holliday 1989; Stafford 1981; Johnson 1995). Well preserved faunal remains (Johnson 1986, 1987) and an exceptional paleoenvironmental record add to the significance of the locality. The extensive literature on this project shows clearly the interdisciplinary character of the research carried out over the last 15 years. Comprehensive stratigraphic, sedimentary and pedogenic analyzes were conducted subsequently by Holliday (1985a, 1995, 1997; Holliday and Allen, 1987). Over 100 radiocarbon ages have been determined for the locality (Holliday and others, 1985).

Rolling Plains

In contrast to the Southern High Plains, the Rolling Plains (Figure 1.2) have more local relief and better developed drainage networks. Quaternary sediments are predominately alluvium, although eolian sands flank many larger valleys. Lacustrine deposits are not extensive, and occur mainly in the western part of the area, near the Llano Estacado escarpment (Gustavson 1986).

The earliest studies of late Quaternary geology and archaeology in the area were conducted near Abilene (Figure 1.2) by Ray, who also collaborated with Kirk Bryan. Although initial publications of Ray's work in this area occurred in 1929-1930, more substantial reports began with the description of the McLean site, a Clovis locality near Abilene (Bryan and Ray 1938; Bryan 1938; Ray 1942). Later, Ray (1944) described the stratigraphy of several sites along the Clear Fork of the Brazos. His report provides initial evidence that late Pleistocene alluvium, usually rich in faunal remains, was buried up to $8 \mathrm{~m}$ below the flood plain, and was covered by Holocene silts that often contained stratified archaeological deposits. Remarkably, the promising localities in the Abilene region have not been studied since Ray and Bryan defined their potential.

In the MacKenzie Reservoir is the Rex Rodgers site, where assemblages with San Patrice-like points were stratified below horizons containing early Archaic side-notched points and bones of extinct bison (Willey and others, 1978). At nearby Lake Theo stratified Folsom, Plainview and Archaic archaeological materials are documented in late Quaternary alluvial/eolian deposits (Harrison and Killen, 1978).

While numerous Paleoindian artifacts have been reported from the Rolling Plains of Oklahoma, archaeological sites of the same period are few (Ferring, 1990a; Hughes 1984; Hofman and Wyckoff, 1991). The well-known Domebo Clovis Site is buried $12 \mathrm{~m}$ below the former floodplain of the narrow, deeply incised Domebo Canyon that is the head for a tributary of the Washita River (Leonhardy, 1966; Ferring and Hall, 1987). At Domebo, a semi-articulated skeleton of Mammuthus columbi and three Clovis spearpoints were found in organic rich sandy clays dated to ca. 11,200 bp., based on numerous radicarbon ages on many materials (Stafford, et al. 1988) (The Washita River Valley, as well as its tributaries (including Domebo Canyon) were all deeply $(8-15 \mathrm{~m}$ ) incised before the beginning of the late Holocene (Goss and others 1972; Ferring 1982; Hall and Lintz 1984; Hofman and Brackenridge, 1988). At a number of other 
drainages over the southern Osage Plains and Gulf Coastal Plain of Texas, the maximum incision probably coencided with the last glacial maximum (Ferring, 1990a, 1993).

Plains Margin: Northcentral Texas

The southeastern margins of the Plains merge gradually with the western fringes of the Gulf Coastal Plain (Figure 1.2). Ecologically and archaeologically, the north central Texas area is a borderlands, but because prairie environments are predominant, it is included within the Southern Plains.

Archaeological geology in northcentral Texas has lagged behind the rest of the Southern Plains, despite a number of early investigations along the Trinity River (Shuler, 1923; Albritton and Patillo, 1940). Until the last 20 years, archaeological studies in this area were dominated by contributions from avocational archaeologists, especially the late R.K. Harris (Ferring, 1986c).

Discovery of the Lewisville Clovis site, north of Dallas on the Elm Fork Trinity River brought immediate attention to the archaeology and geology of the area (Crook and Harris, 1957, 1958). Study of the site was integrated into broader geologic and paleontologic investigations of the Trinity Basin (Slaughter and others, 1962). The system of terrace nomenclature proposed by W.W. Crook (Slaughter and others, 1962) was recently revised, as part of geoarchaeological studies in the Trinity Basin (Ferring 1986c,d, 1987a, 1990, 1993, 1995).

Terraces along the Trinity River are all late Pleistocene and older (Fig. 7). Alluvial fill of the lowest terrace has been dated to ca. 20-23 KA (Willimon, 1972). The age of the Hickory Creek Terrace (Ferring 1993), is estimated to be middle Wisconsin. Thus, the alluvial fill for this terrace is much too old to have been contemporaneous with Clovis occupations as claimed earlier (Crook and Harris, 1958; Slaughter and others, 1962). From borehole data (Ferring, 1986d, 1990) there is evidence that alluvial fill below the flood plain in the Dallas area is over $20 \mathrm{~m}$ thick. Farther upstream, near Denton, the alluvium below the flood plain is about $13-14 \mathrm{~m}$ thick.

Other Clovis localities in north Texas include the Field Ranch Site (Jensen 1968). This site has a quartzite Clovis point base, but little else that can be directly associated with Clovis. The intriguing apparent association between Clovis points and a mastodont skeleton at the Murphey Site at Lake of the Pines (Story 1990:185) would constitute one of three such association in North America, but unfortunately the site has been destroyed. Otherwise, the Clovis culture is known only from widely distributed surface finds of Clovis points (Meltzer 1987; Meltzer and Leper 1995).

In Central Texas, Clovis materials have been notably excavated at Horn Shelter, Southern End (Redder 1985). These included artifacts, hearths and faunal remains. Clovis materials from the Pavo Real Site in San Antonio (Henderson and Goode 1991) are important, but unfortunately are mixed with other Paleoindian materials. Recent work at the Site (Bousman and Collins 1990), Kinkaid Shelter (Collins 1990) have yielded important technological data about Clovis, but unfortunately little concerning subsistence and environment. Continuing efforts at McFadden Beach, on the Gulf Coast illustrates the potential of the site to provide in situ Clovis artifacts and faunas (Long 1977; Story 1990:189). 
In sum, the number of in situ Clovis sites in the Southern Plains is few to say the least. Of these, several include Clovis points and an elephant (Domebo, McLean, Miami, Murphey) while others have yet to yield an in situ camp occupation surface. Further, the stratigraphic record of Clovis is usually underlain by organically sterile sediments (Holliday 1995; Haynes 1984, 1995; Ferring 1990). Thus the all-important environment versus overkill debate on Pleistocene extinctions receives little data from contexts prior to Clovis arrivals (Martin and Wright 1968; Martin and Klein, 1984; Grayson 1987, 1989).

Because Aubrey has organic rich sediments dating from ca. 14,200 yr ago, and because it contains in situ camp debris including faunas, and because it has been very well dated, it provides a most important point on the Clovis map. This report will endeavor to describe and interpret that point. 


\title{
CHAPTER 2
}

\section{THE SITE SETTING, EXCAVATIONS AND METHODS}

\author{
by \\ C. Reid Ferring \\ Introduction
}

This chapter first describes the present day geographic and environmental setting of the Aubrey Clovis site. The second objective of this chapter is to provide an overview of the site itself. The physical setting, the nature of the exposures, and the logistical problems posed by deep burial all are important aspects of the work that was accomplished. Further, the later chapters describe data collected from a variety of trenches, boreholes and excavation blocks. To acquaint the reader with this field situation, the layout of the different investigations is described here.

Physiographic Setting

\section{Environmental Context}

The Aubrey site is located on the Elm Fork of the Trinity River in the Upper Trinity River drainage basin, Denton County, Texas (Figure 1.1). This area of north-central Texas is at the boundary between the southern Osage Plains and the Gulf Coastal Plain physiographic provinces (Fenneman, 1931, 1938). The Trinity River flows south, joining the Gulf of Mexico at Galveston Bay, some $450 \mathrm{~km}$ away. The Upper Trinity River drainage basin is bound by three other major drainage basins: the Red River to the north, the Brazos River to the west-southwest, and the Sabine River to the east (Figure 1.1).

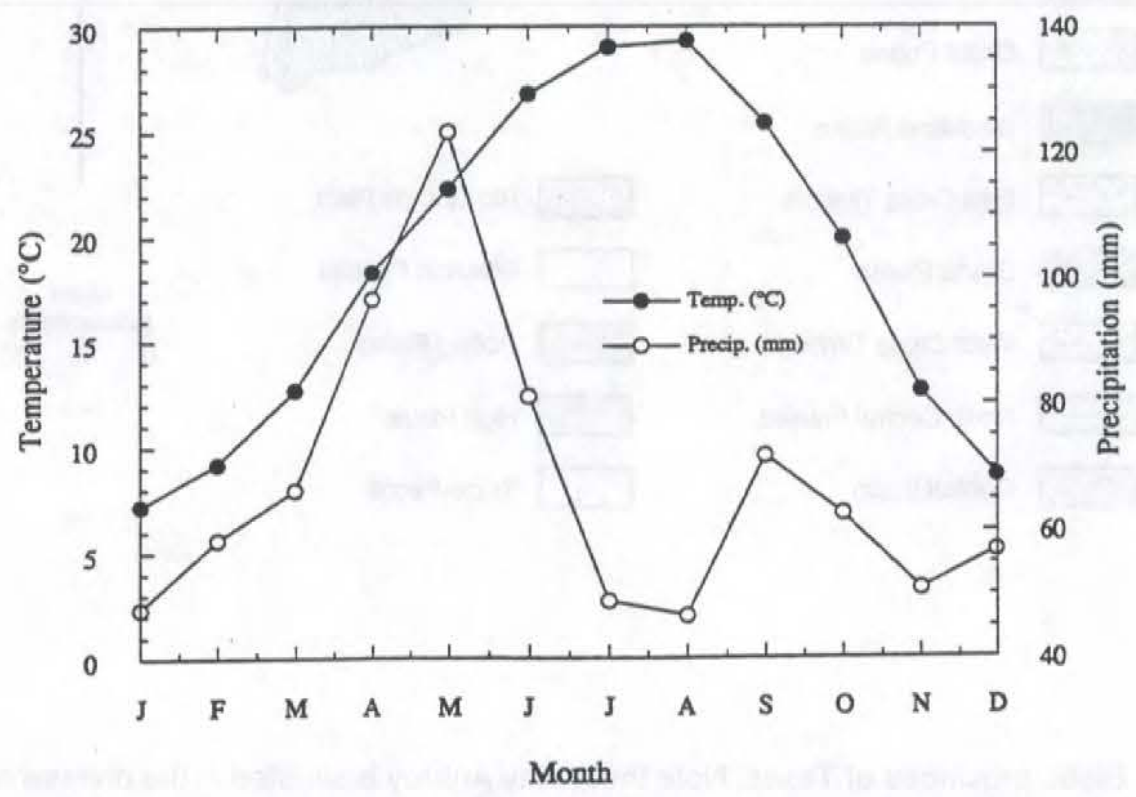

Figure 2.1 Climatic Parameters for Northcentral Texas. Note the weakly seasonal climate, with two main periods of rainfall separated by a hot dry summer. 


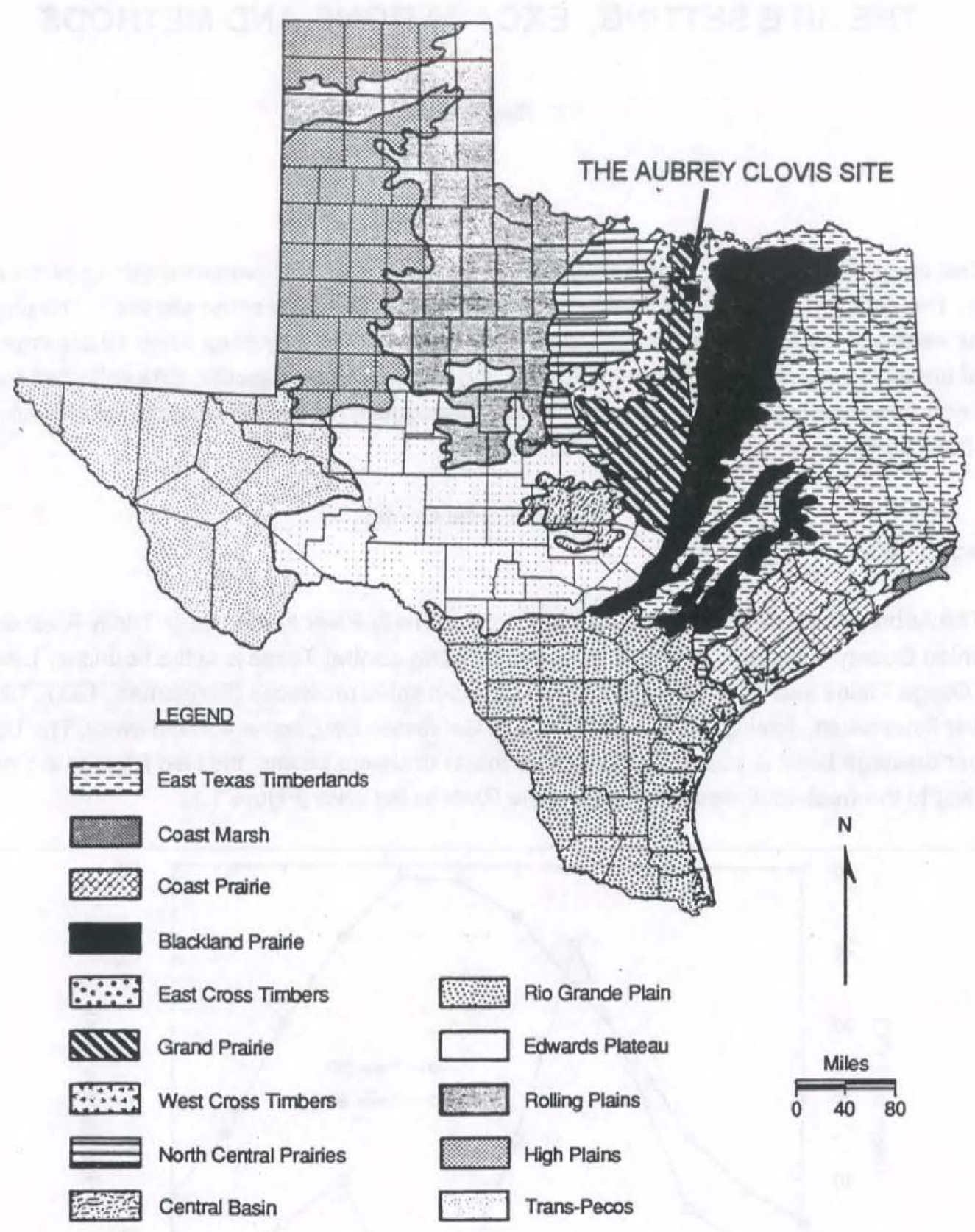

Figure 2.2 Biotic provinces of Texas. Note that today Aubrey is situated in the diverse northcentral Texas region which has strong bedrock-soils controls on vegetation. The late Pleistocene landscape was almost all prairie. 


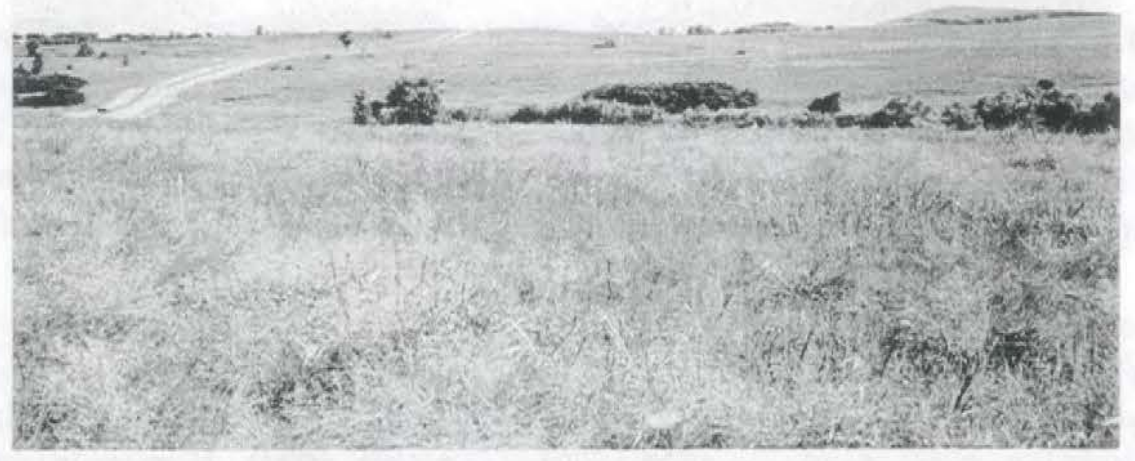

a

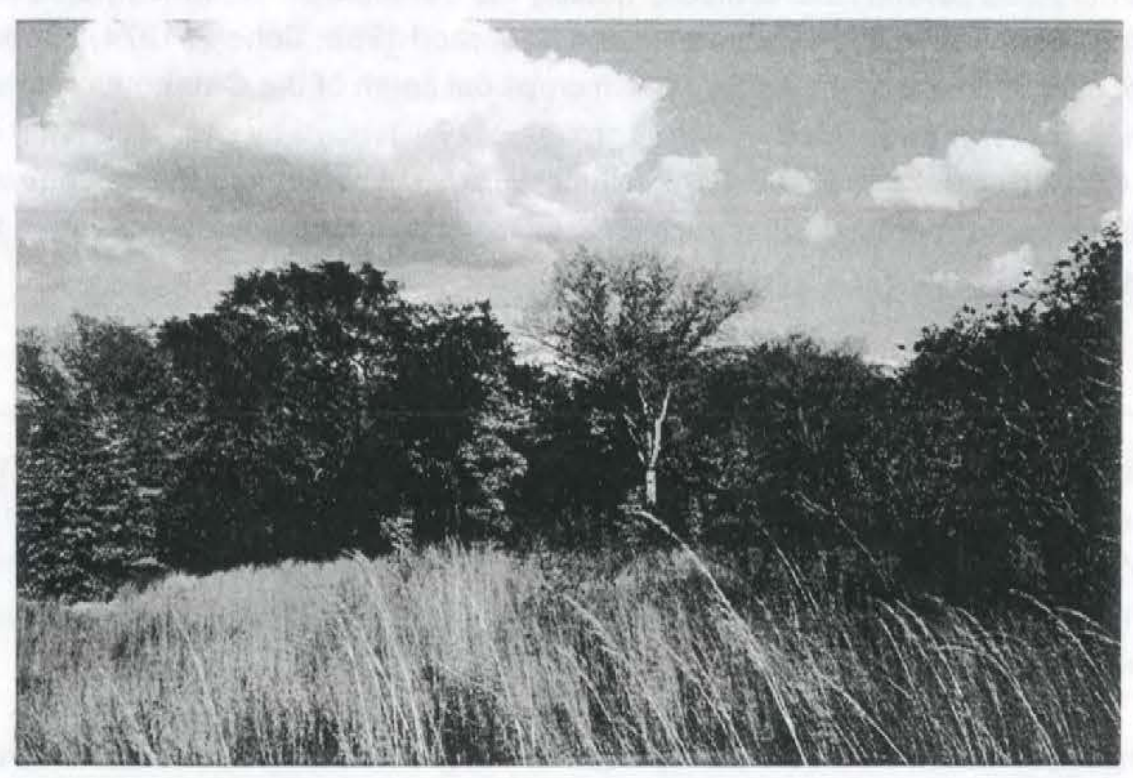

b

Figure 2.3 Photographs of vegetation communities in North Texas. a- typical view of the Fort Worth Prairie, west of Denton, Texas. Local prairies occur on shale, marl and limestone bedrock. ; b- View of the upland oak-hickory savannah north of Fort Worth, Texas. This is locally called the "West Cross Timbers", and corresponds with sandstone bedrock. Pollen data from Aubrey show that these upland forests were not present in the late Pleistocene. 
Just $40 \mathrm{~km}$ north of the Aubrey site is the Red River, the principal drainage of the southern Osage Plains. The Red River facilitates communication from the Southern High Plains (Llano Estacado) to the Ouachita Mountains of Oklahoma and Arkansas, and then to the lower Mississippi Valley. The Aubrey site is thus strategically located with respect to both an east-west route across the Southern Plains, and the north-south route along the Trinity River which provided direct communication with the Gulf Coast.

This location was ideal for exploitation of diverse and widespread biotic communities. It also minimized travel times to lithic raw material sources. The Red River would take folks to gravel and/or bedrock sources of raw materials derived from Triassic bedrock that crops out along the Caprock Escarpment of the Llano Estacado (Banks 1990; Holliday and Welty 1981). Numerous varieties of chert, quartzite and novaculite crop out in the Ouachita Mountains east of Aubrey; those materials can be acquired at the bedrock exposures or as gravel in the streams draining the Ouachitas into the Red River. The Trinity River crosses several lithic sources, notably the Catahoula Fm., which yields high quality quartzite and chalcedony (Thomas 1960; Paine and Meyerhoff 1968; Scheldt 1974). Good knappable quartzite also occurs within the Manning Fm, which crops out south of the Catahoula rocks, closer to the Gulf Coast. The coast was frequented by Clovis groups, as evidenced by scattered finds of Clovis points along the Gulf Coast (Meltzer and Bever 1995). Numerous Clovis points and Pleistocene vertebrate remains have been found in eroded but nonetheless concentrated localities at McFadden Beach near Galveston (Long 1977)

Climate

The climate of this region of Texas has a weakly seasonal, subhumid precipitation regime, and a strongly seasonal, thermic temperature regime (Bomar 1983; Bull 1991:35). Summers are hot and winters are mild except for periods of brief but sometimes intense cold temperatures associated with Arctic fronts locally called "northers". These fronts frequently are accompanied by rain, and less frequently by snow and/or ice storms.

Historical records show that the late spring and early fall are usually the wettest periods of the year, whereas summers are usually hot and dry (Figure 2.1). Dry periods lasting weeks to several months are common in this region. Intense, multi-year droughts occur cyclically and/or periodically, such as in the 1930 's and the early 1950 's. Overbank flooding is common in the spring months when cyclonic storms result from Pacific air masses colliding with warm Gulf air. For example, the town of Pilot Point, located 20 $\mathrm{km}$ northeast of Denton, received 30.3 inches of rain in May, 1982 (Bomar 1983: 225). Occasionally, tropical storms reach this area in the early fall, causing severe flooding. Of the 33 largest floods in Texas since 1899, Bomar (1983: 231) lists seven in the Dallas-Fort Worth area. Five of these were cyclonic storms and two were tropical storms.

Average rainfall in Denton County is $32 \mathrm{in} / \mathrm{yr}(813 \mathrm{~mm} / \mathrm{yr})$ and the average temperature is $65.2^{\circ} \mathrm{F}$ $\left(18.4^{\circ} \mathrm{C}\right)$ (Ford and Pauls, 1980). The region is ecotonal between the prairie plains to the west and the pine- 
broadleaf forests in east Texas. Because of the moderate climate, edaphic controls on vegetational patterns are distinct. Limestones and marls weather to clayey calcareous soils that support prairie ecosystems; in contrast, sandstone bedrock weathers to form sandy, well-drained soils that are good habitat for upland oak savannahs (locally called the "Cross Timbers").

Vegetation and Faunas

Today, vegetation in the Upper Trinity River basin is edaphically controlled. Calcareous clayey soils on Cretaceous limestones, marls, and chalks are associated with prairies. Sandy and loamy soils on Cretaceous sandstones are associated with upland forests. In this area the Woodbine Group sandstones and shales control the distribution of the Eastern Cross Timbers, an upland oak-hickory forest (Dyksterhuis 1948). To the west is the Grand Prairie (Hill 1901). To the immediate east of the Eastern Cross Timbers is the Blackland Prairie. The Aubrey site is today located at the distinct boundary between the Eastern Cross Timbers and the Fort Worth Prairie (Figures 2.2,2.3). Today these two biotic zones have distinct plant and animal communities. The late Pleistocene landscape had radically different features: extinct and extirpated species of animals living on a prairie. This picture is developed in later chapters of this report.

\section{Site Setting}

The Aubrey Clovis site was found in sediments near the base of a 35 foot (10.7 m) deep outlet channel for Lake Ray Roberts (Figures $2.4,2.5$ ). The outlet channel extends about $800 \mathrm{~m}$ from the dam to the natural channel of the Elm Fork Trinity. Below the dam, the outlet channel first crosses the Denton Creek Terrace (Pleistocene) revealing alluvium (Carrollton Alloformation) above the Cretaceous bedrock (Paw Paw Fm. shale and sandstone). East of the terrace scarp, the late Pleistocene (Aubrey Alloformation) and Holocene (Sanger and Pilot Point Alloformations) sediments are exposed. Borehole logs reveal a total thickness of ca. $14 \mathrm{~m}$ of those sedimets below the floodplain.

At the time of discovery, intact sediments were only visible in the lower part of the outlet channel; the rest of the channel slopes were thickly vegetated or had a veneer of gravel and sand that had been dredged from the channel axis. But fortunately all of the Clovis age deposits were exposed in the channel slopes. The channel was about three years old at the time of discovery. Had it been visited much earlier, neither the late Quaternary sediments nor the Clovis materials may have been visible. A few years' erosion cleaned up the outlet channel's slopes quite a bit.

Discovery has its price. The outlet channel cut through the site and probably removed much material, especially in Areas B and C, where artifacts were found on both sides of the outlet channe (Figure 2.6). Area $C$ was also impacted by the outlet for a collector channel that enters the main outlet channel across from Block B. After all is done, however, the outlet channel exposed a fragment of the Clovis world that could otherwise have lain undetected almost indefinitely. The damage done in the process of exposure was worth the price, especially since we don't know exactly what that price was.

The only access to the deeply buried Clovis surface was down the outlet channel slope. This position pose serious logistical constraints on our ability to explore the deposits during testing. The outlet 


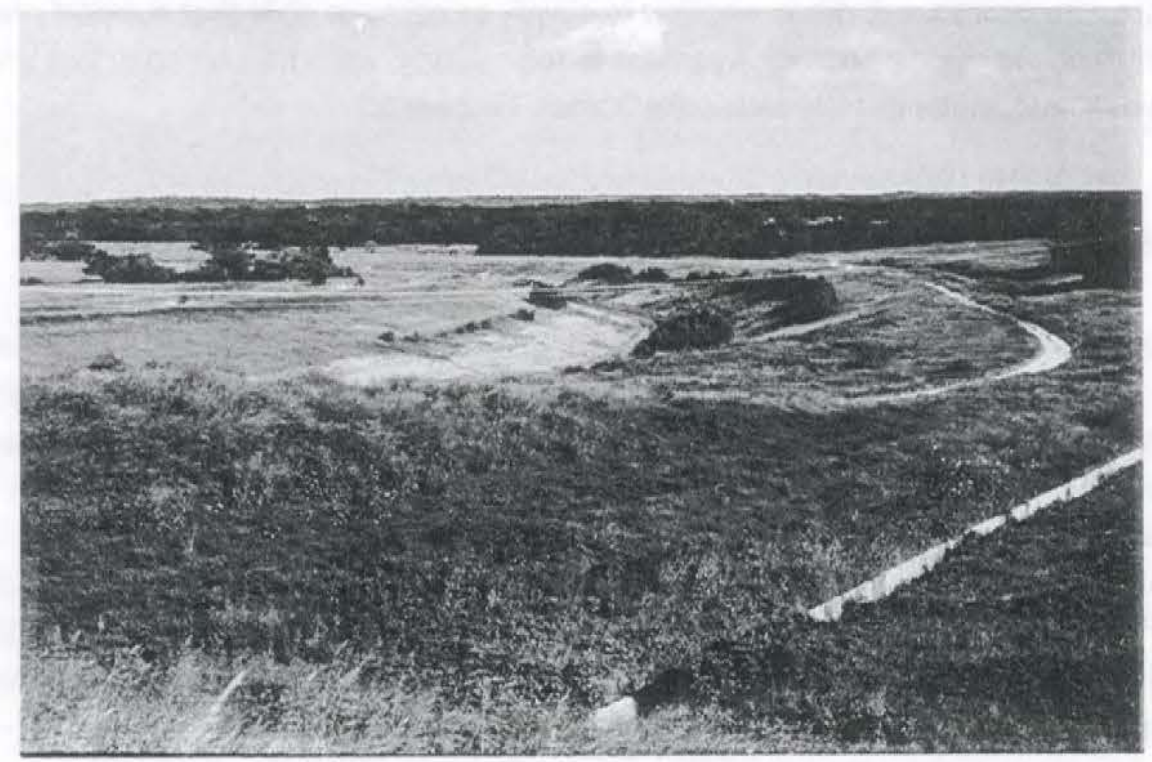

Figure 2.4 Photograph of the outlet channel for Ray Roberts Lake. View is from the dam to the southsoutheast. Surface at curve in road is a late Pleistocene terrace. Beyond that is the present floodplain, and the high ground beyond supports the upland forests called the "East Cross Timbers" (see Figures 2.2, 2.3).

channel was designed to have 1:3 slopes; the final result was close to that. The steep slope made it extremely difficult to use a backhoe during testing. Only the great skill of Crew Chief Bob Skiles enabled us to take a backhoe down the slope to excavate the stratigraphic trenches that proved critical to formulating a strategy for the initial phase of excavations (Figure 2.5). Ideally, we would have exposed the Clovis sediments in a ca. $150 \mathrm{~m}$ long trench parallel to the outlet channel. This could not have been done without causing great damage to the site. Such a trench would have to be dug near the base of the outlet channel slope, so that the Clovis age deposits could be exposed. This would have required building an access ramp down to the base of the channel slope, and also dozing a bench parallel to the channel for the backhoe. To avoid that damage, we utilized the available exposures in the outlet channel, and excavated several short perpendicular trenches along the channel. More trenches were excavated later in the field investigations to help resolve stratigraphic problems and to expose Clovis materials. The steeper north slope of the outlet channel further limited backhoe access, so that only one trench was excavated there. Area $\mathrm{C}$ was tested by a series of hand-excavated 1x1 m Test Units (Figure 2.6). 


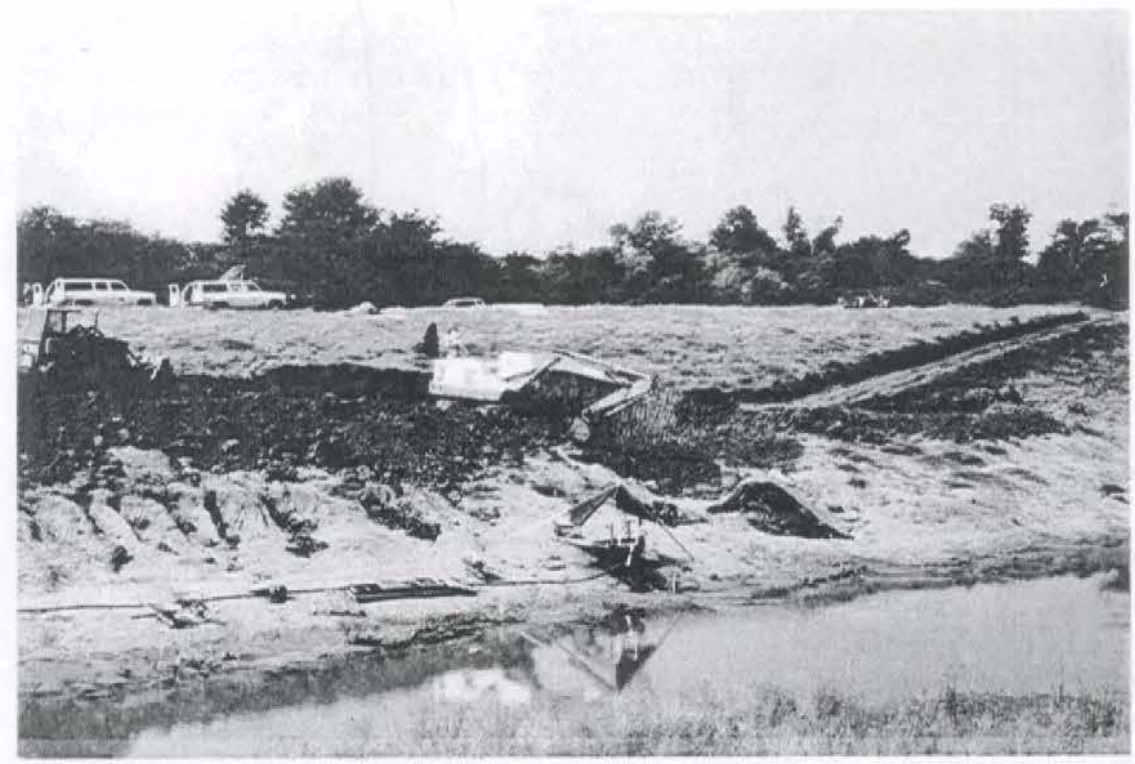

Figure 2.5 Photograph of overburden removal at Aubrey. Work here is exposing block in "Camp B" by removal of over 2,000 cubic meters of floodplain deposits that accumulated in the Holocene. The Clovis occupation surface is ca. $1.3 \mathrm{~m}$ above water level here in the Camp B area.

The lowest Clovis materials in the pond axis sediments (within Area A) were about $60 \mathrm{~cm}$ above the water table, which was the same elevation as the water surface in the outlet channel. Most of Backhoe Trench 2, in the western part of the pond deposits, was excavated below the water table, which helps explain the excellent preservation of organic materials. Major setbacks to the excavation schedule were caused by the unusually heavy rains of the spring of 1989 , which filled Lake Lewisville to its emergency levels. This backed up Lake Lewisville water all along the outlet channel and inundated the Aubrey site for days on end. We joked that this was the second Clovis site that Lake Lewisville had inundated, the first being the Lewisville site about $30 \mathrm{~km}$ downstream (Crook and Harris 1957, 1958).

\section{Overview of the Excavations}

Clovis occupation and activity areas were principally excavated in four blocks that were spaced along the south side of the outlet channel. Clovis people had occupied or used several places at the Aubrey locality. As described later, these occupation areas were located on both shores of the Clovis-age pond, 

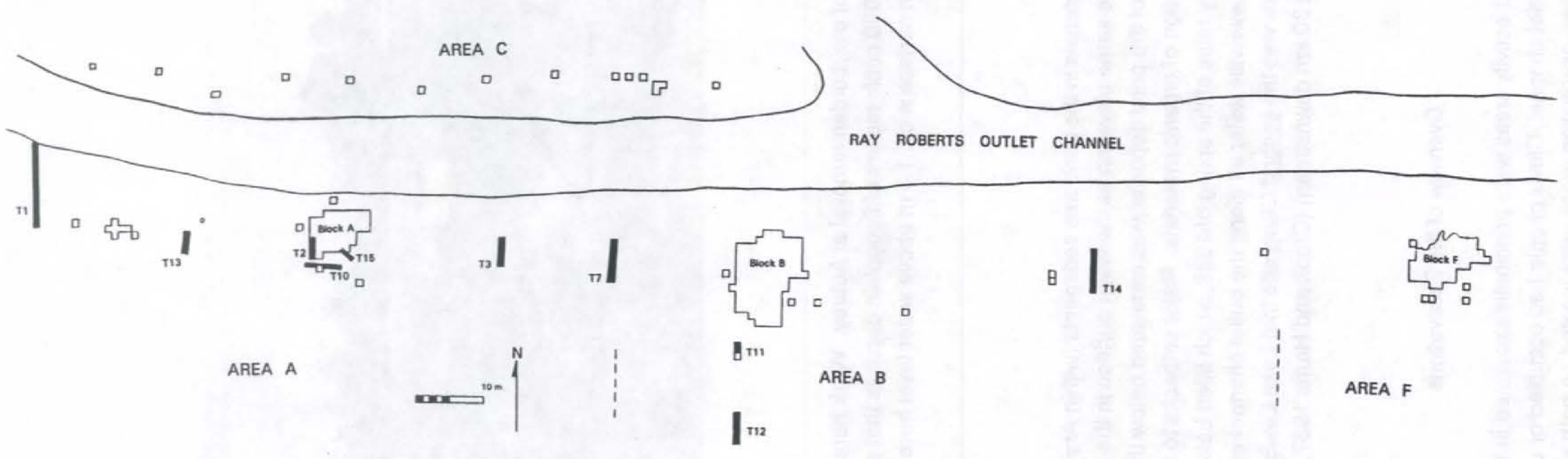

Figure 2.6 Map of excavations at Aubrey. Note the large site complex, composed of discrete concentrations of artifacts and faunal materials at excavation block locations. Block $A$ is at western edge of Clovis-age pond near spring. Block $B$ is the Clovis camp on the east shore of the pond. Block F is on west bank of Clovis age river, and artifacts also occur on east bank of the paleoriver in Area G. Outlet channel apparently bisected Camp B, as shown by small area with in situ materials in Area C on north side of outlet channel. 
and also at several places along the Clovis-age river channel. In these settings we found artifacts and faunal materials, and, after test excavations, opened blocks for intensive data recovery (Figure 2.6).

For main excavations, we had to remove huge volumes of clay overburden to expose the Clovis surface. Using a trackhoe and a dump truck, 2,000 cubic meters of overburden were removed to prepare Block B (Figure 2.4). A smaller volume of overburden was removed in similar fashion for Block $A$ (pond axis). Overburden removal for Block $F$ was done entirely with the backhoe. All of the excavated areas at Aubrey were backfilled at the end of excavations.

The Aubrey locality is so large that our horizontal grid system was divided into $100 \mathrm{~m}$ long segments on either side of the outlet channel. Excavation blocks were named after their grid cell (A pond axis, A red wedge, Block B and Block F). In Figure 2.6, note that the blocks are actually positioned according to the Clovis age landscape.

Trench 1 is located on the spring. Block $A$ is in the middle of the Clovis age pond. Block $B$ is situated on the eastern shore of the pond. Block $F$ is located on the western bank of the Clovis age river (which flowed to the south at this point). Backhoe trenches between these blocks, and 17 boreholes drilled 45 feet $(16 \mathrm{~m})$ deep from the floodplain, were used to better define the subsurface geology of the site. 
22 


\title{
CHAPTER 3 \\ GEOLOGY OF THE AUBREY CLOVIS SITE
}

\author{
by \\ C. Reid Ferring \\ Introduction
}

The $800 \mathrm{~m}$ long outlet channel below the Ray Roberts dam exposed about $9 \mathrm{~m}$ of deposits above the water level, enabling discovery of the deeply buried (7.5-9 m) Aubrey site. The ca. 3:1 slope of the outlet channel walls then made it possible to open relatively large surface areas for excavation, at depths of $7-9 \mathrm{~m}$ below the floodplain. This chapter presents a description and synthesis of the geology of the locality and its broader setting, providing the basis for discussion of the environmental context and the formation history of the site.

Considerable work on the Quaternary geology of the upper Trinity Valley had been done prior to the discovery of the Aubrey site (Ferring 1986a, 1990a). Nonetheless, a significant part of the studies at Aubrey was devoted to developing a detailed picture of the depositional (sedimentary) and post-depositional (diagenetic and pedogenic) features of the deposits. This geologic component of the research was charged with meeting immediate needs to guide excavations and collect environmental data during fieldwork. We also needed to collect sufficient geologic data to support the contextual, archaeological and paleoenvironmental analyses which were done following the field investigations.

\section{Regional Geologic Context of the Aubrey Site}

The regional late Quaternary geologic context of Aubrey is important to understanding both the broad site setting and the specific if not unique geologic characteristics of the site. The regional late Quaternary geomorphic and stratigraphic framework is important in three main ways. First, that framework helps explain why in situ Paleoindian sites are so rarely found. Second, it is a foundation for collecting and interpreting paleoenvironmental data pertinent to finding and studying Paleoindian sites. Last, the late Quaternary geology of the Upper Trinity River basin provides a basis for assessing the possibility of "preClovis" age occupations in the region. This can be done probabilistically by defining patterns of preservation and exposure of "pre-Clovis" sediments, and, perhaps better, by developing and implementing archaeological survey strategies. This "pre-Clovis" issue may seem quite peripheral to study of the Aubrey site. But in later summation discussions the issue of possible occupations older than Aubrey in this region will be shown to be important indeed to interpreting the record from Aubrey.

\section{Bedrock Geology}

The entire Upper Trinity River drainage basin has developed over Cretaceous and Pennsylvanian sedimentary rocks (Hill, 1901; Shuler, 1918; Winton, 1925; Barnes, 1967; 1988; Hendricks, 1976). The upper part of the West Fork of the Trinity drainage, northwest of Fort Worth, is underlain by Pennsylvanian limestone, shale and sandstone (Figures 3.1, 3.2). All other portions of the Upper Trinity River drainage basin have developed over mixed carbonate and siliciclastic Cretaceous rocks (Table 3.1).

Diverse alluvial sources are reflected in both textural and lithologic variability of late Quaternary alluvial deposits at two scales. First, the sediments vary with local sedimentary environments such as point 

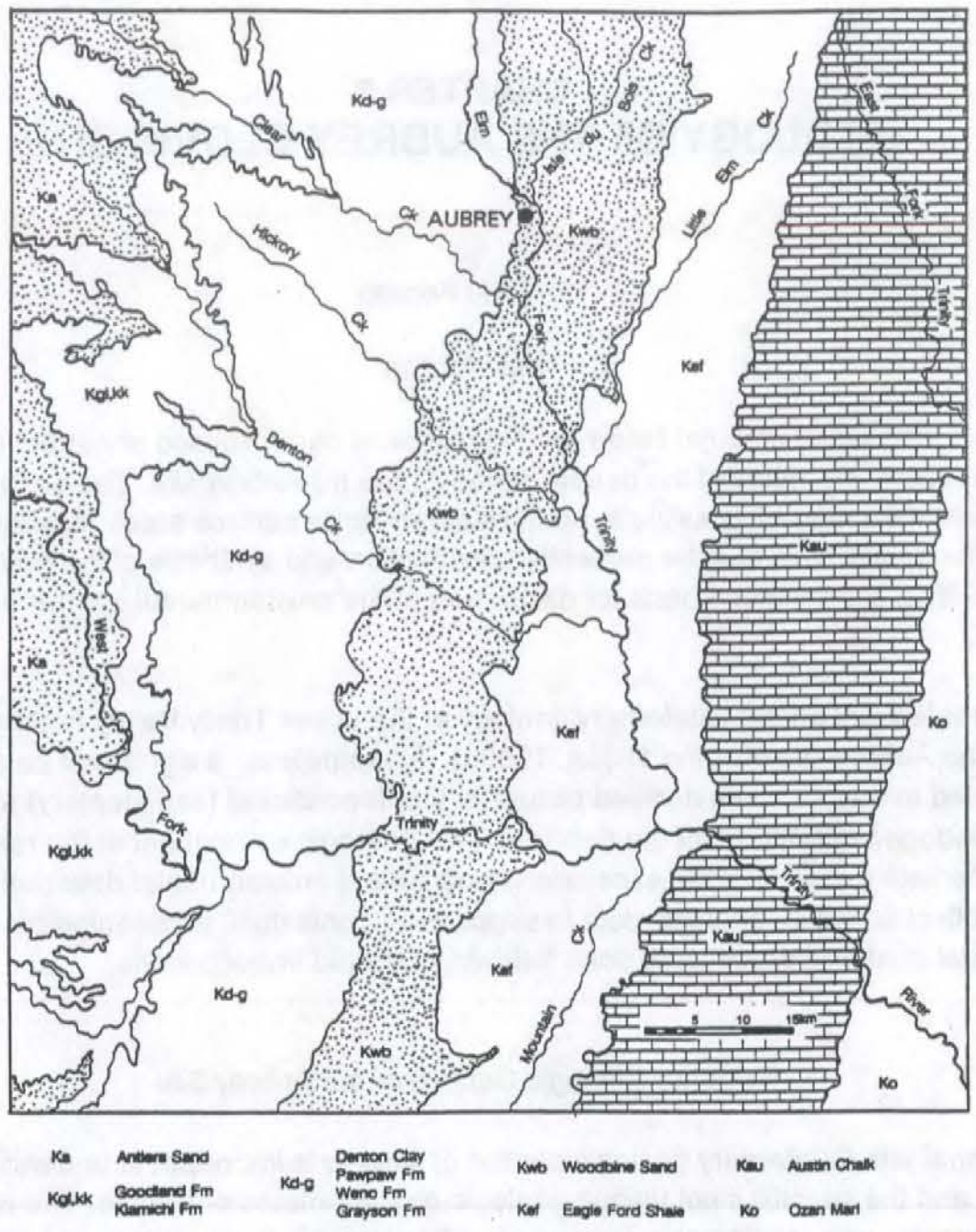

Figure $3.1 \quad$ Geologic map of northcentral Texas

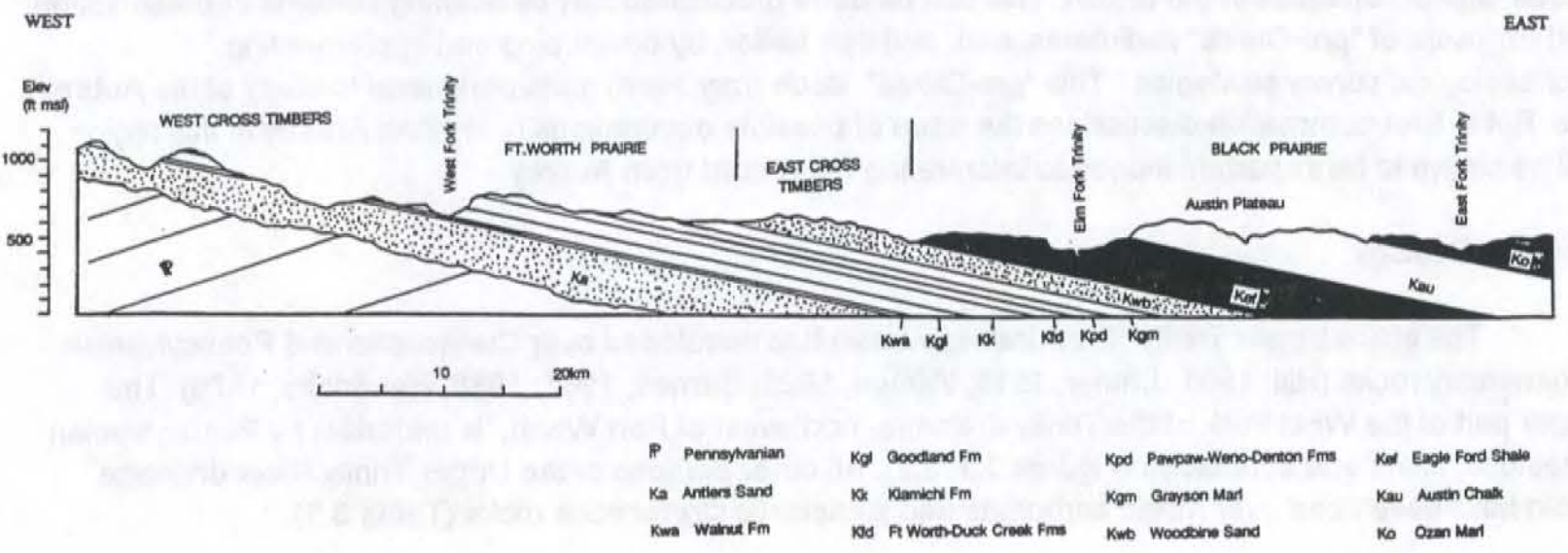

Figure 3.2 Geologic cross-section of northcentral Texas 
Table 3.1 Cretaceous Stratigraphy of Northcentral Texas.

\begin{tabular}{|c|c|c|}
\hline STRATIGRAPHIC UNIT & $\begin{array}{l}\text { Thickness } \\
\text { (feet) }\end{array}$ & LITHOLOGY \\
\hline \multicolumn{3}{|l|}{ Upper Cretaceous } \\
\hline Austin Chalk & $400-600$ & $\begin{array}{l}\text { massive chalk with thin marl interbeds; } \\
\text { weathers white }\end{array}$ \\
\hline Eagle Ford Group & $250-350$ & $\begin{array}{l}\text { gelenitic shales with thin sandstone } \\
\text { beds and calcareous concretions; } \\
\text { weathers gray }\end{array}$ \\
\hline Woodbine Formation & $200-350$ & $\begin{array}{l}\text { predominantly fine grained sandstones } \\
\text { with thinner shale beds and members. } \\
\text { Weathers red with numerous ferruginous } \\
\text { concretions. }\end{array}$ \\
\hline \multicolumn{3}{|l|}{ Lower cretaceous } \\
\hline Grayson Marl & $30-60$ & $\begin{array}{l}\text { marl and calcareous clay with few thin } \\
\text { limestone beds. weathers yellowish } \\
\text { brown. }\end{array}$ \\
\hline Main Street Limestone & $10-25$ & $\begin{array}{l}\text { fossiliferous } 1 \text { imestone and } \\
\text { calcareous shale. weathers light gray } \\
\text { to white. }\end{array}$ \\
\hline Pawpaw Formation & $15-50$ & $\begin{array}{l}\text { sandstones with shale interbeds. Many } \\
\text { ferruginous concretions. weathers } \\
\text { brown. }\end{array}$ \\
\hline Weno Limestone & $60-130$ & $\begin{array}{l}\text { marl and limestone; many concretions, } \\
\text { fossiliferous. weathers gray. }\end{array}$ \\
\hline Denton Clay & $20-45$ & $\begin{array}{l}\text { calcareous shaley clay and thin } \\
\text { limestones; weathers brownish gray. }\end{array}$ \\
\hline Fort Worth Limestone & $25-35$ & $\begin{array}{l}\text { massive and burrowed limestone with } \\
\text { thin marl interbeds; fossiliferous, } \\
\text { weathers yellowish brown. }\end{array}$ \\
\hline Duck Creek Formation & $50-100$ & $\begin{array}{l}\text { fossiliferous limestone with thin marl } \\
\text { interbeds. weathers yellowish brown. }\end{array}$ \\
\hline Kiamichi Formation & $20-50$ & $\begin{array}{l}\text { marl and thin limestone with a few thin } \\
\text { calcareous sandstones. weathers } \\
\text { yellowish gray and brown. }\end{array}$ \\
\hline $\begin{array}{l}\text { Goodland Limestone and } \\
\text { Walnut Clay }\end{array}$ & $30-90$ & $\begin{array}{l}\text { massive and nodular limestone with beds } \\
\text { of marl and clay. weathers dark gray to } \\
\text { brown. }\end{array}$ \\
\hline Antlers Sand & $500-650$ & $\begin{array}{l}\text { sand, clay and conglomerate; carbonates } \\
\text { increase to south. weathers yellowish } \\
\text { brown. }\end{array}$ \\
\hline
\end{tabular}

bars, floodbasins, etc. In response to Late Quaternary climatic-environmental changes, larger scale variation in stream type is expressed as major changes in textural lithofacies associated with both meandering suspended load and sandy bedload stream deposits (Ferring 1993). The Late Quaternary alluvial geology of the Trinity is discussed below, as a framework for the record at the Aubrey site. 


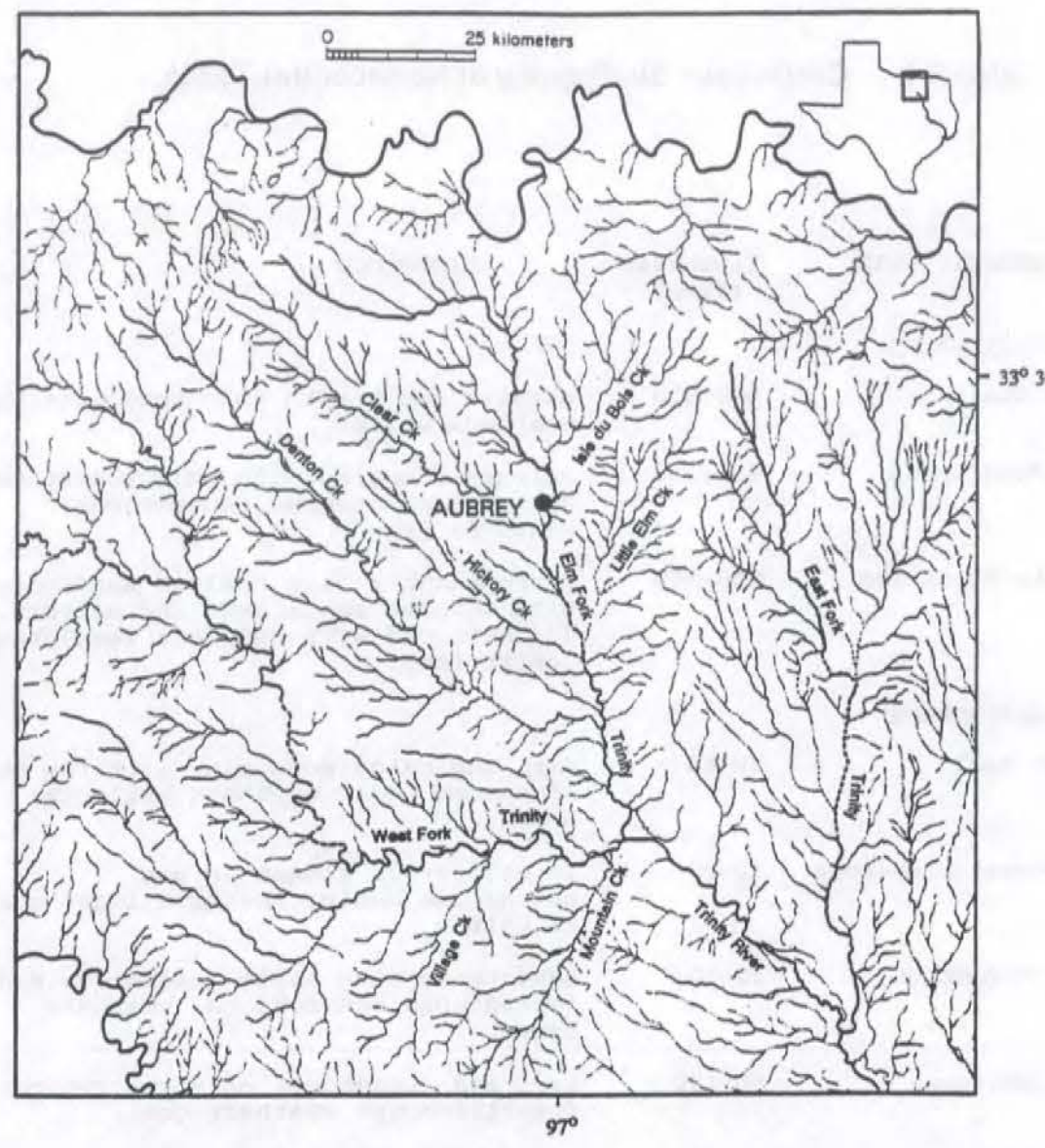

Figure 3.3 Drainage networks in northcentral Texas

In the Cretaceous bedrock of the Upper Trinity River Basin knappable stone materials are completely absent (Banks 1990). A number of cherts and quartzites occur in Pennsylvanian rocks west of Decatur, Texas (Figure 3.2) The only lithic raw materials available locally to the Aubrey site are gravel deposits, that contain metaquartzite, ferruginous sandstone and fossil wood. The most common of those materials is "Ogallala Quartzite", which is a crystalline to cryptocrystalline metaquarztite derived from the southern Rocky Mountains, and found in local surface concentrations in uplands (Menzer and Slaughter, 1968). These raw materials are common in the Archaic and Late Prehistoric assemblages from this region, but none were found in the Aubrey lithic assemblages. For the Aubrey occupants, they could have, but chose not to use local materials, which for the most part have poor knapping properties; instead, they elected to import knappable stone over long distances by procurement and/or trade. Long-distance transport of raw materials is a commonly documented aspect of Clovis lithic technology (Frison 1993; Frison and Bradley 1999; Stanford 1999; Meltzer 1988, 1989; Tankersley 1994; Meltzer and Bever 1995 ). Agreement on whether the materials were acquired directly or exchanged is not commonly documented. Regardless, the Aubrey lithic assemblage loudly reiterates the theme of long-distance stone procurement. 
Regional Geomorphology and Soils

Bedrock lithology is the principal factor influencing regional morphogenesis. Four major upland physiographic subdivisions are recognized (Hill, 1901; Fenneman, 1938): Western Cross Timbers, Fort Worth Prairie, Eastern Cross Timbers and Black Prairie (Figures 3.2). Because climatic variation within this region is minor, differences in landforms, soils and vegetation among the four upland subdivisions are attributed to different bedrock lithology. A characteristic feature of this region is its mosaic of soils; calcic Mollisols and Vertisols are associated with calcareous bedrock and alluvium, whereas Alfisols are associated with sandstone bedrock and sandy alluvium.

The Western Cross Timbers region corresponds with the area underlain by the Antlers Formation (Figures $3.2,2.4$ ). North of Fort Worth the Antlers Formation is comprised mainly of fine grained sandstone and some shale. South of Fort Worth the correlative Twin Mountains, Glen Rose and Paluxy Formations have more diverse lithology. The Western Cross Timbers region is a rolling to deeply dissected area with sandy soils. Especially in the northern part of this area, steep canyons have incised into friable sandstone bedrock. Soils in the Western Cross Timbers region are mainly Paleustalfs. The climax vegetation is an oak savannah (Dyksterhuis, 1946; 1948). The overstory is dominated by Post Oak (Quercus stellata) and Blackjack Oak (Q. marilandica). Trees are more common in this area today than in pre-settlement time because of fire control. Grasses and a variety of forbs constitute the understory vegetation.

The area with outcrops of Antlers Sandstone is a major recharge zone for the Antlers aquifer farther east. As late as the 1920's numerous artesian wells flowed from this aquifer in the Dallas-Denton area (Hill 1901; Shuler 1918). At Aubrey, a groundwater spring flowed in the late Pleistocene (see discussions below). That spring appears to have been defined by local fractures in bedrock, and was probably comparable to some of the artesian springs noted more than nine decades ago by Hill. Today the Antlers Sandstone remains an important aquifer in this region, although none of the wells have artesian flow.

The Fort Worth Prairie is the central portion of the Grand Prairie, situated between the West Fork Trinity River and the Red River (Hill 1901; Figure 2.4). The Fort Worth Prairie is underlain by generally hard, resistant Cretaceous limestone, from the Goodland Fm. in the west to the Grayson Fm. in the east. Differences in bedrock lithology have controlled development of local relief, including upland prairie topography and also the configuration of tributary alluvial valleys. Overall, the Fort Worth Prairie is a level to gently rolling surface that follows the gentle bedrock dip to the east (ca. $25 \mathrm{ft} / \mathrm{mile}-4.74 \mathrm{~m} / \mathrm{km}$ ). The stream valleys on the Fort Worth Prairie are quite straight and deep, with many steep, short tributaries. Soils on the Fort Worth Prairie vary according to bedrock parent material. Most of the upland soils are mainly clayey and calcareous Chromusterts, Calciustolls or Haplustolls; Paleusterts and Paleustalfs are less extensive (Ford and Pauls 1980).

The Eastern Cross Timbers subdivision, which follows the exposure of Woodbine sandstone, is a narrow north-south belt of low hills that stand above the prairies on either side. Paleustalfs are the most common soils, having formed in deep sandy parent material. Edaphic controls on vegetation are similar to the West Cross Timbers, as oak forests are important components of the climax vegetation. Because the Woodbine Fm is thinner than the Antlers Sandstone, the Eastern Cross Timbers is narrower than the Western Cross Timbers.

The Black Prairie subdivision is immediately east of the Eastern Cross Timbers, and corresponds with Upper Cretaceous rocks, including the Eagle Ford Fm (shale, clay and marl), the Austin Chalk and the Ozan Marl. Thick calcareous and clayey soils are predominant in this subdivision. The climax vegetation 
was comprised of mixed grass prairies, with "breaks" of cedar and oak trees on the in-facing "White Rock Escarpment" formed by the western edge of the Austin Chalk (Figure 3.2) North and south of Dallas, the Austin Chalk has weathered to form a tableland frequently blanketed by deep, black Vertisols, the Houston Black Clay soils (Ford and Pauls 1980). The more-easily eroded Eagle Ford shale has been sculpted into valleys that separate the Woodbine sandstone hills from the White Rock plateau (Figure 2.5).

Alluvial geology shows that this regional bedrock setting was fully in place during the Clovis occupations of Aubrey. Pollen data, however, reveal that the upland forests, the Cross Timbers, did not exist during the Clovis period, but rather were established during the middle to late Holocene (Hall, this volume; Ferring 1993). Apparently prairies stabilized the upland landscape during much of the upper Pleistocene. The major geomorphic changes included the lateral and headwards expansion of the floodplain which became the Hickory Creek Terrace. The terrace surface increases in elevation above the modern floodplain from about $15 \mathrm{~m}$ to ca. $23 \mathrm{~m}$ between the Aubrey site and Dallas. The second major change was the relatively rapid incision of the valleys by their channels. This incision appears to have always reached bedrock, and the large bedload channels left prominent scarps created as cutbanks of the large meanders that were the major erosive agents. The pond at the Aubrey Site formed in and around one of those cut-off meanders, as will be detailed shortly.

\section{Alluvial Geomorphology and Stratigraphy of the Upper Trinity River Basin}

The geomorphic context of the Aubrey site within the Upper Trinity River Basin will be described from a vantage point of the Late Quaternary geomorphic evolution of the valley (Figure 3.4). This broader geomorphic context is an important component of regional investigations, including stratigraphic correlations of Aubrey with other drainage basins as well as the development of site survey strategies

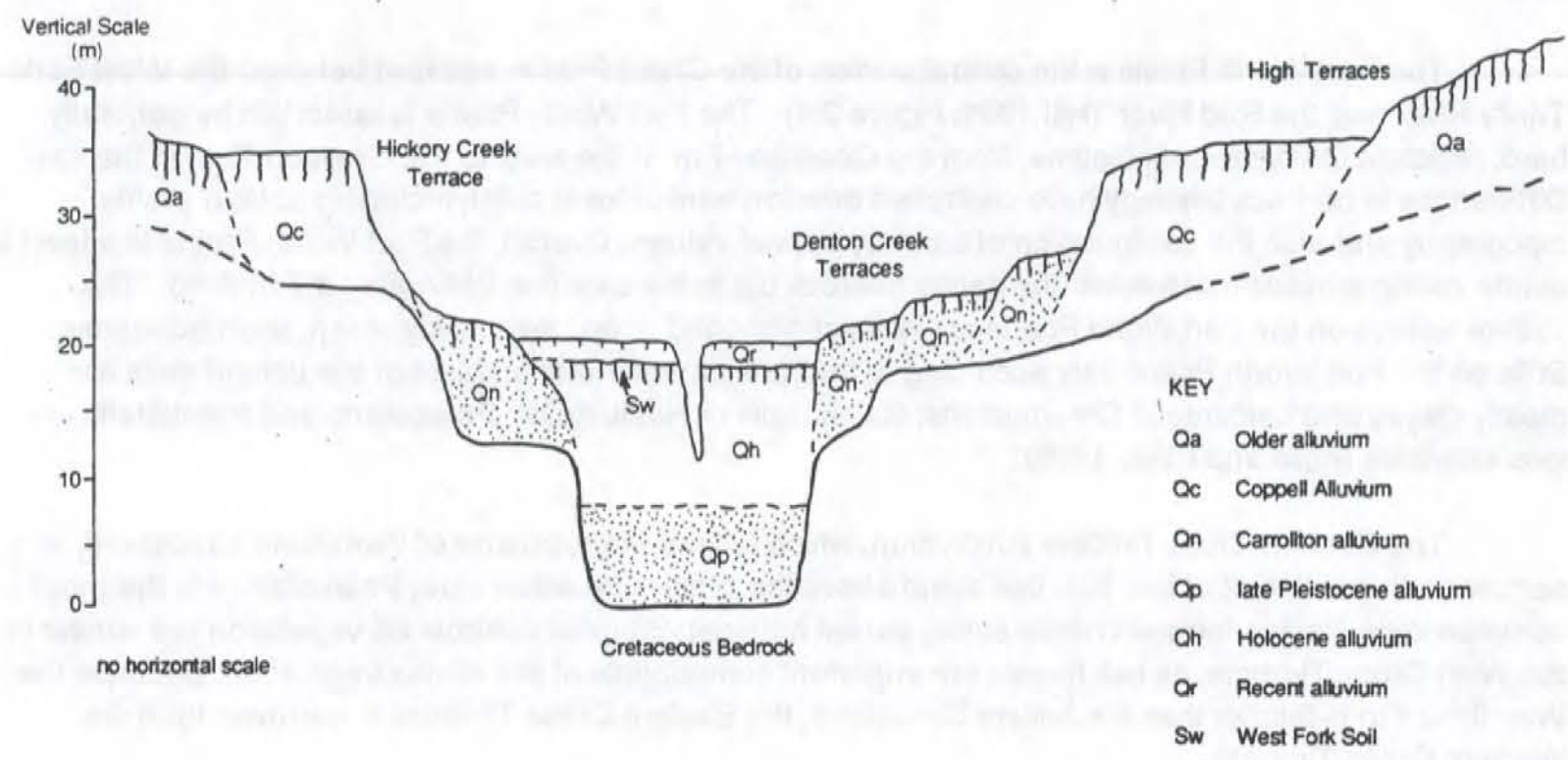

Figure 3.4 Diagrammatic Cross-Section of the Upper Trinity River Basin. 


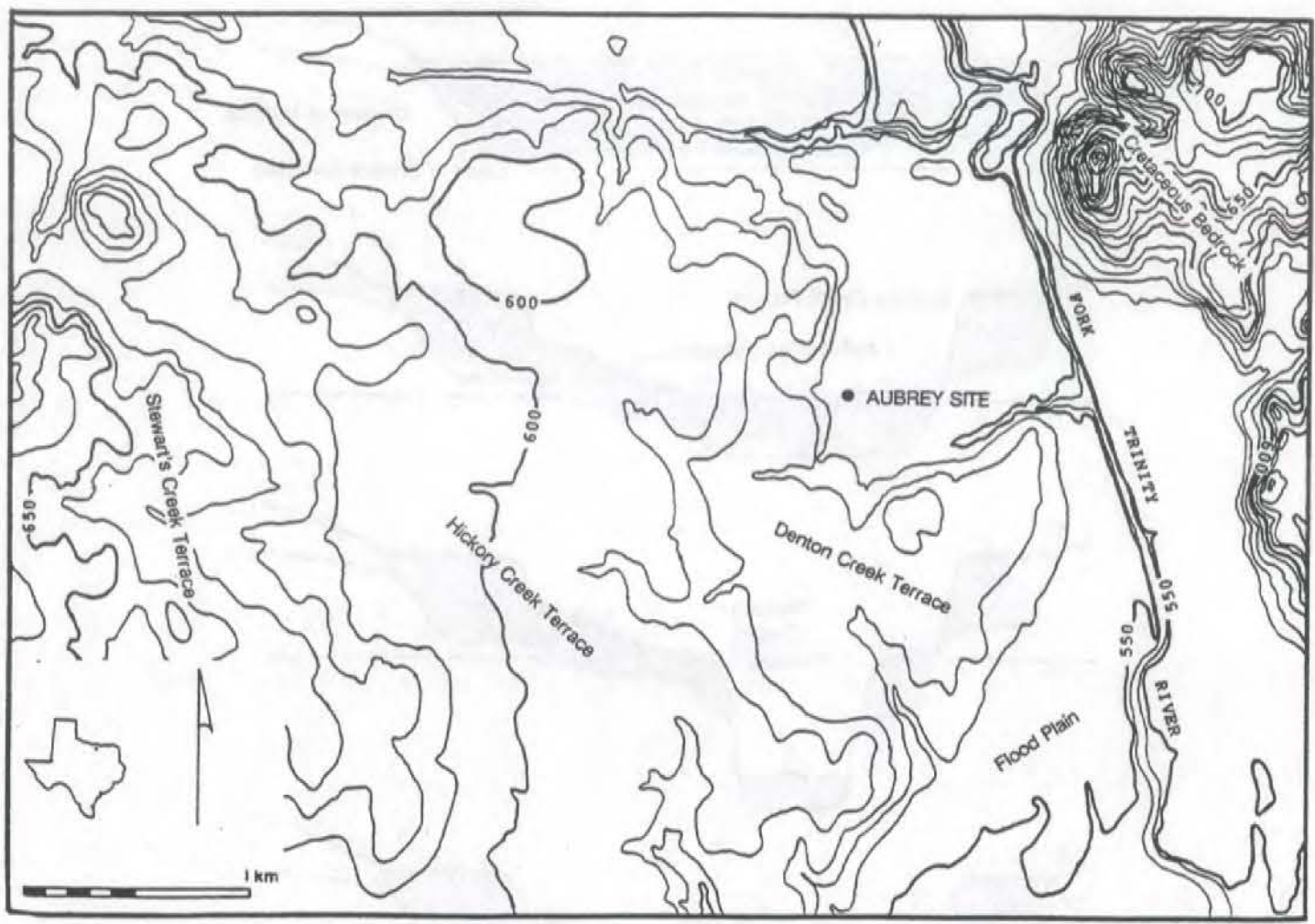

Figure 3.5 Topographic map showing terraces in vicinity of the Aubrey site. Note Hickory Creek Terrace at left, and lower Denton Creek Terrace overlooking floodplain setting of the site. The Denton Creek Terrace juts out into the valley, perched on a bedrock strath, and incised by a large late Pleistocene meander.

(Ferring 1994). Also, substantial revisions have been made to previous alluvial stratigraphic schemes, including interpretations of the geologic contexts of Paleoindian sites in this region, including the Lewisville site, about $20 \mathrm{~km}$ south of Aubrey (Crook and Harris 1957, 1958; Slaughter et al., 1962). The more recent geologic investigations began in 1985, as part of a geoarchaeological assessment of the Trinity Valley for the U.S. Army Corps of Engineers (Ferring 1986, 1990a, 1991). That work was extended by projects at Lake Lewisville and Lake Ray Roberts (Ferring 1995,1997, 1998), and by the author's PhD dissertation research (Ferring 1993).

The following discussions describe the morphostratigraphy of the Upper Trinity River Basin. The terraces and floodplain are next the context for the alluvial stratigraphic units. alluvial stratigraphy followed by alluvial stratigraphy he evidence for late Quaternary geomorphic features that are buried beneath the floodplain is presented. These data are essential components of the geologic record needed for reconstruction of the landforms that existed before during and after Clovis occupations.

Terraces

To the west of the Aubrey Site, there are three terraces above the floodplain of the Elm Fork Trinity (Figure 3.5). The topographic cross-section of the valley is asymmetric along the upper reaches of the Elm Fork. Because the channel has been migrating down bedrock dip, and encountering resistant rocks to the 

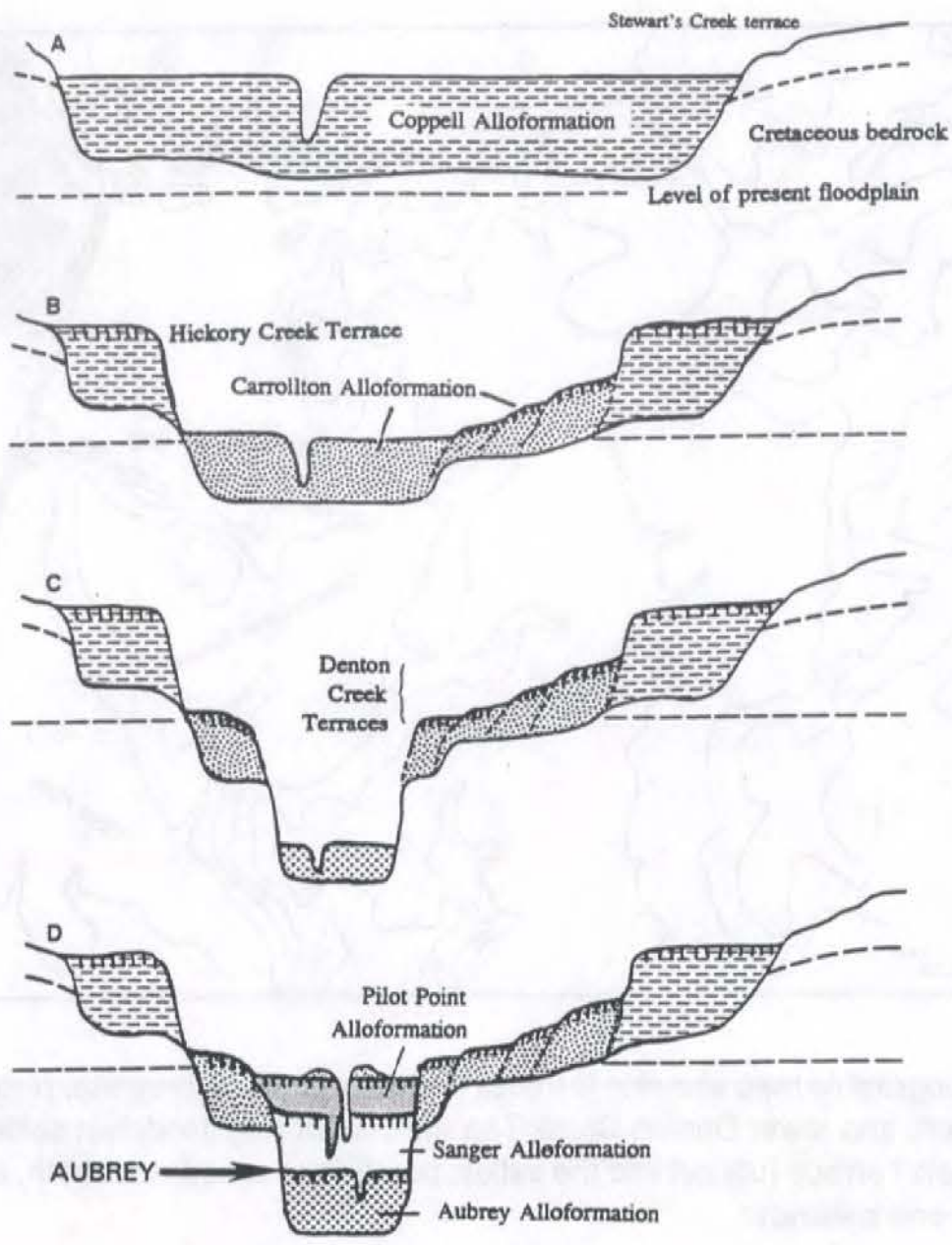

Figure 3.6 Geologic history of the Upper Trinity River Basin. Abandonment of Hickory Creek floodplain estimated to have been ca. 35-40 Ka. Lowest Denton Creek Terraces are ca. $20-22 \mathrm{Ka}$. They are followed by continued incision until Last Glacial Maximum. Aubrey site is positioned on lag of late Pleistocene channel sands, overlain by thick Holocene alluvium which began aggrading at the time of Clovis occupations.

east, the alluvial terraces are predominantly on the west side of the valley and are therefore unmatched to the east. Along Isle du Bois Creek, northeast of the site, softer rocks have accommodated formation of broad, matched terraces (Figure 3.6).

The highest terrace above the site is one of the Stewart's Creek Terraces (Ferring 1993). This is highly dissected and is expressed as isolated remnants of alluvium overlying bedrock. The age of these terraces is not known save that they are at least Middle Wisconsin and probably earlier.

The Hickory Creek Terrace forms a broad bench along the major streams of the whole Upper Trinity River drainage network. The terrace is about $14 \mathrm{~m}$ above the floodplain west of the site (Figures 3.4 , 3.5). This terrace was formerly called the Lewisville or "T2" terrace by Slaughter et al (1962) and Crook and Harris (1958). The alluvium between the terrace surface and the bedrock strath at the base of the alluvium 
On a broad scale, the site is situated just downstream from a major bedrock constriction of the Elm Fork Valley (Figure 3.5). This constriction was exploited for dam construction. The eastern valley wall exposes resistant bedrock: limestone and sandstone of the Main Street Fm. and the Woodbine Group (Table 3.1). The opposite, western edge of the valley has alluvium overlying bedrock, forming a terrace scarp below the Hickory Creek Terrace. This scarp extends along the western margin of the site area, then loops back across the valley to the east (Figure 3.5). This projection of alluvium-capped bedrock comprises a second valley constriction below the one on the dam axis. The arcuate shape of the terrace scarp south and east of the site was defined by a large late Pleistocene channel of the Elm Fork Trinity that was incising into bedrock. This meander scarp is matched by one on the opposite side of the valley that has about the same radius as the one near the site. Other similar meander scarps have been mapped along the Trinity Valley (Ferring 1993), and they appear to be roughly the same age. In combination with the stratigraphicradiometric data from the site described below, it is clear that the large channel that was cutting these scarps and incising into bedrock were part of a late Wisconsin stream system that was radically different from modern streams. Those old stream patterns will be discussed below. The geomorphic consequence of the stream to the site was that a scarp below the Denton Creek Terrace overlooked the channel that was apparently the last channel to incise bedrock. This channel eventually became the spring pond at the site.

Today, the entire Aubrey site is buried by thick floodplain clays that dominate the sediments along the Trinity River floodplain. These deposits conceal the buried geomorphic features that existed at the time the site was occupied. The floodplain here, as over most of the valley, is almost devoid of depositional geomorphic features (such as natural levees, cut-off channels, oxbows, etc.). With an almost constant elevation of 560-562 feet MSL, the floodplain here was an aggradational surface until the dam was constructed. Periodic floods covered the floodplain and deposited fresh black clay.

\section{Buried Geomorphic Units}

Exposures in the outlet channel and borehole data were used to define and map the geomorphic features buried below the floodplain. Borehole data from the USCE were used in 1986 to construct a crosssection on the dam axis (Figure 3.7). This showed a major lithologic change from the basal gravel/sand to the overlying clay in the thick (ca $14 \mathrm{~m}$ ) sediments below the floodplain, and a quite horizontal bedrock strath below that. The major lithologic change was seen in borehole data downstream as well; this contact was speculated to be approximately the age of the Pleistocene-Holocene boundary (Ferring 1986a), and therefore of potential use in locating Paleoindian sites. Another set of borehole logs was available for the outlet channel south of the dam (Figures $3.8,3.9$ ). These also showed the lithologic change, as well as a quite level bedrock strath that extended across the valley from its western edge to near the modern channel. None of these borehole logs clearly revealed the buried and filled channels that are inset into the gravel-sand deposits.

The gravel-sand deposits of the Aubrey Alloformation (Unit A) vary in thickness, especially becoming thicker south of the excavation areas (Figures 3.8, 3.9). Exposures in the outlet channel, borehole data and resistivity profiling reveal two old channels in the site area. The first is the one that parallels the scarp of the Denton Creek Terrace (Figure 3.10a). This filled channel is bound by bedrock on its outer edge, and by Unit A alluvium on its inner (bar) edge. The channel extends south from the site area, following the terrace scarp, and then in exposed again in the outlet channel about $800 \mathrm{~m}$ east of the site, where it is set against resistant limestones of the Main Street Fm. This channel is about $95 \mathrm{~m}$ wide, which is approximately 7-9 times the size of modern channels. In the site area, this channel was cut off, and became the spring pool for the spring located at the western edge of the locality. 

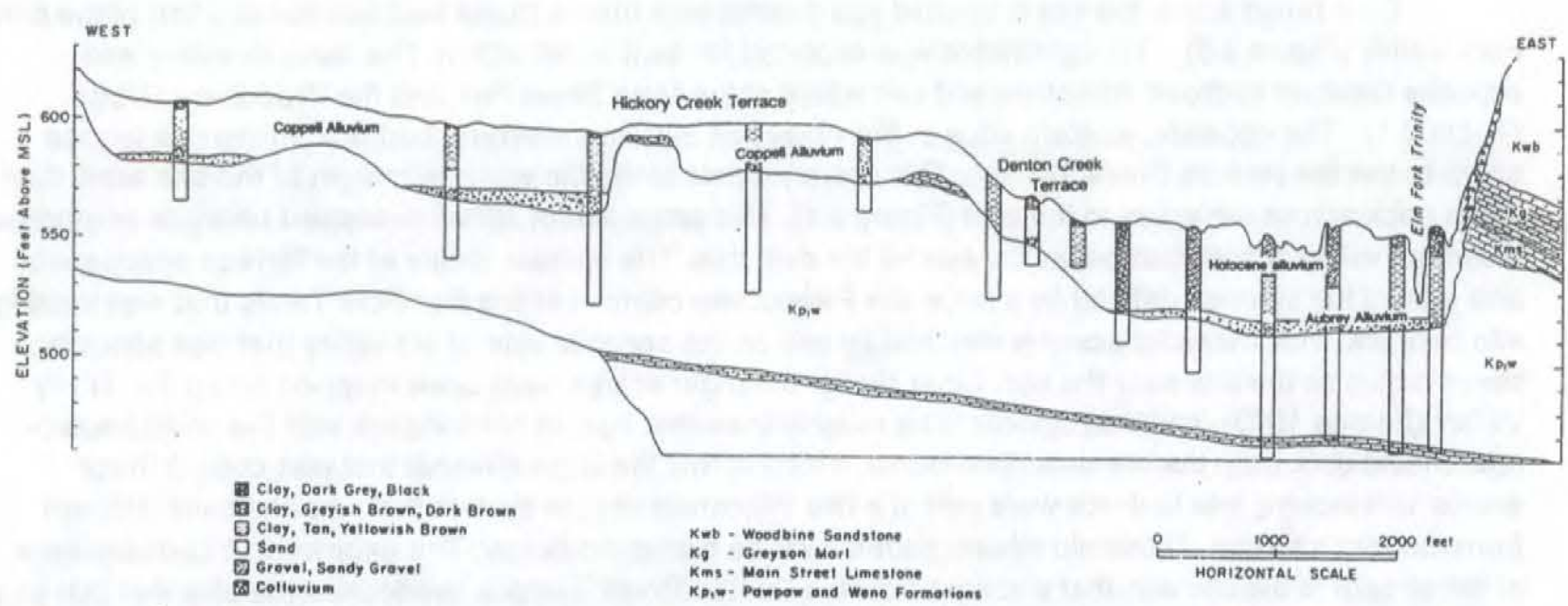

$\mathrm{K}=\mathrm{b}=$ Woodbine Sandstone

$\mathrm{Kg}$ - Greyson Morl

Kms - Main street Limestone Kp, : Powpow and Wene Formations

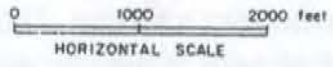

Figure $3.7 \quad$ Borehole Cross-section at the Ray Roberts Dam. Note assymetry of terraces resulting from dip-plane migration of channel. The stratigraphic position of the Aubrey site is at the top of the Aubrey Alloformation, at its contact with the overlying floodplain deposits of the Sanger and Pilot Point alloformations. See Figure 3.8 for locations of boreholes on dam axis. Figure modified from Ferring (1986).

The second channel is exposed about $100 \mathrm{~m}$ east of the older one described above. It is about the same width, and extends south from the site area, bending back around to the east, where it reemerges into the outlet channel cut (3.10a). This channel appears to have been the active stream channel before and during Clovis occupations, as the old channel was a pond during that interval (Figure $3.10 \mathrm{~b}-\mathrm{c}$ ). Between the two rivers was a higher remnant of Unit A sediments. This separated the river from the pond and, fortunately, provided a surface for Clovis peoples to occupy. Despite its elevation above the pond and paleoriver, the "Unit A surface" was a good setting for the burial and preservation of Clovis artifacts and faunas.

The spring was located at the northern end of the pond, on the western edge of the paleovalley adjacent to the bedrock scarp that had been cut previously by the river. As described later, this was a groundwater spring before Clovis occupations, and, during Clovis occupations was a seep spring. By Clovis time, however, the spring area had been covered by a fan of colluvium that prograded from the terrace scarp above the western edge of the pond. This colluvial fan would have made the descent to the pond from the west somewhat easier, although that slope would have provided Clovis hunters an ideal vantage point form which to stalk and ambush any animals feeding or watering in the pond. Standing at the terrace edge, one would have looked down about $8 \mathrm{~m}$ to the pond axis, which was only $50 \mathrm{~m}$ away (Figure 3.11). Thus the terrace scarp was an extremely important geomorphic feature of the Clovis landscape at Aubrey.

No less important was the pond (or spring pool) itself. This was about $80-90 \mathrm{~m}$ wide when water was high. By Clovis time, however, the pond was seasonally dry. The pond extended for about $400 \mathrm{~m}$ south and east of the site area, bound on its western-southern margin by the terrace scarp. 


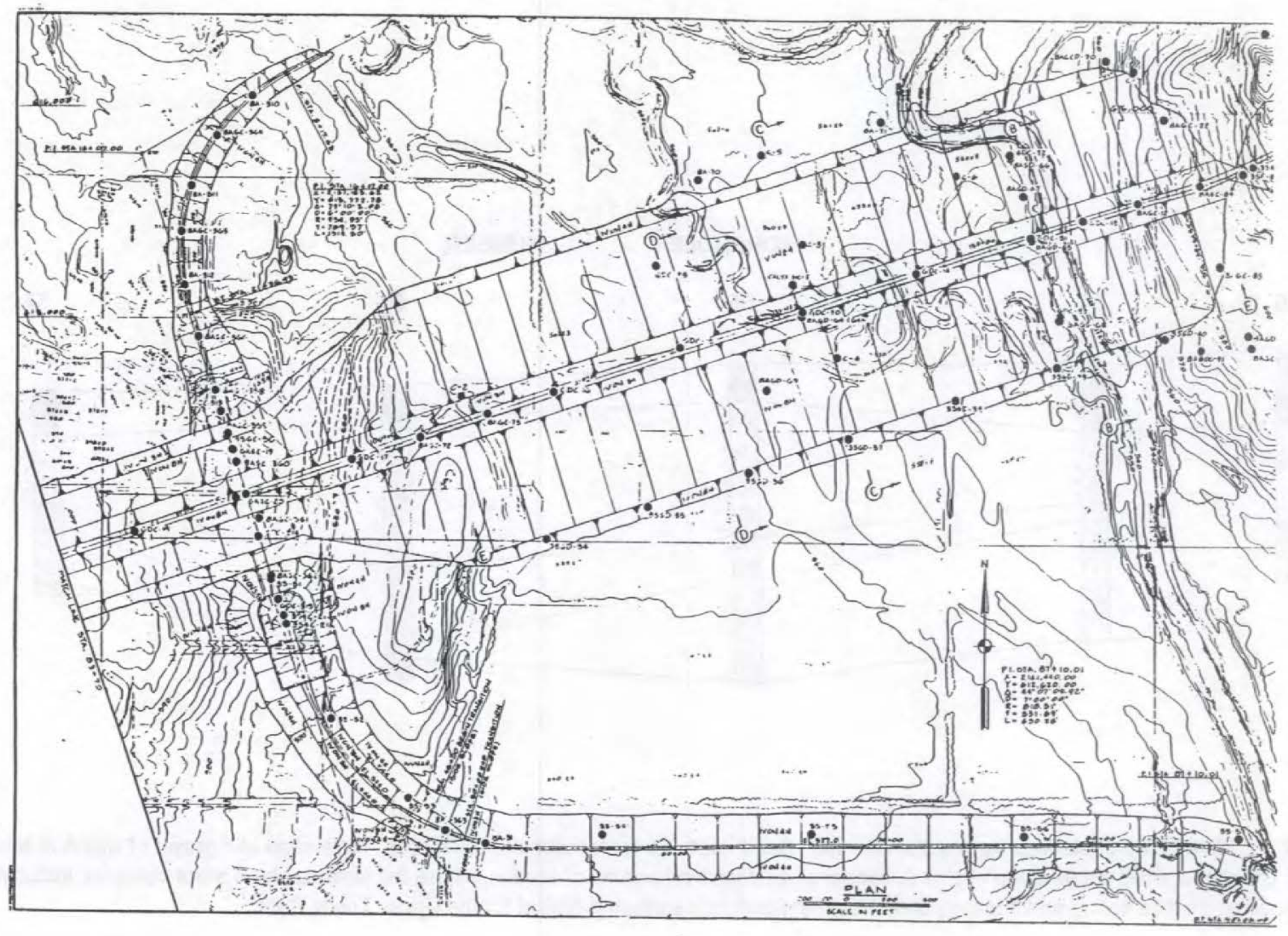

Figure 3.8 Map of site area with USACE borehole locations. Note borehole cross sections for dam axis (Figure 3.7) and along outlet channel (Figure 3.9). 
BOREHOLE NUMBER
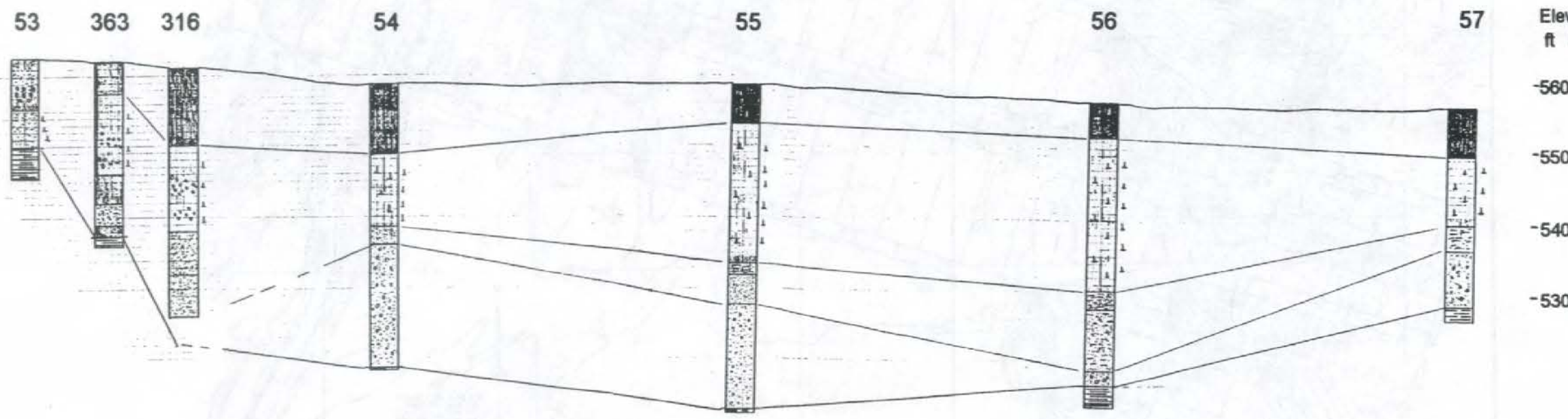

Figure 3.9 USACE borehole logs from outlet channel. See Figure 3.8 for locations of boreholes. Note sand and gravel of Unit A at base of deposits. Clovis materials occur at top of Unit A, except at westernmost portion of section, where the stratigraphy is more complex, including deposits associated with a spring and a large pond. Very flat floodplain surface is typical for the Upper Trinity River. 

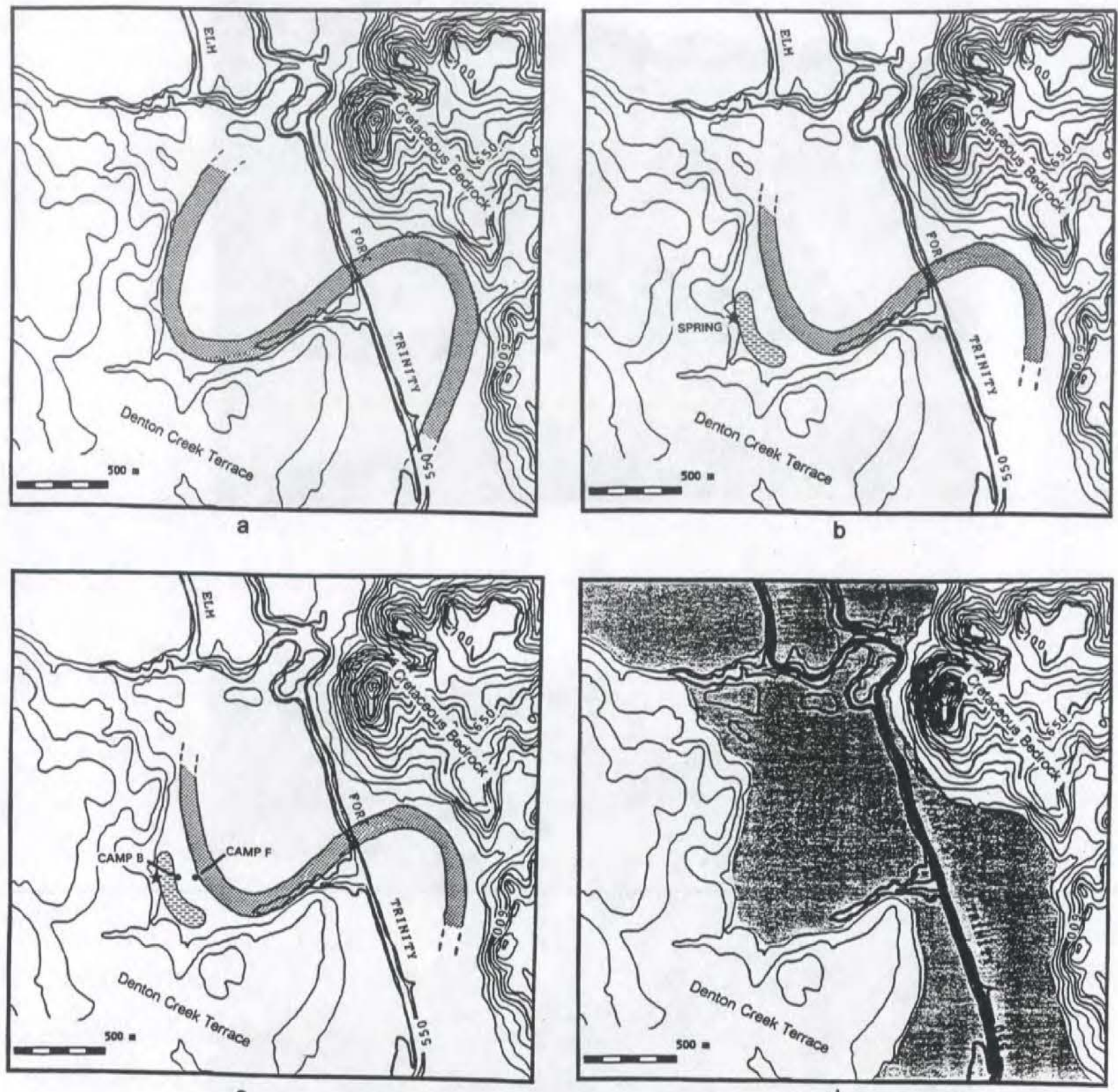

d

Figure 3.10 Geomorphic history of the Aubrey site area. a - Late Pleistocene oversized channel of a bedload meandering stream incised the valley and eroded the meander scarps in bedrock valley walls. Channels were 6-8 times larger than the modern suspended load meandering channel; maximum incision attained ca. 19-18 Ka. b - channel shifts east, possibly by chute cut-off, creating the large oxbow pond, which is fed by a groundwater spring emanating from fractures in Cretaceous bedrock at the boundary between the floodplain and the Denton Creek Terrace; pond sediments begin to accumulate by ca. $14.2 \mathrm{Ka}$, and until ca. $12.3 \mathrm{Ka}$ with mere traces of alluvium; a change to a smaller seep spring is followed by deflation of the pond deposits and drastic reductions in mollusc population diversity, all pointing towards increasing aridity. c-Clovis occupations of the locality, ca. $11.5 \mathrm{Ka}$ deposit artifacts and faunas along the banks of the pond and the river; alluviation commences during or immediately after occupations. d - River channel apparently avulses to valley axis, and alluviation continues throughout Holocene, burying Clovis materials $7.5-9.0 \mathrm{~m}$ below the floodplain. 


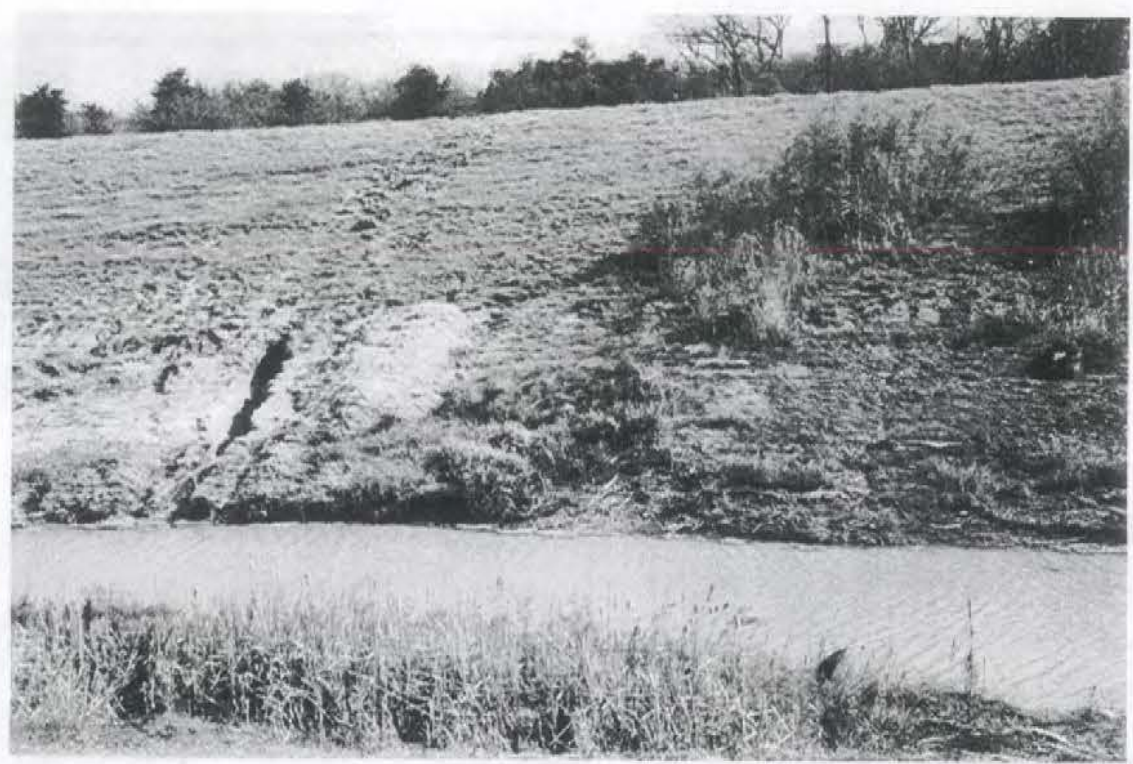

a

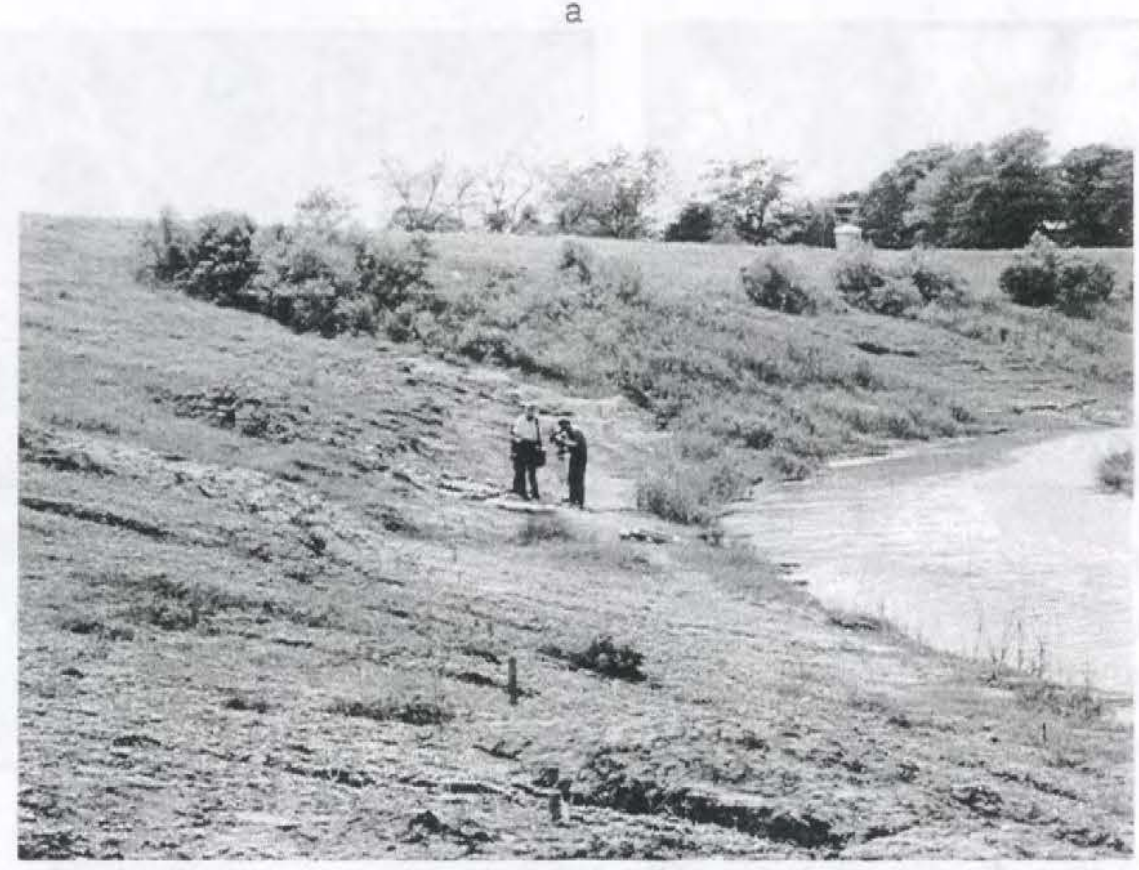

b

Figure 3.11 Photos of south slope of outlet channel, western part of Aubrey Site. a - to south, with Trench 1 shortly after excavation (see Figures $2.6,9.1$ ). Spoil piled on west side; intact sediments on left (east) - Stratum B (dark) at base, overlain by Stratum C (white). b - to west; figures are next to Trench $2 \mathrm{~A}$, in pond axis, Trench 1 in background. Note shrubby willows and cattails precisely delineate Cretaceous shale and clay, with larger willow clumps along outcrops of gravel on bedrock at base of Pleistocene terrace alluvium. Vertical tree/shrub line follows terrace scarp and contact with inset Pleistocene and Holocene alluvium below floodplain. 


\section{Stratigraphy}

The sediments under the floodplain at Aubrey have been divided into eight local stratigraphic units. These local units are all parts of three formal allostratigraphic units, which pertain to the Upper Trinity River alluvium (Ferring 1993). All of the sediments of immediate concern are inset against the late Pleistocene scarp that exposed Cretaceous bedrock as well as the overlying terrace alluvium (Figures 3.11, 3.12).

\section{Formal Stratigraphic Units}

The Aubrey Alloformation is defined as ca. 6-9 m of sand and gravel with occasional beds of finer alluvium, marl or lacustrine sediment. Trench 14 at Aubrey, located between blocks B and F, exposed $4 \mathrm{~m}$ of Aubrey Alloformation deposits (Figure 3.13). The type section is at the Aubrey Clovis Site. The lower boundary of this unit is the deepest bedrock surface below the floodplain. The upper boundary is the erosional contact with the overlying Sanger Alloformation, a marked textural change to finer overlying alluvium, and a weakly to moderately developed soil. The lateral boundaries to the Aubrey Alloformation are bedrock valley walls or in some cases modern channels. Aubrey Alloformation sediments are clearly discernable in borehole sections at Ray Roberts Dam, Lewisville Dam, on the West Fork Trinity between Dallas and Fort Worth, and below the Trinity River floodplain south of Dallas (Willimon 1972).

The maximum valley incision is bracketed by the youngest radiocarbon ages from Carrollton sediments of ca. 22-20 ka (Willimon 1972) and the oldest age from the Aubrey Alloformation at the Aubrey Site of ca. $14.2 \mathrm{ka}$. The end of Aubrey Alloformation deposition is radiocarbon dated to ca. $11.5 \mathrm{ka}$ at the Aubrey Site. At Aubrey, this includes Strata A, B, C and D.

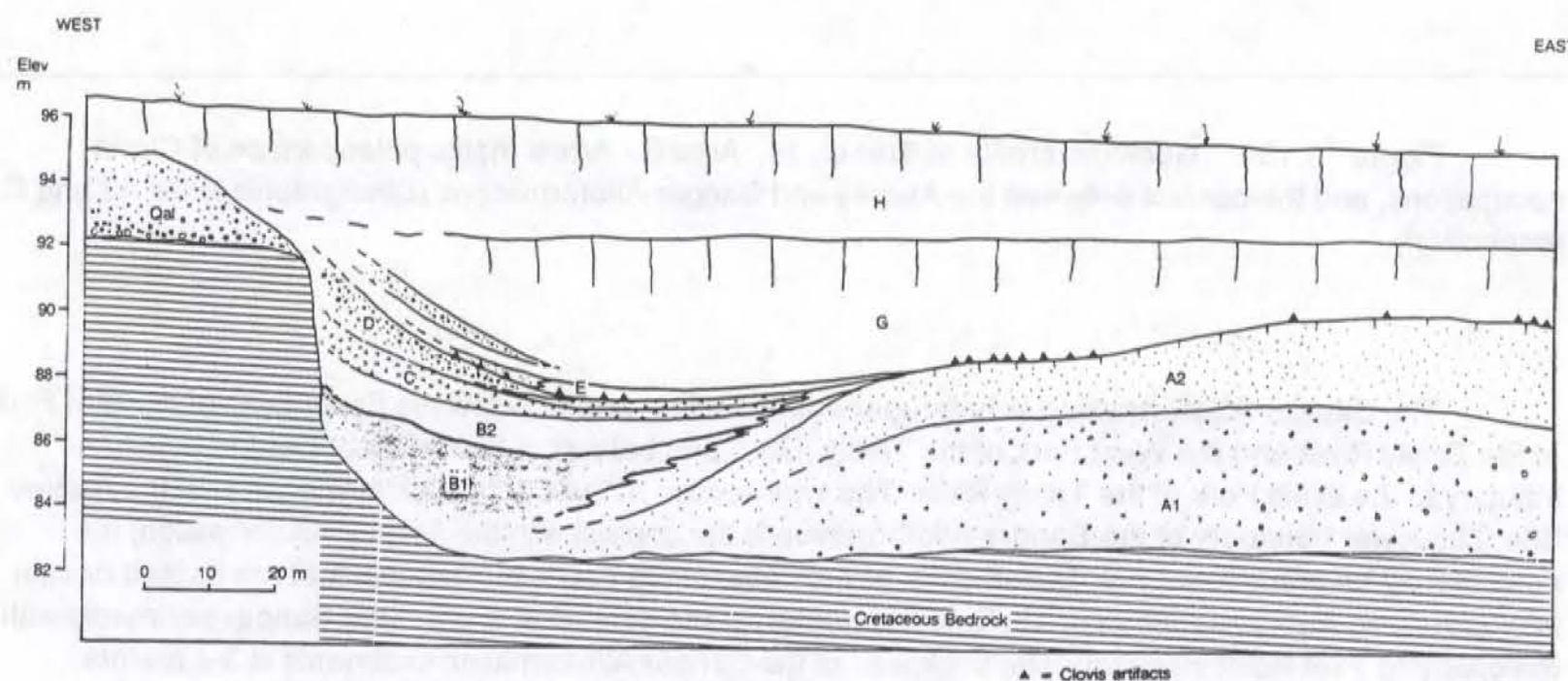

Figure 3.12 Geologic cross-section of the Aubrey locality. 


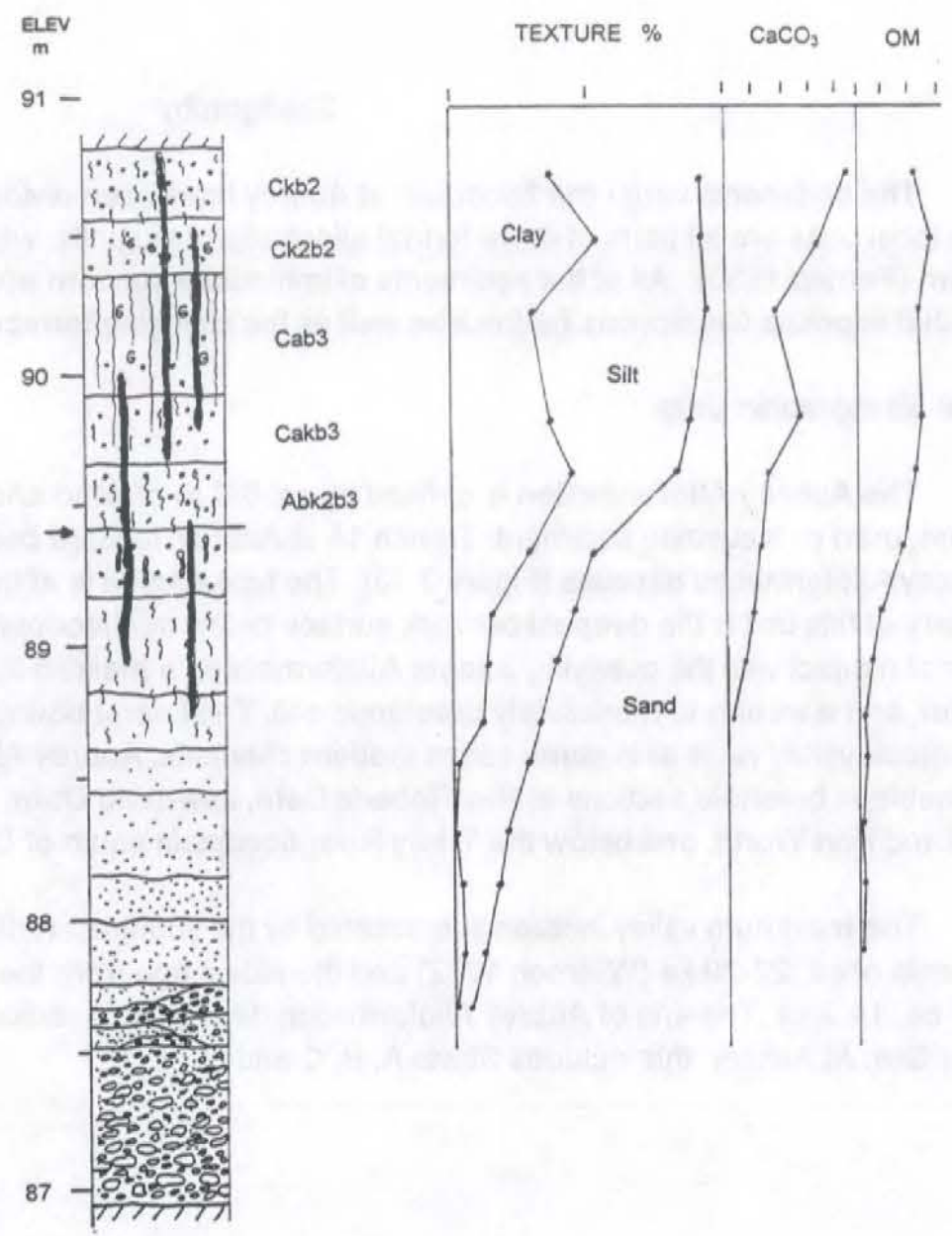

KEY TO SYMBOLS:

soil

base of trench
top of trench
conformable contact
erosional contact
sand
silt-clay
gravel
tufa
peat
carbonate filaments
carbonate concretions
laminated sediments
snails
root traces
crayfish burrows

गाIा

.

's

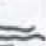




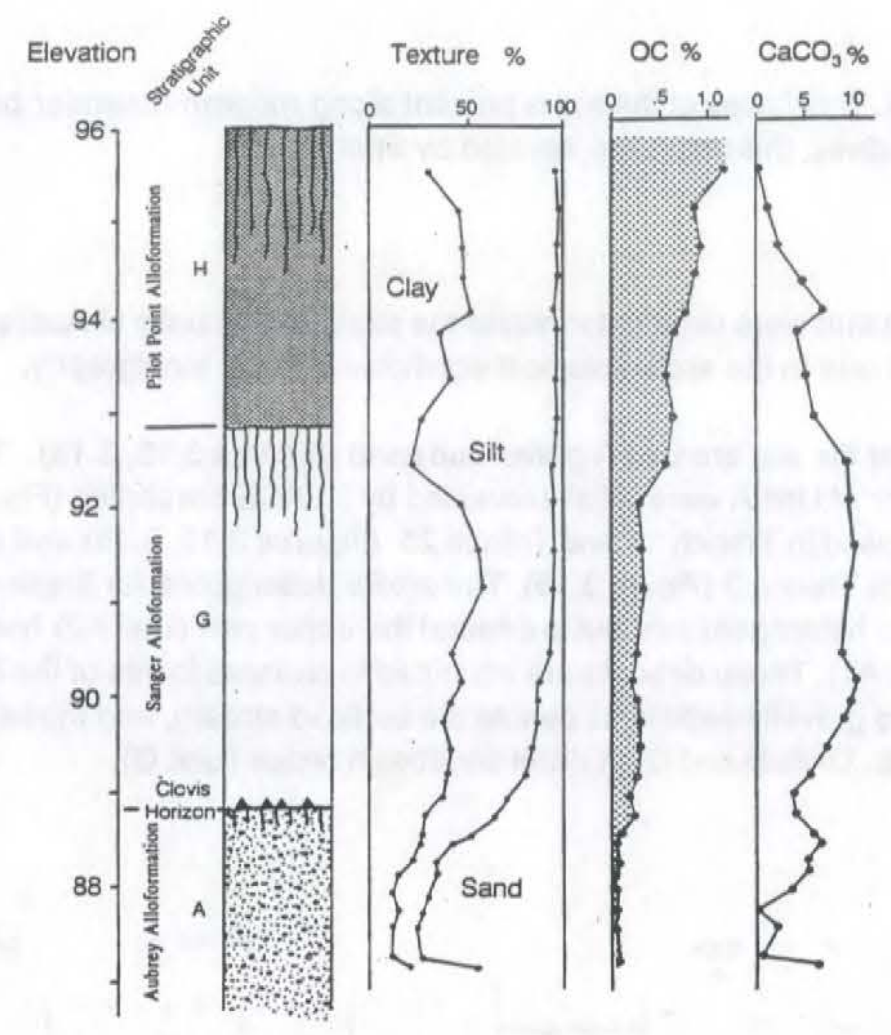

Figure 3.14 Geologic profile of Trench 25, Area B. See Figure 2.6 for location of profile. This section is at the south edge of Block B, a Clovis camp situated on the east shore of the Late Pleistocene pond.

The Sanger Alloformation is well dated to the early Holocene by 14 radiocarbon ages. These range from ca. $11.5 \mathrm{ka}$ at the Aubrey Site, through ca. $7.5 \mathrm{ka}$ at Aubrey and to ca. $6.0 \mathrm{ka}$ at other localities along the West Fork of the Trinity River and along Denton and Catlett Creeks. The terminal ages are from soil organic matter and exhibit some temporal range because the middle Holocene soil continued forming until ca. 4.5 ka. At Aubrey, this unit Includes Strata E, F and G.

The Pilot Point Alloformation occurs below the floodplains of the higher order streams in the upper Trinity River drainage basin. The lower boundary of the unit is defined by geomorphic setting, and is either a) the contact with the underlying Sanger Alloformation where flood basin facies are superposed, or b) truncated Carrollton alluvium, or c) an erosional contact with Sanger/Aubrey or older alluvium along present meander belts. Away from present meander belts, as at the Aubrey Site, the upper boundary of the Pilot Point alluvium is the floodplain surface, where a thick cumulic soil has formed in Pilot Point sediments. Along present meander belts, the upper boundary of the Pilot Point sediments is the contact with overlying recent alluvium. In the latter situations, a thin cumulic or pachic soil, the "West Fork soil" frequently has formed in the upper part of Pilot Point alluvium (Ferring 1986b; 1990c).

Renewed valley alluviation took place in late Holocene time, resulting in the gradual aggradation of the Pilot Point alluvium. The cumulic "West Fork soil" formed on floodplains between ca. $4.5 \mathrm{ka}$ and present. A facies of the "West Fork soil" formed along meander belts as the rate of lateral migration of 
channels slowed ca. 1.8-1.4 ka. This facies of the soil is present along modern meander belts, and is often buried by recent alluvium. At Aubrey, this unit is represented by Stratum $\mathrm{H}$.

\section{Aubrey Site Stratigraphic Units}

The sections at the site that were used to formulate the stratigraphic units at Aubrey are described below. Particular reference is made to the archaeological significance of the stratigraphy.

The oldest sediments at the site are Unit A gravel and sand (Figures 3.12, 3.13). The total thickness and general character of Unit A were initially revealed by USACE boreholes (Figure 3.9). The upper part of this unit was exposed in Trench 14 and Trench 25 (Figures $3.13,3.14$ ) and a partly colluvial facies of the unit was exposed in Trench 3 (Figure 3.15). The profile descriptions for these sections are in Appendix A. These deposits are heterogeneous, but in general the upper part (Unit A2) has much less gravel than the lower part (Unit A1). These deposits are attributed to channel facies of the large stream that incised into bedrock. Sandy and gravelly sediments denote the bedload stream, and these contrast sharply with the overlying lacustrine (eg., Units B and C) or distal floodbasin facies (Unit G).

KEY TO SYMBOLS:
soil
base of trench
top of trench
conformable contact
sand
gilt-clay
tufa
peat
carbonate filaments
carbonate concretions
laminated sediments
snails
root traces
crayfish burrows
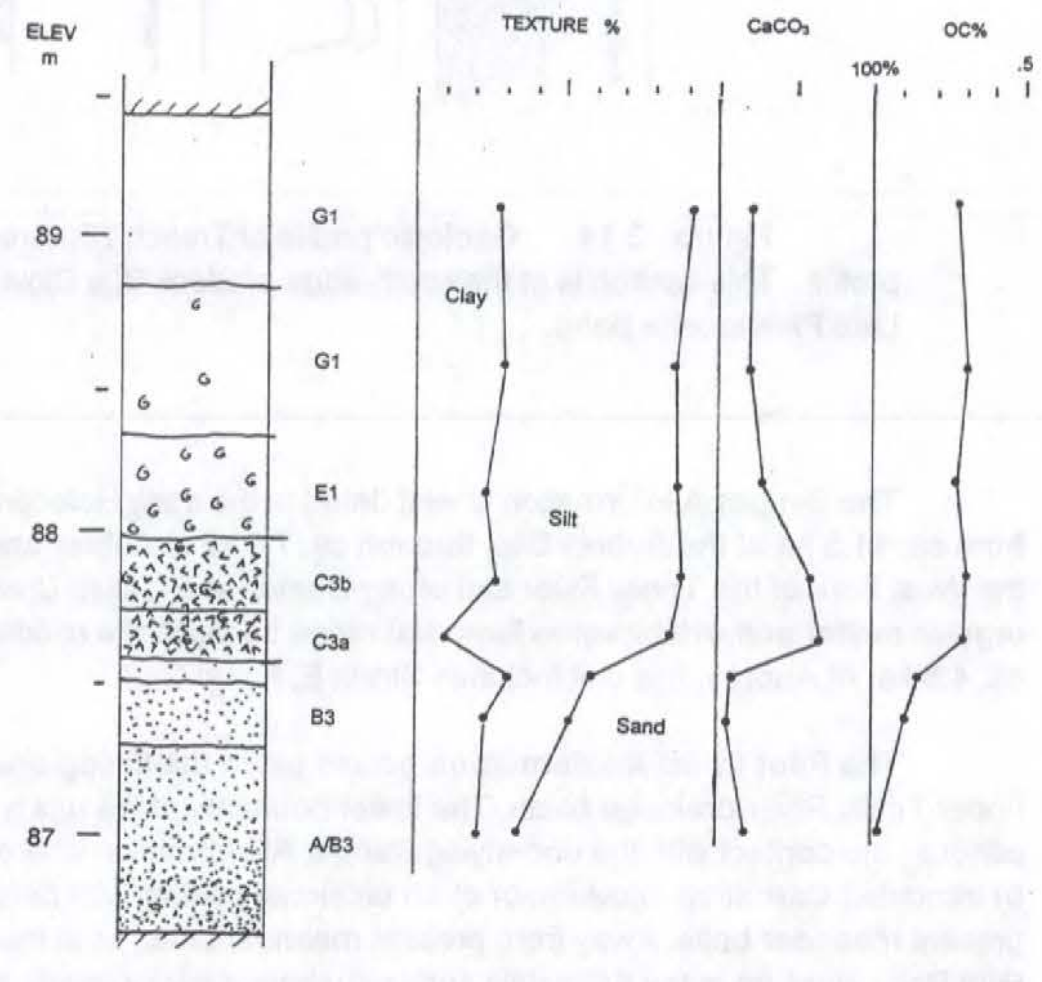

Figure 3.15 Geologic profile of Trench 3, Area B. Trench is located in western part of pond, near Camp B (see Figure 2.6). This profile reveals the contacts between the Late Pleistocene channel sand and gravel (Stratum A; Aubrey Alloformation), the overlying lacustrine clay and marl (Units $\mathrm{C}, \mathrm{E})$ and Holocene alluvium (Unit G). Clovis paleosurface is at $\mathrm{C} / \mathrm{E}$ contact. 


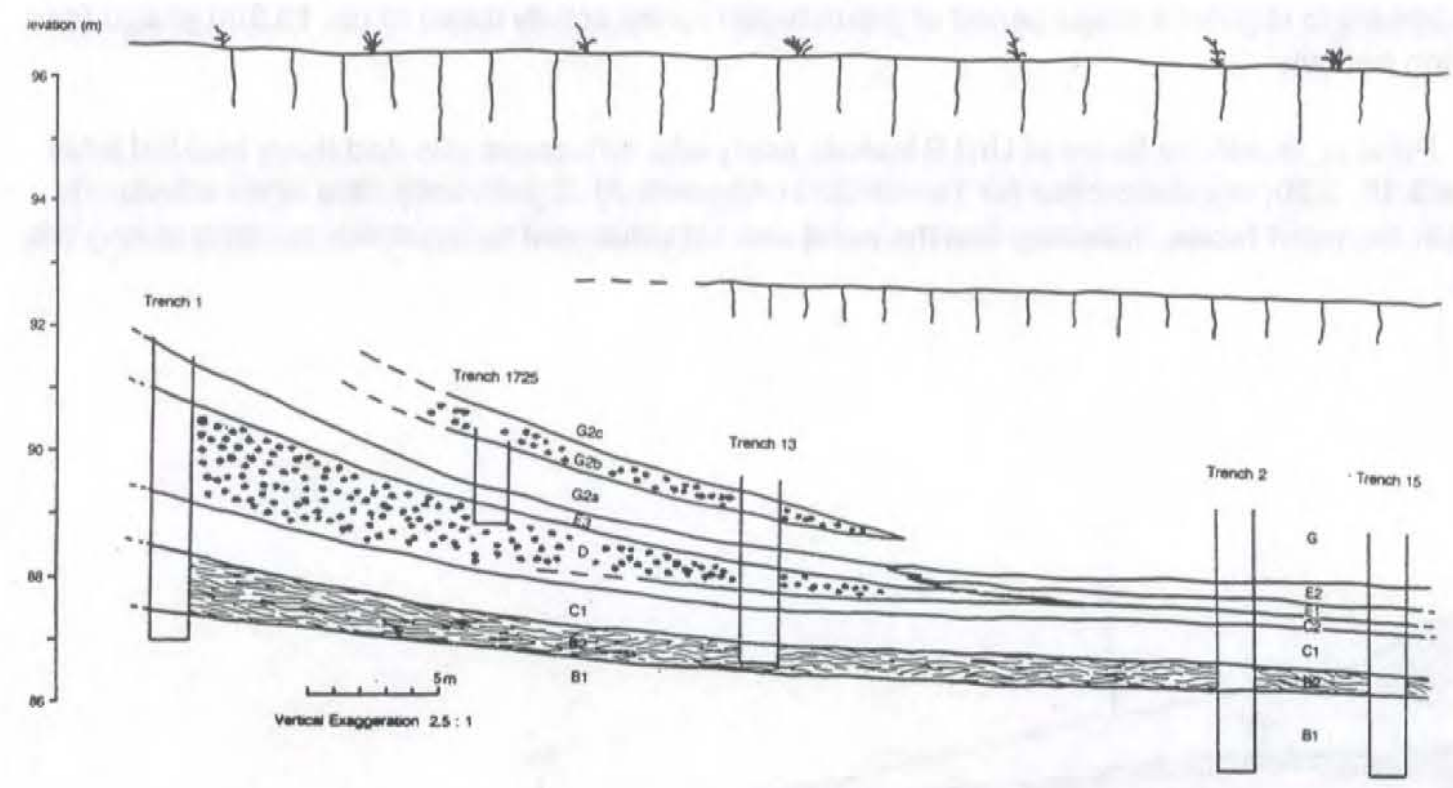

Figure 3.16 Geologic cross-section of Area A, with profile locations.

A soil formed in the upper part of A2 (probably before and during, but definitely after Clovis occupations), as revealed by the ubiquitous carbonate concretions adhering to artifacts. These loamy sediments would probably have supported good ground cover, although the area of Camp B on the eastern pond margin would have been isolated from the spring waters delivered to the western pond margin.

Unit $B$ is the oldest part of the pond fill sequence, located in the western part of the locality (Figure 3.12). The contact between Units A and B is exposed only along the eastern pond margin, near Camp B. There, the contact is gradual, has been heavily bioturbated and appears to reflect mixing of colluvial sand delivered off the eastern pond shore (which would later become the Clovis camp surface) with clay and marl of Units B and C (see Figure 3.15). In addition to borehole data, Unit B sediments were exposed in several trenches in the western part of the site, where they include spring and lacustrine facies (Figures 3.16-3.18). It was in this part of the site that key samples for dating and paleoenvironmental reconstruction were collected. One of the regionally significant aspects of the Aubrey geologic record are the organic-rich terminal Pleistocene sediments that predate the Clovis occupations. Sediments of this age are notoriously rare at sites in the western U.S. (Haynes 1984).

Spring facies of Unit B were exposed only in Trench 1, the westernmost exposure at the locality (Figures 3.16-3.18). Descriptions of Trench 1 sediments are in Appendix A. In the vicinity of the spring, a complex suite of peats, marls and tufas are interstratified. These include sediments that are both rare and ideal for paleoecological studies: calcareous peats. These sediments contain the pollen, insects and plant macrofossils common to acidic peat, but also preserve molluscs. The lowest sediments exposed in Trench 1 are peat and marly peat (Units B2x, B2a). These are overlain by marls and peaty marls (B2b, B2c3-5). Within Unit B2, however, are tufa-filled spring conduits and feeders (Units B2c1 and B2c2). The largest feeder exposed (Unit B2c1) appears to have nourished a peat mound that is associated with a thin bed of compressed peat that can be traced out into the pond axis (Unit B2d). This is called the "marker peat" 
which appears to register a major period of groundwater spring activity dated to ca. 13,300 yr ago (see discussion below).

Pond or lacustrine facies of Unit B include peaty silts, tuffaceous silts and thinly bedded tufas (Figures 3.19, 3.20; see description for Trench 2A in Appendix A). Significantly, little or no alluvium is present in the pond facies, indicating that the pond was not influenced by overbank flooding during this interval.

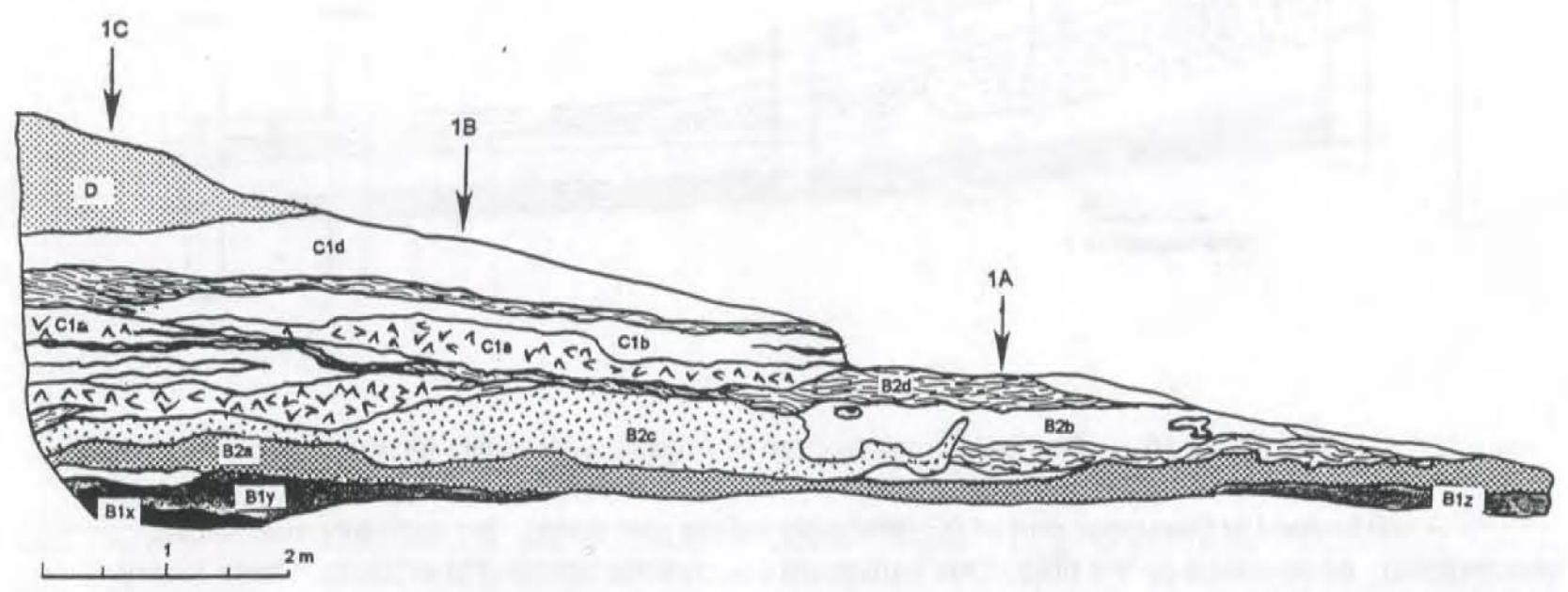

Figure 3.17 Geologic profile of Trench 1, Area A.

Subsequent to deposition of the "marker peat", spring activity waned, and a seep spring replaced the groundwater spring. Near Trench 1, indicated by the absence of any feeders and also the finely bedded to laminated tufa and peat deposits that characterize the upper part of the Unit B sediments. The seep spring contributed to deposition of laminated marls and thin peaty marls above the "marker peat" in Stratum $\mathrm{C}$, which conformably overlies Unit B. In the pond axis, Unit C is comprised of white tufas and gray humic tufas (Figures $3.18,3.19$ ). These exhibit an upwards decline in snail densities (and changes in molluscan diversity as well [see Neck, this volume]). The upper surface of Unit $\mathrm{C}$ is a deflational disconformity in the pond axis. Deflation is the only mechanism that seems to reasonably explain the disconformity, since there is no sand or gravel at the disconformity that would accompany erosion.

The upper part of Unit C2 has many iron-stained rootlet traces, recording plant growth on that surface. It is not known whether the plants were aquatic or terrestrial, but they could have been either or both, given the molluscan record of water levels in the pond at that time (Chapter 7).

Vertical crayfish burrows and their bulbous basal "nests" are ubiquitous in Unit C sediments and in all sediments above Unit C. Color differences suggest different generations of burrows, and discovery of exoskeletons attest to modern burrows as deep as $8 \mathrm{~m}$ below the floodplain. These not only disturbed the archaeological deposits, but slowed excavations considerably, since all burrows were mapped and excavated separately to avoid mixture of materials. In the area of the "red wedge", upper C sediments are overlain by the colluvial sand and gravel deposits of Unit $D$. 
KEY TO SYMBOLS:

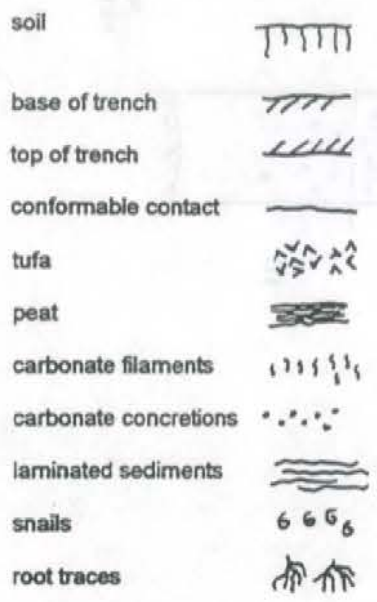

$\mathrm{CaCO}_{3} \quad \mathrm{OC} \%$

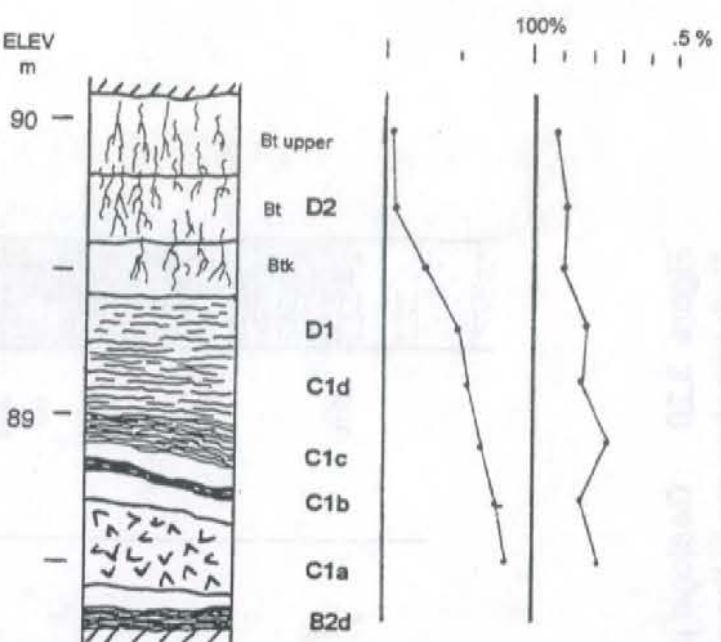

Figure 3.18 Geologic profile of Trench 1C, Area A

$\underset{m}{\text { ELEV }}$

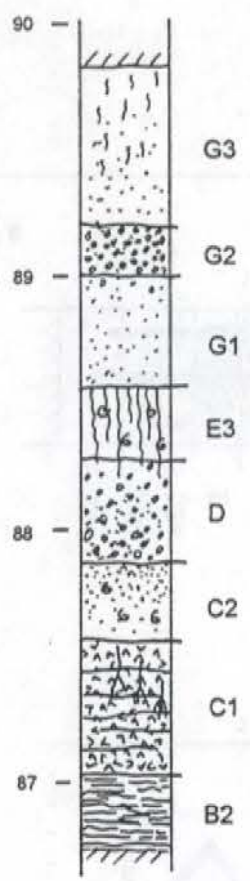

TEXTURE \%

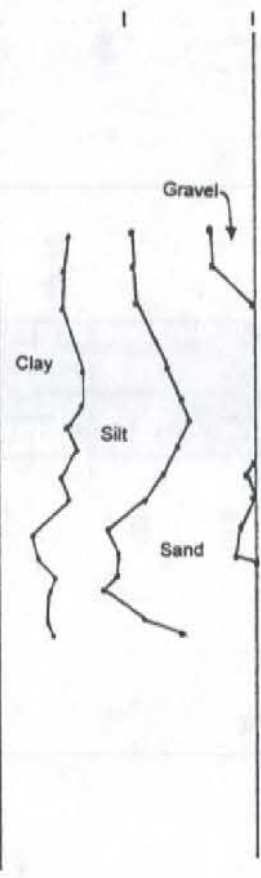

$\mathrm{CaCO}_{3}$

OM \%

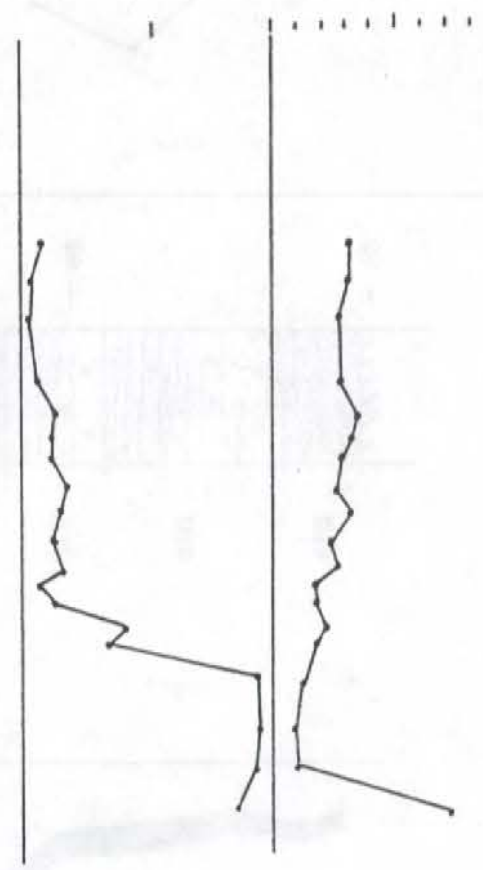

Figure 3.19 Geologic cross-section of Trench 13, Area A 


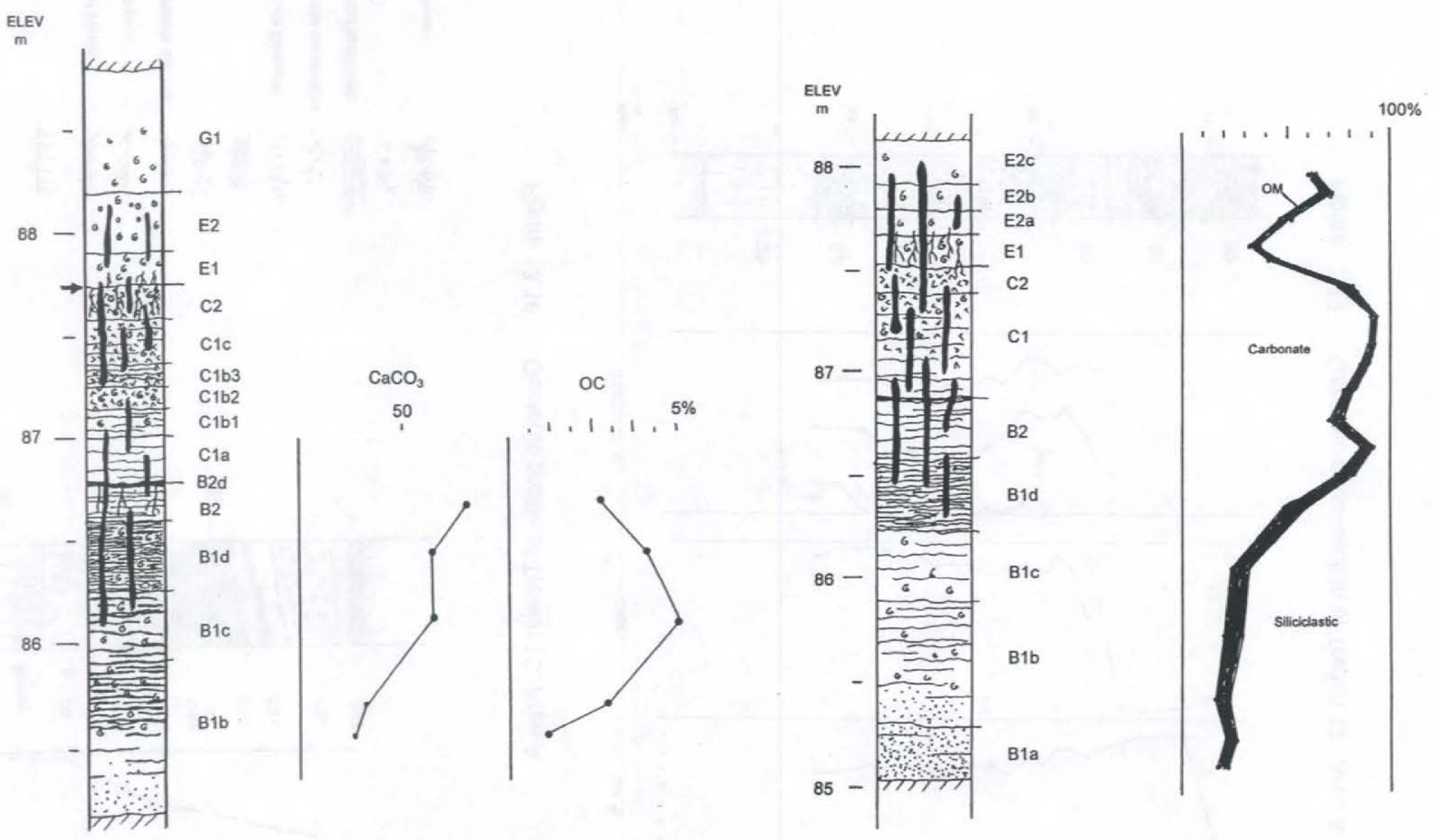

Figure 3.20 Geologic profiles of Trenches 2 and 15, Area A. a- Trench 2; b- Trench 15. See Figure 2.6 for locations. Both trenches are in the pond axis, east of the spring and the presently buried terrace scarp. Note radical change from siliciclastic to carbonate sedimentation between Strata B and C; also note "marker peat" (unit B2d) in both profiles. 


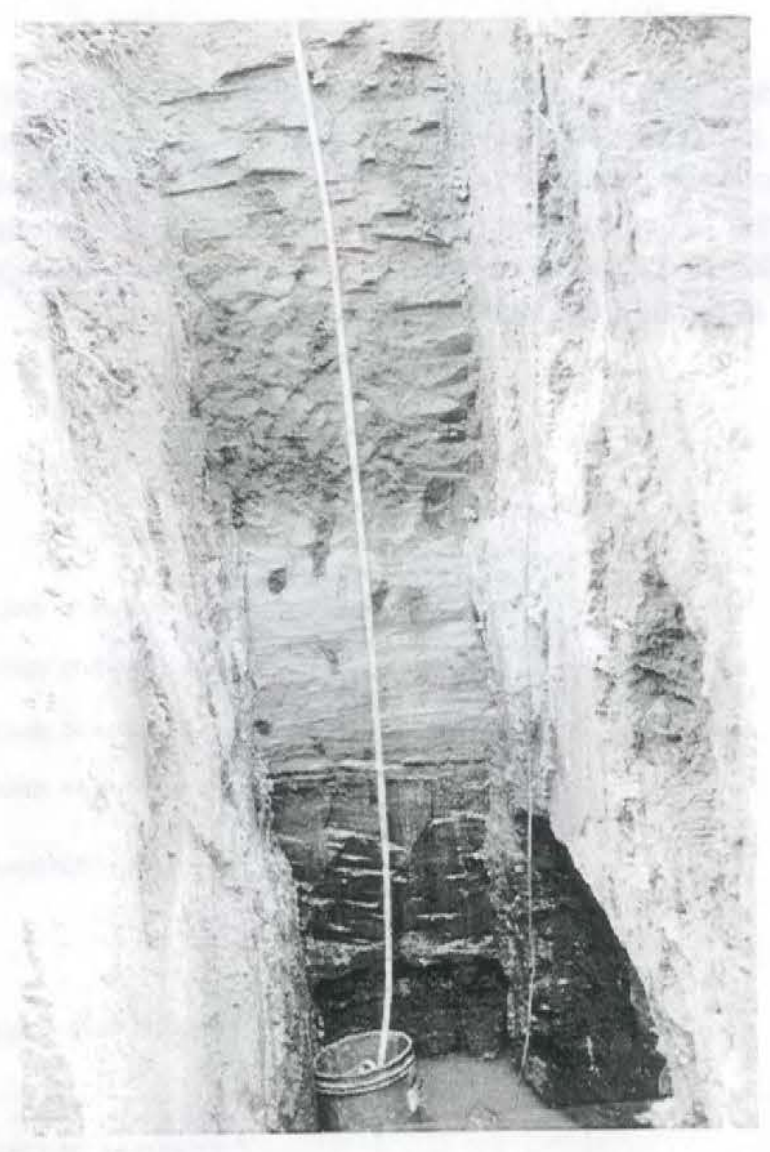

Figure 3.21 Photograph of the south wall of Trench 2. Compare to Figure 3.20a. Arrow marks position of Clovis paleosurface at contact of deflated surface of Stratum C2 with the superjacent black clay of Stratum E1. Note lower part of section is covered by wall collapse and water. See later chapters by Hall, Elias, Neck, Yates and Lundelius and Humphrey and Ferring for respective analyses of pollen, insects, molluscs, vertebrates and stable isotopes from this key profile. This section is in the axis of the pond that existed here from ca. $14.5 \mathrm{ka}$ to ca. $10.5 \mathrm{ka}$.

Unit D (the "Red Wedge") is a colluvial deposit that prograded over the western edge of the pond before, and probably during Clovis occupations. It is well exposed in the outlet channel cutbank (Figure 3.11a), as well as in several trenches in Area A (Figures 3.16-3.18). These colluvial fan deposits did not extend to the pond axis; in the central and eastern part of the pond, therefore, there is a disconformity between Units C2 and $E 1$, upon which were found Clovis artifacts and Clovis age faunas.

Unit E includes lacustrine and alluvial facies in the pond axis in Area A (Figures 3.20, 3.21). It also has colluvial facies that were deposited on top of the Red Wedge, as shown in Trench 13 (Figure 3.19). In the pond axis, Units E1 and E2 are tuffaceous clays and humic tufas. These indicate continued spring activity, but, they also register the first overbank flooding accompanied by deposition of alluvial clays. This change is recorded clearly in the carbon isotope record from sediments in the pond axis (see Chapter 4). 
Unit $F$ is the fill of the Clovis-age channel located about $100 \mathrm{~m}$ east of the pond (Figure 3.12). Only the upper part of this unit is exposed. Borehole $C$ penetrated the channel fill to a depth of ca. $82 \mathrm{~m}$ (local datum). The lowest deposits in the borehole are laminated clays with many snail shells, suggesting an oxbow environment during the period following avulsion or a large meander cut-off. A radiocarbon age of $10,360 \pm 360 \mathrm{bp}$ [Beta-32002] was attained on a sediment sample from the uppermost part of the channel fill, but the age of the lower laminated deposits is not known.

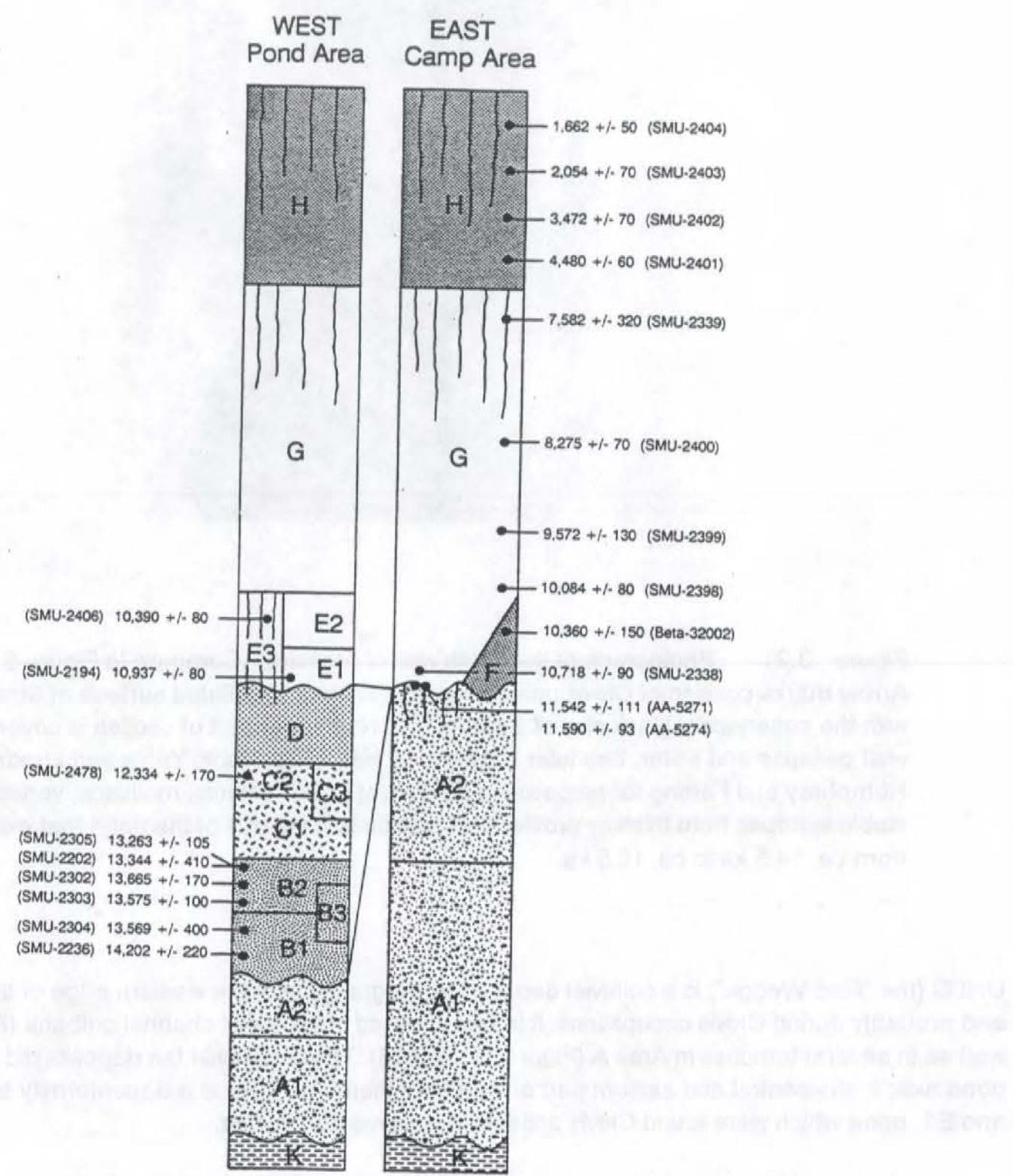

Figure 3.22 Stratigraphic columns with radiocarbon ages from Aubrey. 

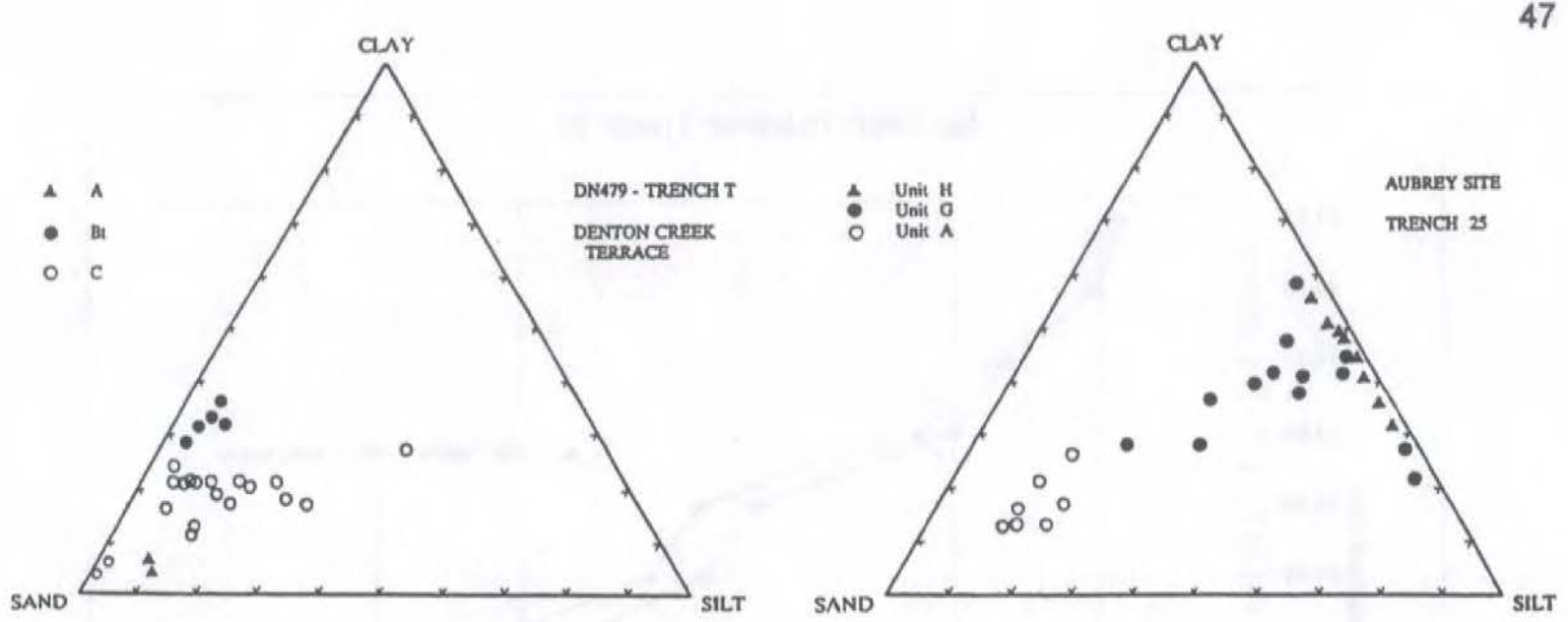

Figure 3.23 Ternary textural diagrams for alluvium at the Aubrey locality. Note uniformly coarse textures for Carrollton Alluvium in Denton Creek Terrace above Aubrey site, and similar facies for the Aubrey Alloformation at base of floodplain section (Unit A; see Figures 3.6, 3.12). These deposits register the bedload meandering to braided streams associated with late Pleistocene valley incision (ending ca. 19-17 ka). After Clovis occupations, rapid alluviation began, with fine-grained floodbasin facies predominant (Units $\mathrm{G}$ and $\mathrm{H}$ ).

Unit $\mathrm{G}$ includes alluvium that buried all Clovis-age materials at the locality (Figure 3.12). At the western valley margin, the alluvium is interbedded with colluvial gravel lenses (Figure 3.16). In the area of Camp B (Trench 25) Unit G fines upward from loams to clays, in a distal floodplain setting without the colluvial input (Figures $3.22,3.23$ ). A moderately developed soil formed in the upper part of Unit G sediments during the Middle Holocene, in response to slowed sedimentation rates and drier climates (Ferring 1995; Figure 3.24).

Unit $\mathrm{H}$ includes the black clays that mantle the floodplain and overlie Unit $\mathrm{G}$ alluvium (Figures 3.12, 3.13). These reflect the distal floodplain setting of the site during the Late Holocene. Because of this geomorphic setting, and the rapid rate of sedimentation (Table 3.2), Unit G sediments are essentially a cumulic soil.

\section{Geochronology}

Twenty three radiocarbon ages were obtained on samples from the Aubrey Site, providing an excellent geochronology of the deposits as well as precise dating of the Clovis occupations (Table 3.2, Figure 3.23). No datable materials could be recovered from Unit A sediments, but these are bracketed by ages of ca. 22-21,000 bp at localities near Dallas (Willimon 1971) and by the oldest ages from Aubrey of ca. 14,200 bp.

The radiocarbon ages document the following sequence of events at the Aubrey Site. The first paleochannel of the Trinity was incising bedrock during the late Pleistocene, culminating with the maximum incision approximately $18-19,000 \mathrm{bp}$. This coincides with the last glacial maximum, but since none of the rivers in this region carried glacial meltwaters, the incision history must be explained with reference to 


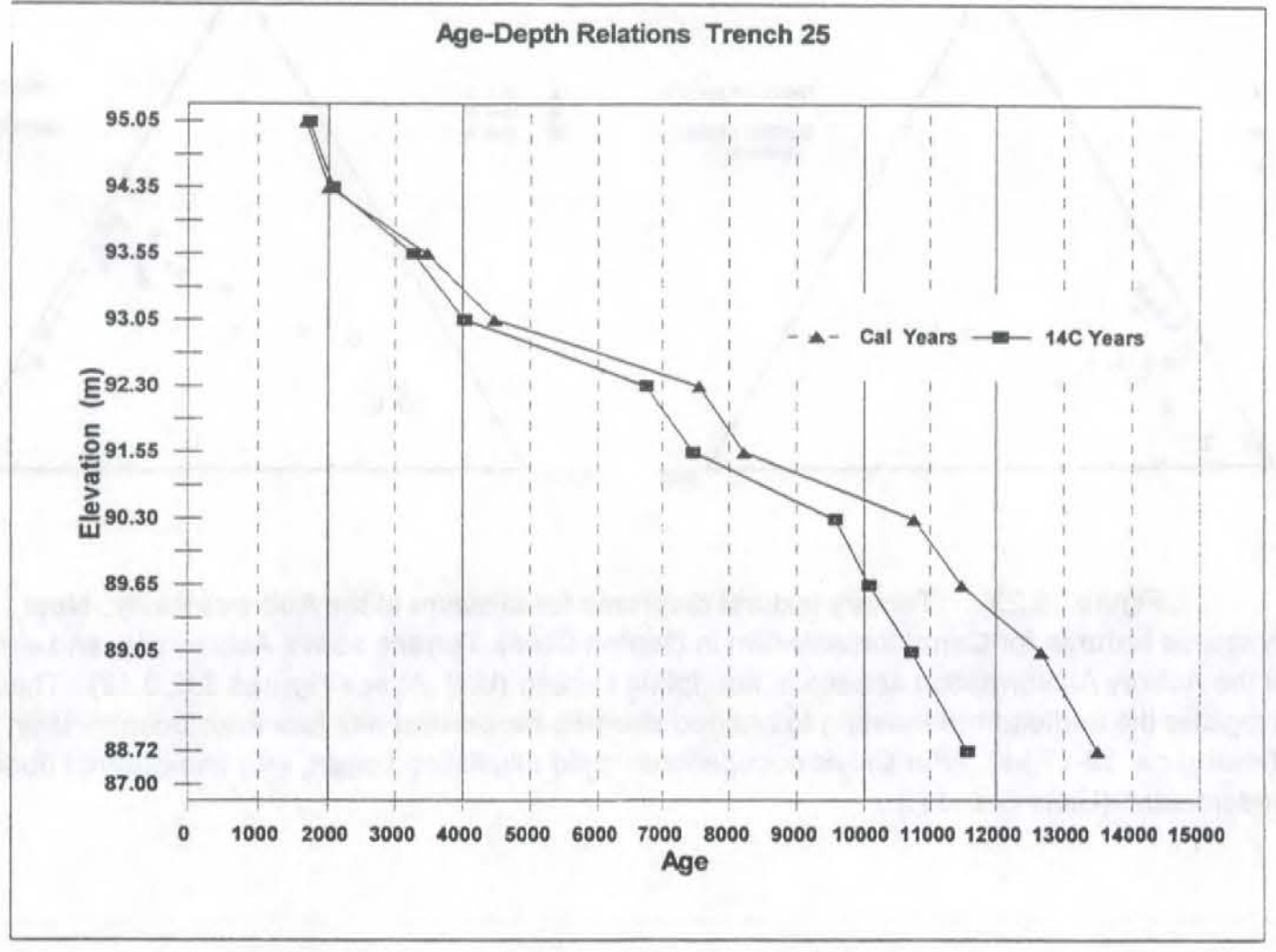

Figure 3.24 Age-depth relationships in Trench 25, Aubrey site. Note rapid early Holocene rates of sedimentation, associated with burial of Clovis horizon. Slower deposition characterises middle Holocene, accompanied by floodplain soil formation. Rapid alluviation follows in late Holocene.

climatic and/or eustatic mechanisms (Ferring 1993). By no later than ca. $14,200 \mathrm{bp}$, a meander loop on the western floodplain edge was cut off forming an oxbow pond. This began filling with spring and lacustrine sediments (Units B and C) until some time shortly after ca. ca. 12,300 bp. This is the youngest age in Unit C2, immediately below the Clovis surface, but is considered a maximum age for cessation of Unit C2 deposition, since that unit had been deflated prior to Clovis occupations.

After $\mathrm{C} 2$ sediments accumulated in the pond, they were deflated, and the Unit $D$ "red wedge" sediments prograded over the spring area on to the western shore of the pond. The presence of Clovis materials, including artifacts, faunal remains and the "well" described later, in the uppermost part of the "red wedge" deposits suggests that the unit may have been aggrading slowly or episodically at the time of Clovis occupations; but the slope of these deposits suggests caution in this interpretation. The abrupt distal edge of the red wedge and the continuous distribution of artifacts and faunal remains on the red wedge and the adjacent deflationary surface (on Unit C2 sediments) in the pond axis, indicate that red wedge deposition and deflation of $\mathrm{C} 2$ and Clovis occupations all occurred in a short period. Significantly, however, the deflation of the pond marls occurred prior to Clovis occupations. 


\begin{tabular}{|c|c|c|c|c|c|c|c|c|c|c|c|c|c|c|}
\hline TRENCH & STRAT & $\begin{array}{r}\text { ELEV } \\
(\mathrm{m})\end{array}$ & LAB No. & Mat. ${ }^{1}$ & ${ }^{{ }^{13} \mathrm{C}}$ & $\begin{array}{c}\text { Age } \\
\text { bp }\end{array}$ & $\begin{array}{l}\text { Calib } \\
\text { Age }^{4}\end{array}$ & $\begin{array}{l}\text { sed } \\
\text { thick. }\end{array}$ & $\begin{array}{l}{ }^{14 C} \\
\text { age }\end{array}$ & $\begin{array}{c}\text { calib } \\
\text { age }\end{array}$ & $\begin{array}{c}{ }^{14} \mathrm{C} \\
\text { sed, rate } 5 \\
\end{array}$ & $\begin{array}{c}\text { calib } \\
\text { sed. rate }\end{array}$ & $\begin{array}{c}\Delta \\
\text { years }\end{array}$ & $\begin{array}{c}\Delta \\
\text { sed rate } \\
\end{array}$ \\
\hline \multicolumn{15}{|c|}{25} \\
\hline & H & 95.05 & SMU-2404 & H & -16.6 & $1730 \pm 50$ & 1676 & & & & & & 1676 & \\
\hline & & & & & & & & 30 & 350 & 332 & 0.086 & 0.090 & & 0.005 \\
\hline & $\mathrm{H}$ & 94.35 & SMU-2403 & H & -16.8 & $2080+70$ & 2008 & & & & & & 2008 & \\
\hline & & & & & & & & 20 & 1180 & 1462 & 0.017 & 0.014 & & -0.003 \\
\hline & $\mathrm{H}$ & 93.55 & SMU-2402 & H & -16.4 & $3260+70$ & 3470 & & & & & & 3470 & \\
\hline & & & & & & & & 50 & 770 & 1000 & 0.065 & 0.050 & & -0.015 \\
\hline & H & 93.05 & SMU-2401 & H & -16.3 & $4030+60$ & 4470 & & & & & & 4470 & \\
\hline & & & & & & & & 75 & 2710 & 3080 & 0.028 & 0.024 & & -0.003 \\
\hline & G & 92.30 & SMU-2339 & H & -18.1 & $6740+320$ & 7550 & & & & & & 7550 & \\
\hline & & & & & & & & 75 & 720 & 660 & 0.104 & 0.114 & & 0.009 \\
\hline & G & 91.55 & SMU-2400 & H & -18.5 & $7460+70$ & 8210 & & & & & & 8210 & \\
\hline & & & & & & & & 125 & 2110 & 2540 & 0.059 & 0.049 & & -0.010 \\
\hline & G & 90.30 & SMU-2399 & $\mathrm{H}$ & -18.9 & $9570+130$ & 10750 & & & & & & 10750 & \\
\hline & & & & & & & & 65 & 510 & 725 & 0.127 & 0.090 & & -0.038 \\
\hline & G & 89.65 & SMU-2398 & $\mathrm{H}$ & -18.6 & $10080+80$ & 11475 & & & & & & 11475 & \\
\hline & & & & & & & & 60 & 640 & 1175 & 0.094 & 0.051 & & -0.043 \\
\hline & G & 89.05 & SMU-2338 & H & -17.0 & $10720+90$ & 12650 & & & & & & 12650 & \\
\hline \multicolumn{15}{|c|}{ 然 } \\
\hline & $G / A$ & & AA-5271 & c & & $11540+110$ & 13460 & & & & & & 13460 & \\
\hline & & & & & average & 11565 & 13490 & 23 & 845 & 840 & 0.027 & 0.027 & 1925 & 0.000 \\
\hline & $G / A$ & & AA-5274 & c & & $11590+90$ & 13520 & & & & & & 13520 & \\
\hline \multicolumn{15}{|c|}{13} \\
\hline & E3 & 88.45 & SMU-2406 & $\mathrm{H}$ & -16.9 & $10390+80$ & 12290 & & & & & & 12290 & \\
\hline & & & & & & & & 125 & 1940 & 2120 & 0.064 & 0.059 & & -0.005 \\
\hline & $\mathrm{C} 2$ & 87.20 & SMU-2478 & H & -24.2 & $12330+170$ & 14410 & & & & & & 14410 & \\
\hline \multicolumn{15}{|c|}{ a } \\
\hline & E1 & 87.80 & SMU-2194 & $\mathrm{H}$ & -18.3 & $10940+80$ & 12860 & & & & & & 12860 & \\
\hline & & & & & & & & 105 & 2320 & 2970 & 0.045 & 0.035 & & -0.010 \\
\hline & B2d & 86.75 & SMU-2305 & $P$ & -29.0 & $13260+105$ & 15830 & & & & & & 15830 & \\
\hline & & & & & & & & 125 & 940 & 1200 & 0.133 & 0.104 & & -0.029 \\
\hline & B1b & 85.50 & SMU-2236 & $\mathrm{P}$ & -28.0 & $14200+220$ & 17030 & & & & & & 17030 & \\
\hline 1 & & & & & & & & & & & & & & \\
\hline & B2d & 87.95 & SMU-2202 & $P$ & -23.4 & $13340+410$ & 15940 & & & & & & 15940 & \\
\hline & B2d & 87.95 & SMU-2195 & $\mathrm{H}^{2}$ & -27.9 & $13710+80$ & 16440 & & & & & & 16440 & \\
\hline & B2d & 87.95 & SMU-2199 & $\mathrm{H}^{3}$ & -27.6 & $13810+880$ & 16560 & & & & & & 16560 & \\
\hline & $\mathrm{B} 2 \mathrm{~b}$ & 87.75 & SMU-2303 & $P$ & -28.3 & $13575+100$ & 16260 & & & & & & 16260 & \\
\hline & B2a & 87.20 & SMU-2302 & H & -28.3 & $13665+170$ & 16380 & & & & & & 16380 & \\
\hline & B1 & 87.35 & SMU-2304 & $\mathrm{P}$ & -28.0 & $13570+400$ & 16260 & & & & & & 16260 & \\
\hline
\end{tabular}

$1 \mathrm{H}$-humates C-charcoal P-peat

2 first humate extraction
3 second humate extraction; very low carbon yield

4 all ages corrected to $\delta 13 \mathrm{C}$ 
The stratigraphy and radiocarbon ages of sediments from the pond-red wedge (Area A) bracket the Clovis occupations between ca. $12,330 \mathrm{bp}$ and $10,940 \mathrm{bp}$, based on dates from Units C2 and E1, respectively (Table 3.2). The reliability of these bracketing ages is substantiated by the numerous superposed dated samples both below and above the Clovis occupation surface, significantly reducing or eliminating concerns that the estimated age of the occupations could be in error, either on the young or the old side. Aubrey appears to have more bounding radiocarbon ages in good stratigraphic order than any other Clovis locality. Even more precise dating is realized when the radiocarbon ages from Camp Area B are assessed.

Two ages were determined on charcoal samples from the Clovis occupation surface in Camp B. These are 11,540 \pm 110 [AA-5271] and 11,590 \pm 90 [AA-5274], with an average of 11,565 bp. There are no dated materials below the Camp B surface (in the eroded Unit A deposits, dated to greater than ca. 14 $\mathrm{ka})$, but there are nine samples in the overlying alluvium, that yielded a consistent sequence of ages beginning at $10,970 \mathrm{bp}$ and continuing up to the youngest age of $1,730 \mathrm{bp}$ (Table 3.2, Figure 3.22). These cover the entire Holocene and provide an excellent chronology of floodplain aggradation and soil development for the Upper Elm Fork Trinity River basin (Ferring 1993).

The estimated age for the occupations at Aubrey of 11,565 bp makes Aubrey the oldest Clovis site known thus far from anywhere in North America (see Taylor, Haynes and Stuiver 1996, Fiedel 1999 and Holliday 2000) for discussions of Clovis geochronology). In assessing the reliability of these ages, we should consider them relative to their stratigraphic positions, in terms of their precision (including inter-lab variability), and also with regard to consistency among the materials that were dated.

An additional factor is the degree to which the samples were recently exposed to the atmosphere via excavation of the outlet channel. As determined by Haas, Holliday and Stuckenrath (1986), organic matter in buried soils that are exposed in artificial trenches will begin to deteriorate quickly after exposure. Because the different components of the soil organic matter deteriorate differentially, increased organic loss correlates with decreased apparent radiocarbon age. This effect can be realized within a few years of the initial exposure. The outlet channel at Aubrey had been excavated four years prior to discovery of the site, so organic deterioration could have been a problem if samples had been collected very close to the outlet channel walls. Virtually all samples for dating were collected from profiles at least $50 \mathrm{~cm}$ from an exposed surface. Those from Trench 2 were all over a 1.5 meters from a surface. In Trench 25, the surface closest to the sample locations is the floodplain.

The whole set of radiocarbon ages from Aubrey corresponds extremely well with their stratigraphic positions. Above Stratum B2d in fact, their are no inversions or out-of-sequence ages whatsoever. The minor inversions in the peat deposits in Unit B2d all derive from samples taken in the spring area (Trench 1) rather than the pond axis (Trench $2 A$ ). These inversions are probably results of some mobility of humates within these deposits. The key ages from the pond area are those that immediately bracket the Clovis surface (the disconformity between Strata C2 and E1). Those samples yielded ages that are fully complimentary to the 11,565 bp age estimate. In sum, there is overall excellent correspondence between the defined lithostratigraphy and the radiocarbon chronology at Aubrey.

A feature of this locality that is obvious but should be mentioned to allay any possible concerns, is that the Clovis horizon here is situated well above bedrock, such that "contamination" of samples by Cretaceous organic matter is unlikely (Figure $3.12,3.22$ ). Careful sample inspection and preparation, and consideration of isotope data failed to reveal evidence of any contamination (see Nordt et al 1994 for excellent discussion of these issues). These comments also pertain to Hall's (this volume) speculation that Cretaceous organic matter may have contaminated the radiocarbon samples and also the samples studied 
for stable isotopes by Humphrey and Ferring (1994 and this volume). Such contamination of carbon isotopic compositions is virtually obviated by the fractionation mechanisms involved, as verified by the correlation between carbon isotope compositions of paired organic and carbonate samples. Possible bedrock signatures with respect to oxygen isotopes were carefully studied at Aubrey, and were defined at low levels close to the spring that declined with distance from the spring across the pond. Indeed, the sample preparations, humate extractions, plant macrofossil confirmation, and isotopic studies make it very clear that contamination at Aubrey is not an issue in dating the site. At a Paleoindian symposium at the 1996 SAA meeting, Dr. Anna Roosevelt suggested that the dates from Aubrey (among other Clovis sites) were unreliable because Aubrey is located upstream from the Lewisville site, where lignite was probably included in the samples dated in the 1950's, yielding ages > 37,000 bp (Crook and Harris 1957, 1958; Stanford 1983). This naive understanding of the data from Aubrey and other Clovis sites renders those concerns unjustified, for the same reasons cited for Hall's concern about isotopic "contamination".

The last issue is that of the precision of the radiocarbon ages at Aubrey. The two ages from the Clovis surface in Camp B overlap at one sigma, which is good. Those ages do not overlap at two sigma with any of the bounding ages above or below the Clovis paleosurface in the camp or in the pond section. Further, the humate ages above the Clovis surface could be considered minimal ages because of possible/probable downwards translocation of humates as part of pedogenesis.

In brief, the estimated age of 11,565 bp for the Clovis occupations at the Aubrey site is substantiated by the number of consistent radiocarbon ages from strata above and below the Clovis surface. All but three of the ages were provided by Dr. Herb Haas, then of the SMU Radiocarbon Laboratory. The AMS ages from the camp were run at the Arizona Accelerator dating lab, and one sample from the upper fill of the Clovis paleochannel was run by Beta Analytic, Inc. [Beta-32002]. Each of these three ages fit well into the radiocarbon chronology established by Dr. Haas's outstanding work.

Paleoenvironments

Full discussion of paleoenvironments, integrating the evidence presented in the following chapters by the several contributors, will be presented in Chapter 10. Here the discussions are limited to geologic evidence for past environments at the Aubrey locality. The geologic history of Aubrey is summarized in Table 3.3. Sediments and their geomorphic relationships are an important part of the overall environmental record at Aubrey. They not only contain fossil evidence of plants and animals at the locality, but also allow independent assessment of surficial processes such as spring activity, flood patterns and episodes of landscape stability and weathering.

Paleolandscape: Site Occupation Context

The significant aspects of the Clovis age landscape at Aubrey can be seen in Figures 3.10 and 3.12. The terrace overlooking the floodplain provided an excellent position from which hunters (or even scavengers) could purvey the Trinity River floodplain. This terrace should have been a logical place for a camp. At other localities, notably the Clovis Site (Hester 1972) and Murray Springs (Haynes 1981), Clovis camps were established on higher ground above the pond or arroyo where large game butchering took place. Camp materials could well have been deposited on the terrace at Aubrey as well. If so, they may remain buried (by Holocene alluvium) or disturbed by construction and/or earlier gravel quarrying near the site. 
At Aubrey, however, the Unit A surface, between the pond and the Clovis paleochannel to the east, provided an alternative camp location which the Clovis occupants used at least once. The geomorphic position of that surface favored accumulation and preservation of the archaeological materials in Camps B and F. In settings such as Murray Springs, the record of camp-related activities has, because of shallow burial, suffered more from weathering and possibly physical disturbance as well. The camp occupation records at Aubrey were certainly afected by weathering and some physical disturbance. However, the intensity of those processes was significanty arrested by rapid burial below the aggrading early Holocene flood plain. Deep burial in calcareous sediments continued to buffer adverse geochemical or physical effects until the site was exposed by outlet channel construction.

One somewhat subtle aspect of the geomorphological-archaeological record at Aubrey is the sheer size of the "site". This dimension is sometimes not obvious, the tiny scale printed on each diagram. As will be described later, there is a distinct and unfalsifiable chance that the Clovis activities at Aubrey were part of one occupation episode- and perhaps a brief one at that. If, for the sake of argument, that was indeed the case, then we have here a record of a group utilizing several microhabitats over an area that has one linear dimension of about $320 \mathrm{~m}$. This is the distance along the outlet channel from the spring to the artifact cluster in Area G. We have no grasp of the site's second dimension. Whether Aubrey represents one occupation episode or several is quite irrelevant to the point that this is a huge site in a complex geologic context. When deep burial is added to the picture it becomes clear that other "Aubreys" are going to be difficult to find and study. It should also remind us that our understanding of Aubrey, for the time being, will be practically "unidimensional" with respect to the Clovis landscape at Aubrey they potentially utilized.

\section{Geoarchaeology: Site Formation Context}

With respect to site formation processes and geoarchaeological approaches to them, several points are clear. First, the Clovis landscape was quite "friendly" with respect to site constructional processes (cf. Ferring and Peter 1982). Activities were conducted on relatively level surfaces, diminishing postoccupational erosion potentials. The western shore of the pond in Area A had a steeper slope than did the surfaces in Areas B or F. Movement of bones down into the oond axis is evident there, and bone preservation is clearly better in the pond sediments than on the adjacent slope.

Second, this site was buried very rapidly. Given the state of bone preservation, especially in the "high" portions of Area B and Area F, rapid burial is readily apparent. This fact is further supported by the radiocarbon ages from the sediments overlying Clovis materials. While bone preservation was good in the lacustrine deposits, it is extremely fortunate that it was even "fair" in the camp areas. In alluvial contexts, rapid burial of Clovis and other Paleoindian occupation sites is evidently a pattern over much of the southern mid-continent. Valley incision during the Late Pleistocene is documented over most of the Southern Plains, the Gulf Coastal Plain west of the Mississippi, and also in drainages of the southwestern US and the High Plains (Ferring 1990, 1993). In turn, rapid early Holocene aggradation is also registered in numerous valleys in those regions. The extent of this pattern of Late Pleistocene valley incision and Holocene aggradation can be inferred from the stratigraphic schemes proposed by Haynes $(1968 ; 1984)$ for localities ranging from Hell Gap, Wyoming, to Lindenmeier, Colorado, and even to sites in Arizona such as Murray Springs and Lehner. At those localities he has not only documented the general patterns in sedimentation and stratigraphy, but has also recorded the "black mats" (thin, highly melanized sedimentary units thought to include algal organic matter) that now serve as uncannily precise stratigraphic markers. Even at Aubrey, a thin black clay (Stratum E1; Figures 3.20, 3.21) overlies the Clovis materials on the deflated paleosurface in the pond sediments. 
Table 3.3 Summary of Geologic History of the Aubrey Clovis Site

1. >15 ka (ca. 25ka?)

2. $>15 \mathrm{ka}(25 ?-15 \mathrm{ka})$

3. ca, $15-13.8 \mathrm{ka}$

4. ca. $13.8-13.3 \mathrm{ka}$

5. ca. 13.3-12.3 ka

6. ca. 12,3-11.5 ka

7. ca. $11 \cdot 5-10,950 \mathrm{ka}$

8. ca. $10,950-10,500 \mathrm{ka}$

9. ca. $10,900-7,600 \mathrm{ka}$

10. ca. $7,600-4,500 \mathrm{ka}$

11. ca. 4,500 - present
Deposition of coarse alluvium on bedrock bench by large bedload or braided stream. These sediments (Carroliton alluvium) are now below the Denton Creek terrace surface above the Aubrey locality. A moderately developed soil has formed at the terrace surface. Molluscs from the lower part of the terrace fill suggest a braided stream environment.

Incision into bedrock. Unit A sand, gravel left as lag channe/bar deposits. These sediments were stable or eroding during deposition of pond sediments (Units B,C), and formed the surface that Clovis folk used for camps near the pond and river channel.

Unit B1 silts, clays and peats deposited in spring pool. This was a period of low spring discharge and limited if any alluvial deposition.

Unit B2 peats, spring travertines and tufas deposited in spring pool, with no apparent alluvium. This was a period of increased spring activity, compared to B1. The spring was a groundwater spring, with major conduits and feeders at the western edge of the pond. Peat deposits, probably related to floating sedge mats, were present near the spring, and periodically spread over much of the pond. There is no evidence for fluvial deposition.

Unit $\mathbf{C}$ cross-bedded tufas and marts deposited in spring pool by seep spring. Gradual change to silty, sandy marl at western margin of pond as colluvium began to wash in from terrace above pond.

Unit D colluvium prograded over western margin of spring pool, forming the "red wedge". The colluvium is sand and gravel, derived from the terrace above the western margin of the pond. This was followed by stability of the "red wedge" and probable deflation of pond marls in the pond axis. Clovis occupation debris and vertebrates occur on the surface of the "red wedge" and on the deflated surface of the marls in the pond axis.

Clovis occupation of locality. Artifacts and faunas occur on the surface of the "red wedge", on the deflated disconformity in the pond axis, and on the surface of Unit A sands at the eastern margin of the pond and about $125 \mathrm{~m}$ farther east near the Clovis paleochannel of the Elm Fork Trinity River.

Unit E alluvial clay, interstratified with thin marl beds, deposited in pond above Clovis age faunas and artifacts. This is also period when alluvial fill (Unit F) continued to aggrade in paleochannel at eastem part of locality. This is the first evidence of fluvial activity since ca. $15 \mathrm{ka}$.- a major change in environments.

Unit G alluvium (overbank clays-silts) aggrades, continuing burial of Clovis site. This documents an early Holocene phase of rapid alluvial deposition.

Slow aggradation, with soil formation. The middle Holocene period is characterized by diminished flooding and probable diminished precipitation.

Unit $\mathrm{H}$ alluvium (distal flood plain clays-silts) aggrades. The late Holocene period is characterized by increased flood frequency-magnitude, probably the result of increased precipitation.

Third, most of the the sediments at Aubrey are relatively fine-grained and calcareous. This inhibited erosional displacement of artifacts, and provided an akaline context that enhanced bone and shell preservation. The textures of the sediments at the Clovis paleosurface are similar in Areas B and A (Red Wedge). But, because of the proximity and water chemistry of the spring, and/or because of greater limestone rock fragments in the sand fraction, the sediments in Area A have a carbonate content of $11.7 \%$ compared to $3.9 \%$ in Area B.

The occupation surfaces at Aubrey were all affected by pedogenesis during and after occupations. The principal physical effect was pedoturbation, the effect of which appears to have been mainly in the vertical positions of artifacts. As discussed in Chapter 9, translocation of artifacts above and below the 
occupation surface is evident, but the net effect does not appear to be significant. Pedogenesis also resulted in etching and dissolution of bone, and the cementation of both bone and lithic artifacts by pedogenic carbonate concretions (see discussions in Chapters 8 and 9).

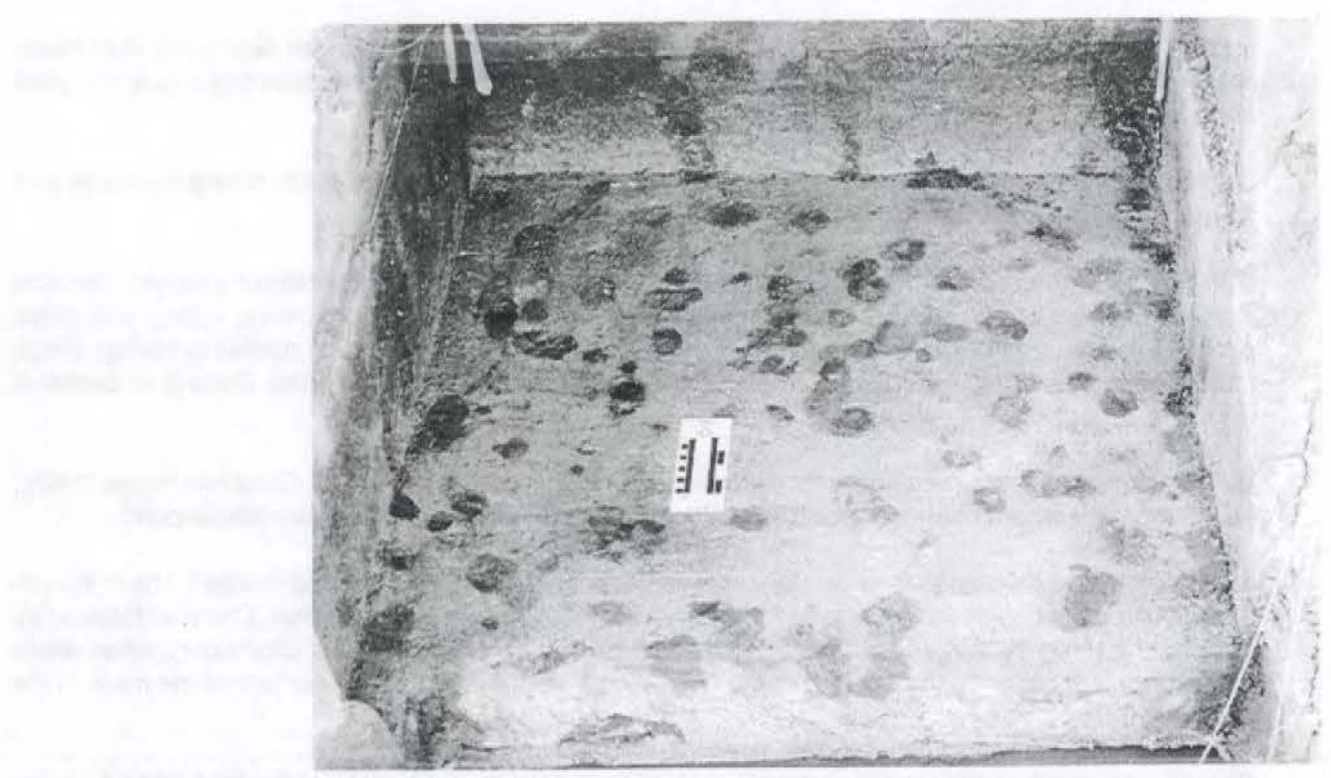

Figure 3.25 Floor of excavation unit in pond area, showing crayfish burrows. This surface is in Stratum C1, below the Clovis paleosurface. In all excavations, the fill of these burrows was excavated separately and discarded. Special care was exercised to avoid these features during collection of samples for pollen, mollusc, insect, radiocarbon and other analyses.

The Aubrey site has been extensively burrowed by crayfish (Figure 3.25). Excavation techniques (and especially sample collection for dating and paleontology) were carefully adjusted to this fact. But a sizable portion of the Clovis surface was punctured by crayfish on their way to the water table. With this principal bioturbation agent in mind, it is still quite remarkable to consider how intact the Aubrey sites appears to be. Excellent spatial patterning is evident in each of the three areas investigated. Indeed, the principal vector of movement at the site is vertical. My late friend Jonathon Davis, on hearing about these aspects of the Aubrey site over a beer, commented that this sounded like a great opportunity to measure rates of "artifact diffusion": a clayey site, one occupation and critters moving sediment up and down. This is indeed evident here, and it was our challenge to exercise the greatest caution in our field excavation methods. 


\title{
CHAPTER 4
}

\section{LATE QUATERNARY STABLE ISOTOPES OF THE AUBREY CLOVIS SITE}

\author{
John D. Humphrey and C. Reid Ferring
}

Introduction

The Aubrey site contains a rich record of carbonates that precipitated in spring, lacustrine and pedogenic environments. These carbonates were chosen for study of stable isotopes of carbon and oxygen in order to develop proxy records of vegetation and temperatures at the locality. Since we had well dated sediments from the late Pleistocene through recent, in one stratigraphic section, this represented one of the best opportunities in this region to investigate past environments using stable isotope analysis. Further, this approach was an ideal addition to the interdisciplinary efforts at the site to reconstruct the setting of Clovis occupations at Aubrey.

The isotopic analyses were conducted at the University of Texas at Dallas, Program in Geosciences. Fifty-eight carbonate samples were collected at the site, representing all stratigraphic units as well as local bedrock, limestone gravel and modern travertines that formed below seep springs. This chapter describes the results of those analyses, and is a modified version of Humphrey and Ferring (1994).

\section{Methods}

Individual carbonate samples were fine-ground and passed through an 80 -mesh $(180 \mu \mathrm{m})$ sieve. Organic matter was removed through reaction with $\mathrm{H}_{2} \mathrm{O}_{2}$. Carbonate mineralogy was determined by powder X-ray diffraction analysis on a Scintag XDS-2000 diffractometer; all samples were determined to be low-Mg calcite ( $<2 \mathrm{~mol}_{\%} \mathrm{MgCO}_{3}$ ). Stable isotope data were collected for $\mathrm{CO}_{2}$ gas liberated from carbonate samples through reaction with $100 \%$ phosphoric acid. Samples were reacted off-line in individual reaction vessels at $90^{\circ} \mathrm{C}$ until completion of reaction (generally $<30 \mathrm{~min}$ ). Stable isotope compositions were analyzed on a Finnigan MAT Delta $E$ stable isotope ratio mass spectrometer. All numbers are reported in standard notation as per mil (\%॰) difference from the PDB standard, with the appropriate ion corrections applied (Craig, 1957). Precision from the repeated analyses of in-house calcium carbonate standards run during sample data collection is $0.03 \% \circ$ for carbon and $0.07 \% \circ$ for oxygen. Machine precision (internal) is better than $0.015 \% \circ$ for carbon and $0.02 \% \circ$ for oxygen.

Isotopic composition of organic carbon was analyzed at Southern Methodist University. $\mathrm{CO}_{2}$ samples evolved from the $\mathrm{NaOH}$-soluble humate fraction (used for ${ }^{14} \mathrm{C}$ analysis) were analyzed on a Finnigan MAT Delta $\mathrm{E}$ mass spectrometer. 


\section{Results}

Fifty-eight calcium carbonate samples were analyzed for their stable carbon and oxygen isotopic composition. These were collected from a series of trenches at the site that collectively exposed all the strata (Figure 4.1; Table 4.1). Ages of the samples were interpolated from the 22 radiocarbon ages on samples from these sections (Table 4.2). Samples range from primarily lacustrine to primarily pedogenic, as well as modern groundwater seep tufas and Cretaceous bedrock for comparison. Table 4.3 lists sample type, stratigraphy, and isotopic composition for the 58 samples. Figure 4.2 shows all data for the Aubrey site plotted in carbon-oxygen space.

WEST

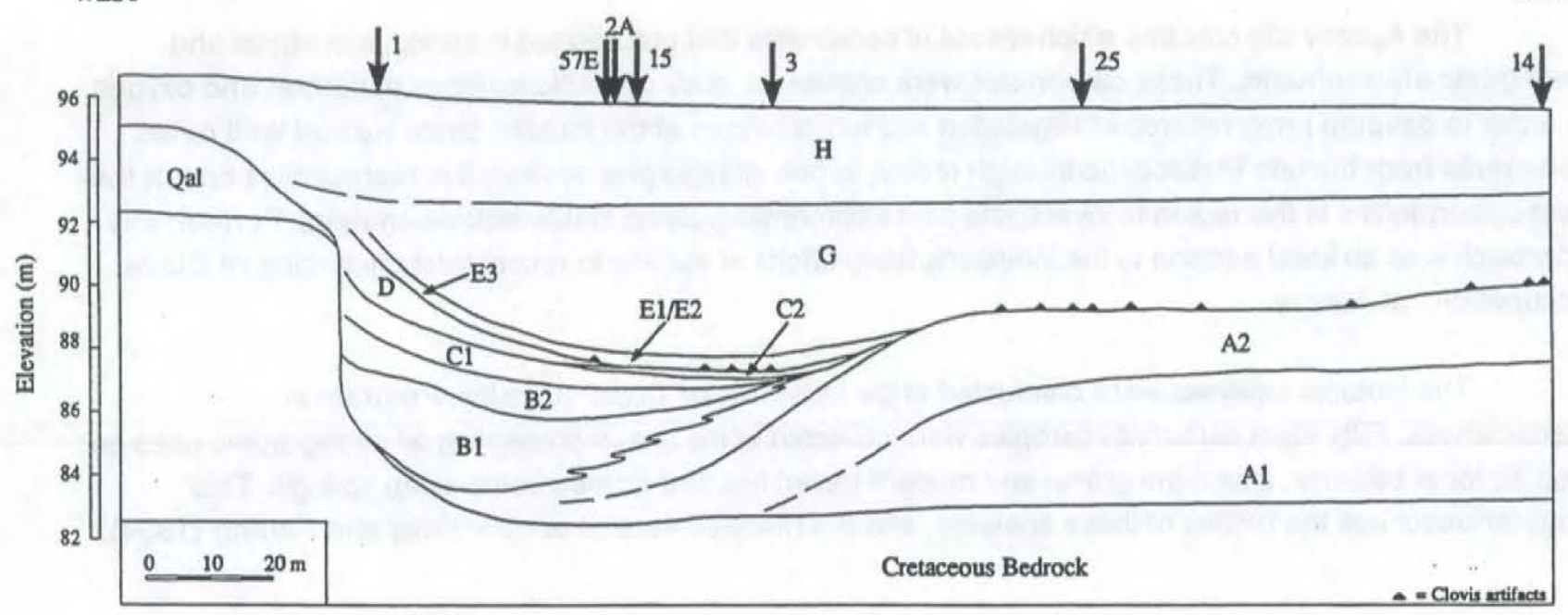

Figure 4.1 Cross-section of Aubrey site with trench locations

Samples from Trench 1, located at the westernmost edge of the pond, consist of spring and pondmargin tufas and marls. Oxygen isotopic composition has a mean value of $-4.23 \% \circ(10=0.47 \% \circ)$ and is as enriched as $-3.45 \%$ and as depleted as $-4.98 \%$. Carbon varies from -3.36 to $-7.25 \%$, with a mean of $5.73 \%$. Focusing only on pond sediments from Stratum C, the samples from Trench 1 are located nearest the seep spring. These samples average $-4.50 \% \circ(10=0.42 \% \circ)$ and $-6.11 \% \circ(10=1.00 \% \circ)$ for oxygen and carbon, respectively.

Trench $2 \mathrm{~A}$ is located on the pond axis and exposes the late Pleistocene lacustrine sequence and overlying Holocene alluvium. This section contains the most depleted oxygen values, averaging $-5.06 \%$ 。 $(10=0.38 \% \circ)$. Carbon shows an overall trend toward lighter values upsection, ranging from -1.23 to $5.38 \% \circ$, and averaging $-4.00 \% \circ$. Pond-axis samples of Stratum $C$ average $-4.98 \% \circ(10=0.21 \% \circ)$ and $5.09 \% \circ(10-0.26 \% \circ)$ for oxygen and carbon, respectively. 
Table 4.1 Stratigraphic Summary for the Aubrey Site

\begin{tabular}{|c|c|c|c|}
\hline Stratum 1 & $\begin{array}{l}\text { Time Interval } \\
\left(10^{3} \text { yr B.P.) }\right.\end{array}$ & Lithology & $\begin{array}{l}\text { Depositional } \\
\text { Environment }\end{array}$ \\
\hline \multirow[t]{2}{*}{$\mathrm{H}$} & 4.5 - Present & $\begin{array}{l}\text { Dark silt; clay; cumulative } \\
\text { soil with pedogenic } \mathrm{CaCO}_{3}\end{array}$ & $\begin{array}{l}\text { Distal flood plain, } \\
\text { Rapid aggradation }\end{array}$ \\
\hline & $7.6-4.5$ & Silt, clay & $\begin{array}{l}\text { Pedogenesis, very slow } \\
\text { flood plain aggradation }\end{array}$ \\
\hline G & $10.9-7.6$ & $\begin{array}{l}\text { Silt, clay, with } \\
\text { pedogenic carbonates }\end{array}$ & Distal flood plain \\
\hline $\mathrm{E}$ & $11-10.4$ & $\begin{array}{l}\text { E1, E2: clay, marl } \\
\text { E3: clay, sand }\end{array}$ & $\begin{array}{l}\text { Alluvial, lacustrine pond fill (E1,E2) } \\
\text { Pond margin, terrace slope (E3) }\end{array}$ \\
\hline D & $12.3-11.5$ & $\begin{array}{l}\text { Colluvial sand, } \\
\text { gravel }\end{array}$ & Terrace slope \\
\hline C & $13.2-12.3$ & $\begin{array}{l}\text { Laminated marl, thin peat, } \\
\text { humic marl }\end{array}$ & Lacustrine and spring \\
\hline B & $15-13.2$ & Clay, marl, and peat & Lacustrine and spring \\
\hline A & $25 ?-15$ & Sand and gravel & $\begin{array}{l}\text { Channel lag, bar (deposited during } \\
\text { incision into Cretaceous bedrock) }\end{array}$ \\
\hline
\end{tabular}

Samples from Trench 3, located at the eastern margin of the pond near Trench 25, represent two different facies. The two lower samples come from lacustrine marls and the third is a pedogenic nodule from the overlying alluvium. The pedogenic sample is identical in physical appearance to nearby Trench 25 nodules and has very similar isotopic composition. Marl samples from Stratum C average $-5.28 \%$ 。 $(10=0.14 \% \circ)$ in ${ }^{18} \mathrm{O}$ and $-4.15 \% \circ(10=0.75 \% \circ)$ in ${ }^{13} \mathrm{C}$.

Only one sample (a calcite-cemented gravel from Stratum A1 in late Pleistocene sands at $87.40 \mathrm{~m}$ - local datum) was analyzed from Trench 14, located $55 \mathrm{~m}$ east of Trench 25 . Cement was carefully sampled using a microsampling drill and binocular microscope. The cement likely precipitated in the vadose zone, as indicated by meniscus and pendant cement fabrics. The isotopic composition of this meteoric phase is very similar to that of pedogenic carbonates occurring within the same interval in Trench 25. 
Table 4.2 Radiocarbon Ages from the Aubrey Site

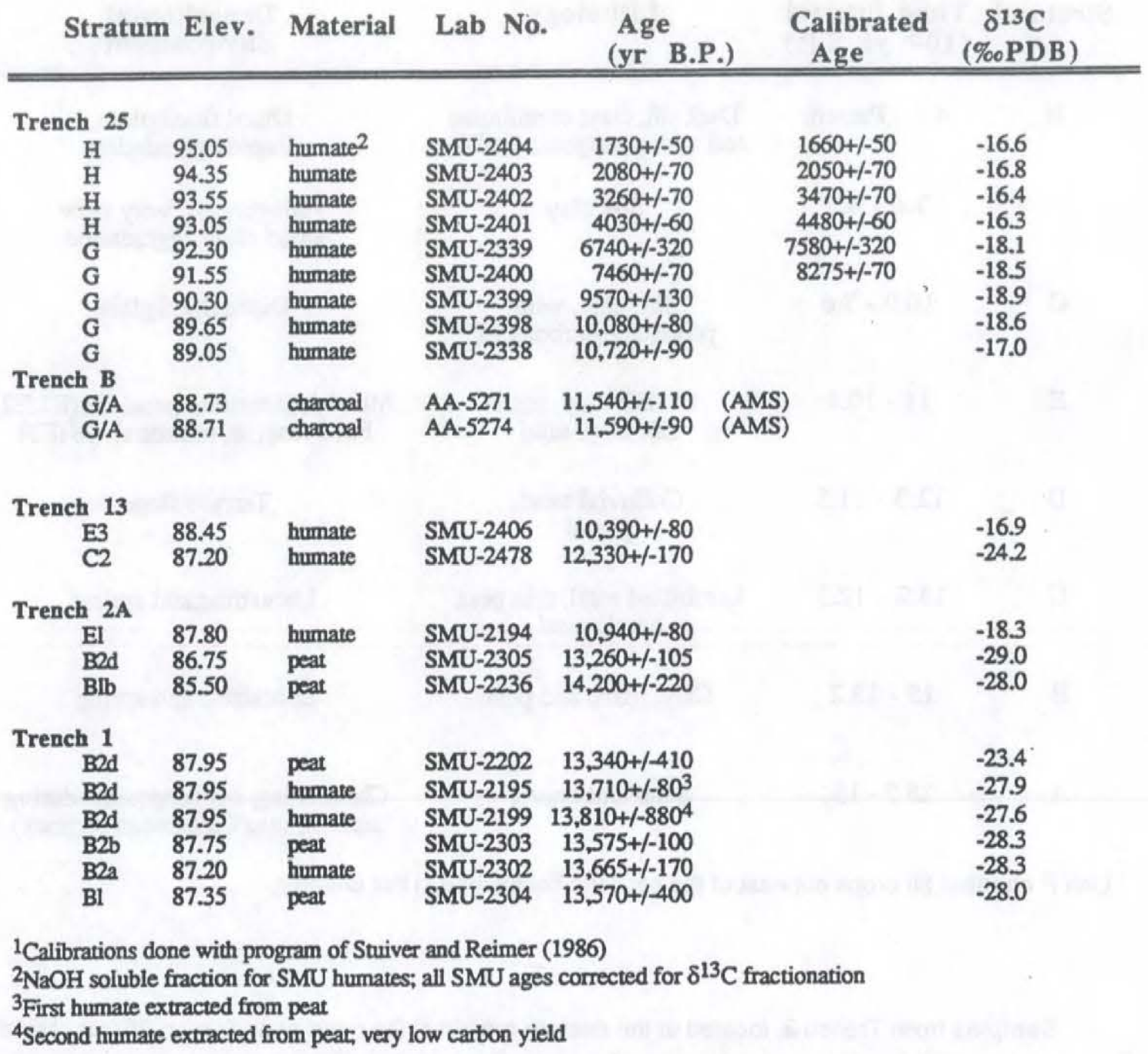

Three pond samples from Trench 15, approximately $4 \mathrm{~m}$ from Trench $2 \mathrm{~A}$, were analyzed. All three samples come from the lowest portion of Stratum B1, and are the oldest (ca. 14,600-14,200 yr B.P.) carbonate samples in the study area. These dark-brown clayey marls represent the initial stages of pond development from the ground-water-fed spring. The isotopic composition of these samples closely resembles the composition of the carbonate Cretaceous bedrock, suggesting groundwater control. Oxygen averages $-3.57 \% \circ(10=0.43 \% \circ)$ and carbon averages $+0.34 \% \circ(10=0.52 \% \circ)$. 


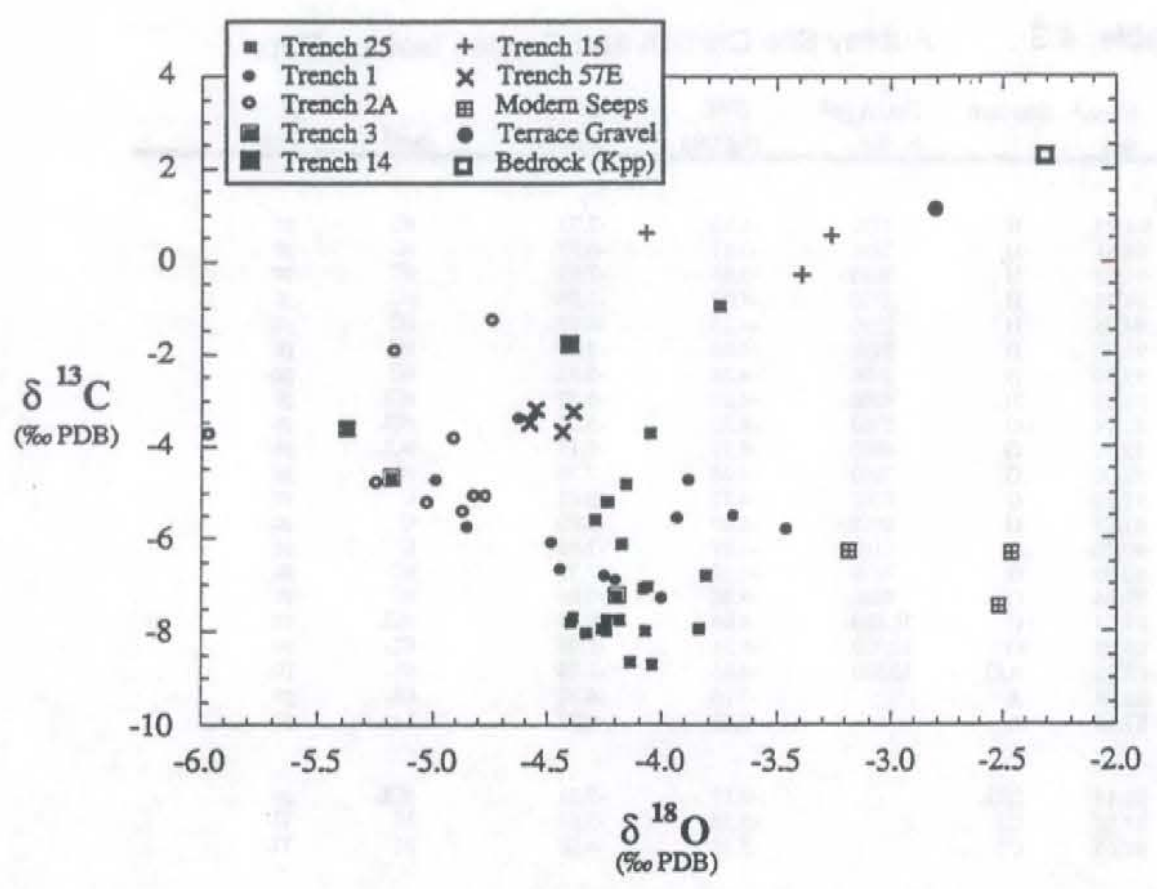

Figure 4.2 Carbon-oxygen cross-plot for samples from Aubrey

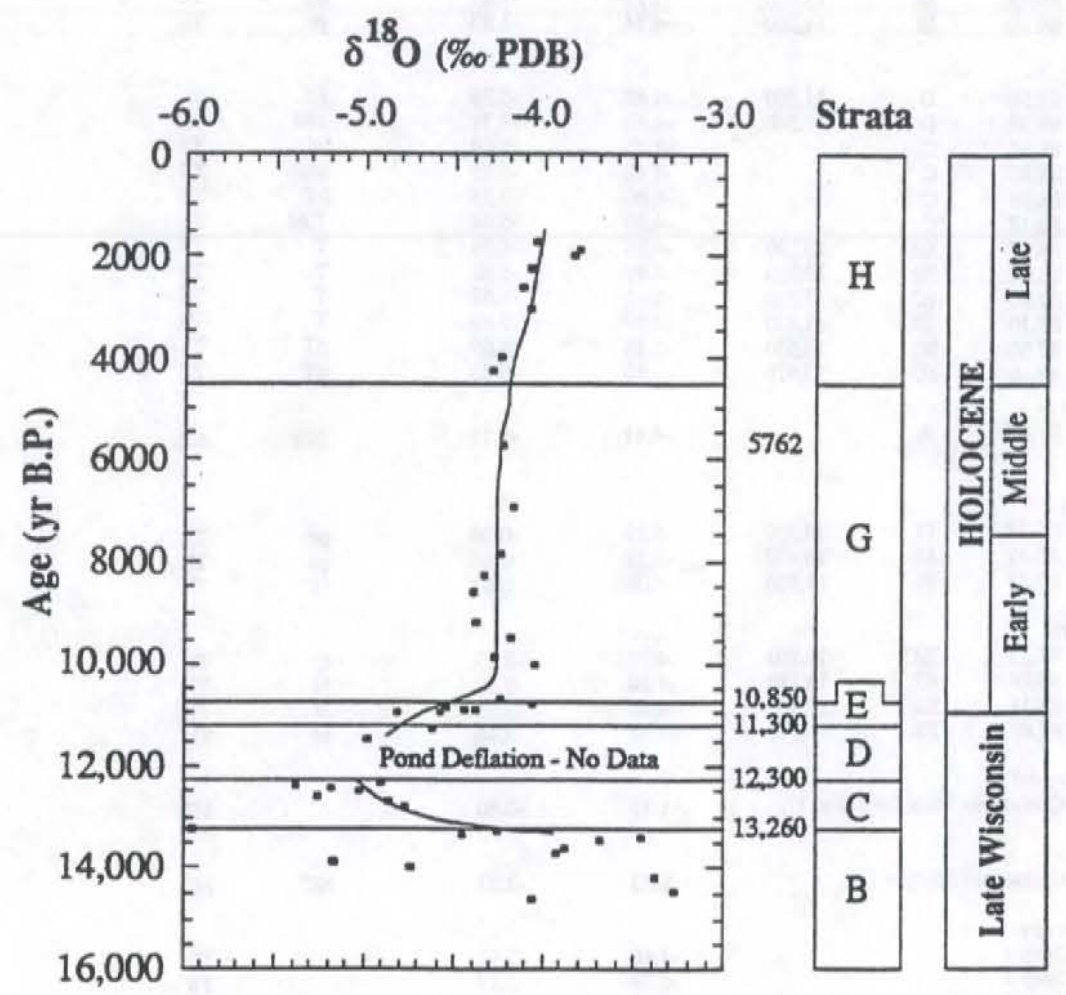

Figure 4.3 Composite oxygen isotope record from Aubrey 


\begin{tabular}{|c|c|c|c|c|c|c|c|}
\hline \multirow{4}{*}{ Trench } & \multirow{2}{*}{$\begin{array}{l}\text { Elev. }{ }^{1} \\
\text { (m) }\end{array}$} & \multirow[t]{2}{*}{ Stratum } & \multirow{2}{*}{$\begin{array}{l}\text { Est. Age } 2 \\
(\mathrm{yr} \text { B.P.) }\end{array}$} & \multirow{2}{*}{$\begin{array}{c}\delta^{18} 0 \\
(\% 2 D D B)\end{array}$} & \multirow{2}{*}{$\begin{array}{c}\delta^{13} \mathrm{C} \\
\text { (GaPDB) }\end{array}$} & \multicolumn{2}{|c|}{ Lithology } \\
\hline & & & & & & $\operatorname{Sed}^{3}$ & Carb $^{4}$ \\
\hline & \multicolumn{7}{|l|}{25} \\
\hline & 94.93 & $\mathbf{H}$ & 1730 & -4.05 & -3.73 & $\mathrm{sC}$ & pc \\
\hline & 94.61 & H & 1910 & -3.81 & -6.77 & sC & $\mathrm{pc}$ \\
\hline & 94.43 & H & 2010 & -3.84 & -7.93 & sC & pc \\
\hline & 94.23 & H & 2270 & -4.07 & -7.96 & $\mathrm{sC}$ & $\mathrm{pc}$ \\
\hline & 94.05 & H & 2590 & -4.13 & -8.67 & $\mathrm{sC}$ & $\mathrm{pc}$ \\
\hline & 93.80 & $\mathrm{H}$ & 3030 & -4.08 & -7.07 & sC & $p$ \\
\hline & 93.30 & $\mathrm{H}$ & 3980 & -4.24 & -5.22 & sC & $p c$ \\
\hline & 93.15 & $\mathrm{H}$ & 4280 & -4.29 & -5.59 & $\mathrm{sCl}$ & pe \\
\hline & 92.74 & G & 5760 & -4.23 & -5.21 & $s \mathrm{Cl}$ & pc \\
\hline & 92.45 & G & 6960 & -4.17 & -6.11 & sCL & pc \\
\hline & 92.00 & G & 7860 & -4.24 & -7.76 & $s \mathrm{C}$ & pc \\
\hline & 91.50 & G & 8280 & -433 & -8.01 & 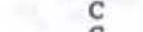 & pc \\
\hline & 9123 & G & 8610 & -4.40 & -7.80 & C & pc \\
\hline & 90.70 & G & 9160 & -4.39 & -7.69 & C & pc \\
\hline & 90.40 & G & 9470 & -4.19 & -7.77 & sC & pe \\
\hline & 89.94 & G & 9860 & -4.26 & -7.95 & $\mathrm{sC}$ & pc \\
\hline & 89.74 & G & 10,010 & $-4,04$ & -8.69 & sCL & pc \\
\hline & 89.05 & G & 10,720 & -4.24 & -7.98 & CL. & pc \\
\hline & 88.95 & $A N G$ & 10,800 & -4.05 & -7.04 & $\mathrm{CL}$ & pe \\
\hline & 88.64 & A & & -4.16 & -4.82 & CL & $\mathrm{pc}$ \\
\hline & 87.10 & A & & -3.75 & -0.97 & L & pe \\
\hline \multicolumn{8}{|c|}{ Trench 3} \\
\hline & 89.15 & $E / G$ & & -4.19 & -7.21 & sCL & pc \\
\hline & 87.85 & $\mathrm{C} 3$ & & -5.38 & -3.62 & M & IL \\
\hline & 87.65 & C3 & & -5.18 & -4.68 & $\mathrm{M}$ & TL \\
\hline \multirow[t]{10}{*}{ Trench } & \multicolumn{7}{|l|}{$2 \mathrm{~A}$} \\
\hline & 87.85 & El & 10,950 & -4.82 & -5.04 & M & TL \\
\hline & 87.70 & $\mathrm{C}_{2}$ & 12,300 & -4.91 & -3.79 & $\mathrm{~T}$ & $\pi$ \\
\hline & 87.45 & $\mathrm{Cl}$ & 12,500 & -5.03 & -5.17 & $\mathrm{~T}$ & IL \\
\hline & 87.30 & $\mathrm{Cl}$ & 12,600 & -5.25 & -4.68 & $\mathrm{~T}$ & $\mathrm{IL}$ \\
\hline & 87.07 & $\mathrm{Cl}$ & 12.700 & -4.87 & -5.38 & $\mathrm{~T}$ & $\pi$ \\
\hline & 86.90 & $\mathrm{Cl}$ & 12,800 & -4.78 & -5.05 & $T$ & TL \\
\hline & 86.70 & $\mathrm{~B} 2$ & 13,260 & -5.96 & -3.72 & pT & $\mathrm{TL}$ \\
\hline & 86.45 & BI & 13,900 & -5.17 & $-i .87$ & pT & IL \\
\hline & 86.10 & Bl & 14,000 & -4.74 & -1.23 & ps & $\pi$ \\
\hline Trench & 1 & & & & & & \\
\hline & 89.50 & D & 11,300 & -4.62 & -3.36 & gri. & $\mathrm{pc}$ \\
\hline & 89.30 & D & 11,500 & -4.98 & -4.71 & SM & c \\
\hline & 88.65 & C & & -4.85 & -5.69 & M & TS \\
\hline & 88.50 & C & & -4.48 & -6.05 & hM & TS \\
\hline & 88.35 & C & & -4.00 & -7.25 & hT & TS \\
\hline & 88.10 & C & & -420 & -6.84 & $T, M$ & TS \\
\hline & 88.17 & B2 & 13,290 & -4.25 & -6.74 & $\mathrm{~T}$ & TS \\
\hline & 88.07 & B2 & 13,320 & -4.45 & -6.62 & $\mathrm{~T}$ & TS \\
\hline & 87.90 & $B 2$ & 13,370 & -3.45 & -5.58 & $\mathrm{~T}$ & TS \\
\hline & 87.70 & $\mathrm{~B} 2$ & 13,420 & -3.69 & -5.46 & $\mathrm{~T}$ & TS \\
\hline & 87.30 & B2 & 13,570 & -3.88 & -4.69 & pT & TS \\
\hline & 87,40 & $\mathrm{~B} 2$ & 13,670 & -3.93 & -5.53 & pT & TS \\
\hline Trench & 14 & & & & & & \\
\hline & 87.40 & A & & -4.41 & -1.71 & $S G r$ & $\operatorname{cem}$ \\
\hline Trench & 15 & & & & & & \\
\hline & 85.77 & $\mathrm{BI}$ & 14,200 & -3.39 & -0.26 & ps & IL \\
\hline & 85.47 & BI & 14,400 & -3.27 & 0.60 & ps & $\mathrm{IL}$ \\
\hline & 85.27 & BI & 14,600 & -4.06 & 0.67 & es & $\pi$ \\
\hline Trench & 57E & & & & & & \\
\hline & 88.33 & E/G & 10.850 & -4.55 & -3.17 & C & $\mathrm{TL}$ \\
\hline & 88.24 & E2 & 10,870 & -4.38 & -3.22 & M & $\pi$ \\
\hline & 88.13 & E2 & 10,900 & -4.44 & -3.65 & M & IL \\
\hline & 87.87 & E2 & 10,940 & -4.58 & -3.46 & M & $\pi$ \\
\hline Terrace & $\begin{array}{l}\text { Gravel } \\
\text { Cretaceous }\end{array}$ & & & & & & \\
\hline & (2) & 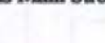 & ral $(t)$ & 1.19 & -2.80 & & ML \\
\hline Be & Cretaceous & is Pawpaw $\mathrm{F}$ & & 2.32 & -2.32 & NC & ML \\
\hline Modern & Seeps & & & & & & \\
\hline & Seep 1 & & & -7.40 & -2.52 & & TS \\
\hline & Seep 2 & & & -6.23 & -3.19 & & TS \\
\hline & Seep 3 & & & -6.24 & -2.46 & & TS \\
\hline
\end{tabular}

1Elevation measured relative to arbitrary ternace datum of $100 \mathrm{~m}$.

${ }^{2}$ Estimated age based on linear interpolation between ${ }^{14} \mathrm{C}$ ages reported in Table 2 and Figure 4.

${ }^{3}$ Sediment: C- clay; SC- silty clay; SCL - silty clay loam; CL- clay loam; L- loam; grL-gravelly loam; SM- sandy marl; hM- humic marl; hT- humic tufa; M- mart; T- tufa; pT- peary tufa; ps- peaty silt; cs-calcareous silt; SGr-sandy gravel; NC-nodular coquina

${ }^{4}$ Carbonates: pc- pedogeric concretion; TL- lacustrine tufa; TS- spring tufa; cem-cement; ML-marine limestone 
Stable isotopic data for the complete Holocene section comes from Trench 25, which exposes about $7.5 \mathrm{~m}$ of Holocene alluvium. The Pleistocene/Holocene boundary (and Clovis occupation horizon) lies at $88.7 \mathrm{~m}$ elevation in the section. Holocene pedogenic oxygen isotopic compositions are remarkably constant, averaging $-4.16 \% \circ(10=0.16 \% \circ)$. Carbonate ${ }^{13} \mathrm{C}$ varies from about -3.73 to $-8.69 \%$ in the Holocene section, and becomes heavier by several per mil in the underlying Pleistocene pedogenic carbonates.

The upper part of Stratum E, with interstratified alluvial clays and thin lacustrine marls, was sampled in Trench 57E, located just $2 \mathrm{~m}$ from Trench 2A. Samples chosen from 57E consisted of lacustrine marls of early Holocene age. Isotopic composition of these samples, vertically separated by less than $1 \mathrm{~m}$, cluster tightly, with oxygen averaging $-4.49 \% \circ(10-0.09 \% \circ)$ and carbon averaging $-3.37 \% \circ$ $(10=0.22 \% \circ)$.

Samples of gravel at the base of the Pleistocene terrace above the site include limestone cobbles, reworked hematite concretion, and some siliciclastic pebbles and cobbles. Limestone samples were taken for comparison with the Quaternary precipitates. The analyzed sample of marine limestone from the terrace gravels is likely from the Lower Cretaceous (Albian) Main Street Formation. Bedrock exposed near the site belongs to the Albian Pawpaw Formation (Kpp), which is composed of shale, silt-stone, and beds of nodular coquina with a hematite matrix. Powder for isotopic analysis was derived from pelecypod fragments in one of these coquinas. Both Cretaceous samples have typical marine limestone isotopic compositions, with slightly positive carbon values and slightly negative oxygen values. These values are significantly different from the in situ Quaternary samples that are the focus of this study, except for the aforementioned samples from Trench 15.

Three samples of modern carbonate were taken from a slope below a seep-spring within a construction trench. The samples have precipitated since the trench was constructed, within the last $5 \mathrm{yr}$. These organic-rich tufas are a product of algal precipitation, with the carbonate occurring in association with dense masses of filamentous blue-green algae. Oxygen composition averages $-2.72 \%$ and carbon averages $-6.62 \%$. Here ${ }^{13} \mathrm{C}$ composition of the modern tufas is quite different from that of the Cretaceous bedrock from which the spring is emerging.

Temporal Variability in Oxygen Isotopes at the Aubrey Site

Due to the excellent age control, a composite section of oxygen data can be constructed and plotted in time (Figure 4.3). The oldest samples (from Stratum B), although demonstrating significant scatter, are the most enriched. As noted above, these lacustrine marl samples may have been influenced by groundwater isotopically enriched in ${ }^{18} \mathrm{O}$ of about $2 \%$. Unfortunately, there is a break in the data here because of a deflational disconformity in the sediments of Stratum D. Above this break, however, there is at least a $0.5 \%$ o increase in ${ }^{18} \mathrm{O}$ in the interval dated from ca. 11,300 to $10,850 \mathrm{yr}$ B.P. in Stratum E. We maintain that a meteoric water signal is being recorded by the lacustrine marls because there is no break in the isotopic composition between Stratum E marls and the superposed Stratum G pedogenic carbonates, which are directly sampling meteoric precipitation. Other than minor variation in the early Holocene samples, the entire Holocene record in Strata $\mathrm{G}$ and $\mathrm{H}$ shows quite constant ${ }^{18} \mathrm{O}$ values, with only a slight upward trend in the upper part of the section to compositions more enriched in ${ }^{18} \mathrm{O}$. 
The late Pleistocene oxygen isotope record from the Aubrey site clearly registers significant changes in ${ }^{18} \mathrm{O}$ through time. Although one objective of our analysis was to reconstruct an approximate paleotemperature record at the locality based on oxygen isotopes, other controls on isotopic variation need to be considered. The first, and perhaps most important, control is the source and oxygen isotope composition of late Pleistocene meteoric waters. Although today this region receives moisture from the Pacific and the Gulf of Mexico, the latter is the closest and by far the most dominant source.

In the late Pleistocene, the oxygen isotope composition of northern Gulf of Mexico waters was largely controlled by glacial ice volume and the influx of meltwaters via the Mississippi River. Emiliani et al. (1975) showed that during the last glacial maximum, northern Gulf of Mexico waters had very enriched ${ }^{18} \mathrm{O}$ values (Figure 4.4). With the onset of rapid deglaciation ca. 14,000 yr B.P. (Broecker et al., 1989),

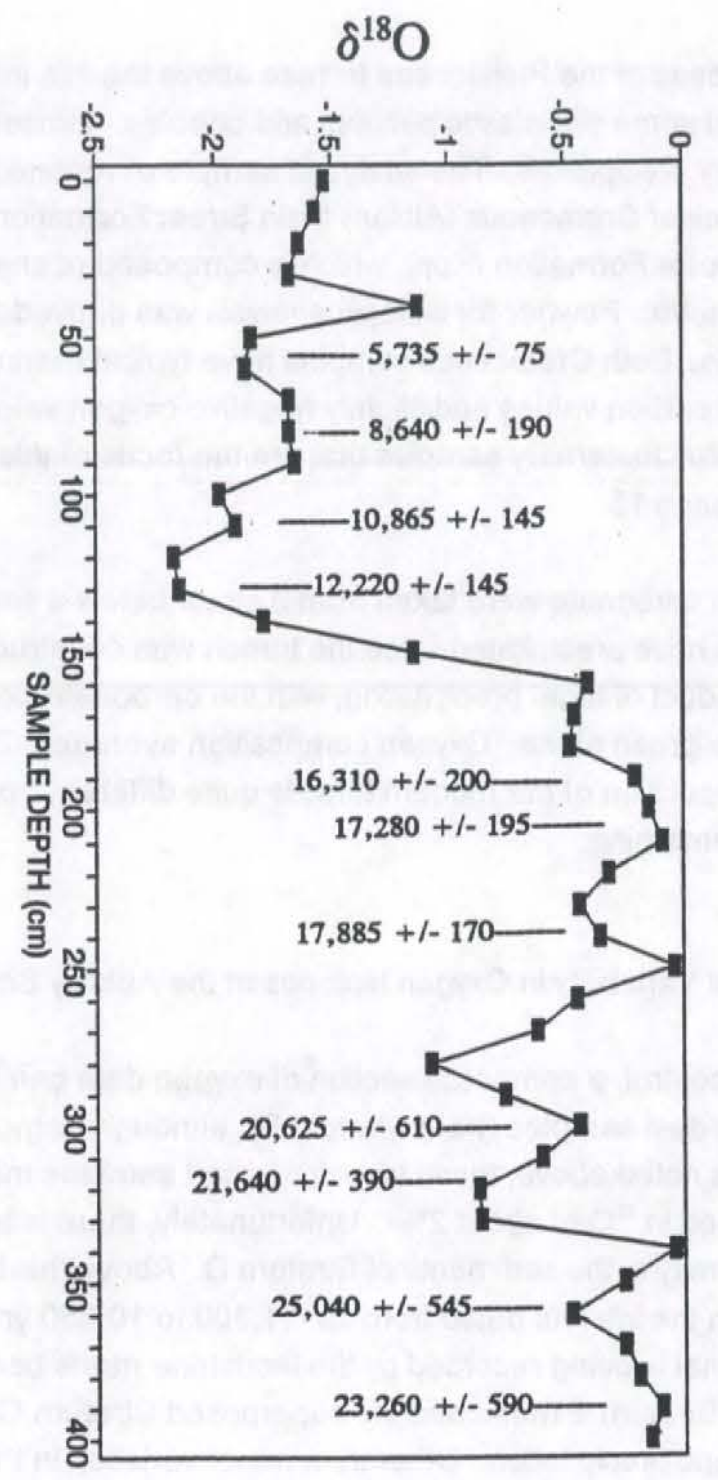

Figure 4.4 Gulf of Mexico oxygen isotope record from G. rubra (Modified from Emeliani et al 1975) 
meltwater discharge simultaneously decreased the ${ }^{18} \mathrm{O}$ composition and the salinity of Gulf waters. The rapid decrease in ${ }^{18} \mathrm{O}$ culminated in minimum values ca. 12,000 P.P.; at ca. 11,000 yr B.P. there is a shift to more depleted compositions (Emiliani et al., 1975). More detailed analyses of oxygen isotopic compositions of dated foram tests by Broecker et al. (1989) and Aharon (1992) confirm the overall trends observed by Emiliani et al. (1975), but show a ${ }^{18} \mathrm{O}$ minimum at ca. 12,000 yr B.P., higher values between ca. 11,200 and 10,000 yr B.P., and a rapid shift to lower (near-modern) ${ }^{18} \mathrm{O}$ values ca. 10,000 yr B.P. Broecker et al. (1989) attribute the higher ${ }^{18} \mathrm{O}$ values between 11,200 and $10,000 \mathrm{yr}$ B.P. to the diversion of meltwaters from the Mississippi to the St. Lawrence during the Younger Dryas cold episode of the northern Atlantic and northwestern Europe. The melt-water diversion mechanism as a cause for the Younger Dryas even has been supported by other workers (e.g., Ruddiman, 1987). However, Fairbanks (1989) argues against the diversion mechanism and favors a stepped deglaciation model.

Of immediate concern here is the relationship of the Aubrey oxygen isotope record to Gulf of Mexico waters as the principal meteoric source, and the possible paleoclimatic implications of the late Quaternary fluctuations in ${ }^{18} \mathrm{O}$ at Aubrey. We note the remarkable correspondence between the oxygen isotope records from the Aubrey site and that of the northern Gulf of Mexico. While Pacific water sources cannot be discounted at this time, it appears that late Quaternary meteoric waters in the vicinity of the Aubrey site were largely influenced by moisture derived from the Gulf of Mexico. Although colder surface water temperatures for the Gulf of Mexico can be estimated by analysis of the isotope data from foram tests (Emiliani et al., 1975), we think it is premature to derive paleotemperature estimates from the Aubrey data. Clearly, the late Pleistocene oxygen isotope data from Aubrey cannot be read simplistically as a relative paleotemperature signal. Rather, these data appear to register the isotopic composition of Gulf of Mexico waters, which, as emphasized above, was defined by glacial ice volume and meltwater influx patterns.

At first we regarded the excursion to lighter isotopic compositions in the Aubrey record at ca. 12,000 yr B.P. as possible evidence for the Younger Dryas event (Humphrey and Ferring, 1991). At Aubrey, sediments with low ${ }^{18} \mathrm{O}$ values are dated to $\mathrm{ca} .13,000$ to $11,300 \mathrm{yr}$ B.P., which corresponds quite well with several published records for the Younger Dryas (e.g., Overpeck et al., 1989; Patterson et al., 1991) identified changes in climatic patterns in the Gulf of Mexico and variation in Caribbean upwelling coincident with Laurentide Ice Sheet meltwater discharge into the Gulf of Mexico. Strongest upwelling occurred from 12,600 to about $10,000 \mathrm{yr}$ B.P. in the Cariaco Basin.

However, comparison of these records to the Greenland ice core data based on annual layer counting requires calibration of radiocarbon ages, as is now possible for the late Pleistocene (Stuiver and Reimer, 1993). While a review of these calibrated radiometric ages is not warranted here, it is now clear that calibration places many of the claims for Younger Dryas phenomena 1000 to $2000 \mathrm{yr}$ earlier than the ice core. Furthermore, the oldest part of the Aubrey record, dated to ca. 14,000 to $13,000 \mathrm{yr}$ B.P., would correspond to the late-glacial (ca. 16,500 to 14,500 calendar years ago) record of the Greenland ice cores. However, the isotopic data from this interval at Aubrey suggest, at face value, conditions that were as warm or even warmer than today. Such a conclusion contradicts climate model results and insect data from Aubrey that indicate significantly colder temperatures (see Chapter 5). While we initially suspected that these older samples from Aubrey carried a groundwater signature (Humphrey and Ferring, 1991), we now suggest that they dominantly exhibit a meteoric water signature ultimately tied to the Gulf of Mexico water composition. An et al. (1993) report a somewhat comparable situation in central China. Therefore, the late Pleistocene oxygen isotope record at Aubrey cannot be read as a straightforward paleotemperature proxy. 
With respect to Younger Dryas problem, calibration of ${ }^{14} \mathrm{C}$ ages, as well as evaluation of meteoric water sources, suggest that the Younger Dryas is not recognizable here, or that its signature is masked by complex changes in meltwater influx rates to the Gulf of Mexico.

Temporal Variability in Carbon Isotopes at the Aubrey Site

Changes in the isotopic composition of soil organic matter result in changes in soil-gas composition. Bicarbonate in the meteoric soil water isotopically exchanges with soil $\mathrm{CO}_{2}$ prior to carbonate precipitation. Authigenic in situ pedogenic carbonates in the precipitating water. Thus, pedogenic carbonates should reflect the changing make up of soil organic matter, given no lithogenic contamination in the analyzed materials. We suggest that the pedogenic nodules from the Aubrey site sampled for isotopic analysis contained no or inconsequential amounts of lithogenic carbonate.

Microscopic examination indicates that all pedogenic carbonate fabrics resulted from dissolutionreprecipitation. Although the Aubrey site alluvium may originally have contained as much as $10 \%$ lithogenic (Cretaceous) carbonate material, no matrix appears to be included in the dense soil-zone nodules. Further evidence for the limited influence of lithogenic carbonate comes from the difference between organic and carbonate carbon isotopes.

Table 4.4 Carbon Isotopes from Organic and Carbonate Carbon

\begin{tabular}{|c|c|c|c|c|c|c|}
\hline Trench & Stratum & & rial & $\delta^{13} C_{\text {(org) }}$ & $8^{13} \mathrm{C}_{(\mathrm{CaCO})}$ & $\Delta\left(\delta_{\mathrm{CaC} 03}-\delta_{\text {org }}\right)$ \\
\hline 25 & $\begin{array}{l}H \\
H \\
H \\
H \\
H \\
G \\
G \\
G \\
G \\
G\end{array}$ & $\begin{array}{c}\text { Organic } \\
\text { h } \\
\text { h } \\
\text { h } \\
\text { h } \\
\text { h } \\
\text { h } \\
\text { h } \\
\text { h } \\
\text { h }\end{array}$ & $\begin{array}{l}\mathrm{CaCO}_{3} \\
\propto \\
\propto \\
\propto \\
\propto \\
\propto \\
\propto \\
\propto \\
\propto \\
\propto\end{array}$ & $\begin{array}{l}-16.6 \\
-16.8 \\
-16.4 \\
-16.3 \\
-18.1 \\
-18.5 \\
-18.9 \\
-18.6 \\
-17.0\end{array}$ & $\begin{array}{l}-3.73 \\
-7.92 \\
-7.06 \\
-5.59 \\
-6.11 \\
-8.01 \\
-7.77 \\
-8.69 \\
-7.98\end{array}$ & $\begin{array}{r}12.87 \\
8.88 \\
9.34 \\
10.71 \\
11.99 \\
10.49 \\
12.03 \\
9.91 \\
9.02\end{array}$ \\
\hline $2 \mathrm{~A}$ & $\begin{array}{l}\mathrm{E} 1 \\
\mathrm{~B} 2 \\
\mathrm{~B} 1\end{array}$ & $\begin{array}{l}\mathrm{h} \\
\mathrm{p} \\
\mathrm{p}\end{array}$ & $\begin{array}{l}\text { tw } \\
\text { tw } \\
\text { tw }\end{array}$ & $\begin{array}{l}-18.3 \\
-29.0 \\
-28.0\end{array}$ & $\begin{array}{l}-5.05 \\
-3.72 \\
-1.22\end{array}$ & $\begin{array}{l}13.25 \\
25.28 \\
26.78\end{array}$ \\
\hline 1 & B2 & $\begin{array}{l}\mathrm{p} \\
\mathrm{ph} \\
\mathrm{ph}\end{array}$ & tw & $\begin{array}{l}-23.4 \\
-27.9 \\
-27.6\end{array}$ & $\begin{array}{l}-6.74 \\
-6.74 \\
-6.74\end{array}$ & $\begin{array}{l}16.66 \\
21.16 \\
20.86\end{array}$ \\
\hline & $\begin{array}{l}\text { B2 } \\
\text { B2 } \\
\text { B1 }\end{array}$ & $\begin{array}{l}\mathrm{ph} \\
\mathrm{ph} \\
\mathrm{p}\end{array}$ & $\begin{array}{l}\text { tu } \\
\text { tu } \\
\text { tu }\end{array}$ & $\begin{array}{l}-28.3 \\
-28.3 \\
-28.0\end{array}$ & $\begin{array}{l}-5.57 \\
-5.46 \\
-5.53\end{array}$ & $\begin{array}{l}22.73 \\
22.84 \\
22.47\end{array}$ \\
\hline
\end{tabular}

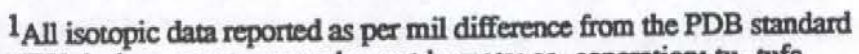
KEY: h- humate; p- pear; ph-peat humate; $c c$ - concretion; tu- tufa 


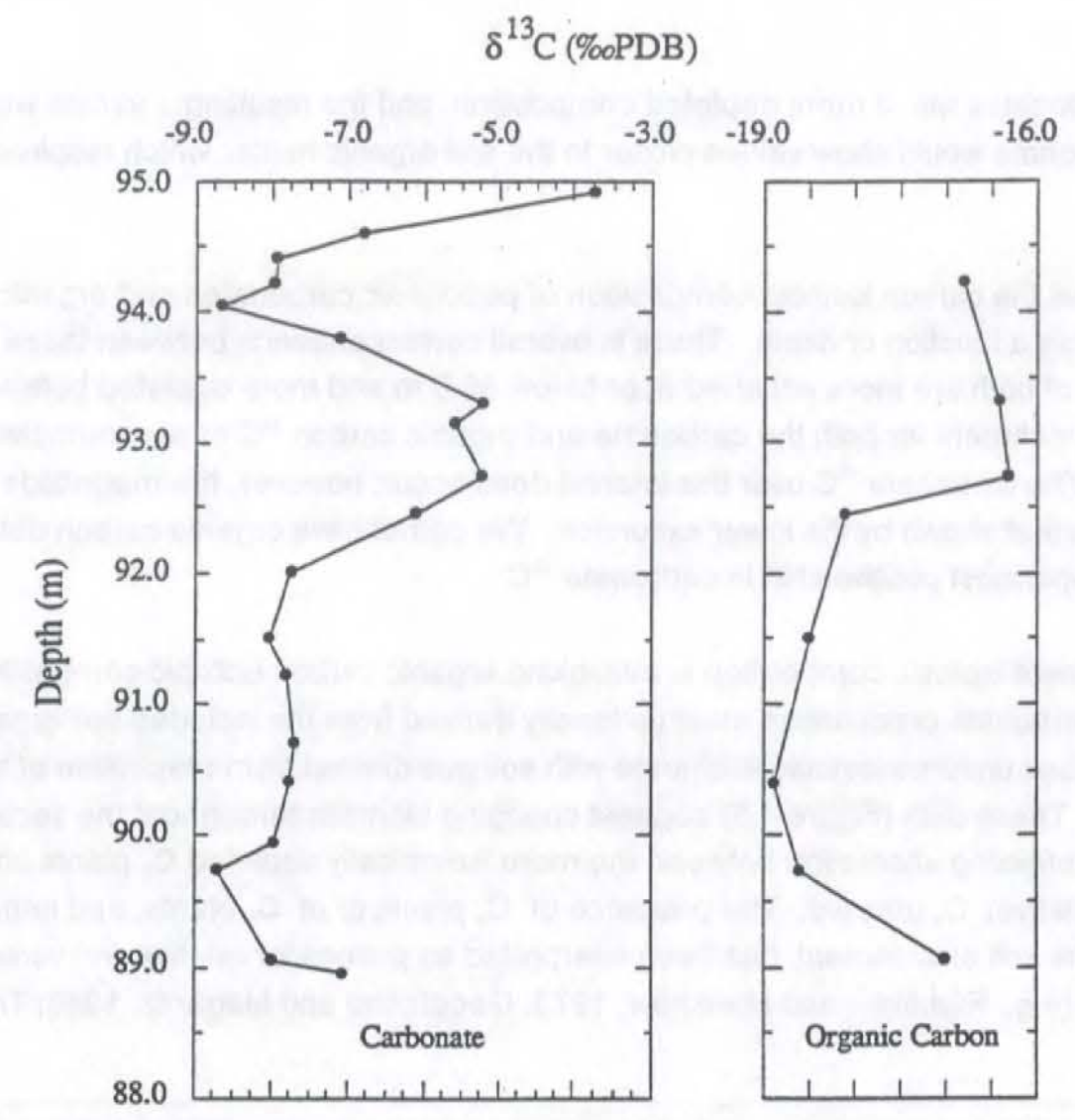

Figure 4.5 Carbon isotope record for pedogenic and organic carbon

Cerling et al. (1989) indicated that there should be a $\Delta\left(\mathrm{Caco3}^{-}{ }^{-}\right.$org $)$of $14-16 \%$ 。 for coexisting pedogenic carbonate and soil organic matter in locations with high soil respiration rates. The $\Delta$ value for Aubrey site coexisting pedogenic carbonate and organic matter ranges from 8.88 to $12.87 \% \circ$ (Table 4.4). This range is lower than that reported values, i.e., we should expect a smaller $\Delta$ value if there is no Cretaceous material incorporated. On the other hand, adding more and more lithogenic material would drive the $\Delta$ values higher and higher. The discrepancy between the Cerling et al. (1989); however, if Cretaceous lithogenic material $\left({ }^{13} \mathrm{C}=+1-+3 \%\right.$ ) were acting as contamination, the $\triangle$ values would approach or surpass their reported values, i.e., we should expect a smaller $\Delta$ value if there is no Cretaceous material incorporated. On the other hand, adding more and more lithogenic material would drive the $\Delta$ values higher and higher. The discrepancy between the Cerling et al. (1989) $\Delta$ range of 14$16 \% \circ$ and our lower range may be due to differences in soil horizon $P_{\mathrm{co} 2}$ in the study areas. We suggest that a higher $P_{\mathrm{co} 2}$ was maintained at the Aubrey site. Elevated $P_{\mathrm{co} 2}$ at the study site is probably related to a high initial organic content and commensurate high respiration rates (surface soil horizon presently contains $1.2 \%$ total organic carbon).

The inference that $P_{\mathrm{co} 2}$ is high near the Aubrey site is supported by data from local Trinity River water that contains high total dissolved inorganic carbon values (annual mean of $225 \mathrm{mg} / \mathrm{liter} \sum \mathrm{CO}_{2}$; Pillard, 1988), higher than equilibrium $\mathrm{CaCO}_{3}-\mathrm{H}_{2} \mathrm{O}-\mathrm{CO}_{2}(\mathrm{~atm})$ values. A higher $P_{\mathrm{co2}}$ the soil environment would 
result in pedogenic carbonates with a more depleted composition, and the resulting $\Delta$ values would be less; i.e., the pedogenic carbonate would show values closer to the soil organic matter which respires to produce the elevated $P_{\infty 02}$.

Figure 4.5 shows the carbon isotopic composition of pedogenic carbonates and organic carbon from Trench 25 plotted as a function or depth. There is overall correspondence between these two records. Compositions of both are more enriched at or below $89.0 \mathrm{~m}$ and more depleted between 89.0 and $92.5 \mathrm{~m}$. Note that an enrichment for both the carbonate and organic carbon ${ }^{13} \mathrm{C}$ of approximately $3 \%$ 。 occurs above $92.5 \mathrm{~m}$. The carbonate ${ }^{13} \mathrm{C}$ over this interval does occur; however, the magnitude of variation is not as pronounced as that shown by the lower excursion. We do not have organic carbon data corresponding to the uppermost positive shift in carbonate ${ }^{13} \mathrm{C}$.

Because carbonate isotopic composition is mimicking organic carbon isotopic composition, the carbon for pedogenic carbonate precipitation must be locally derived from the included soil organic matter. Soil water bicarbonate ions undergo isotopic exchange with soil gas derived from respiration of soil organic matter (Cerling, 1984). These data (Figure 4.5) suggest changing biomass throughout the section through time, with the variation reflecting alternation between the more isotopically depleted $\mathrm{C}_{3}$ plants and the more isotopically enriched (relative) $C_{4}$ grasses. The presence of $C_{3}$ plants or of $C_{4}$ plants, and hence their carbon contribution to the soil environment, has been interpreted as proxies for relative wet versus dry conditions, respectively (e.g., Rightmire and Hanshaw, 1973; Goodfriend and Magaritz, 1988; Tieszen and Boutton, 1989).

Figure 4.6a shows a ${ }^{14} \mathrm{C}$ time-series of carbonate carbon isotopic data. Note two periods of more depleted isotopic composition at ca. 11,000 to 7500 and ca. 3500 to $2000 \mathrm{yr} \mathrm{B.P.} \mathrm{In} \mathrm{contrast,} \mathrm{the} \mathrm{period}$ spanning 7000 to $4000 \mathrm{yr}$ B.P. is represented by relatively more enriched (by about $2.5 \% \circ$ ) compositions. Figure 8B is modified from Ferring (1990) and was constructed independently of the isotopic data using regional geologic, faunal, and pollen records. Indeed, not only were the climatic interpretations based on geologic/paleontologic data, but the isotope data were not acquired until more than $1 \mathrm{yr}$ after the Ferring (1990a) curve was published. Note the correspondence between the two diagrams. Rapid alluviation occurred under periods of higher precipitation when a predominance of the more humid $\mathrm{C}_{3}$ and ${ }^{13} \mathrm{C}$ depleted flora would be expected. Conversely, periods of slow alluviation and pedogenesis occurred under drier conditions during which a predominance of more enriched $\mathrm{C}_{4}$ grasses would be expected. Our data show evidence for a moist early Holocene, dry middle Holocene, and overall moist late Holocene, although with a dry excursion from ca. 2000 to $1000 \mathrm{yr}$ B.P.

Haynes (1991) identified a Clovis-age drought in western North America, lasting from ca. 11,300 to $10,900 \mathrm{yr}$ B.P., that was coeval with megafaunal extinctions. Subsequent to this drought, water tables rose and lacustrine sedimentation resumed, signifying onset of more humid conditions (Haynes, 1991). A similar sequence of events is noted at the Aubrey site. Prior to the early Holocene, isotopic, faunal, and botanical evidence at the Aubrey site suggest a latest Pleistocene climate that was cool and dry. Pond desiccation and deflation occurred sometime after ca. 12,000 yr B.P. Clovis artifacts occur on this deflationary surface and on the surface of Unit D (deposited up to ca. 11,000 yr B.P.). Shortly after Clovis occupations, alluviation resumed at the Aubrey site with deposition of Unit E sediments, and carbon isotopes shifted toward lighter values (Figure 4.6). 


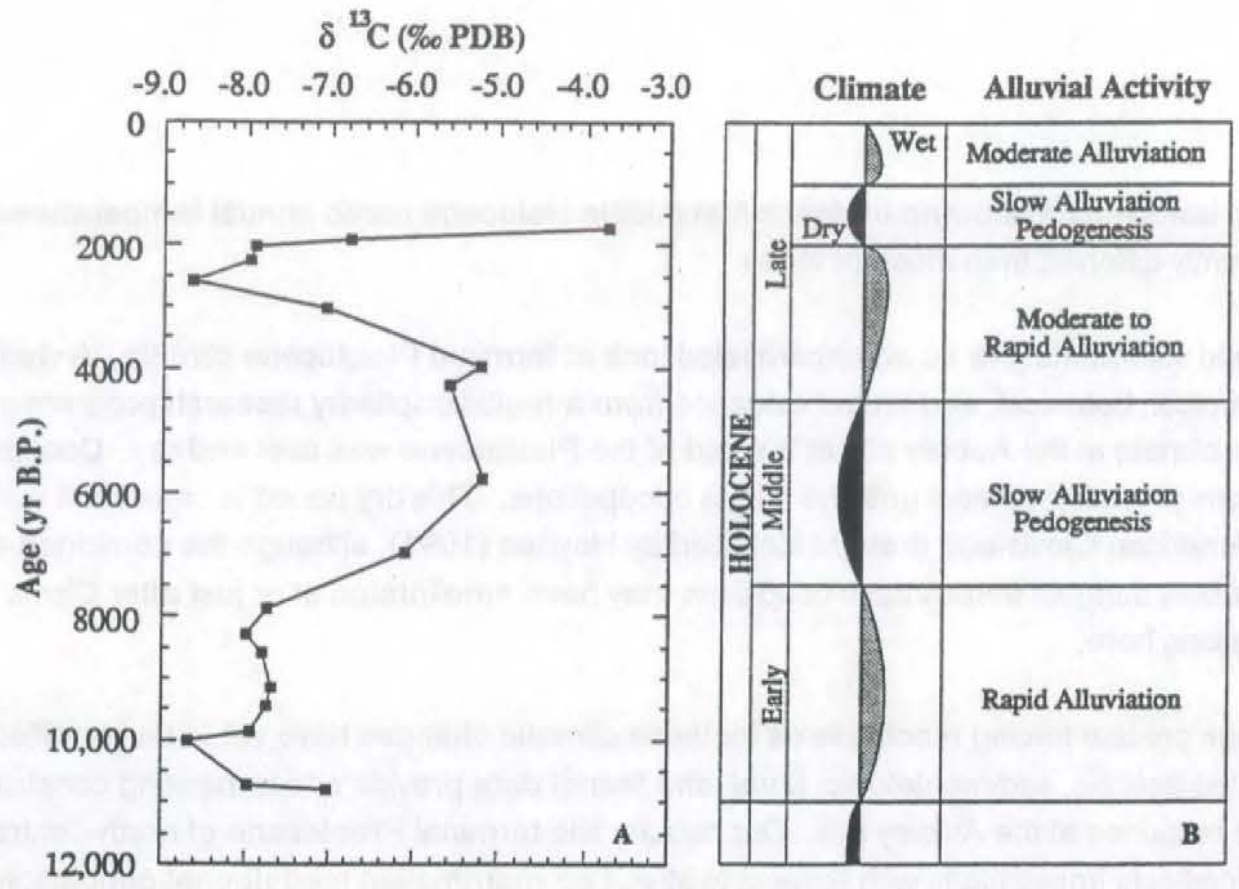

Figure 4.6 Pedogenic carbon isotope data and inferred climate history

The timing of the middle Holocene dry period noted at Aubrey corresponds with the Southern High Plains drought identified by Holliday (1989) which culminated between ca. 6500 to $4000 \mathrm{yr}$ B.P. In contrast to evidence cited by Holliday, however, the Aubrey oxygen isotopic data show no evidence for higher middle Holocene temperatures (Figure 4.3). The Aubrey data suggest that mean annual temperatures were not significantly different from those of the present regime; however, we cannot exclude the possibility that differences in middle Holocene seasonality may have existed.

\section{Conclusions}

Stable isotope and independent data indicate changing climatic conditions in northcentral Texas from late Pleistocene to present:

(1) Late Pleistocene to early Holocene oxygen isotopic compositions of lacustrine and pedogenic carbonates at the Aubrey site indicate that variability is tied to the changing isotopic composition of northern Gulf of Mexico waters.

(2) Carbon isotope data corroborate independent evidence for more humid early Holocene, drier middle Holocene, and overall more humid late Holocene conditions. 
(3) Oxygen isotope data show no evidence that middle Holocene mean annual temperatures were significantly different than those of today.

(4) The pond sediments give us an unparalleled look at terminal Pleistocene climate. A wealth of geochemical, botanical, and faunal evidence from a multidisciplinary research program suggests that the climate at the Aubrey site at the end of the Pleistocene was cool and dry. Cool grassland conditions prevailed at least until the Clovis occupations. This dry period is consistent with the North American Clovis-age drought identified by Haynes (1991), although the combined evidence from Aubrey suggest that climatic conditions may have ameliorated at or just after Clovis occupations here.

(5) Although precise forcing mechanisms for these climatic changes have yet to be identified, integrated isotopic, sedimentologic, floral, and faunal data provide encompassing constraints on climate response at the Aubrey site. Our data for the terminal Pleistocene of north-central Texas have significant implications with respect to stress on mammalian megafaunal populations, as well as adaptations of Clovis populations. 


\title{
CHAPTER 5
}

\section{PALEOENVIRONMENTAL SIGNIFICANCE OF LATE GLACIAL INSECT FOSSIL ASSEMBLAGES FROM THE AUBREY SITE, NORTHCENTRAL TEXAS}

by

Scott A. Elias

\begin{abstract}
Two insect faunal assemblages were studied from late glacial-age organic sediments at the Aubrey Clovis site in northcentral Texas. Fossils from Unit B1 were deposited in a spring pool between about 15,000 and 13,800 B.P. The other fossil-bearing unit, B2, was deposited between about 13,800 and 13,300 yr B.P. Many of the identified species live today only in regions well north of Texas. Several are found in the boreomontane regions of North America. However, there are not tree-dwelling taxa in the fossil assemblages. The insect assemblages present a picture of gradually warming local environments from about 14,000 to $13,300 \mathrm{yr}$ BP. Assemblages from both the lower and upper units are indicative of a small pond, situated in a treeless, open landscape.
\end{abstract}

Methods

Organic detritus was concentrated from the sediments by gravity separation. The organic fraction of each sample was then wet sieved on a $300 \mu \mathrm{m}$ screen, and insect fossils were isolated from plant residues by the kerosene flotation method (Coope, 1968). Flotants were then washed in detergent, and sorted in alcohol under low power binocular microscope. Robust insect fossil specimens were mounted on modified micropaleontology cards with gum tragacanth. Duplicate and fragile specimens were stored in vials of alcohol. Specimens were identified by comparison with modern, identified specimens in the U.S. National Museum of Natural History (Smithsonian). Washington, D.C. Some specimens were referred to taxonomic specialists, as noted in the acknowledgements.

Results

The late glacial sediments from the Aubrey site yielded abundant, diverse insect assemblages, dominated by beetles. In all, 74 taxa have been identified, including 20 specific determinations (Table 5.1; Figures 5.1, 5.2). Riparian taxa are important in most of the 13 assemblages studied, as well as aquatic and semiaquatic taxa. The assemblages are divided into those from near the shore of an ancient pond, and those from near the center of this pond. While it is not surprising that the littoral zone faunas are dominated by riparian and emergent vegetation-zone insects, even the profundal zone assemblages are 


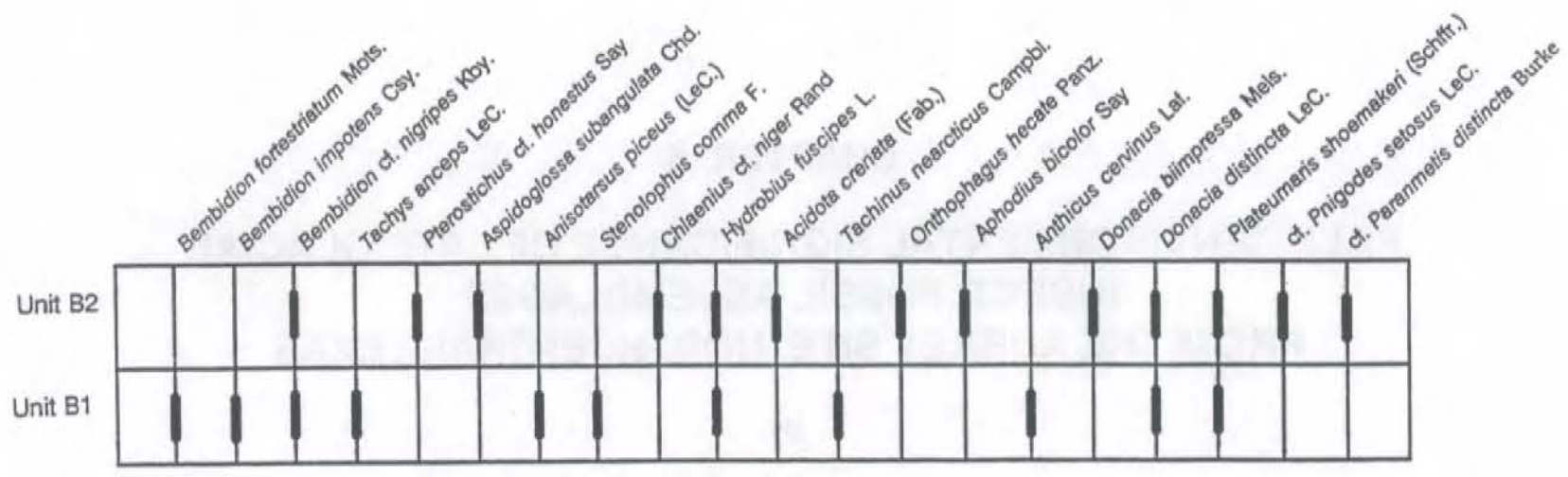

Figure 5.1 Stratigraphic distribution of selected insect taxa from Aubrey.

dominated by these groups. In fact, of the aquatic beetles identified from sediments in the axis of the pond, only two taxa are associated with open water.

Many of the identified species live today only in regions well north of Texas. Several are found in the boreo-montane regions of North America. However, there are no bark beetles or other tree-dwelling taxa in the fossil assemblages. Several of the identified taxa merit further discussion.

\section{Discussion of Selected Taxa}

Several species of ground beetles (Carabidae) were identified from the Aubrey assemblages Table 5.1; Figure 5.1). Species of the genus Bembidion are generally riparian in habit. B. Fortestriatum is often found in oligotrophic swamps, with Carex rostrat (sedge), Potentilla palustre (marsh cinquefoil), Menyanthes (buckbean) and Smilacina trifoliata (false Solomon's seal). Today, this beetle is found across the boreal zone of Canada and Alaska (Lindroth, 1963), with outlying populations in the mountains of Washington, Oregon, Colorado, and New England (Figure 5.2a).

Chlaenius niger is another swamp inhabitant, found in areas of rich vegetation at the edges of pools. It lives today across much of southern and central North America (Lindroth, 1969). Bembidion impotens lives on open shores of lakes and rivers, on clay and sand substrates. This species is found today throughout the United States, ranging north just into southern Canada (Lindroth, 1963).

Bembidion nigripes lives at the margins of lakes and ponds, on firm, moist substrates with little vegetation. This is another boreo-montane species, found today across Canada and Alaska, with extensions into the mountains of Washington, Oregon, and Colorado (Lindroth, 1963). Tachys anceps is also riparian, but found in the upper, or epilittoral zone, on exposed, rather dry sand (often mixed with clay), where vegetation is sparse. This beetle is found today across much of eastern and central North America, as far south as Texas, and as far north as central Canada (Lindroth, 1966). Stenolophus comma occupies similar habitats, but is more widespread across North America. 
Table 5.1 Fossil Insect Faunal List, Aubrey Site. Minimum Number of Individuals Per Sample.

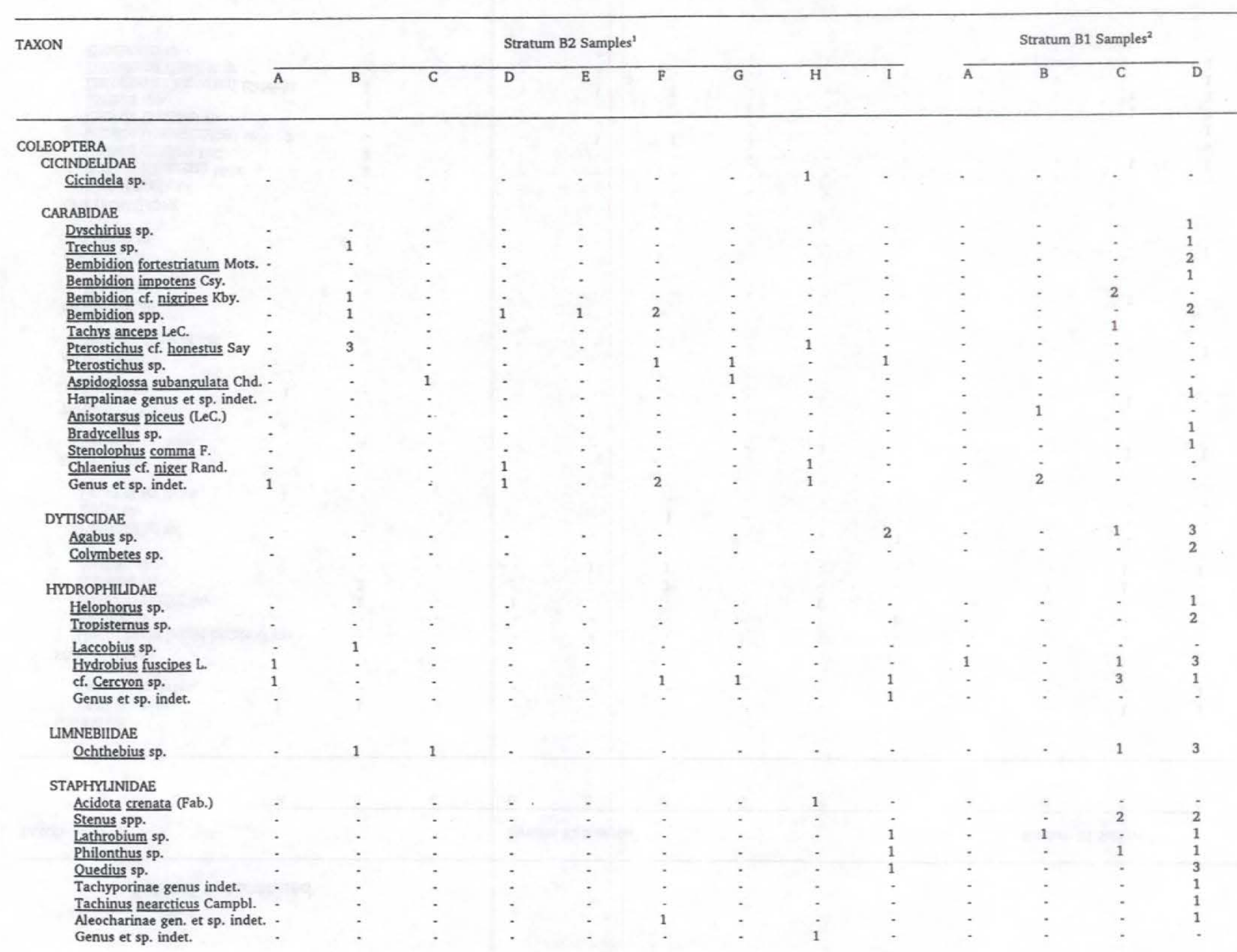


Table 5.1, continued.

\begin{tabular}{|c|c|c|c|c|c|c|c|c|c|c|c|c|c|}
\hline \multirow{2}{*}{ TAXON } & \multicolumn{9}{|c|}{ Stratum B2 Samples' } & \multicolumn{4}{|c|}{ Stratum B1 Samples ${ }^{2}$} \\
\hline & $\bar{A}$ & B & $\mathrm{C}$ & D & $\mathrm{E}$ & $\mathbf{F}$ & G & $\mathrm{H}$ & 1 & $\overline{\mathrm{A}}$ & B & C & $\bar{D}$ \\
\hline \multicolumn{14}{|l|}{ LEIODIDAE } \\
\hline Agathidium sp. & 1 & 1 & - & - & - & . & - & - & - & - & - & 1 & 1 \\
\hline Genus et sp. indet. & . & . & - & $\cdot$ & $\cdot$ & - & - & $\cdot$ & $\cdot$ & $\cdot$ & $\cdot$ & $\cdot$ & 1 \\
\hline \multicolumn{14}{|l|}{ SCARABAEIDAE } \\
\hline Onthophagus hecate hecate (Panz & anz.) & . & - & . & - & - & 1 & - & . & - & - & - & - \\
\hline Aegialia sp. & $\because$ & - & - & - & - & . & . & - & 1 & - & - & - & - \\
\hline Aphodius bicolor Say & - & 1 & - & 1 & - & - & - & 1 & - & - & - & - & . \\
\hline Aphodius spp. & . & 2 & - & 1 & - & 2 & - & . & . & . & 1 & 1 & - \\
\hline Ataenius sp. & - & . & . & . & 1 & 1 & - & - & . & - & . & 1 & 1 \\
\hline Psammodius sp. & - & . & . & . & . & . & . & - & 1 & - & - & - & . \\
\hline Serica sp. & - & - & - & . & - & 1 & - & - & - & - & $\cdot$ & - & . \\
\hline Genus et sp. indet. & 1 & - & - & - & - & $\cdot$ & - & $\cdot$ & - & · & $\cdot$ & - & - \\
\hline \multicolumn{14}{|l|}{ ELATERIDAE } \\
\hline Genus et sp. indet. & - & $\cdot$ & - & - & - & $\cdot$ & $\cdot$ & 1 & - & - & $\cdot$ & 1 & 1 \\
\hline TENEBRIONIDAE & & & & & . & . & . & - & - & . & - & 1 & . \\
\hline Eleodes sp. & 1 & - & $\cdot$ & $\cdot$ & - & $\cdot$ & & & & & & & \\
\hline \multicolumn{14}{|l|}{ ANTHICIDAE } \\
\hline Anthicus cervinus Laf. & - & $\cdot$ & $\cdot$ & $\cdot$ & $\cdot$ & $\cdot$ & - & - & ${ }^{-}$ & & & & 1 \\
\hline \multicolumn{8}{|l|}{ PHALAACRIDAE } & . & . & . & - & 1 & . \\
\hline Phalacrus sp. & - & $\cdot$ & - & $\cdot$ & - & 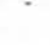 & 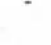 & & & & & & \\
\hline \multicolumn{12}{|l|}{ COLYDIIDAE } & - & \\
\hline Cervlon sp. & - & - & - & $\cdot$ & $\cdot$ & - & - & $\cdot$ & ${ }^{-}$ & & & & 1 \\
\hline \multicolumn{11}{|l|}{ CHRYSOMELIDAE } & & 1 & \\
\hline Neohaemonia sp. & - & i & : & $\cdot$ & : & : & : & $\dot{.}$ & : & . & $\therefore$ & . & . \\
\hline $\begin{array}{l}\text { Donacia biimpressa Mels. } \\
\text { Donacia distincta LeC. }\end{array}$ & - & $\begin{array}{l}2 \\
2\end{array}$ & $\therefore$ & : & $:$ & 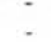 & - & . & . & . & . & 1 & \\
\hline $\begin{array}{l}\text { Donacia } \\
\text { Donacia } \\
\text { (Donaciomima) sp. }\end{array}$ & $\dot{2}$ & 2 & . & - & 1 & $i$ & . & . & . & - & - & . & . \\
\hline $\begin{array}{l}\text { Donacia (Donaciomima) sp. } \\
\text { Donacia (Subtilis) sp. }\end{array}$ & 2 & : & . & . & . & . & - & - & . & - & . & - & 1 \\
\hline & . & 4 & . & . & - & . & 1 & . & . & 1 & - & 1 & \\
\hline & 1 & 1 & . & . & 1 & 1 & . & . & - & - & . & 1 & 1 \\
\hline $\begin{array}{l}\text { Plateumaris shoemakeri (Schfr.) } \\
\text { Plateumaris }\end{array}$ & . & : & . & . & . & . & . & - & . & - & - & - & 1 \\
\hline Plateumaris sp. & . & - & - & - & - & - & - & $\cdot$ & - & $\cdot$ & . & - & 1 \\
\hline
\end{tabular}


Table 5.1, continued.

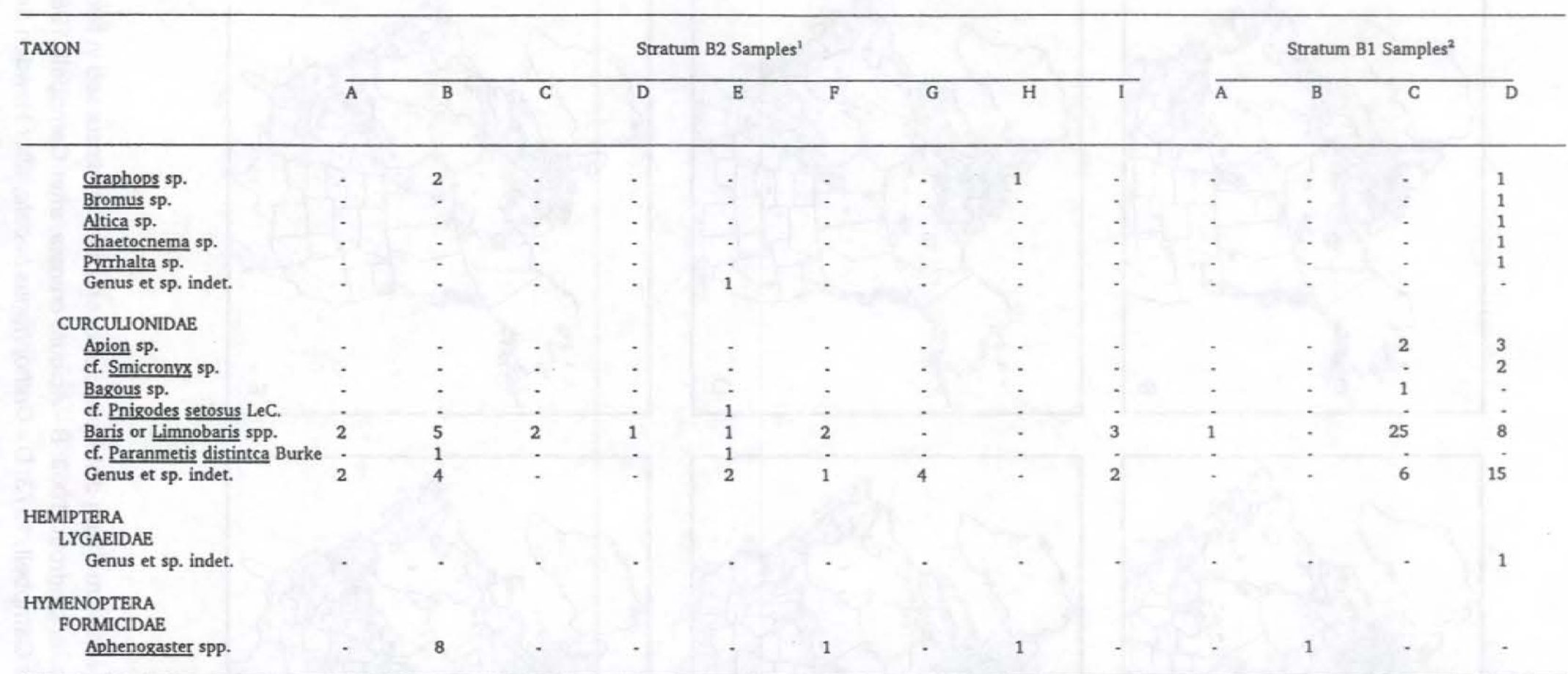

${ }^{1}$ Stratum B2 Samples: A - Trench 1A, Unit B2d, 88.15-88.02 m; B - Trench 1A, Unit B2d, 88.06-87.77m; C - Trench 1, Unit B2d, +10 to $+20 \mathrm{~cm}$; D - Trench 1, Unit B2b, 0 to -10 cm; E - Trench 1 , Unit B2b, -10 to $-20 \mathrm{~cm}$; F - Trench 1A, Unit B2b, 87.9-87.77 m; G - Trench $1 \mathrm{~A}$, unit B2b, 87.77-87.68 m; H - Trench 1, Unit B2a, 0 to $-10 \mathrm{~cm} ; \mathrm{I}-$ Trench 1 , Unit B2a, -40 to $-50 \mathrm{~cm}$.

${ }^{2}$ Stratum B1 Samples: A - Trench 1, Unit B1z, -60 to $-70 \mathrm{~cm}$; B - Trench 1A, Unit B12, 87.23-87.10 m; C - Trench 15, Unit B1d, 170-180 below nail; D - Trench 15, Unit B1bc, 210-230 below nail. 

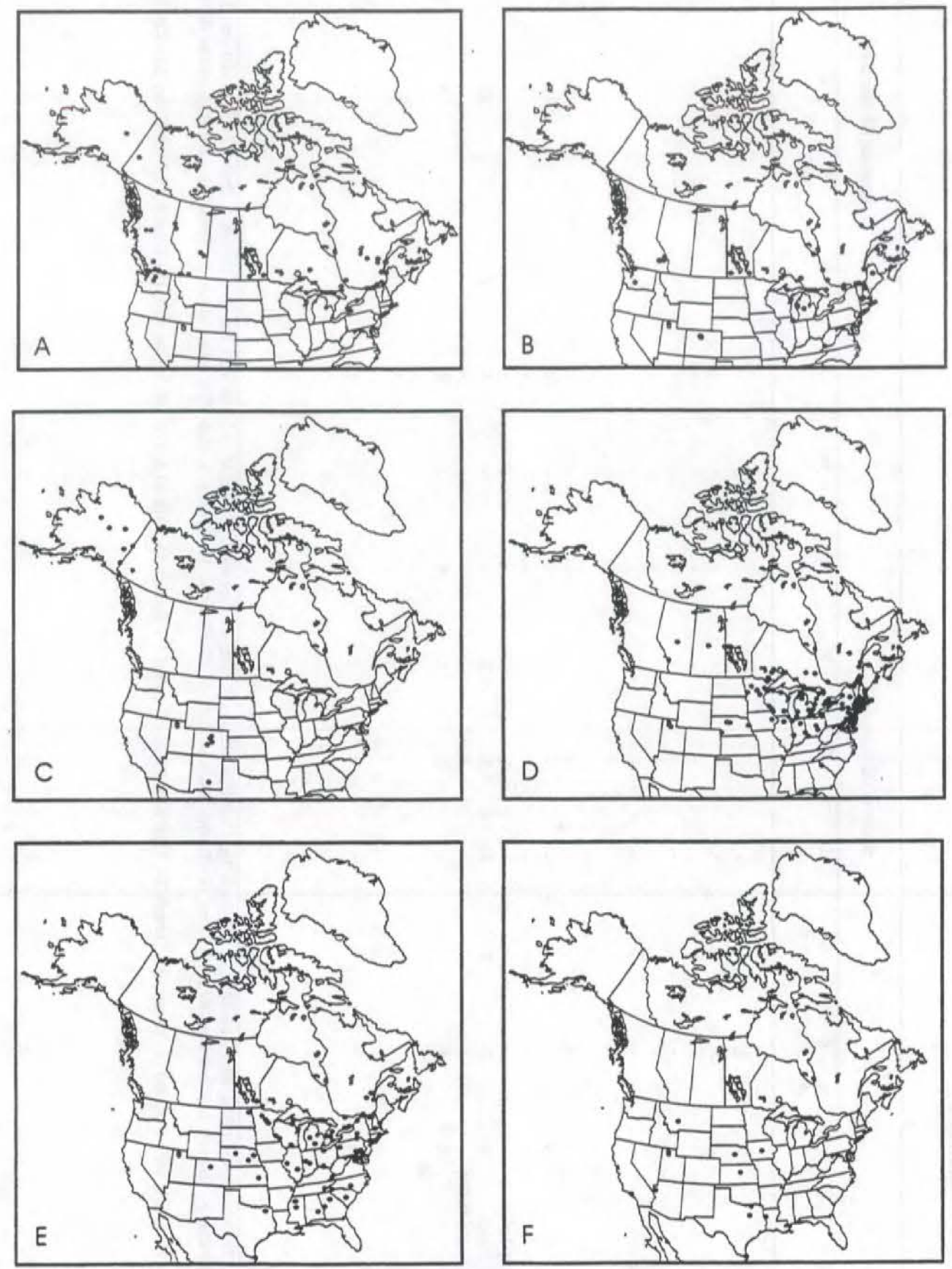

Figure 5.2 Known modern North American distribution of beetle species discussed in text. A Bembidion fortestriatum, after Lindroth, 1963; B - Acidota crenata, after Campbell, 1982; C Tachinus nearcticus, after Campbell, 1973; D - Onthophagus hecate, after Howden and Cartwright, 1963; E - Donacia biimpressa, from I. Askevold, University of Manitoba, written communication, June, 1990; F - Pnigodes setosus, after Tanner, 1943. 
Pterostichus honestus is a predator in deciduous forests, where it is found in shaded localities, under logs, stones and debris. It lives in the southeastern Canada and the eastern United States, as far south as North Carolina and west to Michigan (Lindroth, 1966). Aspidoglossa subangulata is found among sparse vegetation growing on wet clay near the margins of ponds and streams. It is widespread today in the eastern and southeastern United States, as far west as southeastern Texas (Arnett, 1973). Anisotarsus piceus is an upland species of ground beetle, found on dry, open, sandy ground in the eastern and central United States as far south as Texas (Lindroth, 1968).

The variety of predaceous diving beetles (Dytiscidae) and water scavenger beetles (Hydrophilidae) also attest to the presence of a local pond or small lake with abundant vegetation in the littoral zone and open water in the profundal zone. However, in contrast to the gastropod record from the pond deposits, the profundal zone sediments did not contain substantial numbers of open water aquatic beetles. Most of these beetles are in the family Dytiscidae (predaceous water beetles). Only two taxa of dytiscids were found in the Aubrey assemblages. Most of the water scavenger beetles (Hydrophilidae) are associated with the margins of standing water, or with damp habitats near water.

Two species of rove beetles (Staphylinidae) were identified from the Aubrey site assemblages. Acidota crenata is a widely distributed, boreal, Holarctic species. In North America, it ranges across the boreal zone of Canada and Alaska (Figure 5.2b), ranging south to Michigan, northern Indiana and Washington with relict populations in the mountains as far south as North Carolina and Colorado (Campbell, 1982). It has been found living in Polytrichum and Sphagnum bogs at low elevations, in moist leaf litter and wet bog meadows in mountains, as well as dry habitats in pine forests. Tachinus nearcticus is likewise a boreal species, ranging from Labrador to Alaska, with relict populations in the mountains of Colorado and New Mexico (Figure 5.2c). Modern specimens have been collected from grass clumps, dung, moist fungi on Populus, and from under Populus bark (Campbell, 1973).

Two species of dung beetles (Scarabaeidae) were identified. Onthophagus hecate is widespread in North America (Figure 5.2d), feeding on many kinds of dung as well as rotting fruit and fungi (Howden and Carwright, 1963). It shows a preference for cow dung, and in prehistoric times undoubtedly fed on bison dung, which is virtually identical to cow dung. Aphodius bicolor feeds primarily on deer dung. It ranges today from New York to Florida, and west to Kansas and Texas (Gordon, 1983).

Most of the leaf beetles (Chrysomelidae) found in the Aubrey site assemblages are semi-aquatic. Several species of Donacia and Plateumaris were found. The larvae of these genera live submerged in water in the littoral zone of ponds, lakes, and streams. They breathe by piercing the hollow stems of plants (e.g., Typha and Scirpus) with abdominal spines. The adults feed on the exposed parts of the plants. $D$. biimpressa feeds on a variety of semi-emergent vegetation, ranging across the eastern and central United States (Figure 5.2e). Plateumaris shoemakeri has primarily been collected in the eastern United States, but its range extends west to Utah and Alberta (I. Askevold, Entomology Dept., University of Manitoba, written communication, 6/90).

The weevils (Curculionidae) identified from the Aubrey site include specimens tentatively identified as Pnigodes setosus and Paranmetis distincta. P. setosus is found today in the western United States, as far east as Louisiana and lowa (Figure 5.2f). In Texas, it is known to feed on Lepidium (pepper grass) roots 
(Tanner, 1943). P. distincta is known only from Gillespie Co., Texas, where it was collected by sweeping mixed, low vegetation at the edge of a sparsely wooded area (Burke, 1960).

\section{Paleoenvironmental Interpretations}

The insect assemblages from the late glacial sediments at the Aubrey site present a picture of gradually warming local environments from about 14,000 to $13,300 \mathrm{yr}$ BP. Assemblages from both the lower and upper units (Strata B1 and B2, respectively) are indicative of a small pond, situated in a treeless, open landscape. While the pond had open water at the center, the margins were well vegetated with sedges, reeds, and rushes. At least some of the strand around the pond was sparsely vegetated, or barren of vegetation cover.

By plotting the distributions of predatory and scavenging species in the assemblages (i.e., those taxa which are not directly tied to particular vegetation), a region or zone of mutual habitability was found for each the various units of the two strata. The region of distributional overlap for the species in the B1 fossil assemblages is a narrow zone, extending from southwestern Michigan on the west to Vermont on the east, encompassing central Michigan, southern Ontario, and upstate New York. This zone represents a distributional shift of more than $1300 \mathrm{~km}$ from the Aubrey site. Modern mean July temperature at Denton, Texas is $29^{\circ} \mathrm{C}\left(84.5^{\circ} \mathrm{F}\right)$ (National Oceanic and Atmospheric Administration, 1982). The fossil insect record suggests, then, that summer temperatures in the Aubrey site between 14,200 and 13,500 yr BP were depressed by about $10^{\circ} \mathrm{C}$ from modern levels. This is about the same degree of cooling shown by contemporaneous fossil insect faunas from the Lamb Spring site, near Denver, Colorado (Elias and Nelson, 1989; Elias and Toolin, 1990).

The region of distributional overlap for species in the B2 assemblages is farther south, extending from south-central Michigan on the east to northwestern Illinois on the west. Mean July temperatures in this region fall between 20.7 and $23.7^{\circ} \mathrm{C}\left(69.2-74.6^{\circ} \mathrm{F}\right)$, suggesting that regional climatic warming had commenced in north-central Texas by about $13,500 \mathrm{yr} \mathrm{BP}$. The amelioration was on the order of $2^{\circ} \mathrm{C}$ above the summer temperatures at $14,000 \mathrm{yr}$ BP.

This paleoenvironmental reconstruction appears to agree well with the paleobotanical interpretation of the late glacial sediments at the Aubrey site. While the beetle evidence suggests a climatic regime warm enough to support coniferous forest, the assemblages comprise a climatic regime warm enough to support coniferous forest, the assemblages comprise an open ground fauna, which is in agreement with the contemporaneous grassland flora identified from Aubrey. Perhaps there was insufficient effective moisture in the region to support trees in the early late glacial. 


\section{ACKNOWLEDGEMENTS}

The scarabaeid beetle, Aphodius bicolor, was identified by Dr. Robert Gordon, U.S. National Museum of Natural History (Smithsonian), Washington, D.C. The chrysomelids in the genera Donacia and Plateumaris were identified by $\mathrm{Dr}$. Ingolf Askevold, University of Manitoba, Winnipeg. The weevils, Pnigodes and Paranmetis were identified by Dr. Robert Anderson, Canadian Museum of Nature, Ottawa. Scanning electron micrographs of fossil specimens were taken at the U.S. Geological Survey, Denver, with the help of P.E. Carrar and J. Nishi, and at the University of North Texas, with the help of Reid Ferring. 


\title{
CHAPTER 6
}

\section{POLLEN ANALYSIS OF LATE-GLACIAL POND AND SPRING DEPOSITS, AUBREY CLOVIS SITE, DENTON CO., TEXAS}

by

\author{
Stephen A. Hall
}

Introduction

\begin{abstract}
Late-glacial-age pollen records in the southern Great Plains are rare. Sediments at the Aubrey site provide an unusual opportunity to document past vegetation during the transition from glacial to postglacial climates in northcentral Texas. Pollen-bearing pond and spring deposits at the site are radiocarbon-dated 13,200 to 14,200 years BP, providing a 1000-year record of local and regional lateglacial vegetation. Unfortunately, younger Pleistocene and Holocene alluvium overlying the pond and spring sediments are either barren of pollen or the pollen grains are too poorly preserved to allow a reliable reconstruction of past vegetation.
\end{abstract}

\section{Methods}

Pollen samples were collected by the writer from four stratigraphic sections that were open in January 1989. The pollen record comes from Sections $1 A$ and $2 A$. Pollen grains are not well preserved or are absent in Sections $1 \mathrm{~B}$ and $1 \mathrm{C}$ and in the upper part of $2 \mathrm{~A}$. The pollen succession is a combination of two stratigraphic sections that, together, total about $215 \mathrm{~cm}$ of pollen-bearing sediments. The lower section, about $130 \mathrm{~cm}$ thick, is from the pond deposits (Trench 2A, stratigraphic Unit B1) and is characterized by high percentages of Poaceae and low percentages of Cyperaceae. The upper section, about $85 \mathrm{~cm}$ thick, consists of spring deposits (Trench 1A, Stratigraphic Unit B2) that overlie the pond sediments and are characterized by comparatively low percentages of Poaceae and high percentages of Cyperaceae.

Initial sample preparation was done by Dr. John Jones, Palynology Laboratory, Texas A \& M University. Sample preparation followed routine laboratory procedures, preceded by the addition of a spike of $L y$ copodium-spore tablets $(11,267 \pm 370$ spores per tablet; batch 201890$)$ to the dried and weighed sediment. Spiked samples were washed in $\mathrm{HCl}, \mathrm{HF}$, heavy liquid separation with zinc chloride, a second $\mathrm{HF}$, and finally acetolysis. The resulting residues were stained in safranin $\mathrm{O}$ and counted by the writer at the Palynology Laboratory, University of Texas at Austin. In addition to pollen grains and fern spores, colonies of algae (Pediastrum and Botryococcus), and recycled Cretaceous spores, pollen, and dinoflagellates were also counted. 
Modern Pollen from Surface Duff

Two modern surface samples were collected from near the Aubrey site for comparison of the pollen signature of the modern vegetation with that from the late-glacial deposits. The modern pollen counts are included in Table 6.1. Surface sample A (SS-A) was collected from tallgrass rangeland of the Grand Prairie about one mile west of the Aubrey site. Surface sample B (SS-B) was collected about onehalf mile east of the Aubrey site from the post-oak/blackjack oak forest of the Eastern Cross Timbers, Denton County, Texas. The boundary between the Grand Prairie and the Eastern Cross Timbers in northcentral Texas is sharp, related to clayey versus sandy soils.

Within ten miles of the Aubrey site, a series of Tauber traps was established in the tallgrasses of the Grand Prairie, providing pollen influx data for the year 1984 (Hall 1992). Pollen data from these traps correspond to pollen from SS-A and together show the relationship between modern vegetation and the pollen assemblages produced by that vegetation.

\section{Results}

The pollen analyses are based on large counts, generally in excess of 800 grains, in order to document the presence of rare pollen taxa. Also, grass pollen grains dominate the lower part of the section, averaging $90 \%$, which can mask the presence of other taxa. All pollen counts, including data from two modern surface-duff samples, are presented in Table 6.1.

\section{Pollen Preservation}

In the south-central United States beyond the glacial border, pollen-bearing material from lateQuaternary stratigraphic sections are not common. Over the years, Vaughn Bryant and the writer have completed numerous pollen studies of sediments from various geologic and archeological contexts (Bryant and Hall 1993; Bryant and others 1994; Hall 1995). Bryant and I have identified several criteria, discussed in the above papers, by which the credibility of a pollen assemblage can be evaluated. The pollen record presented in this paper is based on very well preserved pollen assemblages. Pollen concentrations range from 5,000 to 97,000 grains per gram of processed material, a large amount of pollen but similar to the pollen content of other lacustrine sediments in the region (Hall and Valastro 1995). Individual grain preservation from the spectra presented and discussed here is also excellent.

\section{Recycled Cretaceous Spores, Pollen, Dinoflagellates}

A noteworthy aspect of the palynology of the Aubrey site pond and spring deposits is the presence of numerous recycled Cretaceous palynomorphs. The late Pleistocene sediments of the Aubrey site occur within a small valley that previously had been eroded into Cretaceous bedrock. Several hundred feet north of the site are exposures of fossiliferous marls of the Weno Limestone (Barnes, 1967). The palynology of the Denton Shale, occurring under the Weno, has been studied previously (Wingate, 
Table 6.1. Pollen counts, Aubrey Clovis Site, Denton Co., Texas

\begin{tabular}{|c|c|c|c|c|c|c|c|c|c|c|c|c|c|}
\hline pollen taxa & $\$ 1$ & \#2 & \#3 & $\# 4$ & $\# 5$ & 16 & $\$ 7$ & "⿻8 & \#9 & $\# 10$ & $\# 11$ & SS-A & SS-B \\
\hline Picea & 1 & 2 & 2 & 1 & 3 & 1 & 3 & 3 & 1 & 0 & 1 & 0 & 0 \\
\hline Pinus & 1 & 2 & 1 & 5 & 12 & 12 & 9 & 13 & 8 & 26 & 16 & 13 & 1 \\
\hline Juniperus & 5 & 5 & $\theta$ & 7 & 22 & 29 & 38 & 22 & 32 & 13 & 11 & 16 & 1 \\
\hline Quercus & 14 & 24 & 15 & 15 & 15 & 33 & 28 & 28 & 35 & $\theta$ & 43 & 60 & 210 \\
\hline Carya & 0 & 0 & 0 & 1 & 0 & 1 & 0 & 1 & 3 & 0 & 0 & 6 & 39 \\
\hline Ulmus & 0 & 0 & 0 & 0 & 0 & 0 & 0 & 0 & 0 & 0 & 0 & 13 & 34 \\
\hline Thilia & 0 & 0 & 0 & 1 & $\therefore 0$ & 0 & 0 & 0 & 0 & 0 & 0 & 0 & 0 \\
\hline Celtis & 0 & 0 & 0 & 0 & 0 & 0 & 0 & 0 & 0 & 1 & 0 & 0 & 0 \\
\hline Corylus & 1 & 4 & 4 & 3 & 4 & $\theta$ & 5 & 8 & 11 & 0 & 0 & 0 & 0 \\
\hline Fraxinus & 3 & 8 & 2 & 3 & 7 & 13 & 6 & 13 & 7 & 9 & 6 & 8 & 10 \\
\hline Acer saccharum & 0 & 0 & 0 & 0 & 0 & 1 & 0 & 0 & 0 & 0 & 0 & 0 & 0 \\
\hline Acer rubrum & 0 & 0 . & 0 & 0 & 0 & 0 & 1 & 0 & 0 & 0 & 0 & 0 & 0 \\
\hline Betula & 0 & 0 & 0 & 0 & 0 & 0 & 0 & 1 & 0 & 0 & 0 & 0 & 0 \\
\hline Prosopis & 0 & 0 & 0 & 0 & 0 & 0 & 0 & 0 & 0 & 0 & 0 & 3 & 2 \\
\hline Populus & 6 & 1 & 5 & 1 & 2 & 3 & 0 & 0 & 4 & 2 & 8 & 0 & 0 \\
\hline Anus & 2 & 6 & 7 & 6 & 100 & 22 & 86 & 36 & 29 & 246 & 2 & 0 & 0 \\
\hline Salix & 2 & 1 & 0 & 1 & 14 & 19 & 35 & 4 & 10 & 5 & 2 & 1 & 2 \\
\hline Planera aquatica & 1 & 3 & 5 & 8 & 0 & 16 & 3 & 18 & 2 & 0 & 0 & 0 & 0 \\
\hline Poacaae & 675 & 641 & 763 & 750 & 134 & 138 & 141 & 97 & 115 & 125 & 72 & 94 & 63 \\
\hline Ambrosia & 7 & 7 & 9 & 3 & 37 & 31 & 14 & 22 & 26 & 41 & 62 & 101 & 61 \\
\hline Franseria & 2 & 3 & 2 & 2 & 1 & 0 & 0 & 0 & 0 & 4 & 5 & 0 & 0 \\
\hline Cirsium & 1 & 0 & 0 & 0 & 7 & 2 & 4 & 2 & 1 & 3 & 0 & 0 & 0 \\
\hline Artemisia & 6 & $\theta$ & 7 & 7 & 13 & 10 & 22 & 18 & 11 & 6 & 15 & 4 & 1 \\
\hline Ligulifforae & 0 & 0 & 0 & 0 & 0 & 0 & 0 & 0 & 0 & 0 & 0 & 0 & 1 \\
\hline Asteraceae short 2-4um & 7 & 3 & 7 & 18 & 78 & 52 & 35 & 45 & 53 & 42 & 93 & 50 & 21 \\
\hline Asteraceae tong $>4 \mu \mathrm{m}$ & 12 & 15 & 10 & 17 & 85 & 64 & 62 & 44 & 44 & 29 & 17 & 78 & 1 \\
\hline Chenopodiaceae & 4 & 0 & 1 & 1 & 7 & 6 & 8 & 6 & 5 & 4 & 8 & 14 & 11 \\
\hline Amaranthaceae & 0 & 0 & 0 & 0 & 0 & 0 & 2 & 0 & 0 & 0 & 0 & 0 & 0 \\
\hline Rubus & 0 & 0 & 0 & 0 & 0 & 18 & 1 & 7 & 0 & 0 & 0 & 0 & 0 \\
\hline Urtica & 0 & 0 & 0 & 0 & 0 & 10 & 0 & 3 & 2 & 0 & 0 & 0 & 0 \\
\hline Myrica & 0 & 0 & 0 & 0 & 0 & 0 & 1 & 1 & 0 & 0 & 0 & 0 & 0 \\
\hline Rumex & 0 & 0 & 0 & 0 & 0 & 0 & 0 & 3 & 0 & 0 & 0 & 0 & 0 \\
\hline Rhus & 0 & 0 & 0 & 0 & 0 & 0 & 0 & 0 & 0 & 0 & 0 & 1 & 1 \\
\hline Eriogonum & 0 & 0 & 0 & 0 & 0 & 0 & 1 & 0 & 0 & 0 & 0 & 0 & 0 \\
\hline Onagraceae & 0 & 0 & 0 & 0 & 0 & 0 & 0 & 0 & 0 & 1 & 0 & 0 & 0 \\
\hline Rosaceae & 0 & 2 & 1 & 0 & 0 & 0 & 1 & 0 & 2 & 0 & 0 & 0 & 0 \\
\hline Apiacaee & 3 & 1 & 3 & 5 & 16 & 22 & 15 & 8 & 14 & 12 & 24 & 0 & 0 \\
\hline Brassicaceae & 6 & 1 & 7 & 1 & 38 & 2 & 0 & 13 & 9 & 11 & 33 & 4 & 1 \\
\hline Caryophyllaceae & 1 & 0 & 0 & 0 & 0 & 0 & 0 & 0 & 0 & 0 & 0 & 0 & 0 \\
\hline Polygonaceae & 0 & 0 & 0 & 0 & 1 & 0 & 0 & 0 & 2 & 0 & 0 & 0 & 0 \\
\hline Lamiaceae & 0 & 0 & 0 & 0 & 4 & 0 & 0 & 0 & 0 & 0 & 0 & 0 & 0 \\
\hline Thalictricum & 1 & 0 & 1 & 0 & 0 & 8 & 1 & 6 & 6 & 1 & 1 & 0 & \\
\hline Uliaceae & 0 & 0 & 0 & 0 & 0 & 1 & 5 & 1 & 3 & 0 & 0 & 0 & 0 \\
\hline Cyperaceae & 53 & 48 & 41 & 161 & 147 & 237 & 393 & 298 & 405 & 333 & 534 & 2 & 0 \\
\hline Typha latifolia & 0 & 1 & 4 & 10 & 6 & 6 & 3 & 5 & 5 & 0 & 1 & 0 & \\
\hline T. angustifolia/Sparganium & 1 & 1 & 3 & 2 & 12 & 10 & $\theta$ & 12 & 11 & 10 & 3 & 2 & \\
\hline Nuphar & 0 & 0 & 0 & 1 & 0 & 0 & 0 & 0 & 0 & 0 & 2 & 0 & 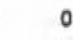 \\
\hline Nymphaea & 0 & 0 & 0 & 0 & 0 & 0 & 2 & 0 & 0 & 0 & 0 & 0 & \\
\hline Sagittaria & 4 & 5 & 2 & 5 & 0 & 4 & 0 & 3 & 0 & 1 & 0 & 0 & 0 \\
\hline Utricularia & 0 & 1 & 1 & 2 & 0 & 0 & 0 & 0 & 0 & 0 & 0 & 0 & 0 \\
\hline Myriophyllum & 1 & 0 & 1 & 0 & 1 & 0 & 2 & 5 & 0 & 0 & 1 & 0 & 0 \\
\hline Polypodiaceae & 0 & 0 & 0 & 0 & 2 & 5 & 1 & 1 & 3 & 3 & 2 & 0 & 0 \\
\hline Pediastrum & 10 & 0 & 5 & 3 & 0 & 1 & 3 & 1 & 4 & 0 & 0 & 0 & 0 \\
\hline Botryococcus & 8 & 2 & 0 & 0 & 1 & 2 & 4 & 0 & 8 & 0 & 0 & 0 & 0 \\
\hline unknown & 14 & 6 & 13 & 12 & 36 & 39 & 39 & 16 & 28 & 24 & 13 & 13 & 4 \\
\hline indeterminable & 6 & 5 & 10 & 4 & 34 & 13 & 26 & 11 & 13 & 4 & 38 & 7 & 6 \\
\hline total & 858 & 806 & 941 & 1056 & 837 & 840 & 1005 & 773 & 913 & 962 & 1013 & 480 & 470 \\
\hline lycopod spike counted & 14 & 33 & 33 & 25 & 295 & 118 & 140 & 105 & 109 & 133 & 75 & 42 & 31 \\
\hline grams processed & 36.6 & 27 & 22.5 & 19.6 & 25.5 & 19 & 14.9 & 17.6 & 14.4 & 19.7 & 22.6 & 8.8 & 7.4 \\
\hline Iycopod tablets added & 4 & 4 & 4 & 4 & 4 & 4 & 3 & 3 & 3 & 4 & 4 & 4 & 4 \\
\hline concentration/gram & 75,300 & 40,800 & 57,100 & 97,100 & 5,010 & 16,900 & 16,300 & 14,100 & 19,700 & 16,400 & 26,900 & 59,100 & 92,300 \\
\hline K spores/pollen & 209 & 73 & 33 & 21 & 57 & 32 & 84 & 42 & 50 & 28 & 36 & 0 & 0 \\
\hline K dinoflageliates & 68 & 33 & 46 & 3 & 76 & 20 & 85 & 33 & 56 & 13 & 13 & 0 & 0 \\
\hline K palynomorph concigram & 24,400 & 5,360 & 4,800 & 2,210 & 797 & 1,040 & 2,740 & 1,370 & 2,280 & 705 & 1,300 & 0 & 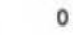 \\
\hline
\end{tabular}


1980). The writer sampled and processed material from the Weno and found it to contain large amounts palynomorphs at the Aubrey site, excluding range from 2 to $24 \%$ of all of the Cretaceous and Quaternary Cretaceous palynomorphs ranges from 700 to 24,000 per grarticles. The concentration of recycled site.

The Cretaceous spores and pollen are readily distinguishable from late Quaternary spores and pollen by their distinctive morphology. The Cretaceous material also takes on a darker stain in safranin 0 than does the Quaternary pollen, a characteristic of recycled organic-walled microfossils observed in Quaternary deposits hav4). Similar cases of Cretaceous spores and pollen becoming recycled into late examples, recycled Cretaceous pollen stained New Mexico and Colorado (Hall 1977). In all of these staining can be helpful in recognizing Cretaceous pollen the Quaternary pollen. Although differential pivotal criterion is grain morphology.

The presence of large numbers of Cretaceous palynomorphs in the late-glacial sediments indicates that clastic-sediment transport, likely via fluvial processes, contributed significant amounts of particles to the pond and spring basins. This indicates as well that the late-glacial-age pollen small watershed of the late-glacial predecesonent of stream derived pollen grains originating from the include a strong signal from upland non-ripari of the Elm Fork Trinity River. In turn, the pollen spectra communities.

\section{Recycled Cretaceous Pollen, Radiocarbon Dating, $\delta{ }^{13} \mathrm{C}$}

Recycled "old" or "dead" carbon is always a potential source of error in radiocarbon-age determinations of sediments. The large amount of dead carbon that occur in the late Pleistocene Aubrey deposits, in the form of recycled Cretaceous palynomorphs, represent a source of error in radiocarbon of solid organic matter from the valley fill deposits would sediments. Furthermore, carbon isotope content Cretaceous organic-walled microfossils. The infle would also be affected by the presence of recycled content of the sediments is unknown.

\section{Discussion}

\section{Pollen Diagram}

The pollen data shown in the pollen diagram are divided into three habitat categories: upland, riparian, and wetland-lacustrine (Figure 6.2). The percentages of upland taxa are calculated independent of the counts of taxa from other habitats. The percentages of riparian taxa are calculated from a 

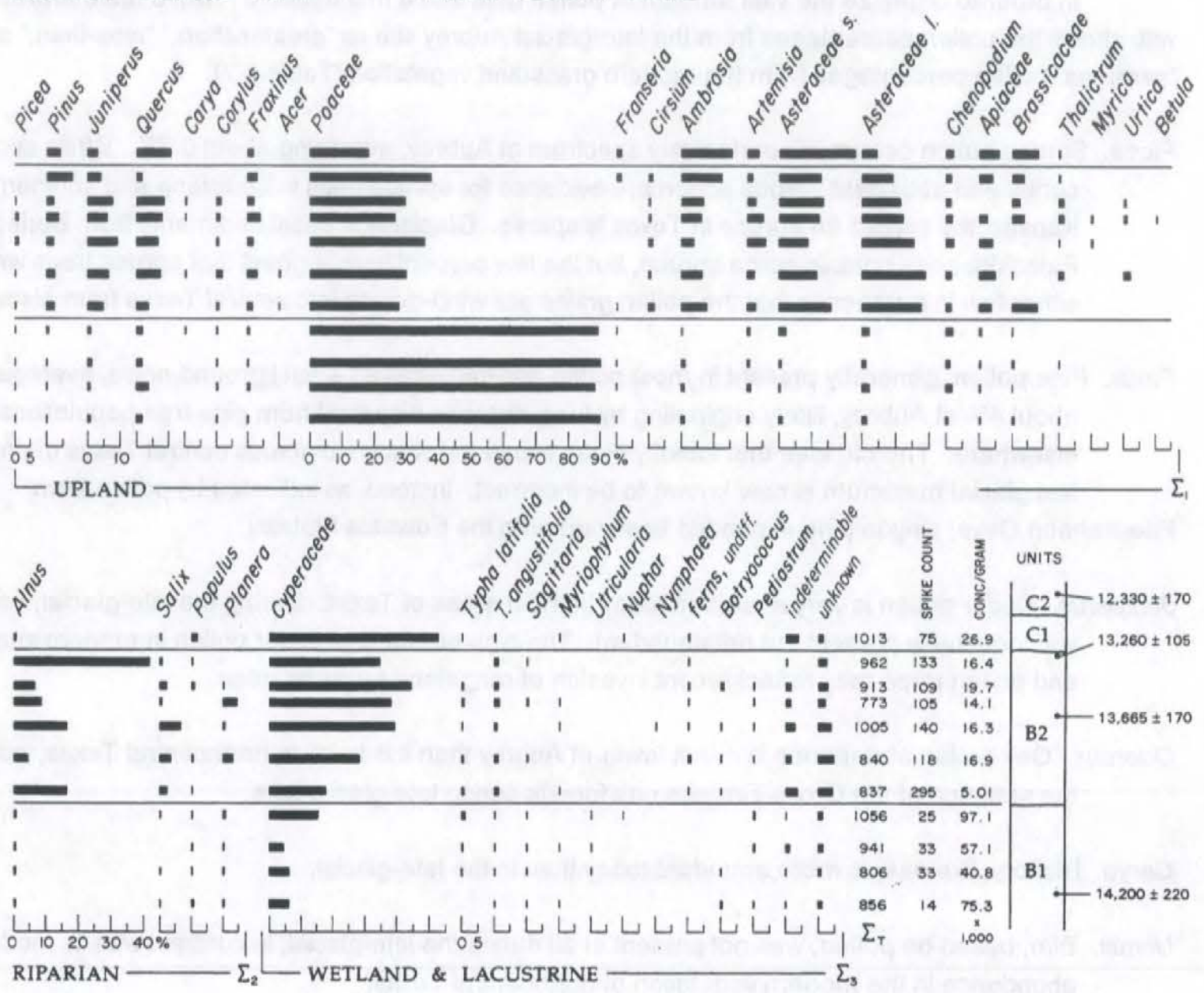

Figure 6.1 Summary Pollen Diagram of the Aubrey Clovis Site. Samples are from pond (Unit B1) and spring (Unit B2) deposits. The pollen record extends through $215 \mathrm{~cm}$ of sediments radiocarbon-dated ca. 13,200 to $14,200 \mathrm{bp}$.

cumulative pollen sum based on both upland and riparian taxa. Finally, the percentages of wetlandlacustrine taxa are calculated from the sum of all the pollen counts. In this way, the percentages of upland pollen taxa are not influenced by non-upland pollen counts. This procedure does not get around the problem that some pollen grains, such as those from grasses, could originate from plants that thrive in all three habitats. 
In order to organize the vast amount of pollen data into a manageable form, a table is presented with shows the pollen percentages from the late-glacial Aubrey site as "greater-than," "less-than," and

Picea. Spruce pollen occurs in nearly every spectrum at Aubrey, averaging about $0.5 \%$. While spruce cones and abundant spruce pollen are evidence for spruce trees in Louisiana and southern Kansas, the record for spruce in Texas is sparse. Glacial-age basal sediments from Boriack and Patschke bogs contain some spruce, but the low percentages suggest that spruce trees were either few in number or that the pollen grains are wind-drifting into central Texas from elsewhere.

Pinus. Pine pollen, generally present in most pollen assemblages as a background noise, averages only about $4 \%$ at Aubrey, likely originating by long-distance dispersal from pine tree populations elsewhere. The old idea that loblolly pines expanded westward across central Texas during the

Friesenhahn Cave, pinyon pine known to be incorrect. Instead, as indicated by pollen from

Juniperus. Cedar pollen is very abundant today in most areas of Texas. During the late-glacial, cedar was nominally present but not abundant. The high amounts of cedar pollen in modern samples and pollen traps may reflect recent invasion of rangeland by cedar trees.

Quercus. Oak pollen abundance is much lower at Aubrey than it is today in northcentral Texas, indicating the absence of the Cross Timbers oak forests during late-glacial time.

Carya. Hickory, like oak, is more abundant today than in the late-glacial.

Ulmus. Elm, based on pollen, was not present at all during the late-glacial, in contrast with its moderate abundance in the modern vegetation of northcentral Texas.

Fraxinus. Ash abundance appears to be about the same today as in the past.

Corylus. Hazelnut was present during the late-glacial even though it is absent today from the Texas flora.

Planera aquatica. The water-elm is a small tree which inhabits swamps and flooding river bottoms in east Texas and adjacent states. The Aubrey site is the first fossil record of the species in Texas.

Alnus. Alder occurs in riparian habitats in Texas today. During the late-glacial, however, alder was abundant at the Aubrey site as well as other riparian localities such as at Boriack and Patschke

Poaceae. Grass pollen is very abundant at the Aubrey site. The grass percentages in the upper part of the diagram are significantly higher than grass percentages from modern prairies in the Great 
Table 6.2. Late-Glacial Pollen Percentages vs. Modern Grassiand Pollen Percentages

\section{GREATER-THAN-TODAY LESS-THAN-TODAY SAME-AS-TODAY}

$\begin{array}{ll}\text { Picea } & \mathrm{X} \\ \text { Pinus } & \mathrm{X} \\ \text { Corylus } & \mathrm{X} \\ \text { Poaceae } & \mathrm{X} \\ \text { Artemisia } & \mathrm{X} \\ \text { Asteraceae short } & \mathrm{X}\end{array}$

Quercus

$x$

Carya

$x$

Ulmus

Ambrosia

$x$

$\mathrm{x}$

Chenopodiaceae

$x$

Fraxinus

$x$

Asteraceae long

$\mathrm{x}$

Plains. In the lower half of the diagram, the $90 \%$ values of grass are virtually unprecedented in U.S. pollen records. The extremely high percentages may represent aquatic grasses in the pond habitat of the Aubrey site. A similar relationship has been documented at the Garnesy bison kill site in New Mexico where higher percentages of grass pollen were associated with late Holocene spring deposits.

Ambrosia. Ragweed pollen is much more abundant today than during the late-glacial. How much of this modern abundance is due to historic human disturbance and agriculture and how much is natural plant-community development is not yet known. Part of the definition of Ambrosia pollen is spine length, less than $2.0 \mu \mathrm{m}$. Some workers define Ambrosia spine length less than $3.0 \mu \mathrm{m}$. One of the issues concerning the identification of Ambrosia pollen is that, when pollen grain preservation is poor, spines tend to shrink in size. The Ambrosia and other Asteraceae pollen grains in this study, however, are excellently preserved and their spine lengths are true.

Franseria. This genus has been recently placed in synonymy with Ambrosia. However, its pollen-grain morphology is distinct from Ambrosia and is separated out in this study. 
Asteraceae. The sunflower family includes hundreds of species in this region. Pollen grains in the family are difficult to identify to genus and species. In this study, Asteraceae pollen is divided into two "Asteraceae long" with spin: "Asteraceae short" with spines 2 to $4 \mu \mathrm{m}$ in length, and abundant during the late-glacial, while $4 \mu \mathrm{m}$ in length. Asteraceae-short pollen was more as today.

Artemisia. Sagebrush, or sand sage, pollen was more abundant during the late-glacial, although in low percentages. An Artemisia-grassland was present on the southern High Plains during the last transport from the and the late-glacial Artemisia pollen at Aubrey may represent long-distance

Apiaceae. Pollen grains from plants in the carrot family are much more common during the late-glacial
than today.

Brassicaceae. Plants in the mustard family were evidently more abundant during the late-glacial than
today.

Chenopodiaceae. Chenopods seem to have had the same abundance during the late-glacial as today.

\section{Late-Glacial Upland Grassland Vegetation}

The pollen spectra are dominated by grasses (Poaceae) and flowers from the sunflower family (Asteraceae), the mustard family (Brassicaceae), and the parsley family (Apiaceae). Tree pollen is a minor component of the pollen spectra. Pollen of spruce (Picea) and pine (Pinus) are in such low tree populations far a mackground rain of pollen originating by long-distance transport from Indeed, their percentages may also represend cedar (Juniperus) were much less abundant than today. modern-day Cross Timber oak vegetation was nockround rain from distant trees (Hall 1990, 1994); the rare or present only at some distance from the present during the late-glacial. Hickory (Carya) was the region. The upland vegetation was clear the Aubrey site, and elm (Ulmus) was completely absent from somewhat more abundant than in the regioly a treeless grassland. Although Artemisia pollen was grassland that occurred in the southern 1995). Instead it was treeless, shrubless grasslains during the last glacial maximum (Hall and Valastro Plains. 
Riparian Vegetation

The small late-glacial valley, a predecessor to the modern Elm Fork, was dominated by trees and shrubs of alder (Alnus), willow (Salix), water-elm (Planera aquatica), and a few cottonwoods (Populus). The late-glacial riparian vegetation was very different from the riparian vegetation of north and east Texas today in which alder and water-elm are rare elements on floodplains. It is not clear why the late-glacial riparian plant communities differ from those of today.

Wetland and Lacustrine Vegetation

The pond and spring deposits indicate a locally high watertable, with respect to the floodplain, during late-glacial time, and the pollen content reflects those environments. The late-glacial wetland and lacustrine pollen record is dominated by sedges (Cyperaceae). The presence of common cattail (Typha latifolia), narrow-leaved cattail (Typha angustifolia or bur-reed Sparganium; pollen is indistinguishable), water-lily (Nymphaea), cow-lily (Nuphar), water-milfoil (Myriophyllum), arrowhead (Sagittaria), and bladderwort (Utricularia) all indicate a shallow, permanent pond. All the above species except cattails are perennial aquatics, requiring a permanent pond with a sufficiently shallow water depth to allow the plants to form roots in pond mud. The presence of colonies of freshwater green algae Pediastrum and Botryococcus also indicates a former aquatic environment (Batten, 1996; Batten and Grenfell, 1996).

\section{Conclusions and Summary}

Paleovegetation

A late-glacial record of well-preserved pollen, radiocarbon dated 13,200 to 14,200 years yr B.P., is documented from pond and spring deposits at the Aubrey Clovis site. The pollen spectra are characterized by high percentages of grasses and other herb taxa and by low percentages of tree taxa. The pollen assemblages compare favorably with those from modern grasslands in the southern Great Plains. Thus, the late-glacial upland vegetation is interpreted as a grassland.

The late-glacial riparian vegetation on the floodplain of the predecessor of the Elm Fork was characterized by trees and shrubs of alder, willow, and water-elm, different from modern-day floodplain plant communities. The pond and spring areas were characterized by sedges, cattail, water-lily, and other aquatic plants that require permanent, shallow water. The pollen record shows that the locally high water table and associated spring and pond persisted a minimum of 1000 years, the time period represented by the pollen-bearing sequence. 


\section{Paleoclimate}

Today, grasslands occur in a wide range of climates in North America, both with greater and lesser amounts of precipitation and higher and lower temperatures than found today in northcentral Texas. Consequently, a paleoclimatic reconstruction for the late-glacial grassland likely falls within the climatic parameters of modern prairies but, specifically, is inconclusive. 


\title{
Chapter 7
}

\section{MOLLUSCAN REMAINS FROM THE AUBREY SITE (41DN479)}

\author{
by \\ Raymond W. Neck
}

Introduction

Molluscan shells can provide detailed information about Quaternary environments. The existence of sediments at the Aubrey Site (41DN479) that have been dated by radiocarbon analysis and contain a large number of molluscan shells representing a large number of species provides an opportunity to examine environments during the Late Wisconsinan of north-central Texas.

\section{Methods and Results}

Sediment samples representing a terrace swale fill $(\mathrm{Qa})$ and both the pond margin (B1y, B1z, B2a, $\mathrm{B} 2 \mathrm{~b}$, and B2d) and the pond axis (B1b, B1c, B2, C1, C2, E1, and E2) of the Aubrey Site were provided to the author. These samples were water-screened through a nested seris of standard soil sieves (\#8, \#16, \#30), except for the Qa sample, which consisted of shells already separated from the matrix. After the resultant material was air dried, the shell material was manually separated and placed into containers awaiting the identification process.

Identification was accomplished by familiarity with many of the species due to previous experience in either field collection of live material or lab identification of shell material from previous studies on molluscan paleoassemblages. Shell material not immediately identifiable was compared to standard identification manuals (Pilsbry 1939-1948; Burch 1962, 1972, 1975, 1982; Cheatum and Fullington 1971, 1973; Fullington and Pratt 1974; Fullington 1978; Clarke 1981) and the author's personal reference collection. Use of the latter resource was particularly valuable when only portions of the original shell remained in the paleoassemblages. Paleoenvironmental reconstruction techniques involved assimilating the preferred habitats of extant populations of the constituent species with knowledge of the geographical and geological location of the source of the particular paleoassemblage. Counts were made of the adult and immature shells of each species. The resultant counts are provided in Tables 7.1 - 7.3.

\section{Annotated List of Species}

A total of $\mathbf{4 5}$ molluscan species were recovered from sediment samples removed from the Aubrey Site (41DN479). The five freshwater bivalve species include two fingernail clams and three pea clams. The gastropod assemblage of 40 species includes 13 freshwater (three prosobranchs and 10 pulmonates) and 27 terrestrial species (one prosobranch and 26 prosobranchs). Range and habitat information provided below are derived from the author's personal observation or from literature sources (identification manuals listed above in addition to Hubricht 1985). Nomenclature follows Turgeon and others (1988). 
Table 7.1 Molluscan remains from the Carrollton Alluvium - Terrace Swale.

\begin{tabular}{|c|c|c|c|}
\hline TAXON & Adults & Immature & Total \\
\hline \multicolumn{4}{|l|}{ BIVALVES } \\
\hline Sphaerium striatinum & 8 & & 8 \\
\hline Musculium transversum & 1 & & 1 \\
\hline Pisidium caesertanum & 5 & & 5 \\
\hline OPERCULATE GASTROPODS (Freshy & \multicolumn{3}{|c|}{7} \\
\hline Valvata tricarinata & 76 & 276 & 352 \\
\hline Pomatiopsis cincinnatiensis & 8 & 22 & 30 \\
\hline \multicolumn{4}{|c|}{ PULMONATE GASTROPODS ( Freshwater) } \\
\hline Gyraulus parvus & 19 & 62 & 81 \\
\hline Heliosoma anceps & 4 & 7 & 11 \\
\hline Fossaria obrussa & 0 & 4 & 4 \\
\hline Physella gyrina & 4 & 1 & 5 \\
\hline \multicolumn{4}{|l|}{ PULMONATE GASTROPODS (Terrestrial) } \\
\hline Strobilops texasiana & 0 & 1 & 1 \\
\hline Heliodiscus singleyanus & 4 & 0 & 4 \\
\hline TOTAL & 129 & 373 & 502 \\
\hline
\end{tabular}

Taxa in bold are extirpated from region

Sphaerium striatinum found in moving or high-quality still water
Canada, the United States, and Mexico.

Musculium transversum typically found in large lakes, sloughs, and moving streams on a mud substrate in Canada, the United States, and Mexico.

Pisidium casertanum

probably the most widely distributed freshwater bivalve in the world. This species is found in a great variety of freshwater habitats throughout North and South America, Eurasia, Africa, and Australia.

Pisidium compressum

Pisidium nitidum

Oligyra orbiculata normally found associated with aquatic vegetation in permanent lakes, streams, ponds, and rivers throughout North America and southward into Mexico.

may be found in various types of permanent, shallow water bodies in North America, Mexico, Eurasia, and northern Africa.

the only terrestrial operculate that occurs in the central Texas area. This species is found in a wide variety of habitats that have been a certain amount of cover material in the form of wood or rock. Substrate is usually calcareous in nature. This species ranges from Kentucky and Oklahoma southward into Florida, Texas, and northeastern Mexico. 
Table 7.2 Molluscan Remains from Pond Margin at Aubrey Site

STRATUM

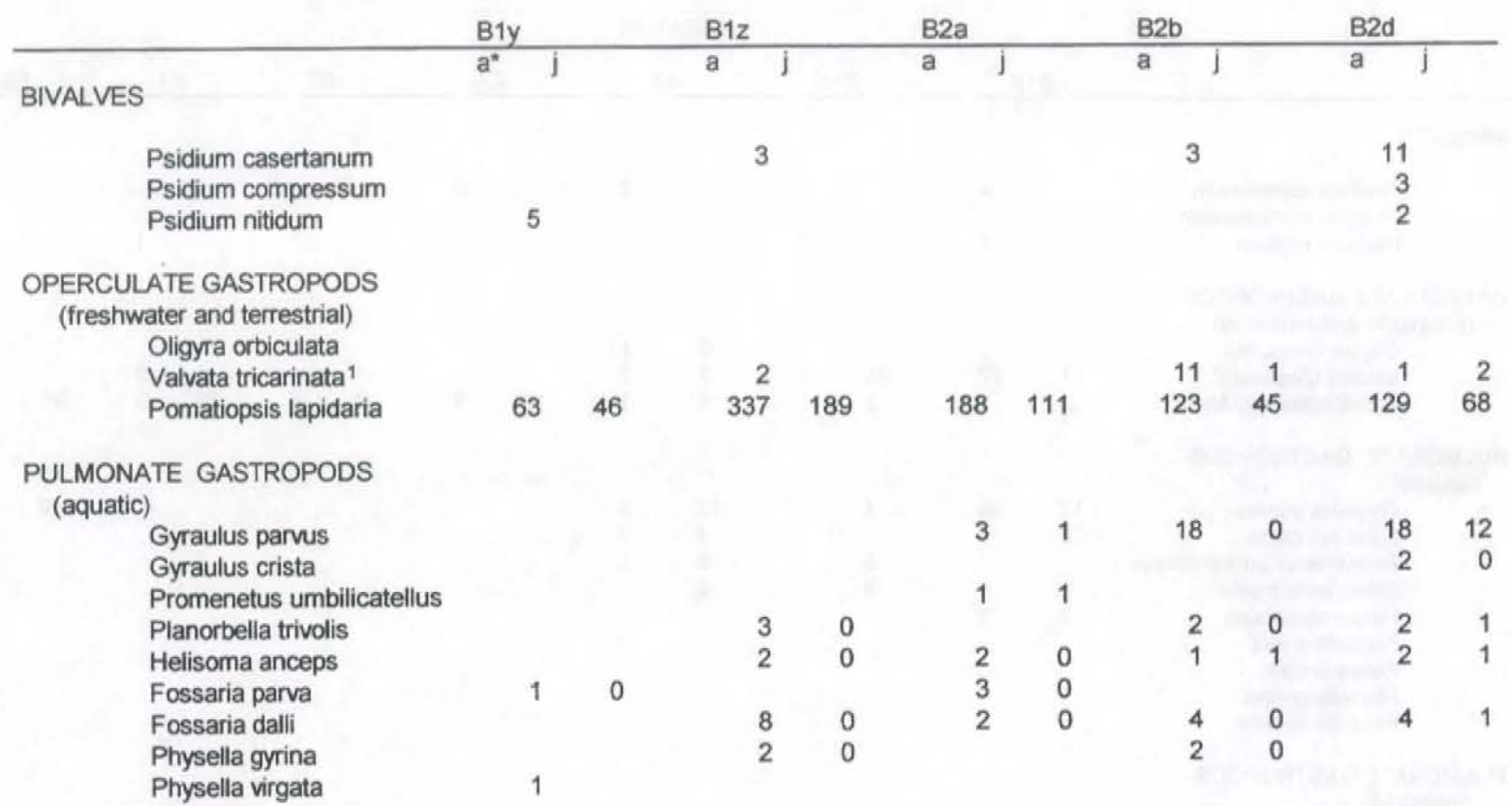

PULMONATE GASTROPODS

(terrestrial)

Carychium exiguum

Vallonia parvula

Pupoides albilabris

Gastrocopta armifera

Gastrocopta contracta

Gastrocopta pentodon

Gastrocopta tappaniana

Gastrocopta procera

Gastrocopta cristata

Vertigo ovata

Vertigo gouldi

Strobilops texasiana

Oxyloma retusa

Catinella avara

Succinea ovalis

Discus cronkhitei

Heliodiscus parallelus

Heliodiscus singeyanus

Deroceras laeve

Glyphyalinia indentata

Hawaiia miniscula

Zonotoides arboreus

Euconulus fulvus

Euconulus trochulus

Euchemotrema leai

Mesodon thyroidus

NISP

30

1

NISP Total

Percent immature

ata

1

10

$\begin{array}{rl}3 & 0 \\ 6 & 0 \\ 37 & 2 \\ 6 & 0 \\ 7 & 0 \\ 2 & 0\end{array}$

$$
\begin{array}{ll}
2 & 0 \\
4 & 0 \\
2 & 0
\end{array}
$$$$
5
$$$$
\begin{array}{ll}
1 & 0 \\
4 & 0 \\
8 & 0
\end{array}
$$

20

31

20

$$
6
$$$$
12
$$$$
\begin{array}{rr}
14 & 15 \\
5 & 0
\end{array}
$$

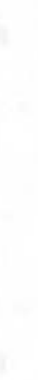


Table 7.3 Molluscan Remains from Pond Axis at Aubrey Site

STRATUM

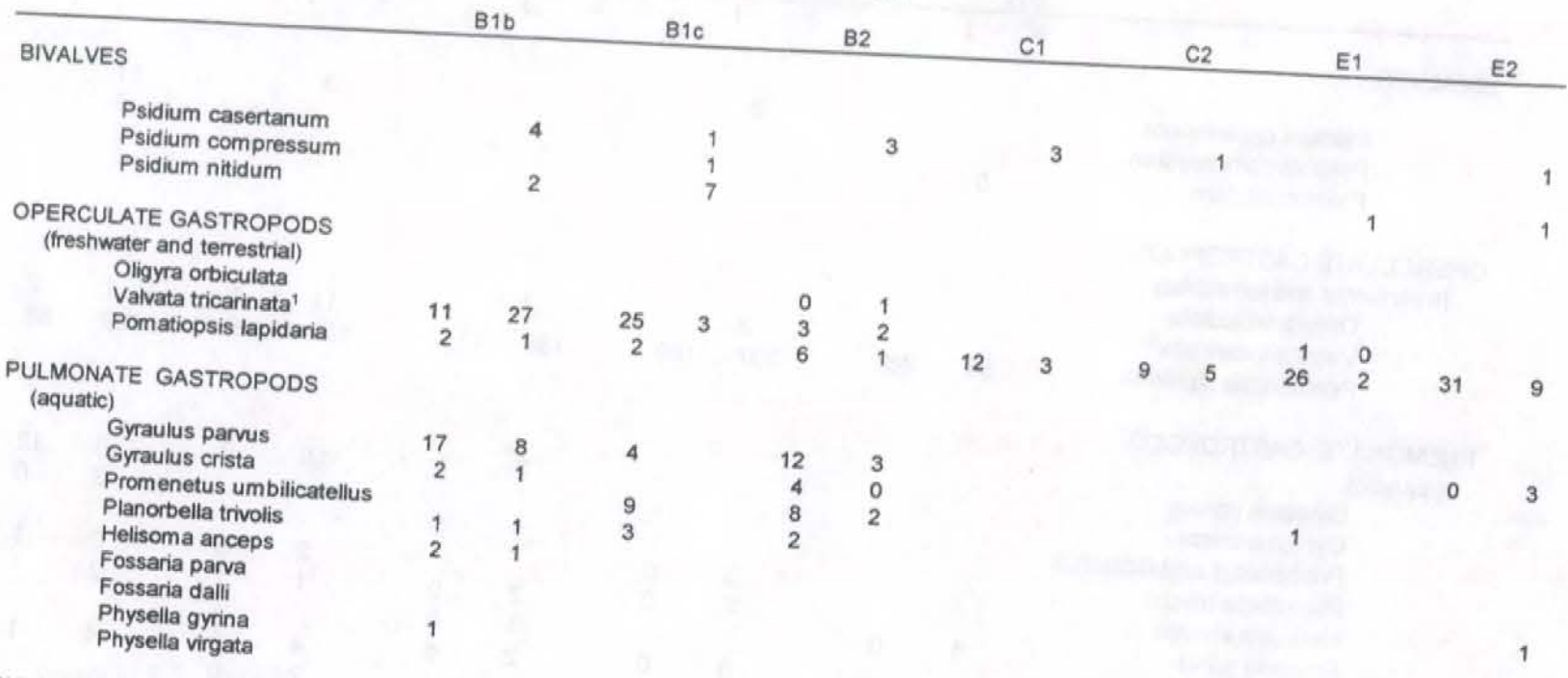
PULMONATE GASTROPODS
(terrestrial)

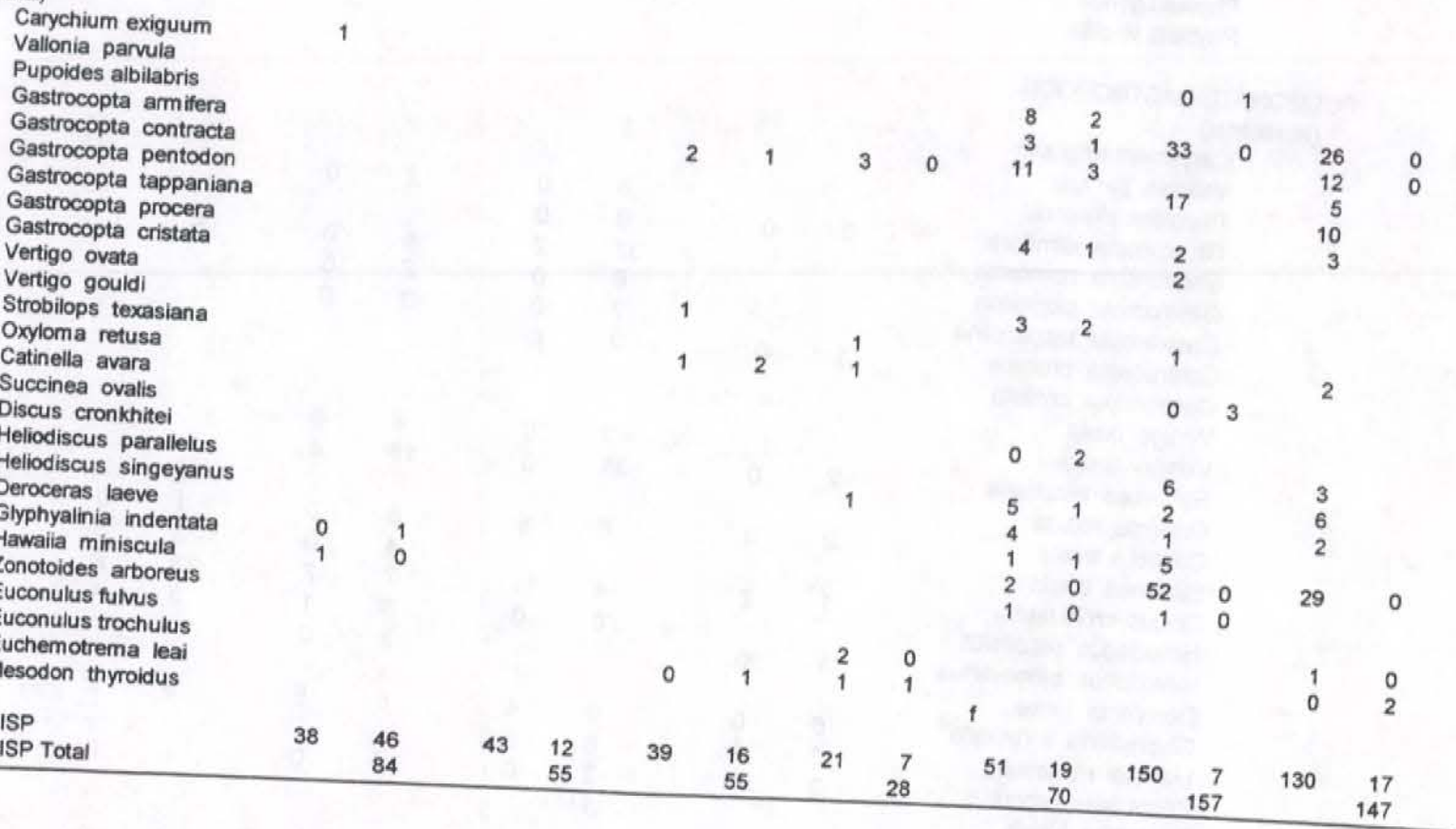


Valvata tricarinata

found in permanent ponds, lakes, and streams with cold water in Canada and the northern United States as far southward as Virginia and Nebraska.

Pomatiopsis cincinnatiensis

found in lakes and rivers with sand or mud bottoms at frequently at depths over a meter in southern Canada and the northern United States south to Utah, Oklahoma, and Pennsylvania.

Pomatiopsis lapidaria

an amphibious species that is found among wet vegetation and litter along the shore of ponds and streams. Modern distribution of this species includes extreme southeastern Canada and the eastern United States westward to South Dakota, Oklahoma, and Mississippi.

Gyraulus parvus

a small aquatic snail that is found in small spring pools and on aquatic vegetation in slow-moving water in Canada, the eastern United States, northern Mexico, and the Antilles.

Gyraulus crista

found among dense vegetation in ponds and sluggish streams in Eurasia, Canada, and the eastern United States from Mexico to Minnesota.

Promenetus umbilicatellus found in temporary pools, marshes, and flood plain pools in western North America from Alberta and British Columbia to New Mexico.

Planorbella trivolvis

found in ponds, slow-moving streams, and lakes with some submerged vegetation and mud substrate in Canada, the United States, and Mexico.

Helisoma anceps

a medium-sized aquatic snail that is found in stream-run streams over limestone gravel in the the Texas Hill Country. This species ranges from southern Canada southward to Georgia, Texas, and northwestern Mexico.

Fossaria obrussa

found in shallow, slow-current bodies of water - including ponds, creeks, and marshy floodplains - as well as the wet amphibious zone surrounding them. This species ranges throughout North America from northern Canada southward into northern Mexico.

Fossaria parva

an amphibious species that lives in shallow water or out of the water on river banks, mud flats, and lake shores as well as in marshes in central North America as far south as Arizona and Texas.

Fossaria dalli

typically found in shallow, clear, slightly-flowing water or in the adjacent amphibious zone from southern Canada southward to Arizona and Texas.

Physella gyrina

can be found in almost any type of permanent water body as well as temporary swamps and pools in central and western North America as far south as California and New Mexico.

Physella virgata

a freshwater gastropod that is found in ponds and streams with slow-moving water in central and western North America from Nebraska to California southward to Texas and Mexico.

Carychium exiguum found in moist, protected habitats that have saturated soil conditions during a significant part of the year. The modern range of this species is eastern North America as far south as South Carolina and Colorado. 
Vallonia parvula

Pupoides albilabris

Gastrocopta contracta

Gastrocopta pentodon

Gastrocopta tappaniana

Gastrocopta procera

Gastrocopta cristata

Vertigo ovata

Vertigo gouldi

Strobilops texasiana

Oxyloma retusa

Catinella avara

Succinea ovalis

Discus cronkhitei
Gastrocopta armifera

frequently found in grassy areas under rocks and downed wood in the Midwest and Great Plains as far south as northern Texas (the Panhandle).

a small terrestrial gastropod that is found in a variety of habitats with cover in the form of wood, rocks, or deep leaf litter in eastern North America.

usually found in open, calcareous habitats in eastern North America, although some protection from desiccation is necessary, particularly in the southern part of its range.

occurs in varoius habitats but is usually found in most areas with cover of wood or rocks with leaf litter in eastern North America.

found in protected woods that are mesic in nature in eastern North America.

found in wooded areas with sufficient cover to conserve moisture in eastern North America.

a small terrestrial gastropod that is found in rather open, often semi-arid habitats in eastern North America as long as protective cover is available.

found in open, calcareous habitats, often ones that are quite dry or well-drained in nature in the southwestern and south central United States.

typically found in wet habitats associated with ponds and swamps in eastern North America.

may be found in upland woods with thick leaf litter in the northeastern United States.

another small terrestrial gastropod that is found in mesic microhabitats, often in subhumid habitats in the southeastern United States. This species is usually found under downed wood, usually associated with woody vegetation.

found in the amphibious zone bordering marshes and streams in the northern United States as far south as Illinois and New Mexico.

can be found in habitats that are seasonally very dry, but saturated soil is usually present for part of the reproductive season in eastern North America.

found on moist wooded slopes and along the margins of streams in the eastern United States as far south as northern Georgia and Arkansas.

found in moist areas with some form of cover and can be found in woods, marshes, roadsides, and urban yards in eastern North America as far south as North Carolina and South Dakota.

Helicodiscus parallelus usually found in closed woodlands in floodplains and mesic upland slopes in eastern North America.

Helicodiscus singleyanus a small disc-shaped gastropod that is often found in rather dry habitats with a minimum of cover objects in eastern North America. 
Deroceras laeve

Glyphyalinia indentata

Hawaiia minuscula

Zonitoides arboreus

Euconulus fulvus

Euconulus trochulus small gray to brownish slug that is found in protected habitats underneath rocks or downed wood, under which it may burrow to deeper soil layers with sufficient moisture. This species may also be found around the margins of wetlands marshes, ponds, or small streams - where it may actually enter the aquatic habitat to forage and absorb water. This species is found in Eurasia and North America.

found in floodplain forests and mesic upland woodlands in eastern North America as far west as eastern Texasn and eastern Kansas.

found in a variety of habitats with some woody vegetation and associated cover objects in North and Central America.

can be found in both floodplain and upland woods in North America.

a terrestrial gastropod that is common in many of the Late Pleistocene and Early Holocene molluscan paleoassemblages in the central portion of the United States. Living populations of this species are restricted to the northeastern United States as far south as the Applachian Mountains with disjunct populations present in montane habitats of the Trans-Pecos Texas.

found in mesic woodlands over much of the southeastern United States as far west as west central Texas.

Euchemotrema leai aliceae found in floodplain and mesic slope woodlands in the southeastern United States as far west as central Texas.

Mesodon thyroidus occurs in floodplain and hillside forests usually under downed wood in the eastern United States as far west as central Texas.

Interpretation of Paleoassemblages

Paleoenvironmental interpretations will be presented first for the terrace swale fill deposits followed by sequential interpretation of the pond margin samples in ascending order from the lowermost available sample to the uppermost sample. Following these interpretations will be the interpretations of the paleoassemblages present in the samples from the pond axis.

Terrace Swale Fill

Qa - This paleoassemblage is dominated by aquatic species that indicate the occurrence of permanent, cold water at this time with the presence of submerged vegetation. A mesic band around the water body was present for some of the aquatic species that often crawl among the margin of the water. The terrestrial environment surrounding the water may not have been suitable for terrestrial gastropods. This paleoassemblage appears to represent an in situ pond, i.e., a permanently inundated swale in the floodplain of the Trinity River at some time in the Late Pleistocene. 
Pond Margin

B1y (from trench 1C)- This paleoassemblage contains a moderately diverse group of species that is numerically dominated by Pomatiopsis lapidaria. Very few truly aquatic species are present, but none of the terrestrial species are abundant. Many more terrestrial species than aquatic/amphibious species are present, however. A ponded area was present with substantial leaf litter present on the soil around the margins of the pond. During this time period the pond may have been intermittent in nature. Woody plant species may have been present as indicated by several of the terrestrial gastropods present in this paleoassemblage.

B1z (from trench 1A) - This paleoassemblage contains a very diverse group of molluscan species, and is especially rich in terrestrial species (Table 7.4). Although the number of terrestrial species is high, the number of indicated terrestrial habitats is somewhat limited. A continuum of habitats from hydric marsh to moist soil with leaf litter is indicated. Only a few species indicating well-drained habitats are present. A few species - Mesoden thyroidus, Euchemotrema leai, and Zonitoides arboreus - are typically found in woodlands with leaf litter and downed wood. The abundance of Pomatiopsis lapidaria indicates the occurrence of shallow water to mesic, sub-aerial leaf litter habitats that surrounded a smaller, deeper permanent pool. Several of the aquatic species indicate the occurrence of a shallow marsh with no indication of submerged aquatic vegetation. The presence of Valvata tricarinata indicates a permanent pool of cold, well-oxygenated water.

Table 7.4 Summary of Postulated Ambient Conditions Surrounding Aubrey Pond. Indicated by Analysis of Molluscan Remains from Pond Margin.

STRATA
Change in Environment
Between Samples
Climate Description

(In relative terms of temperature, precipitation and effective moisture)

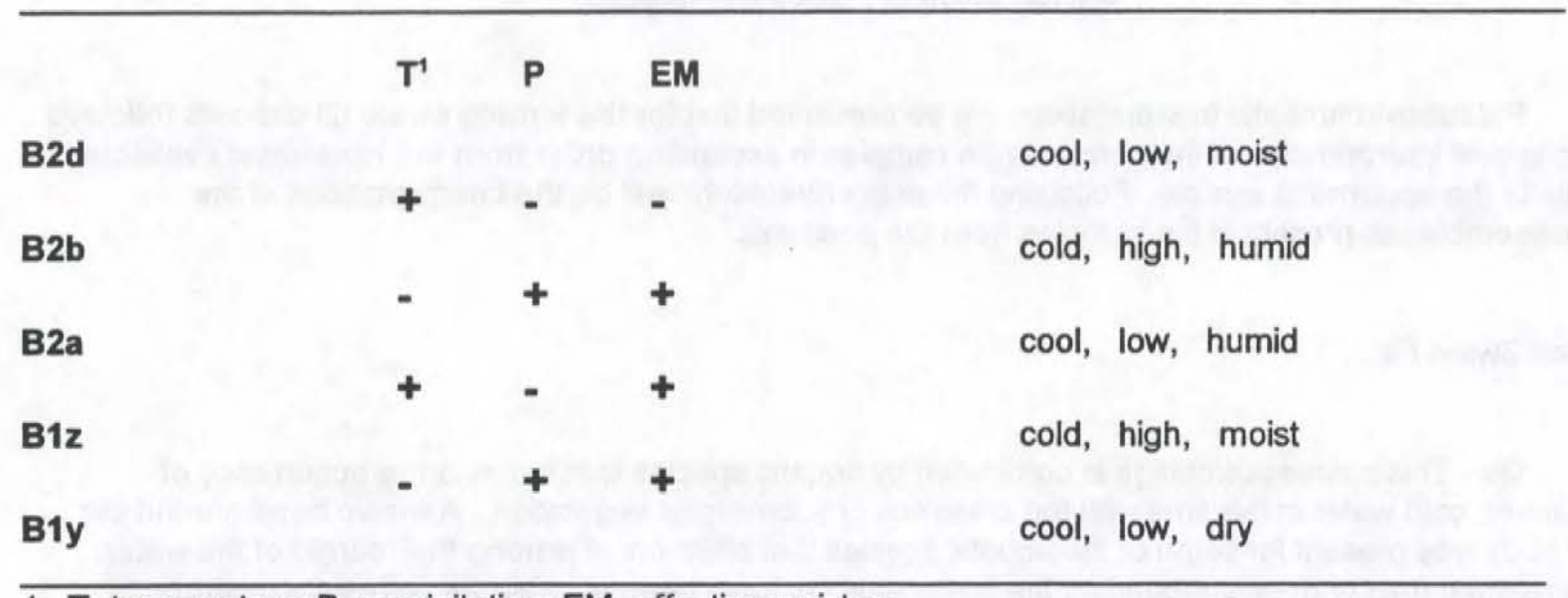

1 T-temperature; P-precipitation; EM- effective moisture 
B2a - This paleoassemblage contains a moderately diverse group of species that is dominated by terrestrial forms in number of species present, but the most common species is still Pomatiopsis lapidaria. Additional truly aquatic species indicate that shallow water was present. This body water may have been intermittent (or possibly just smaller in size), but the substrate remained moist. The terrestrial species present indicate abundant leaf litter and cover objects, probably wood, on the surface of the soil.

B2b - Species diversity is moderately high in this paleoassemblage, but the number of terrestrial species is considerably reduced from the lower sample (discussed immediately above). Aquatic species present indicate the occurrence of shallow marsh habitats with submerged aquatic vegetation abundant surrounding a deeper pond of cold water. Marsh margin and mesic leaf litter habitat was present, but the typically marsh-dwelling pupillids are not present in this paleoassemblage. The most abundant species present in this paleoassemblage is Pomatiopsis lapidaria. Significant in this paleoassemblage is the return of Valvata tricarinata, a cold spring indicator species that is absent from the above paleoassemblage.

B2d - This paleoassemblage exhibits a moderate diversity of terrestrial species, and a slight increase in diversity of aquatic species in comparison to the above sample (stratigraphically below this one in column). Both eastern (Mesodon thyroidus and Euchemotrema leai) and western/boreal (Gastrocopta arminfera, Succinea ovalis, Vertigo gouldi) mesic-adapted species are still present. The aquatic species represented in this paleoassemblage indicate the occurrence of a spring pond that was surrounded by a well-developed marsh with submergent vegetation. The limited nature of the marsh margin may have been the result of steep-sided margins of the topographic depression.

\section{Pond Axis}

B1b - This paleoassemblage is almost completely dominated by aquatic species. Two terrestrial species and the amphibious Pomatiopsis lapidaria are present but are represented by very few individuals. The aquatic species present indicate the occurrence of deep, cold water as well as shallow marshy areas with submergent vegetation. The site of this sample was permanently inundated by water.

B1c - This paleoassemblage is similar to the one discussed above but contains no terrestrial species. Pomatiopsis lapidaria is present only in very low numbers. The environment indicated is a totally aquatic system, possibly with steep sides that allowed little or no existence of a mesic terrestrial margin. Certainly, there was very little postmortem downslope creep by shells of terrestrial species, if present.

B-2 - Dominated by aquatic species, this paleoassemblage indicates the existence of a cold water spring with broad, shallow margins in the pool. A definite hydric margin existed around the pond, allowing the presence of a limited number of terrestrial species in hydric marsh and slightly wooded habitats.

Significant is the presence of an austral species, Oligyra orbiculata, in this paleoassemblage (although only one immature shell was recovered). The occurrence of shells of several terrestrial species in this sample is probably an indication of a somewhat smaller pond of cold water (also indicated by the reduced number of Valvata tricarinata).

C1 - The limited number of species and individuals present in this paleoassemblage indicates a small, intermittent pond. No truly aquatic gastropods are present, and the single bivalve species present (Pisidium casertanum) can survive surface desiccation of temporary water bodies. The terrestrial species present are either austral in zoogeographic affinity or are wide-ranging species. 
C2 - This paleoassemblage is again almost totally composed of terrestrial species with only a few amphibious species present (Table 7.5). An intermittent pond (probably smaller than the C1 pond) was present. A very mesic terrestrial margin was present and may have contained woody plants. This terrestrial margin was probably subject to seasonal desiccation, but thermal stress was still not critical. At least one boreal species (Discus cronkhitei) was still present.

Table 7.5 Summary of Postulated Ambient Conditions Surrounding Aubrey Pond. Indicated by Analysis of Molluscan Remains from Pond Axis.

STRATA

\section{Change in Environment Between Samples}

\section{Climate Description}

(In relative terms of temperature, precipitation and effective moisture)

\begin{tabular}{lllll}
\hline & F & P & EM & \\
& + & - & - & warm, low, dry \\
E1 & + & + & + & cool, medium, moist \\
C1 & + & - & - & warm, low, dry \\
B2 & + & - & - & warm, low, dry \\
B1C & + & + & + & cool, medium, moist \\
B1b & - & + cold, low, moist
\end{tabular}

1 T- temperature; P-precipitation; EM- effective moisture

E1 - This paleoassemblage contains a moderately diverse group of species and is dominated by terrestrial species. The amphibious species Pomatiopsis lapidaria is abundant; the few aquatic species present in this paleoassemblage are quite rare. The pool present during this time period was undoubtedly seasonal in size, but a small permanent, cold-water "core" pool was present. Substantial marsh margin with moist leaf litter is indicated.

E2 - The paleoassemblage from this layer is very similar to that frome E1, although the "core" pool was reduced in size, being very shallow and possibly with slightly warmer water temperature. The immediate terrestrial environment around the site was quite similar. 


\section{Discussion}

In an attempt to easily discuss rather complex set of paleoassemblages from a single site through a significant period of time, the samples have been grouped again into floodplain swale, pond margin, and pond axis samples. Samples from these two groups will be discussed in temporal sequence beginning with the oldest samples. Subsequently, a synthesis of the information presented and an overall discussion of the results of the analysis of the paleomolluscan samples from this site will be presented.

\section{Significance of the Floodplain Swale}

Although sequential samples are not available from this site and the actual date of the deposit is only known in a very relative scale, the paleoassemblage from the floodplain swale is significant in relation to the pond samples. From relative position in the landscape of the fluvial deposits associated with the Elm Fork of the Trinity River in this area, the floodplain swale probably dates to approximately 25,000 B.P. The requirement for slightly moving or very "clean" water by several of the aquatic species present indicates that the swale was likely filled with groundwater during a time of high water table elevations. Slight downslope movement by the groundwater would be sufficient to keep the water "clean." Groundwater temperatures were low as indicated by the abundance of Valvata tricarinata.

\section{Temporal Changes in the Pond Margin}

Five samples are available from deposits interpreted as pond margin: two samples from stratum B1 and three samples from stratum B2.

The two samples from stratuim B1 are from a period between 15,000 and 13,800 B.P. The lower sample, B1y, indicates an environment with a wide area of moist to intermittently inundated habitat that supported a dense population of the amphibious gastropod, Pomatiopsis lapidaria. The terrestrial zone supported a divere, but low-density fauna of several species of terrestrial gastropods. The sample from B1z indicates a slightly different environment with increased diversity and density of both terrestrial and aquatic/amphibious species. P. Lapidaria is much more abundant in B1z than in B1y. Comparing these two samples from B1 to determine the environmental differences between them is hampered somewhat by their origin in slightly different locations in the pond margin. Sample B1y came from trench 1C at depth of 87.15-87.10, whereas sample $B 1 z$ came from trench $1 A$ at a depth of 87.28-87.16. These two samples may indicate horizontally variability between two essentially contemporaneous samples. On the other hand, temporal differences in spring flows may also have been involed, although the direction of change is somewhat problematic. The increase in abundance of $P$. Lapidaria indicates a broader amphibious zone, which could result from either a higher or lower pond surface level, depending upon the shape of the bottom slope of the pond. However, the increase in terrestrial habitat area indicates that a lower pool level is the more likely explanation. The appearance of the cold-water indicator species, Valvata tricarinata,may indicate that less water occurred in the pool but that the water temperature was slightly lower.

The three samples from B2 encompass a rather short period of time from 13,800 to 13,000 B.P. Sample B2a is rather similar to sample B1z, although a few less terretrial species are present. Aquatic species diversity is increased and the abundance of Pomatiopsis lapidaria decreased significantly (although it is still quite abundant). Sample B2b contains still fewer terrestrial species, maintains a moderate diversity of aquatic species, and also reveals the relative abudance of the cold-water indicator, Valvata tricarinata. Sample B2d exhibits an increase in species number for both terrestrial and aquatic species, although $V$. Tricarinata becomes rather rare. These patterns in relative species abundance probably indicate an apparent decrease in available moisture from $\mathrm{B} 1 \mathrm{z}$ to $\mathrm{B} 2 \mathrm{a}$, followed by a rise in pond elevation by $\mathrm{B} 2 \mathrm{~b}$, and followed subsequently by a slight drop in pond elevation in B2d. A slight rise in pond water temperature is suggested by the near loss of Valvata tricarinata B2d. 
Temporal Changes in the Pond Axis

Seven samples are available from samples interpreted as representing pond axis deposits: two samples from stratum B1, one sample from stratum B2, two samples from stratum C, and two samples from stratum $E$ (Table 7.5).

The two available samples from stratum B1 again represent some time period between 15,000 and 13,800 B.P. The lowermost sample, B1b, indicates the occurrence of a well-developed pond containing cold water with submerged vegetation. Very few shells of terrestrial species were recovered, indicating the permanance of the water and negligible input of shells from the terrestrial environment via downslope movement. By comparison, sample B1c contains no shells of terrestrial species and approximately the same number of aquatic species, although the species composition is slightly different. The presence of Promenetus umbilicatellus indicates the occurrence of temporary water, e.g., vernal ponds, but the continuing relative abundance of Valvata tricarinata indicates the presence of a permanent cold-water pond. Perhaps, the pond was larger but somewhat more variable in volume than in B1c. Sample B2 is somewhat similar to sample B1b in the presence of a few uncommon terrestrial species with a moderately diverse aquatic fauna. However, the relative rarity of $V$. Tricarinata (the beginning of a trend seen in subsequent samples) indicates that either the water supply was less dependable or experienced a moderate increase in temperature. Also of signifigance in B2 is the appearance of Olygyra orbifculata, an austral species with requirements for warmth and well-drained soil.

The samples from stratum C (approximately 12,300 to 13,300 B.P.) indicate major changes in the local environment. Overall, the number of both terrestrial and aquatic species are reduced, but the terrestrial species present indicate the occurrence of hydric soil conditions in subaerial habitats. The only abundant "aquatic" species, Pomatiopsis lapidaria, actually indicates the occurrence of seasonally wet leaf litter. Sample C2 contains the same aquatic species, but the terrestrial fauna is significantly more diverse and indicates an increase in the amount and diversity of the terrestrial environment. Both marshy and mesic terrestrial habitats are indiated with the likelihood of some woody vegetation being present. The most significant environmental change in the pond axis at this time appears to a major reduction in total flow or a significant increase in the seasonality of outflows of groundwater at this site. In either case, a catastrophic (to some of the molluscan species present) failure of groundwater supply is indicated.

The two samples from stratum E (approximately 10,950 to 10,500 B.P.) complete the molluscan paleoassemblages available from this site. Sample E1 indicates the existence of a diverse, well-developed terrestrial environment that surrounded a depression that was likely a small permanent pond surrounded by a vernal zone with some submerged vegetation. A broad population of Pomatiopsis lapidaria. Sample E2 contains a paleoassemblage similar to E1. However, variations in species presence and relative abundance of some species present in both samples indicate the occurrence of a significant loss in effective moisture, probably due to a warming trend between the two samples.

Synthesis of Results

\section{Climatic Reconstruction at Aubrey Site From Molluscan Paleoassemblages}

Molluscan remains in paleoassemblages are first line habitat proxies that can be used to reconstruct environments of the Holocene and Pleistocene. Strictly speaking, molluscan remains are not direct climatic proxies, although they have been use to reconstruct past climates during several decades of plaleomolluscan studies. However, once the various paleoenvironments have been described and the environmental changes between successive samples have been summarized, the climatic changes that caused the observed changes in the reconstructed paleoenvironments can then be investigated. Even so, the secondary nature of this climatic reconstruction must be kept in mind as the climatic reconstructions are formulated. 
Postulated relative changes in temperature, precipitation, and effective moisture/relative humidity are presented in Tables 7.4 and 7.5 for the samples from the pond margin and pond axis, respectively. The direction of the changes in these three environmental parameters were estimated after a comparison of successive paleoassemblages, particularly in reference to moisture requirements for the terrestrial fauna and water temperature and dependability requirements for the freshwater species. The direction of change $(+$ or -$)$ is from the earlier sample to the later sample for any pair of successive samples.

Admittedly, this analysis is somewhat subjective, but restriction of the results to direction of change without quantitative estimates of change will mitigate a large part of this subjectivity. The directions of changes were determined following an outline classification of the successive reconstructed habitats that concentrated on amount and permanence of surface water, amount mesic amphibious zone, abundance of terrestrial species that occupied the high-humidity zone surrounding the pond, and amount of woody vegetation indicated by certain terrestrial species. The oldest sample was characterized to climate in relation to the modern climate of the Aubrey area and the geographical areas now occupied by those species no longer extant in the Aubrey area. Successive climates were characterized in relation to this initial climatic characterization.

Table 7.6 Summary of Postulated Ambient Environmental Changes for Aubrey Pond. (Tables 7.4 and 7.5 combined)

$\begin{array}{ll}\text { STRATA AGE Climate Description } & \begin{array}{l}\text { Overall environmental change } \\ \text { between successive samples and } \\ \text { habitat effects }\end{array} \\ & \end{array}$

$\begin{array}{llll}\text { E2 } & 10,300 \mathrm{bp} & \text { warm, low, dry } & \begin{array}{l}\text { increased temperature, decreased } \\ \text { rainfall and humidity }\end{array} \\ \text { E1 } & 11,000 \mathrm{bp} & \text { cool, medium, moist } & \begin{array}{l}\text { decreased temperature, increased } \\ \text { rainfall and humidity; groundwater } \\ \text { recharge }\end{array} \\ \text { B2 } & 12,300 \mathrm{bp} & \text { warm, low, dry } & \begin{array}{l}\text { increased temperature, decreased } \\ \text { rainfall and humidity; failure of } \\ \text { groundwater supply }\end{array} \\ \text { B1 up } 13,500 \mathrm{bp} & \text { cool, medium, humid } & \begin{array}{l}\text { increased temperature, rainfall } \\ \text { and humidity }\end{array} \\ \text { int } & \text { cold, low, moist } & \begin{array}{l}\text { decreased temperature and rainfall; } \\ \text { increased humidity }\end{array}\end{array}$

B1 low 14,200 bp cool, moderate, dry

1 T- temperature; P- precipitation; EM- effective moisture 
An additional source of uncertainty in using this technique in analysis of the Aubrey pond area is the lack of completely paired samples between the two habitat types. In the lower portion of the section samples are available from both habitats but later samples are only available from the pond axis habitat (although the upper section is at a time when the pond was disappearing and the previous pond axis had become the pond margin). The lower portion of the section then provides two estimates of climatic change from roughly separate data sets. The trends listed in Tables 7.4 and 7.5 are then combined with weighting being taken into account for the relative amount of information from terrestrial and aquatic systems. The resulting trends are presented in Table 7.6 along with approximate radiocarbon ages and habitat effects.

Effect of Environmental Change on Molluscs at Aubrey Site

The truly boreal element among the molluscan species recovered from samples at the Aubrey Site suffered local extirpation in the Late Pleistocene. These species did not survive into the Early Holocene. The boreal aquatic species - Valvata tricarinata and Gyraulus crista - survived no later than about 13,500 B.P. The extirpation of the local populations of these psecies resulted fromloss of groundwater supply that was accompanied by an increase in ambient temperatures, and quite likely also that of the groundwater. Two boreal terrestrial species, Discus cronkhitei and Vertigo gouldi, survived until approximately 12,300 B.P., indicating that an increase in the air temperature and evaporative power probably eliminated suitable habitat (marshy, hydric soil with woody or leaf litter cover) in this area. The other boreal terrestrial species Succinea ovalis - apparently was extirpate as early as 13,000 B.P., probably from decreased moisture levels in surface soil due to increasing temperature and fluctuating moisture availability (loss of surface cover objects could also have been significant).

The return to cooler conditions between 11,000 and 12,000 B.P. probably occurred too late to save the boreal element and some of the mesic element of the terrestrial gastropod fauna in the area of the Aubrey Site. Dispersal routes between the nearest populations and the Aubrey Site area were probably not suitable for migration of these slow-moving species. Although aquatic species may make rapid geographic progress via avian phoresy, suitably cold, permanent ponds were not present in this general area. Local recharge of groundwater occurred and the cold-water species, Valvata tricarinata, was able to experience an increase in population with an amelioration of the ambient temperatures and moisture stress. However, this recovery was short-lived and was followed by local and regional extirpation, although the timing of the extirpation in this area awaits the analysis of suitable deposits from the early Holocene in this region.

Local Nature of Paleoenvironmental Reconstruction From Molluscs at Aubrey

The length of the discussion of the molluscs recovered from various sediments at Aubrey indicates that this author believes that these shells are of value as direct habitat proxies and indirect climate proxies at this site. However, all of the analyses presented in this discussion can only be applied to the restricted pond environment and whatever terrestrial habitats existed in the apparently restricted drainage basin of this pond. The molluscan habitats at this site were so controlled by the availability of emergent groundwater thtat little, if any, paleoenvironmental conclusions about the general environment of the area an be formulated with any degree of accuracy. Therefore, I present no conclusions about the likely vegetational communities and climatic conditions about the region of north-central Texas during this time period. 


\title{
CHAPTER 8 \\ VERTEBRATE FAUNAL REMAINS FROM THE AUBREY CLOVIS SITE
}

\author{
by \\ Bonnie C. Yates and Ernest L. Lundelius, Jr.
}

Introduction

A total of 22,617 fragments of animal bone were examined and recorded from the Aubrey Clovis site. The bones were recovered from excavations in a heavy clay matrix or were found eroding from the surface exposures. Preservation at the site was exceptional, given radiocarbon ages spanning the last 12,000 years, but the bone became friable upon exposure to air and light and the only workable recovery methods (see below) inevitably added to the fragmentation. Therefore, only about $12 \%$ of the total bone was identifiable to the level of vertebrate class or lower. Higher percentages were seen in some excavated areas.

Excavations were conducted at seven loci within the site's boundaries (see Figure 2.6). In Area A, there are three loci that produced faunal remains:

Locus "AS" - From Stratum C1d in the spring-lacustrine marls at the western margin of the locality. These are the oldest bones from the Aubrey site, estimated to be ca. 12,300-13,300 BP, based on bracketing radiocarbon ages.

Locus "Pond Axis" - From Strata C2 and E in the pond axis (Block A). These lacustrine deposits produced the largest part of the faunal sample. These materials are younger than bones from the spring locus, and include those of Clovis age. The Clovis occupation surface corresponds with the C2-E1 contact in the pond axis (see Chapter 3).

Locus "Red Wedge" - While stratigraphically correlated with the C2-E1 contact in the pond axis, the deposition and preservation qualities here are different, indicating that the bones lying in the upper part were buried more slowly after Clovis occupation. Weathered bison bones come from this area and most likely represent a kill site.

Area $\mathbf{B}$ has been designated a Clovis camp locus. It is located at the eastern margin of the pond about $60 \mathrm{~m}$ from the pond axis. The majority of lithic artifacts and burned bone occur here.

Area $\mathbf{C}$ is an extension of Camp B across the outlet channel for the dam. Bones were buried quickly, and may have been affected by minor slope wash and some vertical bioturbation by crayfish.

Area $\mathrm{F}$ has been designated as another Clovis camp, situated on the west bank of the Clovis paleoriver about $100 \mathrm{~m}$ east of Camp B. Faunal densities are lower than in Camp B, and there are significant compositional differences as well. Mammoth ribs have been excavated over the past years as they erode from the deposits of the ancient river bank. They were first found over a year after the fieldwork stopped at the site. 


\section{Methods}

Standard zooarchaeological methods were used to retrieve, sort, identify, curate, and report on the animal bones recovered from Aubrey. The term animal bone is used for all residue of vertebrate animals, including teeth, otoliths, and exoskeletal elements, such as scales and scutes. The bones were initially processed in the field during the course of excavation. Each quad of each level was soaked in its matrix, which in most instances contained a high proportion of clay. The quad load was washed through quarterinch and window screens at the site, using pumped channel water. The resultant recovery samples were dried and organic (faunal and floral remains), as well as any cultural items, were hand picked from each sample. The animal bones were initially identified and quantified by Yates in the Institute of Applied Sciences' Zooarchaeology Laboratory (ZL) at the University of North Texas, and subsequently the extinct faunas were examined and all findings were verified by Lundelius at the Museum of Vertebrate Paleontology at the University of Texas.

All material examined was encoded for computerized data management. Unidentified fragments were divided into unburned and burned categories and counted. The attributes of identified elements were recorded as taxon, body part, side of body, element portion, age, condition (burning), modification, and taphonomic appearance. Species and attribute codes follow the protocol developed at the $\mathrm{ZL}$, but the databases were manipulated and queried using the $\mathrm{dBase}$ support program developed for Shaffer and Baker (1992) and also the SAS (1978) statistical programs available at the UNT computing center. For this report, quantification of faunal assemblages is summarized as the number of identified specimens per taxon (NISP) calculated for each locus.

The faunal data tables consist of standard species lists, providing for each analysis unit a count of elements (NISP) attributed to each taxonomic category. An appendix has been generated to itemize the skeletal elements attributed to each taxon, following standard paleontological practices. All faunal data will be curated with the collections.

The comparative skeletal collection at the ZL (Institute of Applied Sciences, University of North Texas) was adequate for most of the identifications of the animal bones. Because of the paleontological components involved, the material was also examined by Dr. E.L. Lundelius, Jr. at the Vertebrate Paleontology Laboratory, University of Texas in Austin. His observations and commentary will be appended. Osteological nomenclature and reference to standard osteological keys follows such texts as Olsen (1960, 1964, 1968), Gilbert et al. (1981), Hillson (1986), Schmid (1972), and Sisson and Grossman (1953).

Only positive identifications resulted in assigning elements to genus or species. Higher taxonomic assignation was used otherwise in order to provide an estimate of the type of faunal presence represented by fragmentary remains. Elements of non-diagnostic skeletal value (e.g., ribs, long bone shafts; see Olsen 1961) are tabulated in what is called a "indeterminate" ("Indet.") category by class and size range. Recording these bones in a size category allows as fine a level of observation as the specimen permits; otherwise, the specimen would be considered unidentifiable ("Vertebrate unid."). In small samples, noting size categories of non-diagnostic elements and non-specific taxonomic categories broadens the utility of the 
derived from pig, deer, elk, cattle, bison, horse, or larger (megamammals). Or the entry "Deer/Pronghorn" is used to account for those elements, which especially in fragmentary conditions, are not diagnostic for either species; however, their overall morphology restricts them to those artiodactyls (notably present in archaeological assemblages) of the size and confirmation of deer and/or pronghorn, as opposed to elk or bison. The intent is to provide a taxonomic assignation as close as possible and yet conservative, given the fragmentary nature of archaeological faunal remains.

Other factors affecting conclusions that can be gleaned from zooarchaeological investigations include all of the forces that have acted upon the assemblages prior to recovery. These forces affect the distribution, state of degradation, and composition of faunal assemblages and may be divided as attributable to human and nonhuman agents (Baker et al. 1991). Nonhuman forces that alter bone were noted as root-etching, weathering cracks, and chemical dissolution. The study of these taphonomic forces may also shed light on site formation processes, such as duration of stable surfaces, rapid burial, leaching, etc. (Ferring 1989a; Yates 1991; 1993).

To accommodate multiple manifestations of taphonomic forces, a suite of descriptors (codes) were used. For example, if a bone were root etched and gnawed, a single code was used that accounted for both effects. Although recorded for each identified bone, taphonomic effects on the remains of the large mammals were deemed by the investigators to have bearing on the interpretation of the site.

Cut marks and other forms of human alteration of bone (other than burning) were coded when encountered under a separate heading called "Modification." These observations served to note whether a bone had been modified and/or used as a tool; exhibited striations or abrasions that might indicate tool manufacture; had cut marks suggestive of carcass processing (i.e., skinning, dismemberment, or filleting cuts); other processing indicators (i.e., spiral fractures, charred breaks); or combinations of these characteristics. Analysis of cut marks and attribution to steps in carcass processing were made following Binford's human modes of bone modification (Binford 1981:Table 4.04).

Fragmentation and burning are the most notable conditions found in the Aubrey bone assemblages. Both affect how many bones survive to be identified. While charring may alter the moisture content and improve the cohesiveness of the bone matrix, complete calcination may render the bone subject to pulverization, and incineration renders bone into ash. Therefore, there is a continuum of burn conditions in any archaeological faunal sample that stem from a variety of human behaviors and site formation processes. Similarly, a variety of causes of bone fragmentation (cultural and natural) have been at work on a bone sample: marrow extraction, bone grease rendering, gnawing, trampling, compaction, weathering, etc. The elements that get identified have often been through one or several of these processes and activities.

Destruction by either human or nonhuman agents is a constant in zooarchaeology that can be linked to taphonomy and preservation. These factors must be considered as part of the faunal interpretation because they directly affect the sample that ultimately gets analyzed. For example, the bones of small species of fish, amphibians, reptiles, and birds can rarely withstand processing, scavenging, digestion, and/or deposition without total disintegration or decimation. This introduces a strong bias in favor of mammalian remains, which by virtue of size tend to survive better than other vertebrates. For humans, larger mammals are most cost effective to procure. Nevertheless, conscientious effort to recover, 
TAXON

$A s^{1}$ Ap Arw $^{2}$

\section{CLASS OSTEICHTHYS}

Lepisosteus sp. $(\mathrm{gar})^{\mathrm{A}}$

Amia calva (bowfin) ${ }^{A}$

Catastomidae (sucker) ${ }^{A}$

Ictaluridae (catfishes) ${ }^{A}$

Centrarchidae (sunfish/bass) ${ }^{A}$

Aplodinotus grunniens (drum) ${ }^{A}$

Fish, indet. fish - small ${ }^{A}$

Fish, indet.

A

CLASS AMPHIBIA

Anura (indet. toad/frog) ${ }^{R}$

Caudata (indet. salamander) ${ }^{R}$

CLASS REPTILIA

Chrysemys/Trachemys sp. (pond turtle) ${ }^{A}$

Terrapene carolina (box turtle) ${ }^{\mathrm{E}}$

Kinosternidae (mud/musk turtle) ${ }^{A}$

Trionyx sp. (soft-shell) ${ }^{A}$

Chelonia (indet. turtle)

Lacertilia (indet. lizard)

Nerodia sp. (watersnake) ${ }^{A}$

Colubridae (non-poisonous snake)

Viperidae (viper)

Serpentes (indet. snake)

\section{CLASS AVES}

Anseriformes (waterfowl)A

Cathartidae (vulture)

Colinus virginianus (bobwhite quail) ${ }^{\mathrm{G}}$

Passeriformes (perching birds)

Bird, indet. - small

Bird, indet. - medium

\section{CLASS MAMMALIA}

Soricidae (shrews)

Scalopus aquaticus (eastern mole) ${ }^{R}$

Mephitis mephitis (skunk) ${ }^{R}$

Carnivora (indet. carnivore)

Spermophilus sp. (ground squirrel) ${ }^{6}$

Sciuridae (squirrel)

Reithrodontomys sp. (harvest mouse)

Peromyscus of. maniculatus (white-footed mouse)
1

2

2

2

1

1

1

54

1

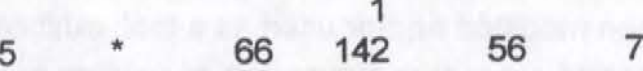

2

* $5 \quad 1$

* 1

1

161

*

1

2

4

$2 \quad * \quad 1$

1

1

12 


\begin{tabular}{|c|c|c|c|c|c|c|}
\hline & $\mathbf{A s}^{1}$ & Ap & Arw & B & C & $\mathbf{F}$ \\
\hline Oryzomys palustris (rice rat) ${ }^{R}$ & & * & & & & \\
\hline Sigmodon hispidus (cotton rat) ${ }^{\mathrm{E}}$ & & * & & 6 & & 2 \\
\hline Neotoma sp. (woodrat) & & & 1 & & 2 & \\
\hline Microtus sp. (vole) & 8 & * & 17 & 19 & 7 & 1 \\
\hline Synaptomys cooperi (lemming) ${ }^{R}$ & 1 & * & 1 & 1 & & \\
\hline Ondatra zibethicus (muskrat) ${ }^{A}$ & & & & 2 & 3 & \\
\hline Perognathus sp. (pocket mouse) ${ }^{G}$ & & & & 2 & & \\
\hline Dipodomys sp. (kangaroo rat) ${ }^{\mathrm{G}}$ & & & & & & \\
\hline Geomys bursarius (plains pocket gopher) ${ }^{\mathrm{G}}$ & & * & 23 & 23 & 14 & 18 \\
\hline Rodentia (indet. rodent) & 8 & * & 18 & 57 & 15 & 11 \\
\hline Sylvilagus floridanus (eastern cottontail) ${ }^{E}$ & & & 1 & 3 & 3 & \\
\hline Lepus cf. californicus (jackrabbit) ${ }^{G}$ & & & 1 & 1 & & \\
\hline Leporidae (rabbit) & & & 1 & & & \\
\hline Glossotherium harlani (Harlan's ground sloth) ${ }^{\mathrm{E}}$ & & * & & 1 & & \\
\hline Equus caballus (horse) $^{G}$ & & * & & & & \\
\hline Platygonus sp. (peccary) ${ }^{\mathrm{G}}$ & 23 & & & & & \\
\hline Odocoileus cf. virginianus (white-tailed deer) ${ }^{\mathrm{E}}$ & & * & & 16 & & 6 \\
\hline Odocoileus/Antilocapra (deer/pronghorn) & & * & & & & \\
\hline Bison cf. antiquus (bison) ${ }^{\mathrm{G}}$ & & * & 5 & 3 & & \\
\hline 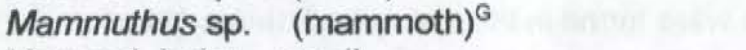 & & & & 3 & & 4 \\
\hline Mammal, indet. - small & 6 & * & 5 & 97 & 46 & 16 \\
\hline Mammal, indet. - medium & 1 & * & 1 & 107 & 1 & 8 \\
\hline Mammal, indet. - large & & * & 52 & 252 & & 37 \\
\hline Total identified & 66 & & 208 & 782 & 152 & 113 \\
\hline Total unidentified & & & 1843 & 1916 & 200 & 215 \\
\hline
\end{tabular}

1 Key to Loci: As $=$ Area A Spring Ap $=$ Area A Pond Arw $=$ Area A Red Wedge B $=$ Camp B $\mathrm{C}=$ Area $\mathrm{C} \quad \mathrm{F}=\mathrm{Camp} \mathrm{F}$

2 See Tables $8.2,8.3$ for data by stratigraphic unit

Key to Habitat Types: $A=$ Aquatic $R=$ Riparian $G=$ Grassland $E=E d g e$ (woodland/grassland)

examine, and record as much information as possible was expended on the Aubrey fauna in order to draw from it some picture of subsistence activity from this important early site.

\section{Environment and Faunal Resources}

Located in the upper Trinity River valley, the Aubrey site is found in the modern juncture of the easternmost Texan and western edge of the Austroriparian biotic provinces of Blair (1950). The Texan biotic province is a vast ecotone between the eastern deciduous/pine forests and the true prairies of the Southern High Plains. Blair (1950:99) emphasizes that the boundary of the Austroriparian is somewhat arbitrary and that its characteristic ecological associations "extend beyond this boundary in some local, edaphically favorable areas." These favorable areas are those in which the soils and moisture are conducive to forest 
habitats, which is essentially what is found in the riparian zones along the creeks and rivers of this part of Texas. In prehistoric times, this region is thought to have been much the same as now, characterized as an ecotone in which forests and grasslands shrank or enlarged as moisture regimes fluctuated (Collins and Bousman 1990). This tendancy surely perservered from even earlier times, perhaps as far back as the end of the Pleistocene.

The animal life in these areas is marked by diversity, if not abundance, because of the extent and variety of edge-type habitat. Edge habitats are those where forest meets meadow or along river and creek banks or at the interface of floodplain and upland. Hunters and gatherers in these locales have a wide variety of animal and plant foods for exploitation. Seasonal collecting forays would be generally small in maximum distance because there is usually something available in one or more of the multiple microzones that exist in edge habitats.

Faunal Remains

Area A Spring Sediments

The oldest faunas recovered from the Aubrey site were found in the spring sediments (Stratum B2) of Area A (Table 8.1). Given the age of the deposit (bounded by radiocarbon ages of ca. 13,275 and $12,330 \mathrm{yr} b p)$, the material was in very good condition.

The sample is small, however, with only 66 elements that could be identified to vertebrate class or lower. Most notable are the 23 elements attributable to a sub-adult peccary of the genus Platygonus. The elements consist primarily of foot and lower leg bones (astragalus, metapodials, phalanges). Platygonus is known from Levi Rock Shelter in central Texas (Anderson 1963) with an age of about $10,000 \mathrm{yr} b p$. Other occurrences range from Pennsylvania to South Dakota, with ages from 34,000 to 4,000 years bp (Meltzer and Mead 1985: Table 1).

The avian remains from the Spring are unique for the site. Two entirely different forms were identified: waterfowl and raptor. The waterfowl is a small duck, such as a teal, but the raptor is a large vulturine bird. Finding duck remains in a spring-fed pond seems appropriate to the setting. However, vulture remains are not common, except in boggy situations where they become entrapped while scavenging off carcasses mired in the same substrate. Tar pits such as La Brea have large numbers of vulturine and other scavenging birds, but occurrences in Texas sites are extremely rare. It is tempting to imagine that the dead peccary attracted the vulture, but cause of death of either animal is not detectable.

The remainder of the identified remains are fragmentary and very small. Turtle shell, snake vertebrae, and small mammals comprise these remnants. The shrew, small squirrel-possibly a ground squirrel, and microtine rodents, as burrowers, may have become associated with sediments that filled in the spring upon drier conditions. The only exception perhaps is the lemming (Synaptomys cooperi), a denizen of bogs and moist meadows, now relegated to more northern climates (Lundelius 1989). 
Area A - Red Wedge

A total of 2,051 bone fragments were recorded from the Red Wedge (Table 8.1), which is about $10 \%$ of the total bone from Area $A$. The identified assemblage is dominated by turtle shell, rodents, and large mammal remains. There are at least two different kinds of turtles, a small musk or mud turtle (Kinosternidae) and a larger aquatic turtle, probably of the genus Chrysemys (Trachemys). The rodent remains are predominately fossorial types and therefore may be intrusive, not associated with the cultural material. Other rodents and the rabbits, however, are large enough to have been caught during passive foraging activities.

The bison bones and other large mammal elements (which may also be bison remains) constitute almost one-third of the identified material from the Red Wedge. A piece of mandible with a first molar present was found in unit 1725; the wear pattern on this molar is consistent with bison about $2.0-3.5$ years age at death (after Frisonand Reher 1970). Several vertebrae fragments and an adult distal humerus fragment were recovered; however, age could not be determined from these fragments to see if they were from an animal of the same age.

Between 1991-1994, several other bones and two chert blades were found eroding from the Red Wedge sediments, and a bison scapula was found just below the distal edge of the red wedge in the pond sediments. These materials were mapped and removed. The bison bones document a second animal from this location, as decribed below.

The left calcaneus of a subadult bison was recovered. The proximal epiphysis is unfused to the body of the bone indicating the animal was immature. A proximal epiphysis of a calcaneus was recovered in the proximity to the calcaneus, but not be directly articulated with it. Due to fragmentation and post depositional rounding that has altered the original surfaces, the calcaneus body and epiphysis could not be directly articulated, although it appears that they are of the same bone.

Several additional small bone fragments were recovered that could possibility be portions of the proximal epiphysis of the calcaneus, but were too fragmented for exact identification or articulation.

The distal extension of the calcaneus sustentaculum for articulation with the fourth tarsal was broken from the body of the calcaneus, but this portion was recovered and articulates exactly.

One complete left astragalus was recovered that articulates with the calcaneus and most likely is from the same sub-adult bison. These bones were found within a few $\mathrm{cm}$ of each other, buried on the surface of the red wedge.

An additional large bone fragment was recovered adjacent to the previous two that appears to be the lateral, posterior corner of the proximal end of a bison left metatarsal. Fragmentation and destruction of surface landmarks precludes a positive identification. While the epiphysis is fused, the epiphysis on this bone fuses early in life and therefore could potentially be affiliated with the subadult calcaneus and astragalus. 
Two additional bone fragments were recovered with the metatarsal that were unidentifiable specimens from a large animal, perhaps in the deer or bison size range.

The bison scapula is complete, and is from a mature bison. It was crushed in place, but was otherwise intact. It's long axis was perpendicular to the red wedge slope.

\section{Comments: Taphonomy}

All of the specimens recovered exhibit post depositional alteration, mostly resulting in superficial degradation of surficial features, apparently due to moisture and possibly post depositional movement resulting in abrasion or rounding of some features. While the bones were recovered from an exposed surface, there is no indication of prolonged surface exposure with the exception of some bleaching and surficial cracking that all appears to be the result of the recent exposure and not the result of exposure prehistorically. The specimens are stained, apparently by the minerals present in the surrounding clay matrix. This clay has become incorporated into virtually all negative space features, such as fossae or grooves, normally present on the bone surface.

All fragmentation observed is dry-bone fragmentation indicating that the breaks occurred after the bones had lost collagen. This most likely occurred during post depositional processes.

There is no indication of intentional human exploitation on the elements such as burning, spiral fracturing or dynamic impact marks, or cut marks, although cut marks would have been difficult to identify given the condition of the bone surface. An exception to this is the apparent hammer-anvil fracture of a bison distal humerous.

Only $5 \%$ of the total recovery was burned bone. Turtle shell was the only identified burned bone. No cut marks were detected, and no activity areas were discernable in the distribution of faunal remains. However, such activity areas would be difficult to recognize, given the minimal exposures of those sediments. The presence of three blades amongst the bison bones on the red wedge, and the ancient well that was found there are discussed later in Chapter 9.

\section{Area A - Pond Sediments}

The 17,077 remains of fauna from the Pond Sediments (Tables 8.1-8.3) are best examined as accumulations in the slowly aggrading pond. The lower stratum, indicated as $\mathrm{C} 1$ in the tables, was deposited prior to Clovis occupations at Aubrey. The diversity of taxa identified in these strata is not great. No fish and few non-mammals are identified except to the level of order (i.e., Caudata, Chelonia, Serpentes) or higher in this lowest stratum. Preservation is of course a factor, but as was seen in the Spring sediments, age alone does not affect preservation since well preserved extinct fauna was recovered there. Here on the bottom of the pond, the paucity of remains may reflect genuine low diversity; otherwise, fish remains should at least be present. Mammals are restricted to vole and undiagnostic rodent remains. 
Table 8.2 Bone from Pond Sediments, Area A.

\begin{tabular}{lrrrrrrr} 
& \multicolumn{2}{c}{ S T R A T U M } & & & \\
& C1 & C2 & C2/E1 & E1 & E1/E2 & E2 & Surface \\
TOTAL & 151 & 811 & 972 & 14006 & 12 & 908 & 217 \\
\% Ident. & 14 & 13 & 12 & 8 & 25 & 8 & 15 \\
$\begin{array}{l}\text { Unidentifiable } \\
\text { Large } \\
\quad \text { Unburned } \\
\quad \text { Burned }\end{array}$ & 10 & 69 & 99 & 2931 & 0 & 123 & 151 \\
$\begin{array}{l}\text { Small } \\
\quad \text { Unburned } \\
\text { Burned }\end{array}$ & 0 & 2 & 5 & 183 & 0 & 4 & 2 \\
$\begin{array}{l}\text { Burned } \\
\text { Burned }\end{array}$ & 114 & 603 & 720 & 9742 & 9 & 697 & 0 \\
& 6 & 36 & 29 & 105 & 0 & 9 & 32 \\
& 4.6 & 5.4 & 4.0 & 2.2 & 0.0 & 1.6 & 18.4
\end{tabular}

Strictly speaking the C2/E1 contact was the surface during Clovis occupations. Trampling, soil cracking, and weight accumulation of sediments could accomodate intrusion of some bone fragments into the layers just below the original occupation surface. This could account in part for the gradual increase in diversity of taxa and overall amounts of bone from C2 to E1 (Table 8.3). However, the bone from Stratum $\mathrm{C} 2$ are at face value older than the Clovis age materials above them.

The total amount of bone from Stratum E1 alone accounts for $76 \%$ of all bone from the Pond and constitutes the most diverse assemblage of vertebrates from the entire site, especially when considered with the material recovered from the contact zone (Table 8.3). Easily the most important animals represented in this stratum are the large mammals: ground sloth, deer, and bison. While all three are also found in Camp B, deer is under-represented in the Pond sediments and sloth is under-represented in the Camp. This suggests that deer may have been taken whole back to the Camp, leaving only a toe bone and a tooth as identified fragments at the kill site (the Pond). Interestingly, these meager amounts of bone speak loudly. The toe bone (2nd phalanx) is from an adult, and the tooth is from a neonate; therefore, a minimum of two individual deer are indicated from these two bones.

The only identified remains of ground sloth are 135 dermal ossicles, all but one of which were found in the pond sediments, and that stray one was found in Camp B. These small bone pellets are imbedded in the skin of Glossotherium, it is thought, along the upper chest and shoulders, perhaps as additional protection against friction in those areas of the body of a large animal. Dermal ossicles were also recovered from the Kimmswick site (Graham et al.1981; Graham and Kay 1988), and like Aubrey, no other 
Table 8.3 Number of Identified Specimens (NISP) from Deposits in Pond Axis, Area A

Taxon

\section{OSTEICHTHYES \\ Lepisosteus sp. \\ Ictaluridae \\ Fish, indet. - small \\ Fish, indet.}

AMPHIBIA

Anura

Caudata

REPTILIA

Chrysemys $/$ Trachemys sp.

Terrapene sp.

Chelonia

Lacertilia

Nerodia sp.

Colubridae

Viperidae

Serpentes

\section{AVES}

Colinus virginianus

Passeriformes

Bird, indet. - small

Bird, indet. - medium

Bird, indet. - large

MAMMALIA

Soricidae

Scalopus aquaticus

Carnivora

Spermophilus sp.

Reithrodontomys sp.

Oryzomys palustris

Sigmodon hispidus

Neotoma sp.

Microtus sp.

Synaptomys cooperi

Ondatra zibethicus

Perognathus sp.

Dipodomys sp.

Geomys bursarius

Rodentia

Sylvilagus floridanus

Lepus cf. californicus

Leporidae

\section{Stratum*}

C1 C2 C2/ E1 E1/ E2 Surface**

$\begin{array}{lll}2 & 2 & \\ 3 & 1 & 2 \\ & 2 & 4\end{array}$

1

$\begin{array}{lll}1 & 1 & 1 \\ 1 & & 4\end{array}$

1

$\begin{array}{ll}8 & 2\end{array}$

$\begin{array}{llll}1 & 35 & 33 & 232\end{array}$

1

3

1

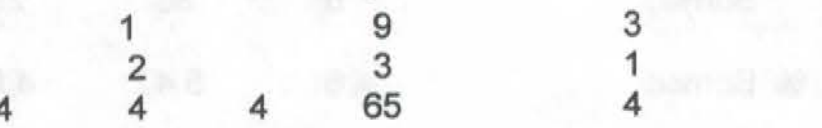

4

4.9

$\begin{array}{rr}2 & 11 \\ & \\ & 3 \\ & 1 \\ & 4\end{array}$

12

1

12

3

1

1

1

1

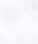


Table 8.3, cont.

Glossotherium harlani

Odocoileus virginianus

Odocoileus/Antilocapra

Bison cf. antiquus

Equus caballus

Mammal, indet. - small

Mammal, indet. - medium

Mammal, indet. - large

Total Identified

Total Unidentified

*Key to Strata

C1 $=($ field stratum 70$)$

$\mathrm{C} 2$ = (field stratum 71$)$

$\mathrm{C} 2 /=\mathrm{C} 2 / \mathrm{E} 1$ contact $($ field stratum 75$)$

$\mathrm{E} 1=($ field stratum 72$)$

$E 1 /=E 1 / E 2$ contact (field stratum 77 )

$E 2=($ field stratum 73$)$

$\begin{array}{rrrrrrr} & & 134 & & & \\ & 2 & 1 & & & 1 \\ 2 & & 18 & & 1 & 4 \\ 13 & 13 & 103 & & 7 & \\ & 2 & 16 & & 4 & 13 \\ 7 & 11 & 86 & 1 & 6 & \\ & & & & & \\ & & & & & \\ 101 & 119 & 1045 & 3 & 75 & 32 \\ 710 & 853 & 12961 & 9 & 833 & 185\end{array}$

**Bones found on surface; elevations are provided in Appendix A for units designated as 0,1540, 1557, and 9999 and stratum designated as 0.

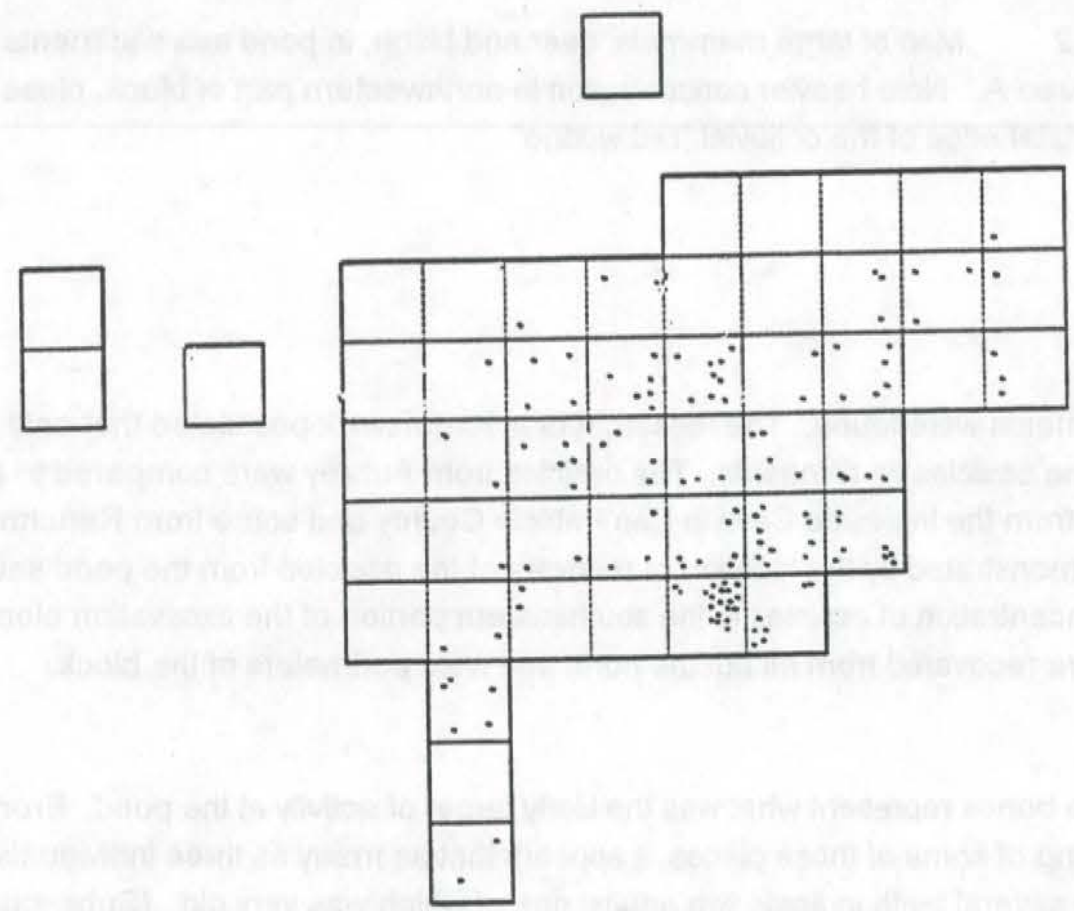

Figure 8.1 Map of ground sloth (Glossotherium harlani) dermal ossicles, Area A. All of these were found in the pond axis, on the Clovis paleosurface. 


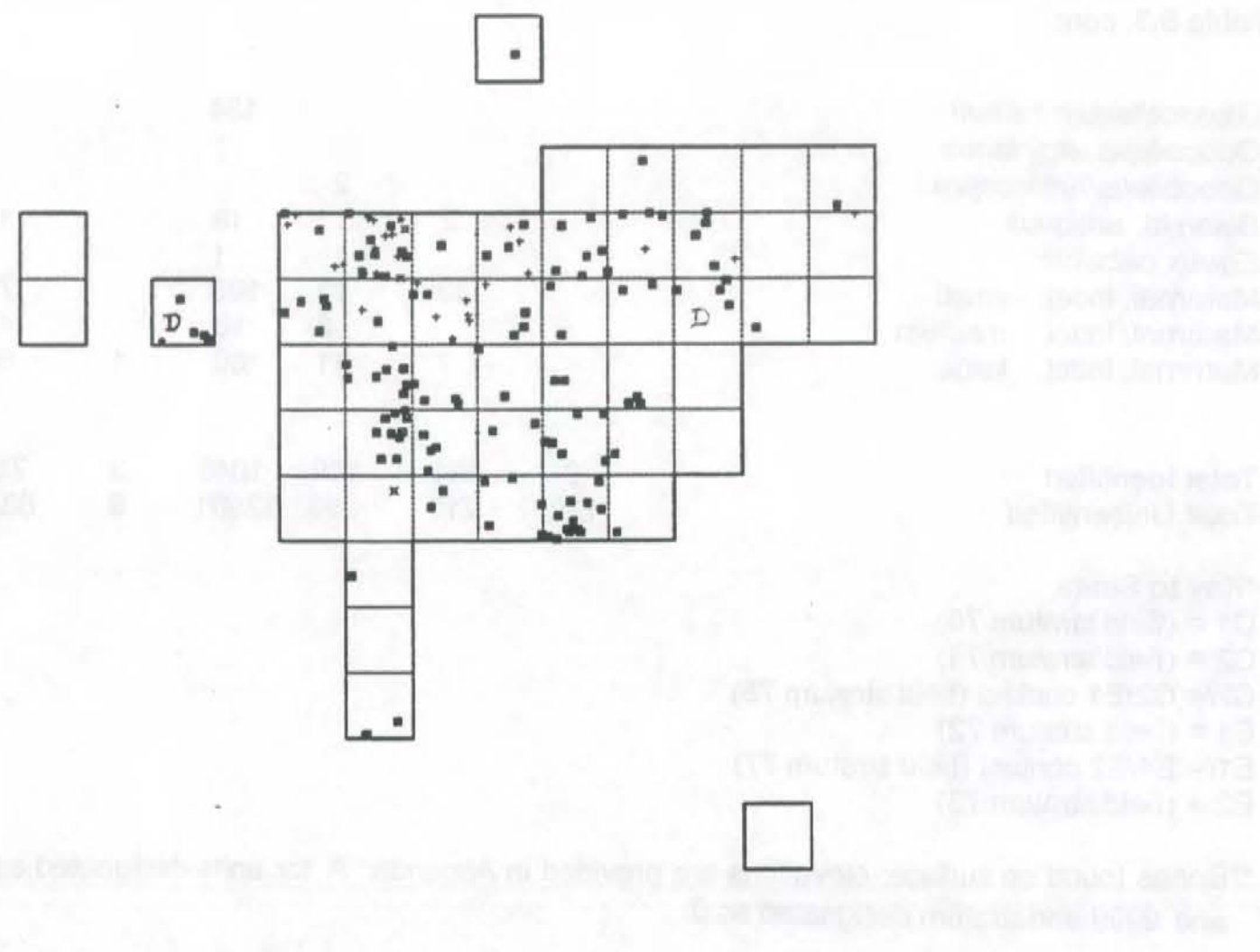

Figure 8.2 Map of large mammals, deer and bison, in pond axis sediments,

Area A. Note heavier concentration in northwestern part of block, close to distal edge of the colluvial "red wedge"

sloth skeletal elements were found. The researchers at Kimmswick postulated that only the skin had been present, leaving the ossicles as remnants. The ossicles from Aubrey were compared to those identified by Lundelius (1972) from the Ingleside Cave in San Patricio County and some from Rancho La Brea.

Bioturbation is demonstrated by the location of recovery of the ossicles from the pond sediments. Figure 8.1 shows the concentration of ossicles in the southeastern portion of the excavation block, but singular and small clusters were recovered from all but the north and west perimeters of the block.

The bison bones represent what was the likely target of activity at the pond. From the elements identified, and aging of some of those pieces, it appears that as many as three individuals were processed. Occlusal wear on several teeth indicate two adults, one of which was very old. (Subsequent excavations at the red wedge resulted in the recovery of remains of a bison calf.) Measurements of the metatarsal indicate that at least one of the adults was female (after Speth 1983). Figure $\mathbf{8 . 2}$ shows the plotted 


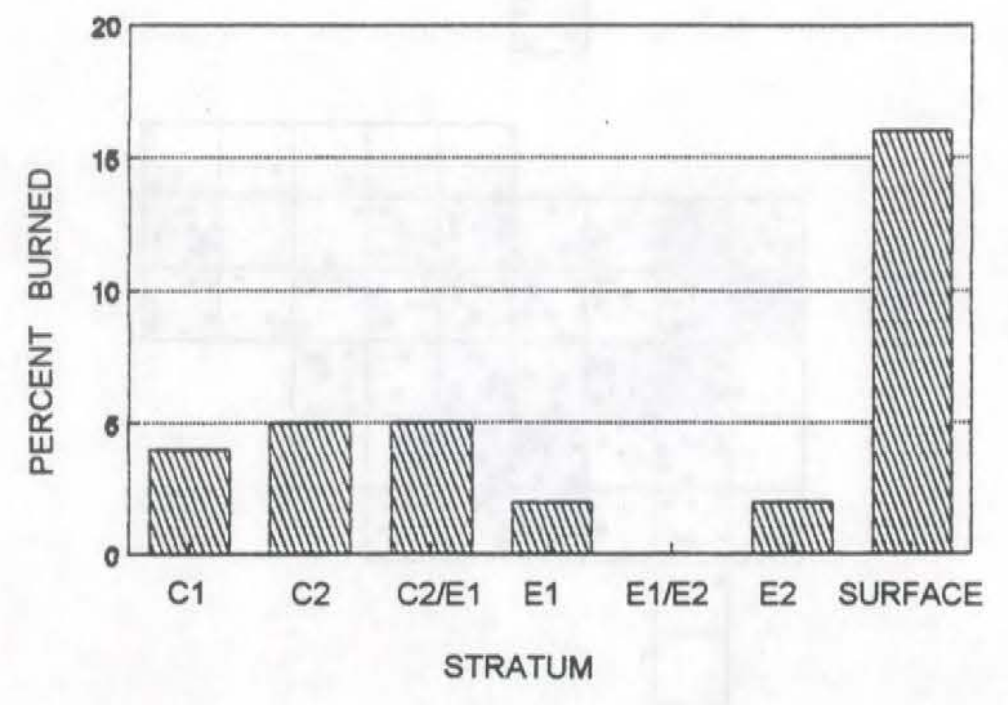

Figure 8.3 Burned bone from pond sediments (Area A) by stratum. Note that Stratum E1 yielded 14,008 bones in this block.

locations of bison remains, as well as elements coded as large mammal and deer. The bison remains cluster in the northwest area of the block, opposite the location of the ossicles, although large mammal fragments are strewn throughout the middle of the block.

Both axial and appendicular elements were left in this processing area, along with skull fragments (alveoli and teeth) and lower leg elements. Meaty elements such as upper limbs and backstrap vertebrae are notable for breakage patterning in the form of smashing, which leaves blow marks such as crushed edges and depressions with splintering (see Johnson 1978). The humerus and tibia exhibit these blow marks, as does a metatarsal from Unit 1556.

One rib fragment of a large mammal was slightly charred, and a deer metapodial fragment had evidence of burning. Total burned bone from the Pond constitutes only about $2 \%$ of the recovery, but some of the identified faunas indicate that at least some cooking took place near the pond (Figure 8.3). Identified bones of fish, turtles, snakes, birds, rodents and other small and medium mammals are burned to varying degrees; some are charred black, while others are calcined white. The low percentage of burned bone, the differential burning states, and the diversity of taxa that exhibit burning all argue against the burned condition being a result of a natural grass fire after occupation. Although no fire pit feature was found, open roasting fires would be difficult to detect. And from the diversity of the animals found among the burned fraction, it is clear that the pond area served at least intermittently and briefly as a place of food consumption as well as food procurement and processing. 


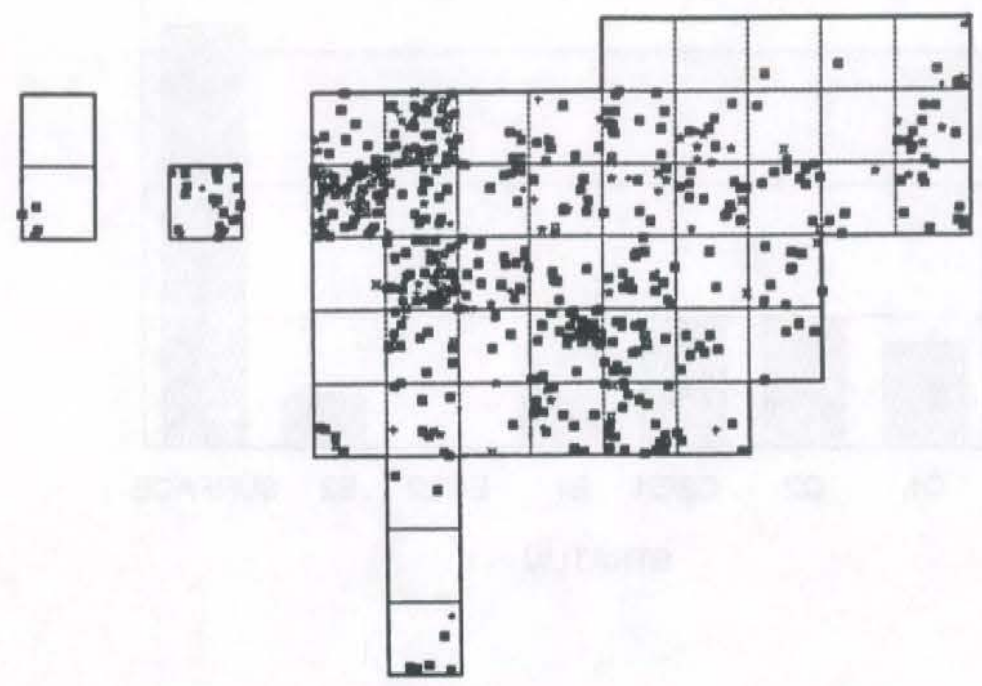

Figure 8.4 Map of small mammals, rabbits and rodents, Area A
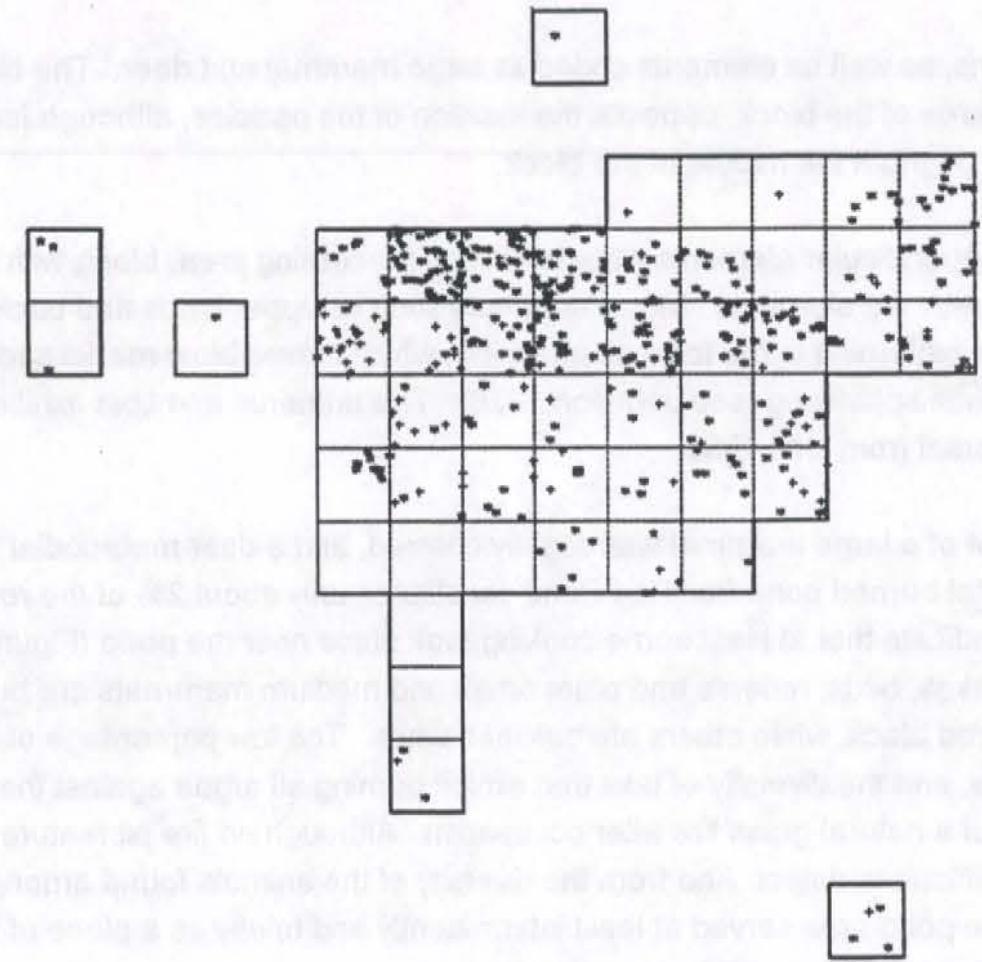

Figure 8.5 Map of reptiles and amphibians, Area A 
The smaller identified faunas listed in Table 8.3 are always problematic in an archaeological context as definite sources of nourishment. Some researchers (e.g., Sobolik 1988, 1991; Walker 1986; Williams-Dean 1978) have demonstrated the utility and likelihood of rodents as food sources. From strata $\mathrm{C} 2 /$ and $\mathrm{E}_{1}, 84 \%$ of the burned bones were from small mammals or non-mammals. By virtue of number of taxa, small mammals outnumber all others. Further, of the identified taxa, the fossorial rodent, Geomys, produced the most charred or burned elements. Passive collecting of rodents cannot be ignored as a subsistence activity here at Aubrey (Figures 8.4 and 8.5).

\section{Camp B}

Located about $60 \mathrm{~m}$ from the axis of the pond, this area has been designated as a camp based on the spatial patterning and composition of the assemblage of over 6,500 lithiuc artifacts, in addition to clustering of both burned and unburned bone. Spatial patterning in Camps $B$ and $F$ are discussed in Chapter 9 . The burned bone consists primarily of burned turtle shell fragments $(n=105)$, but also includes burned snake vertebrae, rodent and other small mammal elements, a rabbit claw, and a medium-sized mammal tooth fragment. These burned but identifiable elements cluster around units in the southern edge of the excavated area. Although no identified elements from large mammals were recorded as burned, the unidentified large burned bone is in direct association with the majority of the large mammal bones from the northern portion of the excavation area.

Over half (54\%) of all large mammal remains recovered at the site come from Camp B. These remains are considered to be identified elements (tibia, tooth fragment, phalanx, etc.) that can be attributed to vertebrate class, order, family, or genus. They are clustered around the open hearth areas in the northern and southern portions of the excavation. Furthermore, the unidentified fraction of bone from the camp is categorized as being from large animals, based on overall size of fragment and bone wall thickness, and these fragments also cluster in the same areas.

None of the large mammal remains or unidentified fragments exhibit modification, either in the form of cut marks or even burning. However, many long bone fragments show spiral fracturing. Attempts were made to conjoin several promising fragments with bison remains recovered from the Red Wedge, but no match was made. In the future, it is hoped that a DNA match could be made with the bison bones from both loci.

It is interesting to note that the taxa lists (Table 8.1) from both Area A and Area B contain many of the same animals, but the contexts of those remains differ greatly. Discounting the non-mammals and micro-mammals, the two areas share remains of rabbits, muskrats, deer, bison, and ground sloth. It is the sample sizes that differ significantly and the preservation of individual bones. For example, deer-size material is numerous, scattered, and highly fragmented in the camp, while deer is not identified at all on the Red Wedge, and only three elements were detected in the pond sediments. Bison bones on the Red Wedge were whole or nearly whole and were recovered in a context that suggests the original kill site. Whereas, bison bones in Camp B number only three elements: two teeth fragments and a horn core fragment. Undoubtedly some of the unidentified fraction are bison bones as well, but this cannot be demonstrated with certainty. Lastly, and perhaps most intriguing of all, are the dermal ossicles of Harlan's ground sloth, which are abundant in the pond sediments, but represented in the camp by a single ossicle. 
Area C

A small sample of animal bone was recovered from Area $C$, which is across the artificial outlet channel from the Camp B excavation block at Aubrey. Table 8.1 lists the taxa that produced the 152 identified elements from this area. No large mammals are represented, and fully one-third of the identified remains are broken fragments of turtle shell. Aquatic animals seem to dominate the assemblage (fish, pond turtles, muskrat) if the fossorial rodents are dismissed as intrusives.

\section{Camp F}

A small faunal assemblage from Camp $F$ is itemized in Table 8.1. Notable there is the predominance of deer and large mammal elements that are probably prey remains. However, nearly all of the remains are from fragmentary teeth. Undoubtedly, some of the carcass is accounted for in the unidentified fraction. Turtle and fish remains were concentrated in the eastern part of the block, as were remains of small and medium mammals. Unidentified large mammal bones were more concentrated in the central part of the block, near the major concentration of lithic debitage.

About $7 \%$ of the unidentified bones has been burned. Between 1991 and 1994 , three mammoth ribs were found eroding from sediments just east of Block F. This identification is tenuous, but the ribs could only belong to a mammoth or mastodon, and paleoenvironmental data suggest that this area would have most likely been inhabited by the former. The largest rib fragment is ca. $35 \mathrm{~cm}$ long, $7.5 \mathrm{~cm}$ wide and $2 \mathrm{~cm}$ thick. Another rib fragment was $85 \mathrm{~cm}$ long, $7 \mathrm{~cm}$ wide and $2 \mathrm{~cm}$ thick.

These ribs were in situ in sediments at the edge of the Clovis age river channel. Their precise stratigraphic position has not been determined however, and there is a possibility that they are in the upper part of Stratum A sediments and not associated with the Clovis occupations. Excavation of a test trench into a complete profile will be necessary to clarify this important issue.

One of the mammoth ribs has green bone fractures that converge to create a point on one of the ribs. The possible significance of this will have to await recovery of more bone in clear stratigraphic context. A scatter of lithic artifacts was found in the same area as the ribs, but no artifacts were found in situ with the ribs. (No formal testing has been done here. These ribs were individually mapped and removed with a minimum of sedimentary matrix). Other than the tooth plates recovered in Area B, these are the only mammoth remains at Aubrey. Their position adjacent to Camp $F$ is intriguing to say the least.

\section{Summary}

At Aubrey, utilization of a variety of habitats is indicated by the diverse array of faunal remains. Figure 8.6 compares the habitat types represented in three loci that yielded the most fauna. Aquatic forms are very important to the activities in Camp B, unusual in that one might expect, if the faunas were strictly 


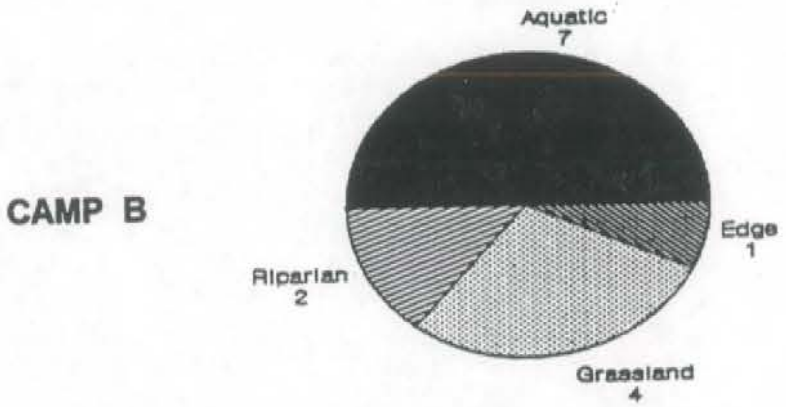

POND AXIS

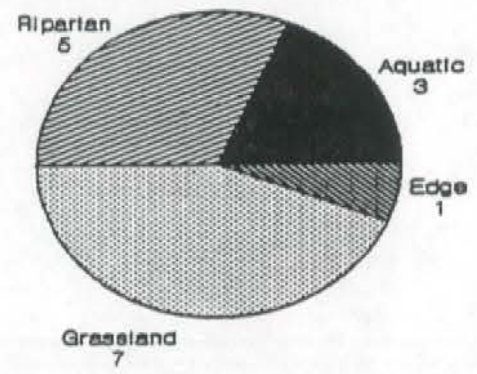

RED WEDGE

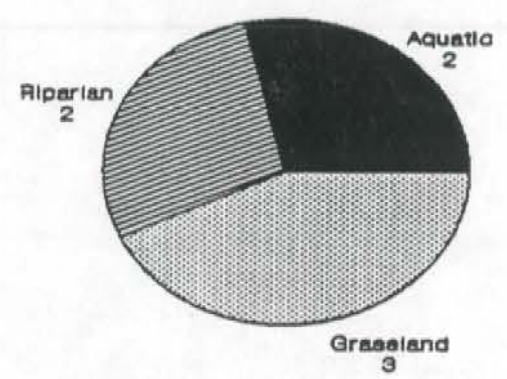

Counts $=$ number of taxa per habitat type

Figure 8.6 Habitats represented by faunas at the Aubrey site

natural in origin, to be the case at the Pond. Edge faunas are low at all loci, but this is a factor of labelling, not really indicative of habitat choice since only three species were labelled for this type - deer, rabbit, and skunk. The exploitation of multiple biomes is clearly indicated. 


\title{
CHAPTER 9
}

\section{ARCHAEOLOGY OF THE AUBREY CLOVIS SITE}

\author{
by \\ C. Reid Ferring
}

Introduction

After discovery, the UNT team spent one year in the field testing, excavating and studying the natural history of the Aubrey site. Here the results of the fieldwork and laboratory analyses of the archaeological materials are described.

\section{Provenience}

\section{Methods}

Horizontal control was maintained within a cartesian grid system that is oriented $5^{\circ} \mathrm{E}$. To facilitate field labeling and projected computer coding of materials, the site was divided into several $100 \mathrm{~m} \times 100 \mathrm{~m}$ areas (designated 41DN479A, B, C, F and G; Figure 9.1). These areas are all on the same cartesian grid, yet each has its own 0,0 point. By this means, all $1 \times 1 \mathrm{~m}$ squares were identified by four digits instead of six. Once coded and entered as computer files, these grids can readily be rectified to the master cartesian system.

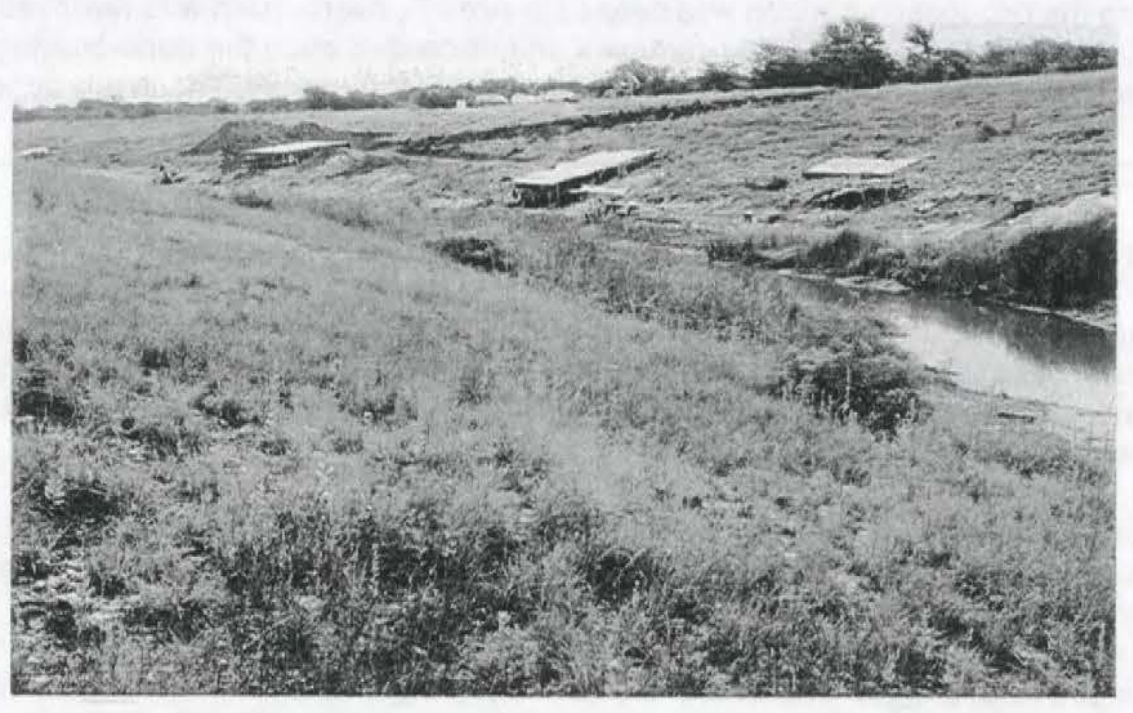

Figure 9.1 Photograph of the Aubrey Site with Excavation Areas. View is to the E-SE, at the south bank of the outlet channel. Excavation areas are: a- block Ar on mid-slope of "red Wedge" at western margin of pond; $b$ - Block $A$ in axis of pond; $c$ - Block $B$, on east shore of pond, and d-Block $F$, on west bank of Clovislage river channel. Note: right edge of photo is within $2 \mathrm{~m}$ of the bedrock scarp of the late Pleistocene valley, with spring, and deposits sloping towards pond axis. Distance from Red Wedge to Camp F is ca. 200 meters. Ground surface is Elm Fork Trinity River flood plain. 
All vertical provenience has been referenced to the local arbitrary datum of $100.00 \mathrm{~m}$. A permanent datum (stamped brass marker set in concrete) with an elevation of $96.669 \mathrm{~m}$ was set southwest of the excavation area, on the other side of the collector ditch that is south of and parallel to the outlet channel. This datum is linked to the Corps benchmark, and numerous other permanent features. Several subdata (metal rods set in concrete) were also emplaced along the south side of the outlet channel just below the present floodplain.

Vertical provenience of all artifacts and bones was recorded whenever possible by piece plotting. Artificial $10 \mathrm{~cm}$ levels were used for most of the remaining materials, except for one square each in Areas B and $F$, which were excavated in $5 \mathrm{~cm}$ levels. After testing, the range of the possible archaeological horizons' elevations were known; the level system was structured to keep the level numerals small, but to allow flexibility in case unanticipated changes in levels had to be made. The $10 \mathrm{~cm}$ level system was established such that level $1=91.00-90.90 \mathrm{~m}$; level $10=90.10 \mathrm{~m}-90.00 \mathrm{~m}$, and so on. This means that the first level in Block B was usually level 19 or 20 . In Block A (pond axis) levels were in the range of 33-35. So the first level of a unit in a block was never " 1 ". Both level number and elevations for that level were written on all records pertaining to that provenience. After test excavations, all excavations were conducted with $1 \times 1 \mathrm{~m}$ squares divided into $50 \times 50 \mathrm{~cm}$ quadrants. The $1 \times 1 \mathrm{~m}$ squares were named with the South+East coordinate of their southeast corner. An example of an excavation unit label is: 41DN479B/1824/SW/20.

\section{Test Excavations}

In Areas A and B, test excavations were implemented on the 1 meter grid system. Arbitrary $10 \mathrm{~cm}$ levels were used, until stratigraphic boundaries were defined, and then these were used as well. All bones and artifacts were piece plotted in three dimensions, using the transit for elevations. All matrix was initially fine screened. Once the occupation horizon was defined in Area B, overburden was removed and stacked on plastic by level. In Area A, overburden was removed and discarded once the bone-bearing horizons were identified. Backhoe trenches were also excavated to reveal stratigraphy. These are described in Chapter 3.

\section{Excavation Blocks}

After the block locations were selected, overburden was removed with heavy equipment. About 2,000 cubic meters of overburden was removed to expose Block B. The transit was used to ensure that overburden removal was done accurately, and the last $30-40 \mathrm{~cm}$ of overburden was taken out with shovels. Thereafter, all excavations were done with trowels.

Every effort was made to plot specimens in situ. Over 800 lithic artifacts, many more bones and also charcoal pieces were mapped in place. Each plotted specimen was given a specimen number and bagged separately. Orientations and dips of long/flat bones were recorded.

All matrix from all excavations was water screened through 1/16" mesh. All material that did not pass the screen was dried in the field, bagged and sent to the lab for picking and sorting. Screeners did place any artifacts or bones found during washing in film canisters to reduce damage. A strip of flagging tape, filled out by the excavator, was kept with the unpicked matrix until the bag was processed in the field. Field bag numbers and specimen number catalogues were constantly audited.

Block A (pond axis). This block was situated over the old pond axis, where bison and deer bones were first discovered. This block was excavated primarily to recover the abundant fauna preserved there, although some lithic artifacts were also found. The block consisted of 64 contiguous $1 \times 1 \mathrm{~m}$ units, and seven outlying $1 \times 1 \mathrm{~m}$ units (Figure 3.1 ). 


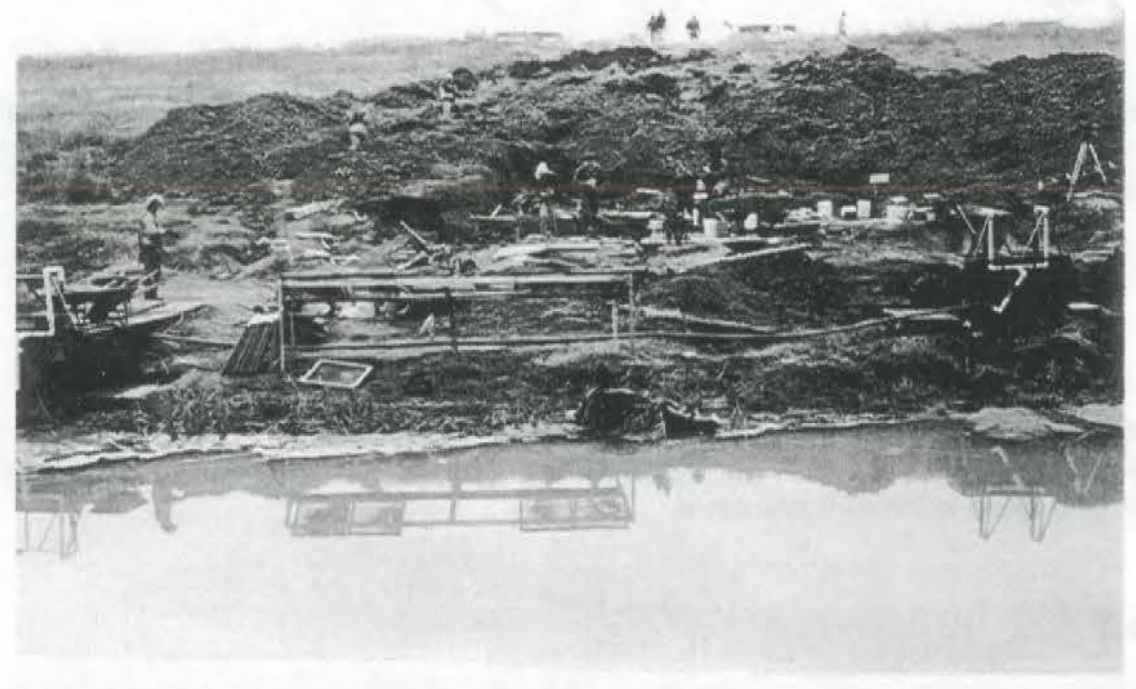

Figure 9.2 Photograph of excavations in progress at Block F. View to south. Note water screening station at left (east) side of photo. All matrix from all excavations was screened through window screen.

Block A (red wedge). A small block of seven contiguous squares was excavated west of the pond sediments to recover artifacts and faunas from the surface of the red wedge. Three additional test units were excavated near the small block.

Block B was the most extensive excavation area (Figure 9.3). It was situated on the east edge of the Clovis-age pond, and contained in situ lithic artifacts, faunas and several hearth areas. The block consisted of 108 contiguous $1 \times 1 \mathrm{~m}$ units and four outlying units.

Block F was located about $125 \mathrm{~m}$ east of Block B, adjacent to the Clovis age paleochannel. It consisted of 64 contiguous $1 \times 1 \mathrm{~m}$ units and four $1 \times 1 \mathrm{~m}$ units near the main block (Figures $3.1 ; 9.2$ ). In situ lithic artifacts as well as a limited fauna were recovered.

Area G was neither tested nor excavated. Quartzite flakes and one stone chopper were found there between 1989-1998. These suggest that in situ cultural remains, on the Clovis paleosurface, are preserved there in at least two areas. The first is on the east bank of the paleochannel opposite the Area F block, where the stream was flowing south-southeast. The other is about $500 \mathrm{~m}$ farther east, on the east bank of the same paleochannel but along the east side of the large meander, where the stream flow was northnortheast.

Area C was only tested, with very limited recovery of artifacts and bones. Eight "strat tests" were dug without screening along the outlet channel to search for bones; no recoveries were made. Seven $1 \times 1 \mathrm{~m}$ test pits, three of which were contiguous, were also excavated. These yielded very few faunal remains and even fewer chips. In the field laboratory all matrix was picked, and the contents were separated into bags for lithics, bone, snail shell, charcoal, etc.

After the fieldwork was completed, all excavations were backfilled. In addition to extensive mapping, a number of measures were taken to facilitate future relocation of our excavation units. Each block perimeter was marked with nylon rope. Also, each corner around the block perimeter was marked 
with a piece of magnetic tape. A number of the plywood squares and small sheets of black plastic were also left in place before backfilling. These had been used during excavations to keep from stirring up the mud after the seemingly endless rains in the spring of 1989.

\section{Features}

Eleven features were identified during the excavations at Aubrey. Only one of these, the well on the red wedge in Area A, is a constructed feature. The rest are either lithic concentrations or hearths that were defined by clusters of burned bone and charcoal.

\section{Features in Camp B}

Except for the several unlined pit hearths at the Murray Springs Site in Arizona (Haynes 1976, 1982), Clovis sites tend to yield evidence only for surface fires (Stanford 1991). Aubrey fits that pattern. Despite extremely slow troweling in areas yielding burned material, no hearth or pit outlines of any kind could be found. Further, The entire fine-screening effort yielded only two stones. One is a limestone pebble about $1.5 \mathrm{~cm}$ in diameter and the other is hematite about $4 \mathrm{~cm}$ long, but with no evidence of grinding. There were definitely no rock-lined hearths in the areas we excavated!

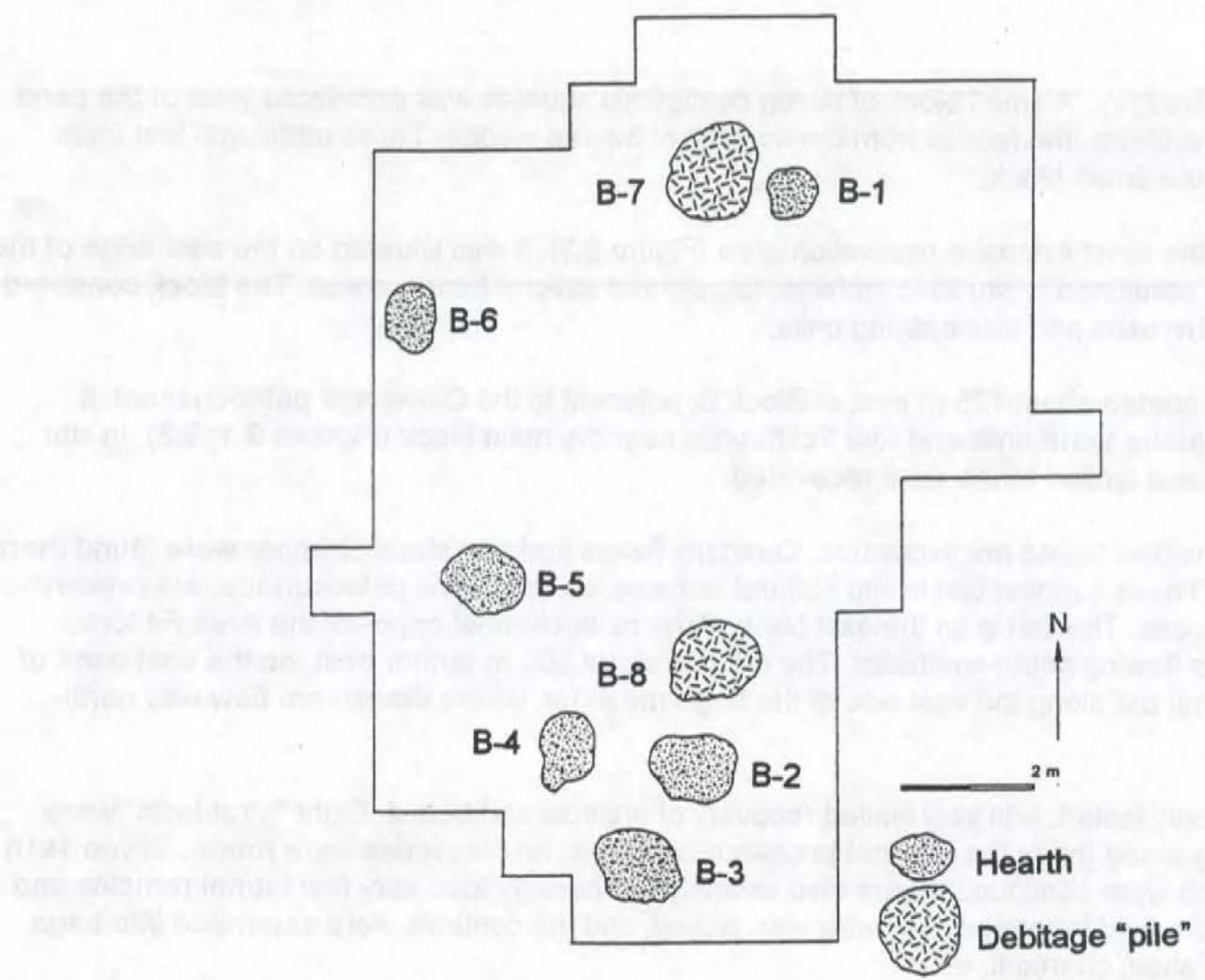

Figure 9.3 Map of Features in Camp B. Hearths are identified by concentrations of burned bone and charcoal, and appear to have all been surface fires. No burned rock was found in any of the excavations. Note the proximity of the two "debitage piles" (Features B-7 and B-8) to hearths. 


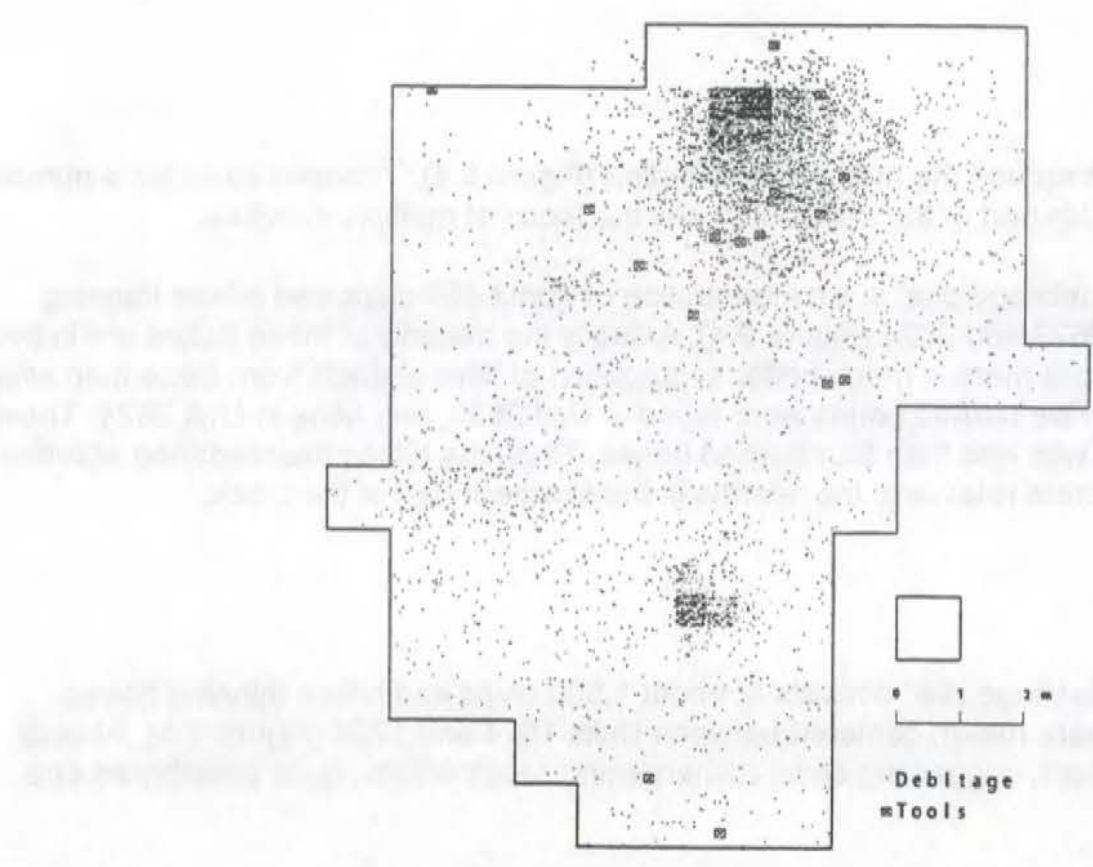

Figure 9.4 Map of Lithic Artifacts in Camp B. About 800 artifacts were mapped during excavation, the rest are shown here as random locations within the $50 \times 50 \mathrm{~cm}$ excavation units. Note that over half of the artifacts occur in the northern cluster, and almost one third occur in Feature B-7 (Figure 9.3).

Feature B-1 is a hearth with a defined center in the northeast part of square 1825 (Figure 9.3). That square contained 62 burned faunal elements; the burned bone distribution extends to the south and southwest. In the square immediately to the west of this bone concentration is the "debitage pile" (Feature B-7). The "debitage pile" in the southern part of the block (Feature B-8) is also next to a hearth.

Feature B-2 is a concentration of burned large mammal bone, burned turtle carapace/plastron and charcoal. There are two additional clusters nearby to the southwest and west, also having concentrations of bone and charcoal (Figure 9.3).

Feature B-3 has burned large mammal bone, a few pieces of burned turtle, and a charcoal concentration. Burned snake is also concentrated in this hearth.

Feature B-4 is about a meter west of Features B-2 and B-3. Despite their close spacing, these hearths appear to be discrete, and have very distinctive artifact concentrations around and between them. See spatial patterning section for discussion.

Feature B-5, located in the west-central part of the block, is marked mainly by burned large mammal bone fragments, and charcoal. of charcoal.

Feature B-6, located in the northwestern part of the block is marked principally by a concentration

Feature B-7, the northern of two "debitage piles" includes about 1,800 pieces of debitage that were found in just one $1 \times 1 \mathrm{~m}$ square (Unit 1824), adjacent to hearth Feature B1. The lithic artifacts are predominantly quartzite chips and biface thinning elements, but also include a few URCs. Refitting and technological analysis showed that at least one large Clovis preform was reduced there. A "halo" of dense 
lithic debris extends for about $2 \mathrm{~m}$ around the major concentration (Figure 9.4). This also includes a number of lithic tools, described below. This part of the site was clearly the focus of multiple activities.

Feature B-8, the south "debitage pile" is a concentration of about 450 chips and biface thinning flakes, centered between Units 2623 and 2624 (Figure 9.4). Actually the majority of those flakes are in two quads- one half square meter. Here there is much better segregation of lithic artifacts from bone than seen in the northern part of the block. Five burned bones were found in Unit 2623, and none in Unit 2624. These squares are surrounded by units with less than four burned bones. Thus, the biface maintenance activities in Feature B-6 were spatially discrete relative to the hearths in the southern part of the block.

\section{Features in Camp F}

Feature F-1, the north "debitage pile" consists of about 1,500 chips and biface thinning flakes located in an area of about 1 square meter, centered between Units 1624 and 1724 (Figure 9.5). At least three raw material types are present, suggesting serial resharpening-repair efforts, quite possibly as one event.

Feature F-2, the south "debitage pile" is a more diffuse scatter of lithic debris, located about two meters south of Feature F1 (Figure 9.5).

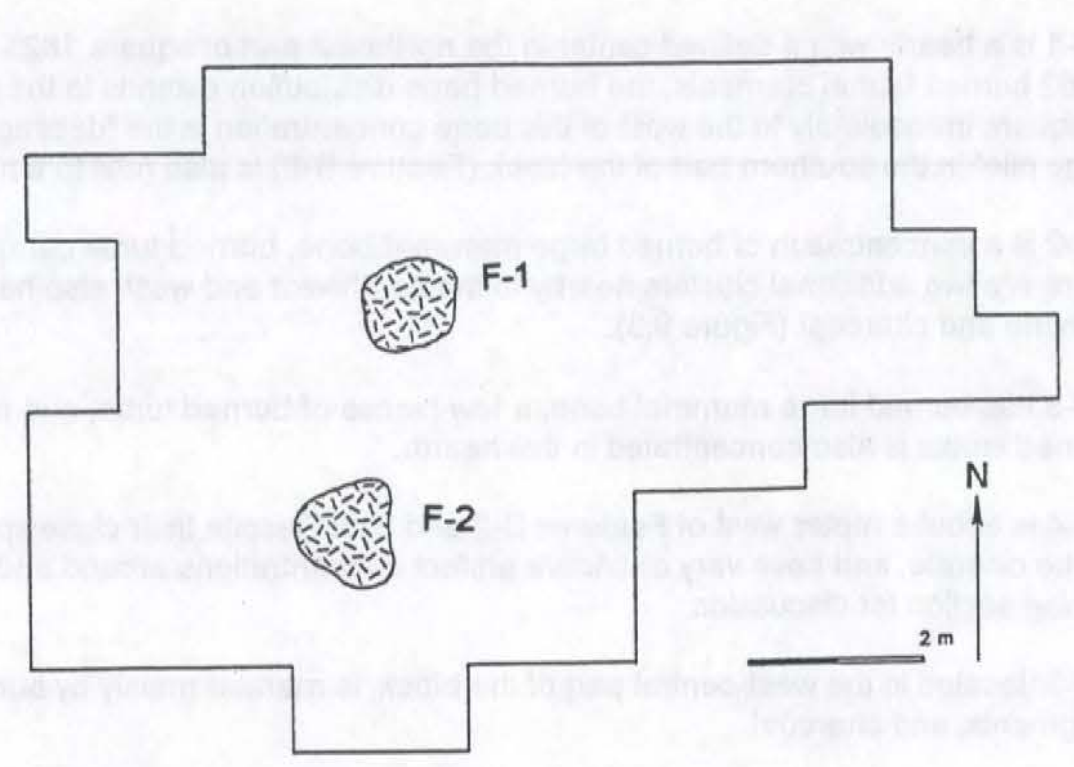

Figure 9.5 Map of Features in Camp F. Both features are concentrations of lithic artifacts. About one half of the artifacts in this excavation block are from Feature F-1. There were no concentrations of burned bone or charcoal in this block. 

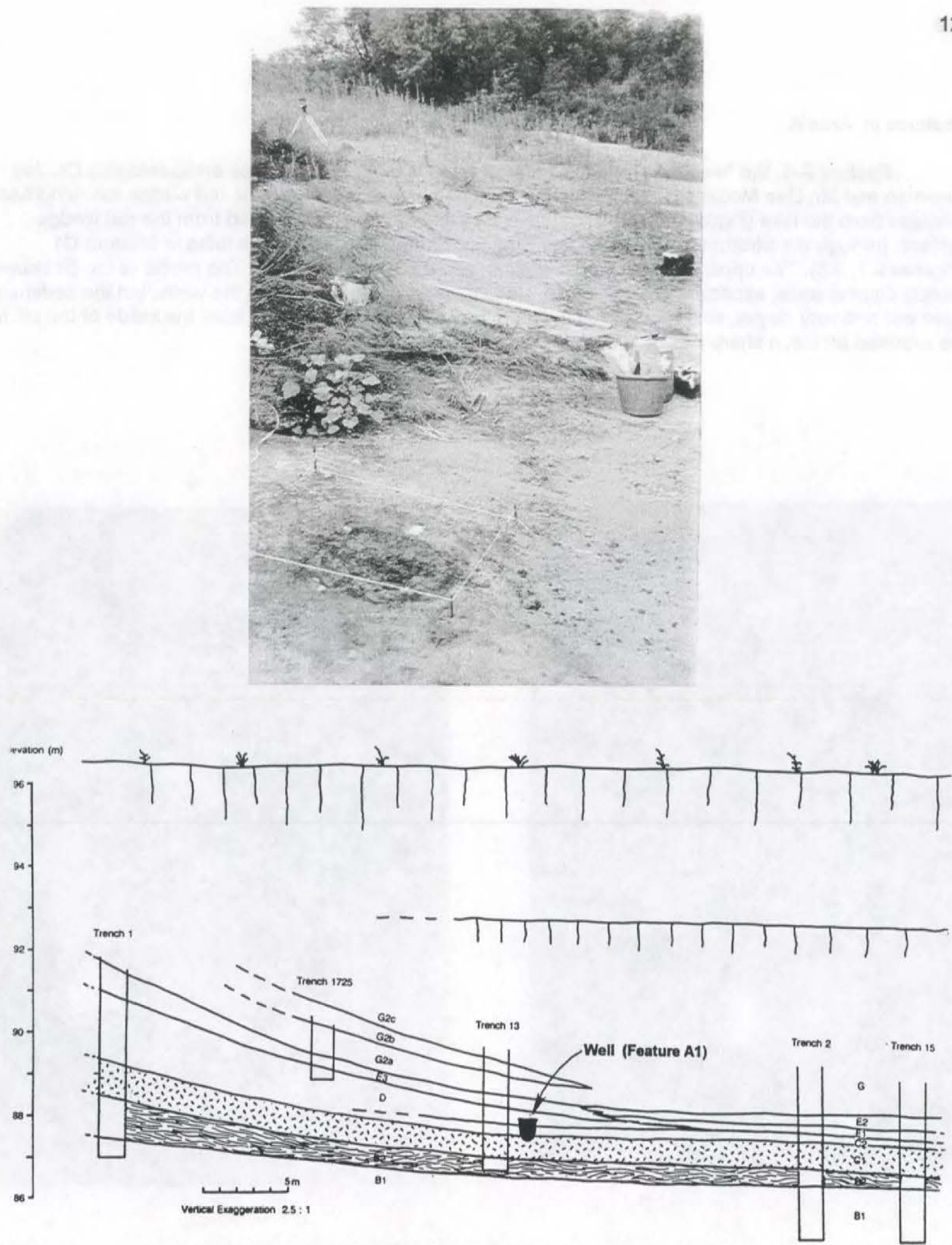

Figure 9.6 Photograph and cross-section of the western pond margin showing position of the well. a- View to west, up Red Wedge surface from pond axis, with well in foreground. Tree line in background is the contact between Cretaceous bedrock and the inset Pleistocene and Holocene deposits and alluvium. b - note that well penetrated porous tufas in Stratum C1, below the base of the pond at time of Clovis occupations. 
Features in Area A

Feature A-1, the "well" was found in 1994 on a visit to the site with Corps archaeologists Dr. Jay Newman and Mr. Dan McGregor to inspect bones that had been exposed on the red wedge following heavy releases from the lake (Figure 9.6). This feature is a pit that had been excavated from the red wedge surface, through the Stratum D red wedge and Stratum C2 marl into the porous tufas in Stratum C1 (Figures $9.7,9.8$ ). The upper part of the pit is circular, about $60 \mathrm{~cm}$ in diameter. The profile of the pit shows steeply dipping walls, especially the south wall. No tool marks could be seen in the walls, but the sediments were wet and very clayey, so it was difficult to carefully expose the wall contact from the inside of the pit. In the exposed profile, a sharp pit wall is evident.
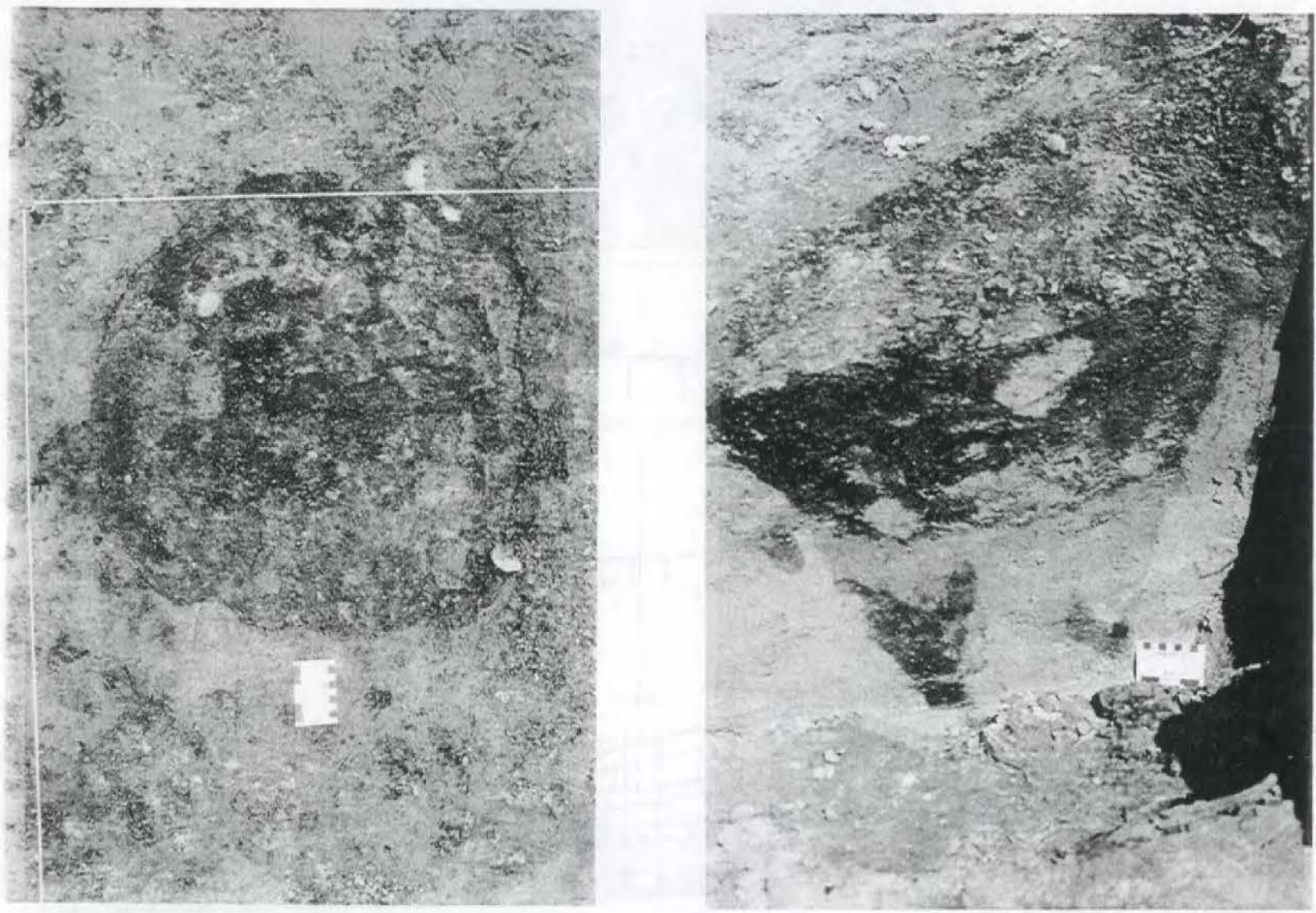

Figure 9.7 Photographs of Feature A-1, the Well. a - Photo to the east, showing plan view of well at surface of red wedge; $\mathrm{b}$ - Profile exposed on north-south midline of the well, looking east. 


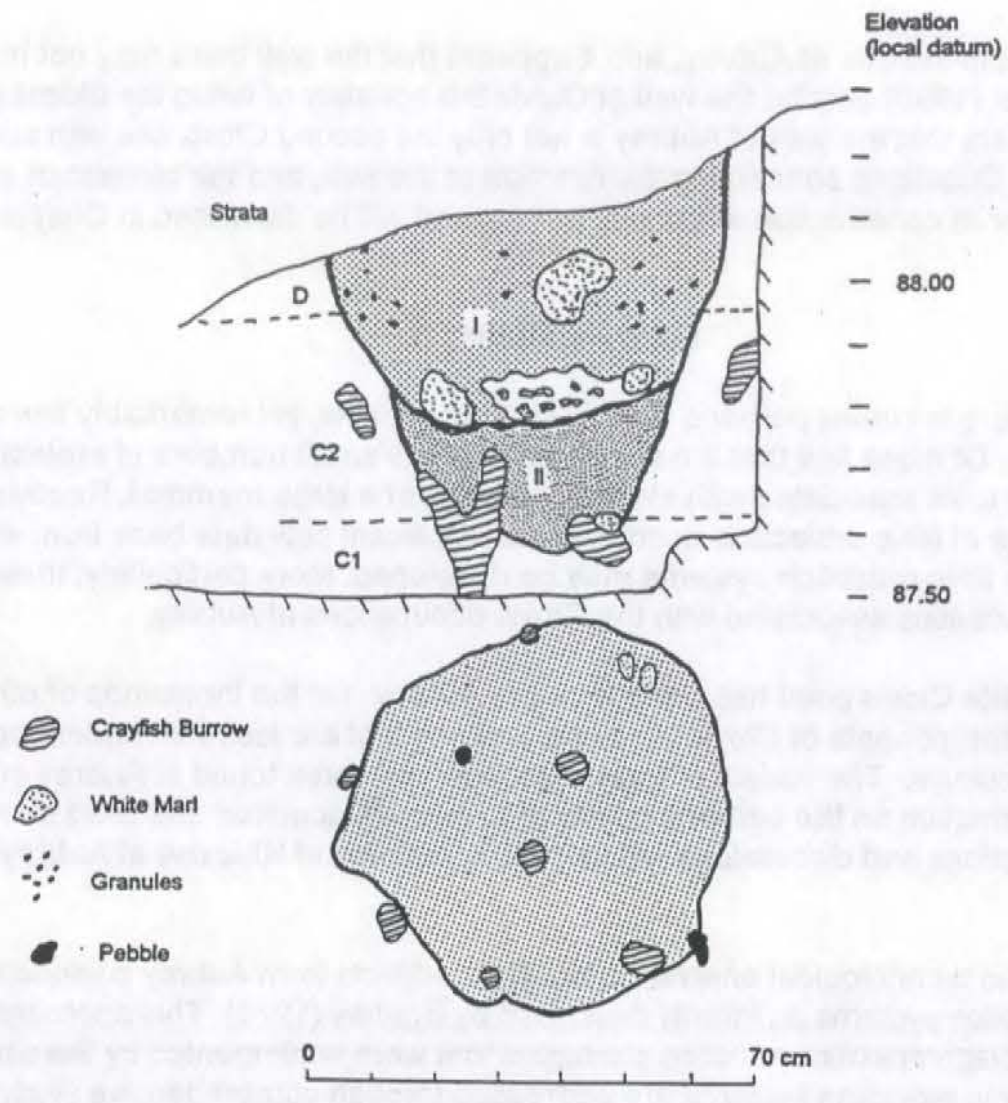

Figure 9.8 Map and Section of the Well. Note two fill units, rip-ups of white tufa from Stratum C1, and sharply defined walls and base. No artifacts or faunal remains were found in well fill.

There is a change in the fill matrix at about $87.95 \mathrm{~m}$ (Figure 9.8). The contact between the two fill units is so abrupt that it suggests either a) a very rapid change in the mode of infilling or b) two serial episodes of excavation and filling with sediment. The upper fill (A) consists of black clays, with inclusions of white marl (from Unit C2), and granules of sandstone and limestone from Unit D. The lower fill consists of gray loamy marl, with fewer inclusions. The base of the pit is clear, and is rounded.

There seems to be little doubt that this is a cultural feature. The fact that it was excavated into very porous sediments implies that the excavators wanted to reach water in that stratum, or intentions to dig a deeper pit were foiled. The base of the pit is below the base of the pond that existed in Clovis time (the $\mathrm{C} 2 / \mathrm{E} 1$ contact in Figure 9.6). Thus this well could have exposed subsurface spring waters, or, it could have back filtered stagnant water from the pond, or, it could have reached a shallowly buried water table that was below the base of the pond.

Wells dug during the Middle Archaic period are documented on the Southern High Plains (Haynes and Agogino 1966; Meltzer 1991). A Clovis age well has been described from the Clovis type site, Blackwater Draw No. 1, near Clovis New Mexico (Haynes 1995; Haynes et al 1999). The feature at Clovis 
is significantly deeper than the one at Aubrey, and it appears that the well there may not have been successful. Haynes et al (1999) ascribe the well at Clovis the notoriety of being the oldest prehistoric well in North America. It appears that the well at Aubrey is not only the second Clovis site with such a feature, but the oldest one as well. Questions concerning the function of the well, and the climatic or seasonal conditions that called for its construction are knotty issues, and will be discussed in Chapter 10.

\section{Lithic Assemblages}

The Clovis culture is known perhaps best by its lithic artifacts, yet remarkably few assemblages have been found in situ. Of those few that are in situ, several are small numbers of projectile points and perhaps a few unifacial tools associated with skeletal remains of a large mammal. Recovery at Aubrey of a large in situ assemblage of lithic artifacts is accordingly a significant new data base from which interpretations of Clovis lithic reduction systems may be developed. More particularly, these artifacts provide a basis for analysis of activities associated with the Clovis occupations at Aubrey.

Not one complete Clovis point has been found at Aubrey. Yet the thousands of other kinds of artifacts are related to components of Clovis lithic use systems that are less well understood than the fluted A type fossil for Clovis culture. The variety of tools, debitage and cores found at Aubrey comprise a valuable source of information on the patterns by which Clovis folk acquired and used stone raw materials. As the following descriptions and discussions will show, the patterns of lithic use at Aubrey are quite variable.

The approach to technological analysis of the lithic artifacts from Aubrey is modeled after the concept of lithic reduction systems as initially described by Bradley (1975). This approach emphasizes the identification of assemblage specific reduction strategies that were implemented by the site occupants. The main components of lithic reduction systems are addressed through comprehensive study of the artifacts in order to identify the patterns of choices made by flint knappers at each stage in lithic processing, use and discard (eg, Ferring 1980; 1988). This approach to lithic analysis is currently in vogue in Old World prehistory, where the concept of "technique" has been replaced by the reconstruction of the "chaine operatoir" (sequence of operations) to determine the precise nature of the reduction strategy (Boeda 1988).

Similarly, lithic tool analysis has in recent years stressed definition of tool life-use histories as opposed to strictly morphological classificatory approaches (eg. Dibble 1993). This is not to say that New World archaeologists have not been doing sound lithic analysis, but that for the most part, analysis of Paleoindian assemblages over the last few decades has been something quite short of the standardized approaches used in the Old World. Uniform systems of classification (but certainly not analysis) of attributes and artifact classes make as much sense in archaeology as systematic taxonomies in biology or mineralogy. New World archaeologists have developed systematic classification schemes in some regions with respect to ceramic or projectile point classifications. But despite the well-recognized possibilities for systematic approaches to lithic artifacts, especially cores and debitage, uniform descriptive and classificatory systems are not used on a significant scale. Analysis of the artifacts from Aubrey has been done with as much traditional terminology and classifications as possible, with a decidedly Old World base for the approach.

\section{Assemblage Overviews}

A total of 9,819 lithic artifacts were recovered and analyzed from the Aubrey site (Table 9.1; Figure 9.9). Since almost all but a few of these were found in situ, this is one of the largest assemblages of Clovis materials found in any context. In the western US, this assemblage is exceeded in size only by that from Murray Springs (Haynes 1971, 1972), although that material has not been fully published. 
Table 9.1 Assemblage Composition, Aubrey Clovis Site

CLASS

DEBITAGE

Chips-chip fragments

Flakes-flake fragments

Biface thinning flakes

Core trimming elements

Blades

Bladelets

Uniface resharpening chips
A R E A

\begin{tabular}{llllllll} 
B & F & Ap & Anw & C & G & Total & $\begin{array}{l}\text { Debitage Class } \\
\text { Frequencies }\end{array}$ \\
\hline
\end{tabular}

$\begin{array}{rrrrrrrrr}4802 & 2947 & 8 & 33 & 9 & 5 & \mathbf{7 8 0 4} & 79.7 & 79.8 \\ 608 & 457 & 1 & 3 & & & 1069 & 10.1 & 12.4 \\ 217 & 204 & 1 & & & & 422 & 3.6 & 5.5 \\ 10 & 1 & & & & & 11 & 0.2 & 0.03 \\ & 1 & & & & & 1 & 0 & 0.03 \\ 7 & 22 & & & & & 29 & 0.1 & 0.6\end{array}$

$\begin{array}{llll}379 & 58 & 1 & 2\end{array}$

$\begin{array}{rrrrrrr} & 1 & & & & & 1 \\ 2 & 2 & & & & & 4 \\ 39 & 14 & & 5 & 1 & 1 & 60 \\ 6064 & 3707 & 10 & 44 & 10 & 6 & 9841\end{array}$

CORES

TOOLS
TOTAL

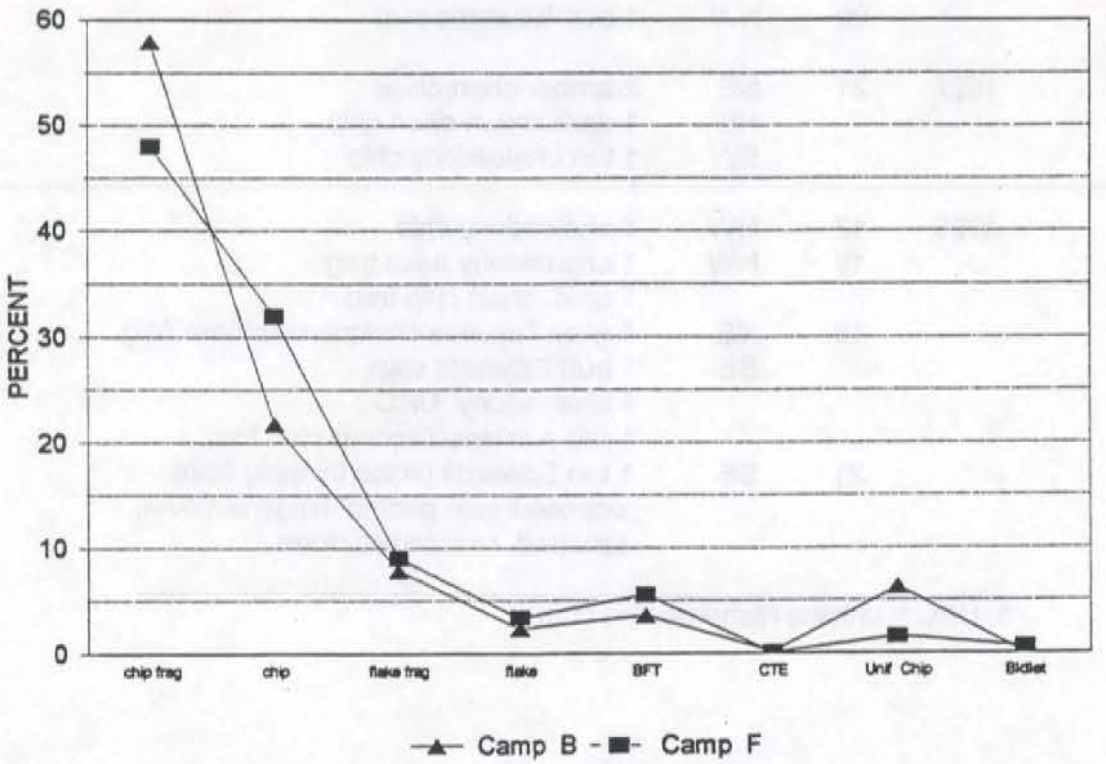

Figure 9.9 Debitage Class Frequencies for Camps B and F Assemblages. Note overall similarity in composition. Very high chip frequencies reflect use of wet fine screening for all excavation matrix. Higher frequencies of BFTs in Camp F and URCs in Camp B are significant indicators of functional differentiation between uses of the two areas. 
Table 9.2 Artifacts from Area A - Red Wedge

\begin{tabular}{|c|c|c|c|}
\hline Unit & Level & Quad & Description \\
\hline \multirow[t]{10}{*}{1624} & 16 & NE & 1 chalcedony chip \\
\hline & 17 & NE & 1 white novachert flake. frag. \\
\hline & 18 & $\mathrm{NE}$ & 1 chalcedony chip \\
\hline & 18 & NW & 1 dark gray Edwards chip \\
\hline & & & $\begin{array}{l}1 \text { white Tecovas quartzite chip frag. } \\
1 \text { light gray Edwards chip frag., burned }\end{array}$ \\
\hline & & SW & 1 white Tecovas quartzite chip \\
\hline & 19 & SE & 1 Amber cht/Edwards chip \\
\hline & & SW & 1 chalcedony chip frag. \\
\hline & & & 1 Alibates/Tecovas chip frag. \\
\hline & & NW & 1 Alibates/Tecovas chip \\
\hline \multirow[t]{11}{*}{1625} & 17 & NW & 1 White Edwards chip \\
\hline & 18 & NE & 1 Amber chert chip \\
\hline & 19 & NE & 1 white Edwards chip \\
\hline & & & 1 brown chert URC \\
\hline & & SW & 1 buff Edwards chip frag. \\
\hline & 20 & SW & 1 gray Edwards chip \\
\hline & & NE & 1 Alibates/Tecovas chip \\
\hline & & & 1 dark gray Edwards chip \\
\hline & 21 & SE & $\begin{array}{l}1 \text { buff Edwards chip frag. } \\
1 \text { amber chert chip }\end{array}$ \\
\hline & & SW & 1 dark gray Edwards chip frag. \\
\hline & 22 & SE & 1 purple Alibates/Tecovas chip \\
\hline \multirow[t]{2}{*}{1626} & 19 & SE & 1 Amber chert chip \\
\hline & 20 & NW & 1 buff Edwards chip \\
\hline \multirow[t]{3}{*}{1627} & 21 & SE & 2 amber chert chips \\
\hline & & NE & 1 dark brown chert chip \\
\hline & & SW & 1 tan chalcedony chip \\
\hline \multirow[t]{7}{*}{1725} & 17 & NW & 1 chalcedony chip \\
\hline & 18 & NW & 1 chalcedony flake frag. \\
\hline & & & 1 unid. chert chip frag. \\
\hline & 19 & $\begin{array}{l}\text { NE } \\
\text { SE }\end{array}$ & $\begin{array}{l}1 \text { gray Tecovas chalquartzite flake frag } \\
1 \text { buff Edwards chip }\end{array}$ \\
\hline & & & $\begin{array}{l}1 \text { chalcedony URC } \\
1 \text { red Alibates/Tecovas chip fraq. }\end{array}$ \\
\hline & 21 & SE & $\begin{array}{l}1 \text { red Alibates/Tecovas chip frag. } \\
1 \text { tan Edwards biface thinning flake }\end{array}$ \\
\hline & & & $\begin{array}{l}\text { opposed scar pattern; hinge removal; } \\
\text { facetted, reduced platform }\end{array}$ \\
\hline
\end{tabular}

$1 \mathrm{URC}=$ uniface resharpening chip

All but 69 of the lithic artifacts are from Camps B and F, where the major excavations were located. In Area A, the few excavation units on the red wedge, and the low density of materials in the pond axis block resulted in small but nonetheless important samples of debitage and tools (Tables 9.2, 9.3). Likewise, a small sample was recovered from Area C, which was only tested (Table 9.4). Except for a limestone chopper, all of the artifacts from Area G (Table 9.5), on the east side of the Clovis paleochannel, were found on the surface. Their location and concentration indicated they almost certainly had eroded from the Clovis age paleosurface there on the east bank of the Clovis age channel. 
Table 9.3 Artifacts from Area A - Pond Axis

\begin{tabular}{llrl} 
Unit & Stratum & Level & Description \\
\hline 1460 SE & E1 & 34 & dark brown unid. chert chip \\
1556 (Test) & E1/E2 & 1 & gray Tecovas chalquartzite chip \\
1559 (Test) & E1/E2 & 4 & gray Tecovas chalquartzite chip \\
1560 NE & E1 & 33 & unid. chert flake fragment \\
$15635 W$ & E1 & 36 & $\begin{array}{l}\text { white Edwards chip; facetted platform, } \\
\text { probably from biface }\end{array}$ \\
$16595 W$ & E1 & 34 & light gray Edwards chip \\
1759 NE & E1 & 34 & chalcedony uniface resharpening chip \\
$1761 \mathrm{NE}$ & E1 & & black quartzite chip \\
$1959 \mathrm{NW}$ & E1 & 34 & chalcedony chip fragment \\
$2056 \mathrm{NE}$ & E1 & 32 & white Tecovas quartzite chip
\end{tabular}

Table 9.4 Artifacts from Area C

\begin{tabular}{|c|c|c|c|}
\hline Unit & Level & Quad & Description \\
\hline \multirow[t]{2}{*}{9476} & 32 & SE & 1 dark gray Edwards chip \\
\hline & 34 & NW & 1 whiteTecovas quartzite chip frag. \\
\hline \multirow[t]{3}{*}{9477} & 32 & SE & 1 dark gray Edwards chip \\
\hline & & SW & 1 gray Tecovas quartzite chip \\
\hline & & NW & 1 chalcedony chip \\
\hline 9575 & 32 & SE & 1 white Tecovas quartzite chip frag. \\
\hline \multirow[t]{2}{*}{9576} & 33 & NW & 1 gray Edwards chip \\
\hline & 35 & SW & $\begin{array}{l}1 \text { amber chert chip } \\
1 \text { chalcedony chip }\end{array}$ \\
\hline
\end{tabular}

Table 9.5 Artifacts from Area G

Locus Art. No. Description

I G-1 White quartzite flake; interior, proximal fragment; finely facetted and ground platform.

G-2 White quartzite flake; interior; reduced dihedral platform

92-1 White quartzite flake; $80 \%$ dorsal cortex; thick, alternate facetted platform (cf. flake from bifacial core)

92-2 Buff Tecovas quartzite distal flake fragment; thin, feathered termination;

II 98-1 Pale gray/white quartzite flake; interior with cortex platform. Unilateral retouch/damage 
The Aubrey assemblage is dominated by chips and chip fragments, which are $79.5 \%$ of the total. Retouched tools are only $0.4 \%$ of the total, and $2.08 \%$ of the non-chip assemblage. This assemblage profile is rare among published Clovis sites simply because there have been few opportunities to use fine screening at in situ sites. Those sites are ones which have been investigated in the last two-three decades, including Murray Springs, Arizona and Kimmswick, near St. Louis.

Because all of the lithic raw materials were brought to Aubrey from long distances, and because no primary knapping activities are indicated at the site, virtually every artifact here is an identifiable specimen. Thus no "chunks" or blocky debris are present, and every artifact has a diagnostic technological attribute such as a ventral surface, platform, etc. The noticeably few biface thinning flakes (just $4.3 \%$ of all debitage) simply reflect the fact that manufacture and use of bifaces were not done as often, or as intensively, as use of unifacial tools here. Perhaps this is strongest signature of a "camp" or residential site, in contrast to Clovis sites where butchering or biface manufacture/repair generated high frequencies of biface thinning debris.

At the same time, the 440 uniface resharpening chips (URCs) reflect the frequent maintenance of well-defined scrapers, usually made on blade blanks, and probably some other unifacial tool types. This number is surely a low one, since many resharpening chips cannot be identified as such. Clusters of chips identified by raw material spatial patterning show the segregation of chips from high density artifact clusters indicating probable tool maintenance activities. This probably included biface maintenance as well as uniface resharpening, since many of the biface thinning flakes and "chips" probably derived from maintenance rather than manufacturing activities.

Another manifestation of the maintenance-dominated activities here is that no broken or discarded bifacial preforms were recovered. Late-stage tool manufacture is indicated by one core and some refitting debitage. For example, many of the quartzite flakes in the large cluster in Camp B are derived from reduction of a large biface preform. An abrader found next to that cluster is the only manufacturing tool found. The only possible hammerstone in the sample would be the limestone "chopper" found in Area G (described below).

The low number of core trimming elements is striking, in that they indicate at least some core reduction probably took place here, especially since a number of these pieces can be refit. A blade core tablet, however, may have been imported as a tool blank. Indeed, blades appear to have all been imported as finished tools or as a few blade blanks. Likewise, the very low percentage $(0.3 \%)$ of cortical elements is sufficient evidence for the lack of primary knapping (Table 9.6). Many of these pieces are chips, probably derived from resharpening tools that were made on imported cortical flake blanks. None of the cortical pieces can be refit, but three fragments of a jasper cortical flake from Camp B are conjoined.

A significant manufacturing activity here is the reduction of at least two bladelet cores in Camp F. Refitting of these pieces demonstrates their manufacture here, despite the fact that the cores were not found. The seven bladelets from Camp B could not be refit.

One additional aspect of the assemblage is the low percentage of bifacial tools, all of which are broken, and only one of which is the "point" itself as opposed to a fragment detached during use or repair. Thus far, Aubrey has a distinction of being a "single point" Clovis site. This is certain to disappoint those who stress point typology in their analyses. But the record of other artifacts, such as resharpening chips, in a context of spatially discrete activity areas, and in association with vertabrate remains, is welcome.

Lithic Raw Materials

Except for the limestone used to make the chopper found in Area G, every piece of raw material at Aubrey was imported from sources that are at minimum $155 \mathrm{~km}$ from the site, and as far as ca. $490 \mathrm{~km}$ (Figures 9.10,9.11). Although no good quality chert occurs in local bedrock, it can be acquired within 100 
Table 9.6 Cortical Pieces from the Aubrey Site

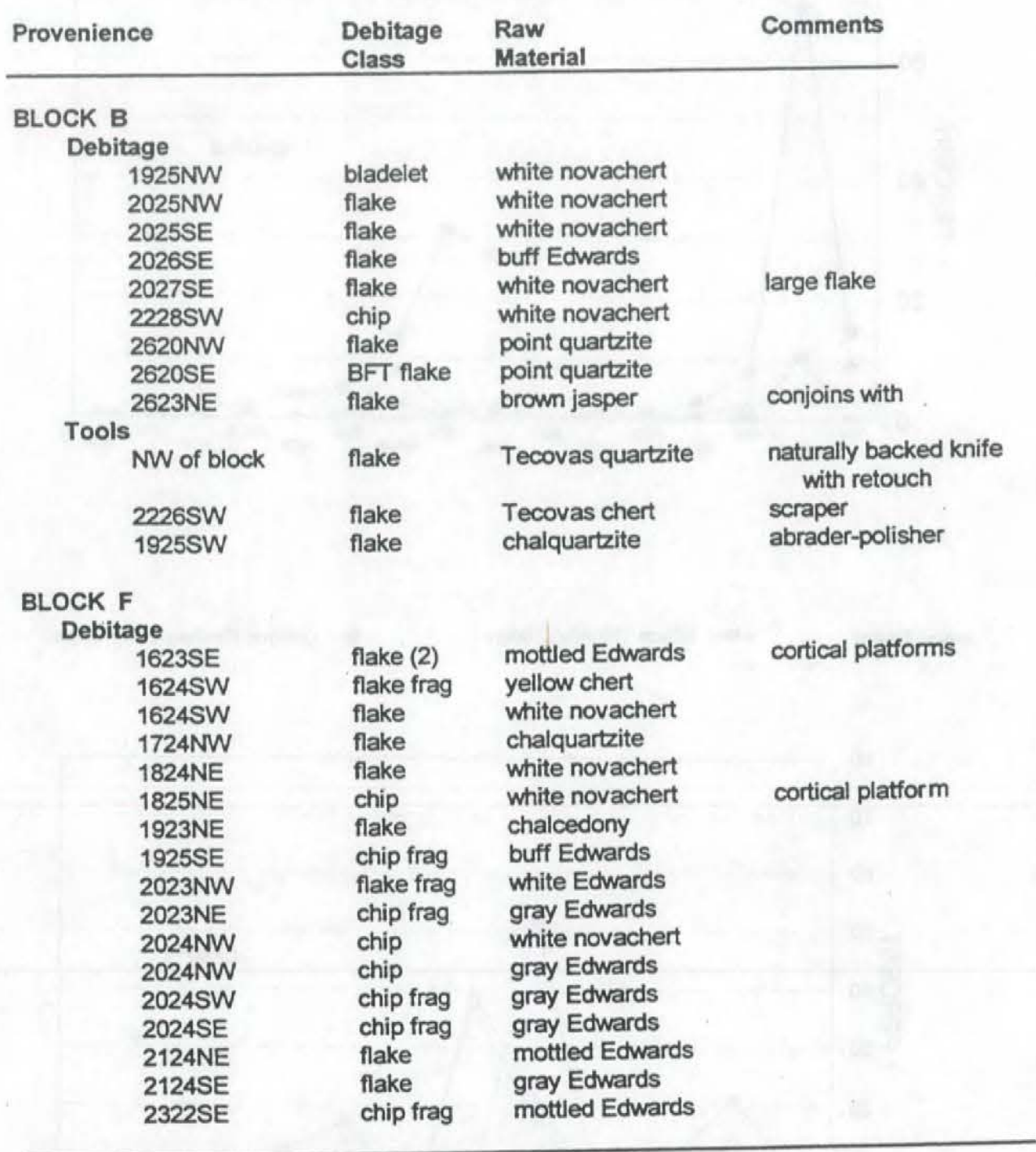

$\mathrm{km}$ to the southwest of Aubrey (Ferring and Yates 1997). Ogallala metaquartzites were transorted to this region by rivers during the Tertiary from the Rocky Mountains; the quartzites are common in North Texas as lags on higher landforms (Menzer and Slaughter 1971; Ferring and Yates 1987). These are mostly poor knapping materials, but good quality materials can be found (banks 1990). These very hard quartzite cobbles are also excellent hammerstones, and one was found at the nearby Lewisville site (Crook and Harris 1957, 1958). Nonetheless, no chert, quartzite or any other materials from North Texas were found at Aubrey.

The diverse lithic materials in the Aubrey assemblage are dominated by Tecovas quartzites and chalquartzites, and also white Edwards chert and white novachert (Table 9.7). Chalcedony is the next most common material, followed by small proportions of several other quartzites and cherts, including other varieties of Edwards and rare $(<1 \%)$ Alibates chert. The only specimen of a volcanic material is a small piece of basalt from Camp B. Descriptions of the major raw material types follow. 


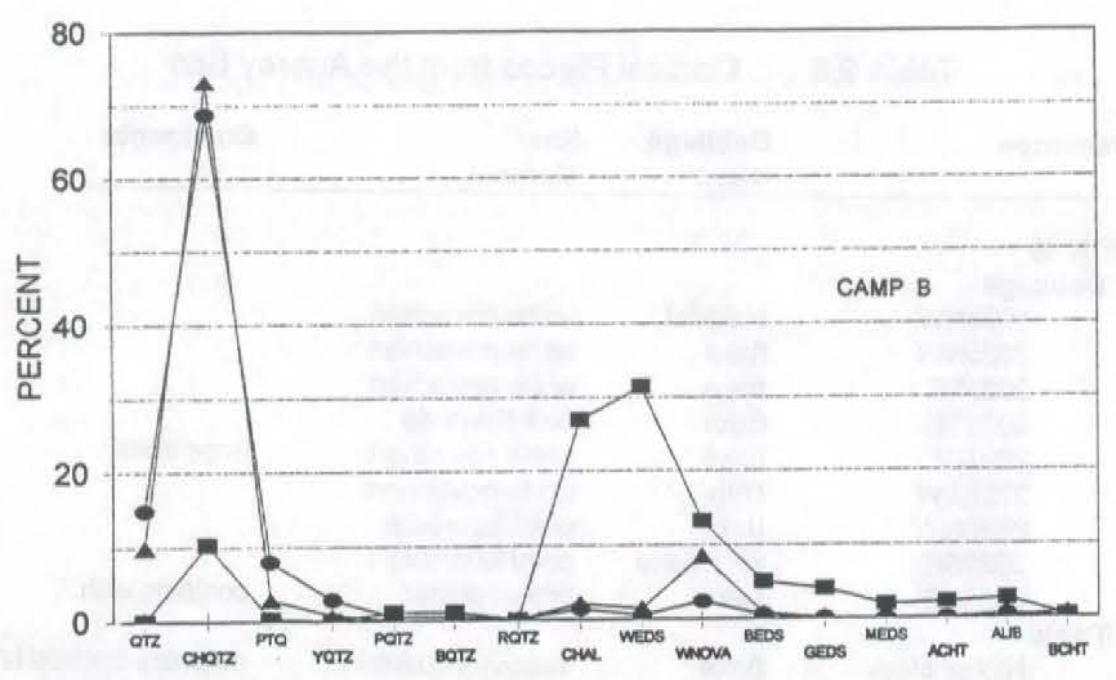

- Flakes - Biface Thinning Flakes - Uniface Resharpening Chips

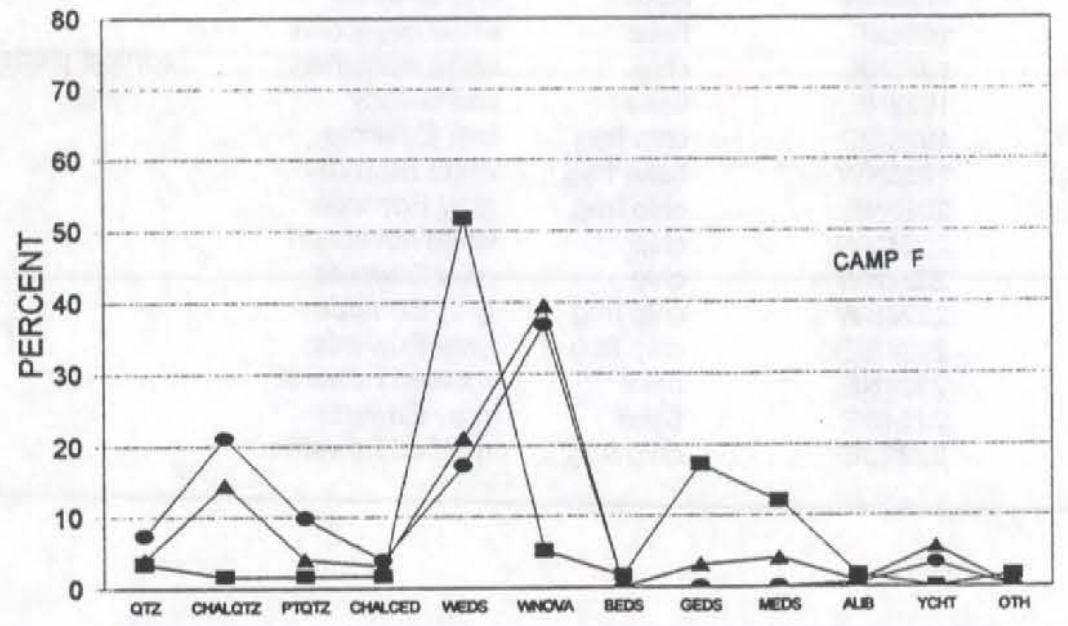

RAW MATERIAL

QTZ-quartzite CHALQTZ-chalquartzite PTQ-point quartzite CHAL-chalcedony WEDS - white Edwards WNOVA white novachert ALIB - Alibates chert BEDS buff Edwards GEDS - gray Edwards MEDS - mottled Edwards ACHT-amber chert OTH - other

Figure 9.10 Raw Material by Debitage Class. a-Camp B. Note uniform raw material frequencies for flakes and biface thinning flakes, dominated by Tecovas chalquartzite; uniface resharpening chips made predominately on chalcedony, white Edwards and white novachert. b - Camp F. Note same types, yet different frequencies; uniface resharpening chips are dominated by several varieties of Edwards cherts. 
Table 9.7 Raw Material for Debitage and Tools

\begin{tabular}{|c|c|c|c|c|}
\hline \multicolumn{5}{|l|}{ RAW } \\
\hline \multirow[t]{2}{*}{ MATERIAL } & \multicolumn{2}{|c|}{ DEBITAGE } & \multicolumn{2}{|c|}{ TOOLS } \\
\hline & CAMP B & CAMP F & CAMP B & CAMP F \\
\hline Tecovas Quartzite & 7.34 & 5.69 & 24.39 & 18.75 \\
\hline Chalquartzite & 66.58 & 28.06 & 26.83 & \\
\hline "Point" Quartzite & 1.10 & 0.76 & 2.44 & \\
\hline Yellow Quartzite & 3.91 & & & \\
\hline Purple Quartzite & 0.31 & & & \\
\hline Brown Quartzite & 0.12 & & & \\
\hline Red Quartzite & 0.27 & & 2.44 & \\
\hline Chalcedony & 6.94 & 3.74 & 4.88 & 6.25 \\
\hline White Edwards & 5.50 & 16.48 & 4.88 & 33.33 \\
\hline White Novachert & 4.11 & 35.29 & 4.88 & 33.33 \\
\hline Buff Edwards & 1.04 & 0.6 & 14.63 & \\
\hline Gray Edwards & 0.56 & 0.87 & 2.44 & 18.75 \\
\hline Mottled Edwards & 0.22 & 0.87 & 2.44 & 18.75 \\
\hline Amber Chert & 0.75 & & & \\
\hline Alibates Chert & 0.48 & 0.11 & & \\
\hline Brown Chert & 0.08 & & 2.44 & \\
\hline Yellow Chert & & 2.63 & 7.32 & \\
\hline Other & 0.20 & & 17.40 & 33.33 \\
\hline $\mathrm{N}$ & 6035 & 3689 & 41 & 16 \\
\hline
\end{tabular}

1. Tecovas quartzite. These orthoquartzites derive from outcroppings of the Tecovas Formation (Triassic) in the Texas Panhandle along the Caprock Escarpment (Banks 1990; Holliday and Welty 1991). The materials in the Aubrey assemblage compare well with samples collected near Quitaque, Texas by the author, Dr. Jack Hughes and Dr. David Meltzer. At those outcrops, and apparently at others along the Canadian River Breaks (Banks 1990), there are distinct changes in the Tecovas lithology that reflect differences in original textures and also varying diagenetic histories.

Marked textural changes are present even within thin beds. Specimens about $10 \mathrm{~cm}$ thick will exhibit change from grain-to-grain contact sandstone with minimal inter-grain space for cement, to chert/chalcedony with almost no sand grains. In between these extremes are zones with gradual reduction in the proportion of sand grains, which "float" within the chert or chalcedony matrix. Marked changes of this sort can be seen on single flakes in the Aubrey assemblage.

All of the material observed at Quitaque, and apparently at other outcrops as well, comes from thin to medium beds of sandstone and silicified shale. Thick, often rough cortical rinds are present along irregular bedding planes. The Tecovas material in a small portion of outcrop varies from a coarse quartzarenite to chert and in some areas chalcedony. The quartzites are predominantly cemented with chalcedony, although some chert cements are present. The sand grains are well rounded and are mainly in the fine to medium size range. Most specimens have less than $1 \%$ grains that are not quartz; these include rock fragments, and lessor amounts of feldspar and opaques. 
Variability in luster and diapheneity are as extreme as those in texture. The material ranges from dull, opaque forms to those that are vitreous and translucent. Again, these changes can be observed on single artifacts. Materials that had "floating" quartz grains in a chalcedony matrix, with moderate to vitreous luster have been called "chalquartzites" in this study. Color variations are also notable; here they are dominated by the following colors: strong brown (7.5YR 4/6), gray (10YR5/6), light gray (10YR6/5; 10YR7/2; 7.5YR7/1), white (10YR8/1) and pale yellow (2.5YR8/3). Single flakes may have both white and yellow or white and purple. These color distinctions may be useful for spatial analysis and/or refitting, but not for source definition.

2. Chalquartzite. These materials have quartz grains that float within a chalcedony matrix. They are almost always vitreous, and attain a duller whitish patina. (The patinated surfaces would turn white in the hands of excavators within a minute or less after the piece was found, apparently as the surface was

dehydrated.) Colors of these materials include: light bluish-gray (5PB7/1; 5PB8/1), light gray (10YR7/1), and much lessor amounts of pinkish gray $(7.5 Y R 6 / 2)$ and white (2.5Y8/1).

Table 9.8 UV Fluorescence of Some Lithic Materials from the Southem Plains

\begin{tabular}{ll} 
MATERIAL & FLUORESCENCE \\
\hline Wave Length: & Short Both Long
\end{tabular}

\section{QUARTZITES}

$\begin{array}{llll}\text { Tecovas } & \mathrm{n} & \mathrm{n} & \mathrm{n} \\ \text { Tecovas } & \text { Gy } & \text { Gy } & \text { Gy } \\ \text { Catahoula } & \mathrm{p} & \mathrm{p} & \mathrm{p} \\ \text { Manning } & \mathrm{n} & \mathrm{n} & \mathrm{n} \\ \text { Morrison } & \mathrm{n} & \mathrm{n} & \mathrm{n} \\ \text { Potter } & \mathrm{n} & \mathrm{n} & \mathrm{n} \\ \text { Morrison-Dakota } & \mathrm{n} & \mathrm{n} & \mathrm{n} \\ \text { Jackfork } & \mathrm{n} & \mathrm{n} & \mathrm{n} \\ \text { Jackfork/Johns Valley } & \mathrm{n} & \mathrm{n} & \mathrm{n}\end{array}$

\section{CHERTS}

Tecovas- white

Tecovas- red

Tecovas-yellow

Alibates

Johns Valley

Edwards:

gray

brown, laminated chalcedony

Blue-Gray Alibates

White Arkansas Novaculite

$\begin{array}{lll}P G & P & P G \\ G & n & G \\ Y & Y & Y G \\ G & G P & G \\ n & n & n \\ Y & Y & Y \\ Y & Y & Y \\ Y & Y & Y \\ Y & Y & Y \\ G & P & G \\ n & n & n\end{array}$

\footnotetext{
Key.

n no fluorescence (purplish-black)

$P$ deep purple

p pale purple
} 
3. Point quartzite. This variety of Tecovas quartzite received its informal name because the single largest Clovis point at Aubrey is made of the distinctive material. However, considerable numbers of flakes and chips of the same material were found in Camp B, and lessor numbers in Camp F. The material is very fine-grained, lustrous quartzite that is light gray $(2.5 Y 7 / 1)$, and has distinctive wispy vugs filled with white or white and dark brown chalcedony cement. There are no gradations between this variety of Tecovas and others at the site. Materials with almost identical color and vugs were collected near Quitaque, Texas.

4. Purple quartzite. As mentioned above, this variety of Tecovas occurs as separate chips and also as zones on pieces of white quartzite.

5. Red Quartzite. This material only occurs in Camp B, where one end scraper and a number of resharpening chips were found, suggesting that the finished tool was imported to the camp, used there and then abandoned. The scraper is one of the few burned pieces in the assemblage. This material is a reddish brown (2.5YR3/1-5/3), fine-grained orthoquartzite. It is lustrous but opaque. It compares very well with Morrison quartzite, including materials collected from outcrop by the author northwest of Amistad, New Mexico.

6. Chalcedony. There are at least two varieties of chalcedony in the assemblage. One is an opaque white (N 8/1; 5PB8/1) form, that does not fluoresce. Large specimens, such as the blade core tablet, have medium to large (ca. $1-3 \mathrm{~mm}$ ) vugs filled with quartz crystals. The other variety (which itself may be multiple types) is milky and translucent. It exhibits yellow fluorescence, and may be from sources in the Edwards Plateau; one possibility is near the Callahan Divide, where Dr. Mike Collins collected chalcedony similar to some of the pieces at Aubrey (Table 9.8). Other possible sources include the Tecovas Formation (Banks 1990). Knappable chalcedony is also within the Miocene Catahoula and Fleming formations on the Gulf Coastal Plain of Texas and Louisiana (Banks 1990; Heinrich 1984; Thomas 1960). Those rocks also yield knappable quartzites.

7. Tecovas Chert. These materials are identified as Tecovas chert on the basis of comparison with the Quitaque samples. The materials from Aubrey for the most part have almost uniform color except for weathering rinds, as opposed to the multicolored variety that can resemble Alibates. These have similar cortex type and lack of fluorescence, as do the samples from Quitaque. Alibates chert has distinctive green fluorescence. The colors here range from yellow (10YR7/6) to pale brown-yellow (10YR7/4) to pale brown (10YR8/4). They are all cryptocrystalline, of high quality. Interestingly, two of the larger tools are made on cortical flakes of this material (Nos. B-405 and C-1).

8. Alibates Chert. Although these few pieces are mostly chips, they have distinctive banded colors in reds, whites, dark browns, etc; additionally, these pieces all exhibit green fluorescence, which appears to distinguish this material from Tecovas very well. Most of the pieces from Camp B are uniface resharpening chips, while only one of those from Camp F is of that class, the remainder apparently associated with biface thinning. Notably, no Alibates tools were recovered, but there were at least two Alibates tools used here.

9. Novaculite (or Novachert). These materials compare well with white Arkansas Novaculite, similar to that described by Banks (1990) from the Hot Springs area of the Ouachitas. While Novaculite can be acquired from the western Ouachitas, it is of poor quality there, as is most of the Caballos Novaculite from the Marathon Basin in west Texas. The materials from Aubrey are "white" (but technically light gray (10YR7/2)); they are grainier than the white Edwards chert, and the Novaculite exhibits no fluorescence (a UV lamp was used to quickly separate these two materials during sorting; this can be done based on texture, but much more time is required). Some of this material is "speckled " with very small (coarse silt) grains of an oxidized mineral or rock fragments. Also, some of these materials from Camp $F$ have patinated to a yellow color, but do not fluoresce. 


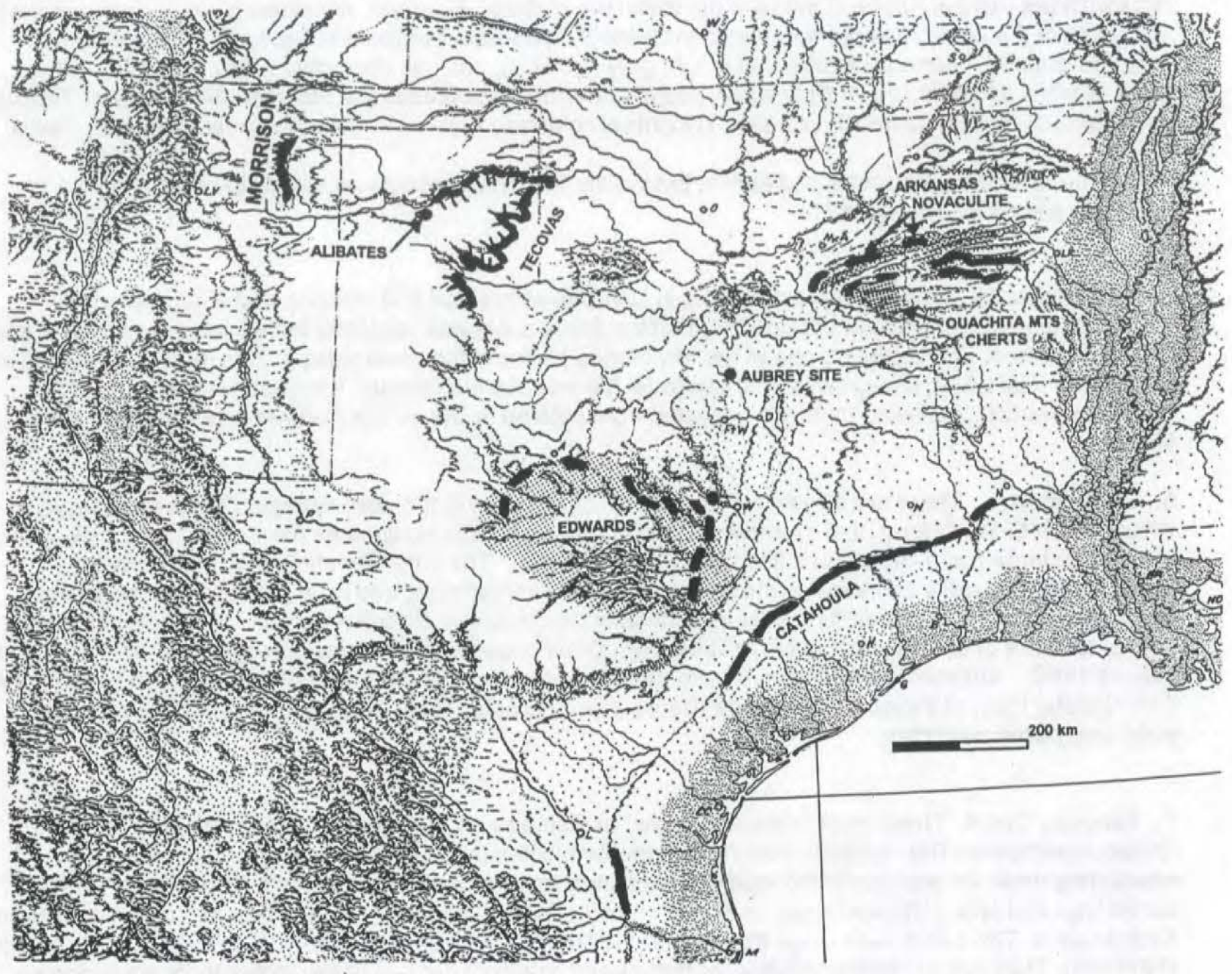

Figure 9.11 Sources of lithic raw materials from Aubrey. The central part of Edwards plateau lacks chert and is surrounded by scattered high-density sources (black) and lower density sources (stipled). Arkansas novaculite crops out widely, along front of the Ouachitas, as well as in the interior ridges. Excellent quality novaculite is noted in the eastern part of the mountains. Note that the term "novachert" is used informally in this report, and differs from the specific connotations of "Nova-chert" in Banks (1990: 46). The "Ouachita cherts" informally encompasses materials that also crop out broadly in the mountains, and include many specific types, such as Bigfork, Battiest, Wapanuka, Woodford, etc. High quality orthoquartzites are also common, at least in the western Ouachitas. These do not resemble the quartzites at Aubrey, but detailed extensive comparisons have not been made. Map base is from Lobeck (1948). Source areas modified from maps in Banks (1990). 
10. Edwards Chert. Various types of Edwards chert, all derived from the Cretaceous rocks of the Edwards Plateau in central-western Texas, are common in Clovis assemblages and in the large samples of Clovis points from the region (Meltzer 1987; Meltzer and Bever 1995). At Aubrey there are five main varieties, as defined by color and/or color patterns:

a. Dark Gray This is the "classic" chert of this class. It is opaque gray (10YR5/1), and usually has no banding, laminations or other fabrics, and often has a waxy luster.

b. Light gray This material is light gray (10YR7/1) to pinkish gray $(7.5 Y R 6 / 2)$, but is about as lustrous as the dark gray materials.

c. Mottled This material has a gray (7.5YR5/1) background, with pale brown (eg., 10YR6/3) irregular patches or "mottles". This is a quite common variety of Edwards. In large specimens from other sites, as well as in materials collected by the author, the pale brown blotches are sometimes similar to burrows and sometimes are larger irregular patterns. The materials at Aubrey include a number of small flakes and chips with cortical platforms.

\section{d. Buff This is a tan to buff brown variety of Edwards.}

e. White This variety of Edwards is similar to materials in the Fort Polk, Texas area, in the northern part of the Edwards Plateau. The material is uniformly white (N8;2.5Y8/1), very fine-grained, lustrous and always has a yellow fluorescence, allowing it to be readily separated from the white varieties of Alibates or Tecovas chert.

11. Amber chert This is a cryptocrystalline to microcrystalline chert/chalcedony that is translucent and lustrous. Its source is unknown.

12. Jasper. Only one large flake of this material was found; it was in Camp B, where three fragments of a single flake could be conjoined. The jasper is yellowish brown (10YR5/5), and has thin irregular cortex suggesting a cobble raw material. The source is not known, but jasper is a common material in gravels of the Red River, and also in the gravels of the Seymour Formation (Plio-Pleistocene) and the Antlers Formation (Lower Cretaceous) to the northwest of Aubrey. This is the only artifact from Aubrey that appears to have a gravel source.

13. Unidentified cherts. Several tools are made of unidentified raw materials; there is no debitage of these materials other than chips or uniface resharpening chips. These further indicate that transportation of finished tools and/or unifacial tool blanks is well represented in the Aubrey assemblage.

a. A projectile point fragment (a distal impact-spall, No. B-602) found in the southern part of Camp B is made of a gray (N6) cryptocrystalline chert that has common white inclusions that appear to be fossil fragments. There is only one other piece of this distinctive material at the site, a burned uniface resharpening chip from Camp F. This is apparently not a variety of gray Edwards Chert, since it exhibits dark purple fluorescence. A source in the Ouachita Mountains is likely but as yet unverified.

b. A large canted end scraper (No. B-186) from Camp B is made on a wide prismatic blade blank that is a finely laminated grayish-brown (10YR3/1) chert. This material is likely to be from the Ouachitas in Oklahoma or possibly Arkansas, where similar high quality laminated cherts or silicified shales occur in the Johns Valley Shale and the Arkansas Novaculite Formations (Banks 1990). Although some laminated varieties of Edwards are known, the dark purple fluorescence of this material indicates the Ouachitas are a more likely source. 
Table 9.9 Debitage Class by Raw Material, Block B

\begin{tabular}{|c|c|c|c|c|c|c|c|c|c|c|}
\hline $\begin{array}{l}\text { RAW } \\
\text { MATERIAL }\end{array}$ & $\begin{array}{r}\text { Chip } \\
\text { Fragment }\end{array}$ & Chip & $\begin{array}{c}\text { Flake } \\
\text { Fragment }\end{array}$ & Flake & BFT & CTE & URC & Bladelet & sum & $\%$ \\
\hline Tecovas quartzite & 246 & 81 & 69 & 14 & 32 & 1 & & & 443 & 7.35 \\
\hline Chalquartzite & 2534 & 835 & 346 & 104 & 149 & 9 & 39 & 2 & 4016 & 66.62 \\
\hline Point quartzite & 120 & 69 & 25 & 4 & 17 & & 1 & & 236 & 1.11 \\
\hline Yellow quartzite & 54 & 29 & 6 & 1 & 6 & & & & 96 & 3.92 \\
\hline Purple quartzite & 4 & 10 & & & 1 & & 4 & & 19 & 0.32 \\
\hline Brown quartzite & 1 & 1 & & & 1 & & 4 & & 7 & 0.12 \\
\hline Red quartzite & 13 & 3 & & & & & & & 16 & 0.27 \\
\hline Chacedony & 206 & 99 & 5 & 3 & 3 & & 102 & 1 & 418 & 6.93 \\
\hline White Edwards & 136 & 70 & 4 & 2 & 1 & & 119 & & 332 & 5.51 \\
\hline White Novachert & 115 & 56 & 10 & 8 & 5 & & 50 & 4 & 244 & 4.05 \\
\hline Buff Edwards & 24 & 15 & 3 & 1 & 1 & & 19 & & 63 & 1.05 \\
\hline Gray Edwards & 10 & 9 & & & & & 15 & & 34 & 0.56 \\
\hline Mottled Edwards & 4 & 2 & & & & & 7 & & 13 & 0.22 \\
\hline Amber chert & 9 & 27 & 1 & & & & 8 & & 45 & 0.75 \\
\hline Alibates & 14 & 4 & & & 1 & & 10 & & 29 & 0.48 \\
\hline Brown chert & 1 & 1 & 1 & 1 & & & 1 & & 5 & 0.08 \\
\hline Other & & & & & & & & & 12 & 0.20 \\
\hline sum & 3491 & 1311 & 470 & 138 & 217 & 10 & 379 & 7 & 6028 & \\
\hline$\%$ & 57.91 & 21.75 & 7.80 & 2.29 & 3.60 & 0.17 & 6.29 & 0.12 & & \\
\hline
\end{tabular}

Table 9.10 Debitage Class by Raw Material, Camp F

\begin{tabular}{|c|c|c|c|c|c|c|c|c|c|c|}
\hline $\begin{array}{l}\text { RAW } \\
\text { MATERIAL }\end{array}$ & $\begin{array}{c}\text { Chip } \\
\text { Fragment }\end{array}$ & Chip & $\begin{array}{c}\text { Flake } \\
\text { Fragment }\end{array}$ & Flake & $\mathrm{BFT}^{1}$ & $\mathrm{CTE}^{2}$ & URC $^{3}$ & Bladelet & SUM & $\%$ \\
\hline Tecovas quartzite & 92 & 66 & 30 & 5 & 15 & & 2 & & 210 & 5.69 \\
\hline Chalquartzite & 567 & 329 & 76 & 18 & 43 & & 1 & 1 & 1035 & 28.06 \\
\hline Point quartzite & 85 & 62 & 25 & 5 & 20 & & 1 & & 198 & 0.76 \\
\hline Chalcedony & 73 & 42 & 10 & 4 & 8 & & 1 & & 138 & 3.74 \\
\hline White Edwards & 230 & 226 & 42 & 26 & 35 & & 30 & 19 & 608 & 16.48 \\
\hline White Novachert & 647 & 386 & 139 & 49 & 75 & 1 & 3 & 2 & 1302 & 35.29 \\
\hline Buff Edwards & 11 & 10 & & 0 & 0 & & 1 & & 22 & 0.60 \\
\hline Gray Edwards & 11 & 5 & 2 & 4 & 0 & & 10 & & 32 & 0.87 \\
\hline Mottled Edwards & 12 & 4 & 4 & 5 & 0 & & 7 & & 32 & 0.87 \\
\hline Alibates & & 1 & & 1 & 1 & & 1 & & 4 & 0.11 \\
\hline Yellow chert & 38 & 41 & 4 & 7 & 7 & & 0 & & 97 & 2.63 \\
\hline Other & 4 & 5 & 1 & 0 & 0 & & 1 & & 11 & 0.30 \\
\hline SUM & 1770 & 1177 & 333 & 124 & 204 & 1 & 58 & 22 & 3689 & \\
\hline$\%$ & 47.98 & 31.91 & 9.03 & 3.36 & 5.53 & 0.03 & 1.57 & 0.60 & & \\
\hline
\end{tabular}

1 Biface thinning flake 2 Core trimming element 3 Uniface resharpening chip 
c. An end scraper on a blade from Camp B (No. B-174) is made from a brownish gray (10YR6/1) chert that resembles tan Edwards in gross appearance, yet has no fluorescence under UV light.

d. A retouched piece from Camp $F($ No. $F-605)$ is made on a very dark gray (10YR3/1) to brown 7.5YR4.5/3) fine chert. This material has red fluorescence, and is unique in the Aubrey assemblage. None of the materials tested for fluorescence from the Southern Plains region exhibit red fluorescence (Table 9.8). Thus, no source can be identified at present.

e. A retouched blade from the Red Wedge in Area A (A-400) is a dark gray (2.5YR4/1) chert with homogeneous cryptocrystalline texture. It exhibits reddish yellow fluorescence. Although this is possibly a variety of Edwards chert, its source is not known.

f. A utilized blade (A-701), also from the Red Wedge in Area A, is a very dark gray (7.5YR3/1) homogeneous cryptocrystalline chert. This material is grossly similar to that of artifact A-400, but has no fluorescence.

14. Black basalt This fine-grained basalt is a unique specimen at Aubrey. Basalt occurs in association with Tertiary volcanoes along the Rio Grande Valley in New Mexico and in the Trans-Pecos of Texas. It also can be found at small outcrops in the Wichita and Arbuckle Mountains in Oklahoma, and at very small Cretaceous sources along the Balcones fault zone between Austin and Uvalde, Texas.

15. Limestone The only artifact made of limestone at Aubrey is the chopper found in Area G, on the east side of the Clovis Paleochannel opposite Camp F. This material is a brownish yellow (10YR6/6) wackestone (mudstone with sparse bivalves and shell fragments). It appears to have been a thin bed or is from a thinly bedded section. This could have come from any of several Cretaceous formations in the vicinity of Aubrey.

\section{Discussion}

As is characteristic of almost all Clovis assemblages, the lithic raw materials left at Aubrey are of high quality. Perhaps unexpected, however, especially given the assemblages from sites such as Clovis (Hester 1972) is that the Aubrey assemblage is dominated by quartzite instead of chert. Although quartzites are present at Clovis they are rare compared to Alibates and Edwards chert. The use of quartzite for Clovis points is documented over much of Texas, but is rare $(<5 \%)$, compared to the use of cherts (see Chapter 10).

With respect to raw materials, the artifacts from all areas of the site are viewed as one assemblage (this risky view is discussed in Chapter 10). Raw material types vary in frequency between Camps $B$ and $F$, for example, yet those differences are equal to or less than the spatially defined differences found within Camp B. Only minor varieties or types of material are not shared, including colored quartzites and rare chert forms found in Camp B but not Camp F (Tables 9.7, 9.9, 9.10). Most of those differences are probably not meaningful with regard to source areas. For example, "yellow" quartzite from Camp B, and absent in Camp F, is identified only as a variety for purposes of spatial analysis, since pieces show the color transition from yellow to white was part of the raw material fabric. The same is true for purple and brown quartzite, but not red (which is tentatively identified as Morrison quartzite from New Mexico), which does occur in Camp F. Thus it appears that the inhabitants of the different parts of the site most likely acquired their material from the same group of sources and used them in different ways both within and between the subareas of the Aubrey site. 
Almost $75 \%$ of the materials in Camp B are quartzite, while that figure is about $34 \%$ in Camp F. The proportion of white Edwards and white Novaculite (or "Novachert") is proportionately higher in Camp $F$ than in Camp B. Much of this difference can be explained by examining the ways the materials were used (Figure 9.10). In Camp B, about $58 \%$ of the uniface resharpening chips are made of white Edwards and white Novachert (Table 9.9). In Camp F, $57 \%$ of the uniface resharpening chips are those materials, as are 21 of the 22 bladelets (Table 9.10). These materials were favored for unifacial tools, so the proportional differences in these materials between Camp B and Camp F appear related to tool use patterns rather than differential use of lithic sources. Biface thinning, as an activity, is also differentially represented between the two areas, but so are the apparent kinds of biface thinning, in addition to the intensity of that activity.

The ratio of uniface resharpening chips (URC) to biface thinning flakes (BFT) is a logical index for examining the relative use of these tool classes, since the small resharpening chips are more likely to have been dropped where they were produced, and since their numbers and locations may be much more reliable clues to on-site activities than are tool frequencies and tool locations. In this case, tool "maintenance ${ }^{4}$ is probably dominated by resharpening of unifacial tools, and both repair and resharpening of bifacial tools. The differences in relative intensity of these two generalized tool uses between Camp B and Camp F are striking:

$\begin{array}{lcccc} & \text { URC / } \text { BFT }^{1} & \text { \% white } \text { BFT }^{2} & \text { \%r } \text { BFT }^{3} & \text { N } \\ \text { Camp B: } & 1.8 & 2.8 & 17.7 & 6028 \\ \text { Camp F: } & 0.3 & 53.9 & 79.1 & 3689\end{array}$

1 Ratio of Uniface Resharpening Chips to Biface Thinning Flakes

2 white $=$ white Edwards Chert and white Novachert

3 Restricted frequency is calculated without chips or chip fragments

Biface use/repair was much less important than uniface use/resharpening in Camp B. However, the flake sizes and patterns of refitted BFTs in both Camp B and Camp F suggest that in both cases, biface resharpening and repair were more commonly done, relative to (final stage) biface manufacture. The proportion of "white BFTs" (see above), is inversely related to the apparent index of uniface resharpening. Again, the raw material differences here appear to relate to activities and raw material preferences for specific tools rather than raw material source.

\section{Lithic Reduction Strategies}

The lithic assemblage from Aubrey shows how diversified Clovis lithic reduction systems were, contradicting old notions that the Clovis people were specialized not only in subsistence, but in technology as well. As much as any Late Paleolithic system in the Old World, the Aubrey lithic assemblage is the product of multiple reduction strategies (Bradley 1975; Ferring 1980, 1988). We can extend or extrapolate the Aubrey data further, and will show that those reduction strategies were different not only in their functional parameters but also in regards to their location (and probably scheduling) on the Clovis landscape. The separate reduction strategies are summarized as follows. 


\section{Blade Production}

Blade manufacture has long been recognized as an important, if not unique component of Clovis lithic technology. Blade and biface manufacture in the same context evoked comparisons with Old World archaeological records, and analogies with the Solutrean have been proposed and debated since the 1930 's. Those debates are as vivid today as then, and in some cases they even upstage the loudly opinionated "Clovis first" exchanges. Blade making in the Solutrean, or virtually any other Paleolithic culture, was not quite as uniform as sometimes assumed. Rather, Clovis folk at Aubrey seem to have been much like their Old World Paleolithic kin (that is the figurative kin of course) and employed various strategies for making blades and other tool blanks. Were the different strategies simply alternatives to blade making sensu lato, or adjustments for different raw materials? Or, did they represent production of different, morphologically specific tool blanks? Before dealing with these interesting questions, the blade reduction strategies will be described.

Strategy I The production of large, usually curved blades derived from elongated conical cores (Figure 9.11). Cores of this type are rare but distinctive in this region (Henderson and Goode 1991; Stanford 1991; Goode and Mallouf 1991). The blades are robust pieces, and typically have very small platforms. Seemingly identical blades have been replicated using a punch technique, holding the core under the foot ("lames sous le pied") as described by Tixier (1974). But Goode (in Collins 1999) has replicated similar blades using direct soft hammer percussion. Replications such as these show that different techniques can result in similar products, with similar technological attribuites, such as platform size, bulbar prominence, etc. A corollary to this is that defining exactly which technique was used in a prehistoric assemblage can be difficult.

Many of the recently excavated blade cores from the Gault site in central Texas (Collins 1999:186) are quite different in morphology from the more common conical cores from Clovis sites. Instead of the deeply facetted circular platform of the conical core shape, these cores have acute platform angles. Several of the ones illustrated appear to have working faces that contract distally to a unilaterally or bilaterally opposed platform. This overall geometry is identical to many Upper Paleolithic traditions in the Near East and Europe (see Ferring 1980, 1988). The core working face necessarily becomes narrower in proportion to the acuteness of the platform angle. This strategy is associated with production of "specialized" blades (Ferring 1988), whereas the conical or pyramidal core shapes are suited for more efficient blade detachments, where every blade scar perpetuates the overall core morphology.

With acute platform angles, the blades removed from the margins of the core working face often have different shape and dorsal scar patterns. The acute platform angle is usually associated with welldefined core working face and a "dorsal" surface. In many cases, the cores were preformed with nearly continuous bifacial flaking, which simultaneously removed cortex. At the appropriate stage, the platform end of the core was chosen. The distal part of the core working face contracted, and was actually a "terminal" unstruck lame a crete (crested blade); and the crest was often left on the dorsal surface of the core, forming a "dorsal keel" (Ferring 1972). This is quite different from the true "wedge-shaped" microblade cores, which are shaped like an elongated boat with a simple V-hull (Chard 1974; Larichev, Khol'ushkin and Laricheva 1992). The cores like the ones from the Gault site are called "opposed platform twisted" blade cores in the Near East. It is interesting, though speculative, to note that the Gault cores are, to me, much more "Upper Paleolithic" in character than the conical cores of wider distribution in the Clovis domain. It makes me wonder if those cores could be older. One of the blades from Aubrey has a very heavily ground platform, and was removed from a core with a narrow working face (Figure 9.12c). The scar pattern shows that the acute platform was not that of a biface.

Acute platform angles also function to reduce the amount of force necessary to initiate fracture (see Faulkner 1972; Speth 1972). The fact that Goode was able to detach "Clovis" blades with a billet and a freely held core may well be the result of using this "wedgen shaped core. [ Incidentally, describing these cores as "wedge-shaped" is unfortunate, as it will cause confusion with the true "wedge" shaped 

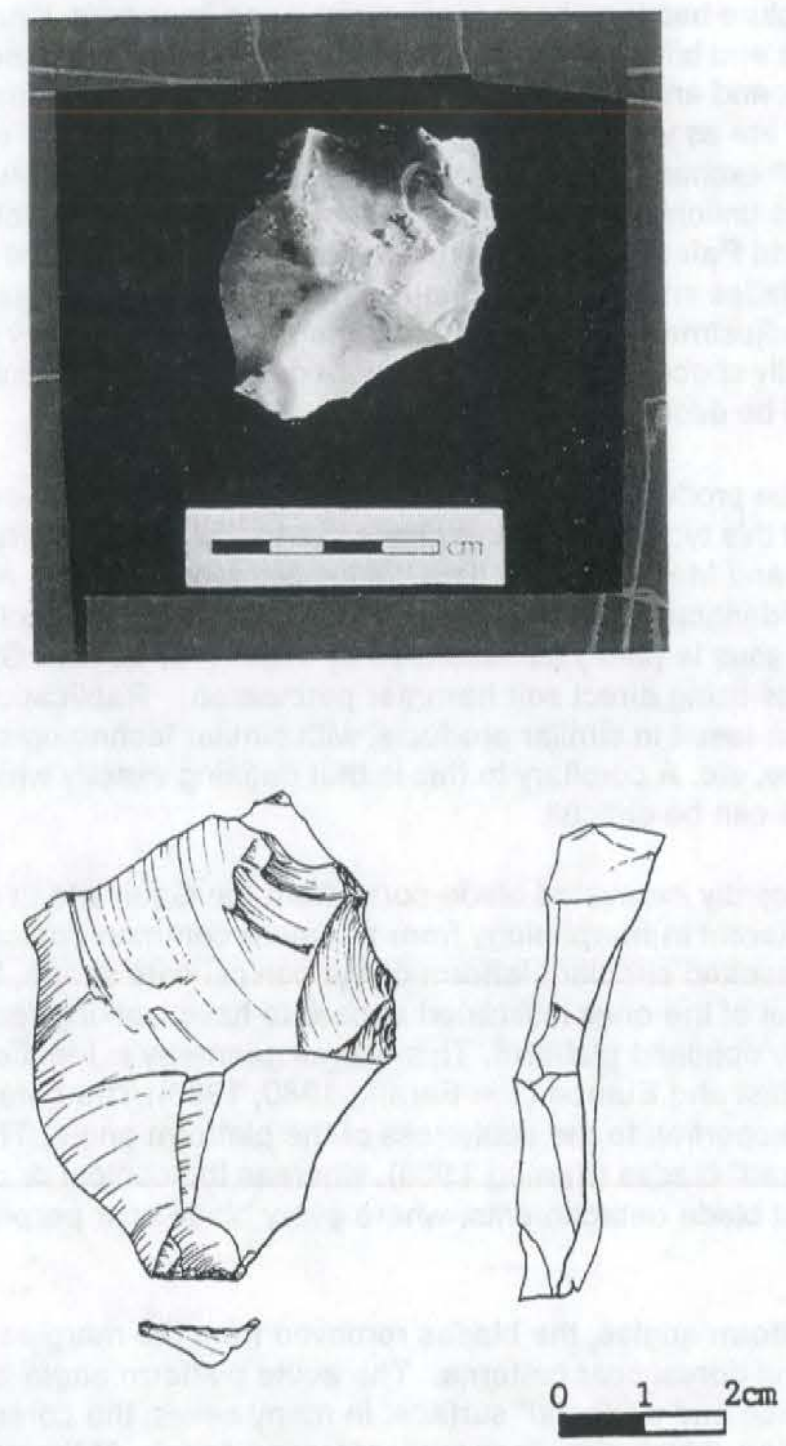

Figure 9.12 Blade core tablet from Camp B. Raw material of this artifact (B-317) is fine, opaque white chalcedony with quartz filled vugs. The piece was burned and/or heat treated while it was still on the core; note large, cupped negative scars on platform and negative scars from blades removed. 
cores of the northeast Asian microblade tradition]. The cores were probably reduced near the raw material source (especially on the Edwards Plateau). The blades of this type apparently were imported to Aubrey, and were used exclusively as blanks for endscrapers. Wear and polish on the arretes of these blades are evidence of transportation (Frison and Bradley 1999:81; Collins 1999). Either the unretouched blade blanks or the finished end scrapers could have been brought to the site. Retouched or slightly damaged blades with very similar morphology and attributes have been found in caches in the region (Hammatt 1970; Young and Collins 1990; Green 1963; Montgomery and Dickenson 1992). These show that at least some of the Clovis people transported and cached blades long distances from the raw material sources.

A core tablet and a partial core tablet from Aubrey add further to the record of this strategy of blade manufacture. The larger tablet (Figure 9.12) is made of chalcedony, while the smaller one is made of white novachert. The raw materials for both of these blanks have have quartz filled vugs. These tablets are typical of the modes of platform preparation for the long conical cores from Clovis sites. Curiously, the large blades at Aubrey are made of Edwards chert, while the smaller blades are made of both Edwards chert and chalcedony. If the blades at Aubrey were made entirely off-site, then the core tablets must have been carried as expedient tool blanks. Wear on arretes of the large core tablet should support that view, but that could also result from platform preparation, and is less meaningful than wear on the blade arretes. Neither of the two core tablets from Aubrey has been retouched.

The larger core tablet was burned (or more likely, heated) before it was detached from the blade core. Then the piece was detached from the core and later was broken in Camp B.

Strategy II With this strategy, small, thin and curved blades (Figures 9.17 a, c, d; possibly 9.18 a,b) were produced from much smaller cores that were either a separate core system, or represent serial strategies on the same cores that were used for Strategy I. In that event, complete repreparation of the core was probably necessary. These smaller blades at Aubrey are made of both Edwards chert and chalcedony. Two of the Edwards chert blades were found eroded from the Clovis paleosurface between Camp B and Camp F. Given the paucity of blades at this site, I believe that these seemingly isolated locations are not circumstantial, but rather suggest discard of blades in those locations where the specific tasks requiring the blades were carried out. This view derives in part from the precedence for discard of blades in Area A, red wedge, where they were apparently used in butchering.

The two small blades from between the camps are made of two different varieties of Edwards chert, neither of which matches any of the other blades in the assemblage. In fact, there are not two blades from Aubrey that are made of the same raw material. I suggest that this "perfect" diversity (ie, no duplications in the sample) is indicative of prolonged tool curation by the group that occupied Aubrey. The assortment of raw materials suggests that people were using tools they had carried for some time, each of which had a different longevity, such that the diversity of raw materials for the whole group increased with time. The composition of resharpening chips' raw materials is later contrasted with the discarded tools to further look at the issue of curation - acquisition.

Strategy III Thin, wide and much less regular blades were produced from either large bifacial blanks (see Bradley 1982; Lahren and Bonnischsen 1974) or large discoidal-type cores (Figure 9.14 a,b,d). It is possible that these were incidentally removed during biface thinning, and then selected from all of the thinning debris that was produced. However, the skill of Clovis knappers in thinning bifaces with large overpassed flakes (or flake-blades) is well documented (Bradley 1993; Frison and Bradley 1999). It is possible that this technique of biface thinning was an intentional effort to generate the largest debitage blanks possible. A similar strategy has been observed among Solutrean assemblages in Spain and France (Stanford, personal communication). These pieces were definitely not removed from cores associated with Strategies I and II. 


\section{Bladelet Production}

The bladelet production strategy in the Aubrey assemblage is very different from any other I know of. The bladelets are extremely small, yet the term "microblade" is avoided since they bear no resemblance to the microblade technology of northeast Asia (Chard 1974; Weniger 1990). Two cores were reduced in Camp F. Heavy stepping (both step and hinge terminations) of the core faces near the platform was corrected by overpassing. The platforms were unfacetted. Refitting shows that for the last removals from the cores a bipolar technique was used. This is indicated by bladelets and narrow flakes with both proximal and distal reversed hinge scars. A bipolar technique could have been used earlier in the reduction, without the hinging. The use of a bipolar technique raises the issue of whether they were producing scaled pieces as a primary product here. Unfortunately, neither core was found, so the full character of this reduction strategy cannot be described at present.

One of the bladelets was retouched into a piece that is best described as a miniature end scraper. It is very carefully and deliberately made. This piece may have had a real function. At the same time, it could be compared to the miniature Clovis points that have been found in a number of sites, including Clovis (Hester 1972), Kimmswick (Graham and Kay 1981) and Vail (Gramley 1982). Miniature points were made by shamen in the Plains bison hunting rituals best illustrated by the Hell Gap site of Jones-Miller (Stanford 1979). Perhaps miniature blades and endscrapers are analogous to the minature points?

\section{Flake Production}

Discoidal cores for flake production were suggested by refits at Aubrey (Figure 9.14) and as a possible way the Type 3 blades were made. Core trimming elements made of chalcedony are somewhat ambiguous, as the flat platform for the transverse flakes may have been a flake core platform, or the broken edge of a biface (Figure 9.13).

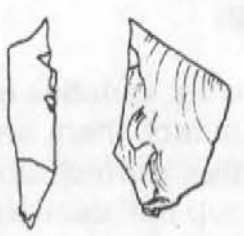

a

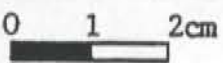

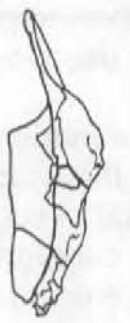

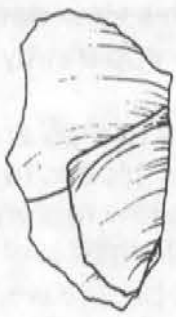

b
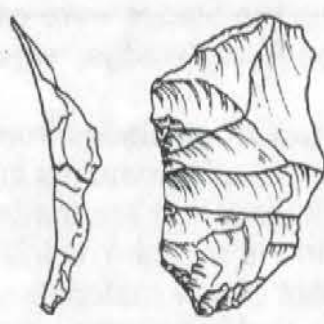

c

Figure 9.13 Refitted core trimming flakes from Camp B. This raw material is a fine chalcedony. A number of other flakes not shown here were removed from same core; a- hinged flake (B-294) was detached after core trimming flake; b-core trimming element, possibly from opposed platform core. Distal fragment (B-1) was first flake found at Aubrey, on Dec. 6, 1988. Proximal fragment (B-146) was found in situ during excavations, in Unit 1825/NW. 


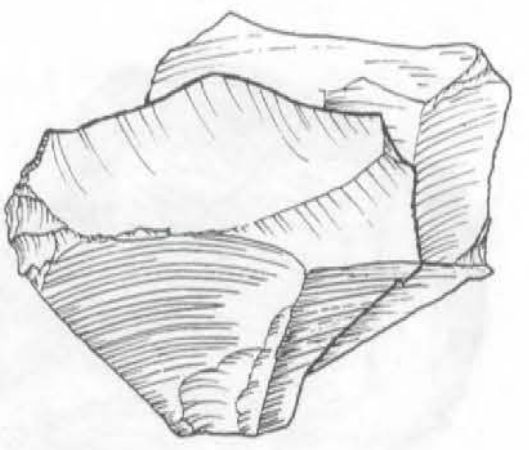

a

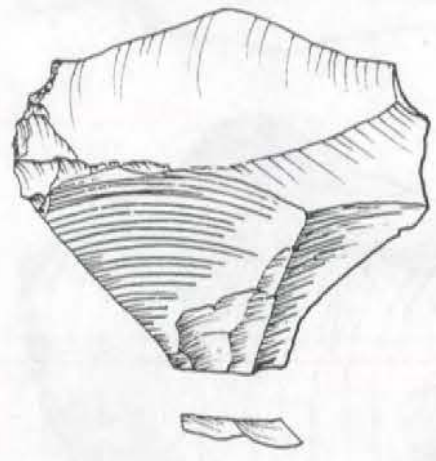

C

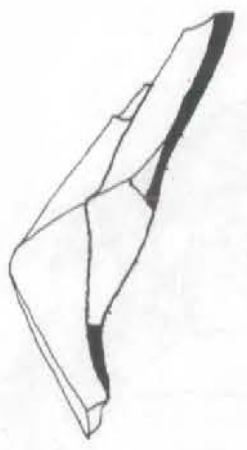

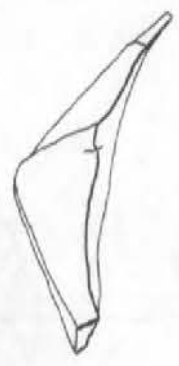
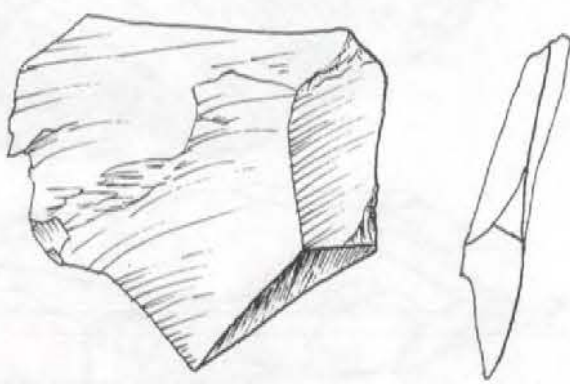

d

Figure 9.14 Refitted flakes of radial core from Camp B. This raw material is a hard, vitreous Tecovas chalquartzite, similar to the material of the abrader (Figure 9.15) and a scraper (Figure 9.16d). aflakes shown together; $\mathbf{b}$ - battered flake tool of identical material $(B-430) ; \mathbf{c}$ - flake retouched into an end scraper (B283); d-flake (B-176) detached after flake B-283, from other side of core. Note curvature of core surface shown by flakes' ventral profiles (a). This core may not have been reduced on site, despite these refits.

A "Levallois-like" technology has been described for a quarry site in the southeast (Goodyear 1996). And large discoidal cores have been found in association (not in situ) at the Crockett Gardens site at San Gabriel Reservoir in central Texas, along with a Clovis point and several large (Type 1) blades (McCormick 1979). Flakes from those cores are large enough to easily have served as blanks for large Clovis points, and certainly as flake blanks for retouched tools (Figure 9.15).

Because large discoidal cores are essentially large bifaces, it could be quite easy to mistake large flakes from these cores for flakes removed from biface blanks or preforms. This problem is pertinent to the materials from Aubrey, since flake and blade blanks represented by single pieces of a particular raw material are present, especially from the Red Wedge in Area A. These pieces, it is assumed, are blanks/tools that were transported for long distances. While the caching and the reduction of large bifaces 

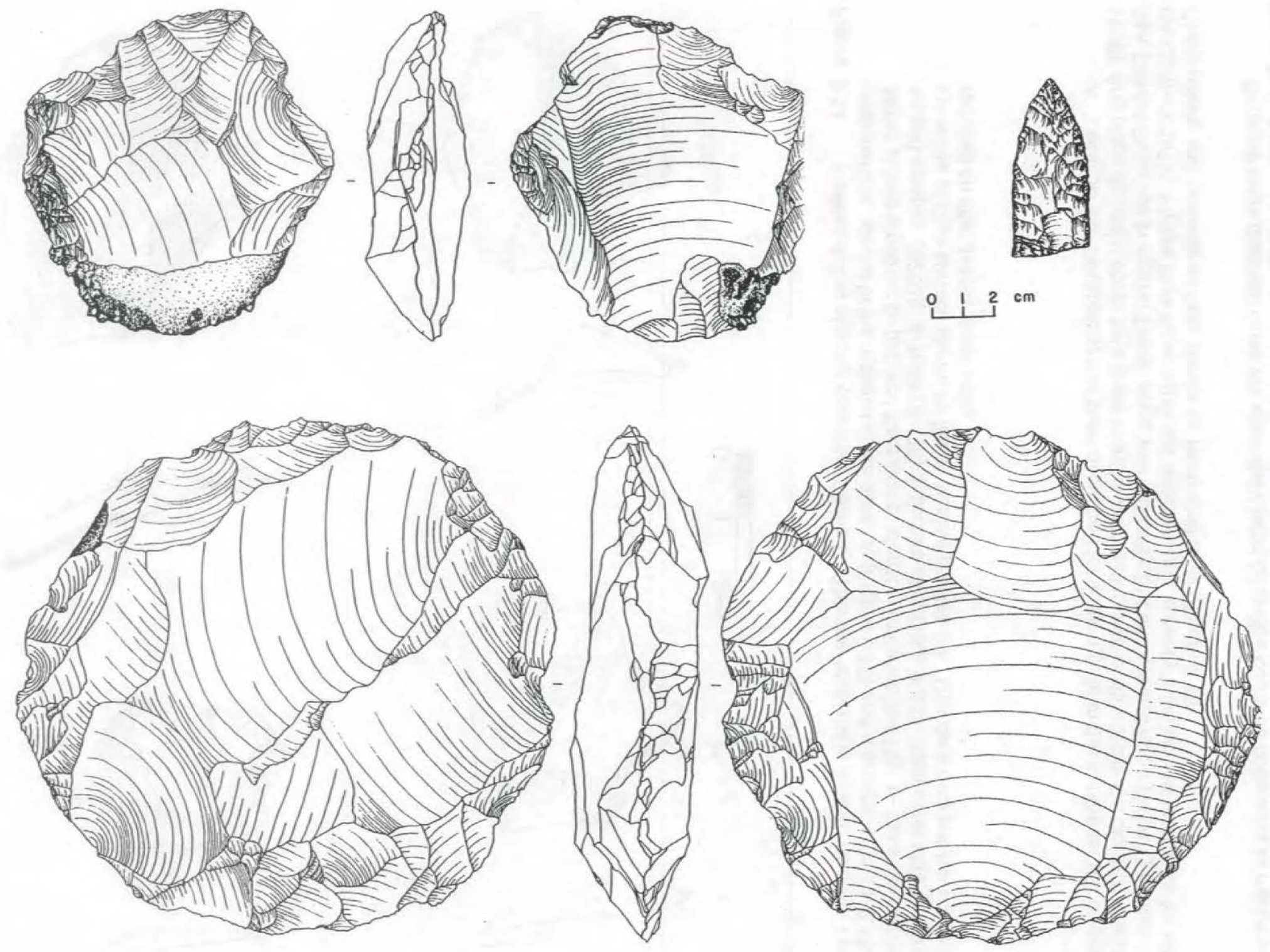

Figure 9.15 Discoidal cores from the Crockett Gardens site. Site is near Granger, Texas, at the northeastern edge of the Edwards chert source are shown in Figure 9.11. Note size of flakes from largest core compared to broken Clovis point from Aubrey site. Such "flake-blades" could be hard to distinguish from large biface thinning flakes (as Type 3 blades). Smaller discoidal cores are represented in Aubrey assemblage (Figure 9.14). From McCormick (1979). 
in Clovis habitation sites is documented, the same documentation for discoidal cores has yet to be established. Discussion of caching cores in Chapter 10 includes the proposal that cores from the Anadarko Clovis cache (Hammatt 1970) are discoidal, and that a shift from discoidal to blade reduction strategies on
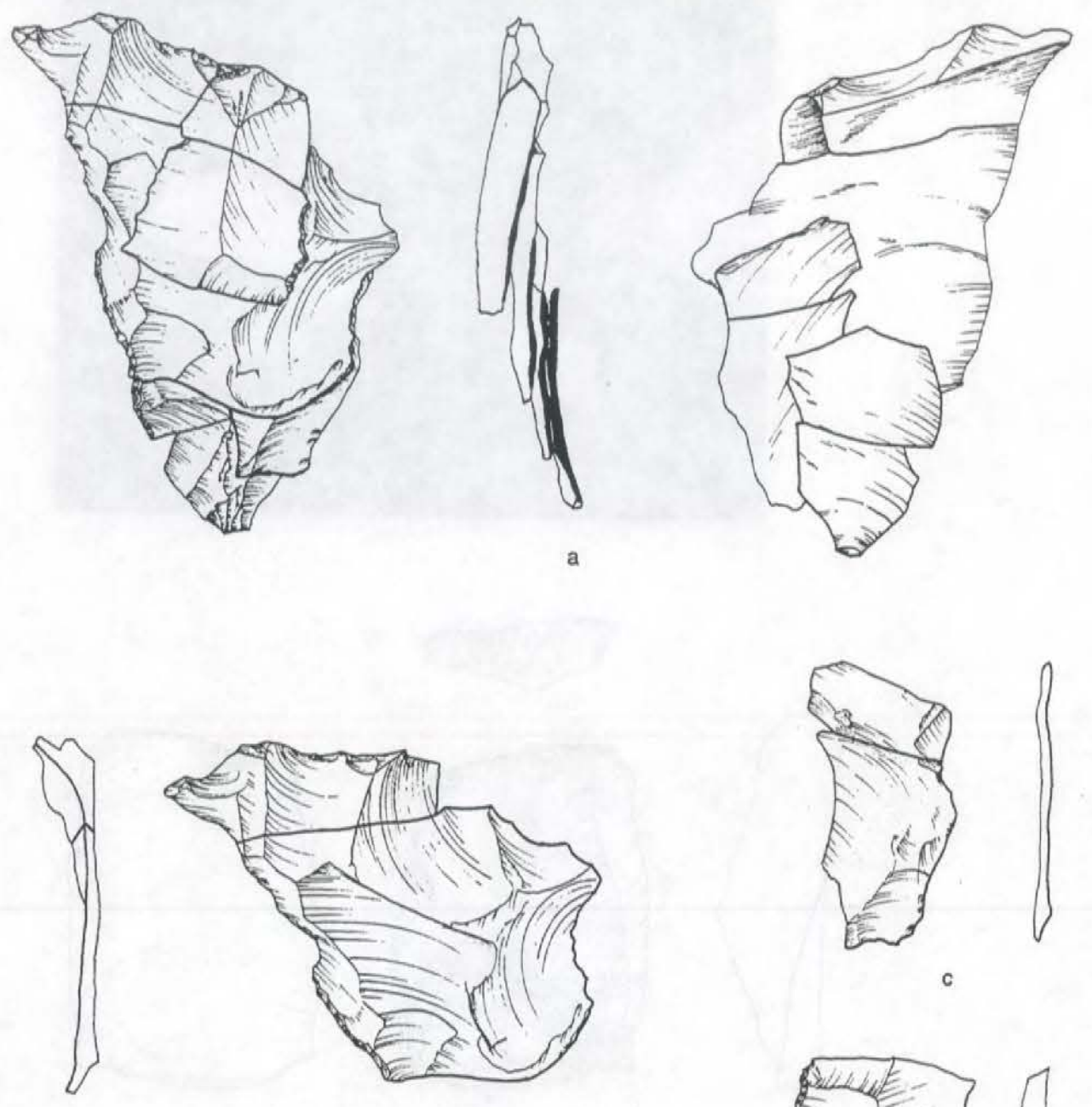

b
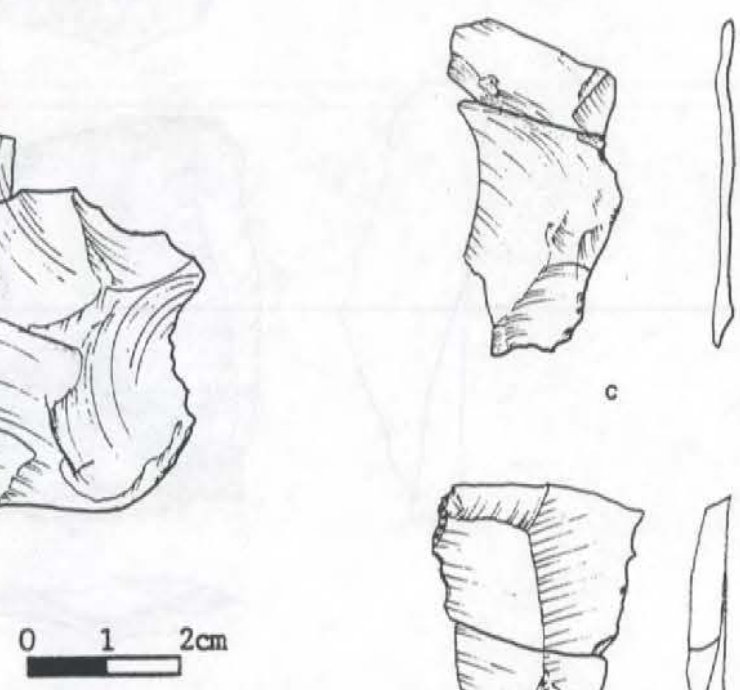

C

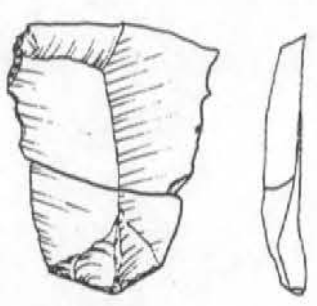

d

Figure 9.16 Refitted biface thinning flakes from Camp B. The upper (outermost on biface) flakes are chalquartzite in the innermost flakes. These puartzite. That lithology grades into a gray, vitreous "debitage pile" in Camp B. They were detached from a large, possibly smashed Bifact, the a- note biface was at least 13 cm wide detached from a large, possibly smashed bifacial blank. overpassed flake (mended B-181 wide, based on conjoined flakes; b- distal portion of large section; note piece is broken and and B-309) with expanding distal profile and extremely thin midbiface (B-240); d- biface thinning flake 

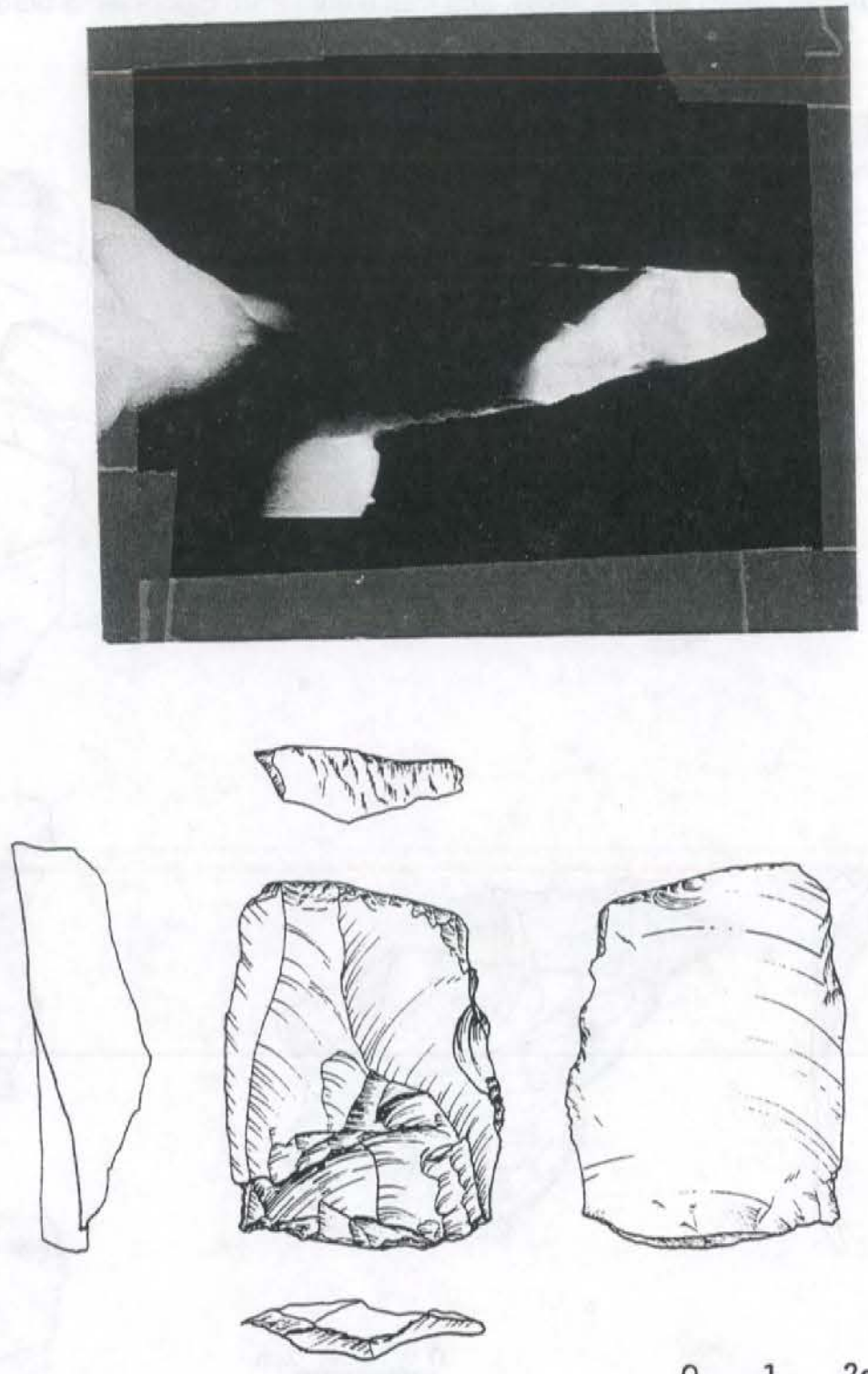

a

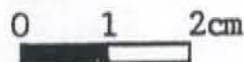

Figure 9.17 Abrader from Camp B. This tool is made of a very hard, vitreous variety of Tecovas chalquartzite. It was found adjacent to the large "debitage pile" (Feature B-7) in Camp B, which had over 1,600 pieces of debitage in less than 1 square meter. a - Note deep scoring and heavy polishing on distal end of piece. b- Left edge of piece is smooth, thin cortical surface, typical of this material when acquired at bedrock outcrop. This piece was possibly removed from a conical blade core. 
the same core, in sequence, may have been practiced. Similarly complex serial reduction strategies are described for Mousterian industries in Central Europe (Baumler 1988). Goodyear (1997) has reported discoidal cores from southeastern Clovis sites, and similar cores are quite common in eastern fluted point sites in the northeast.

\section{Biface Reduction}

In virtually all aspects of biface reduction and in the use of biface related debitage, the assemblage from Aubrey is unmistakably in the Clovis tradition. In fact, the Clovis affinity of this assemblage can be demonstrated firmly and sufficiently using only the debitage, as evidence of Clovis lithic reduction strategies. The same is true for the blade production.

Inspection of the frequencies of debitage and debris classes reveals that bifacial reduction was not a dominant aspect of the lithic processing at Aubrey (Table 9.1). At the same time, biface reduction was significantly more important at Camp $F$ than at Camp B, with restricted frequencies of $27.4 \%$ and $17.8 \%$ BFTs respectively. Spatial patterning of these activities is highly patterned, and is considered later. In addition to the frequency of biface thinning flakes, the raw materials used for bifaces is quite different between the camps, as mentioned earlier (Tables 9.9, 9.10; Figure 9.18). In Camp B, 86\% of

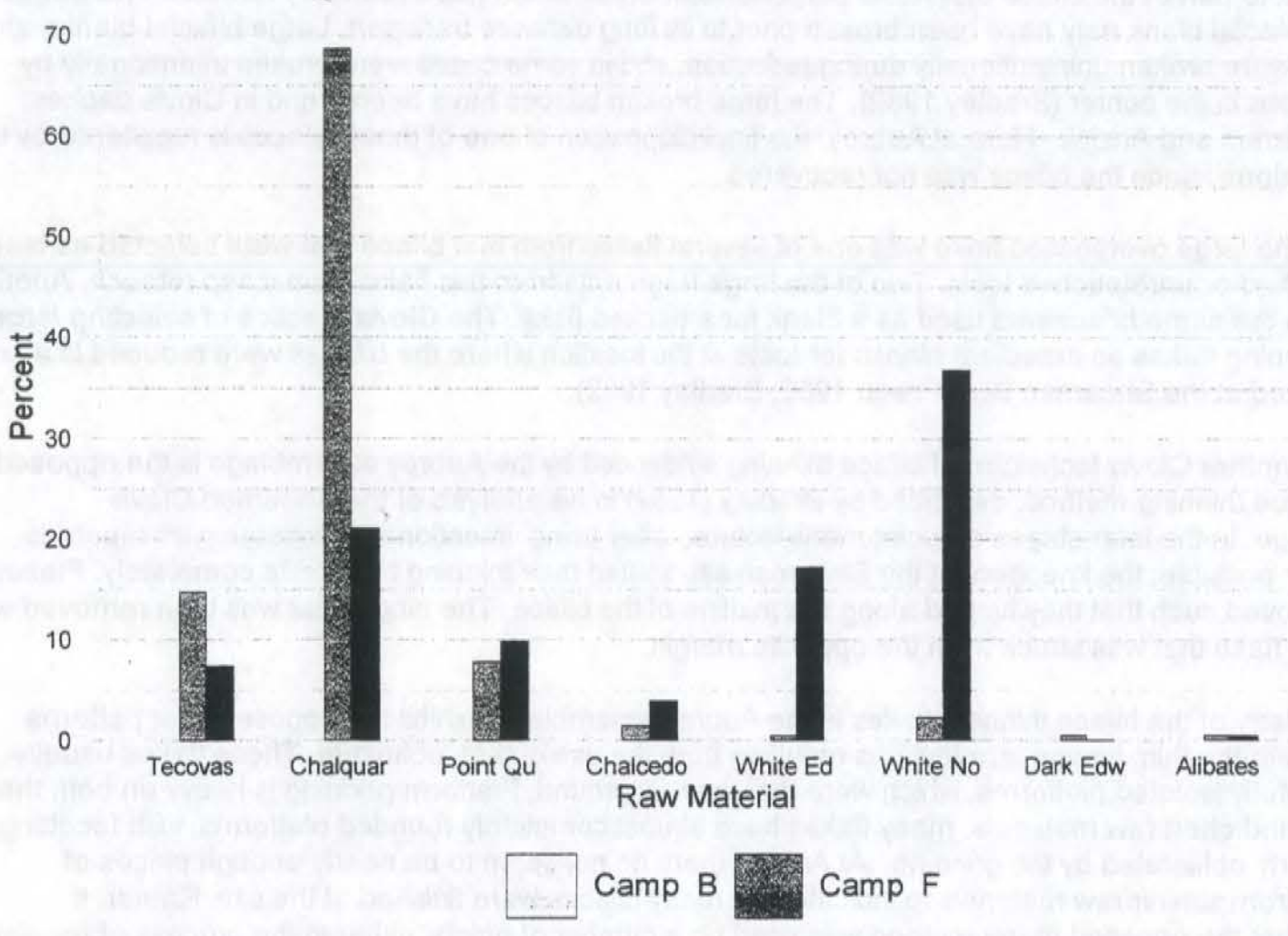

Figure 9.18 Raw materials of biface thinning flakes in Camp B and Camp F. 
the BFTs are made of Tecovas quartzite/chalquartzite. In Camp F, only $28 \%$ of the BFTs are Tecovas quartzite, as there is much higher use of white Edwards and white novachert. Because this raw material difference correlates with an apparent functional difference between these two camps, no cultural or temporal difference is necessarily implied.

The extreme paucity of cortical pieces and large BFTs, and also the total absence of any preforms or blanks, indicates that virtually all of the biface reduction was related to final manufacturing, repair or resharpening tasks. The size and distribution of BFTs suggest that final manufacturing was a rare activity, and perhaps limited to one tool. Tecovas quartzite and chalquartzite BFTs were almost $70 \%$ of the debitage found in Feature B-7, the small, dense debitage pile in the northern part of Camp B (Figures 9.3, 9.4). As mentioned above, these two raw materials grade from one to the other, even on the same flake.

Interestingly, an abrader made on a very thick flake of vitreous Tecovas chalquartzite was found adjacent to the debitage pile (Figure 9.17), and was almost surely used during knapping there. Although such tools are apparently rare in Clovis assemblages, the practice of heavily grinding platforms during reduction is wellknown.

The technique of intentionally overpassing flakes during biface reduction was essentially unique to the Clovis culture in North America (Bradley 1982, 1993; Frison and Bradley 1999). That technique not only yielded superbly shaped bifacial tools, but also it maximized the size of the flakes removed to the fullest degree possible. Use of this technique at Aubrey is well documented by the debris in Feature B-7. That includes a large overpassed flake, among those refitted from the Tecovas quartzite/chalquartzite biface reduced there (Figure 9.16). The biface must have been at least $15 \mathrm{~cm}$ wide, similar to those from caches (Lahren and Bonnischsen 1974; Butler 1963; Stanford 1991; Frison and Bradley 1999). Several pieces refit to part of the biface that has a perpendicular break which has secondary retouch. This suggests that this bifacial blank may have been broken prior to its long distance transport. Large bifacial blanks and preforms were broken unintentionally during reduction, and in some cases were broken intentionally by striking them in the center (Bradley 1982). The large broken bifaces have been found in Clovis caches, such as Simon and Anzick. Here at Aubrey, the final disposition of one of those bifaces is registered by the debitage alone, since the biface was not recovered.

The large overpassed flake was one of several flakes from that biface that were selected as blanks for retouched or unretouched tools. Two of the large fragments from this flake have steep retouch. Another flake from the same biface was used as a blank for a backed flake. The Clovis practice of selecting large biface thinning flakes as expedient blanks for tools at the location where the bifaces were reduced is also documented at the Sheaman Site (Frison 1982; Bradley 1982).

Another Clovis technique of biface thinning evidenced by the Aubrey assemblage is the opposed diving biface thinning method, described by Bradley (1982) in his analysis of the Sheaman Clovis assemblage. In the later stages of point manufacture, after using intentional overpassing as much as needed or possible, the knappers at the Sheaman site shifted their thinning technique completely. Flakes were removed such that they hinged along the midline of the biface. The hinge scar was then removed with a thinning flake that was struck from the opposite margin.

Many of the biface thinning flakes in the Aubrey assemblage exhibit the opposed scar patterns coupled with the thin, hinged terminations resulting from the use of that technique. These flakes usually have carefully isolated platforms, which were then heavily ground. Platform grinding is heavy on both the quartzite and chert raw materials; many flakes have almost completely rounded platforms, with facetting scars nearly obliterated by the grinding. At Aubrey there do not seem to be nearly enough pieces of debitage from similar raw materials to indicate that many bifaces were finished at the site. Rather, it appears that the opposed diving method was used on a number of points, either in the process of repairing broken pieces, or perhaps during resharpening as a means to maintain the width/thickness shape of the point. 
Another tool-making technique used by Clovis folks was to break medium to large sized flakes into fragments that had steep break edges (Bradley 1980; Frison and Bradley 1982). Those edges were ideally shaped (much like burin scars) for scraping or planing tasks. Striking large flakes in the center of their dorsal surface produced triangular shaped "radial break tools" (Bradley 1982; Frison and Bradley 1982). Pieces broken transversely, called "bend break tools" were used in similar fashion. Both kinds of tools, usually made from biface thinning flakes, were recovered from Aubrey and are described below. Notable, however, is that some of the radial break and bend break tools were made on flakes that were imported to Camps $B$ and $F$.

Two white Novachert biface thinning flakes from Camp F were removed from large flake blanks, as shown by their dorsal surfaces, which are part of the bulb on the flake blank. One of these originated from the lateral margin of the flake. The other shows heavy re-grinding of the flake blank platform and detachment on the flake blank axis. There does not appear to be enough debitage to suggest that the flake blanks were being finished into bifacial tools on this site. More probable is that these flakes were imported with other flake blanks to the site, were modified, used, and discarded. However, the number proximal fragments of robust BFTs suggests that the flakes were carried whole, were broken before or during use, and the large distal fragments were removed along with most of the other usable lithic debris. A similar case is described at the Sheaman site, where Frison (1982) found two proximal fragments of large flakes in one of the debitage piles there, while the distal portions were found some meters away, with evidence of use wear. Overall, the use of flakes in this fashion represents just one more iteration of the distinctly Clovis practice of "lithic depletion", by which is meant the serial transformation and transport of stone materials by Clovis migrants on the Great Plains.

\section{Tool Typology}

A total of 64 lithic tools and cores were recovered from the Aubrey site (Table 9.11). Four of these were found on the surface, but because of their location, type and raw material are considered associated with the in situ assemblage. The comments on the tools below are supplemented by tables with technological, typological and taphonomic attributes for each piece (Appendix B).

\section{Tools From Camp B-C}

The largest sample of tools (41) was recovered from Camp B, as might be expected since the excavation area there was the largest. But the tool density there is higher than in Camp $F\left(0.35 / \mathrm{m}^{2}\right.$ vs. $0.25 / \mathrm{m}$. As mentioned above, the assemblage from Camp $B$ is dominated by unifacial tools, as only two fragmentary bifaces were found. The debitage in Feature B-7 are certainly suggestive that a projectile point could have been fabricated there from a well-prepared blank or preform. However, it is also possible that the large biface was being reduced to obtain the flakes, and not to finish the bifacial tool.

In any event, the Camp B sample is quite what one would expect for a camp occupied by a highly mobile group that acquires its stone raw materials at least $200 \mathrm{~km}$ away, at least in terms of the very fragmentary nature of the tools, but also in terms of the different activities conducted there as opposed to at the more common Clovis site- a kill/butchery locus. As later discussions will stress, the Aubrey site also has a remarkable record of tool use based on maintenance and repair debris. This record goes a long way towards addressing some of the deficiencies of discarded tools alone as evidence of task location and intensity, as noted by Dincauze (1993). However, that record is still expanded and strengthened by examination of the tools themselves. 
Clovis Point

Biface fragment

End scraper, canted, w/ graver

End scraper, canted, notched, w/ graver

End scraper, canted

End scraper fragment

End scraper on blade

End scraper, atypical

Double convergent side scraper

Scraper fragment

Raclette

Backed flake

Retouched naturally backed knife

Retouched flake

Retouched flake-blade

Utilized blade

Retouched-denticulated flake

Bend-break tool

Radial break tool

Abrader-polisher

Bec

Graver

Multiple graver

Scaled piece

Chopper
11

23

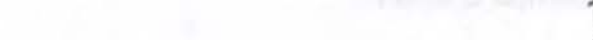

1

122

1201

2

-

1

- 19

$2 \quad 5$

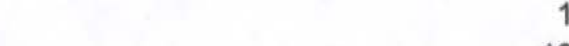

213

122

- $19-1$

4

13

1

$\begin{array}{lll}1 & 1 & 1\end{array}$

Total

41

16

5

1

64

Bifaces

The Clovis Point from Camp B is the largest biface fragment recovered at Aubrey, and is represented by two conjoining fragments (Specimens B-2 and B-607) that were recovered from the northern and southwestern parts of Block B, respectively (Figure 9.19-a). It is made of a distinctive gray Tecovas quartzite, with wispy white/brown chalcedony-filled vugs (the "point quartzite" as informally defined above). The biface was fashioned with small overlapping biface thinning flakes. It was fluted on both sides. The hinged terminations of the flutes have been partially removed by subsequent biface thinning flakes, in the manner described by Bradley (1993). Both edges were abraded and dulled but not polished (see Titmus and Woods 1991) beyond the flute terminations. About $1 \mathrm{~cm}$ of abraded-dulled edge is preserved on either margin of the point.

The point has been resharpened by fine pressure flaking along both edges, down to the edge grinding. This was done so as to leave very slightly and finely serrated margins. There is no evidence of any impact damage to the piece, although this could have been removed by repair. Pressure resharpening of Clovis points is noted on High Plains artifacts, although this may follow percussion flaking (Bradley 1993). 

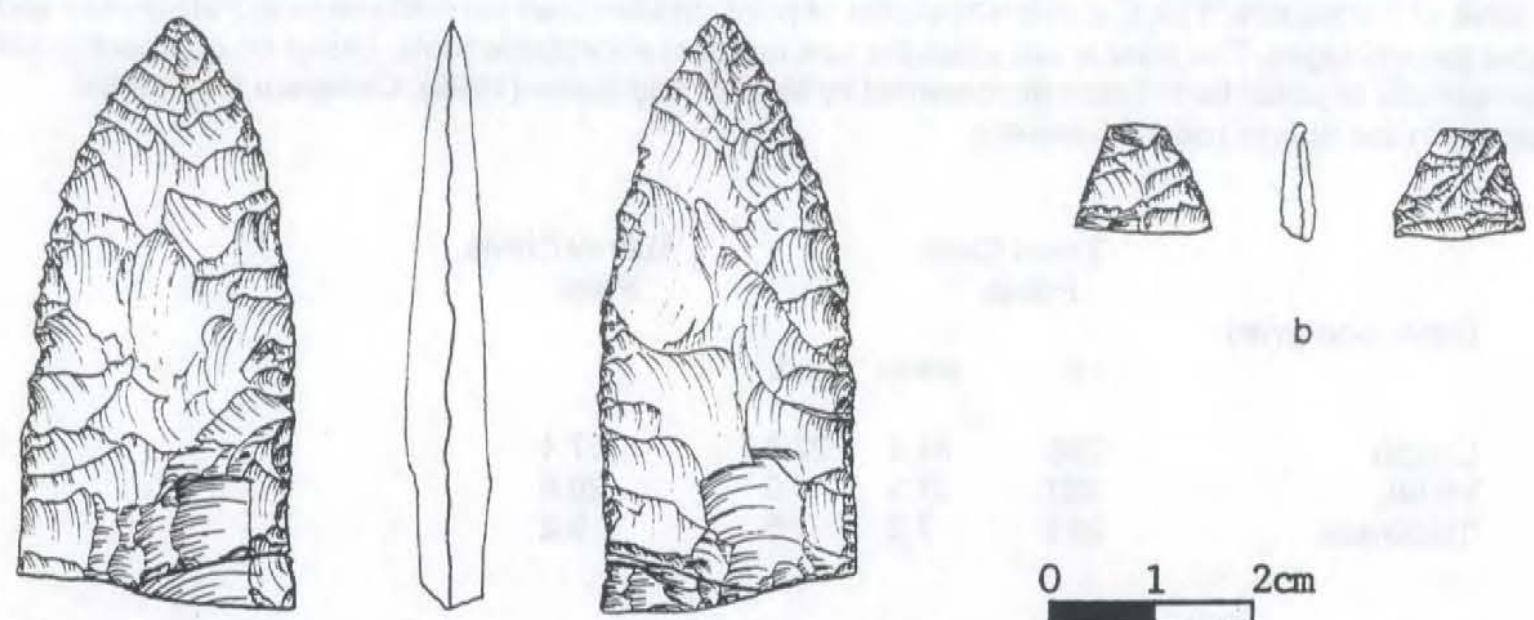

b

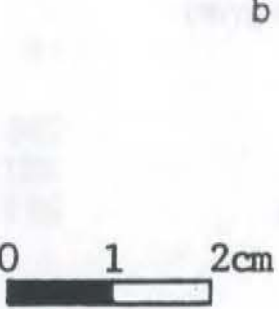

a

Figure 9.19 Clovis point and biface tip from Camp B. a- Clovis point (Tecovas "point quartzite"). Distal portion (B-2) was found in situ, eroding from Camp B. Proximal fragment (B-607) was recovered about 10 $\mathrm{m}$ away, near hearth; b- impact spall from projectile point (B-602) found near hearth in south part of block (unidentified gray spicular chert; possibly Edwards). See Figure 9.30 for map of the quartzite point, the articulating fragment, and associated debitage.

The spatial distribution of the two fragments of the point, and of the flakes and chips of the distinctive raw material, provide evidence of the life history of this tool within the camp area. The spatial patterning of the site is considered later, but the main patterns are indicated here. The large distal fragment of the point was actually the second artifact found at the site. It was found protruding from the edge of a small gully immediately above the location of a quartzite flake that was in the gully about $1 \mathrm{~m}$ away. The point was mapped in place. Excavations showed that the piece was indeed in situ, surrounded by other lithic artifacts and bone fragments, at an elevation of $88.99 \mathrm{~m}$. Excavations in this northern part of the block recovered a number of small pressure flakes that appeared to be resharpening debris. It was assumed that the point had been resharpened in this area of the site prior to discard, and possibly prior to breakage. However, continued excavations recovered the conjoining fragment about $10 \mathrm{~m}$ to the south in Unit 2621. In that area of the site a cluster of biface resharpening debris of the same material was also recovered, but those artifacts include larger flakes that could have resulted from point repair.

Assuming that the small fragment was deposited where the point broke in the haft, it is possible that the point was repaired and used in the southern area and broken there. The distal fragment may then have been used and resharpened again in the northern part of the block and finally discarded. Other interpretations are possible, but they would entail moving the point back and forth between these areas, or that there were other artifacts being used that were made of the same material. In this vein it is important that identical raw material is represented by biface resharpening flakes and chips in Camp F. 
After the breakage in the haft, the fracture was "repaired" by light grinding and minor flaking along both sides of the fracture. This is a different aspect of point curation than normally seen in Paleoindian and younger assemblages. This point is still within the size range of acceptable tools, based on comparison with a large sample of points from Texas documented by Meltzer and Bever (1995). Compare their metric statistics with the Aubrey point dimensions:

\begin{tabular}{lcrrr} 
& \multicolumn{2}{l}{$\begin{array}{c}\text { Texas Clovis } \\
\text { Points }\end{array}$} & & $\begin{array}{c}\text { Aubrey Clovis } \\
\text { Point }\end{array}$ \\
Dimension $(\mathrm{mm})$ & $\mathrm{n}$ & mean & s.d. & \\
& & & & \\
Length & 285 & 61.4 & 27.8 & 57.4 \\
Width & 287 & 27.5 & 4.9 & 26.6 \\
Thickness & 269 & 7.3 & 1.5 & 9.2
\end{tabular}

Even having been broken and repaired, the point is well within the range of points studied by Meltzer and Bever. The thickness of the Aubrey point may be significantly greater than the average thickness of Clovis points from Texas. This could well reflect the quartzite raw material of the Aubrey point, compared to the dominance of chert for Texas points.

While point repair is usually thought of in terms of curating a large basal fragment, this may be a case where the distal part of the point was salvageable. Compared to impact-related damage, it seems quite possible that lateral snapping would generate a shorter basal fragment (perhaps too small to repair) because the stress would be greatest at the haft. Depending on the length of the distal section, repair, and even possible refluting of large distal fragments seems plausible. Even in its present condition, the Aubrey point could be rehafted and used. Given the overall curation of stone here, it would seem unlikely for those folks not to have used this piece after it was broken. One can immediately ask, then, why was it discarded?

Artifact No. B-602 is a small impact fragment from very near the tip of a point (Figure 9.19-b). Its cross-section indicates a point that was distally narrower and thinner than the point described above. It compares well with the morphology of longer, slender points that probably had not been repaired or resharpened, such as one from Kimmswick (Graham and Kay 1981: Figure 2 b-c). This raw material is a distinctive dark gray chert with many white spicules. Neither debitage nor any other tools of the same material were found in Camp B, so there is no evidence that the point was repaired here. However, one scraper resharpening chip of the same material was found in Camp F.

This point fragment was found very close to Features B-2, and B-3, which are hearths in the southern part of Block B. A possible scenario to explain this singular occurrence is that this impact spall was brought to the camp area in stripped meat, and was lost or discarded there as the meat was processed. This interpretation was kindly suggested to me by Vance Haynes. At the Murray Springs site in Arizona, he found an impact fragment in the camp area that conjoined with a Clovis point recovered from the kill-butchery area in the nearby arroyo (Haynes 1971).

\section{Scrapers}

There are six end scrapers, a scraper fragment and a raclette in the sample from Camp B. Most of these are end scrapers on blades, and several are very characteristic of those from other Clovis sites, and from eastern fluted point sites. 

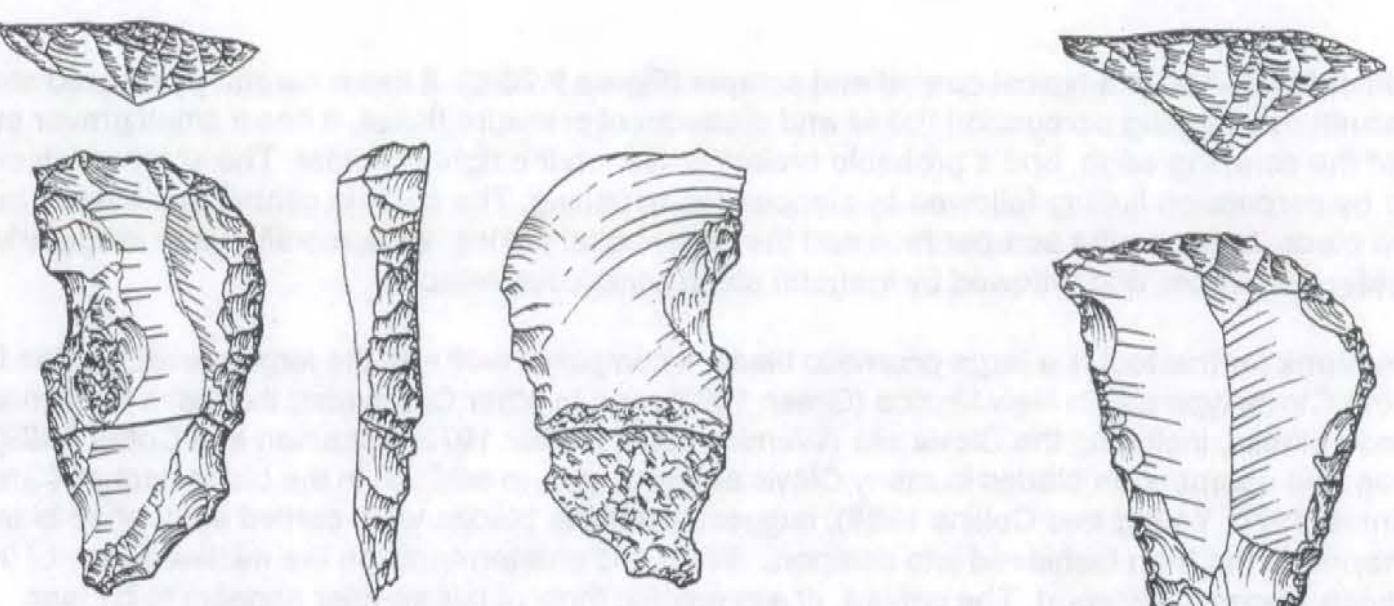

a
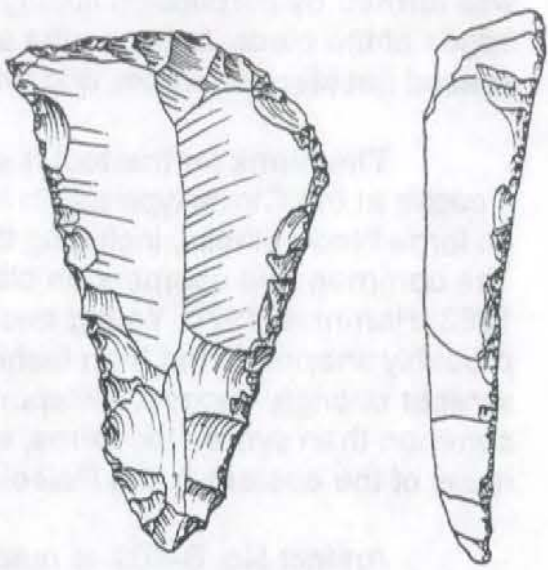

b
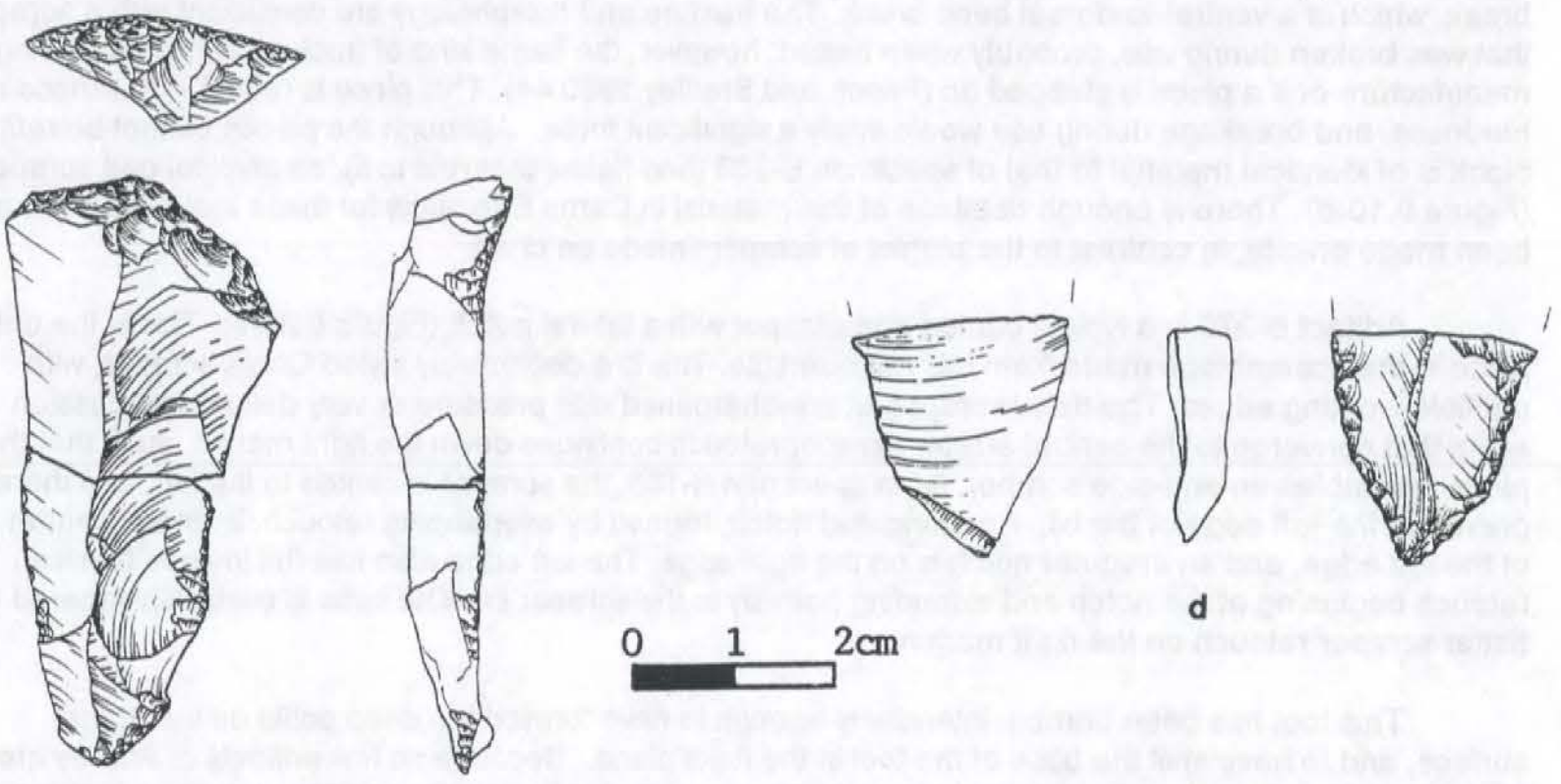

d

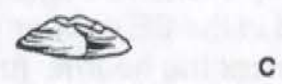

C

Figure 9.20 End scrapers from Camp B. a- canted, notched and spurred end scraper on red DakotaMorrison quartzite blade; burned (B-270); b- canted end scraper on blade; note heavy bilateral retouch for hafting ( B-186); unidentified brown finely laminated chert, possibly from Ouachita Mountains of Arkansas or Oklahoma; c- canted end scraper on blade with probable broken bilateral spurs (white Edwards chert; B-219 and B-23); piece probably broken while hafted; note marginal use or edge damage below break; $d$ - base of probable end scraper on robust chalquartzite blade or flake-blade (B-409); heavy converging retouch assumed to shape piece for hafting; burin spall on ventral surface is probably incidental. 
Artifact No. B-186 is a typical canted end scraper (Figure 9.20-b). It has a carefully prepared stem, formed by small overlapping percussion flakes and subsequent pressure flakes. It has a small graver at the left corner of the scraping edge, and a probable broken graver on the right shoulder. The scraper retouch was formed by percussion flaking followed by stepped resharpening. The piece is canted to the left. The edges of the piece, between the scraper face and the larger basal flaking, were modified with irregularly spaced flat stepped flakes and followed by irregular steep continuous retouch.

The blank for this tool is a large prismatic blade. It compares well with the large curved blades from a cache at the Clovis type site in New Mexico (Green 1963), and to other Clovis sites that have tools made on large blade blanks, including the Clovis site (Warnica 1966; Hester 1972; Boldurian and Cotter 1999). The common end scrapers on blades in many Clovis assemblages, in addition to the blade caches (Green 1963; Hammatt 1970; Young and Collins 1989), suggest that these blades were carried as finished blanks, probably snapped, and then fashioned into scrapers. Wear and chattermarks on the midline arrete of this scraper strongly suggest transport. The canted, or asymmetric form of this scraper appears to be less common than symmetric forms, especially in the western US Clovis sites. Canted scrapers are common in many of the eastern fluted Paleoindian sites, such as Debert, Bull Brook, or Thunderbird (Meltzer 1988).

Artifact No. B-409 is made on a flake or blade of Tecovas chalquartzite. Although fragmentary, it is assumed to be the base of a stemmed scraper (Figure 9.20-d). The piece begins to flare just above the break, which is a ventral-to-dorsal bend break. The fracture and morphology are consistent with a scraper that was broken during use, probably when hafted; however, the same kind of fracture can occur during manufacture or if a piece is stepped on (Frison and Bradley 1980:44). This piece is robust in thickness and hardness, and breakage during use would imply a significant force. Although the pieces cannot be refit, this blank is of identical material to that of specimen B-283 (and flakes that refit to it), an atypical end scraper (Figure 9.10-d). There is enough debitage of this material in Camp B to allow for these tool blanks to have been made on-site, in contrast to the blanks of scrapers made on chert.

Artifact B-270 is a typical canted end scraper with a lateral notch (Figure 9.20-a). This is the only piece in the assemblage made from this red quartzite. This is a distinctively styled Clovis scraper, with multiple working edges. The distal scraper bit is resharpened with pressure or very delicate percussion scars that converge to the central arrete. Scraper retouch continues down the right margin, such that the piece resembles an end-side scraper. As in specimen B-186, the scraper is canted to the left, and there is a graver on the left edge of the bit. An elongated notch, formed by overlapping retouch, is on the central part of the left edge, and an irregular notch is on the right edge. The left edge also has flat inverse (ventral) retouch beginning at the notch and extending halfway to the scraper bit. The base is bilaterally tapered with flatter scraper retouch on the right margin.

This tool has been burned, intensively enough to have formed the deep potlid on the dorsal surface, and to have split the base of the tool in the flake plane. Because so few artifacts at Aubrey are burned, and because burning seems to have been concentrated in discrete hearths, intensive burning of this tool suggests that it may have actually been tossed into a hearth. It was found in the SE quarter of Unit 1924, very close to hearth feature B-1 (Figure 9.3). Four red quartzite chips were near the hearth, just east of the scraper. Seven chips of the red quartzite were found in and around hearth Feature B-5, and a few chips were between those two areas. This piece or another made of the same raw material was apparently resharpened in those locations, but how many tools were involved cannot be fixed at present.

This is the only notched scraper in the assemblage from Aubrey. It is comparable to notched scrapers from eastern fluted point sites; examples include specimens from the Potts Site (NY) (Gramley and Lothrop 1984: Figure 6), Bull Brook II, MA (Grimes et al 1984: Plate 4), Plenge, NJ (Kraft 1973: Plate 11), and Shawnee Minisink DE, (McNett 1985: Figure 6.5).

Artifact B-23 (conjoin with B-219) is a typical canted end scraper (Figure 9.20-c). It has small breaks on either edge of the bit that suggest gravers may have been broken away. The blank tapers to the platform and the piece does not exhibit the retouched base as the others. The piece has a ventral-dorsal 
bend break almost mid-way up the piece from the platform, suggesting it was broken in use. Whether it was hafted is not evident from shaping or from edge wear. The two halves of the tool were found about $2 \mathrm{~m}$ apart in the southern part of Block B.

The blank for this tool is one of the longest blades recovered at the site. It is made of the same white chert that is found as biface and uniface resharpening debris in Camps $B$ and $F$, and as a refitted microcore in Camp F (see below). This piece has attributes indicating a blade produced from a blade core, but one with a very steep platform angle. The blade thickens, expands and curves distally, suggesting an intentional overpass (Ferring 1988). This appears to have been necessary to correct for two deeply hinged scars that originated from trimming blows from the right side of the core. This longitudinal profile made an excellent scraper blank, except that it is proximally thin and was weakened by one of the hinge scars. The platform, with an acute angle, pronounced lip and very diffuse bulb, connotes a blade core with a very acute platform angle (Ferring 1988; Faulkner 1972).

Clovis blade cores are usually described as being conical to cylindrical, with steep platforms (Stanford 1991). Collins $(1990 ; 1999)$ describes Clovis core tablets that have concave faceting scars imparting a much more acute platform angle to the detached blades. The small platforms and curved blade profiles, as seen here, are similarly evidenced in Clovis blade caches from the Clovis site (Green 1963) and from site 41 NV659 in north Texas (Young and Collins 1989). The core tablet from Aubrey (described above) indicated the same reduction strategy (Ferring 1989, 1995).

Artifact B-283 is an atypical end scraper or a lateral end scraper on flake (Figure 9.14-d). This tool is made on the transverse axis of a thick chalquartzite flake with a triangular cross-section. The scraper bit has irregular to slightly denticulate retouch, but with elongated pressure-type scars that follow aretes. It does not appear to have been resharpened much if at all. The flake blank refits with an unmodified flake (B-176), recovered from square 1925 (Figure 9.14-c), and with a retouched/battered flake (artifact B-430) recovered from unit 2823/SW near Feature B-2, a hearth.

Artifact B-405 is a fragment of a scraper, probably a side scraper (Figure 9.21-e). As with Artifact B603 , this is one of the larger flakes (and cortical flakes) from the site. These two, in fact, suggest that they were introduced as tools or blanks. No evidence has been found thus far that suggests on-site reduction of cores or bifaces which still had cortex. We collected varieties Tecovas chert near Quitaque, Texas that had almost identical coloration and cortex. These were the only varieties of that material we collected that had a yellowish fluorescence (Table 9.8). The cortex on this piece indicates procurement from outcrop.

Artifact B-174 is an end scraper that approaches a truncated blade by virtue of the narrow dimension of the distal end of the piece and the steep profile of the retouch (Figure 9.21-d). The steep retouch forms an irregular, almost graver-like projection, similar to that on the chalcedony blade (B-407). Also, this blade shows extensive use of both edges. It was detached from a small prismatic blade core. This raw material has the buff appearance of some Edwards cherts, but has no fluorescence, which probably excludes Edwards as a source.

\section{Retouched Pieces}

Artifact B-603 is a retouched flake, with retouch approaching that of a scraper (Figure 9.21-h). This is one of the largest flakes recovered from Aubrey, and is easily the largest of the few cortical flakes in the assemblage. This kind of tool blank is very rare at Aubrey, whereas at the Clovis type site, large cortical flakes were commonly used as blanks for tools (Hester 1972). The cortex on this piece covers the left margin, forming a naturally backed edge for the proximal right edge, which has been resharpened by a series of overlapping flakes. This may well have served as a butchery tool, as described by Frison and Todd (1986:129), and should be compared to the backed knife (B-245) below. The differences between the two artifacts are also mentioned below. This raw material is typical of the Tecovas quartzites at the site, but it has a reddish hue towards the outside of the mass, inside the cortical rind. The cortex indicates use of nodular or tabular material from bedrock outcrop. 


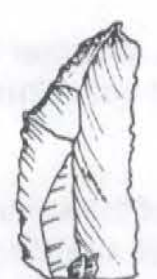
1

a
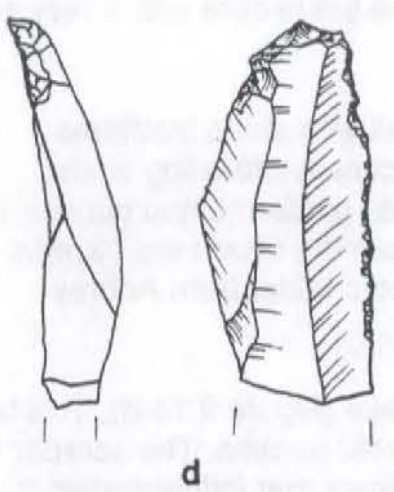

e

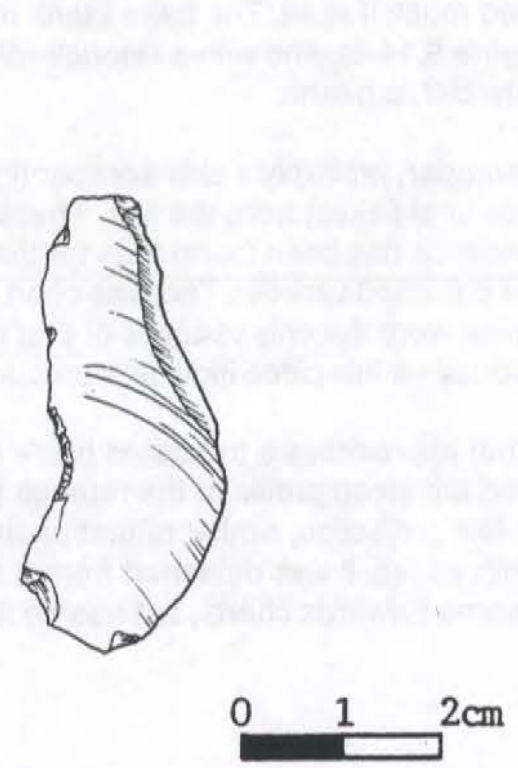

g
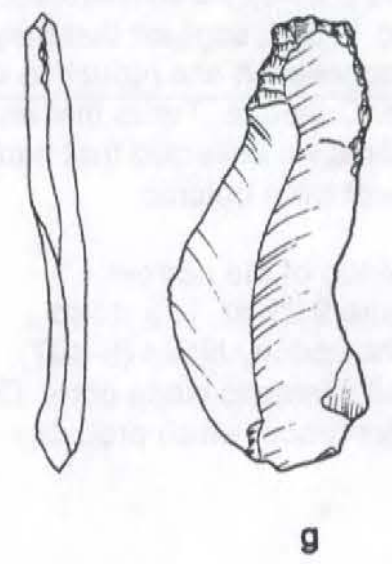
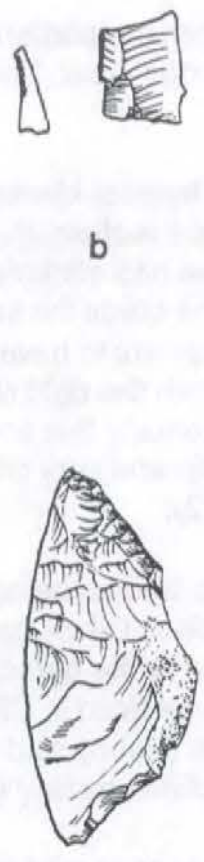

b
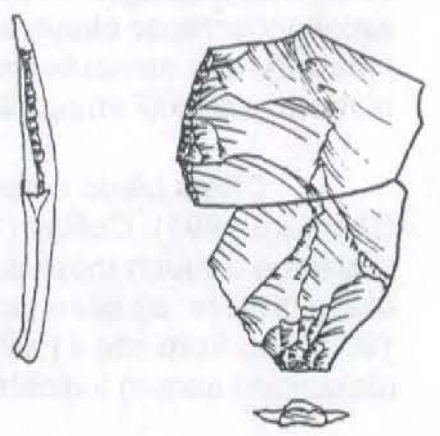

f

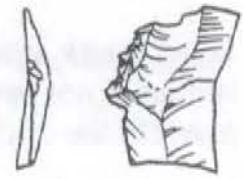

c
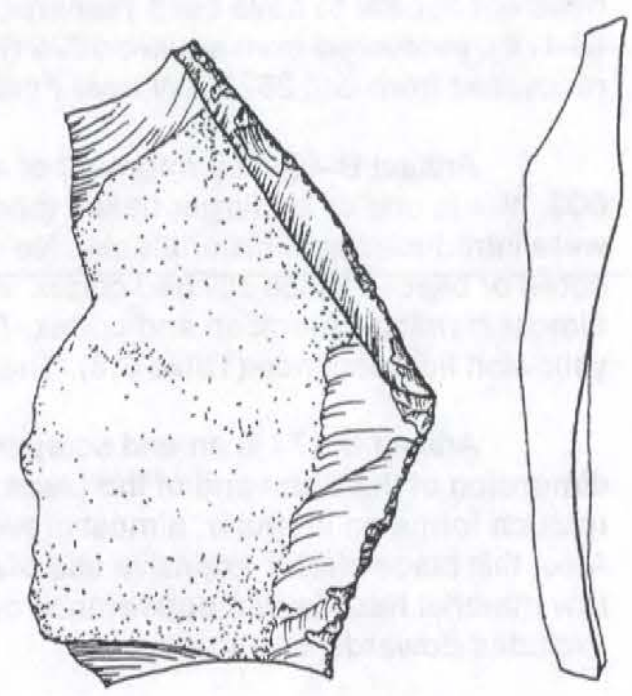

h

Figure 9.21 Unifacial tools from Camp B. a- graver on distal end of retouched chalcedony blade (B-407); note size and strong distal curvature of blade blank; b- retouched blade/flake fragment (B-609; white novachert); c- retouched blade/flake fragment (B-606; Tecovas quartzite); d-atypical end scraper on retouched blade (Buff Edwards; B-174); e- (side?) scraper fragment on cortical flake (yellow Tecovas chert; B-405); f- backed Tecovas quartzite biface thinning flake, possibly bendbreak tools (B-245, distal, conjoined with B-601); g- retouched/utilized Tecovas chalquartzite flake-blade (B-22); $h$ - retouched/utilized Tecovas quartzite cortical flake (B-603); note this is the largest tool found at Aubrey, located a few meters west of Camp B excavation block, in situ at contact of Strata A and G (slope to pond shore). 
Artifact B-22 is a retouched flake (Figure 9.21-g). This piece has extensive retouch modification. There are inverse notches on either side of the platform; there is bilateral and distal retouch at the distal end, and there is ragged inverse retouch on the right side. This is a very irregular blank, apparently derived during reduction of a core-biface in the northern part of the block. The chalquartzite is identical to that used for other tools such as the scraper and retouched pieces that refit (B-283, B-230).

Artifact B-605 is a retouched/denticulated piece. The right proximal edge has obverse semi-steep retouch that is contiguous with right lateral denticulated retouch.

Artifact B-606 is a simple retouched piece (Figure 9.21-c). The retouch is irregular, almost serrated, and is contiguous with a left lateral break on the Tecovas quartzite blank.

Artifact B-609 is a white novachert flake with continuous semi-steep retouch on the left edge, beginning at the small hinge scar on the left side of the piece (Figure 9.21-b). The opposite edge is broken, and the piece is distally broken. The blank has a deeply concave unfaceted platform, similar to that which might derive from a blade core with deep hard hammer faceting, as seen on the core tablet from this block (Figure 9.12); however, it is not clear that the blank actually came from a blade core. The platform is the same as that of Artifact B-51.

Artifact B-51 is a retouched/utilized blade. The chalquartzite blank appears to have come from a blade core that had a deeply flaked platform. The blade platform is concave, as if it were a negative bulbar scar. The blade platform is $4.4 \mathrm{~mm}$ thick, and the piece thins distally. This may be a piece that was removed to steepen the platform angle of the core, perhaps following removal of an overpassed piece. The blade has a trapezoidal cross-section, with a broad central dorsal scar and single narrower scars on either margin. The right edge is steep, with a slightly concave dorsal scar between the right margin of the blade and the first arete on that side of the piece. The left edge angle is much steeper. The right side arete is heavily rounded. Assuming this is the result of use, the piece may have been used as a burin, employing the right edge for scraping/planing action. Whether the rounding happened before or after blank detachment cannot be determined.

Artifact B-128 is a retouched flake. The blank for this tool resembles a twisted microblade, but the platform preparation and scar pattern indicate it probably was derived during biface manufacture or maintenance. The retouch is continuous semi-steep to steep on the thin edge of the blank. The proximal part of the left edge has been snapped, isolating the preserved retouch in the middle section of the edge.

Artifact B-245 [conjoin with B-601] is a backed flake (Figure 9.21-f). This tool has nearly vertical backing along its left edge, opposite the sharp right edge. The backing extends along the middle of the edge but the distal part is missing. The blank is a piece of grainy Tecovas quartzite that is identical in appearance to the abundant debitage from a biface that was being reduced in the area of the major concentration of debitage in the northern part of the block (Feature B-7), and probably refits with other pieces shown in Figure 9.12. Hundreds of chips and flakes of the same material are found there. It may thus belong to the same biface from which tool blank B-181 was derived.

The utility of quartzite biface thinning flakes as butchery tools is explained in detail by Frison and Todd (1986:129) and Frison (1989). Their experiments with elephant butchery showed that quartzite held its sharp edge much longer than chert, and that the quartzite flake knives were extremely efficient not only for skinning but also for disarticulation of the bones. This tool differs from the large cortical flake knife (B-603), which is naturally backed and has been resharpened. This piece is probably too thin to have been resharpened, and it required backing to dull the edge opposite the cutting edge.

Artifact B-181 (conjoin with B-309) is a large, overpassed biface thinning flake with retouch that approaches backing (Figure 9.16-b). Along with pieces that refit to it, this flake shows that the biface preform/core from which it was detached was approximately $15 \mathrm{~cm}$ wide (see discussion above). It was found in the debitage pile (Feature B-7) in the northern part of Camp B. After detachment, or possibly sympathetic to detachment, the robust overpassed distal end of the flake was snapped off, and the flake 
was partially backed, presumably for use as a knife. In the same part of the site, the overpassed distal margin of a large flake was removed by burin-like blows; three of these spalls have been refit. These add support to the observations by Bradley and Frison $(1980,1982)$ that these large overpassed flakes were produced and/or selected as tool blanks.

\section{Gravers and Other Tool Classes}

Artifact B-407 is a translucent chalcedony blade with a very small graver on its distal extremity, and almost continuous bilateral use wear (Figure 9.21-a). Translucent chalcedony biface thinning flakes are represented in both Camp B and Camp F assemblages. But this is the only chalcedony blade from Aubrey, and so is different from the chalcedony of the core tablet from Camp B. This blank is parallel sided, and has strong distal curvature approaching an overpassed termination. This blade is ascribed to blade reduction strategy No. 2 (see technological discussions above). This blade is quite unlike the large blades from which Clovis end scrapers are made, but appears identical to the blades recovered from the Paleoindian blade cache in Oklahoma (Hammatt 1970). The cache illustrates an apparently distinct mode of Clovis blade production, probably evidenced in the Davis-Young cache from north Texas as well (Young and Collins 1989; Collins 1999).

Artifact B-173 is an abrader/polisher (Figure 9.17). This tool has extensive polish, striations and narrow grooves on the distal snap surface. The originally flat snap has been heavily rounded by use, all of which involved movement in the dorsal-ventral direction. It has minor bilateral distal use wear, and a small burin facet on one corner that appears to be accidental. There is slight bilateral rounding of the proximal edges, suggesting either hafting or grinding to dull the sharp edges for hand use. This hard, Tecovas chalquartzite blank has cryptocrystalline texture, save for the few quartz grains floating in the chalcedony matrix. Blade-shaped parallel dorsal scars and multiple deep hinge scars that probably required the stronger force to detach them and clean up the core working face, creating this large, thick blank.
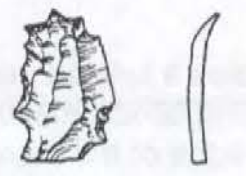

a
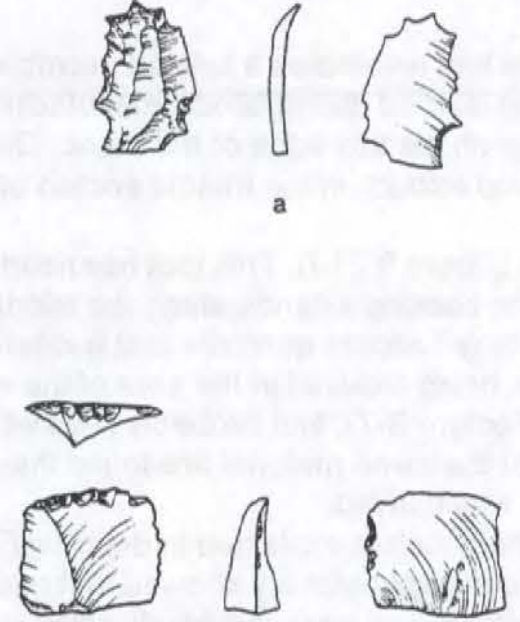

c

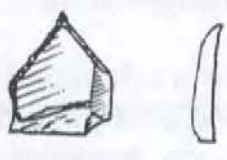

b
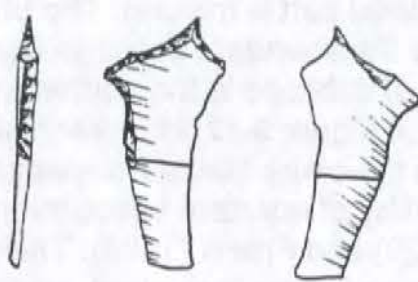

d $2 \mathrm{~cm}$

Figure 9.22 Lithic tools from Camps $B$ and F. a- multiple graver on small buff Edwards chert blade fragment (B-604); b- graver on white Edwards chert flake/blade (F-604); c- micro-end scraper (or raclette) on buff Edwards chert flake ( $F-606)$; $d$ - multiple graver on very thin Tecovas chalquartzite flake (F-175). Note scale of drawings. 
The abrader was found next to the debitage pile in the northern part of Camp B. Its heavy use suggests that it was engaged not only for abrading and polishing the edges of finished points but probably for platform preparation during reduction as well. This tool differs from Early Fluted Tradition grooved abraders, such as from Debert (MacDonald 1985:197) or the Hanson Folsom Site, where grooved abraders were made of sandstone (Frison and Bradley 1980:102). This tool matches precisely the characteristics of archaeological and replicated abraders described by Titmus and Woods (1991). They indicate that abraders are made of hard cryptocrystalline stone such as quartzite that attain grooving and polish with use.

Artifact B-430 is a chalquartzite flake with heavy unilateral use wear, including rounding and stepped dorsal scars (Figure 9.14-b). Slight bifacial crushing on the thinner distal edge suggests use as a wedge. This is one of the retouched tools found in the southern part of Block B, associated with the hearths, debitage pile and common burned faunal remains there. It refits with the end scraper and unmodified flake mentioned above.

Artifact B-604 is a multiple graver, made on a mottled Edwards chert flake or bladelet (Figure 9.22a). This tool has been made by retouching the blank margin to form seven short graver spurs. Three are on the distal end and there are two on either edge. All of the spurs are formed by obverse retouch except the one at the left proximal position, which has been made with inverse retouch. The piece is snapped proximally.

Artifact C-1 is a retouched naturally backed flake (Figure 9.23). This piece has resharpening retouch on the proximal left edge, from the break to the point where the edge of the blank changes to a more acute angle. From there to the distal extremity, the piece has finer continuous retouch. The robust flake blank was removed either from a biface or, more probably from a flake core. Like several of the other large flake tools in the assemblage, this is a cortical flake. These were used extensively for tool blanks at the Clovis type site (Hester 1972) as well as in northern Plains Clovis-Goshen contexts (Frison 1991; Frison 1989).
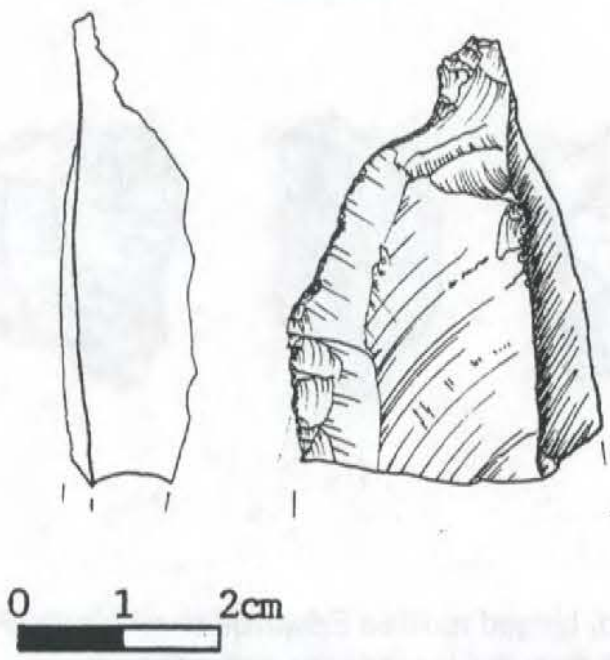

Figure 9.23 Retouched Piece from Area C. Large, naturally backed flake of buff-yellow Tecovas chert (C-1) from Area $\mathrm{C}$ (the northern extension of Area B, on the opposite side of the artificial outlet channel). 


\section{Camp F Tools}

Artifact F-600 is a biface fragment made of translucent chalcedony (Figure 9.24-e). This biface fragment appears to be from a completed point that was being repaired near the large cluster of biface thinning debris in the center of the excavated area. It is the only chalcedony biface recovered at Aubrey, although biface thinning flakes and chips of the same material were recovered in Camp F, and a blade tool of similar material was recovered from Camp B (Artifact B-407; Figure 9.21-a). The profile of the piece is somewhat asymmetric because a manufacturing flake on one side had created a deep concavity. The opposite side has several flake scars and a normal convex profile. This irregular shape apparently contributed to the pervasive fracture that removed the point tip when it was being resharpened, or perhaps, when it was being used.

Artifact $F-601$ is a very small broken tip of a biface; it is $3.4 \mathrm{~mm}$ long and $4.9 \mathrm{~mm}$ wide. This fragment is too small to conclude much about its technological-typological character. It is made on an unidentified gray chert, possibly Edwards. It appears to have been burned, and the fracture seems to be a snap. Its location near the concentration of biface thinning debris suggests that it may have been repaired/resharpened or used there.

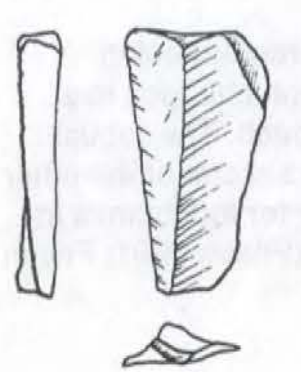

a

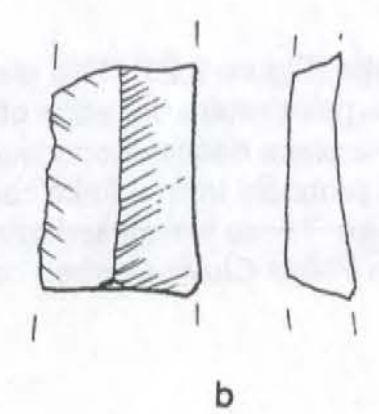

b 
Artifact F-602 is the broken edge of an end scraper made on Edwards chert (Figure 9.24-d). This fragment appears to have been snapped off an end scraper during vigorous use. The fragment is too small to determine the blank form, and the transverse scar pattern could be associated with either a flake or blade.

Artifact F-175 (conjoins with F-603) is a multiple graver made on a Tecovas quartzite blank (Figure 9.22-d). This piece is a typical multiple graver, although other graver spurs could have been present on the broken specimen. The two spurs present were made with steep, almost vertical retouch of this very thin blank. Gravers are found at almost all Clovis sites. At Aubrey gravers were recovered at Camp B and at Camp F.

Artifact F-604 is a graver made on white Edwards chert (Figure 9.22-b). This piece has a small distally located spur. A slight retouched projection at the left proximal snap fracture suggests that this may have been a multiple graver.

Artifact F-605 is a retouched piece (Figure 9.24-c). This piece has continuous and very uniform semi-steep retouch along the preserved edge. The thickness and evenness of the retouch suggests that this may be a fragment of a scraper or perhaps a backed knife. This raw material is similar to Ouachita Mountains chert such as Woodford, but the red fluorescence is unique to the sample from Aubrey.

Artifact F-606 is a small tool with continuous semi-steep to invasive, scraper-type retouch across the distal edge (Figure 9.22-c); these pieces could also be called atypical raclettes, or, "micro endscrapers". Despite its small size ( $8.1 \mathrm{~mm}$ long, $9.7 \mathrm{~mm}$ wide), this is an intentionally retouched piece. It is about the same size as a distally retouched bladelet (Artifact F-148) that has been refit to other bladelets. The function of these small tools is not known, although some kind of composite tool for insertion into a bone or wood shaft is possible, as is the possibility that they have non-utilitarian functions.

Artifact F-148 is a small flake-bladelet with continuous scraper type retouch across the distal end. This piece has been refit to three of seven other small flakes and bladelets from a microcore that was reduced in this part of the site. Removal or loss of other small flakes and bladelets from the core is indicated.

Artifact F-114 is a medial blade fragment of Edwards chert (Figure 9.24-b). The fragment has a triangular cross section formed by two unidirectional scars. This piece appears to have been detached from a polyhedral core, but it is too fragmentary to determine this. Its size and the absence of lateral retouch suggest it could have been used as an unretouched cutting implement, like others from areas $B$ and $A$, or perhaps it is a portion of another tool such as an end scraper.

Tools from Area A : Red Wedge Surface

Artifact A-700 is a retouched/utilized blade (Figure 9.25-d). This is one of the three blades recovered in situ from the lower red wedge surface just west of the pond axis (Figure 9.25-a,b). This piece was detached from a biface, as indicated by the platform preparation and dorsal scar pattern. Its lateral profiles, cross section and distal morphology preclude removal from a well prepared blade core. Selection of large blade-like debris produced during biface thinning is a documented part of Clovis technology on the High Plains (Bradley 1982, 1993), and probably in other regions as well. The blade has continuous retouch of the proximal right edge and irregular retouch of the distal right edge. Both long edges show use wear in the form of continuous nibbled edges.

This piece, and the other two, are located in the apparent center of bison bones on the red wedge (Figure 9.7). It is considered to be a cutting implement, similar to those associated with bison at the Upper Paleolithic site of Amvrosievka in Ukraine (Krotova and Belan 1993). This seems to be the first example of 


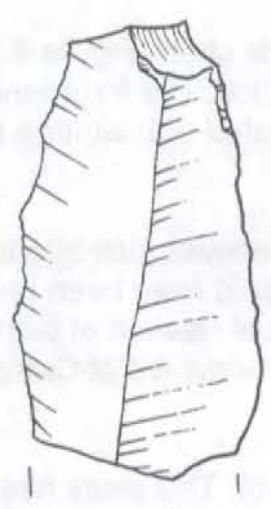

a
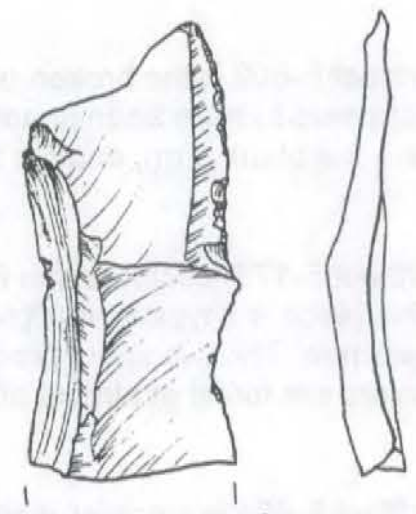

b
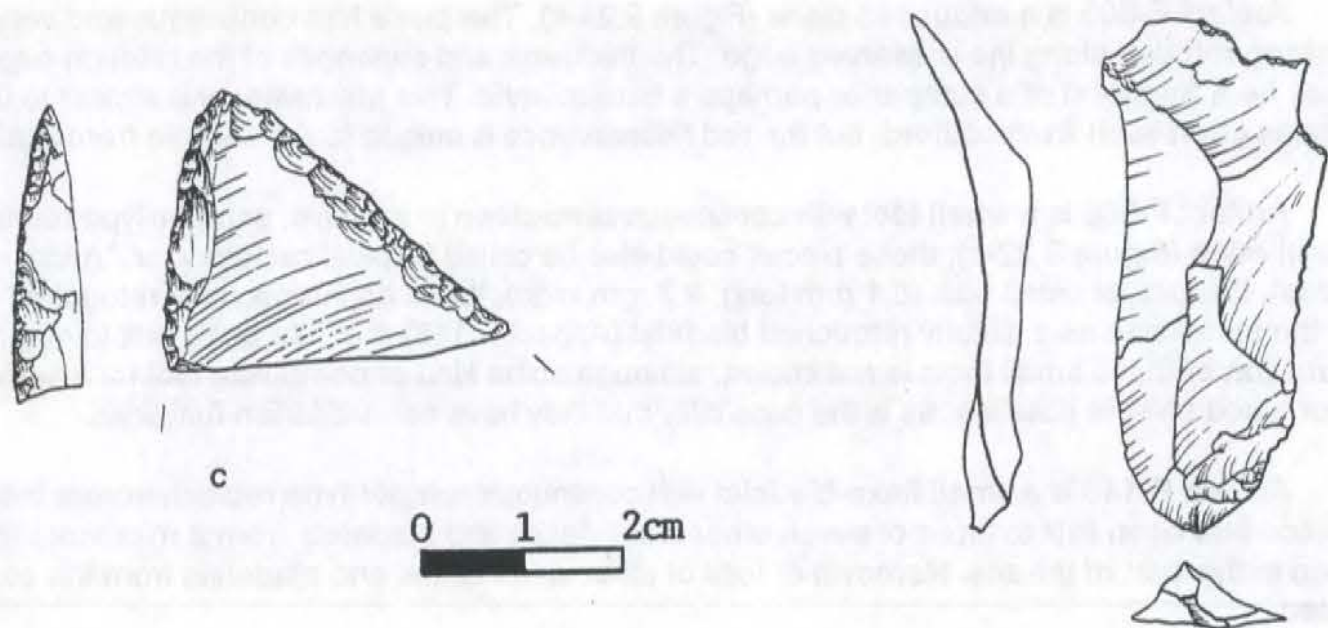

d

Figure 9.25 Tools from upper red wedge (Stratum D), Area A. a- blade on Tecovas orthoquartzite (A330 ; note- retouch is recent damage); b- retouched/utilized blade on unidentified chert (A-701); cdouble converging side scraper on Tecovas orthoquartzite (A-702); d-retouched/utilized blade of unidentified chert (A-700). Note each of these blades was probably removed from a biface rather than a blade core. These four tools were recovered from the midslope of the "red wedge" surface; upslope from the "well" feature, and amongst numerous disarticulated bones of at least one calf and one cow Bison antiquus, and other taxa.

blades being associated with large game butchery, although flake knives are associated with mammoth butchery (Frison and Todd 1986). The source of this raw material is not clearly Edwards, since it does not exhibit short wave fluorescence. This could be an Edwards variant, or from the Ouachitas.

Artifact A-701 is a retouched and probably utilized blade (Figure 9.25-b). This blade was also found in situ on the downslope part of the red wedge surface, about $2.5 \mathrm{~m}$ west of the well. It has regular fine retouch along the distal right edge and use nicks on the left edge. The very dark gray color and the lack of 


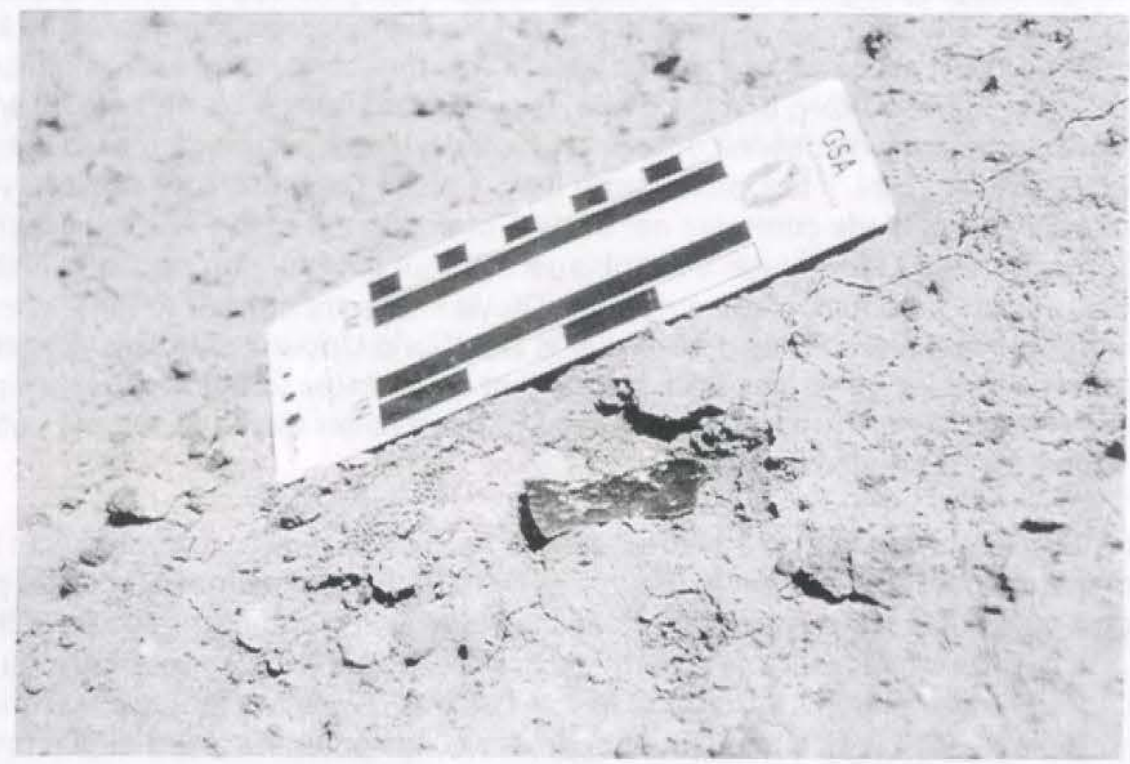

a

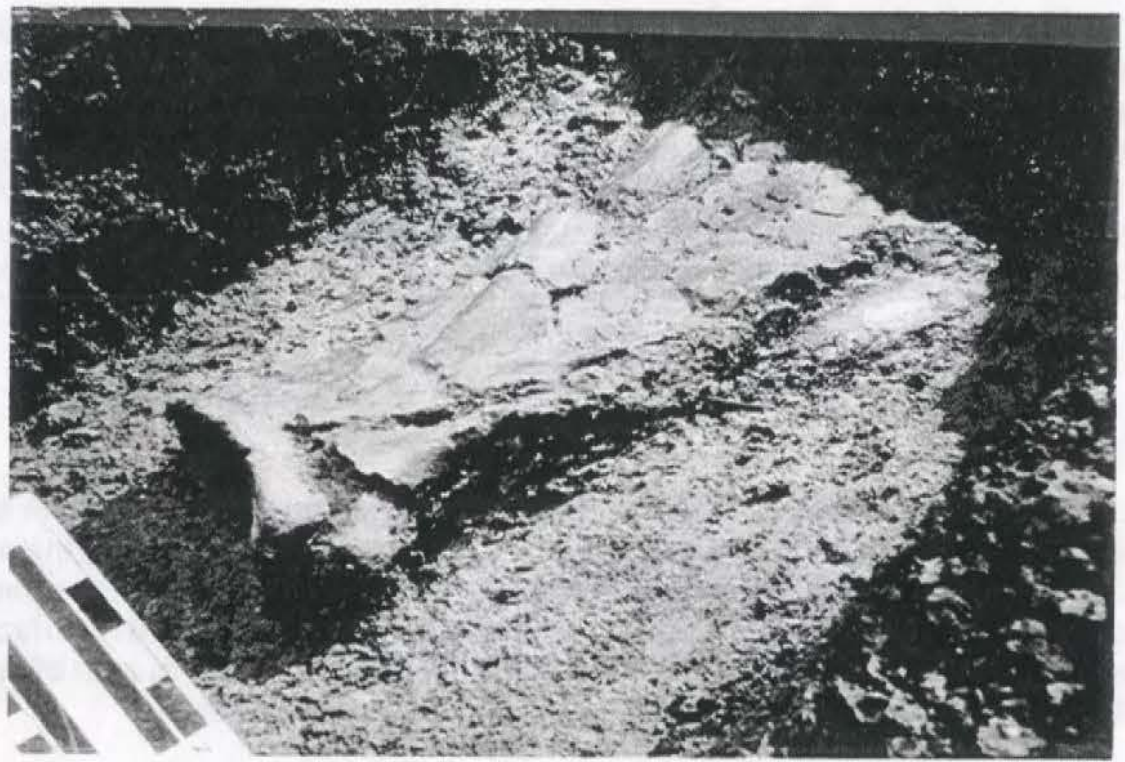

b

Figure 9.26 Photographs of bison scapula and utilzed blade. Both in situ on red wedge surface at west margin of pond (see Figures 2.16, 3.16 for location). Scapula located on lower slope, nearly at distal edge of red wedge colluvial fan; note extreme fragmentation due to compaction by ca. $8 \mathrm{~m}$ of Holocene alluvium. Blade (Figure 9.21b) found upslope from the well (Figure 9.6). Two other blades and convergent side scraper found within $2 \mathrm{~m}$, on same paleosurface, along with numerous bones of bison and turtle. 
fluorescence indicate it is probably not from the Edwards area, but perhaps from the Ouachitas of Oklahoma or Arkansas. The blade blank has deep hinge scars that are perpendicular to the long axis, from the left. Its scar pattern and ventral profile suggest it was detached from a large biface during reduction. It is possible, but less likely, that the blade was removed from a blade core, in which case the transverse scars would be the terminations of core preparation blows perpendicular to the axis of blade removal on the core working face. If this piece came from a blade core, the core must have had opposed platforms. Opposed platform blade cores are not evident from the rest of the Aubrey assemblage nor are they indicated from published Clovis blade assemblages. Rather than use an opposite platform to remove errors such as hinge scars from their blade cores, the Clovis knappers appear to have used intentional overpassing, a common technique for error recovery in Old World Upper Paleolithic contexts (Ferring 1980, 1988). Intentional overpassing generates thick blades that are suitable tool blanks, and it maintains parallel aretes on the core working face. This approach may have been better suited to people curating blade cores some distance from their raw material sources.

Artifact A-330 (Figure 9.25-a) is a blade made of Tecovas orthoquartzite that was found in situ in the upper part of the Red Wedge sediments (Figure 9.26-a). Both the proximal and distal portions of this blade are snapped off, yet the piece is still very close in overall size to the other two from the Red Wedge. This blank has a very simple opposed scar pattern; its scar pattern, thickness and curvature suggest it came from a biface. The raw material is identical to the Tecovas quartzites that are common in Camps B and $F$. Indeed, this piece has the size and curvature to easily refit on to the large biface that was reduced in Camp B; this could not be accomplished unfortunately. The surfaces of the piece are stained reddish yellow as a result of its position in the weathered iron-rich sands of the Red Wedge (Stratum D). The interior color is grayish white.

Artifact A-702 is a broken converging side scraper (Figure $9.25-\mathrm{c}$ ). Although this piece is from the surface, it was found after a heavy rain just below the red wedge surface, about $2 \mathrm{~m}$ west of the nearest chert blade found there. Even broken as it is, this piece should be classified as a double convergent side scraper, a tool type that is common to Clovis assemblages. The differences in working edge angles are in part due to the blank morphology, with the steeper angle associated with the thicker left side of the piece. The quartzite raw material is finer grained than that of the quartzite blade found closer to the pond, but it is still within the range of Tecovas quartzites found in Areas B and F. This is the only side scraper found thus far at Aubrey.

\section{Tool from Area G}

Artifact G-1 is a large limestone chopper (Figure 9.27). This artifact was found in situ, eroding from sediments at the eastern edge of the Clovis paleochannel, opposite (ca. $100 \mathrm{~m}$ east) the artifact cluster in Area $F$ (Figure 3.1). All but one of the other artifacts from area $G$ were found on the surface, below the location of the chopper. One quartzite flake was found eroded from the Clovis paleosurface at the eastern end of the former meander loop in the Clovis age channel, approximately $400 \mathrm{~m}$ east of the artifact cluster in Area G, and thus about $750 \mathrm{~m}$ from the artifacts on the Red Wedge in Area A.

The chopper is made of a dense, sparsely fossilferous limestone (mudstone to wackestone). The limestone could have been derived from any of a number of local Cretaceous rock units. Its source could possibly be defined based on micropaleontology, but this has not been done as it would entail thin sectioning part of the artifact. The chopper has bifacial flaking and battering damage concentrated on one end, and has been battered on the other. Choppers have been found at the Clovis Site (Hester 1972), and the Colby Site (Frison and Todd 1986). 

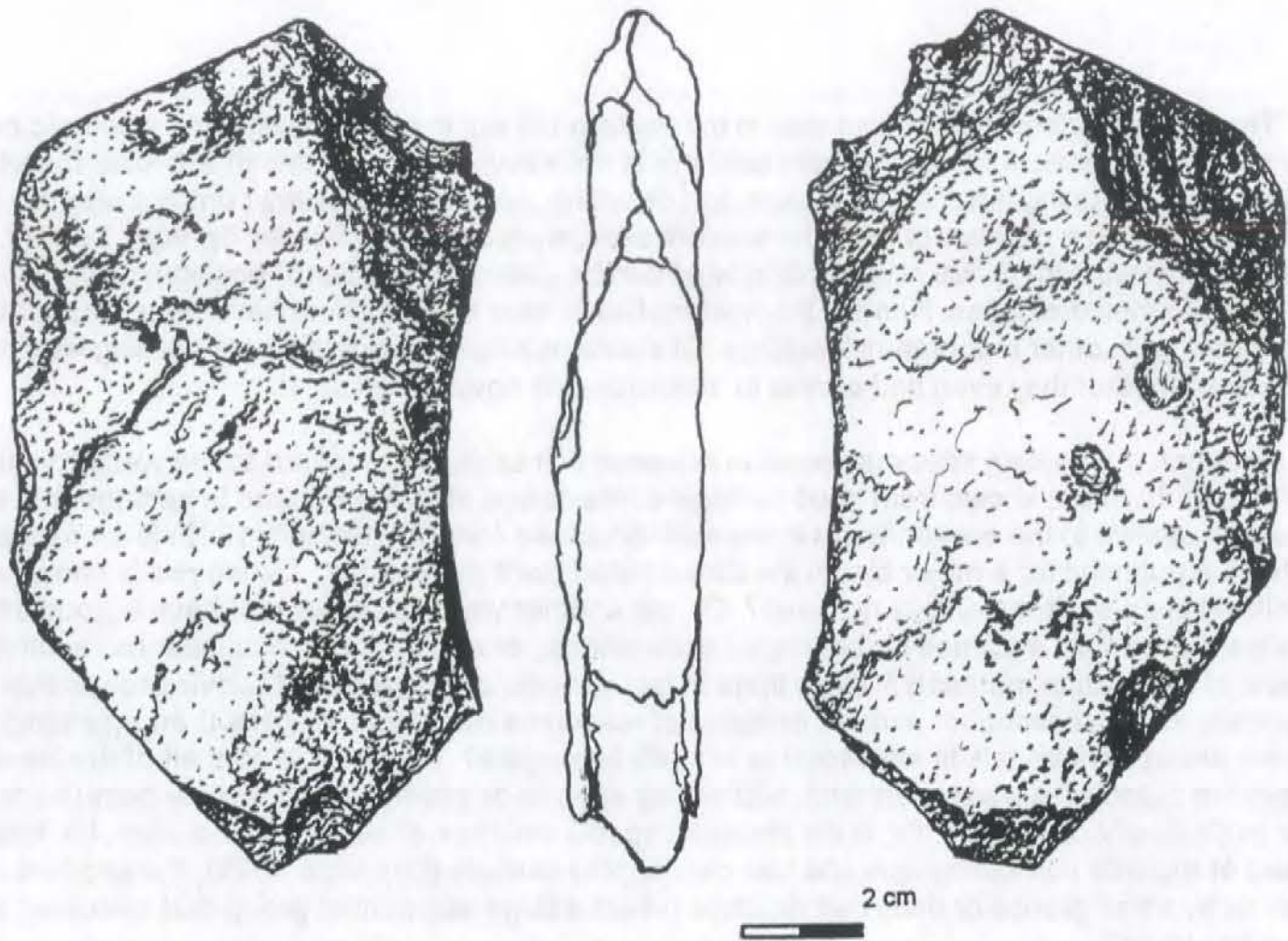

Figure 9.27 Limestone chopper from Area G. This artifact was found in situ at the Clovis paleosurface on the east bank of the Clovis age river channel, opposite Camp F (see Figures 2.6, 3.1). This is the only artifact made of local raw materials in the Aubrey assemblage.

\section{Structure of the Aubrey Site}

Having described the contents of the Aubrey site, including artifacts, features and faunas, the discussion now turns to the structure of the site. By structure is meant the horizontal and vertical patterns of association of the archaeological remains. The structure, or associational patterning, is addressed at three scales. First, patterning is examined within the "occupation clusters", which are the major concentrations of artifacts and faunas, and which were the focus of block excavations. Occupation units are spatial units that would have accommodated multiple aggregates of people occupying a locale at the same time. The area of an occupation cluster is 10 s to 100 s of square meters in area (Ferring, 1984). Clusters of artifacts and /or faunas within an occupation cluster are assumed to reflect activities by one or more persons and are called activity clusters. These have areas of up to a few square meters. By this approach, activity clusters together comprise occupation clusters.

The third scale of structural analysis then is the inter-site scale. For this, a sample of eastern fluted point sites has been assembled (Appendix E). Comparison with Clovis sites per se is hindered by the paucity of known or published sites with "camps" as opposed to kill-butchery sites. The eastern fluted site data base is large, but uneven in quality, and uneven in regards to full reporting of all materials from a given site. Only a few of the 50 -odd clusters at Bull Brook have been reported for example (Gross, 1974). Another limitation of the database is the absence of a consistent classification of lithic artifacts. But what data there are there are. 
The larger sample of published sites in the eastern US are in part related to the geologic contexts of those sites. All of those summarized here (and this is not a complete accounting) are sites found on stable landforms including terraces, interfluves and drumlins. As such these sites contrast with the buried context of Aubrey and a number of the other western sites, such as Clovis, Murray Springs, Lehner. But all of the well-known western Clovis sites occur in what can be called "headwaters" positions, near springs, or at the heads of small drainages. None of the western Clovis sites that I know of have been found along major streams, or in other resource-rich settings. Of course a long-term question concerning western Clovis adaptations is whether they even had access to resource-rich environments.

Although the eastern sites may occur in resource rich settings compared to the western sites, almost none of them are known from good geologic contexts and at the same time in settings that are resource-rich relative to the environments in the east. Shawnee Minisink (McNett, 1982) is an exception.) So, we have a potential for a major bias in the Clovis-fluted point site sample. Do we really know what Clovis folk did in an environmentally rich area? Or, put another way, why do we not have a good sample of "large" sites that contain evidence for prolonged occupations, or at least serial occupations resulting in a palimpsest of occupation materials? Were there in fact periodic aggregations of Clovis groups that reflect the necessary static, seasonal or periodic densities of resources necessary to support an aggregation? Were there enough Clovis folk in any region to actually aggregate? It is possible that all of the known Clovis-eastern fluted sites were short-term, and activity specific or activity limited, simply because the larger sites are geologically obscured? Or, is the recurrent spatial structure of eastern fluted sites, i.e. large sites composed of multiple non-contiguous and non-overlapping clusters (Dincauze 1993), the product of serial occupations by small groups or does that structure reflect a large segmented group that occupied the site once or a few times?

The question of Clovis adaptive demography is therefore one of site structure first, then assessment of structure from a perspective of environmental (resource) constraints. This approach requires the assumption that analysis of site structure yields information on the periodicity and intensity of occupations and on the composition(s) of Clovis settlement groups. So, on to the structure of Aubrey, and then to Clovis environments, especially the character of resource availability.

To reiterate, excavations at Aubrey were conducted in five areas. $B$ and $F$ were blocks next to the Clovis pond and the Clovis River, respectively. These areas are considered "camps". A small block, of testing size was excavated in Area A "Red Wedge", but important artifacts and faunas were also found there. Area A "pond" was a block in the pond sediments, so spatial patterning there is not considered. Area $C$ is the extension of Area B across the outlet channel, and is not considered spatially. And only surface materials were recovered from Area G.

So while aspatial comparisons of these areas may be made, serious intra-cluster analyses are really only feasible for Areas $B$ and $F$. These occupation clusters are about $100 \mathrm{~m}$ apart. And they are therefore very discrete clusters. While over 9,800 artifacts were recovered from the clusters, only about 15 artifacts were found eroding from the sediments in between. Density patterning within the occupation clusters is equally pronounced. In Camp B, half of the artifacts were concentrated in just $3 \%$ of the excavation area (Table 9.12). At Camp F, half the artifacts were in $9.9 \%$ of the excavation area, which is still a high degree of clustering. So at Aubrey, everything is clustered. And the clusters are nested spatially, with artifact "piles" containing most of the artifacts in each occupation cluster. The piles are one form of "activity cluster" mentioned above. Density patterning will be considered first, but then it will become clear that there is a similarly high degree of compositional clustering as well.

Before moving to the spatial data, the question of formation processes needs to be dealt with. Specifically, the question is "are the distinct clusters at Aubrey the result of human activity, or are they an artifact of natural formation processes?" 
Table 9.12 Artifact and Bone Densities in Camps B and F

\begin{tabular}{|c|c|c|}
\hline \multirow[b]{2}{*}{ Excavation area $\mathrm{m}^{2}$} & Camp B & Camp F \\
\hline & 105.25 & 61.75 \\
\hline TOTAL DEBITAGE & 6035 & 3689 \\
\hline Average density $\# \mathrm{~m}^{2}$ & 57.3 & 59.7 \\
\hline Highest density & 1726 & 1039 \\
\hline \multicolumn{3}{|c|}{ Area of debitage sum quartiles 1} \\
\hline $25 \%$ & 0.87 & 1.4 \\
\hline $50 \%$ & 3.23 & 6.1 \\
\hline $75 \%$ & 13.9 & 20.2 \\
\hline TOTAL BONE & 2650 & 326 \\
\hline Average density & 28.04 & 6.27 \\
\hline Highest density & 58 & 8 \\
\hline
\end{tabular}

Differential density and compositional patterning can result from single or multiple occupations. Defining which history created a site is a question of dating the clusters. They are either contemporaneous or they are serial. Dating artifacts on one surface, buried or not, is basically impossible for Clovis sites, including Aubrey. But we can ask if Aubrey is stratified, or were there superposed clusters there? The vertical distributions of artifacts show this to be very unlikely.

In both Camps B and F, two 1-meter square units were excavated well above and below the apparent occupation surface (Figure 9.28). Unit 1624 in Camp F was excavated in $5 \mathrm{~cm}$ levels, and all the others in $10 \mathrm{~cm}$ levels. As for the test and main excavations, all matrix was fine screened. In both blocks, the vertical distributions of artifacts are normal or highly kurtotic, and are negatively (upward) skewed. These patterns match the expected distribution for a single occupation surface with an initial deposit of artifacts that has been subjected to post-occupational and post-burial bioturbation and/or pedoturbation (Ferring and Peter, 1987). The upward skewing is attributed to the prevalent mode of bioturbation at the site, which was by crayfish. Crayfish burrowing, unlike that of fossorial rodents, entails a net upward biotransport of sediment. The downward movement of artifacts is probably the combined result of fossorial rodent turbation, and pedoturbation.

These patterns hold for sections through the camps as well (Figure 9.29). In no areas of the site is there evidence for superposed clusters, and there is no artifactual evidence in the in situ deposits at Aubrey for any Paleoindian occupations save Clovis. So the probability of occupational stratification here appears to be as low as one could define, and the occupation clusters as well as the activity clusters cannot be placed into relative chronological position physically. Therefore, the issue of occupational periodicity within and between clusters must be resolved using spatial-functional analyses (Ferring, 1984).

The contents of the materials in Camps $B$ and $F$ are different, as shown in the descriptive sections of this chapter. The cluster assemblages differ in tool class frequencies, raw material frequencies, functional ratios, such as biface/uniface debris, faunal densities, faunal compositions and frequency of faunal burning. At the assemblage level then, and essentially a priori, the remains in Camps $B$ and $F$ 


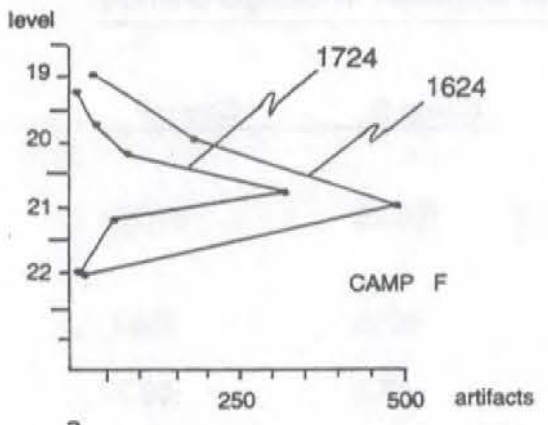

a

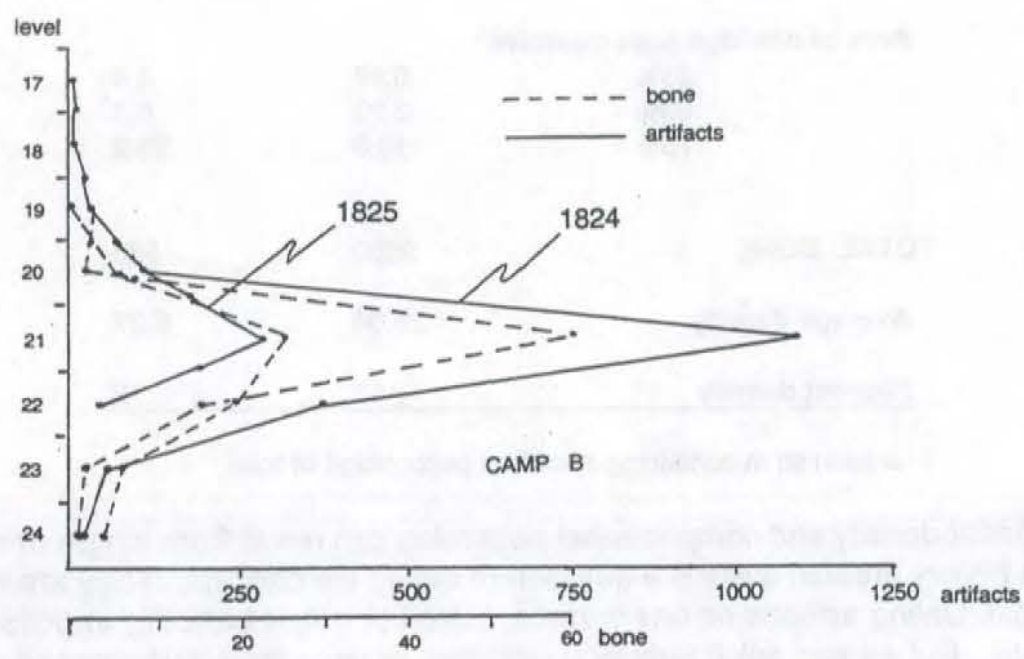

b

Figure 9.28 Vertical patterning of artifacts and bone in Camps B and F. Note parallel bone-lithic distributions, with very pronounced peaks at presumed occupation surface (see following figures). Vertical displacement of artifacts and bones is attributed to pedoturbation and some bioturbation, such as by crayfish (see discussion in text). No horizontal displacement of clustering is evident. This supports all other data and observations that there is only one Clovis occupation surface at Aubrey, and that surface is not overlain by any occupation debris, save the Late Archaic materials near the flood plain surface.

appear to register somewhat different sets of activities. Not clear immediately, however, are the nature of those differences. Are they different frequencies of the same activities, or are some of the activities exclusive to one camp or the other? Is this characteristic of eastern fluted sites as well?

There is quite good evidence that the eastern fluted sites share the pattern of "nested clusters" (Table 9.13; Appendix D.) The eastern sites very clearly are constructed of occupational clusters. They have varying artifact and feature content, but faunal preservation is almost always too poor to permit comparisons. A number of these sites, such as Bull Brook, Debert, Vail, or Thunderbird also have distinct activity clusters nested within the occupational clusters. The simple fact that this "fine grain" of spatial patterning is preserved argues for single occupations as opposed to multiple ones, and brief occupations as opposed to prolonged ones (Ferring 1984; Leonova 1993). 

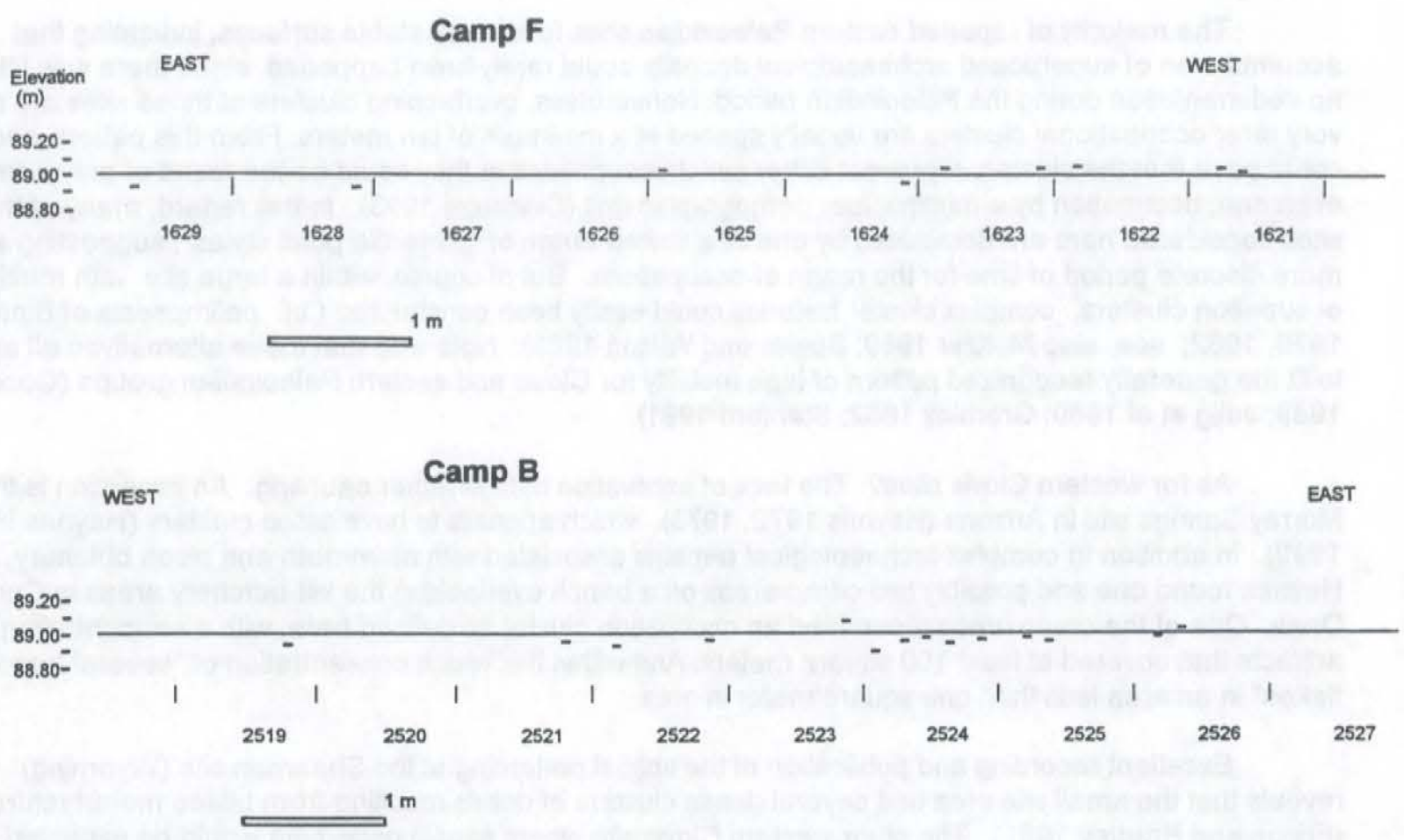

Figure 9.29 Plotted tool elevations in Camps B and F. Note occupation surfaces sloping gently to west towards pond from Camp B, and to east towards Clovis paleochannel from Camp F.

Table 9.13 Cluster Characteristics of Aubrey and Eastem Paleoindian Sites

\begin{tabular}{|c|c|c|c|c|c|}
\hline & \multirow{2}{*}{$\begin{array}{l}\text { Number } \\
\text { of Clusters }\end{array}$} & \multicolumn{4}{|c|}{ Mean Densities (\#/ sq $\mathrm{m}$ ) } \\
\hline & & Debitage & Tools & Cores & Total \\
\hline Aubrey* & 2 & 11.5 & 0.2 & 0.01 & 11.7 \\
\hline Michaud & 8 & 0.1 & 12.5 & 0.04 & 12.7 \\
\hline Shawnee-Minisink & 1 & 37.2 & 1.3 & 0.17 & 38.7 \\
\hline Bull Brook II & 6 & 21.2 & 3.2 & 0.14 & 24.6 \\
\hline Adkins & 1 & 3.1 & 0.4 & 0.03 & 3.5 \\
\hline Thunderbird** & 2 & 958.9 & 12.1 & 4.38 & 975.3 \\
\hline Fisher & 8 & 31.5 & 0.9 & 0.17 & 32.5 \\
\hline Potts & 2 & 4.3 & 0.7 & 0.01 & 5.1 \\
\hline Vail & 9 & 14.9 & 6.9 & 0.07 & 21.8 \\
\hline Debert & 11 & 29.7 & 4.7 & 0.19 & 34.6 \\
\hline
\end{tabular}

" Less Chips "* Features only 
The majority of reported eastern Paleoindian sites formed on stable surfaces, indicating that accumulation of superposed archaeological deposits could rarely have happened, since there was little or no sedimentation during the Paleoindian period. Nonetheless, overlapping clusters at those sites are still very rare; occupational clusters are usually spaced at a minimum of ten meters. From this pattern one could pose that the clusters represent either serial occupations or they could be the result of only a few, even one, occupation by a multinuclear demographic unit (Dincauze 1993). In this regard, many of the sites considered here are dominated by one or a limited range of "projectile point styles", suggesting a more discrete period of time for the range of occupations. But of course, within a large site with multiple occupation clusters, complex cluster histories could easily been constructed ( cf. palimpsests of Binford 1979, 1982; see also Meltzer 1989; Speiss and Wilson 1989). Note also that these alternatives all appear to fit the generally recognized pattern of high mobility for Clovis and eastern Paleoindian groups (Goodyear 1989; Julig et al 1989; Gramley 1982; Stanford 1991).

As for western Clovis sites? The lack of excavation data is rather daunting. An exception is the Murray Springs site in Arizona (Haynes 1972, 1973), which appears to have ested clusters (Haynes et al 1999). In addition to complex archaeological remains associated with mammoth and bison butchery, Haynes found one and possibly two camp areas on a bench overlooking the kill-butchery areas in Currey Draw. One of the camp areas resembled an occupation cluster as defined here, with a concentration of artifacts that covered at least 100 square meters. And within this was a concentration of "several hundred flakes" in an area less than one square meter in area.

Excellent recording and publication of the spatial patterning at the Sheaman site (Wyoming) reveals that the small site area had several dense clusters of debris resulting from biface manufacture (Frison and Bradley 1981). The other western Clovis site where spatial patterning would be expected is the Clovis site itself (Blackwater Draw, Locality No. 1) in New Mexico. Almost all of the Clovis data derived from sporadic excavations that were concentrated in sediments deposited in spring-pond environments, and were dominated by butchery activities (Hester 1972). Higher ground around the depression at this locality would be an obvious place to explore for camp areas; artifacts have been found there, but no camp areas have been excavated. For the western Clovis sites, then, Aubrey appears to be almost singular in its preservation of buried surfaces that contain multiple occupation clusters. The patterning within and between those clusters is the next subject of discussion.

\section{Intra-Cluster Patterning at Aubrey: Camp B}

Spatial differences in the density and location of artifact and faunal remains are exceptional in the Camp B block. Lithic artifacts exhibit several kinds of density-compositional patterning. Most obvious are the two very high density clusters (I called these "artifact piles" for lack of a suitable name, and later found use of the same term by Frison and Bradley for the Sheaman site). Both of the piles at Aubrey have extremely high frequencies ( $\mathrm{ca} .98 \%$ ) of quartzite debitage, but the proportions of debitage types between these two piles are very different (Table 9.14). Biface thinning flake frequencies are high for both piles compared to the rest of the block (Figure 9.30a). But BFTs are more than twice as common in the northern pile (Feature B-7) than the smaller southern pile (Feature B-8) (these frequencies are restricted counts (Table 9.14). URCs have negligible proportions of the pile contents.

The remainder of the spatial patterning is examined using raw materials as a guide to cluster differentiation, followed then by analysis of artifact types. Having the variety of raw materials present at Aubrey greatly expands the possibilities to define separate areas of tool use/manufacture, thereby adding much more "grain" to the locational record.

Point quartzite $(P Q)$ is very concentrated in the W-SW part of the block, associated with the western hearths there (Figure $9.30 \mathrm{~b}$ ). In that cluster is the smaller of the fragments of the Clovis point from Camp B. The small fragment conjoins with the distal portion of the point, which was found in the northernmost part of the block, along with just ten chips of the same material. It seems most likely that 
Table 9.14 Contents of "Debitage Piles" in Camps B and F

\begin{tabular}{lcccc} 
Feature & \multicolumn{1}{c}{$\begin{array}{c}\text { Flakes } \\
\%\end{array}$} & $\begin{array}{c}\text { BFTs } \\
\%\end{array}$ & $\begin{array}{c}\text { URCs } \\
\%\end{array}$ & n \\
\cline { 2 - 5 } B-7 & 21.9 & 68.8 & 9.4 & 96 \\
B-8 & 60.7 & 32.1 & 7.1 & 28 \\
\hline F-1 & 37.6 & 57.6 & 4.7 & 85 \\
F-2 & 24.4 & 35.5 & 40.1 & 45 \\
\cline { 2 - 5 } & & & & \\
B else & 16.9 & 23.1 & 60.1 & 614 \\
F else & 31.6 & 54.2 & 14.1 & 256 \\
\hline
\end{tabular}

these chips were derived from resharpening the point fragment before it was discarded. None could be refit, but the material is very distinctive, and the point was finely resharpened (Figure 9.19).

Transfer of the point after breakage is thus far the only evidence for a single tool having been used in both the northern and southern areas of the block, although spatial patterning of bend-break tools strongly implies integrated or shared tool uses between the two parts of the site. The breakage pattern is consistent with the point having been broken during use as a hafted tool. Assuming this to be the case, then use of that point near Feature 1 must have occurred after the breakage. This is evidence for the temporal relations of these artifact clusters, but there are two main possibilities. One is that the area with a dominance of $P Q$ was occupied before the area around Feature B-7. The other possibility is that these areas were used simultaneously and the tool was simply shared.

Table 9.15 Point Quartzite and White Edwards

Debitage from Camp B

\section{Point Quartzite \\ $\%$}

URCs

0.38

7.2

\section{White \\ Edwards \\ $\%$}

35.84

0.3 


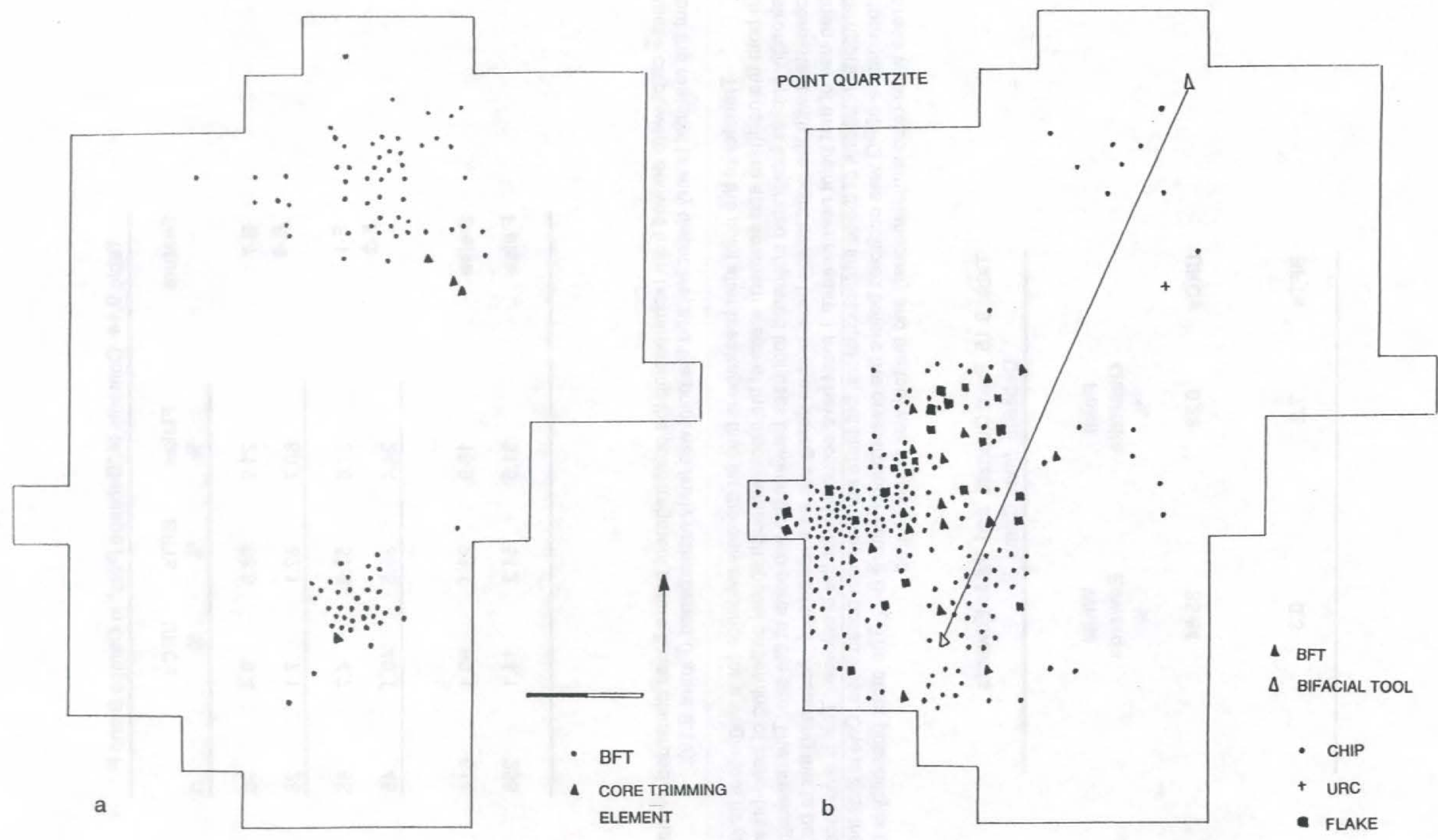

Figure 9.30 Spatial patterning of biface thinning flakes and point quartzite in Camp B. Note highly clustered BFTs. Line connects basal fragment of Clovis point (south) with distal end (see Figure 9.22a). Chips in northern part of block probably detached during resharpening of point. 

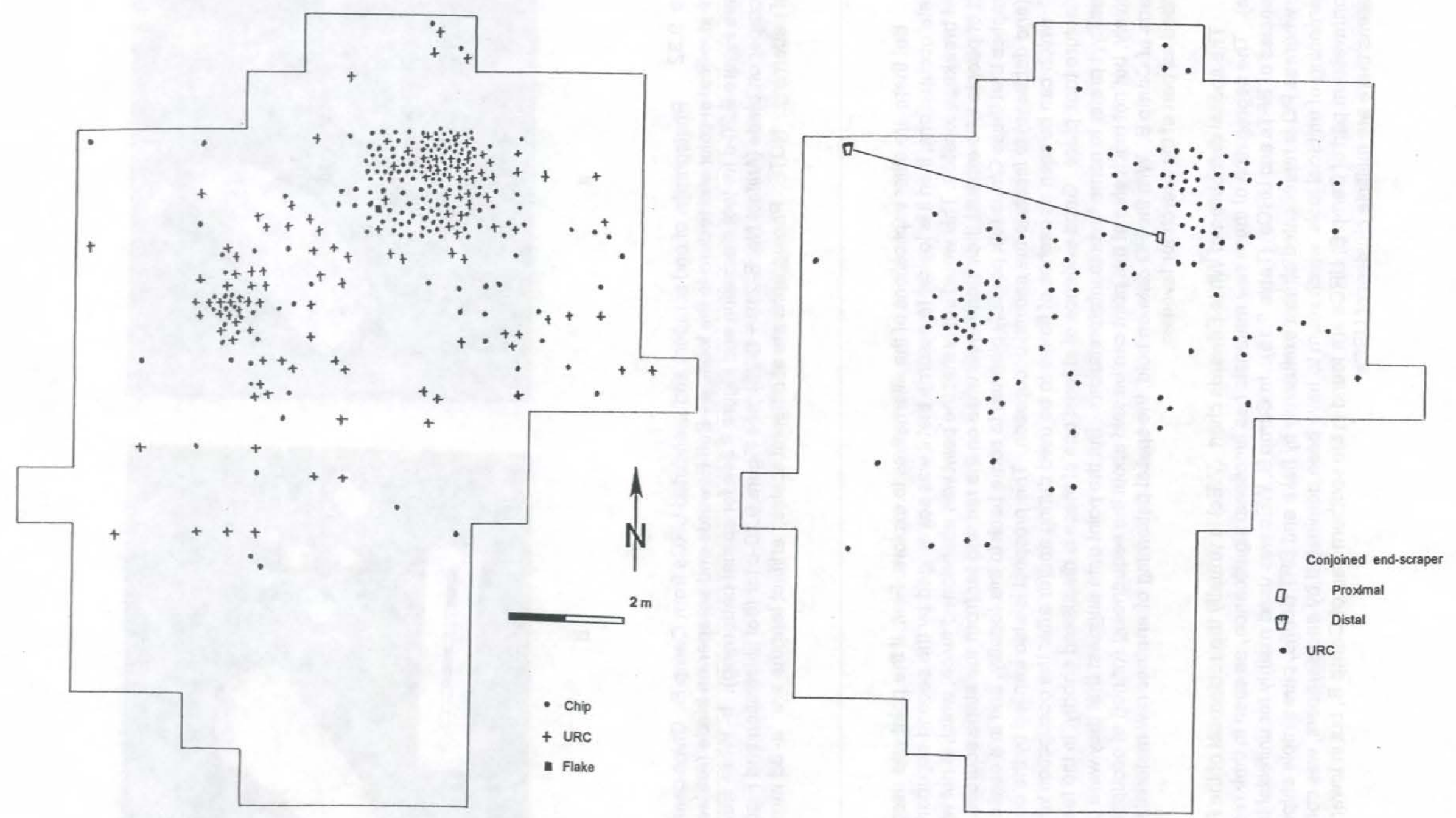

Figure 9.31 Spatial patterning of White Edwards Chert artifacts in Camp B. Note multiple URC clusters and very low densities in south part of block. 


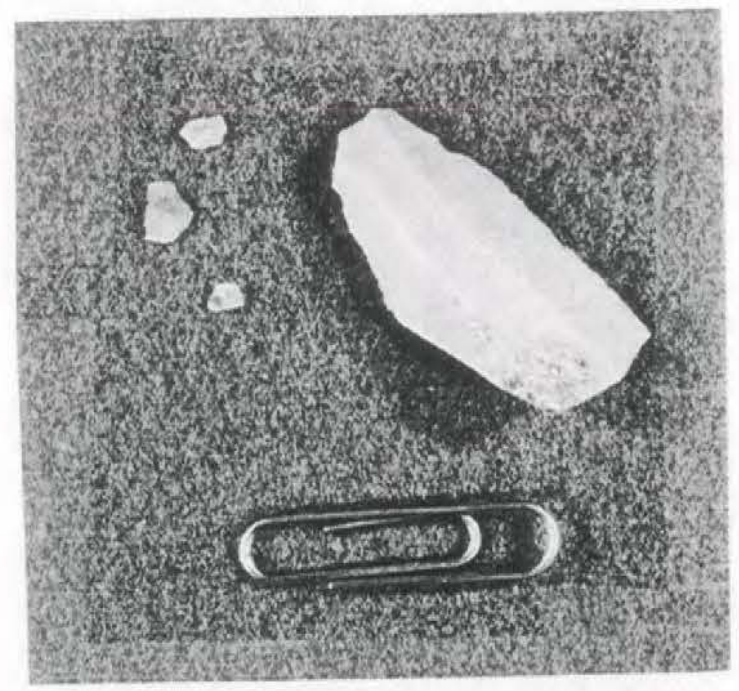

a

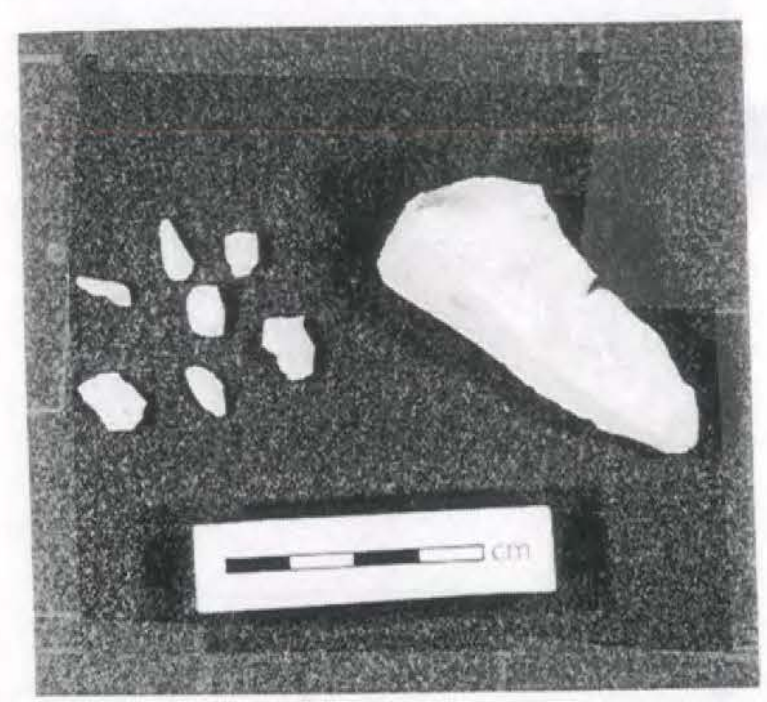

b

Figure 9.32 Photographs of end scrapers and associated URCs from Camp B. Chips cannot be refit, but are identical in color and texture to the tools. a - Buff Edwards end scraper on blade (Artifact No. B174; see Figure 9.20-d for tool illustration and Figure 9.34a for spatial patterning). b- White Edwards chert end scraper on blade (Artifact No. B-219 + B-23) ;see Figure 9.20-c for tool illustration and Figure 9.30 for spatial patterning. NOTE: Photographs are at different scales; artifact lengths are: a- $38 \mathrm{~mm}, \mathrm{~b}-61 \mathrm{~mm}$

But there are other implications of the alternatives to explore. First, if the point was used during two separate occupations, then it is logical to assume that it was scavenged by the second occupants from the original breakage location. This would imply that the point was abandoned twice, which is not what we expect of people who exhaust their stone tools while on the run and far from the stone sources. However, it also implies that these Clovis folk possibly planned to come back to this locality, and in a sense "cached" tools (and debitage) to facilitate the second occupation. This prospect is also implied by the debitage "piles" which can be seen as caches of flakes to be used during and/or after the occupation when manufacture took place. Good evidence of at least one of these is discussed shortly. In the face of equifinality, I prefer to name favorite interpretations. But the point data suggest that they were using stone intensively, but not much else at this point can be said about the sequencing (or not) of occupations in these two parts of Camp B. With the PQ data on hold, the spatial patterning of another raw material will be described as part of the search for favorites.

The spatial distribution of White Edwards chert (WEc) is virtually the reciprocal of the PQ (Figure 9.31-a). The segregation of these raw materials has functional significance, as seen in their respective frequencies of BFTs and URCs (Table 9.15). In Camp B, WEc was used mainly for unifacial tools (Figure 9.31), whereas $P Q$ is represented almost exclusively by flake and BFT debris, plus simple chips.

Resharpening of unifacial tools, which seem to have been dominated by end scrapers, was concentrated in the northwestern part of Camp B; URCs are found in the southern part of Camp B, but in lower densities. In both areas there are multiple clusters of URCs. 


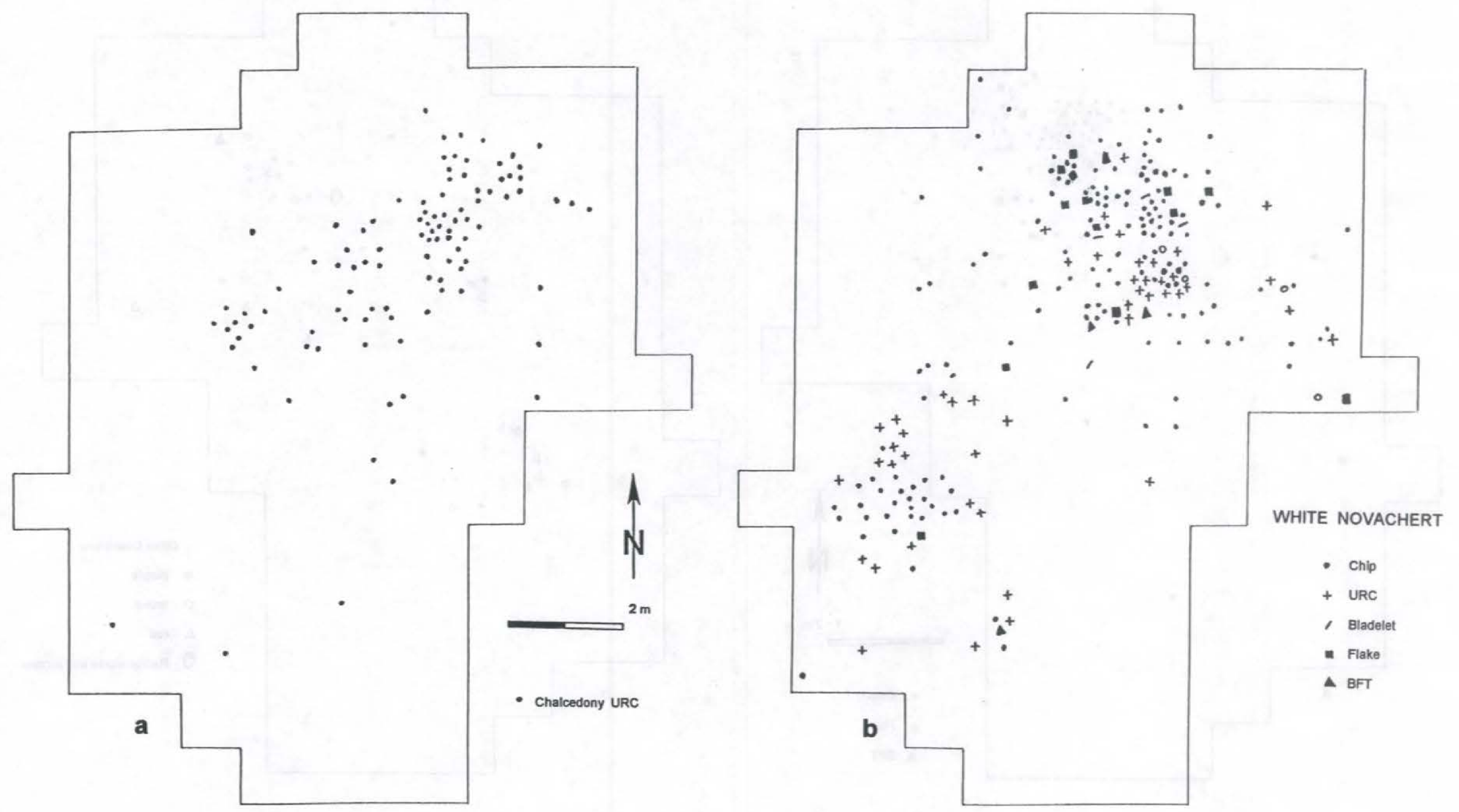

Figure 9.33 Spatial patterning of chalcedony URCs and White Novachert artifacts in Camp B. Note multiple clusters of URCs for both raw materials, and distinct cluster of Novachert in southwest part of block. 


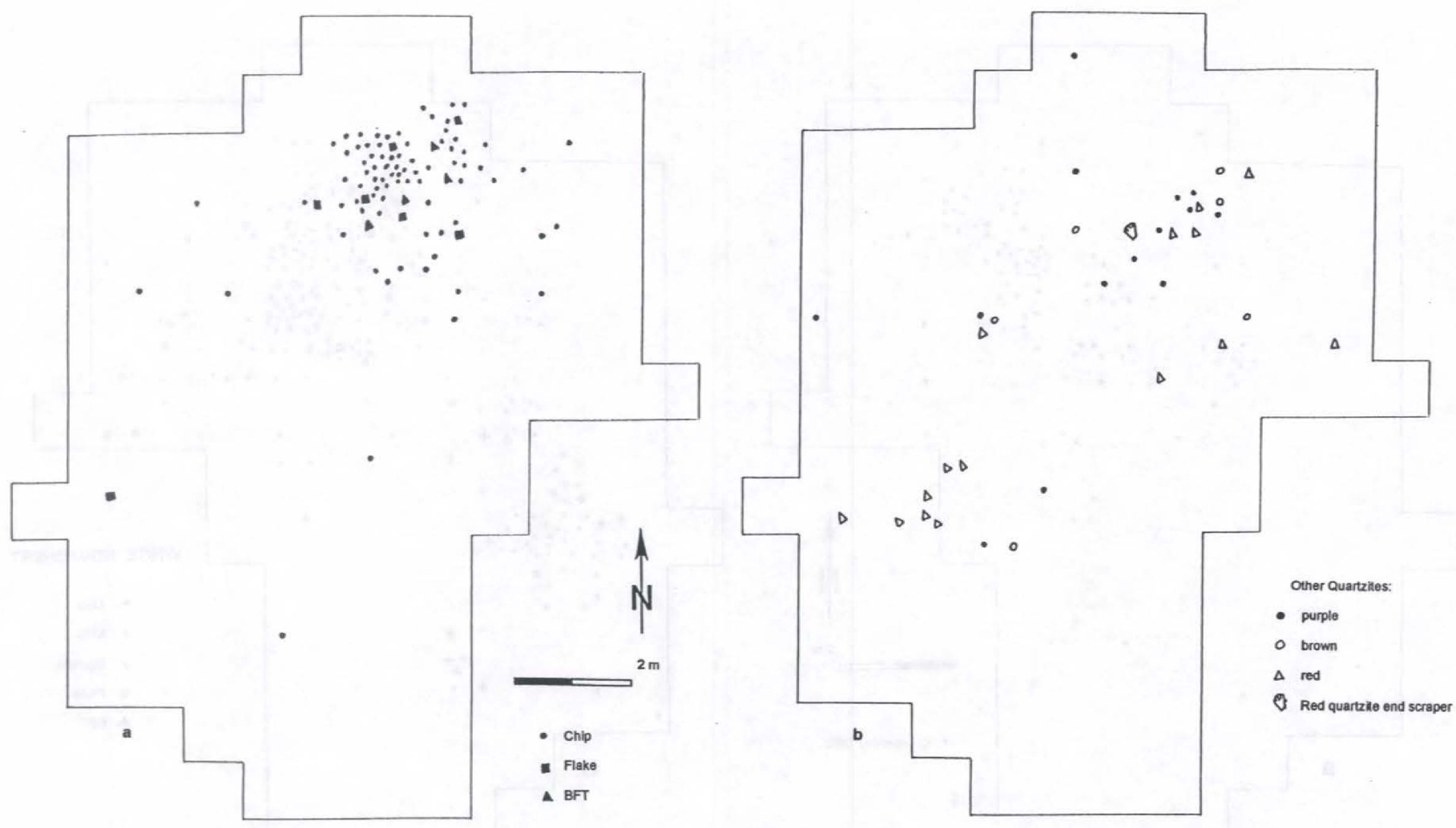

Figure 9.34 Distribution of other quartzites in Camp B. a- Yellow quartzite; this color occurs with or grades into white quartzite on the same piece, but is still informative of spatial patterning; $b$ - Purple, red and brown quartzite; purple and brown occur on some pieces; red quartzite is distinct from others in assemblage, and is attributed to Dakota-Morrison sources in New Mexico-West Texas. 
The proximal end of an end scraper made of WEc was found next to the cluster of URCs I Units 1824-1924. The distal end was found several meters to the west (Figures 9.30-b, 9.31). This is the only WEc tool found in Camp B. Another cluster of about 25 WEc URCs was found in the area centered on Unit $2121 / \mathrm{NE}$. Also, there is a fringe of additional URCs of WEc that wraps around the east side of that cluster. The remainder of the WEc URCs are a low-density scatter in the northern part of Camp B. In the southern part of Camp B, just four URCs and two chips are found near Feature B-3.

Attempts to refit WEc pieces were unsuccessful, despite the clear similarity in materials, mainly because the pieces are so small. Nonetheless, the spatial analysis of this material has to be addressed on distributions of artifacts without the benefit of refitting. The WEc artifacts most likely represent the importation, use and maintenance of either finished tools or blanks that required no more than retouching for their completion, based on the paucity of larger debitage. Save one, the WEc tools were either discarded elsewhere in this camp, or were removed by the departing occupants.

The spatial patterning of WEc reveals more about the use of WEc tools than does the simple high proportion of URCs in the WEc sample. Those artifacts occur as multiple clusters, each with small numbers of URCs. This implies that WEc tools were used frequently, in different locations, but each locus has only a few URCs, suggesting low intensity (i.e. brief) use. The segregation of these clusters leaves open the possibility that the use activities could have been more or less contemporaneous, as opposed to serial. In sum, the pattern suggests multiple use events of low duration, possibly conducted by different individuals and possibly during the same occupation. These use patterns raise the question, why were several tools used briefly? This use pattern implies a brief occupation of multiple individuals engaged in activities that generated these redundant, segregated clusters. Noting that the single WEc scraper was broken, probably in a haft, contributed to this low intensity-per-tool pattern of use, in that the tool may have had to be discarded prematurely. There is quite a bit of useable mass on the distal part of that scraper (Figure 9.32b). That three of the end scrapers in Camp B were broken, all apparently while hafted, is a curiously high breakage rate for what we assume to be tool forms that maximize tool use in settings far form the raw material sources (Goodyear, 1989).

Exactly how many unifacial WEc tools were used here is unknown. In terms of functional associations, the larger cluster of URCs is proximal to two large clusters of large mammal bone in the NE part of the block, one of which is the dense concentration of burned bone in Feature B-1 in Unit 1825. The other clusters have different faunal associations, as described later; but multiple associations, and thus multiple uses, are implied. URCs of other raw materials add additional dimensions to the tool use picture whose first "layer" has been constructed using only White Edwards chert.

Chalcedony (Ch) and White Edwards URCs have very similar spatial distributions (Figure 9.33a). Depending on how the Ch distribution is contoured, there are at least three clusters of URCs, but as many as five. Only one chalcedony tool was recovered from Camp B (Unit 2123/SW), a blade with a distal graver (Figure 9.21-a). The remaining part of that tool does not have retouch that would have produced any URCs, and few could have been produced form that piece in any event. Thus other tools must have been used to generate the URCs. So the chalcedony distribution now complicates that of Wec since distinct overlap in the use areas of these materials is evident.

White Novachert (WN) has two primary concentrations, one in the northern area and the other in the same areas as the PQ debitage near Feature B-3 (Figure 9.34b). URCs of this material are further segregated, with a concentration in Unit 2025 and a minor concentration in Unit 1820. While many pieces of WN are found in and next to Feature B-7 (the debitage pile) and Feature B-5 (hearth), almost all of these are chips or simple flakes (only one WN BFT). But immediately to the SE is the distinct cluster of URCs. Near Feature B-1 (hearth), the same pattern is evident, with chips closer to the hearth than URCs. Minor concentrations in the vicinity of Units 2221 and 2622 fall in or near other materials, and will be mentioned later. 
The "other quartzites" are differentially concentrated in the same areas as the White Novachert. Yellow quartzite (YQ) is considered a variation of the Tecovas Quartzite, since pieces that grade form the white to yellow are present. But its concentration is distinct nonetheless indicating very localized production. Only six pieces fall beyond the primary concentration in and near the northern debitage pile (Figure 9.33a). But in the pile are only chips and one flake, probably associated with primary knapping, while flakes and BFTs, in this case just "larger" pieces, are located south and east of the pile. This may indicate that they were used as expedient tools, but none are retouched. Overall, the distribution of yellow quartzite indicates that it was probably knapped from separate cores than were the other quartzites, especially since it is completely absent form the southern debitage pile (Feature B6). No tools or URCs made of yellow quartzite were found at Aubrey. Its reduction at the site implies manufacture/maintenance of bifaces, or production of flakes for unretouched tools.

Small numbers of purple, red and brown quartzite form clusters southeast of Feature B1 (hearth) and also north of Feature B-5 (hearth) (Figure 9.34b). These pieces tend to occur together, despite their distinctive appearance. Also, these materials segregate completely from the debitage piles, and the brown and purple materials have a high proportion of URCs compared to the Tecovas Quartzite and Tecovas Chalquartzite (Table 9.9). Most curious is the group of three chips in the center of the block. These three are red, brown and purple. Though seemingly (and possibly) a chance association, the three chips form the hub for those three colors of quartzite, with connections to at least four concentrations associated with hearths or the debitage pile. This pattern will be discussed later, as these quartzites are not the only materials that seem to have a "center" in Camp B.

A notched end scraper of red quartzite is the only tool made of these materials (Figure 9.20-a). It was burned and broken adjacent to the northern hearth. The clusters of red quartzite near two hearths very much suggests that tools were being resharpened there. But none of the chips are URCs, so either unifacial or bifacial tool resharpening could be indicated.

The other varieties of Edwards chert are dominated by URCs (Table 9.9, Figure 9.35-a). The largest flake of the buff Edwards chert is a large interior flake that has been broken into four pieces. These refit, showing that the breakage was accomplished by smashing the flake's center. Although use wear cannot be detected, this piece is interpreted as a "bend-break" tool like those found in Clovis and Folsom contexts in the western US (Frison and Bradley, 1980; Frison, 1978, 1996). This tool is not retouched, so the other buff Edwards chips found between Features B-2 and B-3 must have derived from other tools, as do all the other chips and URCs in Camp B, which surround Features B-1 and B-5, especially to the southeast (Figure 9.35a). A few gray Edwards chips occur next to Hearth B-3, but most are found in two main clusters in the northern part of the site. One cluster is within the debitage pile there, and the other is contiguous to the southeast. The few mottled Edwards pieces are in two areas in the northern part of the block; and a multiple graver (Figure 9.22-a) of the same material was discarded just northeast of Hearth B2.

The area between Hearths B-2 and B-3 should be mentioned again now, since the buff Edwards chips and the buff Edwards bend-break tool occur there. In this same area are the size pieces of White Novachert mentioned previously, one yellow quartzite chip, a few pieces of Point quartzite (the PQ point base is nearby), and two Tecovas quartzite flakes. The latter are perhaps associated with the nearby debitage pile of Tecovas quartzite and Tecovas Chalquartzite (Figure 9.29a). A Tecovas Chalquartzite tool, with retouch and a battered edge suggestive of use as a wedge, and the impact damaged tip of the Edwards (?) point are the other tools in this part of the site. So in addition to the debitage pile, the area between the hearths has an interestingly diverse assemblage of raw materials, dominated by chips and URCs. This indicates use of at least nine tools there, but with only two tool discards, one of which may have been the point fragment lodged in meat. This is a subtle, yet "busy" part of the site, lending much more diversity to the probable activities there than would have been discernible from the formal tools recovered. This is a strong cautionary note to the singular use of tool distributions for assessing activity differentiation within the site. 


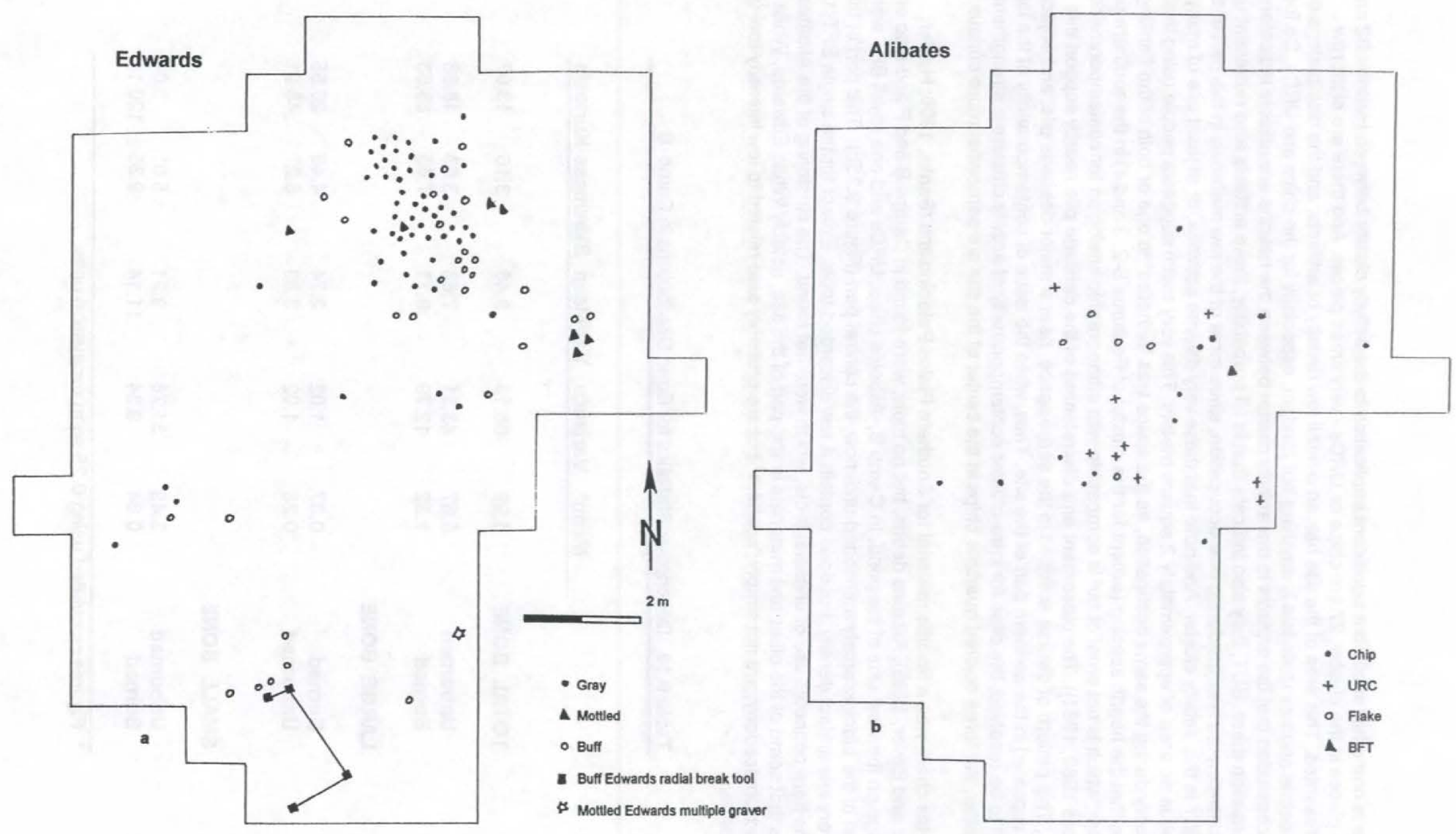

Figure 9.35 Other Edwards and Alibates chert distributions in Camp B. a- Other Edwards; note segregation of Buff Edwards in southern area. In Camps B and F, mottled Edwards is rare, and probably imported as expedient flake blanks; b- Alibates. Note segregation of Alibates from other artifact s; this is the only material that is concentrated in central part of the block. 
There is one other subtle but significant implication to the activity cluster between Hearths B2 and B3. Of the 31 pieces in the cluster, 27 are chips or URCs - very small pieces. And there are eight raw materials represented. This area of the site has an overall low density of artifacts, and the distributions of both types of debris and raw materials is anything but random, especially for the chips and URCs. So form this it can be concluded that the artifacts in the activity cluster between the hearths are reliable indicators of activity differentiation there. BUT, they also indicate that in all probability, these artifacts also represent use of the space between the hearths during one occupation, since most of the raw materials in this part of the site occur ONLY in this activity cluster. And note that these very diverse activities, or at least use of many tools, occurred in an area of approximately 2 square meters. This very much suggests people using that space repeatedly during the same occupation, as the space was "tethered" to one or both of the flanking hearths. (Note that the hearth spacing (except for the cluster of Features B-2, 3 and 4) in the southern part of the site is $3 \mathrm{~m}$, which is not proof of but is compatible with ethnographic analogies for contemporaneous hearths [Binford 1980,1981]). The placement and discreteness of the debitage pile nearby support this interpretation. This pattern of diverse activities in the same space, near a major debitage pile, and adjacent to a hearth is repeated in the northern part of the site. Thus, while the issue of contemporaneity of the larger clusters is still to be resolved, the case for intra-cluster contemporaneity of activity clusters is strengthened. And in this matter, the three colored quartzite chips in the center of the site are somewhat more curious.

Alibates chert, was a favorite material for Southern Plains Paleoindians (Banks, 1990; Hester, 1972; Meltzer and Bever, 1995). Alibates debris, but no tools, were found in Camps B and F and also on the Red Wedge on the west side of the pond. In Camp B, Alibates chips, URCs and one small BFT were found in a part of the block scarcely mentioned until now, the central part (Figure 9.35b). This part of the block has a very low artifact density, but does contain a few discarded tools. Except for the single BFT, the Alibates debris here connotes use of unifacial tools, which were not found. The clustering of the Alibates also suggests that some of the other raw materials in this part of the site, notably White Edwards, White Novachert and Chalcedony, are not simply "scatters" but are probably also related to low intensity tool use and maintenance.

Table 9.16 Descriptive Statistics for Bone Distributions in Camp B

Mean* Variance Var/Mean Skewness Kurtosis

$\begin{array}{llllll}\text { TOTAL BONE } & 6.99 & 66.13 & 9.46 & 3.16 & 13.07 \\ & & & & & \\ \text { Unburned } & 5.67 & 43.31 & 7.63 & 3.63 & 18.68 \\ \text { Burned } & 1.32 & 12.79 & 9.71 & 7.63 & 86.63\end{array}$

LARGE BONE

$\begin{array}{llllll}\text { Burned } & 0.37 & 1.02 & 2.74 & 4.46 & 26.55 \\ \text { Unburned } & 0.28 & 1.02 & 3.83 & 6.27 & 48.21\end{array}$

SMALL BONE

$\begin{array}{lrrrrr}\text { Unburned } & 3.45 & 31.78 & 9.21 & 5.01 & 3.04 \\ \text { Burned } & 0.84 & 9.34 & 11.14 & 9.35 & 120.11\end{array}$

* Figures calculated using $0.25 \mathrm{sq} \mathrm{m}$ excavation units 


\section{Spatial Patterning of Faunal Remains in Camp B}

The taphonomic condition of bone in Camp B was such that identification and state of burning were the principal observations that could be reliably recorded (Yates and Lundelius, this volume). While better preservation would have been great, there should be few complaints that over 3,500 pieces of fauna were recovered. And, as shown below, they preserve an excellent record of activity patterning.

All bone in Camp B has strong patchiness, as measured by the variance/mean ratio (Table 9.16; Figure 9.36). The clumping, or discreteness of the clusters, increases dramatically between unburned and burned bone, reflecting the even greater concentration of the latter.

Large mammal bone occurs in a number of small to medium $(<1-2 \mathrm{sq} . \mathrm{m})$ clusters, predominantly in the northeastern part $f$ the block (Figure 9.37). Two of the identified specimens are deer, both of which are in the northern part of the block. The remainders are bison, which are concentrated in the northeast, but also in the southern areas (Figure 9.37a). Burned large mammal bone is in five primary clusters. The densest cluster is in Feature B-1, where 62 pieces were found in less than $1 \mathrm{sq} . \mathrm{m}$. Smaller concentrations are associated with the hearths in the southern part of the block, and a fourth area in the western part.

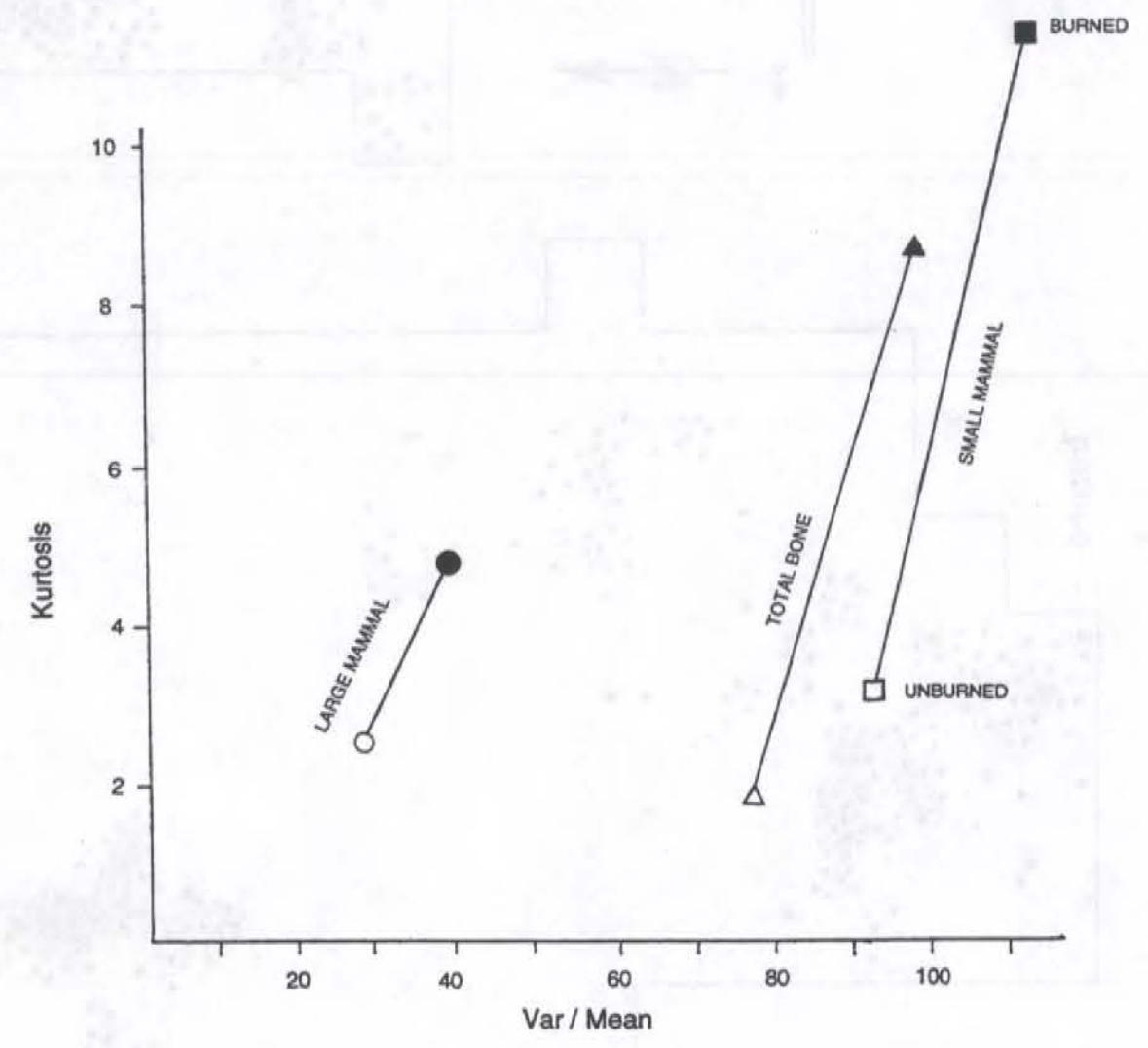

Figure 9.36 Patchiness and packing of bone fragments in Camp B. Variance/Mean ratio used here as measure of patchiness (clustering), and Kurtosis as measure of packing (density of artifacts within clusters). Note much higher packing for all burned bone. 

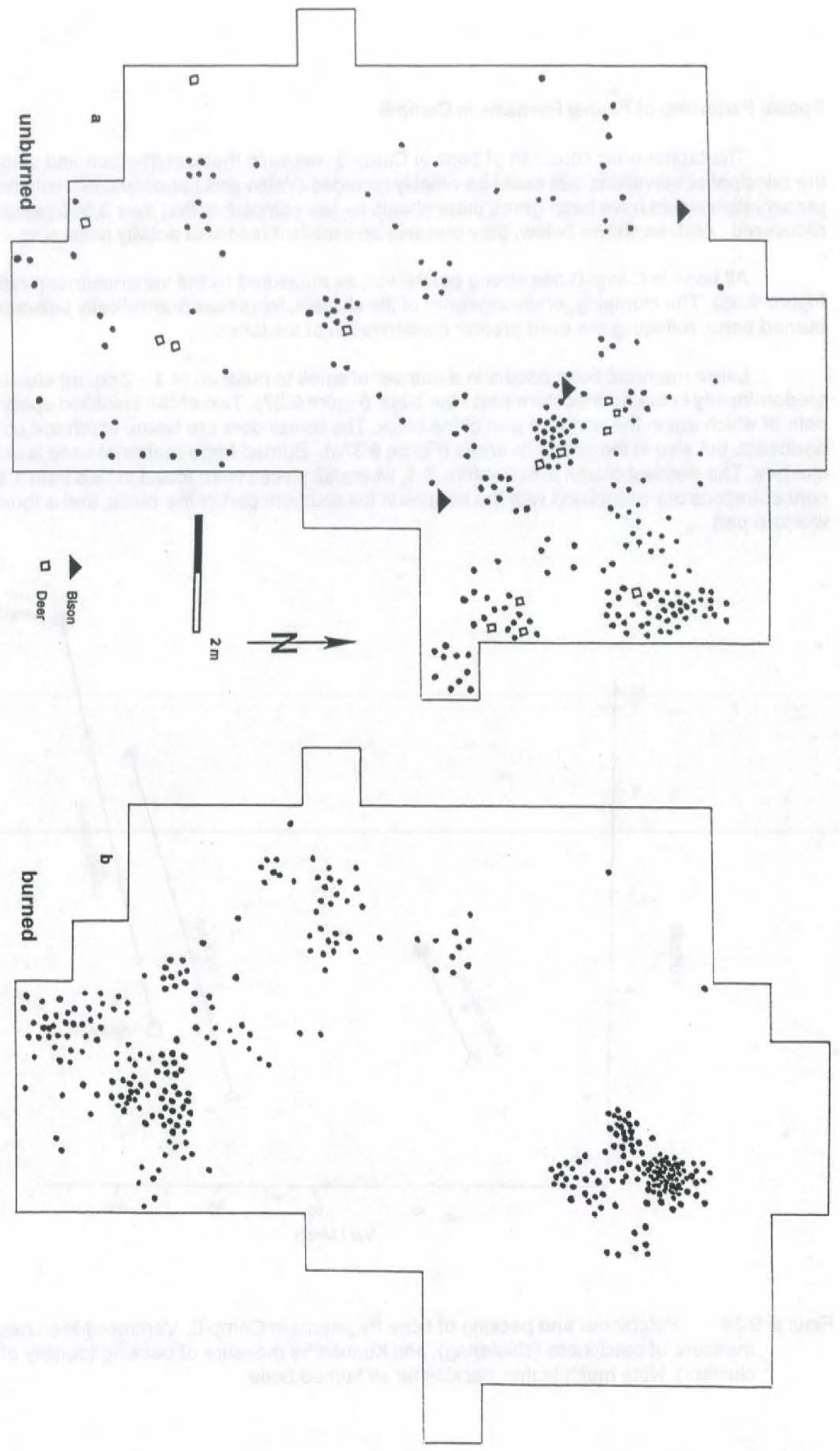
9.37-b). Beyond the "working area" near the hearth, there are several clusters of unburned large bone fragments to the east and south. Tool discard was pronounced about $2 \mathrm{~m} \mathrm{SE}$ and about 4-5 $\mathrm{m}$ southwest of the hearth. The southern part of the block has the same components- hearths, a debitage pile, and clusters of URCs. The density of unburned large bone is much lower there, but the unexcavated areas in the south need to be considered with respect to absences there.

Medium mammals cluster in two areas, one south of Hearth B-1, and the other south and west of of hearths B-3 and B-4 (Figure 9.39-a). The northern cluster coincides with clusters of large unburned bone and several URC clusters. The southern concentration overlaps with Hearth B-2, and coincides with the small, diverse cluster of URCs and tools (including the four bend-break tools, and one "wedge"-like tool) mentioned above. Bone from medium sized mammals in that area segregate from the other bone categories to the west.

The identified small mammal bone distribution does not appear at all to be random (Figure 9.39b), as there are multiple clusters, each comprised of multiple taxa. Each of the rabbit bones is near a hearth, as are the clusters of microtines, gophers and moles. Burned small mammal bone is also near the southern hearths, while the category "rodentia" is quite widely scattered (Figure 9.40a).

Burned snake and turtle are found almost exclusively with the southern hearths, with only three turtle fragments on the west edge of the block (Figure 9.40-b). No burned reptiles were found in the northern area. Six of the ten fish bones are associated with hearths as well, also suggesting a use-related distribution. Overall, the evidence that small game was intensively processed at Aubrey is compelling. Small and medium sized mammal bones are associated with use areas involving multiple tools, and burned bone is obviously clustered. Small and medium animals do not always segregate from larger taxa, especially in the southern part of the block, where common large mammal bone fragments also cluster. But there are small concentrations dominated by small taxa, notably in the west-central part of the block. The falling idol of Clovis subsistence patterns has fallen with quite little in the way of substantive data to support the alternative of a broader food procurement system. Aubrey now adds much to those ideas, at least with respect to animal food procurement and processing.

\section{Spatial Patterning in Block F}

The excavation area of Block $F$ is about half the size of Block B (Table 9.12). Nonetheless, the average density of lithic artifacts is essentially the same. But bone density in Camp F is only $23 \%$ of that in Camp B. The composition of lithic and faunal assemblages from Camp $F$ are different from those in Camp $B$ as well. These assemblage differences are now examined from a structural perspective.

Faunal remain in Camp F differ in gross taxonomic composition, and also in the frequency of burning (Table 9.17). There is a noticeably lower proportion of prey taxa in Camp F, particularly bison, rabbits and turtles. More striking is the difference in burning, which is about one third as common for small taxa and one half as common for large ones (Table 9.17). The frequency of burned lithic artifacts is about the same as in Camp B (Table 9.18). The low numbers of burned artifacts in both areas, contrasted with much higher percentages of burned bone, supports the spatial data for bone burning to be most predominantly cultural.

The distribution of burned bone in Camp F is difficult to assess because of the small sample, but it appears to follow quite closely the distribution of total bone (Figure 9.41). This contrasts with the more distinctive clustering and segregation of burned bone in Camp B.

The vertical distribution of artifacts in Camp F follows a similar pattern to that in Camp B (Figure 9.26a). The $5 \mathrm{~cm}$ level data reveal the kurtosis and the slight upward skewness of the vertical distribution. Mapped lithic tools show the single occupation surface which dips slightly to the east (Figure 9.28a). A few meters beyond the eastern edge of the excavation block, the slope of the paleosurface steepens as it drops into the Clovis age paleochannel. 
190

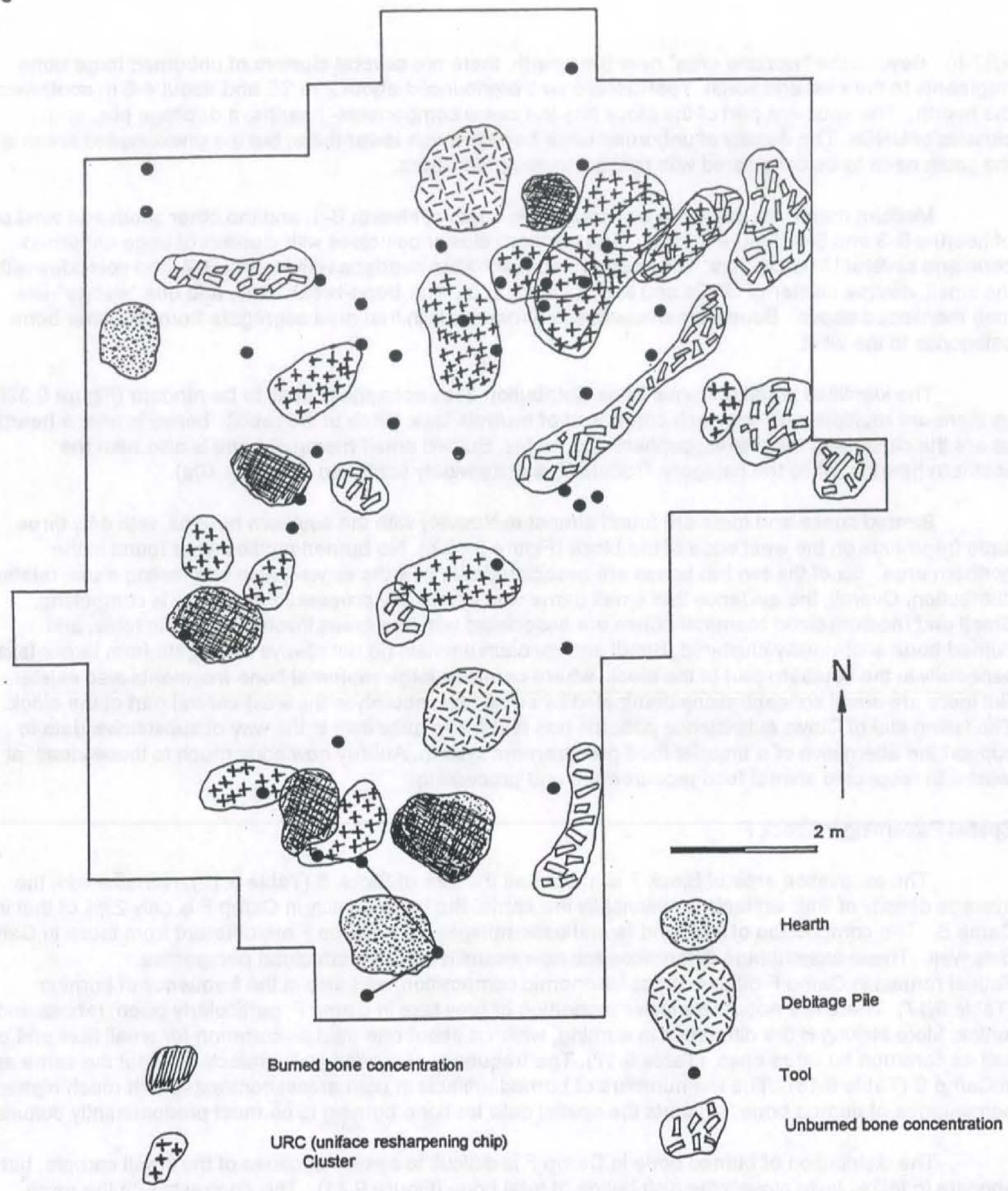

Figure 9.38 Large mammal bone and lithic artifact clusters in Camp B. Note lithic tool locations often segregated from bone or at edge of bone clusters; also note positions of debitage piles adjacent to hearths and excellent segregation from other artifact categories. 

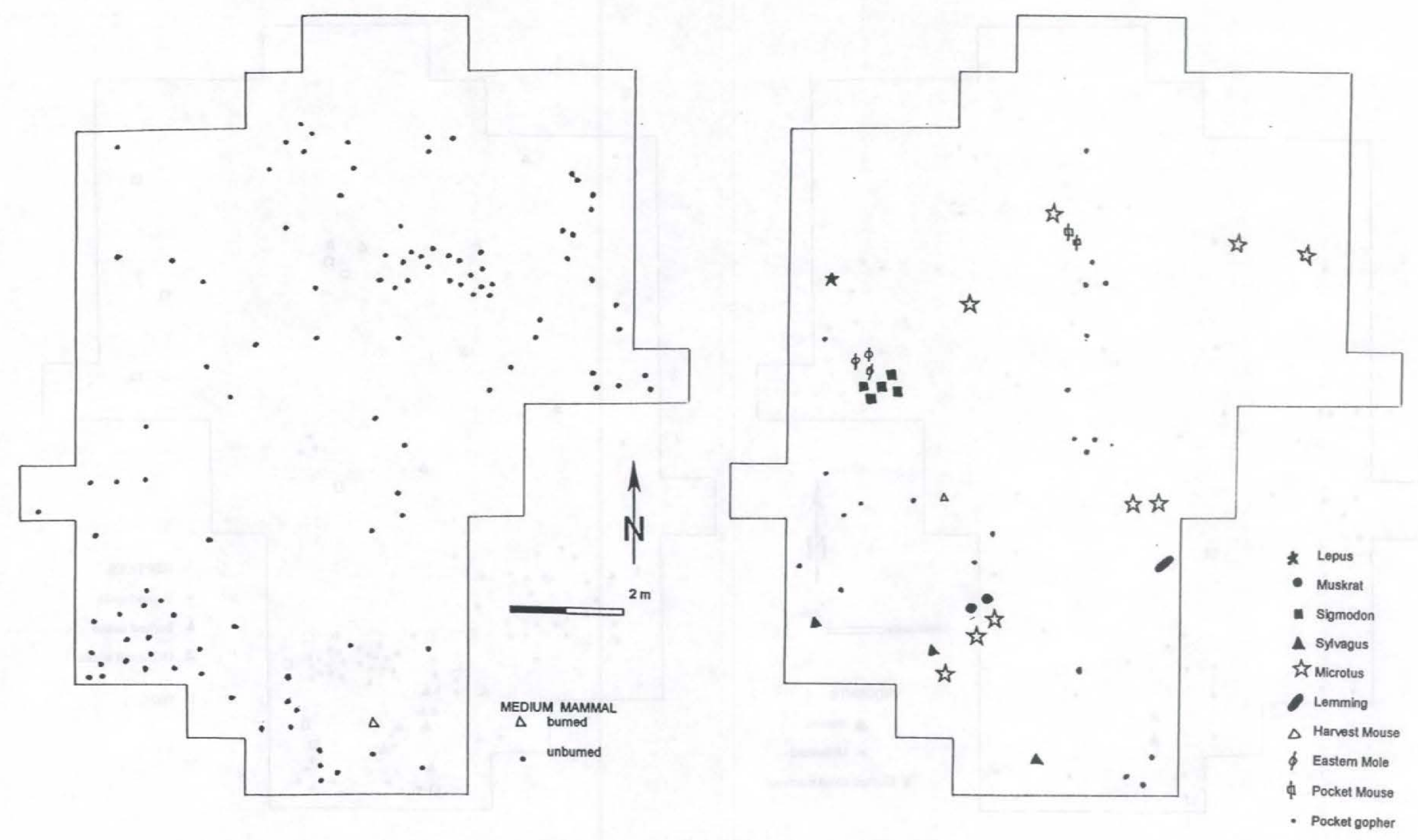

Figure 9.39 Distribution of small and medium mammal bone in Camp B. 


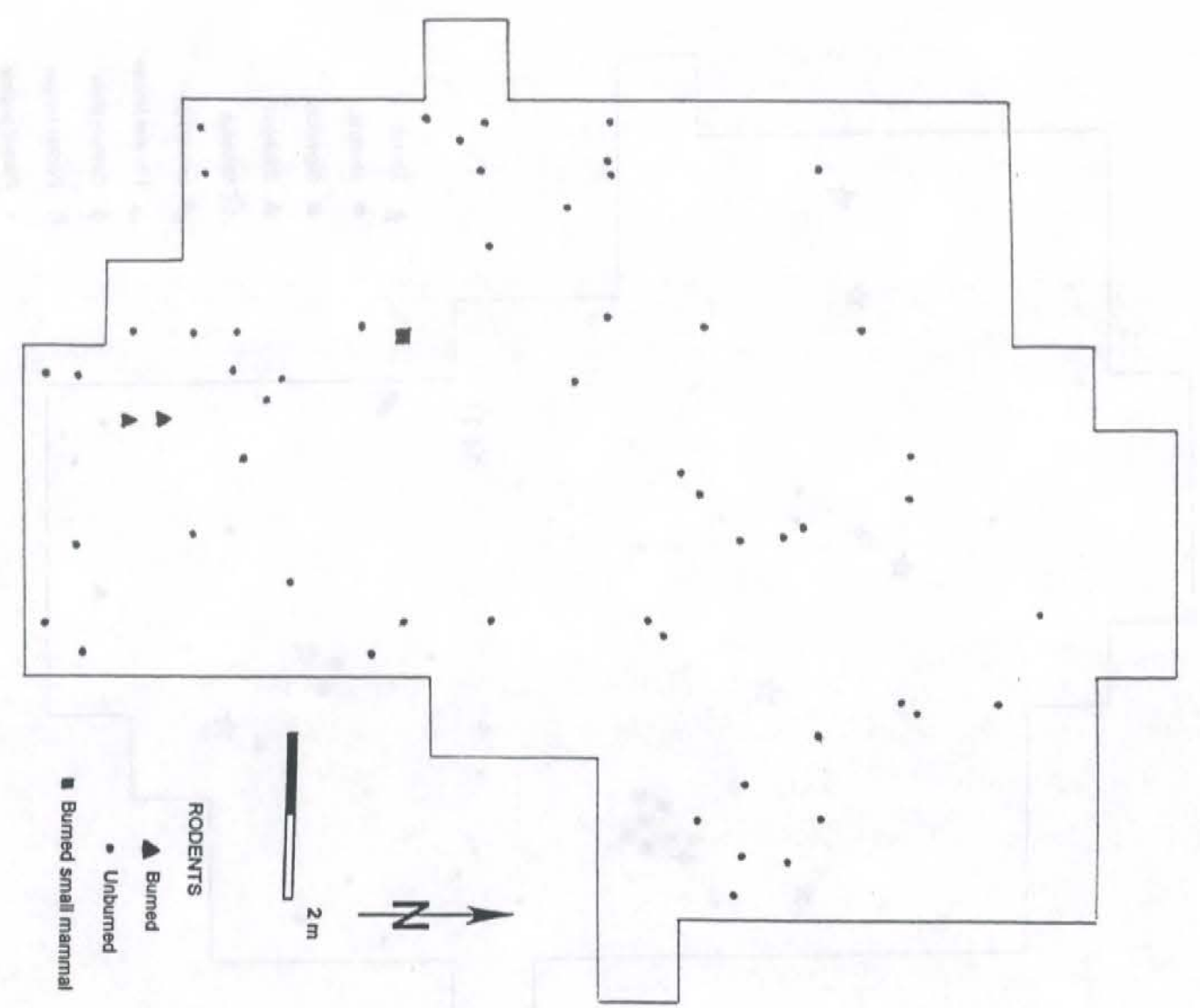

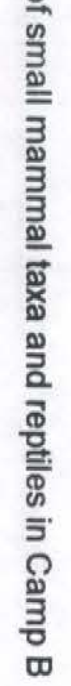

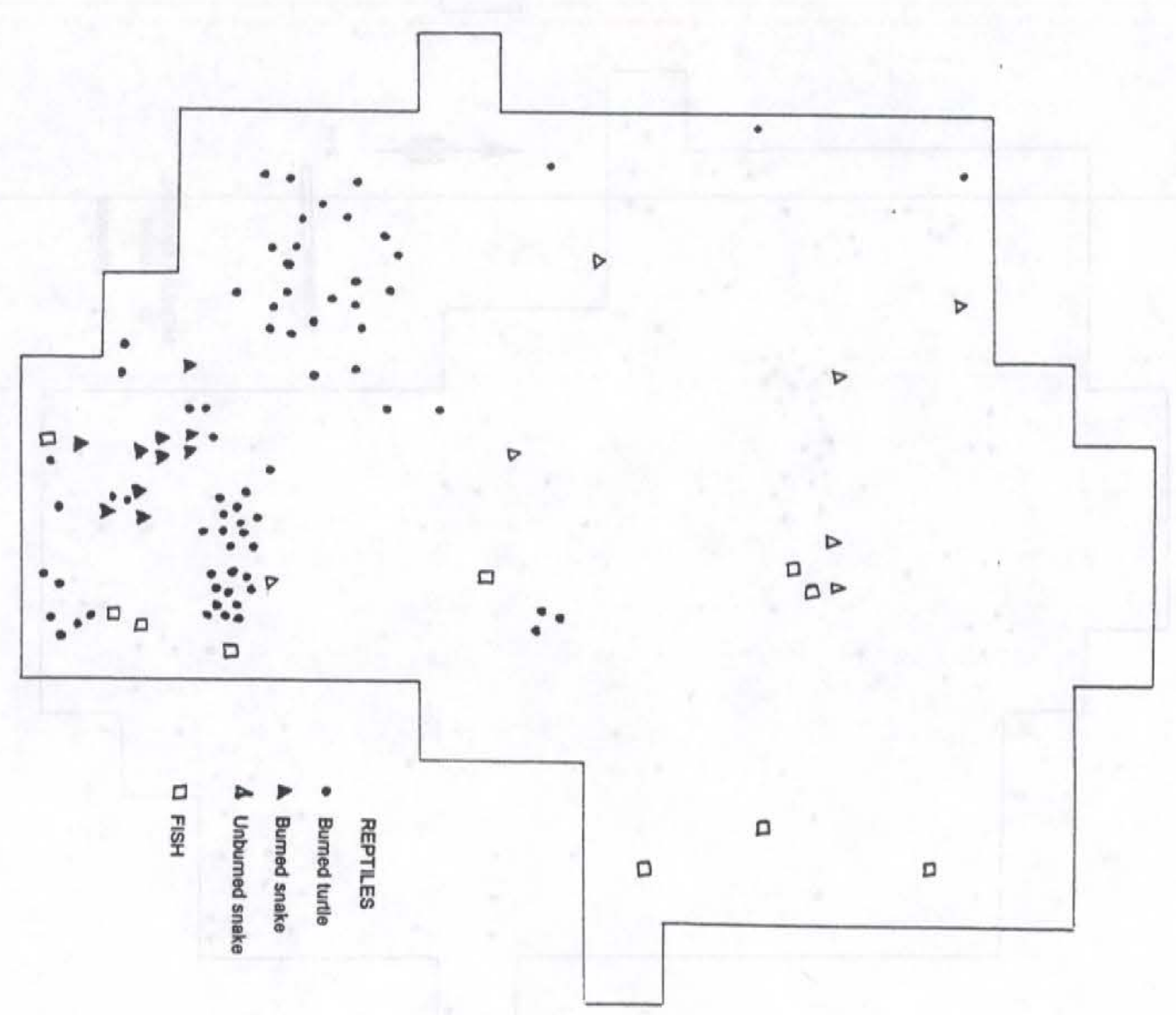


Table 9.17 Comparison of Faunal Assemblages

\begin{tabular}{ll}
\hline Camp B & Camp F \\
\hline
\end{tabular}

\begin{tabular}{lrc} 
Fish & 3.3 & 6.3 \\
Amphibians & 0.6 & \\
Turtle & 46.6 & 14.6 \\
Bird & 0.6 & \\
Rodent & 41.4 & 66.7 \\
Rabbits & 1.3 & \\
Deer & 5.2 & 12.5 \\
Bison & 0.9 & \\
$\mathbf{n}$ & 307 & 48 \\
\hline
\end{tabular}

\section{Burned \%}

$\begin{array}{lrr}\text { Small } & 19.5 & 6.1 \\ \text { Large } & 42.7 & 19.5\end{array}$

Lithic artifacts in Camp F have a similar degree of clustering as in Camp B (Figure 9.42a). The large cluster in Units 1624-1724 contains almost half of the artifacts in the excavated block. With the more diffuse cluster to the south, $50 \%$ of the artifacts are found in just $10 \%$ of the excavated area (Table 9.12). So this occupation cluster is also has a debitage piles, in this case one is closer and not as packed (discrete).

As in Camp B, the debitage types in the two piles are different (Table 9.14). The larger pile is dominated by BFTs, while the smaller one has more URCs (Figure 9.42-b). Overall, however, URCs are much less common than in Camp B, as mentioned earlier (Table 9.14).

The few tools in Camp F were mainly discarded adjacent to the main debitage clusters, as in Camp B (Figure 9.42-b). Edwards chert, which is mainly associated with unifacial tools at Aubrey, is also concentrated on the peripheries of the debitage piles (Figure 9.43-a). In both cases this reveals a segregation of tool manufacture and/or biface maintenance activity clusters from those involving uniface resharpening.

The northern debitage pile in Camp F has BFTs of several raw material types, and the size distribution of these suggest that biface repair or resharpening, rather than manufacture, took place there. Raw materials indicate that at least four bifaces were worked on there. Two biface tips, one of Edwards and one of chalcedony, were found adjacent to the cluster. 


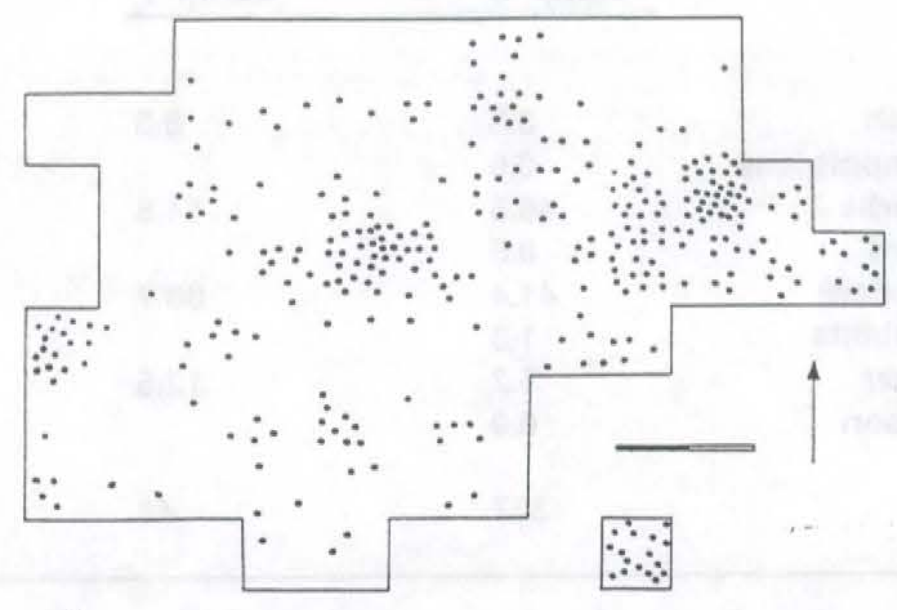

a
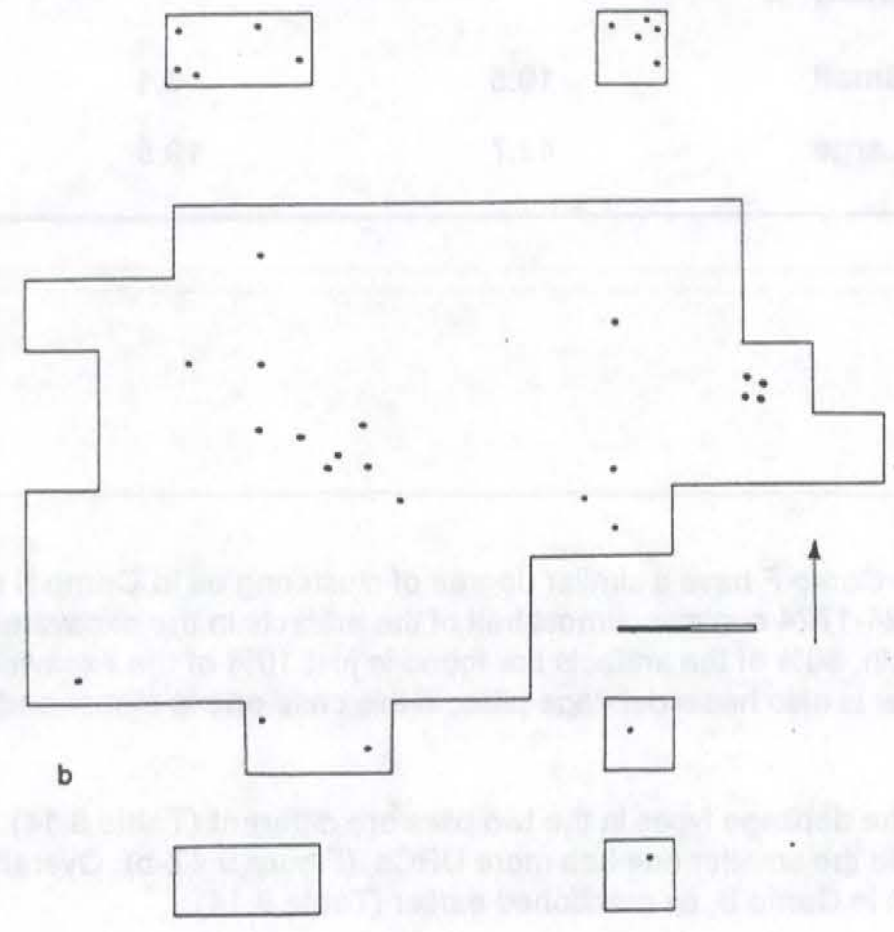

Figure 9.41 Distribution of total bone in Camp F a- unburned b- burned. 


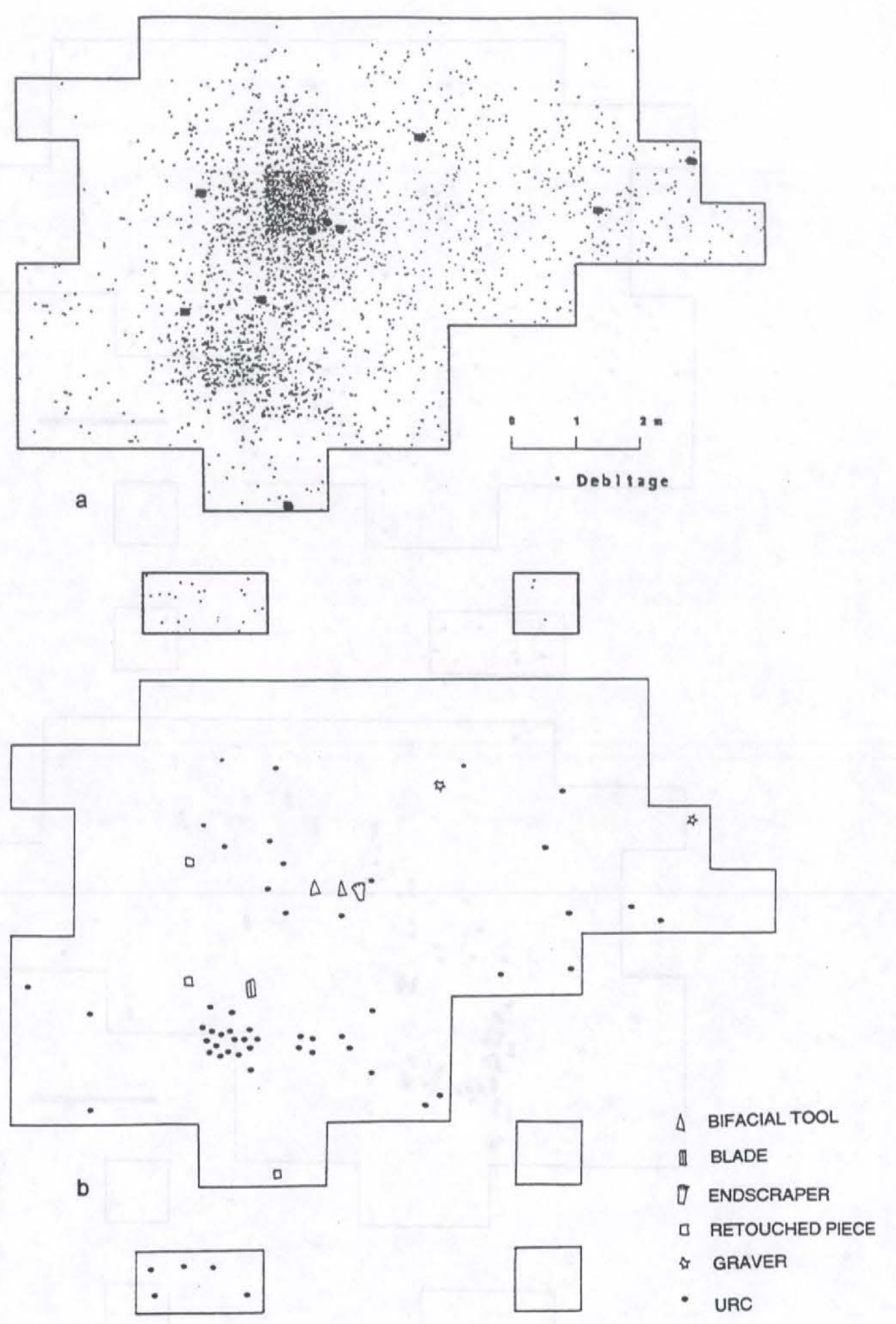

Figure 9.42 Total Artifacts, Tools and URCs in Camp F a- total artifacts b- tools and URCs 

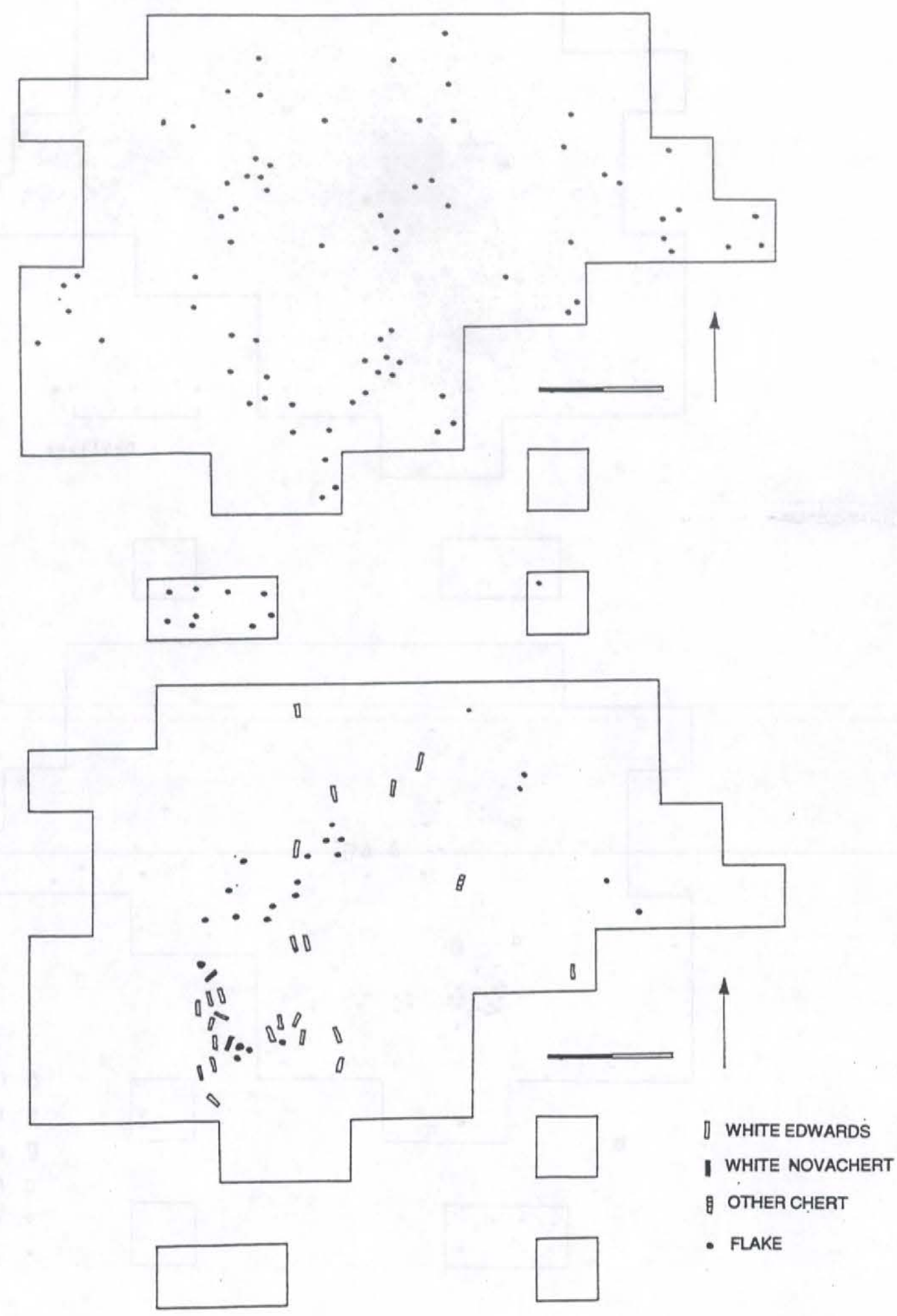

Figure 9.43 Bladelets and Edwards chert artifacts in Camp F. a- Edwards chert; b- bladelets. 

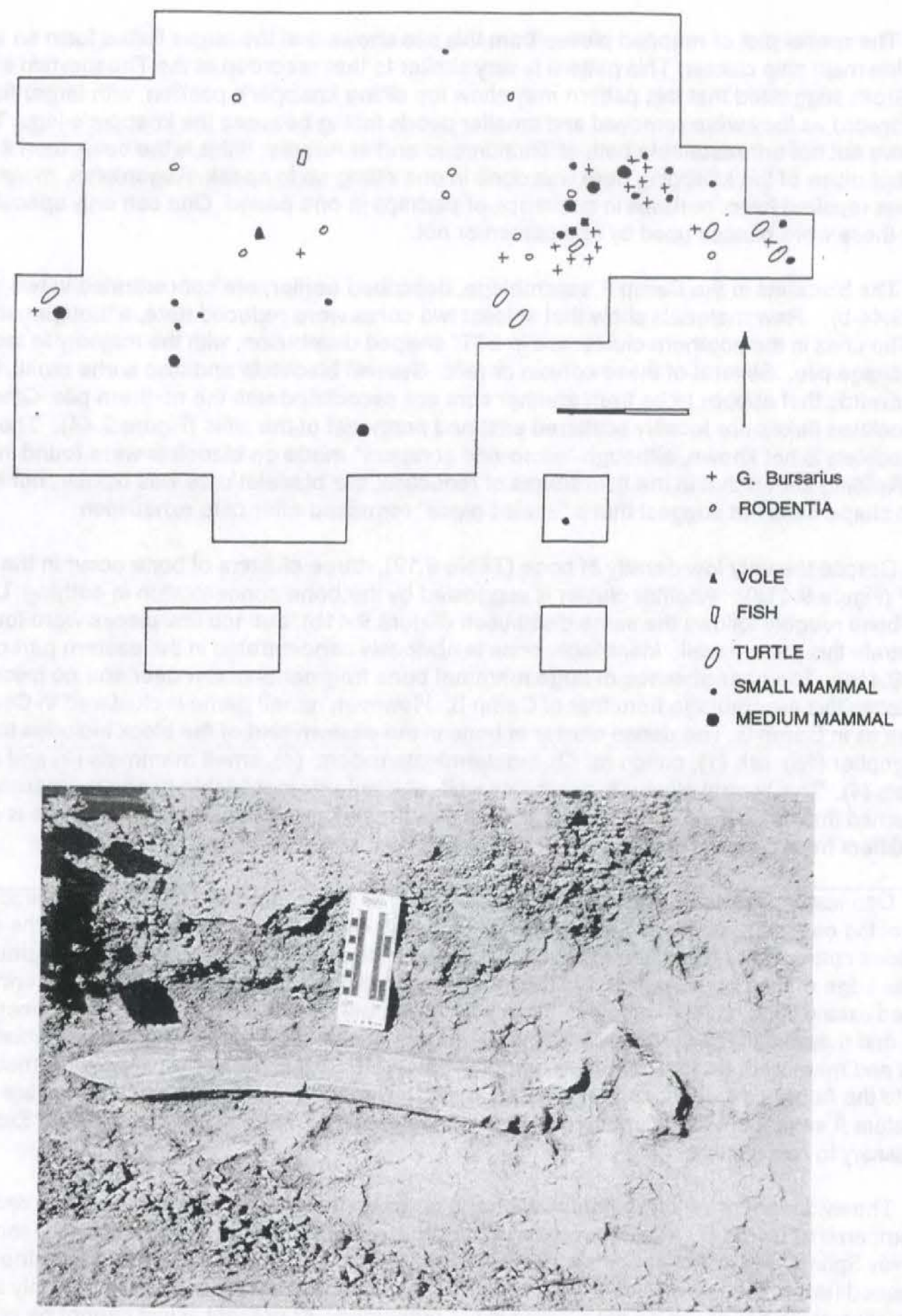

Figure 9.44 Identifiable Bone and Mammoth Rib from Camp F
a- identified bone
b- photo of mammoth rib 
The spatial plot of mapped pieces from this pile shows that the larger flakes form an arc just beyond the main chip cluster. This pattern is very similar to that recorded at the Thunderbird site (Gross, 1974). Gross suggested that this pattern may show the sitting knapper's position, with larger flakes being tossed forward as they were removed and smaller debris falling between the knapper's legs. This is speculative but not unreasonable both at Thunderbird and at Aubrey. If this is the case, then it suggests further that much of the knapping here was done in one sitting so to speak. Regardless, more than one biface was repaired here, perhaps in sequence or perhaps in one period. One can only speculate as to whether these were bifaces used by one person or not.

The bladelets in the Camp F assemblage, described earlier, are concentrated in two clusters (Figure 9.44-b). Raw materials show that at least two cores were reduced here, although neither was found. The ones in the southern cluster are in a "T" shaped distribution, with the majority to the west of the main debitage pile. Several of these conjoin or refit. Several bladelets and also some small, long flakes of White Edwards that appear to be from another core are associated with the northern pile. Other bladelets and associated flakes are loosely scattered east and northeast of the piles (Figure 9.44). The function of these bladelets is not known, although "micro-end scrapers" made on bladelets were found in Camps B and F. Refitting shows that in the final stages of reduction, the bladelet core was bipolar, but the arched platform shape does not suggest that a "scaled piece" remained after core exhaustion.

Despite the very low density of bone (Table 9.12), three clusters of bone occur in the main block at Camp F (Figure 9.41a). Another cluster is suggested by the bone concentration in outlying Unit 2128. Burned bone roughly follows the same distribution (Figure $9.41 \mathrm{~b}$ ), but too few pieces were found to demonstrate this pattern well. Identifiable bone is obviously concentrated in the eastern part of the block (Figure 9.41a). The near absence of large mammal bone fragments (a few deer and no bison), distinguishes this assemblage from that of Camp B. However, small game is clustered in Camp F much the same as in Camp B. The dense cluster of bone in the eastern part of the block includes turtle (5), pocket gopher (15), fish (1), cotton rat (2), indeterminate rodent (4), small mammals (9) and medium mammals (4). The central cluster is diverse as well, with only six identifiable bones representing five taxa. If it is assumed that these clusters are cultural, then the array of small game processed here is high, and maybe differs from Camp B's assemblage mainly because of the sample size.

One last faunal issue at Camp $F$ is the discovery of four mammoth ribs and one tarsal within 10 meters of the east edge of the excavation block (Figure 9.44-b). These were found over the period after excavations ceased, and had been exposed by erosion of the outlet channel bank. The mammoth bones are at the edge of the paleochannel, but their exact stratigraphic position has not been determined, since no controlled excavations have taken place there yet. A number of pieces of debitage have been found on the surface and mapped in the same area as the mammoth bones, but firm stratigraphic associations of the artifacts and mammoth bones cannot be demonstrated yet. So it is not known if the mammoth bones are related to the Aubrey occupations, or if they are even of Clovis age. It is possible that they are in situ deeper into Stratum $A$ sands, but they can also be in situ in the sands on the paleochannel slope. Excavations will be necessary to resolve this.

The evidence for relatively more emphasis on biface resharpening in Camp $F$ is a distinct activity here compared to Camp B. Intensive biface resharpening accompanied mammoth and bison butchery at the Murray Springs site in Arizona (Haynes 1981, 1982, personal communication). There the bifaces were resharpened next to the carcass as it was butchered. At Camp F, the debitage piles are only a few meters from the mammoth bones, so an association is not precluded. At present, it just cannot be proven or rejected. 
One last aspect of the spatial patterning of Camp B demands discussion, for it possibly is significant evidence for integration of the activity areas in the different parts of the excavation block, and hence for their contemporaneous use during a single occupation episode.

The concentration of URC's (uniface resharpening chips) in the central, "low density" part of the excavation block has been mentioned earlier. The compositional frequency of URCs is the inverse of the density patterning of all artifacts in this block (Figure 9.45). It appears that the areas where unifacial tool use (inferred by resharpening chips) was the dominant, if not single, lithic processing activity, segregate from the areas with evidence for diverse tasks involving lithic artifacts. As mentioned earlier, during the lithic analysis the "different" (as opposed to exotic) larger pieces of debitage were segregated for closer inspection. These were mainly varieties of Edwards chert, but also included some other materials, such as colored quartzites, that were notable for their larger size, and by colors and/or textures that distinguished them from the rest of the assemblage. Several bend-break and radial-break tools were quickly identified, and several pieces could be refitted. Also, several pieces "matched" even though they could not be refit.

When the refit and "matched" flake fragments were plotted on the Camp B map, a very striking pattern was evident (Figure 9.46). Most of the pieces had fragments located in the central, low density part of the block, where the high frequency of URCs had been noted. Furthermore, the refits and matches usually led to areas adjacent to the hearths and associated activity areas in the north, south and western areas of the block. It appears as if the "different" flake blanks were brought to the site AS blanks, and were broken into bend-break or radial break tools in the central area, with the fragments then taken to hearth areas where they were used along with other tools in an array of activities. This scenario raises several issues concerning the movement and use of flake blanks, and also concerning the scheduling and integration of activities during the occupation(s?) of Aubrey.

The "distinctive" artifacts whose spatial patterning and use primarily as bend-break and radial-break tools, are part of the Aubrey residents' strategy for conservation and transport of lithic artifact. Flakes were apparently scavenged from their location of manufacture, either as debitage products of a core reduction strategy, or as byproducts of a core or biface reduction strategy. (By now it is clear that Clovis folks employed not just multiple reduction strategies, but many reduction strategies [cf. Ferring 1980, 1988.) These flake blanks (Bradley 1985) were transported on to a next stop, where they were fashioned into tools either by retouching, breaking or smashing.

The "debitage piles" at Aubrey appear to fit into this overall conservation-transport strategy, as a means to concentrate the debris from core or biface reduction (and apparently from other lithic reduction-maintenance activities as well) into discrete "piles" so that scavenging for expedient tool blanks would be facilitated. At the same time, this tactic would help minimize loss of tool blanks. Whether keeping the site tidy was another objective is hard to infer, but the economizing behavior makes great sense when the transport distances are weighed.

While new tool blanks were being made and selected for use from the debitage piles, the imported flake blanks were also being transformed into tools and used. The spatial patterns in Figure 9.46 convincingly show that tools used near all the hearth areas have fragments or matches that occur in a small part of the west-central part of Block B. A logical question is, were the tool fragments exported from the central place or were they imported to that central place? The first pattern makes the most sense, as it supports the notion that there were specific places where the imported flake blanks were kept- perhaps in a bag - and that people went there to get a tool blank, make or begin its transformation into a tool, and move that fragment to a work area for use.

Obviously this detailed a reconstruction is one that can and should undergo more detailed analysis. Nonetheless, I believe that the spatial patterning data show quite clearly that there were several flake blanks that were imported to Aubrey, stored in specific places in the site, 


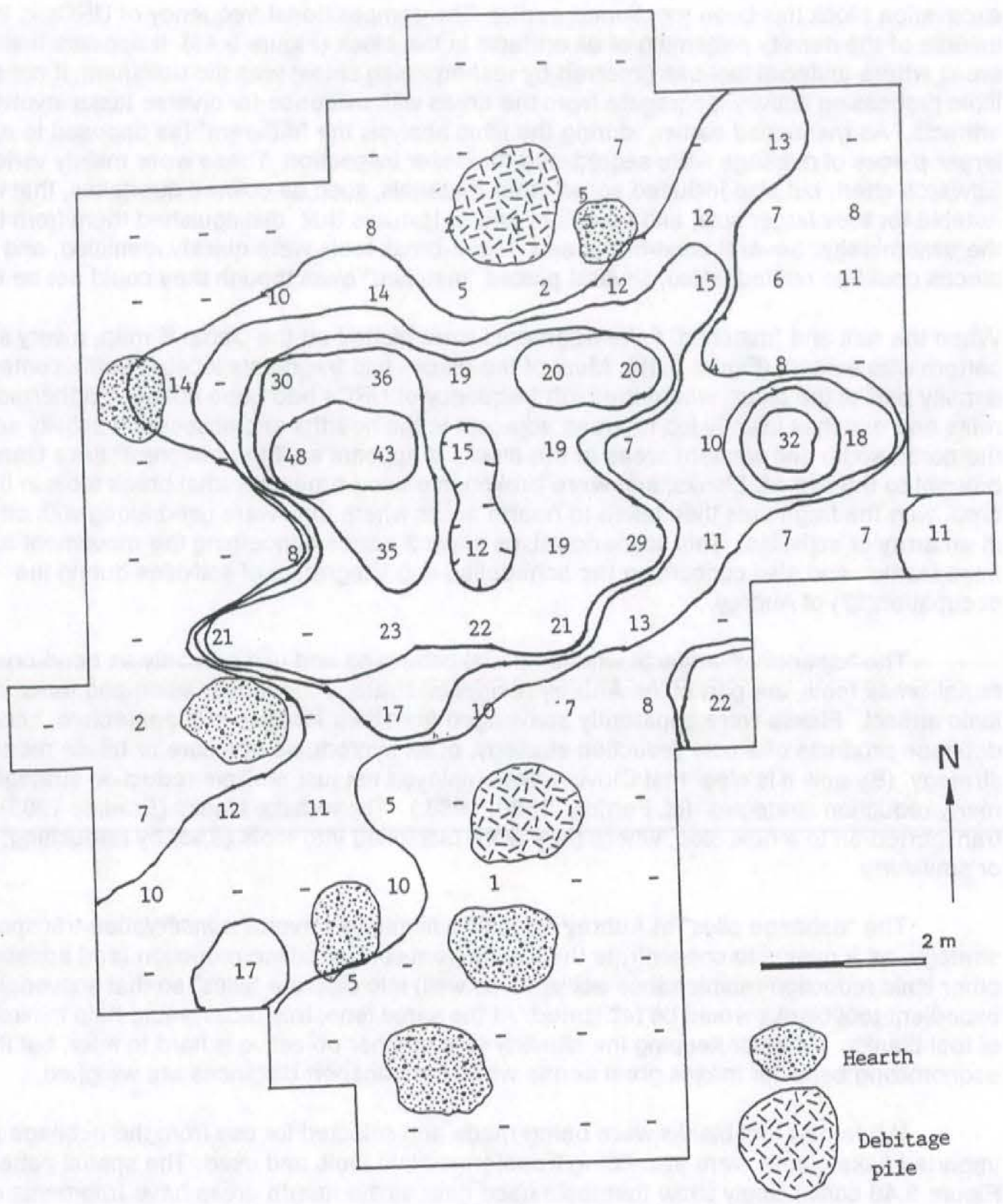

Figure 9.45 Frequency of uniface resharpening flakes by square meter units, Camp B. Note the highest frequencies in the central area between the hearths and other activity areas. 


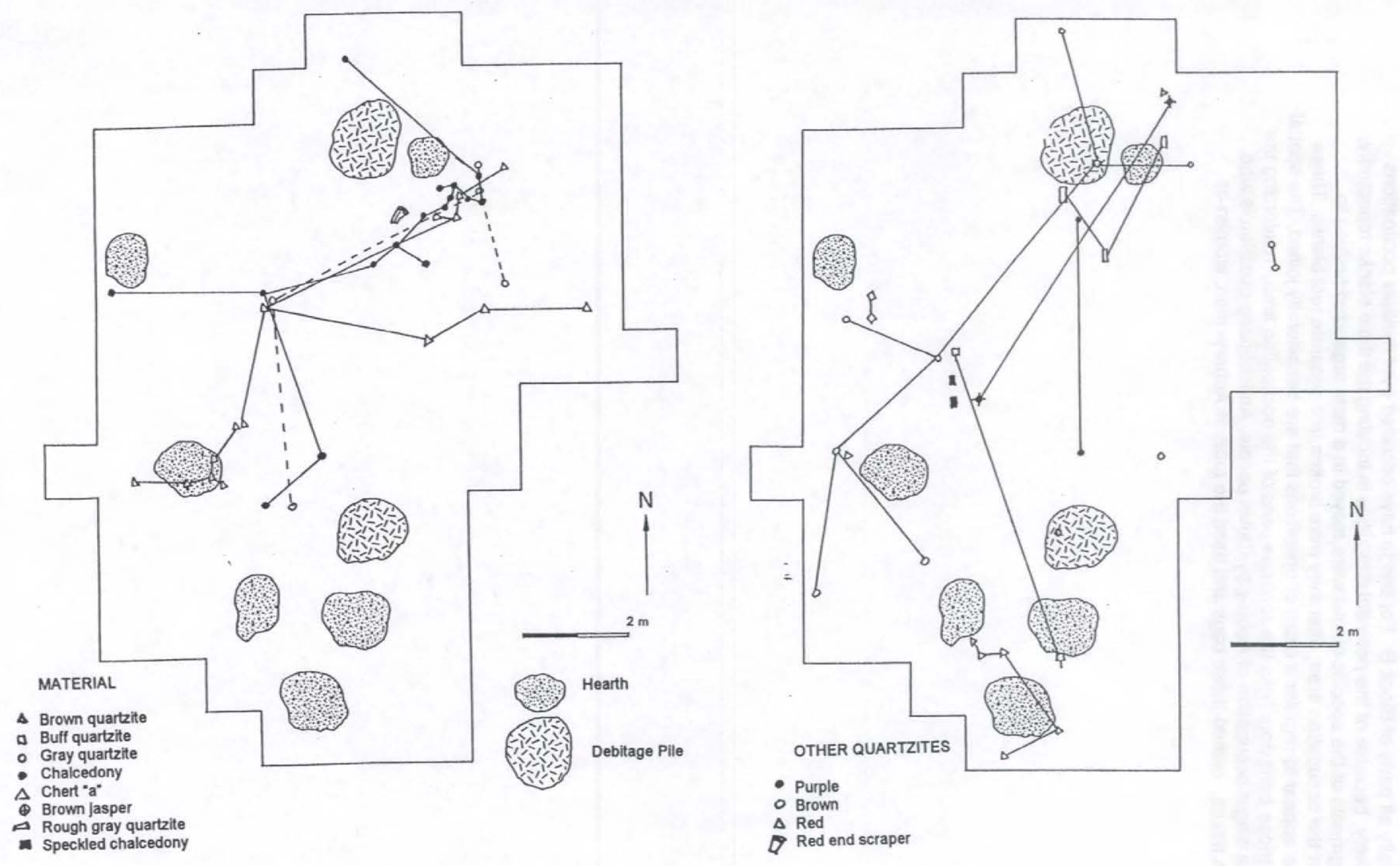

Figure 9.46 Map of refitted and matched bend break and radial break tools from Camp B. a- quartzites with distinctive colors; b- several kinds of chert, Chalcedony, jasper and quartzites. Note that specific pathways of movement of these artifacts, denoted by the connecting lines, are speculative. 
and used in virtually all parts of Block B. For this to have occurred over multiple occupations seems most unlikely, because of the potential difficulties in locating the flake blanks repeatedly, and because fragments of the specific blanks were moved in a quite organized fashion to separate areas of the occupation area, after they were broken into separate tool blanks. These artifacts therefore appear to register a chain of operations that are behaviorally joined. The spatial manifestation of those behaviors links the separate parts of the occupation area, reinforcing the interpretation of a single occupation of Aubrey by Clovis people. An intriguing question is who scavenged those flakes, owned those bags and used the tools at Aubrey- men, women or everybody? 


\title{
CHAPTER 10 SYNTHESIS
}

by

\author{
C. Reid Ferring
}

Introduction

The purpose of this chapter is to examine the Clovis archaeological record at the Aubrey Site in light of what is already known, or supposed, about the first Americans. In cases, the discussions will center about what is not known about the Clovis culture, which often seems to be a much more substantial subject, fed by sparse facts and generous assumptions. The fact that the Aubrey site contains a large amount of "data" pertinent to such a broad array of "data-starved" research issues makes these discussions quite risky. Weakly supported theories are sometimes more difficult to unend than are soundly supported conclusions. This is because weak theories are quite similar to hunches, which are intensely personal, and traditionally immune to question. The breadth of issues surrounding the peopling of the New World is daunting. That migration, or migrations, is one of the profound changes effected by modern humans from Eurasia in the late Quaternary that culminated in the cultural ascendancy of the last glacial maximum. Those cultural systems thrived by grace of the adaptive mechanisms that meaningfully define "modern human behavior." Their adaptations were based in complex new behaviors associated with at least nominal social differentiation, intra- and intergroup solidarity intensified through shared ritual and pervasive visual symbolism and a combination of high mobility and extremely efficient carnivory. In the arid Near East, their contemporaries forged on with domesticating cereals and succumbing to village life.

The peopling of the New World, hundreds of millennia after the first African exodus, has always been the subject of intense debates, many of which were fueled by tenaciously held assumptions concerning the nature of late Pleistocene cultures and the age and pathway of their entry into the New World (see Grayson 1984a, 1984b; Meltzer 1989b, 1995; Meltzer and Mead 1985; Stanford 1982, 1991; Haynes 1990). The "pre-Clovis" debate has been dressed up into alternative early entry versus late entry "models". But from the inception of these debates, the search for understanding of the "first immigrants" has usually been conducted in historical terms: When did they arrive? From where (culturally and geographically) did they come? How many migrations were there? How fast did they spread across the Americas? Did they drive some of their prey to dwarfism or even extinction? Were they generalists or specialists?

The importance of these questions to understanding the colonization of the New World is obvious. But they cannot be answered with Aubrey data alone, or even with data from a number of sites like Aubrey. The process of answering those questions will be aided by new discoveries, but not by "the" discovery. The colonization of the New World is a phenomenon as complex or more complex than comparable problems in the Old World, such as the initial exodus from Africa, or the domestication of cereals, or the fate of Neandertals. In some ways, the students of those testy Old World problems have some substantial, if only potential, advantages over the students of the Paleoindian period here. They enjoy the cumulative work of numerous geologists and paleoecologists who define the contexts for their problems. They enjoy the broad use of formal terminology and typology for lithic and bone artifacts. Old World prehistorians analyze and 
publish new discoveries in peer reviewed venues, and at periodic congresses, much more rapidly than their counterparts here.

Among Old World prehistorians there are well-known differences of substance and philosophy and personality. In too many cases these differences have become divisive and harmful to the science. But in many more cases, the protocols mentioned are generated by, and reinforce, the common recognition that the problems are BIG, and they require broad cooperation within a well-defined framework of concepts, methods and techniques, and unanimous subscription to the idea of science as cumulative acquisition of knowledge. The practice-habit of New World prehistorians to concoct ad hoc, idiosyncratic typologies, as for ceramics or projectile points, would be tantamount to pell mell creation of new names for fossils or minerals in Geology, or impromptu discard of Linnaean taxonomy in Biology.

My point is this: the record of Clovis activities, life ways and adaptive strategies at Aubrey is remarkable in both scope and detail, but probably very short on time. It is a rich glimpse, but a very brief one. The potential gain in knowledge, the potential advancement of Paleoindian studies, and the potential additions to the cumulative effort of archaeological science are diminished, and in some ways compromised, by the near impossibility for subjecting the Aubrey record to comparative analysis with other Clovis/Eastern Fluted Point sites. The published record of Clovis (and many other Paleoindian) sites and assemblages is small in comparison to publications that purport to interpret Paleoindian prehistory. But the publication record is not just small, it is often non-scientific. There is ample reason to suspect that the commonly inadequate training of North American students in lithic analysis has led to poor analyses of Paleoindian assemblages. More than that, this problem may have been a real obstacle for people to recognize a Paleoindian assemblage when it lay scattered before them at the base of a terrace scarp, possibly even lacking fluted bifaces!

In Paleoindian archaeology, there is no accepted system for describing artifacts, let alone a formal typology. Technological data in publications are commonly absent, and only rarely are presented in any detail. Even superb reports on archaeological sites and their internal structure are diminished by their idiosyncratic approach to artifact and assemblage analyses (for illustration of these restrained complaints, the reader is merely invited to get five good Paleoindian site reports, and construct detailed comparative analyses). In many of those cases it is probable, given the diligence of the authors, that an accepted system for description and classification, if available, would have been followed carefully. Those authors did not break ranks with tradition- they simply had no tradition to follow, and were forced to do something on their own. This author was placed in the same position.

These discussions build on the archaeological record at Aubrey described in previous chapters, especially: the periodicity and intensity of occupations, the nature and diversity of within-site activities, the modes of subsistence and the procurement/processing of lithic raw materials. The basis for this synthesis is: 1) descriptive analysis of artifact-feature data from Aubrey (Chapter 9), 2) description of the composition of the faunal remains (Chapters 8 and 9), and 3) definition of the intrasite structure, via compositional and density spatial analyses (Chapter 9), and 4) Aubrey's proxy evidence for past environments, including vertebrates, mollusks, pollen, insects, geology and stable isotopes. 
The Geochronology of Occupations at Aubrey

The age of Clovis occupations at Aubrey is set confidently at ca. 11,550 yr BP, based on two accelerator ages on charcoal from Camp B, and with exceptionally good bounding dates above and below the Clovis horizon at Aubrey (Figure 10.1). At Camp B, a minimal humate age on sediments overlying the Clovis horizon is $10,720 \pm 90 \mathrm{BP}$. In the pond area, the Clovis horizon is bounded by ages of $12,330 \pm 170$ $\mathrm{BP}$ and $10,940 \pm 80 \mathrm{BP}$. Thus there is excellent stratigraphic and radiometric evidence that Clovis occupations took place about 11,550 years ago. This is perhaps the oldest Clovis occupation thus far defined in North America, and is clearly older than fluted point occupations on the High Plains and desert Southwest (Haynes, 1993).

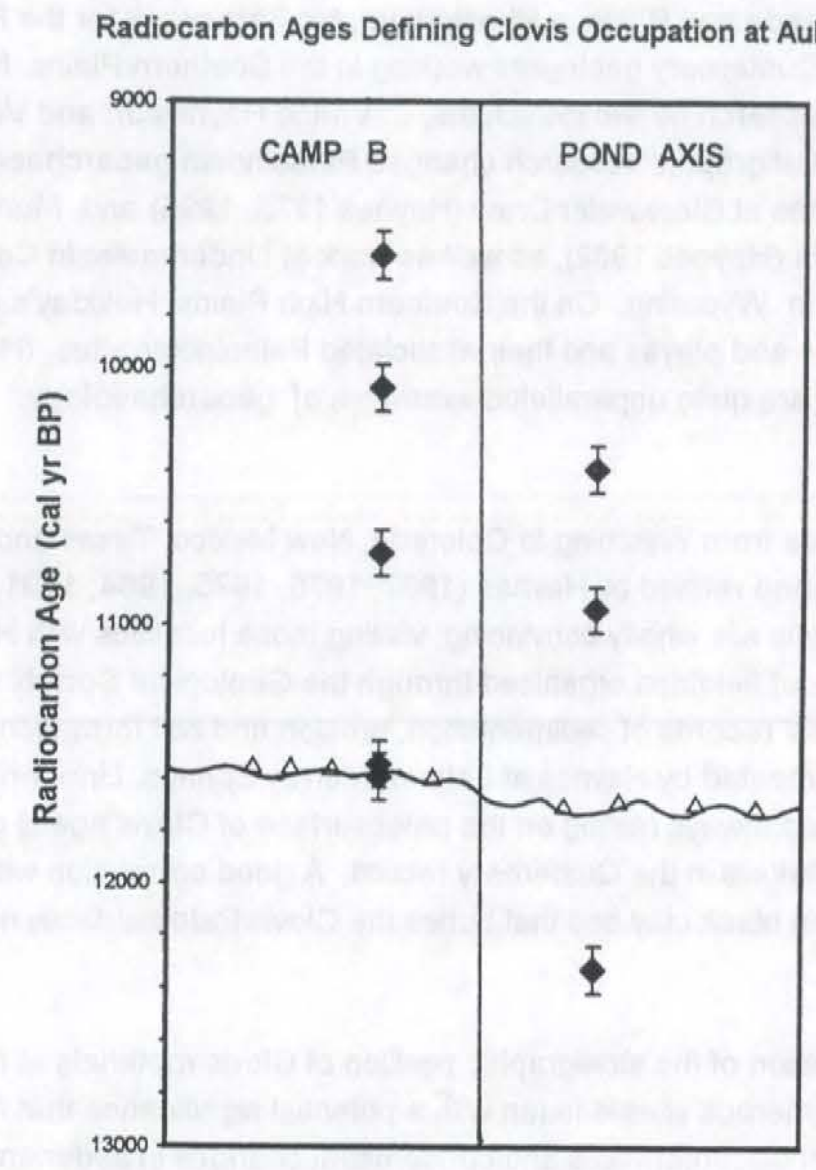

Figure 10.1 Radiocarbon ages defining the Clovis occupation at Aubrey

While the radiocarbon ages from Aubrey establish a good absolute chronology for the site, the lithostratigraphy and the biozonation made possible by analyses of the vertebrate and invertebrate faunas from Aubrey supply critical substantiation for the radiocarbon ages. These records have been reviewed in previous chapters, and will not be reiterated here. However, the eighteen extirpated taxa of mollusks 
discussed by Raymond Neck, the extinct and extirpated vertebrates (Bison antiquus, Mammuthus sp., Glossotherium harlani, and Synaptmys cooperi were all documented in the Clovis strata by Ernie Lundelius and Bonnie Yates. Last, the numerous species of insects discussed by Scott Elias corroborate the findings of the other studies. Lastly, the record of stable oxygen isotopes discussed by Humphrey and Ferring provided a remarkably detailed correlation with the established chronology of meltwater inputs to the Gulf of Mexico (Emeliani et al 1975).

The biozonation and isotopic chronology for Aubrey do corroborate the radiocarbon ages, and vice versa. A last chronological issue is that of the lithostratigraphic correlations of Aubrey with other late Pleistocene localities in the region, including those with Paleoindian occupations. Beginning with the early work of Sellards, Evans, Meade and Bryan, a lithostratigraphic framework for the Paleoindian period has been a recurrent focus for Quaternary geologists working in the Southern Plains. Most notable in that tradition are the results of research by two individuals, C. Vance Haynes Jr. and Vance T. Holliday. Haynes' Late Quaternary stratigraphic research changed Paleoindian geoarchaeology permanently. Of note are his major researches at Blackwater Draw (Haynes 1975, 1995) and Murray Springs (Haynes 1981) and Lehner in Arizona (Haynes 1982), as well as work at Lindenmeier in Colorado, the Folsom site in New Mexico, and Hell Gap in Wyoming. On the Southern High Plains, Holliday's exhaustive studies of the stratigraphy of draws, dunes and playas and their associated Paleoindian sites (Holliday 1995, 1996,1997, 2000 ; Holliday et al, 1994) are quite unparalleled examples of geoarchaeology.

For Paleoindian sites from Wyoming to Colorado, New Mexico, Texas and Arizona, the stratigraphic framework long advocated and refined by Haynes $(1967,1970,1975,1984,1991,1993)$ works extremely well. Although his publications are wholly convincing, visiting those localities with Haynes (the author having had that fortune on a series of fieldtrips organized through the Geological Society of America) the correlations among localities' records of sedimentation, erosion and soil formation is impressive. Just the infamous "black mat" documented by Haynes at Lehner, Murray Springs, Lindenmeier and Hell Gap (among other localities), and always resting on the paleosurface of Clovis age is one of the more provocative stratigraphic markers in the Quaternary record. A good correlation with Aubrey is afforded here, although there is a thin black clay bed that buries the Clovis Paleosurface, not a good, proper "black mat".

Haynes' demonstration of the stratigraphic position of Clovis materials at the erosional /deflationary disconformity defined at numerous sites is laden with a potential significance that has received relatively little discussion. The abrupt disconformities and concomitant changes in sedimentary environments that allow one to identify and correlate the position of Clovis materials in distantly spaced alluvial sections is nothing short of remarkable in the stratigraphic literature. That the disconformity correlates also with the disappearance of the vast majority of remaining Pleistocene megafauna, as stressed by Haynes, makes the disconformity altogether perfect for the lithostratigraphic, biostratigraphic and cultural boundary between the Pleistocene and the Holocene. The many, however, cling with mysterious loyalty to the conventional boundary set at 10,000 radiocarbon years ago, when practically nothing happened that could serve as a guide in the field, with archaeological records or with faunal assemblages. But that is another story. The boundary described by Haynes is dated at ca. 11,000 years ago, which USED to be a fair estimate for the ago of almost any Clovis site. Now there is quite good documentation that the Clovis folk were here at least 
500-600 years, leaving remarkably similar assemblages, and easily considered as a single cultural entity. (But this seeming homogeneity does need serious temper from study of many more in situ and well-dated sites.).

Whereas the Clovis sites that are well dated by radiocarbon spread over those 5-6 centuries, they still remain on that disconformity. In short, this situation suggests that the disconformity represents an environmentally forced geologic change that occurs over a huge region, but in time transgressive mode. The radiocarbon ages line up nicely with lots of overlap between adjacent ages (see Haynes 1984, 1993; Taylor et al 1996; Fiedel 1999), but the localities are different in age, and the differences are important in the context of monitoring rates of Clovis adaptations, possible radiation and Clovis culture change. At Aubrey, the record suggests that Clovis occupations correspond with a shift to greater precipitation, as registered by increased diversity of the molluscan and vertebrate populations. As discussed below, a similar amelioration of environments just about the time of Clovis occupations at a number of Southern Plains localities is suggested by available data. Should this record hold true for this region, it suggests that the "Clovis disconformity" indeed registers cl,imatic and environmental amelioration at the end of the Pleistocene (or at about 11-12,000 BP). Moreover, the time-transgressive association of Clovis occupations with those environmental shifts leads toward an observation that the first occupations of these distant regions of the Southern Plains, the High Plains and the Southwest by Clovis people was not simply a factor of the first Americans expanding their territory subsequent to their landfall. Rather, it suggests the possibility that the ages of the Clovis sites on the "Clovis disconformity" define the age of environmental changes that were sufficient to support such an exploratory expansion. This is suggesting, in other words, that the age of the occupations at Aubrey and other Clovis sites represent the first secure opportunity for those populations to explore inland from the coastal regions.

\section{The Environmental Context of the Clovis Occupations at Aubrey}

Palynology

Until this work at Aubrey, there were no pollen records from the upper Trinity River basin. The Aubrey pollen record (Hall, this volume) unfortunately comments only on the late Pleistocene vegetation prior to Clovis occupations. However, this record is extremely important in terms of environmental changes that may have preceded (or accompanied?) initial occupations of this region, including their implications for Pleistocene extinctions. Using the total pollen data, arboreal taxa can be seen to have been only $10-30 \%$ as those of the modern prairies, and grass pollen have extremely high frequencies (Table 10.1; Figure 10.2). When riparian plant taxa are removed from the data, comparisons of the late Pleistocene oak-grass ratios accentuate the difference between the modern and Pleistocene communities. The vegetation indicated by the Aubrey pollen data is significantly more open than present day conditions. This conclusion I supported by the insect and molluscan data, as discussed below.

Only a few dated pollen spectra are available from peripheral settings (Bryant and Holloway, 1985). Older claims that the full glacial vegetation of the Southern Plains was boreal in character have been seriously challenged. First, Holliday (1987) used pedogenic data from the High Plains (Llano Estacado) to show that podzolization (essential evidence for forested vegetation) was not part of the late Quaternary soils record. Hall's (1992b) analysis of full glacial (ca. 19-17 ka old) pollen from the High Plains showed that a 
Table 10.1 Aubrey Pollen Data. Modified from Hall (this volume)

\begin{tabular}{|c|c|c|c|c|c|c|c|c|c|c|c|c|c|}
\hline \multirow{3}{*}{ TAXA } & \multicolumn{2}{|c|}{ MODERN } & \multicolumn{4}{|c|}{ POND AXIS } & \multicolumn{6}{|c|}{ POND MARGIN/ SPRING VENT } & \multirow[b]{2}{*}{ Stratum } \\
\hline & & & & tra & & B1 & & & & & & & \\
\hline & X-TIMB & PRAIRIE & 1 & 2 & 3 & 4 & 5 & 6 & 7 & 8 & 9 & 10 & 11 \\
\hline Picea & 0 & 0 & 1 & 2 & 2 & 1 & 3 & 1 & 3 & 3 & 1 & 0 & 1 \\
\hline Pinus & 1 & 13 & 1 & 2 & 1 & 5 & 12 & 12 & 9 & 13 & 9 & 26 & 16 \\
\hline Juniperus & 1 & 16 & 5 & 5 & 9 & 7 & 22 & 29 & 36 & 22 & 32 & 13 & 11 \\
\hline Quercus & 210 & 60 & 14 & 24 & 15 & 15 & 15 & 33 & 26 & 28 & 35 & 6 & 43 \\
\hline Carya & 39 & 6 & 0 & 0 & 0 & 1 & 0 & 1 & 0 & 1 & 3 & 0 & 0 \\
\hline Ulmus & 34 & 13 & 0 & 0 & 0 & 0 & 0 & 0 & 0 & 0 & 0 & 0 & 0 \\
\hline Corylus & 0 & 0 & 1 & 4 & 4 & 3 & 4 & 9 & 5 & 8 & 11 & 0 & 0 \\
\hline Fraxinus & 10 & 8 & 3 & 6 & 2 & 3 & 7 & 13 & 6 & 13 & 7 & 9 & 6 \\
\hline sum & 295 & 116 & 25 & 43 & 33 & 35 & 63 & 98 & 85 & 88 & 98 & 54 & 77 \\
\hline Populus & 0 & 0 & 6 & 1 & 5 & 1 & 2 & 3 & 0 & 0 & 4 & 2 & 8 \\
\hline Alnus & 0 & 0 & 2 & 6 & 7 & 6 & 100 & 22 & 86 & 36 & 29 & 246 & 2 \\
\hline Salix & 2 & 1 & 2 & 1 & 0 & 1 & 14 & 19 & 35 & 4 & 10 & 5 & 2 \\
\hline Planera & 0 & 0 & 1 & 3 & 5 & 8 & 0 & 16 & 3 & 18 & 2 & 0 & 0 \\
\hline sum & 2 & 1 & 11 & 11 & 17 & 16 & 116 & 60 & 124 & 58 & 45 & 253 & 12 \\
\hline Poaceae & 63 & 94 & 675 & 641 & 763 & 750 & 134 & 138 & 141 & 97 & 115 & 125 & 72 \\
\hline Ambrosia & 61 & 101 & 7 & 7 & 9 & 3 & 37 & 31 & 14 & 22 & 26 & 41 & 62 \\
\hline Franseria & 0 & 0 & 2 & 3 & 2 & 2 & 1 & 0 & 0 & 0 & 0 & 4 & 5 \\
\hline Cirsium & 0 & 0 & 1 & 0 & 0 & 0 & 7 & 2 & 4 & 2 & 1 & 3 & 0 \\
\hline Artemesia & 1 & 4 & 6 & 9 & 7 & 7 & 13 & 10 & 22 & 18 & 11 & 6 & 15 \\
\hline Asteraceae & 22 & 128 & 19 & 18 & 17 & 35 & 161 & 116 & 97 & 99 & 97 & 71 & 110 \\
\hline Chenopod & 11 & 14 & 4 & 0 & 1 & 1 & 7 & 6 & 8 & 6 & 5 & 4 & 8 \\
\hline Rubus & 0 & 0 & 0 & 0 & 0 & 0 & 0 & 18 & 1 & 7 & 0 & 0 & 0 \\
\hline Urtica & 0 & 0 & 0 & 0 & 0 & 0 & 0 & 10 & 0 & 3 & 2 & 0 & 0 \\
\hline Rosaceae & 0 & 0 & 0 & 2 & 1 & 0 & 0 & 0 & 1 & 0 & 2 & 0 & 0 \\
\hline Apiaceae & 0 & 0 & 3 & 1 & 3 & 5 & 18 & 22 & 15 & 8 & 14 & 12 & 24 \\
\hline Brassicaceae & 1 & 4 & 6 & 1 & 7 & 1 & 38 & 2 & 0 & 13 & 9 & 11 & 33 \\
\hline Thalictricum & 0 & 0 & 1 & 0 & 1 & 0 & 0 & 8 & 1 & 6 & 6 & 1 & 1 \\
\hline Liliaceae & 0 & 0 & 0 & 0 & 0 & 0 & 0 & 1 & 5 & 1 & 3 & 0 & 0 \\
\hline sum & 159 & 345 & 724 & 682 & 811 & 804 & 416 & 364 & 309 & 282 & 291. & 278 & 330 \\
\hline
\end{tabular}

\begin{tabular}{|c|c|c|c|c|c|c|c|c|c|c|c|c|c|}
\hline Cyperaceae & 0 & 2 & 53 & 49 & 41 & 161 & 147 & 237 & 393 & 296 & 405 & 333 & 534 \\
\hline Typha sp & 0 & 2 & 1 & 2 & 7 & 12 & 18 & 16 & 12 & 17 & 16 & 10 & 4 \\
\hline Sagittaria & 0 & 0 & 4 & 5 & 2 & 5 & 0 & 4 & 0 & 3 & 0 & 1 & 0 \\
\hline Myriophyllum & 0 & 0 & 1 & 0 & 1 & 0 & 1 & 0 & 2 & 5 & 0 & 0 & 1 \\
\hline Polypodiaceat & 0 & 0 & 0 & 0 & 0 & 0 & 2 & 5 & 1 & 1 & 3 & 3 & 2 \\
\hline Pediastrum & 0 & 0 & 10 & 0 & 5 & 3 & 0 & 1 & 3 & 1 & 4 & 0 & 0 \\
\hline Botryococcus & 0 & 0 & 6 & 2 & 0 & 0 & 1 & 2 & 4 & 0 & 8 & 0 & 0 \\
\hline sum & 0 & 4 & 75 & 58 & 56 & 181 & 169 & 265 & 415 & 323 & 436 & 347 & 541 \\
\hline unkn & 4 & 13 & 14 & 6 & 13 & 12 & 36 & 39 & 39 & 16 & 28 & 24 & 13 \\
\hline indet & 6 & 7 & 6 & 5 & 10 & 4 & 34 & 13 & 26 & 11 & 13 & 4 & 38 \\
\hline sum & 10 & 20 & 20 & 11 & 23 & 16 & 70 & 52 & 65 & 27 & 41 & 28 & 51 \\
\hline TOTAL & 470 & 490 & 856 & 806 & 941 & 1056 & 837 & 840 & 1005 & 773 & 913 & 962 & 1013 \\
\hline Conc. & 92.3 & 59.1 & 75.3 & 40.8 & 57.1 & 97.1 & 5.0 & 16.9 & 16.3 & 14.1 & 19.7 & 16.4 & 26.9 \\
\hline SUM A & 456 & 462 & 760 & 736 & 861 & 855 & 595 & 522 & 518 & 428 & 434 & 585 & 419 \\
\hline SUM B & 470 & 490 & 854 & 800 & 934 & 1050 & 737 & 818 & 919 & 737 & 884 & 716 & 1011 \\
\hline
\end{tabular}

$\begin{array}{lrrrrrrrrrrrrr}\text { Quercus } & 44.7 & 12.2 & 1.6 & 3.0 & 1.6 & 1.4 & 2.0 & 4.0 & 2.8 & 3.8 & 4.0 & 0.8 & 4.3 \\ \text { Juniperus } & 0.2 & 3.3 & 0.6 & 0.6 & 1.0 & 0.7 & 3.0 & 3.5 & 3.9 & 3.0 & 3.6 & 1.8 & 1.1 \\ \text { Poaceae } & 13.4 & 19.2 & 79.0 & 80.1 & 81.7 & 71.4 & 18.2 & 16.9 & 15.3 & 13.2 & 13.0 & 17.5 & 7.1 \\ \text { Ambrosia } & 13.0 & 20.6 & 0.8 & 0.9 & 1.0 & 0.3 & 5.0 & 3.8 & 1.5 & 3.0 & 2.9 & 5.7 & 6.1 \\ \text { Artemesia } & 0.2 & 0.8 & 0.7 & 1.1 & 0.7 & 0.7 & 1.8 & 1.2 & 2.4 & 2.4 & 1.2 & 0.8 & 1.5 \\ \text { Asteraceae } & 4.7 & 26.1 & 2.2 & 2.3 & 1.8 & 3.3 & 21.8 & 14.2 & 10.6 & 13.4 & 11.0 & 9.9 & 10.9 \\ \text { AP } & & & & & & & & & & & & & \\ \text { AP } & 23.7 & 2.9 & 5.4 & 3.5 & 3.3 & 8.5 & 12.0 & 9.2 & 11.9 & 11.1 & 7.5 & 7.6\end{array}$


AUBREY Oak and Grass Pollen

100

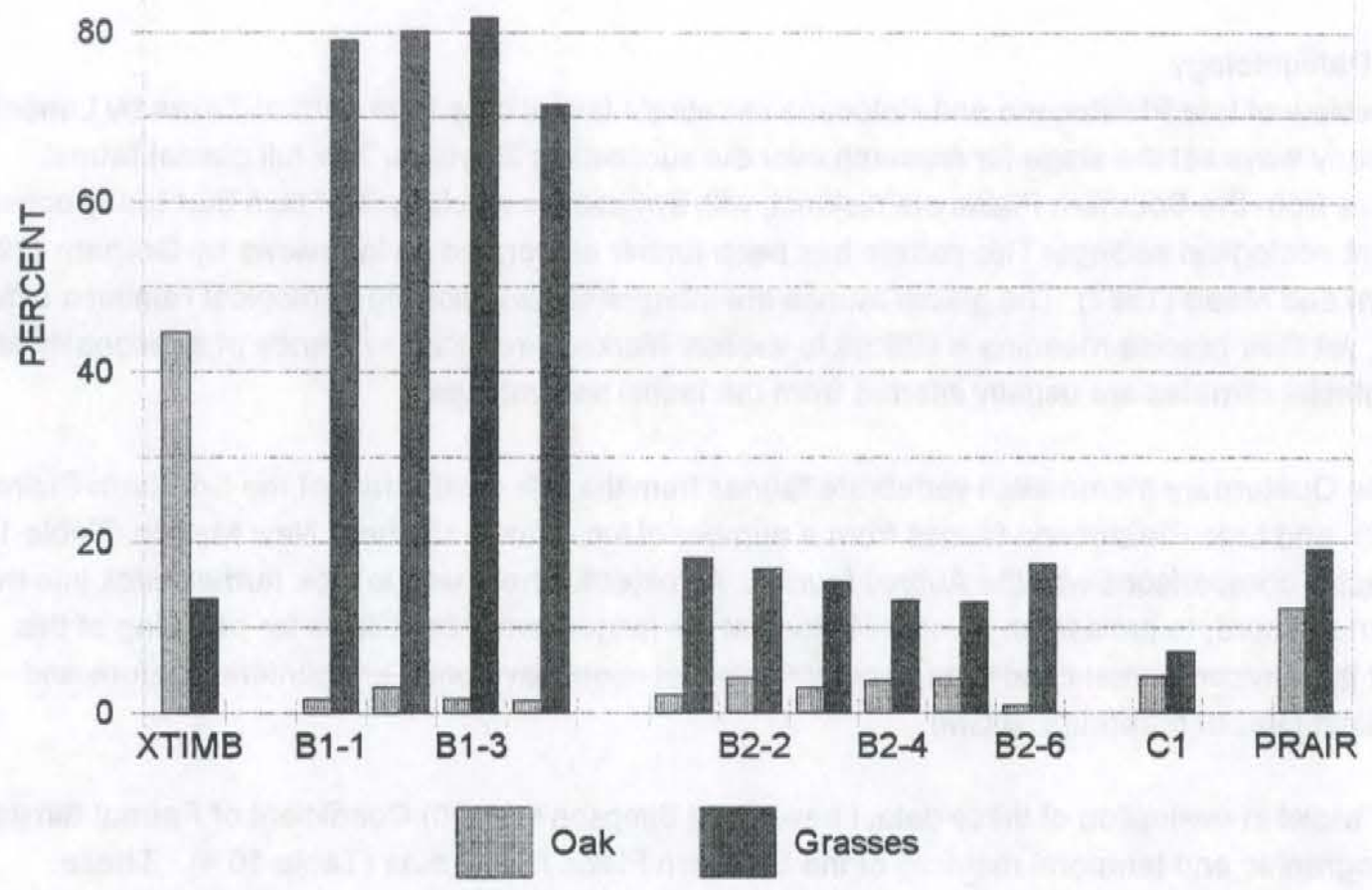

Figure 10.2 Summary of pollen from the Aubrey Site

grassland not unlike the flora of today existed in that interval. The grasslands in the environs of Aubrey between ca. 14.5-12.0 ka, matched by a record of an open prairie at the Domebo Clovis site in Oklahoma, ca. 11.2 ka (Wilson, 1966).

Ferndale Bog, located in the Ouachita Mountains of southeast Oklahoma, was cored and studied initially by Albert (1981). The bog was cored again in 1981 by Holloway and Ferring; their deeper core recovered sediments with well-preserved pollen from late Pleistocene to late Holocene (ca. 11.8 to $0.6 \mathrm{ka}$ ) (Holloway, 1993). The late Pleistocene and early Holocene vegetation was dominated by grass and ambrosia, with moderate frequencies of oak and birch, probably representing sparse upland and riparian arboreal elements, respectively. An ambrosia peak at ca. $11 \mathrm{ka}$ is followed by a grass peak ca. $10 \mathrm{ka}$; declines in these taxa are accompanied by increases in oak and composites. Overall, the early Holocene 
vegetation is one of an open grassland-artemisia steppe, with a succession to an oak savannah. Early Holocene pollen influx values are very high, suggesting high plant biomass.

The pollen data from Ferndale and Boriack suggest that late Pleistocene vegetation reflects successional changes from the full glacial communities, coupled with a general drying trend that appears to have climaxed just before Clovis occupations. Wetter prairie environments followed in the early Holocene, during Folsom-Dalton occupations.

Vertebrate Paleontology

A review of late Pleistocene and Holocene vertebrate faunal data from central Texas by Lundelius (1967) in many ways set the stage for research over the succeeding 25 years. The full glacial faunal assemblages from the Southern Plains are disjunct, with sympatric associations of taxa that today occupy very different ecological settings. This pattern has been further elaborated on in reviews by Graham (1987) and Graham and Mead (1987). The glacial faunas are interpreted as indicating ecological relations different from today, yet their precise meaning is difficult to assess. Markedly reduced extremes of seasonality and wetter full glacial climates are usually inferred from the faunal assemblages.

Late Quaternary mammalian vertebrate faunas from the late Quaternary of the Southern Plains (Table 10.2), and Late Pleistocene faunas from a number of localities in southern New Mexico (Table 10.3) provide specific comparisons with the Aubrey faunas. An objective here was to look farther back into the environmental record, to provide an (overdue?) look at the longer-term possibilities for peopling of this region, and the environmental conditions or constraints that might have been encountered before and during the Last Glacial Maximum (LGM).

To assist in evaluation of these data, I have used Simpson's (1960) Coefficient of Faunal Similarity, for both geographic and temporal matrices of the Southern Plains faunal data (Table 10.4). These comparisons show that faunas of full glacial and Clovis age are significantly more different from each other than are faunas spanning the full glacial to Holocene record within regions, even though those records include all Pleistocene extinctions! Clovis faunas are very diverse compared to early and late Holocene faunas grouped for the whole region. While Clovis faunas are slightly more similar to each other than are the full glacial faunas, the Clovis age faunas have an average Simpson's $C$ that is less than half that of the late Holocene faunas (Table 10.4)

The patterns of faunal change in the late Pleistocene of this region are anything but a gradual or stepped loss of taxa to extinction (Table 10.5). Many taxa, including significant numbers of extinct taxa "fluxed" over the late Pleistocene, with losses and gains characteristic even through the Holocene. Notable is the fact that Clovis age faunas gained more taxa than it lost, attaining a total of 67 taxa, compared to 24 in the modern lists and 34 in late Holocene records. Indeed, a significant pattern of the shifts from glacial to Clovis-age faunas, from the Southern Plains as well as New Mexico, is that diversity INCREASED significantly into the Clovis period. This is hardly the scenario one might expect in a deteriorating post-glacial environment. Notably, ALL of the Clovis age taxa survived the LGM, but many were immigrants to this region following the LGM. Of Clovis age faunas, there are still $20 / 69(29 \%)$ taxa that became extinct. Among Clovis aged faunas, carnivores have notably low frequencies. And the two big fast predators of the Late Pleistocene here, the sabre-tooth and the short-faced bear, are both late arrivals. Most interesting is that there are NO carnivores in the camp faunas from Aubrey, and except for Blackwater Draw, carnivores 
Table 10.2 Late Quaternary Mammalian Faunas from Southern Plains Localities

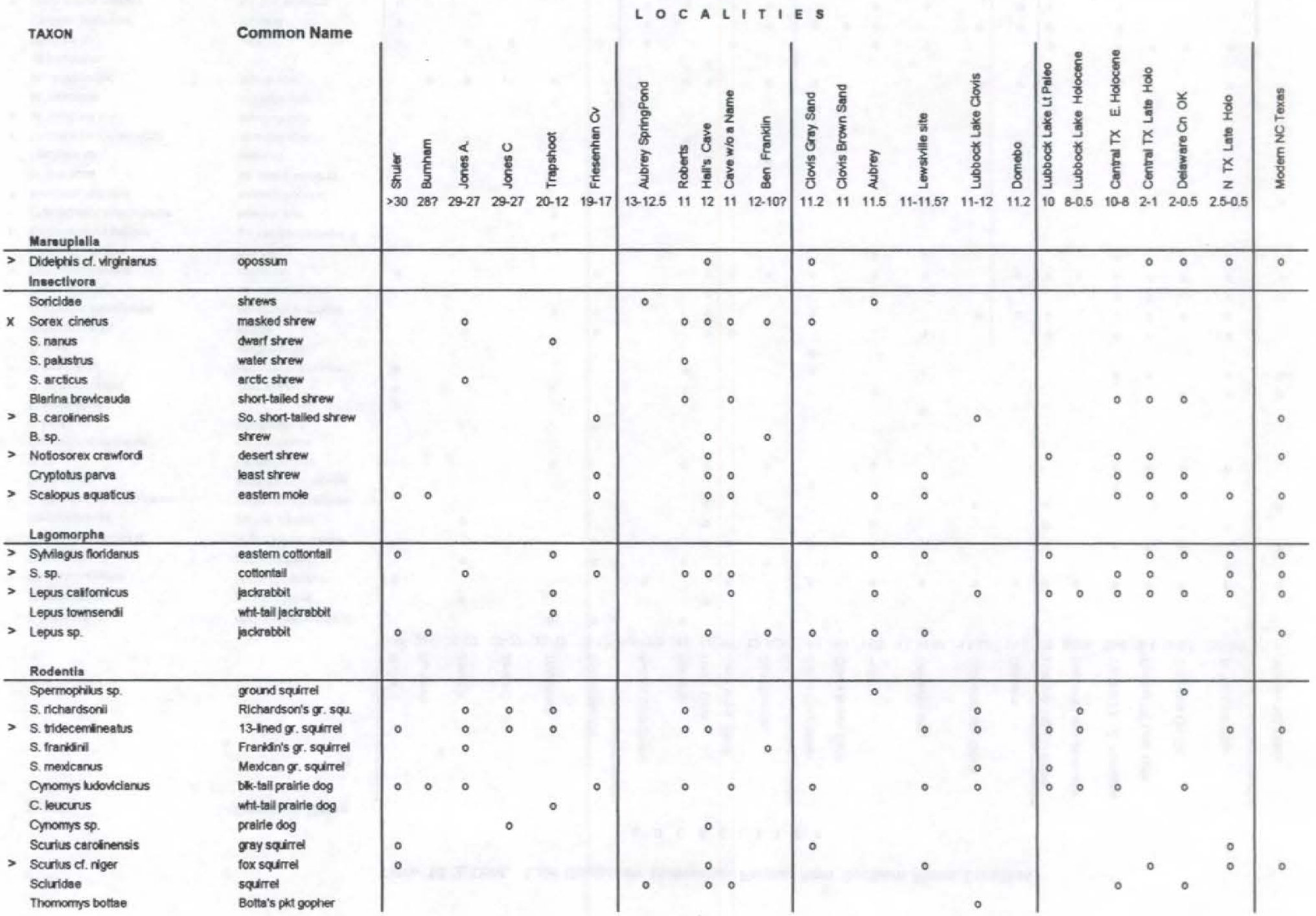




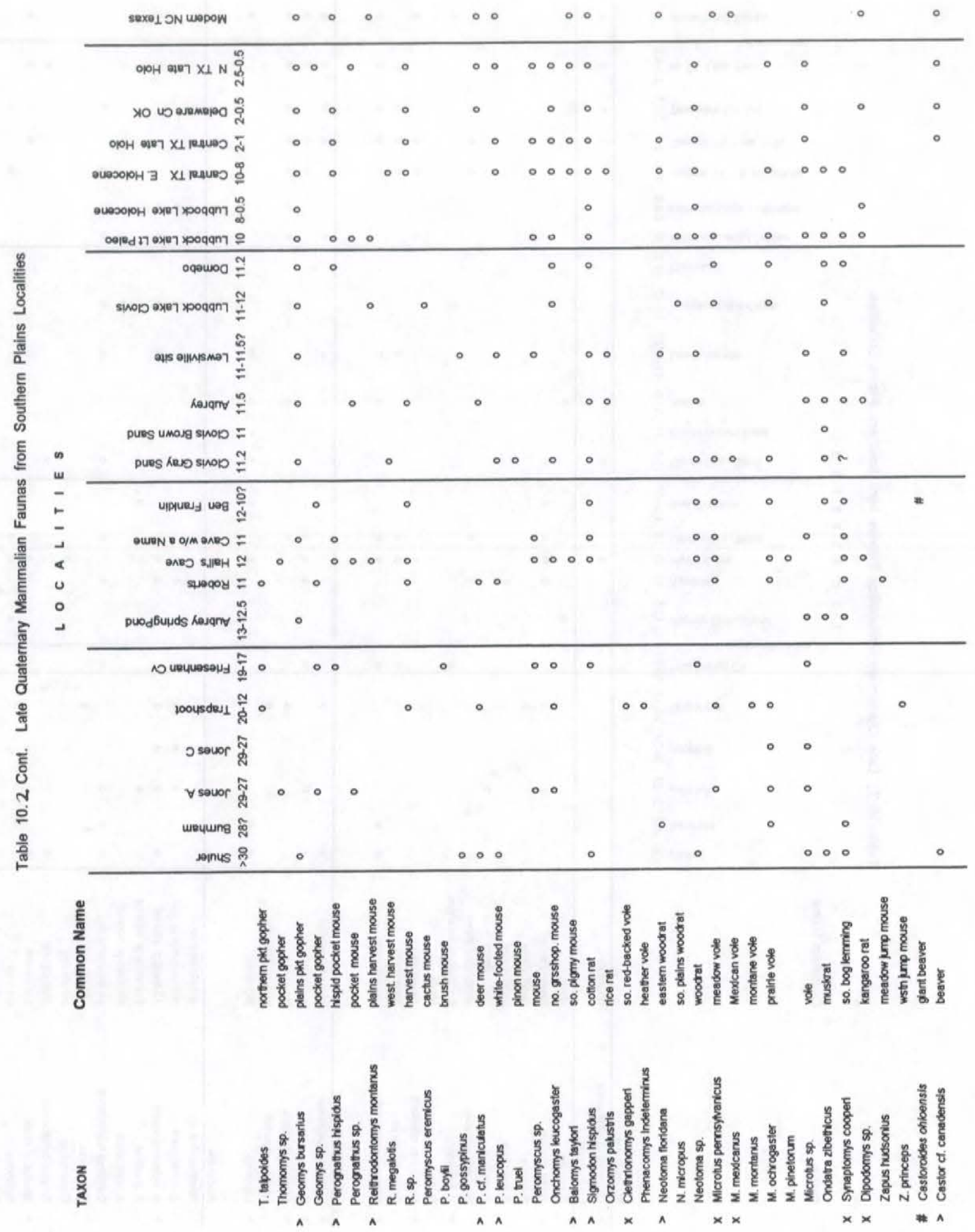


Table 10.2 Cont. Late Quaternary Mammalian Faunas from Southern Plains Localities

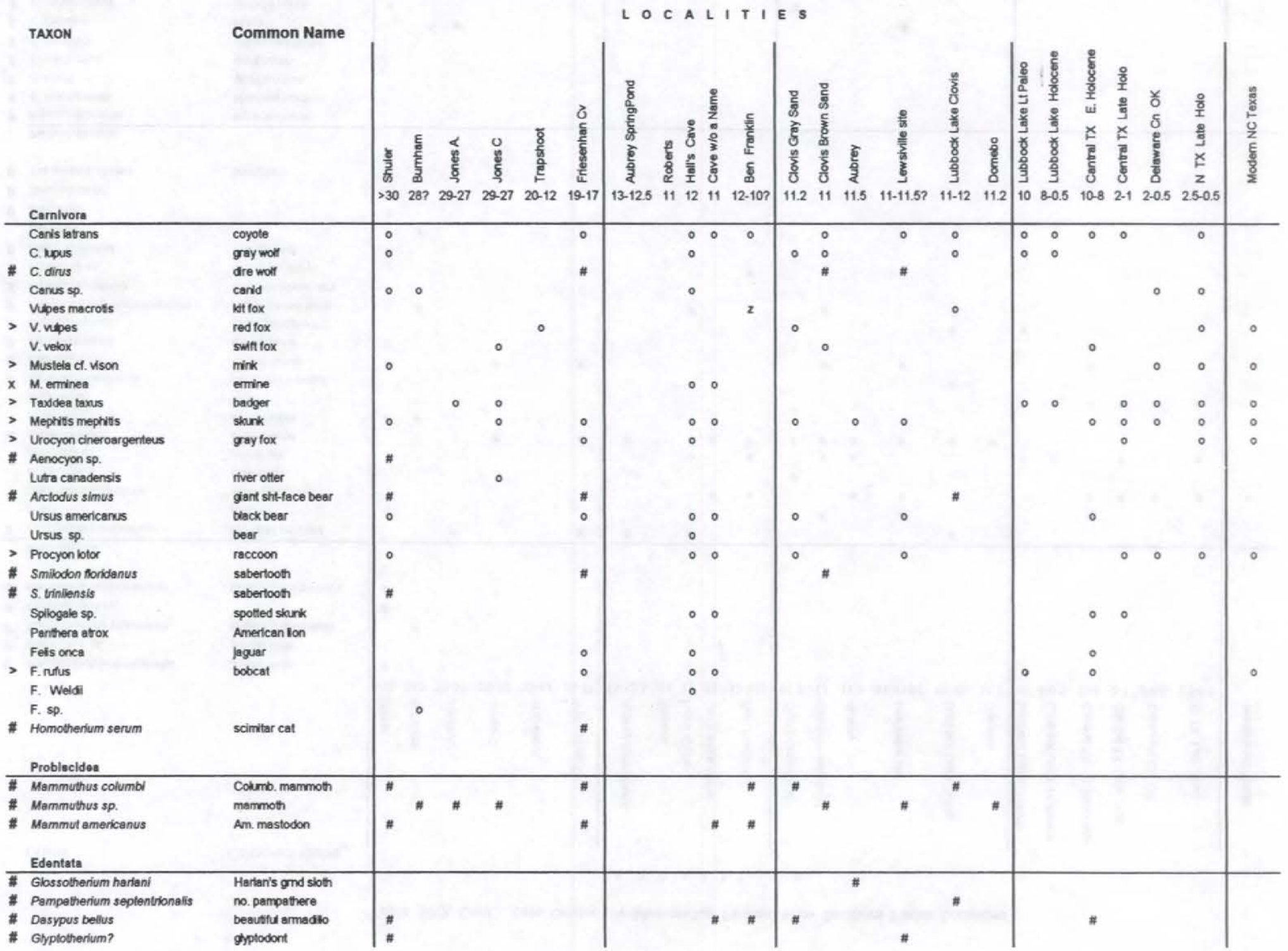


Table 10.2. Cont. Late Quaternary Mammalian Faunas from Southern Plains Localities

TAXON

Common Name

* Megalonyx brachycephalus

* Megalonyx sp.

Nothrotheriops shastensis

\# Paramylodon sp.

- Holmesina septentrionallis

Artiodactyla

\# Platygonus compressus

P. sp.

$>$ Odocolleus virginianus

0 . hemorius

Antliocapra

* Bison antquus

Bison sp.

* Camelops hestemus

\# Camelops sp.

* Tanupolama sp.

- Capromeryx sp.

Hemlauchenia macrocephai

* Mylohyus nasutus

- Mylohyus sp.

\# Dama virgiriana

Cenvidae

\# Dama sp.

\# Breameryx sp.

* Tetrameryx shuier

Perissodectyla

\# Equus mexccanus

\# E. niobrarensis

\# E. scote

\# E. mexdcanus

\# E. francisct

\# E. cabalus

\# E.midandensis

\# E.sp.

\# Tapinus veroensis

\# Tapirus sp.

\section{ground sloth}

ground sioth

Shasta ground sioth

Northern pampathere

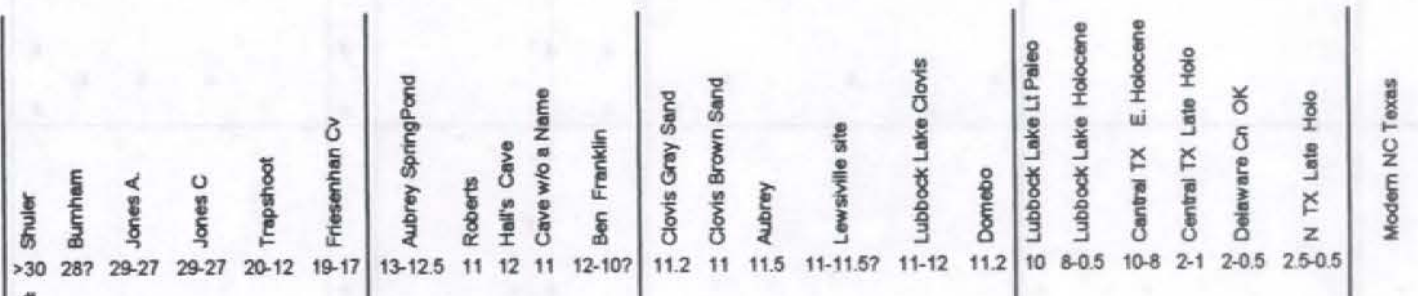

nathead peccary

peccary

whita-talled deer

mile deer

pronghom

extinct bison

exenct bison

yesterday's came

extinct camel

exinct lams

dimin pronghorn

large-headed lame

extinct peccary

extinct deer

LOCALITIES 
Table 10.2 Cont. Late Quaternary Mammalian Faunas from Southern Plains Localities

TAXON

SUMMARIES
Common Name

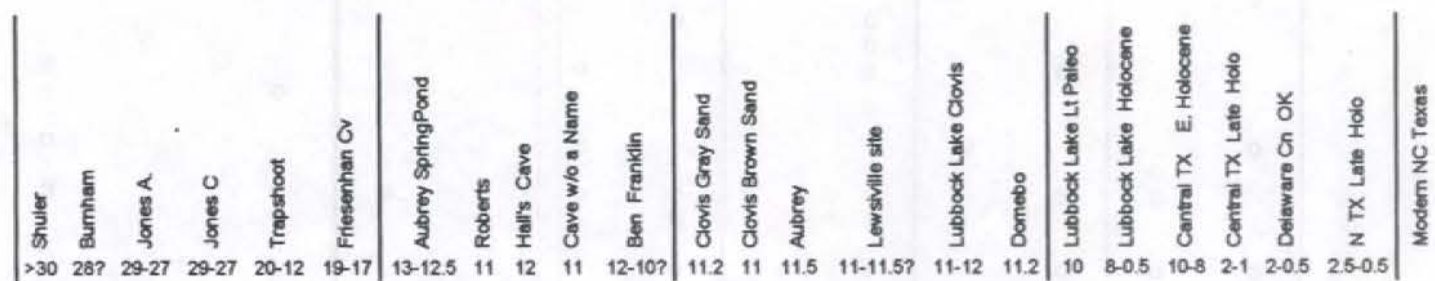

\begin{tabular}{|c|c|c|c|c|c|c|c|c|c|c|c|c|c|c|c|c|c|c|c|c|c|c|c|c|}
\hline Insectivores & 1 & 1 & 2 & 0 & 1 & 3 & 1 & 3 & 5 & 4 & 2 & 1 & 0 & 2 & 2 & 1 & 0 & \begin{tabular}{l|l|}
1 \\
\end{tabular} & 0 & 4 & \begin{tabular}{|l|}
4 \\
\end{tabular} & 3 & 1 & 3 \\
\hline Lagomorphs & 2 & 1 & 1 & 0 & 3 & 1 & 0 & 1 & 2 & 2 & 1 & 1 & 0 & 3 & 2 & 1 & 0 & 2 & 1 & 2 & 3 & 2 & 3 & 4 \\
\hline Rodentia & 14 & 4 & 12 & 5 & 13 & 10 & 5 & 12 & 19 & 10 & 10 & 14 & 1 & 12 & 13 & 13 & 8 & 18 & 7 & 18 & 13 & 13 & 17 & 14 \\
\hline Carnivora & 7 & 2 & 1 & 4 & 1 & 6 & 0 & 0 & 13 & 7 & 1 & 5 & \begin{tabular}{|l|l|}
3 \\
\end{tabular} & 1 & 4 & 3 & 0 & 4 & 3 & 7 & \begin{tabular}{|l|}
6 \\
\end{tabular} & 5 & 8 & \begin{tabular}{|l|}
7 \\
\end{tabular} \\
\hline extinct & 3 & & & & & 4 & & & & & & & 2 & & 1 & 1 & & & & & & & & \\
\hline Probiscidea & 2 & 1 & 1 & 1 & 0 & 2 & 0 & 0 & 0 & 1 & 2 & 1 & 1 & 1 & 1 & 1 & 1 & 0 & 0 & 0 & \begin{tabular}{|l|}
0 \\
\end{tabular} & 0 & 0 & \\
\hline Edentata & 5 & 1 & 0 & 0 & 0 & 0 & 0 & 0 & 0 & 1 & 1 & 1 & 0 & 1 & 1 & 1 & 0 & 0 & 0 & 1 & \begin{tabular}{l|}
0 \\
\end{tabular} & 0 & 0 & \\
\hline Artiodactyla & 7 & 3 & 1 & 2 & 1 & 4 & 2 & 0 & 3 & 1 & 2 & 2 & \begin{tabular}{|l|l|}
3 \\
\end{tabular} & 2 & 2 & 5 & 1 & 1 & 2 & 4 & \begin{tabular}{|l|}
3 \\
\end{tabular} & 3 & 3 & 1 \\
\hline & 1 & & & & & & & & 1 & 1 & 2 & 1 & 2 & 2 & 2 & 0 & & 2 & & 2 & & & & \\
\hline Perrissodactyla & 1 & 1 & 1 & 1 & 0 & 2 & 0 & 0 & 1 & 1 & 0 & 2 & \begin{tabular}{|l|l|}
3 \\
\end{tabular} & 0 & 1 & 2 & 0 & 0 & 0 & 2 & \begin{tabular}{|l|}
0 \\
\end{tabular} & 0 & 0 & \\
\hline TOTAL TAXA & 43 & 14 & 19 & 13 & 19 & 32 & 8 & 16 & 44 & 28 & 21 & 28 & 15 & 24 & 29 & 28 & 10 & 28 & 13 & 40 & 29 & 26 & 32 & 29 \\
\hline
\end{tabular}


Table 10.3 Late Pleistocene Mammalian Faunas from Localities in Southern New Mexico ${ }^{1}$

\begin{tabular}{|c|c|c|c|c|c|c|c|c|c|c|c|c|c|c|c|c|c|c|c|}
\hline $\begin{array}{l}\text { Name } \\
\text { * oxtinet }\end{array}$ & Common Name & \begin{tabular}{|l} 
Room \\
Varishing \\
Floor \\
33,590
\end{tabular} & $\begin{array}{l}\text { Lost } \\
\text { Voley } \\
29,290\end{array}$ & $\begin{array}{l}\text { Sabretooth } \\
\text { Camel } \\
\text { Maze } \\
25,160\end{array}$ & $\begin{array}{l}\text { Muskox } \\
\text { Cave } \\
25-18,000\end{array}$ & $\begin{array}{l}\text { PAt N } \\
\text { W Avimal } \\
\text { Fair }\end{array}$ & $\begin{array}{l}\text { Camel } \\
\text { Room }\end{array}$ & $\begin{array}{c}\begin{array}{c}\text { Avimal Fall } \\
\text { Younger }\end{array} \\
15,030\end{array}$ & 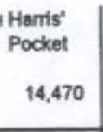 & $\begin{array}{l}\text { Humen } \\
\text { Corridor } \\
<15,000 \\
>12,000\end{array}$ & $\begin{array}{l}\text { Bison } \\
\text { Chamber } \\
<14,470 \\
>10,730\end{array}$ & $\mid \begin{array}{r}\text { Staligg } 17 \\
11,880\end{array}$ & 10,730 & \begin{tabular}{|} 
Sloth \\
Lower \\
11,600
\end{tabular} & $\begin{array}{l}\text { Cave } \\
\text { Upper } \\
10.8-11.8\end{array}$ & \begin{tabular}{|ll}
\multicolumn{2}{|c}{ Biackwater } \\
Gray & B \\
Sand & S \\
$>12,000$ &
\end{tabular} & $\begin{array}{l}\text { or Draw } \\
\text { Brown } \\
\text { Sand } \\
11,200\end{array}$ & $\begin{array}{ll}\text { Wilam's } & B \\
\text { Cave } & C \\
12.1-11,20 \times 12\end{array}$ & $\begin{array}{l}\text { Bumet } \\
\text { Cave } \\
\text { ch2-11,000? }\end{array}$ \\
\hline Didelphis ct. Urginanus & opossum & & & & & & & & & & & & & & & & 0 & & \\
\hline 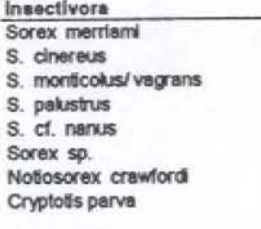 & $\begin{array}{l}\text { Merriam's strew } \\
\text { Masked strew } \\
\text { Vagrant-like strew } \\
\text { Water strew } \\
\text { Dwart strew } \\
\text { shreew } \\
\text { Desert strew } \\
\text { Least strew }\end{array}$ & & 0 & & $\begin{array}{l}0 \\
0 \\
0 \\
0 \\
0 \\
0\end{array}$ & & & $\begin{array}{l}0 \\
0 \\
0 \\
0\end{array}$ & $\begin{array}{l}0 \\
0\end{array}$ & & 0 & 0 & $\begin{array}{l}0 \\
0\end{array}$ & $\begin{array}{l}0 \\
0 \\
0 \\
0\end{array}$ & $\stackrel{0}{\circ}$ & & 0 & 0 & \\
\hline 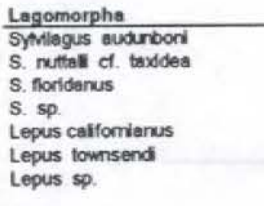 & 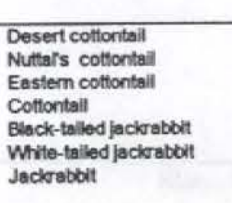 & $\begin{array}{l}0 \\
0 \\
0 \\
0\end{array}$ & $\begin{array}{l}0 \\
0 \\
0\end{array}$ & $\begin{array}{l}0 \\
0 \\
0\end{array}$ & ㅇ & $\begin{array}{l}\circ \\
\circ \\
\circ\end{array}$ & $\begin{array}{l}0 \\
0\end{array}$ & $\begin{array}{l}0 \\
0 \\
0\end{array}$ & $\begin{array}{l}0 \\
0\end{array}$ & $\begin{array}{l}0 \\
0\end{array}$ & $\begin{array}{l}0 \\
0\end{array}$ & $\begin{array}{l}\circ \\
0\end{array}$ & 0 & 0 & : & & $\circ$ & $\begin{array}{l}0 \\
0 \\
0 \\
0\end{array}$ & $\begin{array}{l}0 \\
0 \\
0\end{array}$ \\
\hline 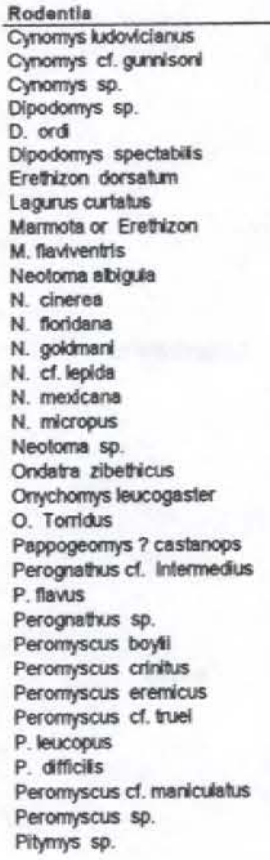 & 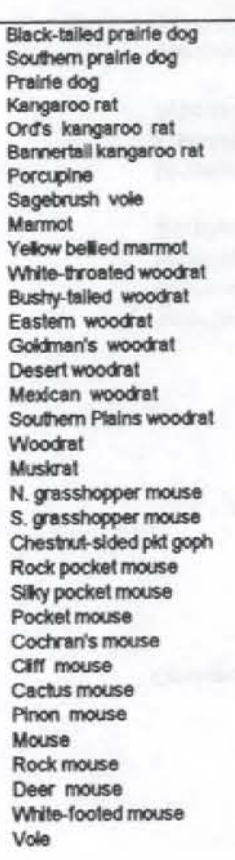 & $\begin{array}{l}0 \\
0\end{array}$ & $\begin{array}{l}0 \\
0 \\
0\end{array}$ & 0 & $\begin{array}{l}\circ \\
\circ \\
\circ \\
0 \\
\circ \\
0\end{array}$ & 0 & 0 & $\begin{array}{l}0 \\
0 \\
0 \\
0 \\
0 \\
0 \\
0\end{array}$ & $\begin{array}{l}\circ \\
0 \\
0 \\
0 \\
0\end{array}$ & : & $\begin{array}{l}0 \\
0 \\
0\end{array}$ & $\begin{array}{l}\circ \\
\circ\end{array}$ & $\begin{array}{l}\circ \\
\circ\end{array}$ & $\begin{array}{l}\circ \\
\circ \\
\circ\end{array}$ & $\begin{array}{l}\circ \\
\circ \\
\circ\end{array}$ & 0 & $\begin{array}{l}\circ \\
\circ\end{array}$ & $\begin{array}{l}\circ \\
0\end{array}$ & $\begin{array}{l}0 \\
0 \\
0 \\
0\end{array}$ \\
\hline
\end{tabular}


Table 10.3 Cont. Late Pleistocene Mammalian Faunas from Localities in Southern New Mexico ${ }^{1}$

\begin{tabular}{|c|c|c|c|c|c|c|c|c|c|c|c|c|c|c|c|c|c|c|c|}
\hline $\begin{array}{l}\text { Name } \\
* \text { extinct }\end{array}$ & Common Name & \begin{tabular}{|l} 
Room \\
Vanishing \\
Floor \\
33,590 \\
\end{tabular} & $\begin{array}{l}\text { Lost } \\
\text { Valley } \\
29,290 \\
\end{array}$ & $\begin{array}{l}\text { Sabretooth } \\
\text { Camel } \\
\text { Maze } \\
\quad 25,160 \\
\end{array}$ & $\begin{array}{l}\begin{array}{l}\text { Muskox } \\
\text { Cave }\end{array} \\
25-18,000 \\
\end{array}$ & $\begin{array}{l}\text { Pit } \mathrm{N} \\
\text { W Animal } \\
\text { Fair }\end{array}$ & $\begin{array}{l}\text { Camel } \\
\text { Room }\end{array}$ & $\begin{array}{r}\begin{array}{r}\text { Animal } \mathrm{Fa} \\
\text { Younger }\end{array} \\
15,030 \\
\end{array}$ & $\begin{array}{l}\text { Pocket } \\
\text { Porris' } \\
14,470 \\
\end{array}$ & \begin{tabular}{|l} 
Human \\
Corridor \\
$<15,000$ \\
$>12,000$
\end{tabular} & $\begin{array}{l}\text { Bison } \\
\text { Chamber } \\
<14,470 \\
>10,730 \\
\end{array}$ & $\begin{array}{l}\text { Stalag } \\
11,880\end{array}$ & $\begin{array}{l}\pi \text { il } \\
10,730 \\
\end{array}$ & \begin{tabular}{|r} 
Slot \\
Lower \\
11,600 \\
\end{tabular} & $\begin{array}{l}\text { th Cave } \\
\text { Upper } \\
10.8-11.8 \\
\end{array}$ & \begin{tabular}{|l} 
Blackwa \\
Gray \\
Sand \\
$>12,000$ \\
\end{tabular} & $\begin{array}{l}\text { ater Dray } \\
\text { Brown } \\
\text { Sand } \\
11,200\end{array}$ & $\begin{array}{l}\text { aw } \\
\text { William's } \\
\text { Cave } \\
\text { Cave.11,20 }\end{array}$ & $\begin{array}{l}\text { Burnet } \\
\text { Cave } \\
\times 12-11,000 ? \\
\end{array}$ \\
\hline Microtus longicaudus & Long-tailed vole & & & & & & & 0 & 0 & & 0 & 0 & & & & & & & 0 \\
\hline M. ochrogaster & Praitie vole & & 0 & & & 0 & & & & & 0 & 0 & 0 & & & & 0 & & \\
\hline $\begin{array}{l}\text { M. mexicanus } \\
\text { M. micropus }\end{array}$ & $\begin{array}{l}\text { Mexican vole } \\
\text { Vole }\end{array}$ & & & & 0 & 0 & 0 & 0 & 0 & 0 & 0 & 0 & 0 & 0 & & & 0 & & o \\
\hline M. pennsytvanicus & Meadow vole & & & & o & & & o & & & & & 0 & & & & 0 & & \\
\hline Microtus sp. & Vole & & & & & & & & & & & & & & & 0 & & & \\
\hline $\begin{array}{l}\text { Reithrodontomys ct. megalotis } \\
\text { R. fulvesens }\end{array}$ & $\begin{array}{l}\text { Western harvest mouse } \\
\text { Fulvus harvest mouse }\end{array}$ & & & & 0 & & & & & & & & & & & & 0 & & \\
\hline $\begin{array}{l}\text { Reithrodontomys sp. } \\
\text { Sigmodon hispidus }\end{array}$ & $\begin{array}{l}\text { Harvest mouse } \\
\text { Hispid cotton rat }\end{array}$ & 0 & & & & & & 0 & & & 0 & & & & & & 0 & & \\
\hline Sigmodon sp. & Cotton rat & & ० & & & & & & & 0 & & & 0 & & & & 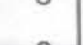 & & \\
\hline $\begin{array}{l}\text { Sciurus of arizonensis } \\
\text { Sciurus sp. }\end{array}$ & $\begin{array}{l}\text { Arizona gray squirrel } \\
\text { Tree squirrel }\end{array}$ & & & & & & & & & & & & & 0 & & & 0 & & \\
\hline $\begin{array}{l}\text { Spermophilus spilosoma } \\
\text { S. variegatus }\end{array}$ & $\begin{array}{l}\text { Ground squirrel } \\
\text { Rock squirrel }\end{array}$ & $\circ$ & & & 0 & & & & & & & & & 웅 & 0 & & & 0 & 0 \\
\hline $\begin{array}{l}\text { S. sp. } \\
\text { S. richardsoni } \\
\text { S. tridecemineatus }\end{array}$ & $\begin{array}{l}\text { Ground squirrel } \\
\text { Richardson's grnd squrl } \\
\text { Thirteen-lined ground squirrel }\end{array}$ & 0 & ० & & ( & & & 0 & $\begin{array}{l}\circ \\
\circ\end{array}$ & & 0 & & & & 0 & & & 0 & 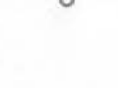 \\
\hline Thomomys talpoides & Northern pocket gopher & & & & & & o & 0 & 0 & 0 & $\circ$ & & & & & & & & \\
\hline $\begin{array}{l}\text { Thomomys bottae } \\
\text { T. umbrinus }\end{array}$ & $\begin{array}{l}\text { Botta's pocket gopher } \\
\text { socox pocket gopher }\end{array}$ & & & & 0 & & & $\circ$ & 0 & 0 & 0 & & 0 & 0 & 0 & & & & 0 \\
\hline Geomys bursarius & Plains pocket gopher & & & & & . & & & & & & & & & & & $\circ$ & & \\
\hline Geomys sp. & Eastern Pocket Gopher & & & & & & & & & & & & & 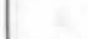 & & 0 & 至 & & \\
\hline Carnlvora & Cipionins & & ( & & & & & & & & & & & & $=$ & & & & \\
\hline Canis ct. latrans & Coyote & O & 0 & & & & & o & O & & & & & & & 0 & & & 0 \\
\hline Canis diris? & Dire wolt & & & & $\#$ & & & & & & & & & \# & & & 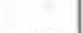 & \# & \\
\hline Canis lupus & Gray wolt & & $\circ$ & & $\circ$ & ㅇ & & 0 & & & & & & & & $\circ$ & 0 & & $\circ$ \\
\hline Conipatus mesoleucus & Hognosed skunk & & & & $\circ$ & 0 & 0 & 0 & & & & & & & 0 & & & 0 & o \\
\hline $\begin{array}{l}\text { Felis concolor } \\
\text { Feils sp. }\end{array}$ & $\begin{array}{l}\text { Puma } \\
\text { Cat }\end{array}$ & & 0 & 0 & 0 & & & 0 & & & & & & & 0 & & & 0 & 0 \\
\hline Lynx rutus & Lymx & 0 & $\circ$ & & o & & & $\circ$ & & $\circ$ & & & & ( & 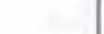 & & & o & 0 \\
\hline \#Smilodon fatalis & Sabretooth cat & & & & & & & & & & & & & & & $\#$ & & & \\
\hline $\begin{array}{l}\text { Mephitinae } \\
\text { Mephitis mephitis }\end{array}$ & $\begin{array}{l}\text { small skunk } \\
\text { Striped skunk }\end{array}$ & & & & & & & 0 & & 0 & & & & & & & 0 & & \\
\hline $\begin{array}{l}\text { Mephitis mephits } \\
\text { Mustela frenata }\end{array}$ & Long-tailed weasel & & o & & 0 & & 0 & o & 0 & 0 & & & 0 & 0 & 0 & & 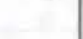 & & \\
\hline M. nigripes & Black-footed ferret & & & & & & & & & & & & & & & & & & 0 \\
\hline $\begin{array}{l}\text { Panthera onca } \\
\text { \#Panthera leo atrox }\end{array}$ & $\begin{array}{l}\text { Jaguar } \\
\text { American fion }\end{array}$ & 0 & & & \# & 0 & & & & & & & & & & & & & \\
\hline Procyon lotor & Raccoon & & & & 0 & & & & & & & & & & & & 0 & & \\
\hline $\begin{array}{l}\text { Bassariscus astutus } \\
\text { Spilogale putorius }\end{array}$ & Ringtail & & & & & 0 & & & & & & & & & & & & & \\
\hline $\begin{array}{l}\text { Spilogale putorius } \\
\text { Taxidea taxus }\end{array}$ & $\begin{array}{l}\text { Spotted skunk } \\
\text { Badger }\end{array}$ & & 0 & & 0 & $\circ$ & & $\stackrel{\circ}{\circ}$ & & & & & & 0 & . & & & & 0 \\
\hline Urocyon cinereoargenteus & Gray fox & o & 0 & 0 & & & 0 & & & & & & & & & & & 0 & S \\
\hline \#Arctodus sp. (7) & Giant short-faced bear & & & & & & & & & 0 & & & & & & & 0 & & $\#$ \\
\hline $\begin{array}{l}\text { Ursus americanus } \\
\text { ct. Ursus arctos }\end{array}$ & $\begin{array}{l}\text { Black bear } \\
\text { Grizzly bear }\end{array}$ & & & & & & & & & 0 & & & & & & & 0 & 0 & \\
\hline cf. Ursus sp. & Bear & 0 & & & & & & & & & & & & & & & & & \\
\hline $\begin{array}{l}\text { Vulpes cf. vulpes } \\
\text { Vulpes cf. velox }\end{array}$ & $\begin{array}{l}\text { Red fox } \\
\text { Switt fox }\end{array}$ & & & 0 & & & 0 & 0 & 0 & 0 & 0 & & 0 & & & 0 & 0 & & $\begin{array}{l}0 \\
0\end{array}$ \\
\hline Vulpes sp. & & & & & & 0 & & & & & & & & & & & & & \\
\hline
\end{tabular}


Table 10.3 Cont. Late Pleistocene Mammalian Faunas from Localities in Southern New Mexico ${ }^{1}$

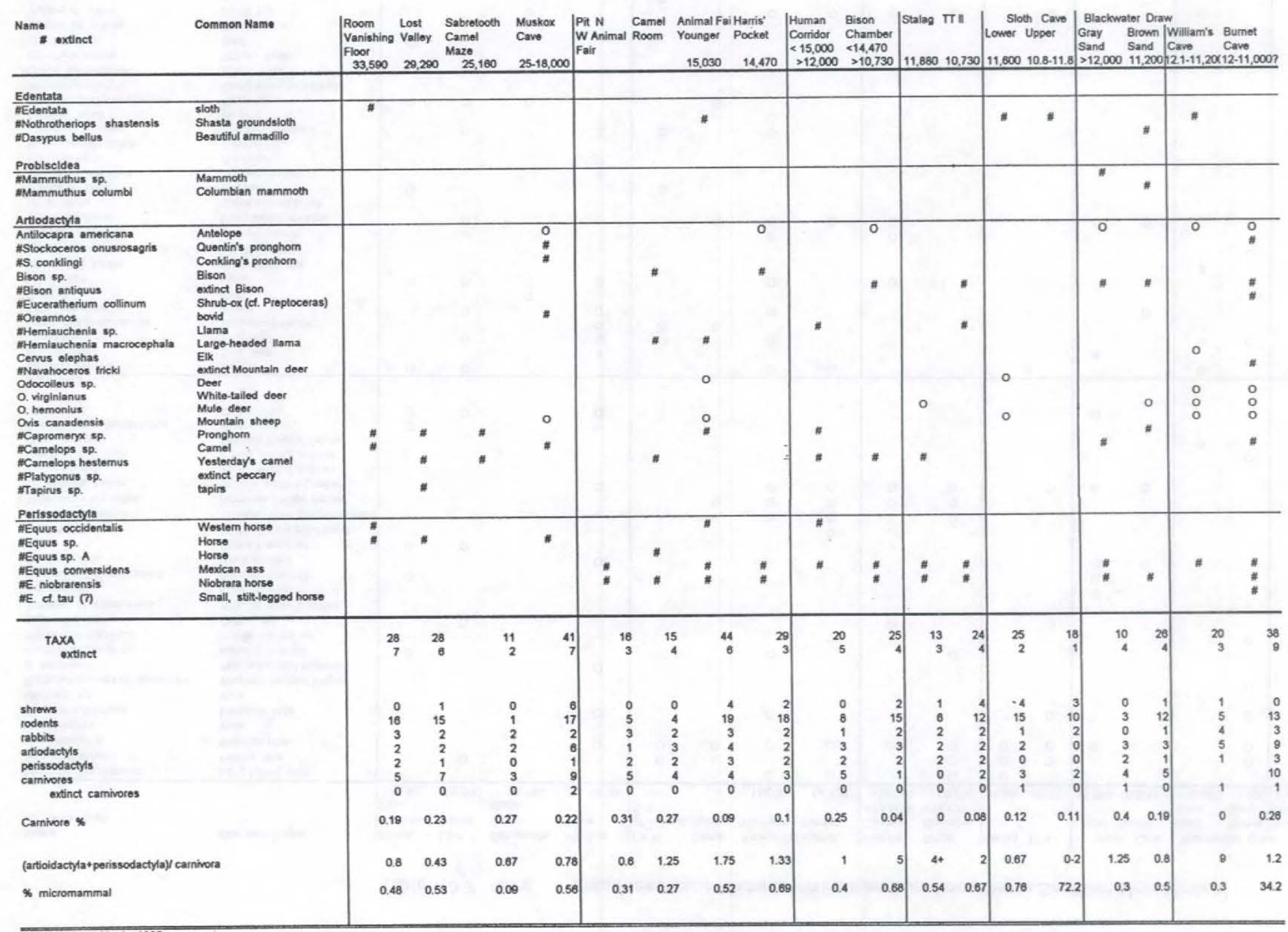

1 Data from Harris 1985 
Table 10.4 Faunal Similarity Matrices for Late Quaternary Mammalian Faunas from the Southern Plains Measure used is Simpson's C. See text for explanation and sources.

\begin{tabular}{|c|c|c|c|c|c|}
\hline \multirow[t]{2}{*}{ North Texas Localities } & \multicolumn{5}{|c|}{ Glacial to Modern } \\
\hline & Ben Franklin & Lewisvi & ville & Aubrey: & Holocene \\
\hline Shuler & 43 & & 69 & 50 & 53 \\
\hline Ben Franklin & & & 33 & 43 & 33 \\
\hline Lewisville & & & & 50 & 48 \\
\hline Aubrey & & & & & 50 \\
\hline Late Holocene & & & & & \\
\hline \multirow[t]{2}{*}{ Central Texas } & \multicolumn{3}{|c|}{ Glaclal to Late Holocene } & & \\
\hline & Cave w/o & Hall's & or & Early Holo & Late Holo \\
\hline Friesenhahn & 57 & & 56 & 53 & so \\
\hline Cave wio Name & & & 71 & 79 & 57 \\
\hline Hall's cave & & & & 55 & 66 \\
\hline Early Holocene & & & & & 59 \\
\hline
\end{tabular}

MEAN

44.5

Southern High Plains

Late Glacial to Holocene

42.3

Clovis Gray Sand

Lubbock Lake Clovis

LL Clovis

LL Late Pal Clovis BSW LL Late Holo

Lubbock Lake Late Paleo

40

$\begin{array}{lll}27 & 27 & 23 \\ 50 & 36 & 54 \\ & 36 & 92 \\ & & 38\end{array}$

Clovis Brn Sand Wedge

Southern Plains

Holocene

Cont TXEH
Cont TX LH
Lubb LK L Pal
Lubb LK Holo
N TX Late Holo

Cent TXLH

LL L Pal

59

61
59

LL. Holo N TX Late H

$\begin{array}{ll}62 & 53 \\ 62 & 83 \\ 92 & 54 \\ & 69\end{array}$

N TX Late Holo

Southern Plains

Late Holocene

67.3

N TX LH
Cent TX LH
LubLK LH
Del Cn LH

Cent TXLH LUbLKLH

$83 \quad 69$

Del Cn LH

Southem Plains

Clovis Period

33.5

Aubrey
Lewisville
Lubb Lake
Clovis GS
Clovis BSW
Ben Franklin

Lewisville Lubb Lake

50

$$
\begin{aligned}
& 17 \\
& 18
\end{aligned}
$$

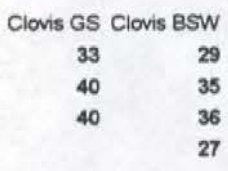

Ben Frank Cave wio

$$
\begin{aligned}
& 43 \\
& 33 \\
& 33 \\
& 27 \\
& 48
\end{aligned}
$$

Ben Franklin

Southern Plains

Glacial

Shuler

Burnham

Jones A

Jones C

Trapshoot

$\begin{array}{rrrrr}\text { Burnhm } & \text { Jones A } & \text { Jones C } & \text { Trapsht } & \text { Friesenhahn } \\ 46 & 16 & 31 & 16 & 38 \\ & 11 & 23 & 14 & 21 \\ & & 46 & 21 & 27 \\ & & & 31 & 38 \\ & & & & 15\end{array}$


are very low at all Clovis sites (2.5-9.3\%) compared to the $15-17 \%$ carnivores found in Holocene faunas. As the herd animals disappeared, so did the large, fast predators- having been replaced it is assumed, by people. Holocene carnivores are generally small and/or reclusive. Carnivory in this region evolved from aggressive hunting to stalking as the large meat eaters became extinct. People seem to have bridged both strategies.

One additional point about the Late Quaternary Southern Plains faunas is that there appear to be no white-tailed deer in the faunal record until the time of Clovis occupations. The mainstay for Archaic and Plains Villagers here, deer in the Late Pleistocene must have had little to no cover and probably little defense against the swift predators of the Late Pleistocene. Interestingly, when people come on the scene,

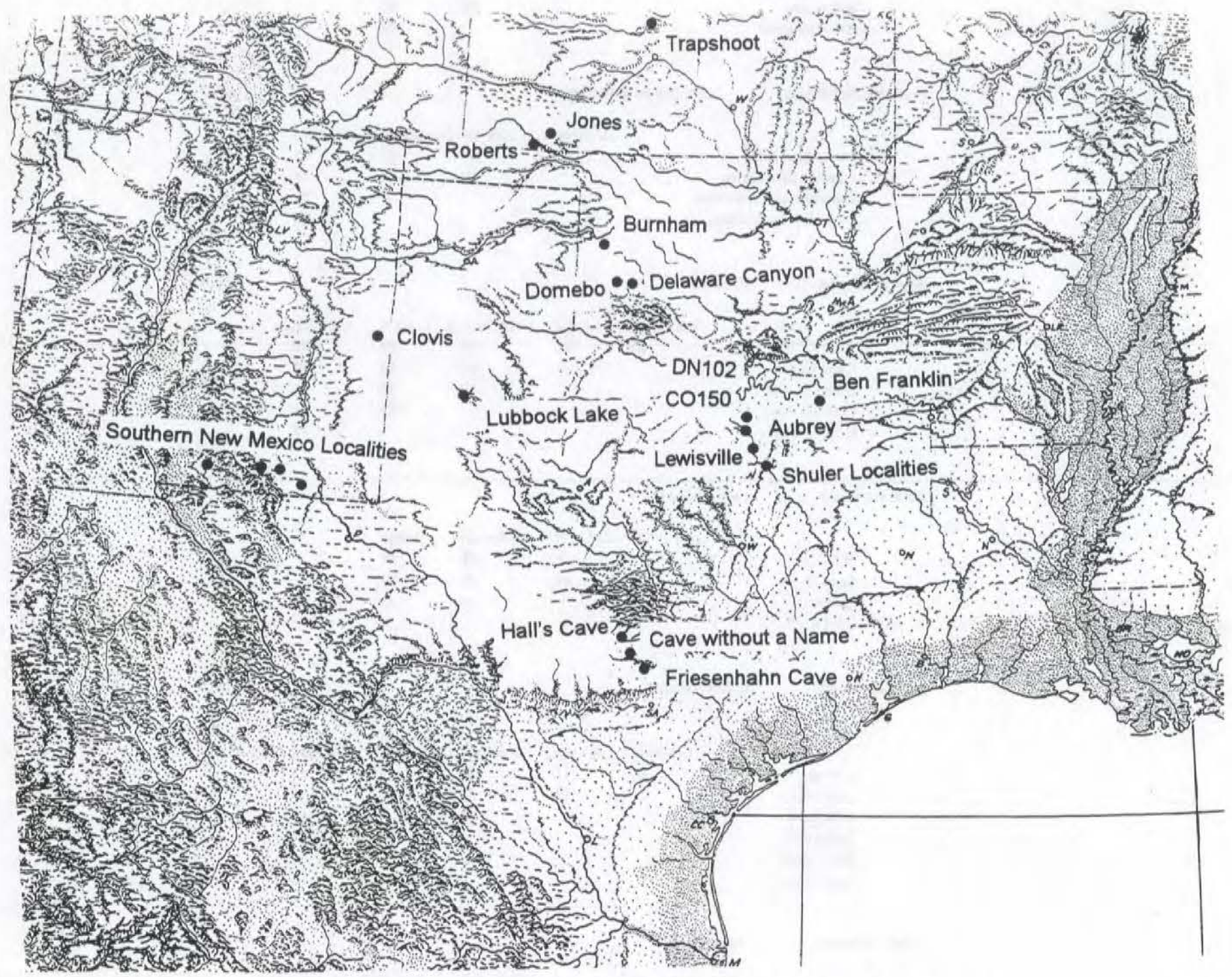

Figure 10.3 Late Quaternary Faunal Localities in the Southern Plains 
Table 10.5 Patterns of Flux in Late Quaternary Mammalian Taxa from the Southern Plains (see Table 10.2)

\begin{tabular}{|c|c|c|c|c|c|c|c|c|c|c|c|c|c|c|c|c|}
\hline \multirow[t]{2}{*}{ CLASS } & \multirow[t]{2}{*}{ GLACIAL. } & \multirow{2}{*}{$\begin{array}{l}\text { LATE } \\
\text { loss }\end{array}$} & \multicolumn{2}{|c|}{ GLACIAL } & \multicolumn{3}{|c|}{ CLOVIS } & \multicolumn{3}{|c|}{ EARLY HOLOCENE } & \multirow{2}{*}{$\begin{array}{l}\text { LATE } \\
\text { loss }\end{array}$} & \multicolumn{2}{|c|}{ HOLOCENE } & \multicolumn{3}{|c|}{ MODERN } \\
\hline & & & gain & net & loss & gain & net & loss & gain & net & & gain & net & loss & gain & net \\
\hline Marsupilia & 0 & 0 & 1 & 1 & 0 & 0 & 1 & 1 & $\overline{0}$ & 0 & 0 & 1 & 1 & 0 & 0 & $\overline{1}$ \\
\hline Insectivores & 3 & 1 & 5 & 7 & 3 & 0 & 4 & 1 & 1 & 4 & 0 & 0 & 4 & 2 & 1 & 3 \\
\hline Lagornorphs & 2 & 1 & 1 & 2 & 0 & 0 & 2 & 1 & 1 & 2 & 0 & 0 & 2 & 0 & 0 & 2 \\
\hline Rodentia & 22 & 8 & 12 & 26 & 8 & 14 & 30 & 8 & 2 & 24 & 9 & 4 & 19 & 9 & 3 & 13 \\
\hline Carnivores & 18 & 9 & 5 & 14 & 8 & 2 & 8 & 6 & $A$ & 6 & 4 & 4 & 6 & 3 & 1 & 4 \\
\hline Probiscidians & 2 & 0 & 0 & 2 & 0 & 0 & 2 & 2 & 0 & 0 & & & & & & \\
\hline Edentata & 6 & 5 & 0 & 1 & 0 & 3 & 4 & 3 & 0 & 1 & 1 & 0 & 이 & & & \\
\hline Artiodactyls & 12 & 10 & 3 & 6 & 1 & 4 & 9 & 5 & 1 & 5 & 4 & 1 & 2 & 1 & 0 & 1 \\
\hline \multirow[t]{3}{*}{ Perissodactyla } & 3 & 2 & 0 & 1 & 0 & 6 & 7 & 4 & 1 & 3 & & & & & & \\
\hline & 68 & 36 & 27 & 60 & 20 & 29 & 67 & 31 & 10 & 45 & 18 & 10 & 34 & 15 & 5 & 24 \\
\hline & reappearance & & & & & 9 & & & 5 & & & 5 & & & & \\
\hline
\end{tabular}

so do deer- and they apparently were being consumed regularly by Clovis folk (Table 10.2). Even with people predators, deer must have found food, cover and decent odds for survival, sharing this landscape with people.

A comment on mammoths and Clovis folk. The chronology and distribution of mammoths in North America, as suggested for many taxa by McDonald (1984) does not go too well with the idea that the environment did them in, with only a little help from people (Agenbroad 1984). Mammoth, like many taxa McDonald reviewed, show a marked increase in the number of radiocarbon dated occurrences towards the end of the Pleistocene (Figure 10.4). While many researchers have focused on the steep terminal tail of the distribution of dates, few emphasize the pronounced increase in mammoth occurrences AFTER the LGM. Inspection of Agenbroad's (1984) data by age and latitude suggest quite dramatic decrease in mammoth range during the LGM, with no dated occurrences of northern $M$. columbi. After the LGM, there appears to have been a NORTHERLY expansion of the territory (and numbers??) of Mammoth, quite possibly following the succession from a conifer-dominated landscape to a much more open one. (It bears repeating that during the LGM, much of North America east of the Rockies supported a spruce-pine dominated landscape that was probably quite inhospitable to most large animals save the Mastodon. The area covered by tundra or mixed steppe was very small compared to Eurasian environments. Reduced seasonality may have promoted faunal disjunction, yet stressful compression of the ranges of adaptively diverse taxa may have been just as important a factor in the many new sympatric-disharmonius faunal associations (see Lundelius 1967; Graham and Lundelius 1984). The LGM was most likely a stressful period for animal populations over large regions of North America. Biomass and biotic diversity may well have been increased towards the broad coastal plains of the Gulf of Mexico-Caribbean basins, as suggested by the marked diversity of Pleistocene taxa in Florida. Most of those coastal regions are noticeably wanting for fossil records.) Like the white-tailed deer, mammoths may have enjoyed better food supplies after the LGM. If so, they could have been another stimulus for people to follow into the continental interior.

If one made the crazy proposition that people had been in North America for "some time", but that they basically had to map on to deer and/or mammoth for survival, then we would not expect to see people 


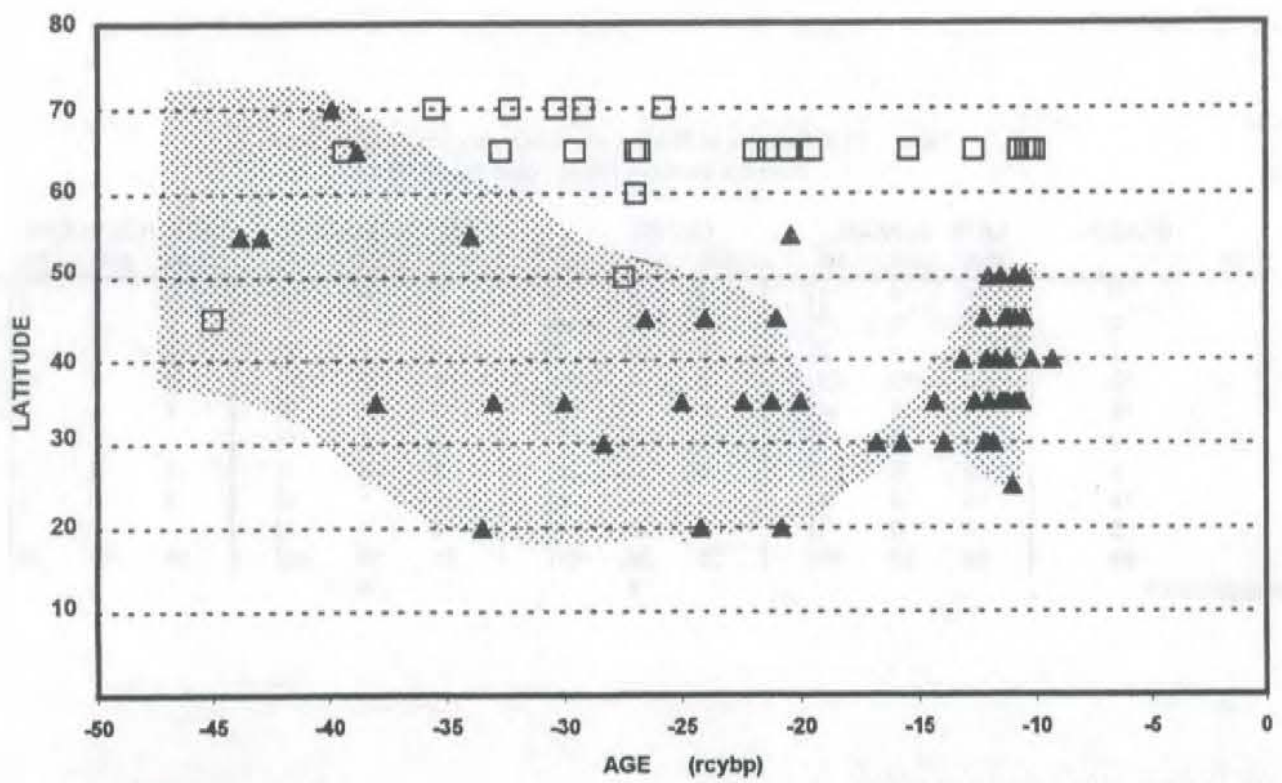

Data from Agenbroad 1984

$\Delta M$. columbia $\square$ M. primigenius

Figure 10.4 Radiocarbon dated mammoths from North America. The shaded area highlights the constriction in the geographic range of dated Mammoth remains for the LGM. Also note the rapid latitudinal expansion in range after ca. 15,000 BP. While many researchers emphasize the abrupt termination of Mammoths before $10,000 \mathrm{BP}$, their apparent increase in numbers and range prior to that has implications for the potential food base for exploration of the continental interior.

in the Southern Plains until about 11-12,000 years ago, when deer and mammoth "come back" after the LGM, Such a crazy proposition would probably require that people and many taxa of now extinct animals were living to the south, perhaps around the Gulf-Caribbean rim.

\section{Mollusks}

Neck's analysis of the Aubrey fauna shows some of the clearest patterns of change here (see Chapter 7). Diverse, cold water taxa of late Pleistocene age decrease in diversity as well as in lacustrine habitat association through the pre-Clovis period, culminating in a near catastrophic decline at ca. 12,000 $\mathrm{BP}$, just before Clovis occupations. The faunas are rejuvenated, albeit without the Boreal taxa, during Clovis occupations, along with evidence of renewed spring activity and a more permanent pond, as well as the first evidence for alluviation at the site since at least $14,000 \mathrm{BP}$.

\section{Stable Isotopes}

Haas and others (1986) analyzed carbon isotopes to assist in environmental reconstruction at the Lubbock Lake locality. Although their samples derived from both marsh sediments and buried soil A horizons, samples dated between ca. 10.0-0.4 ka show a significant shift towards isotopically enriched compositions that persisted between ca. $8 \mathrm{ka}$ and $5.2 \mathrm{ka}$. These data suggested vegetation shifts towards C4 taxa associated with drying climates (see also Holliday, 1989). The study of Haas and others (1986) was followed by carbon isotope study of sediments from Mustang Springs, situated at the southern margin of the 
Llano Estacado (Meltzer, 1991). There, a roughly similar record of isotopic change was obtained; the early Holocene samples are depleted in ${ }^{13} \mathrm{C}$, indicative of lacustrine sediments and apparently wetter climate. About 8-7 ka there is a marked shift to compositions enriched in ${ }^{13} \mathrm{C}$, indicative of a shift to higher $\mathrm{C} 4$ plant biomass.

Humphrey and Ferring (1993) studied a series of 58 lacustrine, spring and pedogenic carbonate samples from the Aubrey Clovis site. The $\delta^{13} \mathrm{C}$ of pedogenic carbonates is ca. 8-12\% greater than that of associated organic carbon, but the trends in carbonate carbon isotopic composition can be used to infer plant biomass (Margaritz and others, 1981; Cerling, 1984; Quade and others, 1989). At the Aubrey Site the Clovis age samples from the pond deposits are the first that contain a record of overbank deposition, including organic detritus from the drainage basin. Prior to that, the stable carbon isotopes of the springpond sediments are probably dominated by algal remains (which have a very light Carbon isotopic composition). Nonetheless, the short temporal range of samples before and during Clovis occupations at Camp B suggest a wetter trend that reverses to a slow drying trend in the early Holocene.

We had hoped that the data from Aubrey would be the first isotopic evidence for Late Quaternary temperature fluctuations in this region. Although these data show a clear episode of ${ }^{18} \mathrm{O}$ depletion in the latest Pleistocene, before $12 \mathrm{Ka}$, this trend in oxygen isotope composition appears to register changes in the Gulf of Mexico waters. During the early post-glacial period, meltwaters flowing down the Mississippi Valley were depleted in ${ }^{18} \mathrm{O}$ (Emeliani and others, 1975; Mix, 1987; Aharon, 1992). The meltwater influx lowered the $\delta^{18} \mathrm{O}$ of northern Gulf of Mexico water, and probably of derived meteoric waters in the western Gulf Coastal Plain region as well.

The Archaeological Record at Aubrey and its Paleoindian Context

The archaeological record that can be used as a contextual basis for assessing the Clovis occupations at Aubrey is significantly less available than the paleoenvironmental one. The paucity of excavated Clovis sites is appreciated at a continental scale (Stanford 1991; Haynes 1984; 1991). There are less than twenty known in situ Clovis sites of which most are kill/butchery localities where a few stone tools are associated with bones of one or more large animals. Only a few sites with well-preserved occupation areas have been carefully excavated, and a number of those, such as Lehner, Murray Springs and Kimmswick, are documented only with brief preliminary reports.

Along the Atlantic coastal plain, and around the Great Lakes region, a large number of early fluted point sites, some having Clovis components have been studied and published, although faunal-floral remains from the sites are rarely present and never extensive.

Lithic Assemblages

Excavations at the Aubrey site yielded approximately 9,800 lithic artifacts, most of which are small chips (all matrix was fine screened). Lithic raw materials are all non-local (Table 10.6). The majority of the material is Tecovas-like quartzite, probably procured at or near outcrops along the escarpment of the Llano 
Table 10.6 Distance from Aubrey to Sources of Lithic Raw Materials

$\begin{array}{lcl}\text { Source Area } & \begin{array}{c}\text { Distance } \\ (\mathrm{km})\end{array} & \text { Materials } \\ \text { Alibates } & 490 & \text { Alibates chert } \\ \text { Quitaque } & 380 & \text { Tecovas quartzite, chert } \\ \text { Callahan } & 250 & \text { Edwards chert; chalcedony(?) } \\ \text { Fredericksburg } & 475 & \text { Edwards chert } \\ \text { Catahoula Fm. } & 315 & \text { Quartzite, chalcedony } \\ \text { Western Ouachitas } & 155 & \text { Novaculite, cherts, quartzites } \\ \text { Hot Springs } & 400 & \text { Novaculite, cherts, quartzites, }\end{array}$

Estacado (Southern High Plains of Texas), some 380 km west of the site (Banks, 1990:92-94; Holliday and Welty 1981). Chalcedony from an unknown source, but possibly the Tecovas Formation, is also very common in the assemblage. Mike Collins (personal communication) provided samples of chalcedony collected from Cretaceous rocks near the Callahan Divide in central Texas. Another possible source for both of these materials has been recently identified as the Catahoula Fm, which crops out on the Gulf Coastal Plain of Texas and Louisiana (Thomas, 1960; Heinrich, 1984). The closest source of the Catahoula quartzite and chalcedony is about $325 \mathrm{~km}$ southeast of Aubrey. Less common materials at the site include Tecovas chert and Alibates chert from the Panhandle of Texas (Banks, 1990:91-92) and Edwards chert from central Texas. Some of the lithic materials are comparable to Ouachita Mountains novaculite, possibly from Oklahoma or Arkansas, but this identification has not been confirmed.

Lithic use activities in Camp B entail both bifacial and blade technologies in a context of obviously intensive raw material curation and long-distance raw material transport. Evidence of bifacial technology documents final tool manufacture as well as tool use and resharpening. The $1 \mathrm{~m}^{2}$ cluster of about 1,600 pieces is dominated by debris that relates to manufacture of a biface from a large Tecovas quartzite preform. An overpassed flake with refits indicate that the preform was at least $8 \mathrm{~cm}$ wide. Transport of large preforms is compatible with data from Clovis caches in the western US (Lahren and Bonnichsen, 1974; Stanford 1994; Mehringer, 1989). Final reduction of this large biface into a projectile point or knife and use of large flakes from the biface for manufacture of tools including retouched pieces and one backed knife are consistent with patterns of biface reduction strategies in other Clovis contexts (Bradley, 1993). Other small clusters of biface resharpening debris indicate loci of tool resharpening. One impact damaged tip of a biface was found next to a hearth in the southern part of the block. The raw material is unique to the camp assemblage, and suggests introduction in a carcass in stripped meat, as was shown at Murray Springs by Haynes (1981).

Blade technology is represented by a diverse assemblage of blade blanks and blade tools. No conclusive evidence of on-site blade core reduction was found. The chalcedony core tablet recovered may reflect blade core maintenance in another part of the site; alternatively the core tablet may have been 


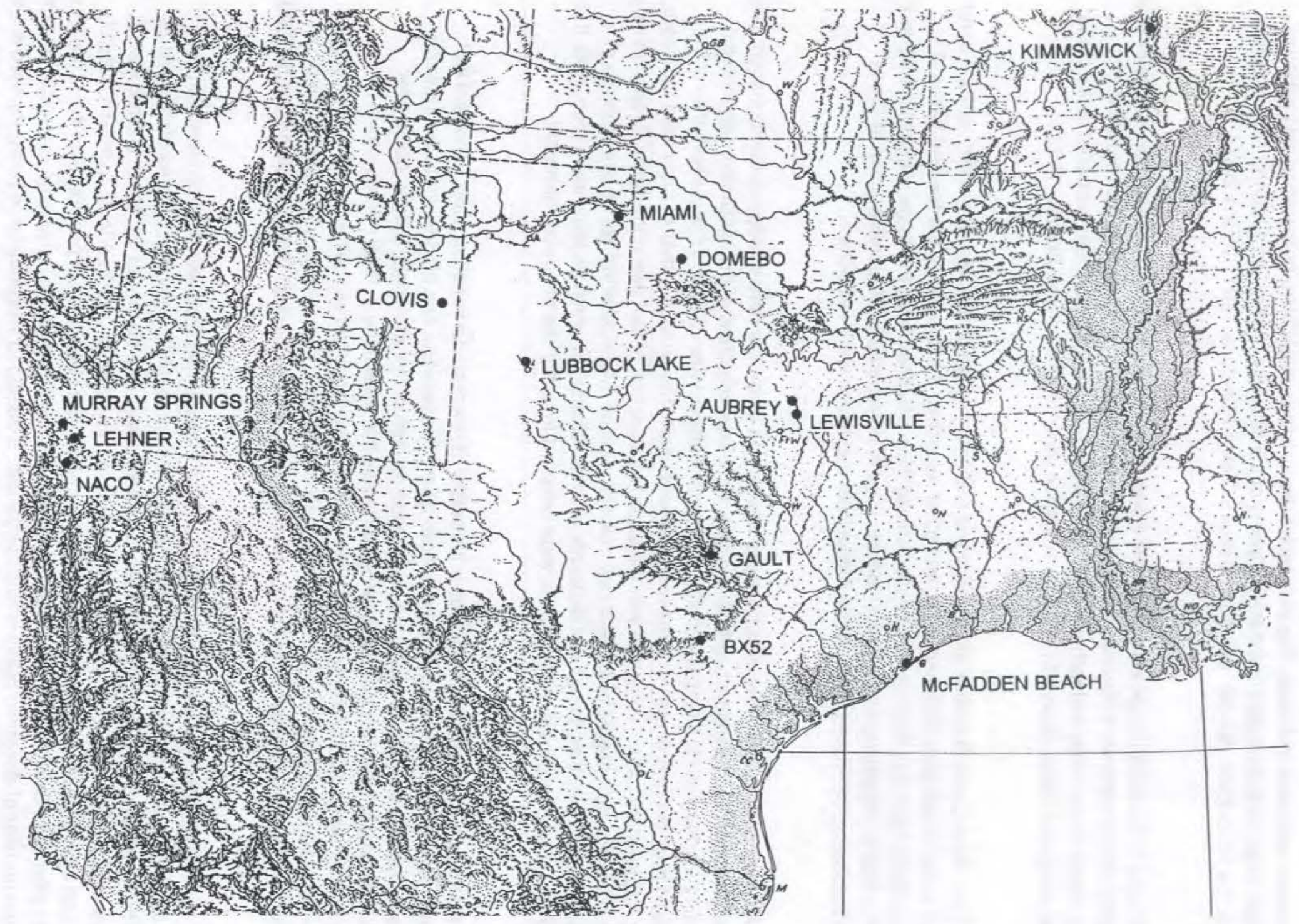

Figure 10.5 Clovis sites in the southern mid-continent. Note the absence of sites on coastal plain other than McFadden Beach, and the lack of sites along major drainages near the coastal plain or the lower Mississippi Valley. 
imported as an expedient tool blank. The core tablet shows that core platform preparation was achieved with multiple direct detachments around the periphery of the circular platform, as documented for blade cores from the Pavo Real (BX-52) and Adams sites in Texas (Stanford, 1991; Collins 2000).

Blades in the assemblage are made from Edwards chert, chalcedony and quartzite. It appears that the Edwards chert blades were imported to the site either as blanks or as finished tools (mainly end scrapers). Blade morphology and technological attributes indicate that blades from prepared blade cores as well as elongated flakes derived from biface reduction were employed (see Bradley 1993).

Tools from Camp B include several spurred and one notched end scraper, gravers, several bendbreak and radial-break tools (Bradley 1982), and other retouched and/or utilized blades and flakes. A backed quartzite flake was made from a biface thinning flake detached from the large preform mentioned above. This tool is morphologically identical to tools used in an experimental reconstruction of Clovis elephant butchering by Frison (1989). Other flakes from that biface were retouched.

A Clovis point made of Tecovas quartzite was broken below the hafted (edge-ground) margin. This point was pressure resharpened along both margins. Resharpening chips of this distinctive raw material were found near the point in Camp B and also in a small cluster in Area F. The impact-spalled tip of the biface found near the hearth area was made of Edwards chert. The small number of tools from this camp, and their fragmentary nature, combined with the abundant evidence of tool use in the form of resharpening chips, all point to a high degree of tool and raw material curation. Many different colors and textures of chips were found, as well as distinct raw materials such as Alibates, of which no tools were recovered. It is probable that some if not many of these tools were removed from the site at its abandonment.

A striking aspect of this assemblage is it diversity of raw material varieties. Only expedient tool blanks from biface manufacture share raw material types. The unretouched blades, and also the larger formal tools, notably the end scrapers, are each made on distinct raw materials. It does not appear, therefore, that any specific raw material source dominates this assemblage. "High" frequencies of Tecovas/Catahoula(?) quartzite may simply be related to a few large pieces that were reduced at the site. Variation in resharpening debris and tool raw materials is quite high. This implies procurement from separate sources within regions with good raw materials, such as the Central Texas Edwards Group (Banks 1991).

The Aubrey lithic assemblage illustrates that raw material transport, use and conservation were partitioned among several reduction strategies. Blades were probably transported both as blanks and as finished tools; while some blade cores are reported from caches (eg. Hammatt 1970), it is not known if they were brought to Aubrey. Bifaces appear to have been imported as finished tools (perhaps hafted?) and at least one large quartzite blank was brought to the site and reduced. It is possible that the blank was smashed prior to its use as a core. Bifacial tools were maintained through resharpening, especially in Camp $F$, but the number of discarded points is surprisingly low. If damaged weapons were being repaired at the site, then either the areas where that happened are not exposed, or the bases were being removed from 
the site by the Clovis people. All of the cortical pieces from the site (which are extremely rare) show only use of bedrock outcrops, never cobbles of secondary origin. The Aubrey folk carried raw material in a remarkably wide variety of forms, including the following:

\begin{tabular}{|c|c|}
\hline IMPORTED & HOW USED \\
\hline Large bifacial blanks-preforms & reduced \\
\hline Finished bifacial tools & repaired, removed (one broken point discarded) \\
\hline Large interior flake blanks, & $\begin{array}{l}\text { retouched, smashed, broken, } \\
\text { some thinned ventrally }\end{array}$ \\
\hline Large cortical flake blanks & retouched \\
\hline Medium-sized flake blanks & smashed, broken \\
\hline Large blades - end scrapers & used, broken, discarded \\
\hline Unretouched small blades & used? \\
\hline Unretouched flake-blades (from bifaces) & used (probably butchering bison) \\
\hline Finished end scrapers-side scrapers & extensively used, resharpened \\
\hline Possible discoidal cores & reduced \\
\hline Possible blade cores & reduced? \\
\hline A core tablet (imported or made at site) & burned \\
\hline Possible bladelet cores & two cores reduced, tools made on bladelets \\
\hline Quartzite core & reduced? \\
\hline Local limestone cobble & used/made into chopper. \\
\hline
\end{tabular}

The Spatial Dimension of Clovis Occupations

The spatial patterning record at Aubrey is exceptionally good, primarily because of three factors: a) the occupation appears to have been brief, and the weight of evidence falls on the side of a single occupation, b) the site was rapidly buried, and no later occupation materials were mixed on the Clovis surface, and c) the burial environment preserved faunal materials, which are extremely rare in reported Clovis camp contexts.

The spatial record at Aubrey is complimentary to the records at other Fluted Point Paleoindian sites, although the majority of spatial data come from published sites in eastern North America and the Great Lakes region (Figures 10.5, 10.6, 10.7; Table 10.7). Despite the near absence of faunal materials for comparison, the similarities between Aubrey and the other sites are evident at two scales. First, these sites all are characterized by multiple, non-overlapping occupation clusters. These have been actively debated with respect to single versus multiple occupations. Based on the published evidence, as well as the record at Aubrey, I think the multiple clusters probably register simultaneous use of the site by large mobile groups that were segregated into subgroups during the occupations.

Secondly, these sites all exhibit marked concentrations of artifacts and features within the occupation clusters. These include compositional clustering of activity specific artifact-feature associations, and also commonly include density-compositional clustering, usually of large volumes of debitage, with or without cores/bifaces. These "debitage piles" at Aubrey are interpreted as a strategy to conserve raw 

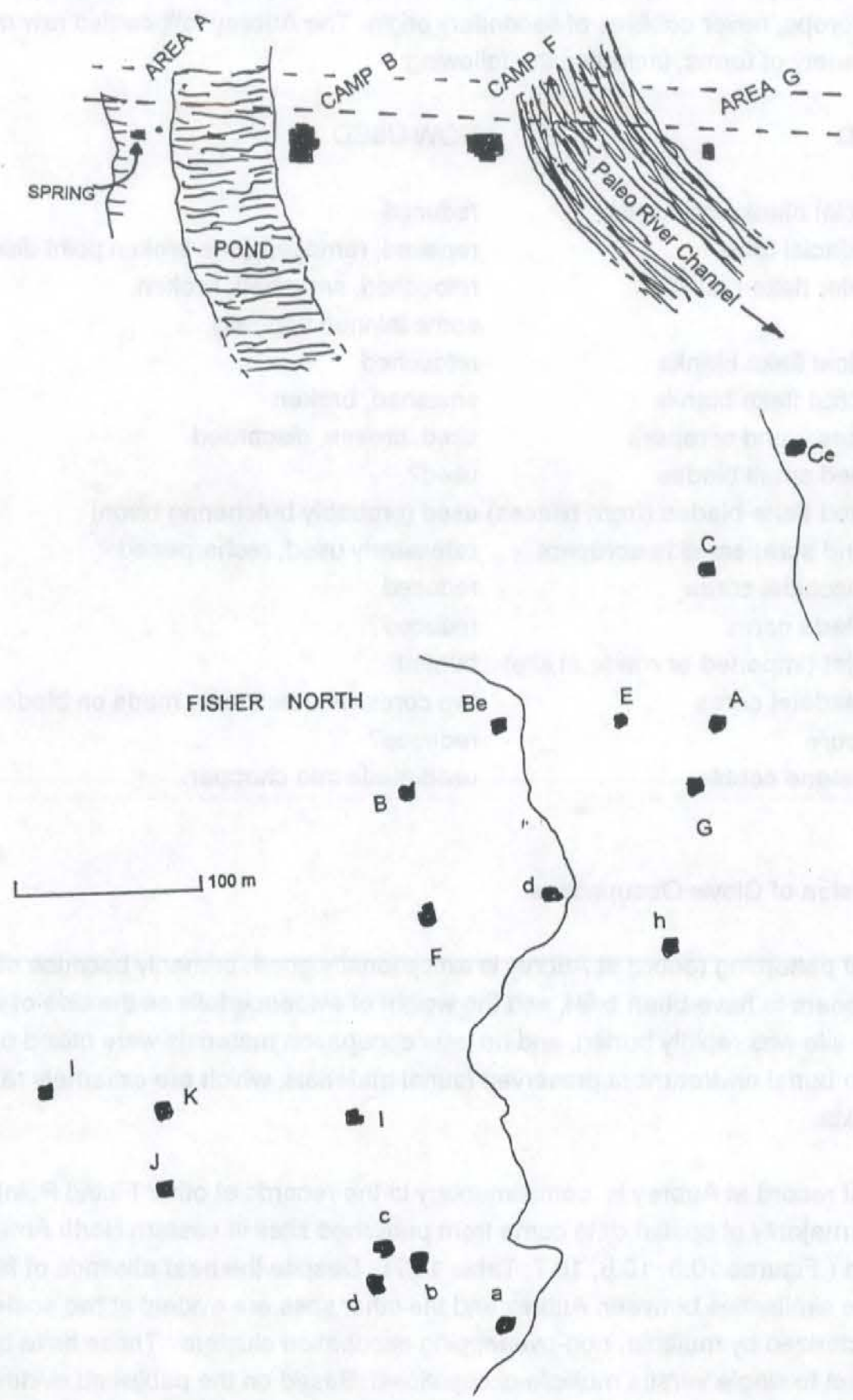

Figure 10.6 Intrasite cluster patterns at Paleoindian sites. All sites drawn to same scale. Shown here are Aubrey and Fisher North (see Figures 10.5 and 10.7 for site locations). Note the Aubrey materials are buried 7-9 meter below the floodplain and are exposed only along a narrow artificial channel. Despite the confining pond, river and terrace scarp at Aubrey, the spacing of occupation clusters at both sites is quite comparable. The Fisher occupations were associated with two (serial) proglacial lake paleoshorelines (Storck 1997). 
MURRAY SPRINGS
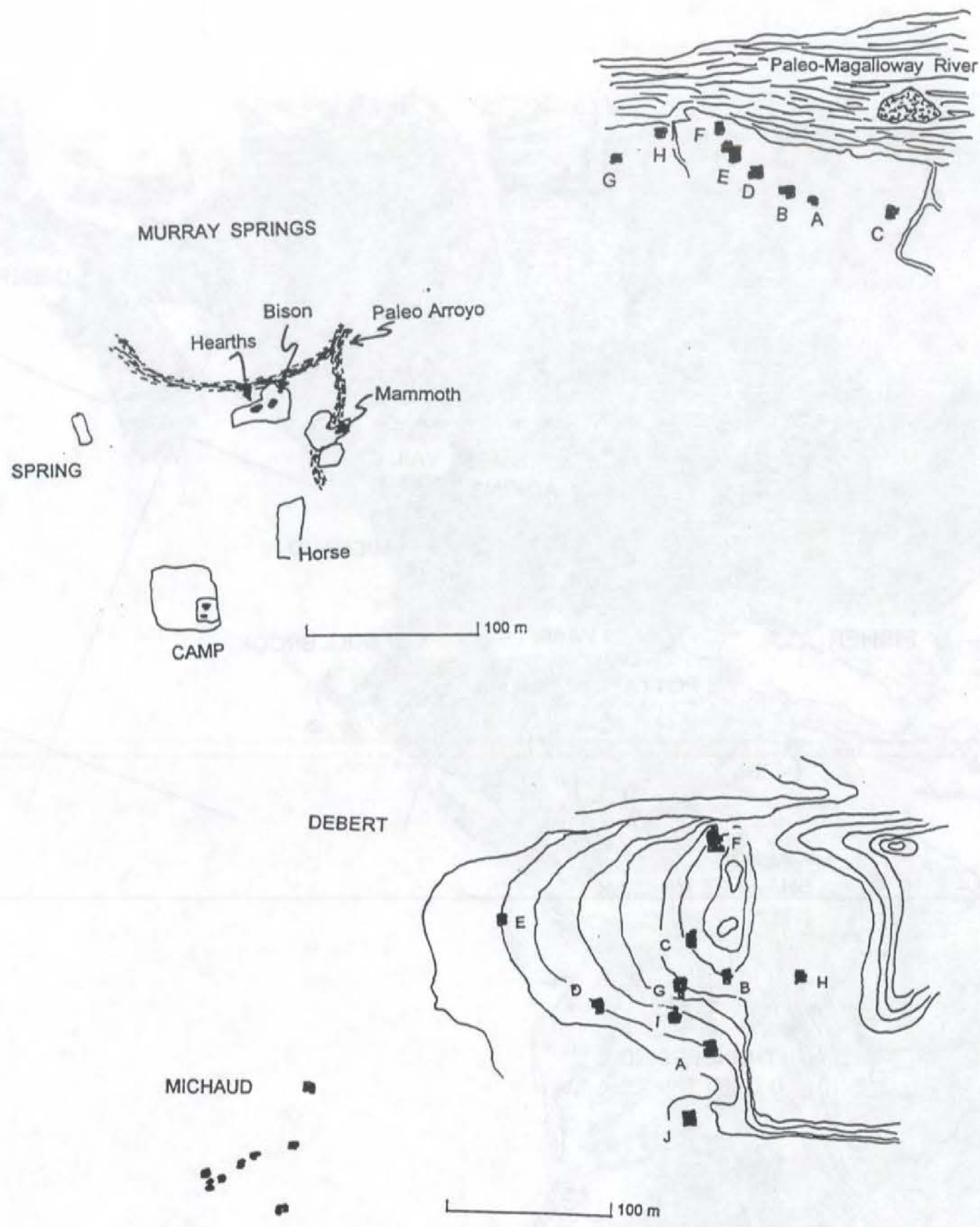

Figure 10.6, cont. Note these sites are all drawn to the same scale. Debert (McDonald 1968), Vail (Gramley 1992) and Michaud (Spiess and Wilson 1987) have apparently closer packing of clusters than Fisher North, and possibly Aubrey, but it is difficult to compare surficial deposits with the deeply buried ones. Notable here is the persistent lack of overlap between clusters. The striking record of tool sharing at Vail could be present at the other sites, as it seems to be present at Aubrey. The separation and scale of butchery areas and camp areas at Murray Springs (Haynes 1981) is similar to the patterns at Aubrey. Evidence for functional differentiation among clusters, as seen at most of these sites, can signify strong task integration within a large segmented occupation group. The same data could mimic a record of seasonal or serial differences in tasks over repeated occupations. 


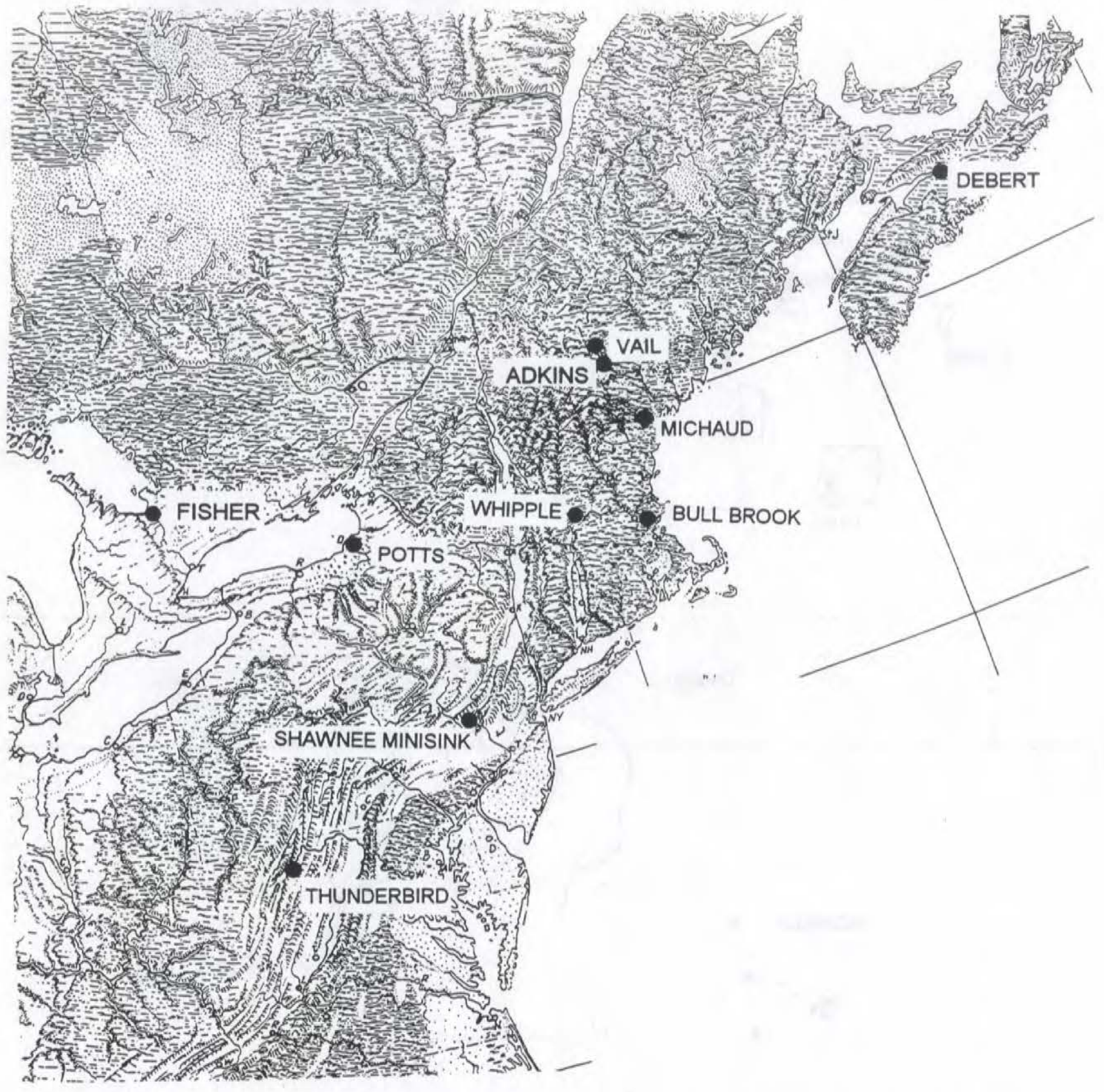

Figure 10.7 Locations of Eastern fluted point sites discussed in text. See Table 10.7 for site data. 
material by concentrating and shielding debitage from dispersal. The objective for this, based on blank analysis at Aubrey, was to facilitate collection of flakes for use as tool blanks, during the immediate occupation, and also for export to the next occupation. At Aubrey the former is illustrated by refitting of biface thinning debitage that had been retouched or used. The latter is demonstrated by study of the "distinctive", usually singular, flake blanks that were introduced to the site, fabricated into tools and discarded. The tools were most often bend-break or radial-break pieces.

Camp B spatial patterning reveals a complex record, rich with detail. Evidence of activities revolves around the hearths and two "debitage piles". The major concentration of lithic artifacts (ca. $1 \mathrm{~m}^{2}$ in area) in the northern part of the block is related to manufacture of a quartzite biface. Surrounding this is a lower density concentration of several thousand quartzite, chalcedony and chert chips and flakes that are dominated by tool maintenance activities. Also present in this part of the site are clusters of large and medium mammal bone, including bison and deer. These are some of the ca. 3,500 bone fragments recovered from this camp. One discrete cluster of burned large mammal bone was located near the biface manufacturing cluster. Clustering of burned bone, as well as the paucity of burned artifacts (less than 20 of the 9,800 ) is evidence that unlined hearths were used at the site. In the southern part of Area B, two discrete clusters of burned turtle bone were found; almost no large or medium mammal remains were associated in this part of the site. A small, dense cluster of about 500 flakes was situated just north of the two hearths.

Camp F, located about $125 \mathrm{~m}$ east of Camp B, is situated on the western margin of the Clovis age paleochannel. Excavations there recovered ca. 3,500 lithic artifacts, dominated by chips and flakes. About 1,500 of these were found in a cluster less than $1 \mathrm{~m}^{2}$ in area. These apparently derive from the repair/resharpening of at least three bifaces, including one that is made of a distinct variety of Tecovas quartzite, identical to that from which the Clovis point in Camp B was made. Area $F$ has significantly more white chert/novaculite than Camp B, but the assemblages are parallel in terms of raw material types. Tools from Area F include broken biface fragments, two scraper fragments, two gravers (one is multiple) and a series of bladelets from two cores; reconstructions show a clear bipolar technique, and the cores (missing) may have looked like scaled pieces (English for pièce ésquillée) The only core recovered at Aubrey was found a few meters west of the Area F excavation block. It is an exhausted Tecovas quartzite flake core about $2.5 \mathrm{~cm}$ long that appears to have been made from a thick biface fragment.

The density of faunal materials in Area $F$ is less than one-fourth that of Camp B, despite apparently identical sedimentary-pedogenic contexts. Proportionally, microfauna are much more common in Area F than in Camp B, and much lower frequencies of turtle and small game are evident. Of significance to Area $\mathrm{F}$ activities (particularly biface resharpening) is the discovery of four mammoth/mastodon ribs in a cluster a few meters from the artifact clusters in Area F. This may signify a butchering event along the paleochannel bank, but no excavations have been conducted there to determine if artifacts are associated with the ribs. [The ribs have been found and individually excavated after periods of erosion along the artificial channel.] On the other hand, the proximity of the 3,500 artifacts adjacent to the channel is quite strong association in itself, and no resharpening or tool discard closer to the probable carcass may have occurred.

It is clear that Area F was used in a different way than Camp B. A much higher use of bifaces, and low density accumulation of unifacial tool debris signify different activities, possibly butchering as opposed to final processing of foods and materials as in Camp B. Overall, however, the stratigraphic position and 


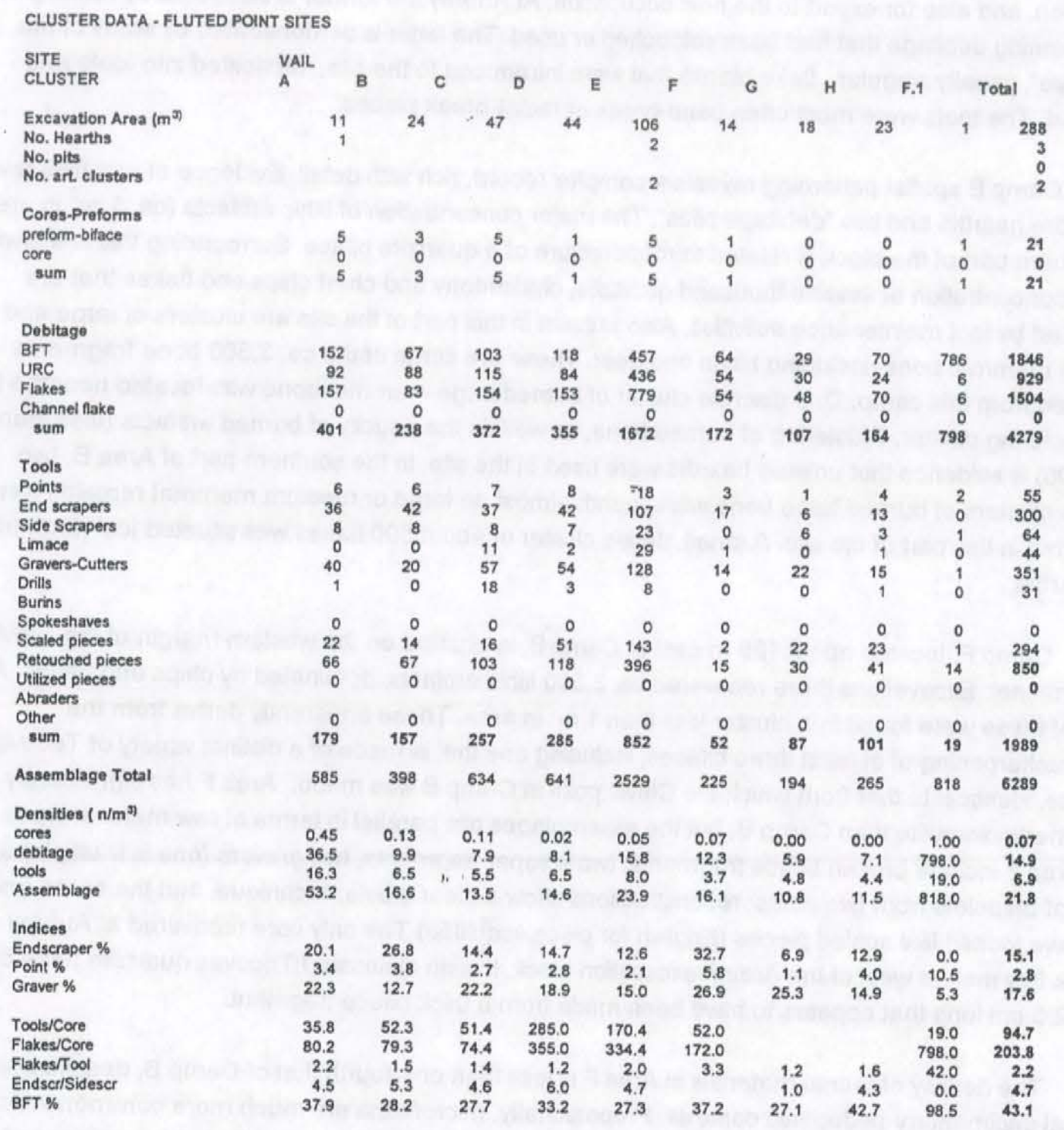




\section{CLUSTER DATA - FLUTED POINT SITES}

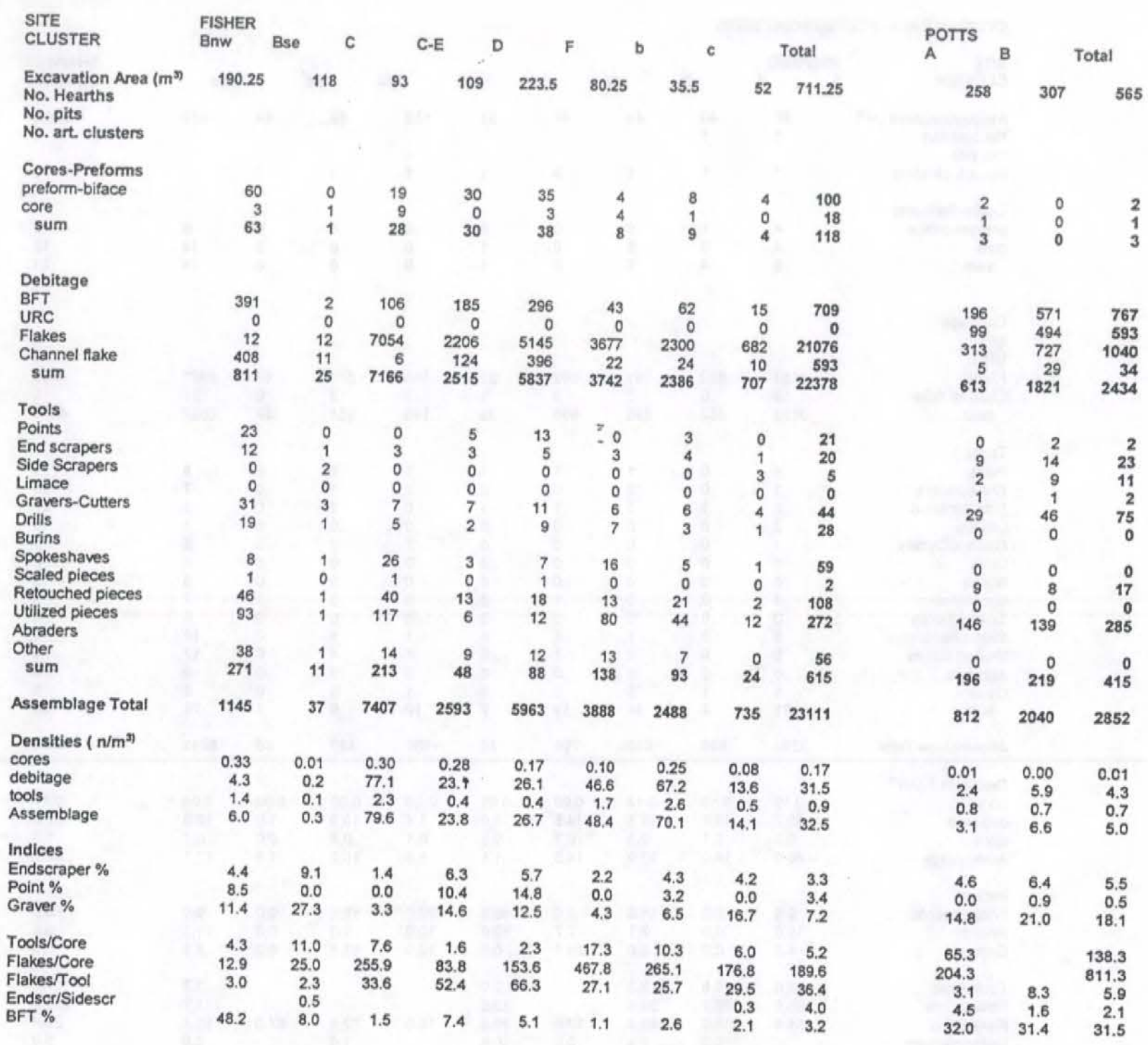




\begin{tabular}{|c|c|c|c|c|c|c|c|c|c|c|}
\hline $\begin{array}{l}\text { SITE } \\
\text { CLUSTER }\end{array}$ & $i_{1}^{\text {MICHAUD }}$ & III & n & $v$ & & & Dx & \multicolumn{2}{|c|}{ Total } & $\begin{array}{l}\text { SHAWNEE } \\
\text { MINISINK }\end{array}$ \\
\hline $\begin{array}{l}\text { Excavation Area }\left(\mathrm{m}^{3}\right) \\
\text { No. Hearths }\end{array}$ & $\begin{array}{r}80 \\
1\end{array}$ & $\begin{array}{r}40 \\
1\end{array}$ & 44 & 48 & 32 & 108 & 58 & 64 & \multirow[t]{3}{*}{474} & 125.4 \\
\hline No. pits & & & & & & & & & & \\
\hline No. art. clusters & 1 & 1 & 1 & 3 & 1 & 1 & 1 & 1 & & 3 \\
\hline \multicolumn{11}{|l|}{$\begin{array}{l}\text { Cores-Preforms } \\
\text { preform-biface }\end{array}$} \\
\hline $\begin{array}{l}\text { preform-bilace } \\
\text { core }\end{array}$ & 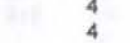 & $\begin{array}{l}1 \\
3\end{array}$ & $\begin{array}{l}0 \\
6\end{array}$ & 0 & $\begin{array}{l}0 \\
1\end{array}$ & $\begin{array}{l}0 \\
0\end{array}$ & 0 & $0_{0}^{0}$ & $\begin{array}{r}5 \\
14\end{array}$ & ${ }_{12}^{9}$ \\
\hline sum & 8 & 4 & 6 & 0 & 1 & 0 & 0 & 0 & 19 & 21 \\
\hline \multirow{2}{*}{\multicolumn{11}{|c|}{$\begin{array}{l}\text { Debltage } \\
\text { BFT }\end{array}$}} \\
\hline & & & & & & & & & & 0 \\
\hline $\begin{array}{l}\text { URC } \\
\text { Flakes }\end{array}$ & 3163 & 632 & 593 & 692 & & & & & & 0 \\
\hline $\begin{array}{l}\text { Flakes } \\
\text { Channel flake }\end{array}$ & $\begin{array}{r}3163 \\
10\end{array}$ & 0 & 0 & 3 & $\begin{array}{c}32 \\
1\end{array}$ & $\begin{array}{r}145 \\
3\end{array}$ & 4 & 0 & 21 & $\begin{array}{r}4669 \\
0\end{array}$ \\
\hline sum & 3173 & 632 & 593 & 695 & 33 & 148 & 581 & 67 & 5922 & 4669 \\
\hline \multicolumn{11}{|l|}{$\begin{array}{l}\text { Tools } \\
\text { Points }\end{array}$} \\
\hline $\begin{array}{l}\text { Points } \\
\text { End scrapers }\end{array}$ & $\begin{array}{l}4 \\
2\end{array}$ & 0 & $\frac{1}{2}$ & 10 & $0_{0}^{1}$ & $\begin{array}{l}1 \\
2\end{array}$ & 0 & $0_{0}^{0}$ & 8 & $\begin{array}{r}1 \\
125\end{array}$ \\
\hline $\begin{array}{l}\text { End scrapers } \\
\text { Side Scrapers }\end{array}$ & 0 & 1 & 5 & 1 & 1 & 0 & 1 & 0 & 9 & 25 \\
\hline Limace & 3 & 0 & 0 & 0 & 0 & 0 & 0 & 0 & 3 & 0 \\
\hline Gravers-Cutters & 1 & 0 & 0 & 3 & 0 & 1 & 1 & 0 & 6 & 0 \\
\hline Drills & 0 & 0 & 0 & 0 & 0 & 0 & 0 & 0 & 0 & 0 \\
\hline Burins & 0 & 0 & 0 & 0 & 0 & 0 & 0 & 0 & 0 & 0 \\
\hline Spokeshaves & 1 & 0 & 0 & 1 & 0 & 0 & 0 & 1 & 3 & 2 \\
\hline Scaled pieces & 0 & 0 & 0 & 0 & 0 & 0 & 0 & 0 & 0 & 0 \\
\hline Retouched pieces & 3 & 0 & 1 & 4 & 0 & 1 & 1 & 0 & 10 & 0 \\
\hline Utilized pieces & 6 & 0 & 2 & 1 & 0 & 4 & 4 & 0 & 17 & 0 \\
\hline Abraders & 0 & 0 & 0 & 0 & 0 & 0 & 0 & 0 & $\theta$ & a. \\
\hline Other & 1 & 1 & 3 & 2 & 0 & 1 & 0 & 0 & 8 & 6 \\
\hline sum & 21 & 2 & 14 & 13 & 2 & 10 & 8 & 1 & 71 & $15 \%$ \\
\hline Assemblage Total & 3202 & 638 & 613 & 708 & 36 & 158 & 589 & 68 & 6012 & 4843. \\
\hline \multicolumn{11}{|l|}{ Densities ( $\mathrm{n} / \mathrm{m}^{3}$ ) } \\
\hline cores & 0.10 & 0.10 & 0.14 & 0.00 & 0.03 & 0.00 & 0.00 & 0.00 & 0.04 & 0.17 \\
\hline debitage & 39.7 & 15.8 & 13.5 & 14.5 & 1.0 & 1.4 & 10.0 & 1.0 & 12.5 & 37.2 \\
\hline tools & 0.3 & 0.1 & 0.3 & 0.3 & 0.1 & 0.1 & 0.1 & 0.0 & 0.1 & 1.3 \\
\hline Assemblage & 40.0 & 16.0 & 13.9 & 14.8 & 1,1 & 1.5 & 10.2 & 1.1 & 12.7 & 38.7 \\
\hline \multicolumn{11}{|l|}{$\begin{array}{l}\text { Indices } \\
\text { Fndecrer }\end{array}$} \\
\hline $\begin{array}{l}\text { Endscraper \% } \\
\text { Point } \%\end{array}$ & $\begin{array}{r}9.5 \\
1900\end{array}$ & 0.0 & $\begin{array}{r}14.3 \\
7.1\end{array}$ & $\begin{array}{l}0.0 \\
7.7\end{array}$ & 50.0 & $\begin{array}{l}20.0 \\
10.0\end{array}$ & $\begin{array}{r}12.5 \\
0.0\end{array}$ & 0.0 & $\begin{array}{r}9.9 \\
11,3\end{array}$ & $\begin{array}{r}78.6 \\
0.6\end{array}$ \\
\hline $\begin{array}{l}\text { Point \% } \\
\text { Graver \% }\end{array}$ & 4.8 & 0.0 & 0.0 & 23.1 & 0.0 & 10.0 & 12.5 & 0.0 & 8.5 & 0.0 \\
\hline Tools/Core & 2.6 & 0.5 & 2.3 & & 2.0 & & & & 3.7 & 7.6 \\
\hline Flakes/Core & 396.6 & 158.0 & 98.8 & & 33.0 & & & & 311.7 & 222.3 \\
\hline Flakes/Tool & 151.1 & 316.0 & 42.4 & 53.5 & 16.5 & 14.8 & 72.6 & 67.0 & 83.4 & 29.4 \\
\hline $\begin{array}{l}\text { Endser/Sidescr } \\
\text { BFT \% }\end{array}$ & & 0.0 & 0.4 & 0.0 & 0.0 & & 1.0 & & 0.8 & 5.0 \\
\hline
\end{tabular}


CLUSTER DATA - FLUTED POINT SITES

\begin{tabular}{|c|c|c|c|c|c|c|c|c|c|c|c|c|}
\hline $\begin{array}{l}\text { SITE } \\
\text { CLUSTER }\end{array}$ & $\begin{array}{l}\text { DEBERT } \\
\mathrm{A}\end{array}$ & $\mathrm{B}$ & C & D & $E$ & $\mathbf{F}$ & G & $\mathrm{H}$ & 1 & $\mathrm{~J}$ & One & Total \\
\hline Excavation Area $\left(m^{3}\right)$ & 41.8 & 48.3 & 106.8 & 62.7 & 30.2 & 139.4 & 97.5 & 30.2 & 32.5 & 79 & 34.8 & 703.2 \\
\hline No. Hearths & 2 & 2 & 1 & 1 & & 5 & 2 & & 1 & 2 & & 16 \\
\hline $\begin{array}{l}\text { No. pits } \\
\text { No. art. clusters }\end{array}$ & 1 & & 2 & 5 & & & & & & & & 8 \\
\hline \multicolumn{13}{|l|}{$\begin{array}{l}\text { Cores-Preforms } \\
\text { preform-biface }\end{array}$} \\
\hline preform-biface & 2 & 2 & 17 & 19 & 1 & 35 & 21 & 10 & 4 & 19 & 6 & 132 \\
\hline core & 0 & 0 & 0 & 0 & 0 & 1 & 0 & 0 & 0 & 0 & 0 & 1 \\
\hline sum & 2 & 2 & 17 & 19 & 1 & 36 & 21 & 10 & 4 & 19 & 6 & 133 \\
\hline \multicolumn{13}{|l|}{$\begin{array}{l}\text { Debltage } \\
\text { BFT }\end{array}$} \\
\hline BFT & 0 & 0 & 0 & 0 & 0 & 0 & 0 & 0 & 0 & 0 & 0 & 0 \\
\hline URC & 0 & 0 & 0 & 0 & 0 & 0 & 0 & 0 & 0 & 0 & 0 & 0 \\
\hline Flakes & 1823 & 897 & 3208 & 6010 & 267 & 4936 & 2343 & 591 & 652 & 2742 & 167 & 20916 \\
\hline Channel flake & 0 & 0 & 0 & 0 & 0 & 0 & 0 & 0 & 0 & 0 & 0 & 0 \\
\hline sum & 1823 & 897 & 3208 & 6010 & 267 & 4936 & 2343 & 591 & 652 & 2742 & 167 & 20916 \\
\hline \multicolumn{13}{|l|}{$\begin{array}{l}\text { Tools } \\
\text { Points }\end{array}$} \\
\hline Points & 3 & 2 & 17 & 19 & 2 & $=25$ & 11 & 0 & 5 & 27 & 0 & 106 \\
\hline End scrapers & 121 & 62 & 225 & 28 & 6 & 362 & 216 & 40 & 45 & 233 & 30 & 1185 \\
\hline Side Scrapers & 11 & 5 & 22 & 6 & 0 & 47 & 43 & 2 & 1 & 61 & 3 & 185 \\
\hline Limace & 0 & 0 & 0 & 0 & 0 & 0 & 0 & 0 & 0 & 0 & 0 & 0 \\
\hline Gravers-Cutters & 6 & 5 & 4 & 3 & 0 & 10 & 60 & 1 & 0 & 8 & 0 & 86 \\
\hline Drills & 1 & 0 & 0 & 2 & 0 & 1 & 0 & 0 & 0 & 2 & 0 & 5 \\
\hline Burins & & & & & & & & & & & & \\
\hline Spokeshaves & 1 & 1 & 4 & 3 & 0 & 5 & 3 & 0 & 0 & 1 & 1 & 17 \\
\hline Scaled pieces & 41 & 34 & 77 & 13 & 0 & 95 & 144 & 22 & 20 & 103 & 0 & 474 \\
\hline Retouched pieces & 49 & 14 & 102 & 11 & 1 & 291 & 138 & 27 & 18 & 103 & 31 & 722 \\
\hline Utilized pieces & 32 & 84 & 102 & 45 & 3 & 106 & 43 & 9 & 7 & 14 & 16 & 345 \\
\hline \multicolumn{13}{|l|}{$\begin{array}{l}\text { Abraders } \\
\text { Other }\end{array}$} \\
\hline Other & 11 & 9 & 31 & 23 & 2 & 42 & 23 & 2 & 1 & 21 & 10 & 155 \\
\hline sum & 276 & 216 & 584 & 153 & 14 & 984 & 681 & 103 & 97 & 573 & 91 & 3280 \\
\hline Assemblage Total & 2101 & 1115 & 3809 & 6182 & 282 & 5956 & 3045 & 704 & 753 & 3334 & 264 & 24329 \\
\hline \multicolumn{13}{|l|}{$\begin{array}{l}\text { Densities }\left(n / m^{3}\right) \\
\text { cores }\end{array}$} \\
\hline cores & 0.05 & 0.04 & 0.16 & 0.30 & 0.03 & 0.26 & 0.22 & 0.33 & 0.12 & 0.24 & 0.17 & 0.19 \\
\hline debitage & 43.6 & 18.6 & 30.0 & 95.9 & 8.8 & 35.4 & 24.0 & 19.6 & 20.1 & 34.7 & 4.8 & 29.7 \\
\hline tools & 6.6 & 4.5 & 5.5 & 2.4 & 0.5 & 7.1 & 7.0 & 3.4 & 3.0 & 7.3 & 2.6 & 4.7 \\
\hline Assemblage & 50.3 & 23.1 & 35.7 & 98.6 & 9.3 & 42.7 & 31.2 & 23.3 & 23.2 & 42.2 & 7.6 & 34.6 \\
\hline \multicolumn{13}{|l|}{$\begin{array}{l}\text { Indices } \\
\text { Endscraper \% }\end{array}$} \\
\hline Endscraper \% & 43.8 & 28.7 & 38.5 & 18.3 & 42.9 & 36.8 & 31.7 & 38.8 & 46.4 & 40.7 & 33.0 & 36.1 \\
\hline Point \% & 1.1 & 0.9 & 2.9 & 12.4 & 14.3 & 2.5 & 1.6 & 0.0 & 5.2 & 4.7 & 0.0 & 3.2 \\
\hline Graver \% & 2.2 & 2.3 & 0.7 & 2.0 & 0.0 & 1.0 & 8.8 & 1.0 & 0.0 & 1.4 & 0.0 & 2.6 \\
\hline Tools/Core & 138 & 108.0 & 34.4 & 8.1 & 14.0 & 27.3 & 32.4 & 10.3 & 24.3 & 30.2 & 15.2 & 24.7 \\
\hline Flakes/Core & 911,5 & 448.5 & 188.7 & 316.3 & 267.0 & 137.1 & 111.6 & 59.1 & 163.0 & 144.3 & 27.8 & 157.3 \\
\hline Flakes/Tool & 6.6 & 4.2 & 5.5 & 39.3 & 19.1 & 5.0 & 3,4 & 5.7 & 6.7 & 4.8 & 1.8 & 6.4 \\
\hline Endscr/Sidescr & 11 & 12.4 & 10.2 & 4.7 & & 7.7 & 5.0 & 20.0 & 45.0 & 3.8 & 10.0 & 6.4 \\
\hline BFT $\%$ & 0.0 & 0.0 & 0.0 & 0.0 & 0.0 & 0.0 & 0.0 & 0.0 & 0.0 & 0.0 & 0.0 & 0.0 \\
\hline
\end{tabular}


CLUSTER DATA - FLUTED POINT SITES

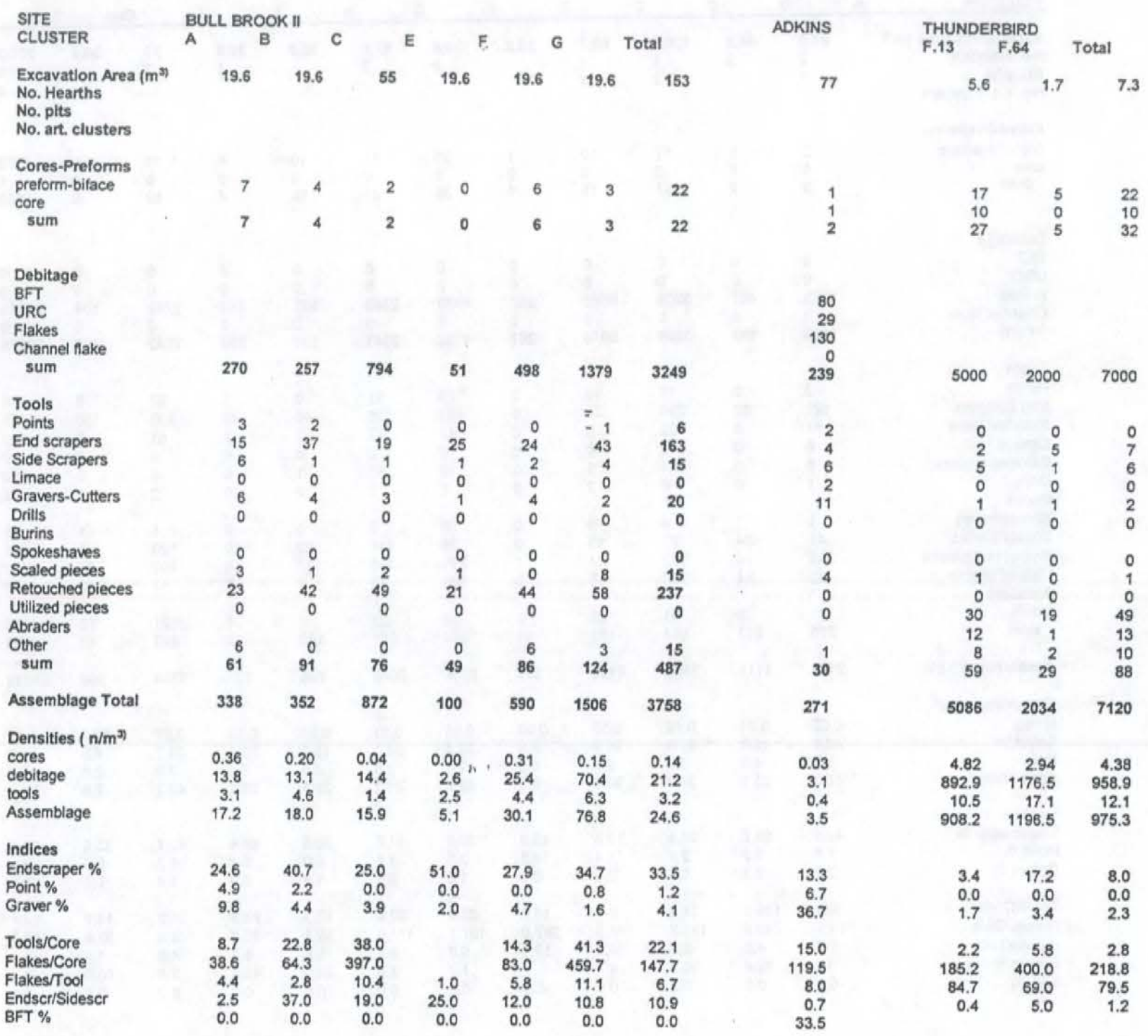




\begin{tabular}{|c|c|c|c|c|c|c|c|c|c|c|}
\hline \multirow{2}{*}{$\begin{array}{l}\text { SITE } \\
\text { CLUSTER }\end{array}$} & \multicolumn{2}{|c|}{ AUBREY (total) } & \multirow[b]{2}{*}{ rotal } & \multirow{2}{*}{\multicolumn{4}{|c|}{$\begin{array}{l}\text { AUBREY (restrictod) } \\
\text { B } \quad \text { F Total }\end{array}$}} & \multicolumn{3}{|c|}{ KOSTENKI } \\
\hline & & & & & B & & Total & $x \mathrm{VII-1} \quad$ & $v-2$ & IV-1 \\
\hline $\begin{array}{l}\text { Excavation Area }\left(\mathrm{m}^{3}\right) \\
\text { No. Hearths }\end{array}$ & 105.25 & 61.75 & 167 & & $\begin{array}{r}105.25 \\
4\end{array}$ & 61.75 & 167 & 60 & 406 & 224 \\
\hline No. pits & & & & & & 0 & 4 & 4 & 10 & 2 \\
\hline No. art clusters & 2 & 1 & & & 2 & 1 & & 1 & & 2 \\
\hline \multicolumn{11}{|l|}{$\begin{array}{l}\text { Cores-Preforms } \\
\text { preform-b flace }\end{array}$} \\
\hline & 0 & 0 & 0 & & 0 & 0 & 0 & 0 & 0 & 0 \\
\hline core & 0 & 1 & 1 & & 0 & 1 & 1 & 12 & 161 & 277 \\
\hline sum & 0 & 1 & 1 & & 0 & 1 & 1 & 12 & 161 & 277 \\
\hline \multicolumn{11}{|l|}{ Debitage } \\
\hline BFT & 217 & 204 & 421 & & 217 & 204 & 421 & 0 & 0 & 0 \\
\hline URC & 379 & 58 & 437 & & 379 & 58 & 437 & 623 & 0 & 0 \\
\hline Flakes & 608 & 457 & 1065 & & 608 & 457 & 1065 & 1044 & 34000 & 12650 \\
\hline Channel flake & 4802 & 2947 & 7749 & & 0 & 0 & 0 & 0 & 0 & \\
\hline sum & 6006 & 3666 & 9672 & & 1204 & 719 & 1923 & 1667 & 34000 & 12650 \\
\hline \multicolumn{11}{|l|}{ Tools } \\
\hline Points & 2 & 2 & 4 & & 2 & -2 & 4 & 1 & 769 & 513 \\
\hline End scrapers & 6 & 1 & 7 & & 6 & 1 & 7 & 19 & 155 & 78 \\
\hline Side Scrapers & 1 & 0 & 1 & & 1 & : & 1 & 0 & 0 & 23 \\
\hline Limace & 0 & 0 & 0 & & 0 & 0 & 0 & 0 & 0 & 0 \\
\hline Gravers-Cutters & 2 & 5 & 7 & & 2 & 5 & 7 & 0 & 0 & 0 \\
\hline Drills & 0 & 0 & 0 & & 0 & 0 & 0 & 0 & 69 & 0 \\
\hline Burins & 0 & 0 & 0 & & 0 & 0 & 0 & 5 & 118 & $2 \pi 7$ \\
\hline Spokeshaves & 0 & 0 & 0 & & 0 & 0 & 0 & 0 & 0 & 0 \\
\hline Scaled pieces & 1 & 0 & 1 & & 1 & 0 & 1 & 0 & 546 & 0 \\
\hline Retouched pieces & 9 & 3 & 12 & & 9 & 3 & 12 & 29 & 1358 & 699 \\
\hline Utilized pieces & 1 & 1 & 2 & & 1 & 1 & 2 & 0 & 0 & 0 \\
\hline Abraders & 1 & 0 & 1 & & & & & 1 & 0 & 0 \\
\hline Other & 1 & 0 & 1 & & 2 & 0 & 2 & 0 & 0 & 0 \\
\hline sum & 24 & 12 & 36 & & 24 & 12 & 36 & 55 & 3015 & 1590 \\
\hline Assemblage Total & 6030 & 3679 & 9709 & & 1228 & 732 & 1960 & 1734 & 37176 & 14517 \\
\hline \multicolumn{11}{|l|}{ Densities ( $\mathrm{n} / \mathrm{m}^{3}$ ) } \\
\hline cores & 0.00 & 0.02 & 0.01 & & 0.00 & 0.02 & 0.01 & 0.20 & 0.40 & 1.24 \\
\hline debitage & 57.1 & 59.4 & 57.9 & H. & 11.4 & 11.6 & 11.5 & 27.8 & 83.7 & 56.5 \\
\hline tools & 0.2 & 0.2 & 0.2 & & 0.2 & 0.2 & 0.2 & 0.9 & 7.4 & 7.1 \\
\hline Assemblage & 57,3 & 59.6 & 58.1 & & 11.7 & 11.9 & 11.7 & 28.9 & 91.6 & 64.8 \\
\hline \multicolumn{11}{|l|}{ Indices } \\
\hline Endscraper \% & 25.0 & 8.3 & 19.4 & & 25.0 & 8.3 & 19.4 & 34.5 & 5.1 & 4.9 \\
\hline Point \% & 8.3 & 16.7 & 11.1 & & 8.3 & 16.7 & 11.1 & 1.8 & 25.5 & 32.3 \\
\hline Graver \% & 8.3 & 41.7 & 19.4 & & 8.3 & 41.7 & 19.4 & 0.0 & 0.0 & 0.0 \\
\hline Tools/Core & & 12.0 & 36.0 & & & 12.0 & 36.0 & 4.6 & 18.7 & 5.7 \\
\hline Flakes/Core & & 3666.0 & 9672.0 & & & 719.0 & 1923.0 & 138.9 & 211.2 & 45.7 \\
\hline Flakes/Tool & 250.3 & 305.5 & 268.7 & & 50.2 & 59.9 & 53.4 & 30.3 & 11.3 & 8.0 \\
\hline Endser/Sideser & 6.0 & & 7.0 & & 6.0 & & & & & 3.4 \\
\hline BFT \% & 3.6 & 5.6 & 4.4 & & 18.0 & 28.4 & 21.9 & 0.0 & 0.0 & 0.0 \\
\hline
\end{tabular}


shared raw materials between Camp B and Area F are suggestive of close affinities between the occupants. The possibility that these two areas were used simultaneously cannot be ruled out, and is even suggested by lithic raw material data.

Of additional interest here is the apparent well, discovered in 1994. It is a $60 \mathrm{~cm}$ diameter pit, at least $60 \mathrm{~cm}$ deep with vertical walls that was excavated from the red wedge surface into a bed of springlacustrine tufas below the colluvium. The coarse, permeable tufas, confined between clayier sediments, would have served as an effective aquifer on the one hand, and should have precluded any "dry" pit functions on the other. The base of the well was below the base of the pond at Clovis time. This well may indicate drought conditions and an absence of surface water (compare to the well at Blackwater Draw [Haynes and Agogino 1966], and the well-like feature at Murray Springs [Haynes 1993]). Alternatively, the well could have been used to obtain clear water by backfiltering stagnant pond waters at the time of bison butchering.

The association of utilized blades with bison butchering is apparently a new aspect of Clovis lithic technology; such associations are known from the Upper Paleolithic, as at Amvrosievka in the Ukraine, where unretouched blades were used for butchering bison (Krotova and Belan, 1993). Each of the three blades with the bison appears to be elongated biface thinning pieces (here called "flake-blades" ) rather than blades detached from conical cores; this kind of blade is described by Bradley (1993). Indeed, one aspect of the Aubrey blade sample is the diversity of core morphologies that were associated with blade and flake manufacture. These range from "typical" large conical cores with facetted platforms, to cores with acute platform angles, to small cores that yielded small blades (too small to use as blanks for hafted end scrapers). The latter, along with the elongated biface thinning flakes, were used as tools, presumably for cutting tasks, and are similar in morphology and use wear patterns to some of those from the Kevin Davis cache in Texas (Young and Collins 1989; Collins 2000), Murray Springs in Arizona, Blackwater Draw Locality 1 in New Mexico (Goebel et. al 1991), and the Anadarko Cache from Oklahoma (Hammatt 1970). The larger blades with curved profiles were used at Aubrey as blanks for hafted end scrapers. These large blade blanks are similar to those in the cache from Blackwater Draw (Green 1963; Montgomery and ickenson 1992; Bouldurian and Cotter 1999; Hester 1972).

The bladelet technology shown at Aubrey by the two cores from Camp F was quite new until Al Goodyear (as Hall 1996) recovered "microblades" from the Big Pine Tree site near Savannah, Georgia. ( suggest that the term "microblade" be reserved for the very distinctive range of reduction strategies (very commonly using split, thick bifaces as true wedge-shaped cores) evident in assemblages from the Dyuktai tradition of eastern Siberia (Mochanov and Fedoseeva 1996) and eastern Beringia (Goebel et al, 1991). ;

Indeed, the diversity of blade reduction strategies indicated by artifacts from Aubrey,and also from publications (often with revealing illustrations) was surprising to one who more or less had grown to assume that those folks had "Clovis" blades and nothing else. All aspects of the Clovis technology are more variable than is usually implied by various writers. Rather than stress a single tool such as a biface that can meet all the needs of wildly mobile people, it seems that Clovis people had a lithic production repertoire that could probably deal very well with any kind of raw material, whether it was abundant or scarce. 


\section{SUBSISTENCE DATA}

The Aubrey faunal data show, perhaps better than any other Clovis assemblage, that a broad range of animals was procured and processed. Spatial analysis lends strong support to the conclusion that small game, including rodents, reptiles, rabbits, squirrels, fish and others, were routinely collected and processed during this occupation. The log NISP-log TAXA plot of the faunal subassemblages from Aubrey show that the faunas from the Camp B surface and from the Clovis paleosurface in the pond do indeed have greater diversity of taxa than expected from the NISP values (Figure 10.8). In addition to the faunal composition, the patterns of burning also show clearly the cultural impact on the Camp B fauna and to a lessor degree that from Camp F (Figure 10.9). In both cases the frequency of burning is well in the range of expectations for intensive use of space (Steiner 1994:147).

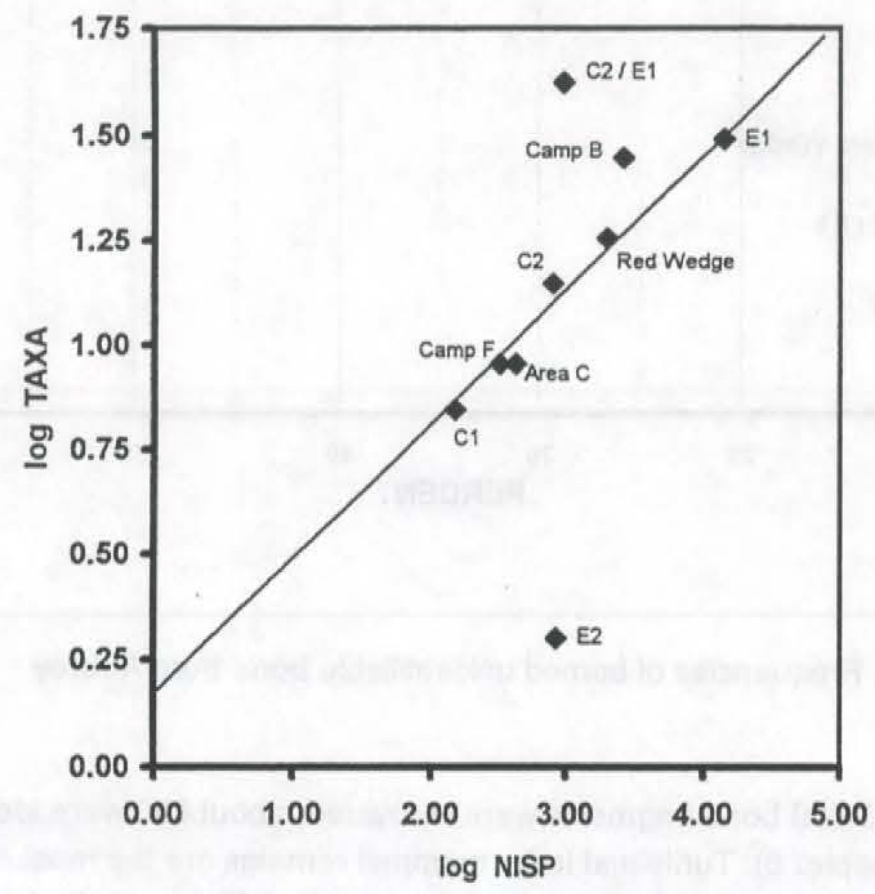

Figure 10.8 Log NISP-Log TAXA diagram for Aubrey faunas. Note the high taxonomic diversity for Camp B and the Clovis paleosurface in the pond area.

Bison appear to have been butchered at the west side of the pond, opposite Camp B. No cut marks on the bones could be identified, but a humerus was split open, apparently with a hammer and anvil technique similar to that used at the Cattle Guard Folsom site in Colorado (Jodry 1991, personal communication). 


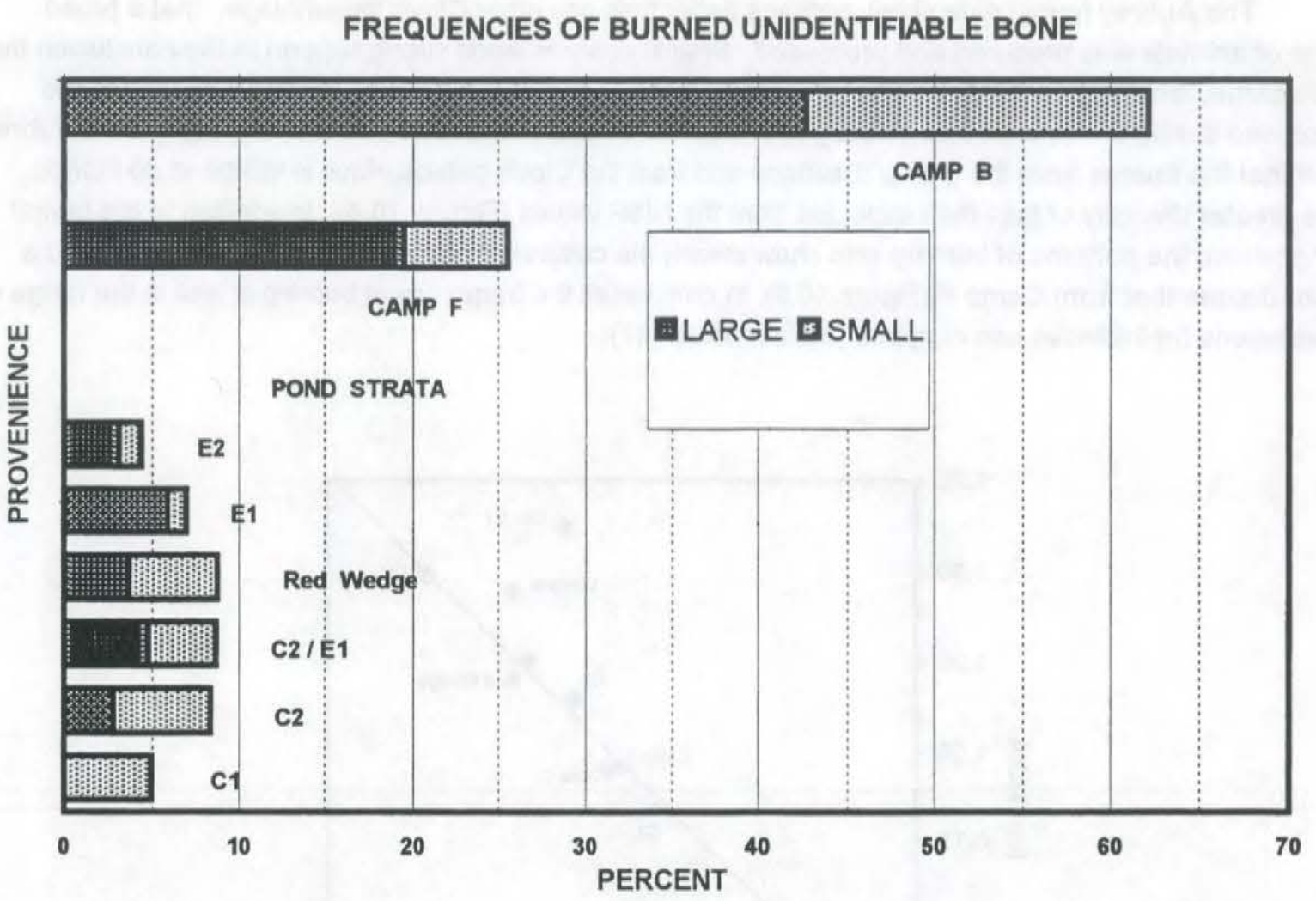

Figure 10.9 Frequencies of burned unidentifiable bone from Aubrey

In Camp B, ca. 3,500 bone fragments were recovered; about 800 were identifiable to some taxonomic level (see Chapter 8). Turtle and large mammal remains are the most common categories. Most of the burned bone at the site is in fact turtle carapace or plastron fragments that occur as discrete clusters in the southern part of the block. Large mammal fragments are quite common, with deer and bison being the only identified taxa. These are clustered in the northeastern part of the block near the major lithic concentration and a hearth. A single mammoth tooth plate fragment is not taken as evidence that mammoth were processed in this area. Small game includes rabbits, squirrel, lemming, muskrat, several kinds of fish and birds and one mussel shell. Bison and deer were utilized, but the bone data suggest that meat stripping at the procurement location was probably practiced, with consequential low importation of bones to the camp area. The impact-damaged spear point tip suggests that at least some of the game was hunted.

With almost no other Clovis camp faunas for comparison, it is difficult to assess the degree to which the Aubrey fauna accurately reflects the breadth and intensity of Clovis vertebrate exploitation, given, of course, some background on the availability of animal resources. The new faunal collections from the 
Table 10.8 Vertebrate Faunas from the Lewisville Site ${ }^{1}$

\begin{tabular}{|c|c|c|c|c|c|c|}
\hline \multirow[t]{27}{*}{ Sample } & Taxon & Common name & Unbumed & Bumed & Total & $\%$ bumed \\
\hline & Osteichthyes & fish & 3 & 1 & 4 & 25.0 \\
\hline & \multirow[t]{2}{*}{ Terrapene carolinensis } & terrapin & 1 & & 1 & \\
\hline & & "turtle" & 13 & 6 & 19 & 31.6 \\
\hline & Viperidae & viperous snake & & 1 & 1 & 100.0 \\
\hline & Colubridae & non-viperous snake & 6 & 6 & 12 & 50.0 \\
\hline & \multirow[t]{2}{*}{ Nerodia sp. } & Water snake & 1 & & 1 & \\
\hline & & Alligator & 1 & 1 & 2 & 50.0 \\
\hline & Falconiformes & raptor & 1 & & 1 & \\
\hline & Aves & birds & & 2 & 2 & 100.0 \\
\hline & Cryptotus parva & Least shrew & 1 & 3 & 4 & 75.0 \\
\hline & Scalopus aquaticus & Eastem mole & 2 & & 2 & \\
\hline & Sylvilagus floridanus & cottontail & 52 & 29 & 81 & 35.8 \\
\hline & Cynomys ludovicanus & Blk tailed prairie dog & 2 & 9 & 11 & 81.8 \\
\hline & Scurius niger & Fox squirrel & 2 & 5 & 7 & 71.4 \\
\hline & Geomys bursarius & Pocket gopher & 4 & 1 & 5 & 20.0 \\
\hline & Orrzomys palustris & Rice rat & & 1 & 1 & 100.0 \\
\hline & Peromyscus leucopus & mouse & 1 & & 1 & \\
\hline & P. $s p$ & mouse & 6 & & 6 & \\
\hline & Sigmodon hispidus & Hispid cotton rat & 11 & 9 & 20 & 45.0 \\
\hline & Neotoma floridana & Eastem woodrat & 4 & 2 & 6 & 33.3 \\
\hline & N. sp. & woodrat & 27 & 12 & 39 & 30.8 \\
\hline & Microtus sp. & Vole & 13 & 2 & 15 & 13.3 \\
\hline & \multirow[t]{2}{*}{$>$ Synaptomys cooperi } & Southem bog lemming & 11 & 5 & 16 & 31.3 \\
\hline & & mouse & 11 & 4 & 15 & 26.7 \\
\hline & \multirow[t]{2}{*}{ cf. Microtine } & vole & 2 & & 2 & \\
\hline & & rodent & 12 & 11 & 23 & 47.8 \\
\hline & \#Canus dirus & Dire wolf & 1 & & 1 & \\
\hline & Mammuthus sp. & mammoth & 1 & & 1 & \\
\hline & Equus sp. & extinct horse & 12 & 3 & 15 & 20.0 \\
\hline & \multirow[t]{4}{*}{ Odocoileus virginianus } & Whitetail deer & 14 & 1 & 15 & 6.7 \\
\hline & & ungulates & 4 & & 4 & \\
\hline & & Indet. Mammal & 19 & 36 & 55 & 65.5 \\
\hline & & TOTAL & 238 & 150 & 388 & 38.7 \\
\hline \multirow{2}{*}{\multicolumn{7}{|c|}{$\begin{array}{l}1 \quad \text { Data from Winkler (nd) } \\
\text { Taxa listed only by Crook and } \mathrm{He}\end{array}$}} \\
\hline & & & & & & \\
\hline & Anura & Ursus americanus & Glyptotherium & & Platygonus : & sp. \\
\hline & Geochleone sp. & Procyon lotor & Lepus sp. & & ?Camelops & $s p$. \\
\hline & Coluber constrictor & Mephitis mephitis & Spermophilus c & cf. trin... & Bison sp. & \\
\hline
\end{tabular}

Lewisville site, the controversial locality down the river from Aubrey (Crook and Harris 1957, 1958), has been analyzed by Dale Winkler (SMU). He kindly provided some of his data (Table 10.8). While the overall composition of the Lewisville faunas is comparable to Aubrey, the much higher incidence of burning, and the paucity of unidentifiable fragments suggest some significant differences in taphonomy between the sites. A detailed comparison is in order. 
At Area F, a much smaller faunal assemblage was recovered, and much of this appears to be naturally deposited microfauna. The medium and large animal fragments may indicate faunal processing, but this is not as clear as at Camp B. The mammoth ribs found at this locality may also indicate butchering, as also suggested by the cluster of biface resharpening debris.

Although large game procurement and processing is evident, the occupants at Aubrey were also acquiring an array of smaller species. At Aubrey, foraging was apparently a component of the overall resource procurement system. In this sense, the Clovis subsistence procurement system here appears much like that of later Archaic occupants of this region, who utilized a broad spectrum of resources from the habitats surrounding their camps. Given the environmental and climatic data from Aubrey, it seems probable that the close association of the spring, pond and river made Aubrey a likely location for encountering diverse game species. Whether the butchery of one or a few large animals was the primary impetus for occupation here is not demonstrated. However, this is a central issue to the character of the Aubrey folk's settlement-subsistence system.

\section{DISCUSSION}

Did Clovis people camp at Aubrey because one or more large animals were encountered there? Would they have bypassed this place if no large game had been encountered there? Was Aubrey used in a residential way or a logistical one? Or is Aubrey possibly an example of a palimpsest of logistical-residential activities (cf. Binford 1980)?

Foraging for diverse game during the same occupation at Aubrey when large game was being processed is quite possible if not probable. Such a scenario has been discussed for other Clovis occupations by Kelly and Todd (1988), although I do not think we can easily "fit" Aubrey and other Southern Plains Clovis sites into the "high technology forager" model as they propose.

The large game component at Aubrey may well have been a food bank for the next move, whether it was of a logistical or a residential nature. I assume that food banking, through drying, was easily within the Clovis technology. While this task was at hand, other game was probably foraged, to make efficient use of the total resources available to the occupants. In this sense the Aubrey Clovis occupations, perhaps like others from the Southern Plains, was that of generalist foragers (cf. Dincauze 1993, Meltzer 1993). Unlike the eastern fluted point cultures however, eastern type "residential" sites in this region are not known, presumably because of greater mobility in a context of low resource density and low resource predictability. This would imply, of course, that many Clovis sites in this region are residential sites of highly mobile groups. Some locations, perhaps Blackwater Draw being an example, were places that could have been repeatedly used, resulting in higher artifact and processed faunal densities. Aubrey is not culturally stratified, and any possible reoccupations would have to be defined through spatial analysis. The lack of overlapping clusters, coupled with shared raw material types among loci at the site suggest, but do not prove the case for Aubrey having been occupied by a single cultural group.

The lack of archaeological redundancy between occupation/activity areas, as well as within those areas at Aubrey suggests at least two alternative scenarios for occupation periodicity. If Aubrey's record is that of a single occupation, then the diversity (ie. non-redundancy) of activities suggests a high degree of 
intra-group task integration, focused on a diverse set of resources. If Aubrey was occupied repeatedly by a group, then the same lack of redundancy would imply a highly flexible system of resource procurement and processing that met changing resource availabilities in the site area. Either case suggests that the Clovis occupants of Aubrey had a demonstrably flexible and generalized subsistence system, as has been argued more broadly by a number of researchers.

Overall, the case could be made that the Aubrey occupations were part of a Clovis tradition of "generalist pioneers" (Mayr 1963:595). Their survival, in the face of a low biomass, strongly seasonal prairie, may well have depended on a general procurement strategy. Exactly how this strategy was implemented with respect to group size, movement patterns and relations with coeval groups, remains to be demonstrated. Likewise, if Aubrey represents a tradition that persisted for several centuries on the Southern Plains in a context of changing environments, then questions are raised as to dynamics within the Clovis trajectory towards later derived cultures, notably Folsom, Dalton and Plainview.

While Aubrey may have shed light on some incorrect perceptions of the Clovis people, there are so many models now in the market place that parts of Aubrey's record can be used by almost everyone. For the Southern Plains region, Aubrey provides a new basis for comparison of records from other sites. Hopefully the records from multiple sites will increase, gradually improving our ability to study the Clovis peoples' adaptations to a unique period in North American cultural and environmental history. 



\section{REFERENCES}

Aaby, B. and B.E. Berglund

1986 Characterization of Peat and Lake Deposits. In, Berglund, B.E. (ed.), Handbook of Holocene Palaeoecology and Palaeohydrology. John Wiley and Sons Ltd., Chichester. p. 231-246.

Agenbroad, L.D.

1984 New World Mammoth Distribution. In, Martin, P.S. and R.G. Klein (eds) Quaternary Extinctions, A Prehistoric Revolution: University of Arizona Press, Tucson p. 90-112 .

Aharon, $P$.

1992 History of Meltwater Events During the Last Deglaciation: A Perspective from the Gulf of Mexico

Based on New Isotope Data. Geological Society of America Abstracts with Programs, 24: 244.

Albert, L.E.

1981 Ferndale Bog and Natural Lake: Five Thousand Years of Environmental Change in Southeastern Oklahoma: Norman, Oklahoma Archaeological Survey, Studies in Oklahoma's Past, No. 7.

Albritton, C.C., Jr.

1966 Stratigraphy of the Domebo site, in Leonhardy, F.C., ed., Domebo: A Paleo-Indian Mammoth Kill in the Prairie-Plains: Lawton, Museum of the Great Plains, Contributions n. 1: 10-13.

1975 Stratigraphy of the Cooperton Site: Great Plains Journal, v. 14, n. 2, p. 133-139.

An, Z.S. Porter, S.C., Zhou, W., Lu, Y. C., Donahue, D. J., Head, M.J., Wu, X. H., Ren, J. Z., and Zheng, H. B.

1993 Episode of Strengthened Summer Monsoon Climate of Younger Dryas Age on the Loess Plateau of Central China. Quaternary Research 29: 45-54.

Anderson, A. D., ed.

1975 The Cooperton Mammoth: An Early Man Bone Quarry: Great Plains Journal 14 (2):130-164.

Antevs, E.

1936 The Occurrence of Flints and Extinct Animals in Pluvial Deposits Near Clovis, New Mexico, Part III: Age of Clovis Lake Beds. Proceedings of the Philadelphia Academy of Natural Sciences, 87: 304-311.

1949 Geology of the Clovis Sites. In, Ancient Man in North America, by. H.M. Worthington. Denver Museum of Natural History, Denver. pp. 185-192.

Arnett, R.H.

1973 The Beetles of the United States, a Manual for Identification. The American Entomological Institute, Ann Arbor, Michigan, 1112 pp.

Baker, B.W., B.S. Shaffer, K.D. Sobolik, and D.G. Steele

1991 Faunal Analysis. Part I: Analysis of the Vertebrate Faunal Remains. In: Ensor, H.B. and D.L. Carlson, eds., Alabonson Road: Early Ceramic Period Adaptations to the Inland Coastal Prairie Zone, Harris County, Southeast Texas. Reports of Investigations No. 8, Archaeological Research Laboratory, Texas A\&M University, College Station. p. 139-246.

Banks, L.D. 1990 From Mountain Peaks to Alligator Stomachs: a Review of Lithic Sources in the Trans-Mississippi 
South, the Southern Plains, and Adjacent Southwest: Norman, Oklahoma Anthropological Society, Memoir 4.

Barnes, V.E.

1967 Geologic Atlas of Texas, Sherman Sheet. University of Texas at Austin, Bureau of Economic Geology, Austin.

1988 Geologic Atlas of Texas, Dallas Sheet. University of Texas at Austin, Bureau of Economic Geology, Austin.

Batten, D. J.

1996 Colonial Chlorococcales. In: Jansonius, J. and McGregor, D. C. (eds.), Palynology: Principles and Applications. American Association of Stratigraphic Palynologists Foundation. 1: 191-203.

Batten, D. J., and Grenfell, H. R.

1996 Botryococcus. In: Jansonius, J. and McGregor, D.C. (eds.), Palynology: Principles and Applications. American Association of Stratigraphic Palynologists Foundation. 1: 205-214.

Becker, B., B. Kromer and P. Trimborn

1991 A Stable-Isotope Tree-Ring Timescale of the Late Glacial/Holocene Boundary. Nature 353: 647649.

Bement, L.C.

1986 Excavation of the Late Pleistocene Deposits of Bonfire Shelter, Val Verde County, Texas. Texas Archaeological Survey, Archaeology Series 1. University of Texas at Austin.

Benson, L., J.W. Burdett, S.P. Lund, M. Kashgarian and S. Mensing

1997 Nearly Synchronous Climatic Change in the Northern Hemisphere During the Last Glacial Termination. Nature 388: 263-265.

Binford, L.R.

1973 Interassemblage Variability- The Mousterian and the $>$ Functional $\cong$ Argument. In, Renfrew, C. (ed.), The Explanation of Culture Change: Models in Economic Prehistory. Duckworth, London. p. 227-254.

1979 Organization and Formation Processes: Looking at Curated Technologies. Journal of Anthropological Research 35: 255-273.

1980 Willow Smoke and Dog=s Tails: Hunter Gatherer Settlement and Archaeological Site Formation. American Antiquity 45:4-20.

1981 Bones: Ancient Men and Modern Myths. Academic Press, New York.

1982 The Archaeology of Place. Journal of Anthropological Archaeology 1: 5-31.

1987 Searching for Camps and Missing the Evidence? Another Look at the Lower Paleolithic. In, 0. Soffer (ed.), The Pleistocene Old World: Regional Perspectives. p. 17-32.

Blaine, J.C., Harris, R.K., Crook, W.W., and Shiner, J.L.

1968 The Acton site: Hood County, Texas: Bulletin of the Texas Archaeological Society, 39: 45-94.

Blair, W.F.

1950 The Biotic Provinces of Texas: The Texas Journal of Science 2 (1): 93-117. 
Blair, F.W. and T.H. Hubbell

1938 The Biotic Districts of Oklahoma: The American Midland Naturalist 20:425-455.

Blanchon, P. and J. Shaw

1995 Reef Drowning During the Last Deglaciation: Evidence for Catastrophic Sea-Level Rise and Ice Sheet Collapse. Geology 23 (1): 4-8.

Boldurian, A.T. and J.L. Cotter

1999 Clovis Revisited. New Perspectives on Paleoindian Adaptations from Blackwater Draw, New Mexico. The University Museum, The University of Pennsylvania. Philadelphia.

Bomar, G.W.

1983 Texas Weather. Austin, University of Texas Press.

Bonnichsen, R.

1991 Clovis Origins. In, Clovis: Origins and Adaptations. Bonnichsen, R. and K.L. Turnmire (eds.). Center for the Study of the First Americans, Corvalis. p. 309-330.

Bonnichsen, R. and K.L. Turnmire, eds

1991 Clovis: Origins and Adaptations. Center for the Study of the First Americans, Corvalis.

1999 Ice Age Peoples of North America. Oregon State University Press. Corvallis.

Bordes, F.

1969 Reflections on Typology and Techniques in the Paleolithic. Arctic Anthropology VI (1): 1-25.

Bordes, F. and D. Crabtree

1969 The Corbiac Blade Technique and Other Experiments. Tebiwa 12 (2): 1-21.

Bousman, C.B.

1998 Paleoenvironmental Change in Central Texas: The Palynological Evidence. Plains Anthropologist 43 (164): 201-219.

Boyer, W.P.

1974 A Preliminary Analysis of the Bifaces from the Thunderbird Site. In, The Flint Run Paleo-Indian Complex: A Preliminary Report 1971-73 Seasons (W.M. Gardner, ed.) . Occasional Publication No. 1, Archaeology Laboratory, Department of Anthropology, The Catholic University of America. Washington, D.C. p. 114-118.

Bradiey, B.

1975 Lithic Reduction Sequences: A Glossary and Discussion. In, Swanson, E. (ed.), Lithic

Technology: Making and Using Stone Tools. Aldine Publishers, Chicago. p. 6-13.

1982 Flaked Stone Technology and Typology. In, The Agate Basin Site, G.C. Frison and D.J. Stanford. Academic Press, New York. p.181-208.

1993 Paleoindian Flaked Stone Technology in the North American High Plains. In, O. Soffer and N.D. Praslov (eds.) From Kostenki to Clovis, Upper Paleolithic - Paleo-Indian Adaptations, Plenum Press, New York. p. 251-262.

Broecker, W.S., Kennett, J.P., Flower, B.P., Teller, J.T., Trumbore, S., Bonani, G., and Wolfli, W.

1989 Routing of Meltwater from the Laurentide Ice Sheet During the Younger Dryas Cold Episode Nature 341: 318-321. 
Bryan, $\mathrm{K}$.

1938 Deep Sites Near Abilene Texas: Bulletin of the Texas Archeological and Paleontological Society 10: 248-262.

1941 Geologic Antiquity of Man in America. Science, 93 (2422): 505-514.

Bryan, K., and Ray, C.N.

1938 Long Channelled Point Found in Alluvium Beside Bones of Elephas columbi: Bulletin of the Texas Archeological and Paleontological Society, 10: 263-268.

Bryant, V.M. Jr.

1977 A 16,000 Year Pollen Record of Vegetational Change in Central Texas. Palynology 1:143-156.

Bryant, V. M., Jr., and Hall, S. A.

1993 Archaeological Palynology in the United States: A Critique. American Antiquity, 58: 277-286.

Bryant, V.M. Jr., and Holloway, R.G.

1985 A Late-Quaternary Paleoenvironmental Record of Texas, In, Bryant, V.M. Jr., and Holloway, R.G., eds., Pollen Records of Late-Quaternary North American Sediments: Dallas, American Association of Stratigraphic Palynologists Foundation, p. 39-70.

Bryant, V. M., Jr., Holloway, R. G., Jones, J. G., and Carlson, D. L.

1994 Pollen preservation in Alkaline Soils of the American Southwest. In: Traverse, A. (ed.), Sedimentation of Organic Particles. Cambridge University Press, New York, p.47-58.

Broecker, W.S., Kennett, J.P., Flower, B.P., Teller, J.T., Trumbore, S., Bonani, G., and Wolfli, W.

1989 Routing of Meltwater from the Laurentide Ice Sheet During the Younger Dryas Cold Episode Nature 341: 318-321.

Burch, J. B.

1962 How to Know the Eastern Land Snails. Wm. C. Brown, Co., Dubuque, lowa.

1972 Freshwater Sphaeriacean Clams (Mollusca: Pelecypoda) of North America. Biota of Freshwater Ecosystems, Identification Manual 3, Environmental Protection Agency, Washington, D. C.

1975 Freshwater Unionacean Clams (Mollusca: Pelecypoda) of North America. Malacological Publications, Hamburg, Michigan.

1982 Freshwater Snails (Molluscs: Gastropoda) of North America. U. S. Environmental Protection Agency, Cincinnati, Ohio, EPA-600/3-82-026:1-294.

1960 A New Genus and Two New Species of Weevils from Texas with Notes on Others (Curculionidae). Coleopterists Bulletin 14: 121-127.

Bull, W.B.

1991 Geomorphic Response to Climatic Change. Oxford University Press, New York.

Butler, B. R.

1963 An Early Man Site at Big Camas Prairie, South-Central Idaho. Tebiwa 6 (1): 22-33.

Butzer, K.W.

1982 Archaeology as Human Ecology: Cambridge, Cambridge University Press.

1991 An Old World Perspective on Potential Mid-Wisconsinan Settlement of the Americas. In, 
Dillehay, T.D. and D.J. Meltzer, eds., The First Americans: Search and Research. CRC Press, Boca Raton. pp. 137-156.

Campbell, J. M.

1973 A Revision of the Genus Tachinus (Coleoptera: Staphylinidae) of North and Central America. Memoirs of the Entomological Society of Canada No. 90.

Campbell, J.M.

1982 A Revision of the North American Omaliinae (Coleoptera: Staphylinidae) 3. The genus Acidota Stephens. Canadian Entomologist 114: 1003-1029.

Caran, S.C. and Baumgardner, R.W. Jr.

1990 Quaternary Stratigraphy and Paleoenvironments of the Texas Rolling Plains: Geological Society of America Bulletin, 102: 768-785.

Cerling, T.E.

1984 The Stable Isotopic Composition of Modern Soil Carbonate and its Relationship to Climate. Earth and Planetary Science Letters 71: 229-240.

Cerling, T. E., Quade, J., Wang, T., and Bowman, J.R.

1989 Carbon Isotopes in Soils and Palaeosols as Ecology and Paleoecology Indicators. Nature 341: 138-139.

Chard, C.S.

1974 Northeast Asia in Prehistory. University of Wisconsin Press. Madison.

Cheatum, E.A. and Allen, D.

1966 Ecological Significance of Fossil Freshwater and Land Shells from the Domebo Mammoth Kill Site, In, Leonhardy, F., ed., Domebo, a Paleo-Indian Mammoth Kill in the Prairie-Plains, Lawton: Museum of the Great Plains, p. 36-43.

Cheatum, E. P. and R. W. Fullington

1971 The Recent and Pleistocene Members of the Gastropod Family Polygyriadae in Texas. Bull. Dallas Museum of Natural History 1(1):1-74.

1973 The Recent and Pleistocene Members of the Pupillidae and Urocoptidae (Gastropoda) in Texas. Bull. Dallas Museum of Natural History 1(2):1-67.

Clark, J.D.

1977 Interpretations of Prehistoric Technology from Ancient Egyptian and Other Sources. Part II: Prehistoric Arrow Forms in Africa as Shown by Surviving Examples of the Traditional Arrows of the San Bushmen. Paleorient 3: 127-150.

Clarke, A. H.

1981 The Freshwater Mollusks of Canada. National Museum of Natural Sciences, National Museums of Canada, Ottawa, Ontario, $446 \mathrm{pp}$.

Collins, M.B. 1990 Observations on Clovis Lithic Technology. Current Research in the Pleistocene 7: 73-74.

1999 Clovis Blade Technology. University of Texas Press. Austin. 
Collins, M.B. and C.B. Bousman

1990 Cultural Implications of Late Quaternary Environmental Change in Northeastern Texas. Draft report submitted to the Texas Historical Commission, Austin.

Collins, M.B., G.L. Evans, T.N. Campbell, M.C. Winans and C.E. Mear

1989 Clovis Occupations at Kincaid Shelter, Texas. Current Research in the Pleistocene 6: 3-4.

Collins, M.B., T.R. Hester, D. Olmstead and P.J. Headrick

1991 Engraved Cobbles from Early Archaeological Contexts in Central Texas. Current Research in the

Conkey, M. W.

1987 Interpretive Problems in Hunter-Gatherer Regional Studies; Some Thoughts on the European Upper Paleolithic. In, O. Soffer (ed.), The Pleistocene Old World: Regional Perspectives.

Coope, G. R.

1968 An Insect Fauna from Mid-Weichselian Deposits at Brandon, Warwickshire. Philosophical Transactions of the Royal Society of London, Series B, 254: 425-456.

Crook, W.W. Jr. and Harris, R.K.

1955 Scottsbluff Points in the Obshner Site Near Dallas, Texas: Bulletin of the Texas Archeological
Society 26: 75-100.

1957 Hearths and Artifacts of Early Man Near Lewisville, Texas and Associated Fauna: Bulletin of the
Texas Archeological Society 28: 7-97.

1958 A Pleistocene Campsite Near Lewisville, Texas. American Antiquity 23 (3): 233-246.

Curran, M.L. and J.R. Grimes

1989 Ecological Implications for Paleoindian Lithic Procurement Economy in New England. In, Ellis, C.J. and J.C. Lothrop (eds.), Eastern Paleoindian Lithic Resource Use. Westview Press, Boulder.
p. 41-74.

Daniel, I.R. and M. Wisenbaker

1989 Paleoindian in the Southeast: The View from Harney Flats. In, Ellis, C.J. and J.C. Lothrop (eds.), Eastern Paleoindian Lithic Resource Use. Westview Press, Boulder. p.323-344.

Darwin, R., Ferring, C.R. and Ellwood, B.

1990 Geoelectric Stratigraphy and Subsurface Evaluation of Quaternary Stream Sediments at Cooper Basin, NE Texas: Geoarchaeology 5 (1): 53-79.

Davis, L.C.

1987 Late Pleistocene/Holocene Environmental Changes in the Central Plains of the United States: The Mammalian Record. In, Graham, R.W., Semken, H.A. Jr. and Graham, M.A., eds., Late Quaternary Mammalian Biogeography and Environments of the Great Plains and Prairies: Springfield, Illinois State Museum, Scientific papers, Vol. 22, p. 88-143.

Delcourt, H.R and P.A. Delcourt

1985 Quaternary Palynology and Vegetational History of the Southeastern United States. In, Bryant, V.M. Jr., and R.G. Holloway, eds., Pollen Records of Late-Quaternary North American Sediments: Dallas, American Association of Stratigraphic Palynologists Foundation, p. 1-37. 
Deller, D.B and C.J. Ellis

1992 Thedford II: A Paleoindian Site in the Ausable River Watershed of Southwestern Ontario.

Memoir 24, Museum of Anthropology, University of Michigan, Ann Arbor.

Dibble, D.S. and D. Lorrain

1968 Bonfire Shelter: A Stratified Bison Kill Site, Val Verde County, Texas. Misc. Papers No. 1, Texas Memorial Museum, University of Texas at Austin.

Dibble, H.L.

1995 Middle Paleolithic Scraper Reduction: Background, Clarification, and Review of the Evidence to

Date. Journal of Archaeological Method and Theory. 2 (4): 299-368.

Dikov, N. N.

1996 The Ushki Sites, Kamchatka Peninsula. In, West, F.H. (ed) American Beginnings, The Prehistory and Palaeoecology of Beringia. University of Chicago Press, Chicago. p. 244-250.

Dillehay, T.D.

1974 Late Quaternary Bison Changes on the Southern Plains: Plains Anthropologist, v. 19, n. 65, p. 180-196.

Dincauze, D.F.

1993 Fluted Points in the Eastern Forests. In, O. Soffer and N.D. Praslov (eds.) From Kostenki to Clovis, Upper Paleolithic - Paleo-Indian Adaptations. Plenum Press, New York. p. 279-292.

Drake, R.J.

1972 The Fossil Non-Marine Molluscs of the 1961-63 Llano Estacado Paleoecology Study. In, Wendorf, F. and J. J. Hester eds., Late Pleistocene Environments of the Southern High Plains: Dallas, Fort Burgwin Research Center, Southern Methodist University. p. 201-246.

Dyksterhuis, E.J.

1946 The Vegetation of the Fort Worth Prairie. Ecological Monographs 16: 1-29.

1948 The Vegetation of the Western Cross Timbers. Ecological Monographs, 18:325-376.

Elias, S.A.

1996 Insect Fossil Evidence on Late Wisconsinan Environments of the Bering Land Bridge. In, West, F.H. (ed) American Beginnings, The Prehistory and Palaeoecology of Beringia. University of Chicago Press, Chicago. p. 110-118.

Elias, S.A.

1995 A Paleoenvironmental Setting for Early Paleoindians in Western North America: Evidence from the Insect Fossil Record. In, E. Johnson, ed., Ancient Peoples and Landscapes. Museum of Texas Tech University, Lubbock. p. 255-272.

Elias, S. A. and A. R. Nelson

1989 Fossil Invertebrate Evidence for Late Wisconsin Environments at the Lamb Spring Site, Colorado. Plains Anthropologist 34: 309-326.

Elias, S. A. and Toolin, L. J.

1990 Accelerator Dating of a Mixed Assemblage of Late Pleistocene Insect Fossils from the Lamb

Spring Site, Colorado. Quaternary Research 33: 122-126.

Elias, S.A. and T.R. Van Devender

1992 Insect Fossil Evidence of Late Quaternary Environments in the Northern Chihuahuan Desert of 
Texas and New Mexico: Comparisons with the Paleobotanical Record. The Southwestern Naturalist 37 (2): 101-116.

Ellis, C.J.

1989 The Explanation of Northeastern Paleoindian Lithic Procurement Patterns. In, Ellis, C.J. and J.C Lothrop (eds.), Eastern Paleoindian Lithic Resource Use. Westview Press, Boulder Colorado.

Emiliani, C., Gartner, S., Lidz, B., Eldridge, K., Elvey, D.K., Huang, T.C., Stipp, J., and Swanson, M.

1975 Paleoclimatological Analysis of Late Quaternary Cores from the Northeastern Gulf of Mexico. Science 189: 1083-1088.

Evans, G.L.

1951 Prehistoric Wells in Eastern New Mexico. American Antiquity 17: 1-8.

Evans, G.L., and Meade, G.E.

1945 Quaternary of the Texas High Plains. University of Texas Bulletin 4401: 485-507.

Fairbanks, R. G.

1990 A 17,000-year Glacio-Eustatic Sea Level Record: Influence of Glacial Melting Rates on the Younger Dryas Event and Deep Ocean Circulation. Nature 342: 637-642.

Farizy, C.

1994 Spatial Patterning of Middle Paleolithic Sites. Journal of Anthropological Archaeology 13: 153160.

Faulkner, $\mathrm{A}$.

1972 The Mechanical Basis of Flintknapping. PhD Dissertation. University Microfilms. Ann Arbor.

Feng, Z., W.C. Johnson, Y. Lu and P.A. Ward III

1994 Climatic Signals from Loess-Soil Sequences in the Central Great Plains, USA

Palaeogeography, Palaeoclimatology and Palaeoecology 110: 345-358.

Fenneman, N.M

1931 Physiography of Western United States. McGraw-Hill, New York.

1938 Physiography of Eastern United States: New York, McGraw-Hill Book Company, Inc., 714 p.

Ferring, C. R.

1980 Technological Variability and Change in the Late Paleolithic of the Negev. PhD Dissertation, Southern Methodist University, Dallas.

1984 Intra-site Spatial Patterning: Its Role in Settlement-Subsistence System Analysis. In, Intrasite Spatial Analysis in Archaeology. H. Hietala (ed.). Cambridge University Press, Cambridge. p.
116-126.

1986 Late Quaternary Geology and Environments of the Upper Trinity Basin, in Yates, B.C. and C.R. Ferring (eds.), An Assessment of the Cultural Resources in the Trinity Basin, Dallas, Tarrant and Denton Counties, Texas: North Texas State University, Institute of Applied Sciences, Denton,

1987 (Assembler) Late Quaternary Stratigraphy, Neotectonics and Geoarchaeology of Southwestern Oklahoma. Friends of the Pleistocene South-Central Cell Field Trip Guidebook. North Texas State University, Institute of Applied Sciences, Denton, Terxas. 
1988 Technological Change in the Upper Paleolithic of the Negev. In: Upper Pleistocene Prehistory of Western Eurasia. H. Dibble and A. Montet-White, (eds.). University of Pennsylvania Press, Philadelphia. p. 333-348.

1989a The Aubrey Clovis site: a Paleoindian Locality in the Upper Trinity River Basin, Texas. Current Research in the Pleistocene 6: 9-11.

1989b Field Guide to the Archaeological Geology of the Upper Trinity River Drainage Basin. Geological Society of America, South-Central Section Field Trip Guidebook, University of Texas at Arlington, Arlington, Texas.

1990a Archaeological Geology of the Southern Plains, in, Lasca, N.P. and J. Donahue, (eds)., Archaeological Geology of North America: Centennial Special Volume 4. Geological Society of America, Boulder Colorado. p. 253-266.

1990b The 1989 Investigations at the Aubrey Clovis Site, Texas. Current Research in the Pleistocene 7: $10-12$.

1990c Late Quaternary Geology and Geoarchaeology of the Upper Trinity River Drainage Basin, Texas. In Guidebook for Geological Society of America Field Trip 11. Dallas Geological Society, Dallas. p. 1-81.

1991 Upper Trinity River Drainage Basin, Texas, in, Morrison, R., (ed.), Quaternary Non-Glacial Geology: Conterminous United States. Geological Society of America, Decade of North American Geology, Vol. K-2. Geological Society of America, Boulder, Colorado. p. 526-531.

1992 Alluvial Soils and Geoarchaeological Research. In: Soils and Archaeology. Holliday, V.T., (ed.). Smithsonian Institution Press, Washington. p. 1-39.

1993 Late Quaternary Geology of the Upper Trinity River Drainage Basin, North Central Texas [PhD Dissertation]. University of Texas at Dallas. University Microfilms, Ann Arbor, Michigan.

1994 The Role of Geoarchaeology in Paleoindian Research. In, Method and Theory for Investigating the Peopling of the Americas, R. Bonnichsen and G. Steele (eds.). Center for the Study of the First Americans, Corvallis Oregon, p. 57-72.

1995a The Late Quaternary Geology and Archaeology of the Aubrey Clovis Site, Texas. In, Ancient Peoples and Landscapes (E. Johnson, ed.), Museum of Texas Tech University, Lubbock, Texas. p. 273-281.

1995b Middle Holocene Environments, Geology and Archaeology in the Southern Plains, in, Bettis, E.A. III, (ed.), Archaeological Geology of the Archaic Period in North America: Geological Society of America Special Paper No. 297. Geological Society of America, Boulder, Colorado. p. 21-35.

Ferring, C.R. and D.E. Peter

1987 Geoarchaeology of the Dyer Site, A Prehistoric Occupation inthe Western Ouachitas, Oklahoma. Plains Anthropologist 32 (118): 351-366.

Fiedel, S.J. 1999 Older Than We Thought: Implications of Corrected Dates for Paleoindians. American Antiquity 64 (1): 95-115. 
254

Figgins, J.D.

1927 The Antiquity of Man in America. Natural History 27(3): 229-239.

Ford, A. and E. Pauls

1980 Soil Survey of Denton County, Texas: U.S. Department of Agriculture, Washington, D.C.

Frison, G.C.

1976 Cultural Activity Associated with Prehistoric Mammoth Butchering and Processing. Science 194: 728-730.

1978 Prehistoric Hunters of the High Plains. Academic Press, New York.

1982 The Sheaman Site: A Clovis Component. In, The Agate Basin Site, G.C. Frison and D.J. Stanford (eds.). Academic Press, New York. p.143-156.

1987 Prehistoric, Plains-Mountain, Large-Mammal, Communal Hunting Strategies. In, Nitecki, M.H. and D.V. Nitecki (eds.), The Evolution of Human Hunting. Plenum Press, New York. p. 177-224.

1989 Experimental Use of Clovis Weaponry and Tools on African Elephants. American Antiquity 54(4): 766-784.

1991 The Goshen Paleoindian Complex: New Data for Paleoindian Research. In, Clovis: Origins and Adaptations. Bonnichsen, R. and K.L. Turnmire (eds.). Center for the Study of the First Americans, Corvalis, Oregon. p. 133-152.

1993 North American High Plains Paleo-Indian Hunting Strategies and Weaponry Assemblages. In, O. Soffer and N.D. Praslov (eds.) From Kostenki to Clovis, Upper Paleolithic - Paleo-Indian Adaptations. Plenum Press, New York. p. 237-250.

Frison, G.C. (ed.)

1996 The Mill Iron Site. University of New Mexico Press. Albuquerque.

Frison, G.C. and B. A. Bradley

1980 Folsom Tools and Technology. University of New Mexico Press, Albuquerque.

1999 The Fenn Cache. One Horse Land and Cattle Company. Santa Fe, New Mexico.

G. C. and C.A. Reher

1970 Age Determination of Buffalo by Teeth Eruption and Wear. Plains Anthropologist 15(50):4650.

Frison, G.C. and Todd, L.C.

1986 The Colby Mammoth Site: Taphonomy and Archaeology of a Clovis Kill in Northern Wyoming. University of New Mexico Press. Albuquerque.

Fullington, Richard W.

1978 The Recent and Fossil Freshwater Gastropod Fauna of Texas. Unpublished Ph. D. Dissertation, North Texas State University, Denton, Texas.

Fullington, R. W. and W. L. Pratt, Jr.

1974 The Helicinidae, Carychiidae, Achatinidae, Bradybaenidae, Bulimulidae, Cionellidae, Haplotrematidae, Helicidae, Helicidae, Oreohelicidae, Spiraxidae, Streptaxidae, Strobilopsidae, Thysanophoridae, Valloniidae (Gastropoda) in Texas. Bulletin of the Dallas Museum of Natural History 1(3):1-48. 
Gallagher, J.

1977 Contemporary Stone Tools in Ethiopia: Implications for Archaeology. Journal of Field Archaeology 4: 407-414.

Gamble, C.

1986 The Palaeolithic Settlement of Europe. Cambridge University Press. Cambridge.

Gardner, W. M. (ed.)

1974 The Flint Run Paleo-Indian Complex: A Preliminary Report 1971-73 Seasons. Occasional Publication No. 1, Archaeology Laboratory, Department of Anthropology, The Catholic University of America. Washington, D.C.

Gilbert, B.M.

1980 Mammalian Osteology. Revised from Mammalian Osteo-Archaeology: North America. Missouri Archaeological Society. B. Miles Gilbert, Publisher, Laramie, Wyoming.

Gilbert, B.M., L.D. Martin, and H.G. Savage

1981 Avian Osteology. B. Miles Gilbert, Publisher, Laramie, Wyoming.

Goebel, T., R. Powers and N. Bigelow

1991 The Nenana Complex of Alaska and Clovis Origins. In, R. Bonnichsen and K. Turnmire (eds.) Clovis: Origins and Adaptations. Center for the Study of the First Americans. Oregon State University, Corvallis, Oregon. p. 49-79.

Goode, G.T. and R.J. Mallouf

1991 The Evant Cores: Polyhedral Blade Cores from North-Central Texas. Current Research in the Pleistocene 8:67-72.

Goodfriend, G.A., and M. Magartiz

1988 Palaeosols and Late Pleistocene Rainfall Fluctuations in the Negev Desert. Nature 332: 144-146.

Goodyear, A.C.

1989 A Hypothesis for the Use of Cryptocrystalline Raw Materials Among Paleoindian Groups of North America. In, Ellis, C.J. and J.C. Lothrop (eds.), Eastern Paleoindian Lithic Resource Use. Westview Press, Boulder, Colorado. p. 1-10.

1997 Clovis Utilization at Southeastern U.S. Quarries: the Big Pine Tree Site, Allendale County, South Carolina. Abstracts of the SAA $62^{\text {nd }}$ Annual Meeting. Society for American Archaeology. Society for American Archaeology, Washington, D.C. p. 95.

Goodyear, A.C., S.B. Upchurch, T. Charles and A.B. Albright

1985 Chert Sources and Paleoindian Lithic Processing in Allendale County, South Carolina. Current Research in the Pleistocene 2: 47-49.

1999 The Early Holocene Occupation of the Southeastern United States: A Geoarchaeological

Summary. In, Bonnichsen, R. and K. Turnmire (eds) Ice Age Peoples of North America. Oregon

State University Press. Corvallis, Oregon. p. 432-481.

Gordon, R. D.

1983 Studies on the Genus Aphodius of the United States and Canada (Coleoptera: Scarabaeidae). VII. Food and Habitat; Distribution; Key to Eastern Species. Proceedings of the Entomological Society of Washington 85: 633-652. 
256

Gould, C.N.

1921 Where Did the Indians of the Great Plains Get Their Flint? Proceedings of the Oklahoma Academy of Science 1: 71-76.

Graham, R.W.

1987 Late Quaternary Mammalian Faunas and Paleoenvironments of the Southwestern Plains of the United States, In, Graham, R.W., H.A. Semken, Jr. and M.A. Graham, (eds.), Late Quaternary Mammalian Biogeography and Environments of the Great Plains and Prairies. Illinois State Museum, Scientific Papers 22: 24-86.

Graham, R.W., C.V. Haynes, Jr., D.L. Johnson, and M. Kay

1981 Kimmswick: A Clovis-Mastodon Association in Eastern Missouri. Science 213: 1115-1117.

Graham, R.W. and M. Kay

1988 Taphonomic Comparisons of Cultural and Noncultural Faunal Deposits at the Kimmswick and Barnhart Sites, Jefferson County, Missouri. In, Laub, R.S., N.G. Miller and D.W. Steadman, (eds.), Late Pleistocene and Early Holocene Paleoecology and Archaeology of the Eastern Great Lakes Region. Bulletin of the Buffalo Society of Natural Sciences, No. 33: 227-240.

Graham, R.W. and E.L. Lundelius

1984 Coevolutionary Disequilibrium and Pleistocene Extinctions. In, Martin, P.S and R.G. Klein, eds., Quaternary Extinctions, a Prehistoric Revolution. The University of Arizona Press, Tucson, Arizona. p. 223-249.

Gramley, R.M.

1982 The Vail Site: A Palaeo-Indian Encampment in Maine. Bulletin of the Buffalo Society of Natural Sciences, Vol. 30.

1990 Guide to the Palaeo-Indian Artifacts of North America. Persimmon Press, Buffalo.

Gramley, R.M. and J. Lothrop

1984 Archaeological Investigations of the Potts Site, Oswego County, New York, 1982, 1983.

Archaeology of Eastern North America 12: 122-158

Grayson, D.K.

1977 Pleistocene Avifaunas and the Overkill Hypothesis. Science 195: 691-693.

1984a Archaeological Associations with Extinct Pleistocene Mammals in North America. Journal of Archaeological Science 11: 213-221.

1984b Explaining Pleistocene Extinctions, Thoughts on the Structure of a Debate. In, Martin, P.S. and R.G. Klein (eds) Quaternary Extinctions, A Prehistoric Revolution: University of Arizona Press, Tucson p. 807-823.

1987 An Analysis of the Chronology of Late Pleistocene Mammalian Extinctions in North America. Quaternary Research 28: 281-289.

1989 The Chronology of North American Late Pleistocene Extinctions. Journal of Archaeological Science 16: 153-165.

Green, F.E.

1962a Additional Notes on Prehistoric Wells at the Clovis Site. American Antiquity 28 (2): 230-234.

1962b The Lubbock Reservoir Site: 12,000 Years of Human Prehistory: Journal of the West Texas 
Museum Association 6: 83-123.

1963 The Clovis Blades: An Important Addition to the Llano Complex. American Antiquity 29: 145-165.

1992 Comments on the Report of a Worked Mammoth Tusk from the Clovis Site. American Antiquity 57 (2): 331-337.

Grimes, J.R., W. Eldridge, B.G. Grimes, A. Vaccaro, F. Vaccaro, J. Vaccaro, N. Vaccaro and A. Orsini 1984 Bull Brook II. Archaeology of Eastern North America 12: 159-183.

Gross, J.I.

1974 Some Patterns of Chipping Activity of the Thunderbird Clovis Component. In, The Flint Run Paleo-Indian Complex: A Preliminary Report 1971-73 Seasons (W.M. Gardner, ed.) . Occasional Publication No. 1, Archaeology Laboratory, Department of Anthropology, The Catholic University of America. Washington, D.C. p. 100-105.

Gruger, J.

1973 Studies on the Late Quaternary Vegetation History of Northeastern Kansas. Geological Society of America Bulletin 26: 121-194.

Gustavson, T.C. (ed.)

1986 Geomorphology and Quaternary stratigraphy of the Rolling Plains, Texas Panhandle: Austin, Bureau of Economic Geology, Guidebook 22.

Gustavson, T.C., Baumgardner, R.W., Caran, S.C., Holliday, V.T., Mehnert, H.H., O'Neill, J.M. and Reeves, C.C.

1991 Quaternary Geology of the Southern Great Plains and an Adjacent Segment of the Rolling Plains, in, Morrison, R., ed., Quaternary Non-glacial geology: Conterminous United States: Denver, Geological Society of America, Decade of North American Geology, K-2: 477-501.

Haas, H., Holliday, V., and Stuckenrath, R.

1986 Dating of Holocene Stratigraphy with Soluble and Insoluble Organic Fractions at the Lubbock Lake Archaeological Site, Texas: An Ideal Case Study: Radiocarbon 28(2A): 473-485.

Hall, D.A.

1996 Site Near Savannah River Yields Clues to Paleoindians. Mammoth Trumpet 11 (1): 10-12.

1997 New Dates at Old Site. Mammoth Trumpet 12(3): 8.

Hall, S. A.

1977 Late Quaternary Sedimentation and Paleoecologic History of Chaco Canyon, New Mexico. Geological Society of America Bulletin 88:1593-1618.

1990 Pollen Deposition and Vegetation in the Southern Rocky Mountains and Southwest Plains, USA. Grana29: 47-61.

1992 Comparative Pollen Influx at a Nine-trap Array in the Grand Prairie of Northern Texas. Texas Journal of Science 44: 469-474.

1994 Modern Pollen Influx in Tallgrass and Shortgrass Prairies, Southern Great Plains, USA. Grama, 33: 321-326.

1995 Late Cenozoic Palynology in the South-central United States: Cases of Post-depositional Pollen Destruction. Palynology 19: 85-93. 
Hall, S. A., and Valastro, S., Jr.

1995 Grassland Vegetation in the Southern Great Plains During the Last Glacial Maximum. Quaternary Research, 44: 237-245.

Hammatt, H.H.

1970 A Paleo-Indian Butchering Kit. American Antiquity 35(2): 141-152.

Harbour, J.

1975 General Stratigraphy, In, Wendorf, F. and J.J. Hester, eds., Late Pleistocene Environments of the Southern High Plains: Dallas, Fort Burgwin Research Center, Southern Methodist University, p. 33-55.

Harris, A.H.

1985 Late Pleistocene Vertebrate Paleoecology of the West. University of Texas Press, Austin.

Harrison, D.

1974 A Prelimanary Analysis of Scrapers from the Thunderbird Site. In, The Flint Run Paleo-Indian Complex: A Preliminary Report 1971-73 Seasons (W.M. Gardner, ed.) . Occasional Publication No. 1, Archaeology Laboratory, Department of Anthropology, The Catholic University of America. Washington, D.C. p. 106-113.

Harrison, B.R. and Killen, K.L.

1978 Lake Theo: A Stratified Early Man Bison Butchering and Camp Site, Briscoe County, Texas, Archaeological Investigations, Phase II: Canyon, Panhandle-Plains Historical Museum, Special Archaeological Report 1.

Haury, E., E.B. Sayles and W.W. Wasley

1959 The Lehner Mammoth Site, Southeastern Arizona. American Antiquity 25:2-30.

Haynes, C.V. Jr.

1967 Geochronology of Late-Quaternary Alluvium, in, Morrison, R.B. and Wright, H.E., eds., Means of Correlation of Quaternary Successions. University of Utah Press, Salt Lake City. p. 591-631.

1970 Geochronology of Man-Mammoth Sites and Their Bearing upon the Origin of the Llano Complex, In: Dort W. Jr. and Jones J.K. Jr., (eds.), Pleistocene and Recent Environments of the Central Great Plains, pp. 77-92. University of Kansas Press, Lawrence.

1975 Pleistocene and Recent Stratigraphy, in Wendorf, F. and Hester, J.J., eds., Late Pleistocene Environments of the Southerm High Plains: Dallas, Fort Burgwin Research Center, Southern Methodist University, pp. 591-631.

1981 Geochronology and Paleoenvironments of the Murray Springs Clovis Site, Arizona. National Geographic Research Reports 14: 243-251.

1982 Archaeological Investigations at the Lehner Site, Arizona, 1974-1975. National Geographic Research Reports 14: 325-334.

1984 Stratigraphy and Late Pleistocene Extinction in the United States, In, Martin, P.S and Klein, R.G., eds., Quaternary Extinctions, a Prehistoric Revolution: Tucson, The University of Arizona Press, p. 345-353.

1985 Mastodon-Bearing Springs and Late Quaternary Geochronology of the Lower Pomme de Terre 
Valley, Missouri. Geological Society of America Special Paper 204. Geological Society of America, Boulder.

1990 The Antevs-Bryan Years and the Legacy for Paleoindian Geochronology, In, L.F. Laporte, ed., Establishment of a Geologic Framework for Paleoanthropology: Boulder, Geological Society of America, Special Paper 242: 55-68.

1991 Geoarchaeological and Paleohydrological Evidence for a Clovis-age Drought in North America and its Bearing on Extinction. Quatemary Research 35: 438-450.

1993 Clovis-Folsom Geochronology and Climatic Change. In, O. Soffer and N.D. Praslov (eds.) From Kostenki to Clovis, Upper Paleolithic - Paleo-Indian Adaptations. Plenum Press, New York. p. 219-236.

1995 Geochronology of Paleoenvironmental Change, Clovis Type Site, Blackwater Draw, New Mexico. Geoarchaeology 10: 317-388.

Haynes, C.V. Jr. and G.A. Agogino

1966 Prehistoric Springs and Geochronology of Blackwater No. 1 Locality, New Mexico: American Antiquity 31: 812-821.

Haynes, C.V. Jr., D.J. Donahue, A.J.T. Jull and T.H. Zabel

1984 Application of Accelerator Dating to Fluted Point Paleoindian Sites. Archaeology of Eastern North America 12: 184-191.

Haynes, C.V. Jr., A. Long and A.J.T. Jull

1987 Radiocarbon Dates at Willcox Playa, Arizona, Bracket the Clovis Occupation Surface. Current Research in the Pleistocene 4: 124-126.

Haynes, C.V. Jr., J.J. Sanders, D. Stanford and G.A. Agogino 1992 Reply to F.E. Green's Comments on the Clovis Site. American Antiquity 57 (2): 3

Haynes, V.T. Jr., D.J. Stanford, M. Jodry, J. Dickenson, J.L. Montgomery, P.H. Shelley, I. Rovner and G.A. Agogino

1999 A Clovis Well at the Type Site 11,500 B.C.: The Oldest Prehistoric Well in America.

Geoarchaeology, An International Journal 14 (5): 455-470.

Heinrich, P.V.

1984 Lithic Resources of Western Louisiana. Louisiana Archaeology 11:165-190.

Henderson, J. and Goode, G.

1991 Pavo Real: An Early Paleoindian Site in South-central Texas. Current Research in the Pleistocene 8: 26-28.

Henry, D.O., C.V. Haynes and B. Bradley

1976 Quantitative Variation in Flaked Stone Debitage. Plains Anthropologist 21 (71): 57-61.

Hester, J. J. (Ed)

1972 Blackwater Locality No.1 A Stratified Early Man Site in Eastern New Mexico. Fort Burgwin Research Center, Southern Methodist University. Dallas.

1975 Paleoarchaeology of the Llano Estacado, In, Wendorf, F. and J.J. Hester, eds., Late Pleistocene Environments of the Southem High Plains: Dallas, Fort Burgwin Research Center, Southern Methodist University, p. 247-256. 
Hill, R.T.

1901 Geography and Geology of the Black and Grand Prairies, Texas, with Detailed Description of the Cretaceous Formations and Special Reference to Artesian Waters: United States Geological Survey, 21st Annual Report, Part 7-Texas.

Hillson, $\mathrm{S}$.

1986 Teeth. Cambridge University Press, Cambridge.

Hofman, J.L.

1988 Dating the Lower Member of the Domebo Formation in Western Oklahoma. Current Research in the Pleistocene 5: 86-88.

1994 Paleoindian Aggregations on the Great Plains. Journal of Anthropological Archaeology 13: $341-$ 370.

Hofman, J.L. and G.R. Brackenridge

1988 Geoarchaeological Investigation of the Lower Member of the Domebo Formation in Western Oklahoma: Program and Abstracts of the Tenth Biennial Meeting, American Quaternary Association, pp. 124.

Hofman, J.L. and D.G. Wyckoff

1991 Clovis Occupation in Oklahoma. Current Research in the Pleistocene 8: 29-32.

Holliday, V. T.

1985a Archaeological Geology of the Lubbock Lake Site, Southern High Plains of Texas: Geological Society of America Bulletin 96: 1483-1492.

1985b New Data on the Stratigraphy and Pedology of the Clovis and Plainview Sites, Southern High Plains. Quaternary Research 23: 388-402.

1985c Early and Middle Holocene Soils at the Lubbock Lake Archaeological Site, Texas. Catena 12: 61-78.

1989 Middle Holocene Drought on the Southern High Plains, Quaternary Research 31: 74-82.

1995 Stratigraphy and Paleoenvironments of Late Quaternary Valley Fills on the Southern High Plains. Geological Society of America, Memoir 186. Boulder, Colorado.

1996 Lithostratigraphy and Geochronology of Fills in Small Playa Basins on the Southern High Plains, United States. Geological Society of America Bulletin 108 (8): 953-965.

1997 Paleoindian Geoarchaeology of the Southern High Plains. University of Texas Press, Austin.

2000 The Evolution of Paleoindian Geochronology and Typology on the Great Plains. Geoarchaeology, An International Journal 15 (3): 227-290.

Holliday, V.T., and Allen, B.L.

1987 Geology and Soils, In Johnson, E., ed., Lubbock Lake, Late Quaternary Studies on the Southern High Plains: College Station, Texas A\&M University Press, p. 14-21.

Holliday, V.T., C.V. Haynes, Jr., J. Hofman and D.J. Meltzer

1994 Geochronology and Geoarchaeology of the Miami (Clovis) Site, Southern High Plains of Texas. Quaternary Research 41: 234-244. 
Holliday, V.T., E. Johnson, S.A. Hall and V.M. Bryant 1985 Re-Evaluation of the Lubbock Subpluvial. Current Research in the Pleistocene 2: 119-121.

Holliday, V.T. and C.M. Welty

1981 Lithic Tool Resources of the Eastern Llano Estacado. Bulletin of the Texas Archaeological Society 52: 201-214.

Holloway, R.

1993 Pollen Analysis of Ferndale Bog, Oklahoma. Report to the Institute of Applied Sciences, University of North Texas, Denton, Texas.

Howard, E.B.

1935 The Occurrence of Flints and Extinct Animals in Fluvial Deposits Near Clovis, New Mexico, Part I: Introduction. Proceedings of the Philadelphia Academy of Natural Sciences 87: 299-303.

Howden, H. F. and O. L. Cartwright

1963 Scarab Beetles of the Genus Onthophagus Latreille North of Mexico (Coleoptera:

Scarabaeidae). Proceedings of the United States National Museum No. 3467; 114: 1-135.

Hubricht, L.

1985 The Distributions of the Native Land Mollusks of the Eastern United States. Fieldiana Zoology (n.s.) 24:1-191.

Huckell, B.

1979 Of Chipped Stone Tools, Elephants and the Clovis Hunters: An Experiment. Plains Anthropologist 24: 177-188.

Hughes, D.T.

1984 The Foragers, Western Oklahoma, In, Bell,R.E (ed.), The Prehistory of Oklahoma. Academic Press Inc., New York. p. 109-117.

Hughes, J.T. and Willey, P.S.

1978 Archaeology at Mackenzie Reservoir: Austin, Texas Historical Commission, Archaeological Survey Report 24.

Humphrey, J. and C.R. Ferring

1994 Stable Isotopic Evidence for Late Pleistocene to Holocene Climatic Change, North-Central

Texas. Quaternary Research 41: 200-213.

Irwin, H.T. and H.M. Wormington

1970 Paleo-Indian Tool Types in the Great Plains. American Antiquity 35: 24-34.

Jackson, L.J.

1983 Geochronology and Settlement Disposition in the Early Palaeo-Indian Occupation of Southern

Ontario, Canada. Quaternary Research 19: 388-399.

Jensen, $\mathrm{H}$.

1968 Report on Excavations at the Field Ranch Site (X41CO-10) Cooke County, Texas. Bulletin of the Texas Archaeological Society 39: 133-146.

Johnson, E.

1978 Paleo-Indian Bison Procurement and Butchering Patterns of the Llano Estacado. Plains Anthropologist Memoir 14 (2): 98-105. 
1986 Late Pleistocene and Early Holocene Vertebrates and Paleoenvironments on the Southern High Plains, U.S.A. Geographie Physique et Quatemaire 40 (3): 249-261.

1987 Lubbock Lake, Late Quaternary Studies on the Southern High Plains. Texas A\&M University Press, College Station, Texas.

1991 Late Pleistocene Cultural Occupation on the Southern Plains. In, R. Bonnichsen and K. Turnmire (eds.) Clovis: Origins and Adaptations. Center for the Study of the First Americans, Corvallis, Oregon. p. 215-236.

1995 Site Formation and Disturbance Processes at Lubbock Lake (Southern High Plains, U.S.A.) During the Terminal Pleistocene. In, Ancient Peoples and Landscapes (E. Johnson, ed.), Museum of Texas Tech University, Lubbock, Texas. p. 315-340

Johnson, E. and V.T. Holliday

1985 A Clovis-Age Megafaunal Processing Station at the Lubbock Lake Landmark. Current Research in the Pleistocene 2:17-19.

1989 Lubbock Lake: Late Quaternary Cultural and Environmental Change on the Southern High Plains, USA. Journal of Quatemary Science 4: 145-165.

Judge, W.J.

1973 Paleoindian Occupation of the Central Rio Grande Valley in New Mexico. University of New Mexico Press, Albuquerque, New Mexico.

Julig, P.J., L.A. Pavlish and R.G.V. Hancock

1989 Aspects of Late Paleoindian Lithic Technological Organization in the Northwestern Lake Superior Region of Canada. In, Ellis, C.J. and J.C. Lothrop (eds.), Eastern Paleoindian Lithic Resource Use. Westview Press, Boulder, Colorado. p. 293-322.

Kay, M.

1996 Microwear Analysis of Some Clovis and Experimental Chipped Stone Tools. In, Odell, G.H. (Ed.), Stone Tools, Theoretical Insights into Human Prehistory. Plenum Perss, New York. p. 5180.

Kelly, R.L. and L.C. Todd

1988 Coming Into the Country: Early Paleoindian Hunting and Mobility. American Antiquity 53(2): 231244.

King, J.E. and J.J. Saunders

1984 Environmental Insularity and the Extnction of the American Mastodont. In, Martin, P.S. and R.G. Klein (eds) Quaternary Extinctions, A Prehistoric Revolution: University of Arizona Press, Tucson p. 315-344.

Klein, R. G.

1969 Man and Culture in the Late Pleistocene, A Case Study. Chandler Publishing Co., San Francisco.

Knox, J.C.

1995 Fluvial Systems Since 20,000 Years BP. In, Global Continental Palaeohydrology (K.J. Gregory, L. Starkel and V.R. baker, eds.), pp. 87-108. John Wiley and Sons, Ltd. New York.

1996 Late Quaternary Upper Mississippi River Alluvial Episodes and Their Significance to the Lower 
Mississippi River System. Engineering Geology 45: 263-285.

Koetje, T.A.

1994 Intrasite Spatial Structure in the European Upper Paleolithic: Evidence and Patterning from the SW of France. Journal of Anthropological Archaeology 13: 161-169.

Kraft, H.C.

1973 The Plenge Site: A Paleo-Indian Occupation Site in New Jersey. Archaeology of Eastern North America 1 (1): 56-117.

Krotova, A.A. and N.G. Belan

1993 Amvrosievka, A Unique Upper Paleolithic Site in Eastern Europe. In, In, O. Soffer and N.D. Praslov (eds.) From Kostenki to Clovis, Upper Paleolithic - Paleo-Indian Adaptations. Plenum Press, New York. p. 125-142.

Kuhn, S.

1994 A Formal Approach to the Design and Assembly of Mobile Tool Kits. American Antiquity 59: 426-442.

Kurten, B. and E. Anderson

1980 Pleistocene Mammals of North America. Columbia University Press. New York.

Lahren, L. and R. Bonnichsen

1974 Bone Foreshafts from a Clovis Burial in Southwestern Montana. Science 186: 147-150.

Lantz, S. W.

1984 Distribution of Paleo-Indian Projectile Polnts and Tools from Western Pennsylvania: Implications for Regional Differences. Archaeology of Eastern North America 12: 210-230.

Larichev, V., U. Kholushkin and I. Laricheva

1992 The Upper Paleolithic of Northern Asia: Achievements, Problems and Perspectives. III. Northeastern Siberia and the Russian Far East. Journal of World Prehistory 6 (4): 441-476.

Larsen, D.A., V.A. Bryant and T.S. Patty

1972 Pollen Analysis of a Central Texas Bog. American Midland Naturalist 88 (2): 358-367.

Laub, R.S., M.F. DeRemer, C.A. Dufort and W.L. Parsons

1988 The Hiscock Site: A Rich Late Quaternary Locality in Western New York State. In, Laub, R.S., N.G. Miller and D.W. Steadman,(eds.), Late Pleistocene and Early Holocene Paleoecology and Archaeology of the Eastern Great Lakes Region. Bulletin of the Buffalo Society of Natural Sciences 33: 67-81.

Leighton, M.M.

1936 Geological Aspects of Findings of Primitive Man Near Abilene, Texas, Medallion Papers, n. 24.

Leonhardy, F.C., (ed.)

1966 Domebo: A Paleo-Indian Mammoth Kill in the Prairie-Plains. Contribution No. 1, Museum of the Great Plains, Lawton, Oklahoma.

Leonova, N.B.

1993 Criteria for Estimating the Duration of Occupation at Paleolithic Sites. In, O. Soffer and N.D. Praslov (eds.) From Kostenki to Clovis, Upper Paleolithic - Paleo-Indian Adaptations, Plenum Press, New York. p. 149-157. 
Lepper, B.T.

1999 Pleistocene Peoples of Midwestern North America. In, Bonnichsen, R. and K. Turnmire (eds) Ice Age Peoples of North America. Oregon State University Press. Corvallis, Oregon. p. 362-394.

Lepper, B.T. and D. J. Meltzer

1991 Late Pleistocene Human Occupation of the Eastern United States. In, Clovis: Origins and Adaptations. Bonnichsen, R. and K.L. Turnmire. (eds.). Center for the Study of the First Americans, Corvalis, Oregon. p. 175-184.

Lindroth, C. H.

1963 The Ground Beetles of Canada and Alaska, part 3. Opuscula Entomologica Supplement No. 24: 201-408.

1966 The Ground Beetles of Canada and Alaska, part 4. Opuscula Entomologica Supplement No. 29: 409-648.

1968 The Ground Beetles of Canada and Alaska, part 5. Opuscula Entomologica Supplement No. 33: 649-944.

1969 The Ground Beetles of Canada and Alaska, part 6. Opuscula Entomologica Supplement No. 34: 945-1192.

Lobeck, A.K

1948 Physiographic Diagram of North America. The Geographical Press, Columbia University. New York, New York.

Long ,R.J.

1977 McFadden Beach. The Patillo Higgins Series of Natural History and Anthropology, No. 1, Spindle Top Museum, Lamar University, Beaumont, Texas.

Lopinau, J. and R. Mandel

1998 The Big Eddy Site: A Multicomponent Paleoindian Site on the Ozark Border, Southwest Missouri. Plains Anthropologist 43 (163):

Lothrop, J.C.

1989 The Organization of Paleoindian Lithic Technology at the Potts Site. In, Ellis, C.J. and J.C. Lothrop (eds.), Eastem Paleoindian Lithic Resource Use. Westview Press, Boulder, Colorado. p. 99-138.

Lowell, T.V., C.J. Heusser, B.G. Anderson, P.I Moreno, A. Hauser, L.E. Heusser, C. Schlnchter, D.R. Marchant and G.H. Denton

1995 Interhemispheric Correlation of Late Pleistocene Glacial Events. Science 269: 1541-1549.

Lull, R.S.

1921 Fauna of the Dallas Sand Pits. American Journal of Science 2: 159-176.

Lundelius, E.L., Jr.

1967 Late Pleistocene and Holocene Faunal History of Central Texas, in Martin, P.S. and H.E. Wright, Jr., (eds.), Pleistocene Extinctions, the Search for a Cause: Yale University Press, New Haven. p. 287-320.

1972a Vertebrate Remains from the Gray Sand. In, Hester, J.J. (Ed.), Blackwater Locality No.1, A Stratified Early Man Site in Eastern New Mexico. Fort Burgwin Research Center, Southern Methodist University. Dallas. p.148-163. 
1972b Fossil Vertebrates from the Late Pleistocene Ingleside Fauna, San Patricio County, Texas. Report of Investigations No. 77, Bureau of Economic Geology, University of Texas, Austin.

1989 The Implications of Disharmonious Assemblages. Journal of Archaeological Science 16: 407417.

Lynott, M.J.

1979 Prehistoric Bison Populations of Northcentral Texas: Bulletin of the Texas Archaeological Society 50: 889-101.

MacDonald, G.F.

1968 Debert: A Paleo-Indian Site in Central Nova Scotia. Persimmon Press, Buffalo.

McCormick, O.

1982 41WM419 (Crockett Gardens Site). In, Archaeologiocal Ibvestigations at the San Gabriel Reservoir Districts, Central Texas. Hays, T.R. (Ed.) Institute of Applied Sciences, University of North Texas. Denton.

McNett, C.W. (editor)

1985 Shawnee Minisink, A tratified Paleoindian-Achaic Site in the Upper Delaware Valley of Pennsylvania. Acadmic Press, New York.

Madole, R.F., C.R. Ferring, S.A. Hall, W.C. Johnson, and C.J. Sorenson

1991 Quaternary Geology of the Osage Plains and Interior Highlands, in, Morrison, R.B., (ed.), Quaternary Non-Glacial Geology: Conterminous United States: Geology of North America, Vol. K-2. Geological Society of America, Boulder, Colorado. p. 503-546.

Mallouf, $R$.

1989 A Clovis Quarry Workshop in the Callahan Divide: the Yellow Hawk Site, Taylor County, Texas. Plains Anthropologist 34 (124): 81-103.

Martin, C.W. and W.C. Johnson

1995 Variation in Radiocarbon Ages of Soil Organic Matter Fractions from Late Quaternary Buried Soils. Quaternary Research 43: 232-237.

Martin, J.E.

1987 Paleoenvironments of the Lange-Ferguson Clovis Kill Site. In, Graham, R.W., H.A. Semken, Jr. and M.A. Graham (eds.), Late Quaternary Mammalian Biogeography and Environments of the Great Plains and Prairies. Illinois State Museum, Scientific Papers 22: 314-333.

Martin, P.S. and R.G. Klein (eds)

1984 Quaternary Extinctions, A Prehistoric Revolution: University of Arizona Press, Tucson.

Martin, P.S and H.E. Wright, Jr. (eds.)

1968 Pleistocene Extinctions, The Search for a Cause. Yale University Press, New Haven.

Mayr, E.

1965 Animal Species and Evolution. Belknap Press. Cambridge, Mass.

McDonald, J.N.

1981 North American Bison, Their Classification and Evolution: University of California Press, Berkeley. 
1984 The Reordered North American Selection Regime and Late Quaternary Megafaunal Extinctions. In, Martin, P.S. and R.G. Klein (eds) Quatemary Extinctions, A Prehistoric Revolution: University of Arizona Press, Tucson p.404-439.

McNett, C.W. Jr. (ed.)

1985 Shawnee Minisink- A Stratified Paleoindian-Archaic Site in the Upper Delaware Valley of Pennsylvania. Academic Press, New York.

Mead, J.I. and D. J. Meltzer

1984 North American Late Quaternary Extinctions and the Radiocarbon Record. In, Martin, P.S. and R.G. Klein (eds) Quaternary Extinctions, A Prehistoric Revolution: University of Arizona Press, Tucson p. 440-450.

Mehringer, P.J. Jr.

1989 Of Apples and Archaeology. Universe 1(2): 2-8.

Meltzer, D.J.

1987 The Clovis Paleoindian Occupation of Texas: Results of the Texas Clovis Fluted Point Survey. Bulletin of the Texas Archeological Society 57:27-68.

1988 Late Pleistocene Human Adaptations in Eastern North America. Journal of World Prehistory 2 (1): 1-52.

1989a Was Stone Exchanged Among Eastern North American Paleoindians? In, Ellis, C.J. and J.C. Lothrop (eds.), Eastern Paleoindian Lithic Resource Use. Westview Press, Boulder, Colorado. p. 11-40.

1989b Why Don't We Know When the First People Came to North America? American Antiquity 54(3): 471-490.

1991 Altithermal Archaeology and Paleoecology at Mustang Springs, on the Southern High Plains of Texas. American Antiquity 56 (2): 236-267.

1993 Is There a Clovis Adaptation? In, From Kostenki to Clovis, Upper Paleolithic - Paleo-Indian Adaptations. O. Soffer and N.D. Praslov (eds.) . Plenum Press, New York. p. 293-310.

1995 Clocking the First Americans. Annual Reviews in Anthropology 24: 21-45.

Meltzer, D. J. and Bever, M.R.

1995 Paleoindians of Texas: An Update on the Clovis Fluted Point Survey. Bulletin of the Texas Archaeological Society 66: 47-81.

Meltzer, D.J. and Collins, M.B.

1987 Prehistoric Water Wells on the Southern High Plains: Clues to Altithermal Climate. Journal of Field Archaeology 14: 9-28.

Meltzer, D.J., and J.I. Mead

1985 Dating Late Pleistocene Extinctions: Theoretical Issues, Analytical Bias, and Substantive Results. In: Environments and Extinctions: Man in Late Glacial North America, J.I. Mead and D.J. Meltzer, (eds) p. 145-173.

Mochanov, Y.A. and S.A. Fedoseeva

1996 Aldansk: Aldan River Valley, Sakha Republic. In, West, F.H. (ed) American Beginnings, The Prehistory and Palaeoecology of Beringia. University of Chicago Press, Chicago. p. 157-214. 
Montgomery, J. and J. Dickenson

1992 Additional Blades from Blackwater Draw, Locality 1, Portales, New Mexico. Current Research in the Pleistocene 9:32-33.

National Oceanic and Atmospheric Administration

1982 Climatography of the United States. Monthly Normals of Temperature, Precipitation, and Heating and Cooling Degree Days by State, 1951-1980.

Neck, R. W.

1987 Changing Holocene Snail Faunas and Environments Along the Eastern Caprock Escarpment of Texas. Quaternary Research 27: 312-322.

1995 Extirpation of Quatrernary Molluscs of the Southern High Plains. In, E. Johnson, (ed.), Ancient Peoples and Landscapes. Museum of Texas Tech University, Lubbock, Terxas. p. 283-288.

Newcomber, M.H.

1971 Some Quantitative Experiments in Handaxe Manufacture. Antiquity. 85-97.

Nordt, L.C.

1992 Archaeological Geology of the Fort Hood Military Reservation, Fort Hood, Texas. United States Army Fort Hood Archaeological Resource Management Series, Research Report n. 25. Ft. Hood, Texas.

Nordt, L.C., T.W. Boutton, C.T. Hallmark, and M.R. Waters

1994 Late Quaternary Vegetation and Climate Changes in Central Texas Based on Isotopic Composition of Organic Carbon. Quatemary Research 41: 109-120.

Odell, G.H.

1996 Economizing Behavior and the Concept of ACuration $\cong$ In, Odell, G.H. (ed.), Stone Tools, Theoretical Insights into Human Prehistory. Plenum Press, New York. p. 51-80.

Oldfield, $F$.

1975 Pollen-analytical Results, Part II, In, Wendorf, F. and J.J. Hester (eds.), Late Pleistocene Environments of the Southern High Plains. Fort Burgwin Research Center, Southern Methodist University, Dallas. p. 121-147.

Ostercamp, W.R., and W.W. Wood

1987 Playa-lake Basins on the Southern High Plains of Texas and New Mexico: Part I. Hydrologic, Geomorphic and Geologic Evidence for Their Development. Geological Society of America Bulletin 99: 215-223.

Olsen, S.J.

1960 Post-cranial Skeletal Characters of Bison and Bos. Papers of the Peabody Museum of Archaeology and Ethnology 35(4):1-64.

1961 The Relative Value of Fragmentary Mammalian Remains. American Antiquity 26:538-540.

1964 Mammal Remains from Archaeological Sites, Part I: Southeastern and Southwestern US. Papers of the Peabody Museum of Archaeology and Ethnology 56(1):1-162.

1968 Fish, Amphibian and Reptile Remains from Archaeological Sites, Part I: Southeastern and Southwestern US. Papers of the Peabody Museum of Archaeology and Ethnology 56(2):1-104. 
1990 The Northwestern European Plain Around 18,000 BP. In, Soffer, O. and C. Gamble (eds.), The World at 18,000 BP; Vol. 1, High Latitudes. Unwin Hyman, London. p. 54-68.

Overpeck, J. T., L.C. Peterson, N. Kipp, J. Imbrie, and D. Rind

1989 Climate Change in the Circum-North Atlantic Region During the Last Deglaciation. Nature 338: 553-557.

Paine, W.R. and A.A. Meyerhoff

1968 Catahoula Formation of Western Louisiana and Thin-Section Criteria for Fluviatile Depositional Environment. Journal of Sedimentary Petrology 38 (1): 92-113.

Patterson, W. S. B., and C.U. Hammer

1987 Ice Core and Other Glaciological Data. In, The Geology of North America (K-3): North America and Adjacent Oceans During the Last Deglaciation. W. F. Ruddiman and H. E. Wright, Jr., (eds.), Geological Society of America, Boulder, Colorado. p. 91-109.

Pielou, E.C.

1991 After the Ice Age. The University of Chicago Press, Chicago.

Pillard, D. A. 1988 Pre-impoundment Estimations of Nutrient Trophic Status. Unpublished Ph. D. Dissertation, University of North Texas, Denton, Texas.

Pilsbry, H. A.

1939-1948 Land Mollusca of North America (North of Mexico). Academy of Natural Science of Philadelphia, Monographs 3: vol. I:1-994; vol. Il:1-1113.

Prikryl, D.J.

1990 Lower Elm Fork Prehistory: Office of the State Archaeologist, Texas Historical Commission, Austin, Texas.

Ranere, A.J. and R.G. Cooke

1991 Paleoindian Occupation in the Central American Tropics. In, Clovis: Origins and Adaptations. Bonnichsen, R. and K.L. Turnmire (eds.). Center for the Study of the First Americans, Corvalis, Oregon. p. 237-253.

Ray, C.N.

1930 Report on Some Recent Archaeological Researches in the Abilene Section: Bulletin of the Texas Archeological and Paleontological Society 2: 45-58.

1938 New Evidences of Ancient Man in Texas, Found During Professor Kirk Bryan's Visit: Bulletin of the Texas Archeological and Paleontological Society 10: 269-273.

1942 Ancient Artifacts and Mammoth's Teeth of the McLean Site: Bulletin of the Texas Archeological and Paleontological Society 14: 137-138.

1944 Stream Bank Silts of the Abilene Region: Bulletin of the Texas Archeological and Paleontological Society 16: 117-147.

Ray, C.N. and K. Bryan

1938 Folsomoid Point Found in Alluvium Beside a Mammoth's Bones. Science 88: 257-258.

Redder, A.J. 
1985 Horn Shelter No. 2: The South End. Central Texas Archaeologist 10: 37-65.

Retallick, H.J.

1966 Geomorphology of the Domebo Site, In, Leonhardy, F.C., (ed.), Domebo: A Paleo-Indian

Mammoth Kill in the Prairie-Plains. Contributions in Archaeology No. 1. Museum of the Great Plains, Lawton, Oklahoma. p. 3-10.

Rigaud, J.-P. and J. Simek

1987 AArms Too Short to Box with Godミ: Problems and Prospects for Paleolithic Prehistory in Dordogne, France. In, O. Soffer (ed.), The Pleistocene Old World: Regional Perspectives. Academic Press, New York. p. 47-62.

Rightmire, C. T. and B.B. Hanshaw

1973 Relationship Between the Carbon Isotope Composition of Soil $\mathrm{CO}_{2}$ and Dissolved Carbonate Species in Groundwater. Water Resources Research 9: 958-967.

Roberts, F.H.H. Jr.

1942 Archaeological and Geological Investigations in the San Jon District, Eastern New Mexico: Smithsonian Miscellaneous Collection 103, No.4

SAS Institute

1978 Statistical Analysis System Introductory Guide. SAS Institute, Cary, NC.

Saunders, J.J., C. V. Haynes, Jr., D. Stanford and G.A. Agogino.

1990 A Mammoth-lvory Semifabricate from Blackwater Locality No. 1, New Mexico. American Antiquity 55 (1): 112-119.

Scheldt, J.C.

1974 Petrology of the Catahoula Sandstones in East Texas. Unpublished M.A. Thesis, University of Texas at Austin, Austin, Texas.

Schmid, E.

1972 Atlas of Animal Bones. Elsevier Publishing Co., Amsterdam.

Schoenwetter, J.

1975 Pollen-analytical Results, Part I, In, Wendorf, F. and J.J. Hester (eds.) , Late Pleistocene Environments of the Southern High Plains. Fort Burgwin Research Center, Southern Methodist University, Dallas. p. 103-120.

Schuur, T.G. and D.C. Wallace

1985 mtDNA Variation in Native Americans and Siberians and Its implications for the Peopling of the New World. In, Who Were the First Americans? Proceedings of the $58^{\text {th }}$ Annual Biology Colloquium, Oregon State University (R. Bonnichsen, editor). Center for the Study of the First Americans, Oregon State University, Corvallis, Oregon. p. 41-78.

Sellards, E. H.

1938 Artifacts Associated with Fossil Elephant: Geological Society of America Bulletin 49: 999-1009.

1952 Early Man in America. University of Texas Press, Austin.

1955 Fossil Bison and Associated Artifacts from Milnesand, New Mexico. American Antiquity 20 (4): 336-344. 
270

Sellards, E. H., G.L. Evans, and G.E. Meade

1947 Fossil Bison and Associated Artifacts from Plainview, Texas. Geological Society of America Bulletin 58: 927-954.

Semken, H.A. Jr.

1988 Environmental Interpretation of the ADisharmonius $\cong$ Late Wisconsinan Biome of Southeastern North America. In: Laub, R.S., N.G. Miller and D.W. Steadman, (eds.), Late Pleistocene and Early Holocene Paleoecology and Archaeology of the Eastern Great Lakes Region. Bulletin of the Buffalo Society of Natural Sciences 33: 185-194.

Shaffer, B.S., and B.W. Baker

1992 A Vertebrate Faunal Analysis Coding System. Technical Report 23, Museum of Anthropology, University of Michigan, Ann Arbor.

Shott, M.J.

1989 Technological Organization in Great Lakes Paleoindian Assemblages. In, Ellis, C.J. and J.C. Lothrop (eds.), Eastern Paleoindian Lithic Resource Use. Westview Press, Boulder, Colorado. p. 221-238.

Shuler, E.W.

1923 Occurrence of Human Remains with Pleistocene Fossils, Lagow Sand Pit, Dallas. Science 57 (1472): 333-334.

1934 Collecting Fossil Elephants at Dallas, Texas. Bulletin of the Texas Archeological and Paleontological Society 6: 75-79.

1935 Terraces of the Trinity River, Dallas County, Texas: Field and Laboratory 3: 44-53.

Simpson, G.G.

1960 Notes on the Measurement of Faunal Resemblance. American Journal of Science 258: 300311.

Sisson, S., and J.D. Grossman

1953 The Anatomy of the Domestic Animals (4th Edition). W.B.Saunders Co., Philadelphia and London.

Slaughter, B.H.

1966 Vertebrates of the Domebo Local Fauna, Pleistocene, Oklahoma. In, Leonhardy, F.C. (ed.), Domebo: A Paleoindian Mammoth Kill in the Prairie Plains. Contributions of the Museum of the Great Plains No, 1. Museum of the Great Plains, Lawton. p. 1-53.

1975 Ecological Interpretation of Brown Sand Wedge Local Fauna, In, Wendorf, F. and Hester, J.J., (eds.), Late Pleistocene Environments of the Southem High Plains. Fort Burgwin Research Center, Southern Methodist University, Dallas. p. 179-192.

Slaughter, B.H., W.W. Crook, Jr., R.K. Harris, D.C. Allen and M. Seifert

1962 The Hill-Shuler Local Faunas of the Upper Trinity River, Dallas and Denton Counties, Texas. Report of Investigations 4, Bureau of Economic Geology, The University of Texas, Austin.

Slaughter, B.H. and B.R. Hoover

1963 Sulfur River Formation and the Pleistocene Mammals of the Ben Franklin Local Fauna, Journal of the Graduate Research Center (Southern Methodist University) 31 (3): 132-179.

Slaughter, B.H. and Ritchie, R. 
1963 Pleistocene Mammals of the Clear Creek Local fauna, Denton County, Texas. Journal of the Graduate Research Center 31 (3): 117-131.

Sobolik, K.D.

1988 Analysis of Caldwell Cave Coprolites: Insight into the Diet and Health of the Prehistoric Inhabitants of Culberson Co., Texas. Paper presented at the 59th Annual Meeting of the Texas Archeological Society, Oct. 28-30, Houston.

1991 Prehistoric Diet and Subsistence in the Lower Pecos as Reflected in Coprolites from Baker Cave, Val Verde County, Texas. Studies in Archeology No. 7, Texas Archeological Research Laboratory, University of Texas, Austin.

Soffer, 0 .

1985 The Upper Paleolithic of the Central Russian Plain. Academic Press, New York.

1990 The Russian Plain at the Last Glacial Maximum. In, Soffer, O. and C. Gamble (eds.), The World at 18,000 BP; Vol. 1, High Latitudes. Unwin Hyman, London. p. 228-254..

Sowers, T. and M. Bender

1995 Climate Records Covering the Last Deglaciation. Science 269: 210-214.

Speth, J.D.

1972 The Mechanical Basis of Percussion Flaking. American Antiquity 37: 34-60.

1983 Bison Kills and Bone Counts: Decision Making by Ancient Hunters. University of Chicago Press, Chicago.

Spiess, A.E. and D.B. Wilson

1987 Michaud: A Paleoindian Site in the New England Maritimes Region. Occasional Publications in Maine Archaeology, No. 6. Maine Historic Preservation Commission and Maine Archaeological Society, Inc. Augusta, Maine.

1989 Paleoindian Lithic Distribution in the New England-Maritimes Region. In, Ellis, C.J. and J.C. Lothrop (eds.), Eastern Paleoindian Lithic Resource Use. Westview Press, Boulder. p.75-98 .

Stafford, T.W.

1981 Alluvial Geology and Archaeological Potential of the Texas High Plains: American Antiquity 46: 548-565.

Stafford, T.W. Jr., K. Brendel and R.C. Duhamel

1988 Radiocarbon ${ }^{13} \mathrm{C}$ and ${ }^{15} \mathrm{~N}$ Analysis of Fossil Bone: Removal of Humates with XAD-2 Resin. Geochemica and Cosmochemica Acta 52: 2257-2267.

Stanford, D. J.

1982 A Critical Review of Archaeological Evidence Relating to the Antiquity of Human Occupation of the New World, in, Ubalaker, D.H. and H.J. Viola, eds., Plains Indian Studies: A Collection of Essays in Honor of John C. Ewers and Waldo Wedel. Smithsonian Institution Press, Washington. p. 208-218.

1983 Pre-Clovis Occupation South of the Ice Sheets, In: R. Shutler (ed.) Early Man in the New World.Sage Publications, Beverly Hills CA. p. 65-72.

1991 Clovis Origins and Adaptations: An Introductory Perspective. In, Clovis: Origins and Adaptations. Bonnichsen, R. and K.L. Turnmire (eds.). Center for the Study of the First 
Americans, Corvalis, Oregon. p. 1-14.

1999 Paleoindian Archaeology and Late Pleistocene Environments in the Plains and Southwestern United States. In, Bonnichsen, R. and K. Turnmire (eds), Ice Age Peoples of North America. Oregon State University Press. Corvallis, Oregon. p. 281-339.

Stanford, D.J. and M.A. Jodry

1988 The Drake Clovis Cache. Current Research in the Pleistocene 5:21-22.

Stanford, D.J., M. Jodry and L. Banks

1995 Early Paleoindian Diet Breadth as Seen from the Lewisville Site: Critter Buffet as an Alternative to Mammoth Barbeque. Paper presented at the 60th Annual Meeting of the Society for American Archaeology. Minneapolis.

Stiner, M.

1994 Honor Among Thieves, A Zooarchaeological Study of Neandertal Ecology. Princeton University Press, Princeton.

Stock, C., and F.D. Bode

1936 The Occurrence of Flints and Extinct Animals in Pluvial Deposits near Clovis, New Mexico, Part III, Geology and Vertebrate Paleontology of the Late Quaternary near Clovis, New Mexico. Proceedings of the Academy of Natural Sciences of Philadelphia, (88): 219-241.

Storck, P.L.

1997 The Fisher Site. Memoir 30, Museum of Anthropology, University of Michigan. Ann Arbor.

Story, D.A.

1990 Culture History of the Native Americans, in, Story, D.A., ed., The Archaeology and Bioarchaeology of the Gulf Coastal Plain, Volume I. Arkansas Archaeological Survey, Research Series, No. 38. Fayetteville, Arkansas. p. 163-366.

Straus, L.G.

1987 Hunting in Late Paleolithic Western Europe. In, Nitecki, M.H. and D.V. Nitecki (eds.), The Evolution of Human Hunting. Plenum Press, New York. p.147-176.

Stuiver, M., and Reimer, P.J.

1986 A Computer Program for Radio-Carbon age Calibration. Radiocarbon 28, 1022-1030.

Tankersley, K.B.

1994 The Effects of Stone and Technology on Fluted Point Morphometry. American Antiquity 59 (3): 498-510.

Tanner, V. M.

1943 A Study of the Subtribe Hydronomi with a Description of New Species, (Curculionidae) Study No. VI. Great Basin Naturalist 14: 1-38.

Taylor, R.E., M. Stuiver and P.J. Reimer

1996 Development and Extension of the Calibration of the Radiocarbon Time Scale: Archaeological Implications. Quaternary Science Reviews, 15: 655-668.

Taylor, R.E., C.V. Haynes Jr. and M. Stuiver

1996 Clovis and Folsom Age Estimates: Stratigraphic Context and Radiocarbon Calibration. Antiquity 70: 515-525. 
Teller, J.T.

1995 The Impact of Large Ice Sheets on Continental Palaeohydrology. In, Global Continental

Palaeohydrology (K.J. Gregory, L. Starkel and V.R. baker, eds.), pp. 109-129. John Wiley and Sons, Ltd. New York.

Thomas, G.L.

1960 Petrography of the Catahoula Formation in Texas. M.A. Thesis, University of Texas at Austin.

Tieszen, L. L., and Boutton, T. W.

1989 Stable Carbon Isotopes in Terrestrial Ecosystem Research. In Stable Isotopes in Ecological

Research (P.W. Rundel, J.R. Ehleringer, and K. A. Nagy, Eds.), pp. 167-195. Springer-Verlag, New York.

Titmus, G.L. and J.C. Woods

1991 Fluted Points form the Snake River Plain. In, Clovis: Origins and Adaptations. Bonnichsen, R. and K.L. Turnmire (eds.). Center for the Study of the First Americans, Corvalis. p. 119-132.

Tixier, J.

1972 Obtention de Lames par Debitage ASous le Pied $\cong$. Bulletin de la Societe Prehistorique Francaise. 69: 134-139.

Todd, L.C.

1987 Analysis of Kill-Butchery Bonebeds and Interpretation of Paleoindian Hunting. In, Nitecki, M.H. and D.V. Nitecki (eds.), The Evolution of Human Hunting. Plenum Press, New York. p.225-266.

Tomanek, G. and Hulett, G.K.

1970 Effects of Historical Droughts on Grassland Vegetation in the Central Great Plains, In, Dort, W. Jr. and Jones, J.K. Jr., eds., Pleistocene and Recent Environments of the Central Great Plains: Lawrence, University of Kansas Press, p. 203-210.

Tomenchuk, J. and P.L. Storck

1997 Two Newly Recognized Paleoindian Tool Types: Single and Double-Scribe Compass Gravers and Coring Gravers. American Antiquity 62 (3): 508-522.

Toomey, R.S.

1989 The Late Pleistocene and Holocene Bat Fauna of Central Texas. Journal of Vertebrate Paleontology 9 (Suppl. to No. 3): 42A.

Toomey, R.S. III, M.D. Blum and S. Velastro, Jr.

1993 Late Quaternary Climates and Environments of the Edwards Plateau, Texas. Global and Planetary Change 7: 299-320.

Toomey, R.S., J.A. Heunbner and T.W. Boutton

1992 Stable Carbon Isotope Ratios of Equus Sp. And Bison Antiquus from the Late Pleistocene Deposits at Hall=s Cave, Kerr County, Texas. Current Research in the Pleistocene 9: 22-23.

Turgeon, D. D. et. al

1988 Common and Scientific Names of Aquatic Invertebrates from the United States and Canada: Mollusks. American Fisheries Society Special Publication 16: 277 pp.

Turner, E.S. and P. Tanner

1994 The McFadden Beach Site on the Upper Texas Coast. Bulletin of the Texas Archaeological Society 65: 319-336. 
274

Ukraintseva, V.V., L.D. Agenbroad and J.I. Mead

1996 A Paleoenvironmental Reconstruction of the "Mammoth Epoch" of Siberia. In, West, F.H. (ed) American Beginnings, The Prehistory and Palaeoecology of Beringia. University of Chicago Press, Chicago. p. 129-135.

Walker, D.N

1986 Archaeological Evidence for the Use of Small Mammals by Prehistoric Inhabitants on the Northwestern High Plains. Paper presented at the 10th Prairie Conference, Denton, Texas.

Warnica, J.N.

1966 New Discoveries at the Clovis Site. American Antiquity 31(3, pt. 2): 345-357.

Wendorf, F. (editor)

1961 Paleoecology of the Llano Estacado: Dallas, Fort Burgwin Research Center, Southern Methodist University.

1975 Summary and Conclusions, in Wendorf, F. and Hester, J.J., eds., Late Pleistocene Environments of the Southern High Plains: Dallas, Fort Burgwin Research Center, Southern Methodist University, p. 257-278.

Wendorf, F., and Hester, J.J.

1962 Early Man's Utilization of the Great Plains Environment. American Antiquity 28: 159-171.

Wendorf, F. and Hester, J.J. (Eds.)

1975 Late Pleistocene Environments of the Southern High Plains. Publication of the Fort Burgwin Research Center, No. 9. Taos.

Wendorf, F., A.D. Krieger and C.C. Albritton

1955 The Midland Discovery. Greenwood Press, Westport, Conn.

Wendorf, $M$.

1989 Diabetes, the Ice Free Corridor, and the Paleoindian Settlement of North America. American Journal of Physical Anthropology 79: 503-520.

Weniger, G.-C.

1990 Germany at 18,000 BP. In, Soffer, O. and C. Gamble (eds.), The World at 18,000 BP; Vol. 1, High Latitudes. Unwin Hyman, London. p. 109-125.

West, F.H. (ed)

1996 American Beginnings, The Prehistory and Palaeoecology of Beringia. University of Chicago Press, Chicago.

Wheat, J.B.

1974 First Excavations at the Lubbock Lake Site, in Black, C.C.(ed), History and Prehistory of the Lubbock Lake Site: The Museum Journal. 15: 15-42.

Whitely, D.S. and R.I Dorn

1992 New Perspectives on the Clovis vs. Pre-Clovis Controversy. American Antiquity 58 (4): 626647.5

Williams-Dean, G.

1978 Ethnobotany and Cultural Ecology of Prehistoric Man in Southwest Texas. Unpublished Ph.D. dissertation, Dept. of Botany, Texas A\&M University, College Station. 
Willig, J.A.

1991 Clovis Technology and Adaptation in Far Western North America: Regional Pattern and

Environmental Context. In, Clovis: Origins and Adaptations. Bonnichsen, R. and K.L. Turnmire. (eds.). Center for the Study of the First Americans, Corvalis. p. 91-118.

Willimon, E.L.

1972 New Local Faunas and Paleoecology (Pleistocene) of North Central Texas. The Texas Journal of Science, 23(4):449-469.

Wilmsen, E.N.

1970 Lithic Analysis and Cultural Inference, A Paleo-Indian Case. Anthropological Papers of the University of Arizona, No. 10.

Wilson, L. R.

1964 Recycling, Stratigraphic Leakage, and Faulty Techniques in Palynology. Grana Palynologica, 5: 425-436.

1966 Palynology of the Domebo site, in Leonhardy, F.C., ed., Domebo, a Paleo-Indian Mammoth Kill in the Prairie-Plains, Lawton: Museum of the Great Plains, p. 44-50.

Wingate, F. H.

1980 Plant Microfossils from the Denton Shale Member of the Bokchito Formation (Lower

Cretaceous, Albian) in southern Oklahoma. Norman, Oklahoma Geological Survey, Bull. 130.

Winkler, D.A.

1982 Re-evaluation of the Vertebrate Fauna from the Lewisville Archaeological Site, Denton County, Texas. Report Submitted to the U.S. Army Corps of Engineers, Fort Worth District.

Winkler, A.J.

1990 Small Mammals from a Holocene Sequence in Central Texas and Their Paleoenvironmental Implications. Southwestem Naturalist, 35(2): 199-205.

Witte, A.H.

1935 Archaeology of a Section of Upper Red River Drainage: Bulletin of the Texas Archeological and Paleontological Society, 7: 47-56.

1942 Channelled Points from Clear Fork Sites in North Texas: Bulletin of the Texas Archeological and Paleontological Society, 14: 27-31.

Wormington, H.M.

1957 Ancient Man in North America: Denver, Denver Museum of Natural History.

Wyckoff, D.G.

1985 The Packard Complex: Early Archaic, pre-Dalton Occupations on the Prairie-Woodlands Border: Southeastern Archaeology. 4 (1): 1-26.

Yates, B.C.

1991 Faunal Analyses. In, Archaeological Testing of the Lewisville Lake Shoreline, Denton County, Texas, edited by K.L. Brown and S.A. Lebo. Institute of Applied Sciences, University of North Texas, Denton. Submitted to U.S. Army Corps of Engineers, Ft. Worth District, Contract No. DACW63-86-C-0098.

1993 Zooarchaeology of Four Woodland/Caddoan Sites at Cooper Lake. In: Excavations at the Tick, Spike, Johns Creek, and Peerless Bottoms Sites, Cooper Lake Project, Delta \& Hopkins 
276

Counties, Texas, edited by R.C. Fields et al., pp. 307-333. Reports of Investigations No. 91, Prewitt and Associates, Inc., Austin.

Young, B. and M.B. Collins

1989 A Cache of Blades with Clovis Affinities from Northeastern Texas. Current Research in the Pleistocene, 6:26-28.

Young, D.

1985 The Paleoindian Skeletal Material from Horn Rock Shelter in Central Texas. Current Research in the Pleistocene 2: 39-40. 


\section{APPENDIX A FAUNAL ATTRIBUTES}

PROC FORMAT PRINT:

VALUE COUNTY

$1=$ 'DENTON'

$2=$ ' COOKE

$3=$ ' GRAYSON

$4=$ 'DELTA

COUNTY HAS BEEN OUTPUT.

$5=$ 'HOPKINS':

VALUE CLASS

$0=$ 'UNID',

$1=$ 'F ISH'

$2=$ 'AMPHIBIAN'

$3=$ 'REPTILE'

$4=$ 'BIRD'

$5=$ 'MAMMAL

$8=$ 'CLASS UNCERTAIN'

CLASS HAS BEEN OUTPUT

$9=$ 'INVERTEBRATE' ';

VALUE TAXON

$1=$ 'INDET. FISH

$2=$ 'FISH LARGE

$3=$ 'FISH SMALL

$4=$ ' GAR

$5=$ 'BOWF IN'

$6=$ 'CATF ISH

$7=$ 'DRUM

$8=$ ' SUCKERFISH'

$9=$ ' CARP

$10=$ 'BASS/SUNF ISH'

11 ' 'SEE NOTE 1 '

$15=$ ' SHAD

$17=$ 'PIKE /PICKEREL'

$18=$ 'STR IPED MULLET'

$20=$ 'TOAD/FROG'

$21=$ 'INDET. FROG '

$22=$ ' BULLFROG'

$23=$ 'SEE NOTE 2 '

$24=$ ' TOAD

$25=$ 'SALAMANDER

26 =' SEE NOTE 3 .

27 ' 'MOLE SALAMANDER'

$30=$ 'SLIDER TURTLE'

$300=$ 'SLIDER OR MAP TURTLE'

$31=$ 'SNAPPING TURTLE'

$32=$ 'MUSK/MUD TURTLE

$33=$ ' BOX TURTLE'

$34=$ ' SOF TSHELL TURTLE'

$38=$ ' SEE NOTE 4 '

$380=$ ' MUD TURTLE'.

$381=$ 'MUSK TURTLE

382 = 'MAP TURTLE'

$383=$ 'RED - EARED TURTLE'

$39=$ ' INDET. TURTLE'

$40=$ ', INDET SNAKE

$401=$ 'RAT SNAKE

$41=$ ' NON-POISONOUS SNAKE

$42=$ ' $V I P E R$

$422=$ ' COPPERHEAD'

423 = ' COTTONMOUTH'

$\mathbf{4 2 4}$ = 'RATTLESNAKE',

$43=$ 'WATER SNAKE'

$45=$ 'SEE NOTE 5

$46=$ 'SPINY LIZARD'

$47=$ 'HORNED LIZARD'

$48=$ ' INDET ' LIZARD'

$49=$ ' SEE NOTE 6

$490=$ ' WHIPTAIL LIZARD'

$50=$ 'DUCK OR GOOSE'

$53=$ 'BOBWHITE QUAIL'

$54=$ ' GREAT BLUE HERON '

$544=$ ' LITTLE BLUE HERON'

$544=$ ' LITTLE BLUE
$545=$ 'CATTLE EGRET'

$546=$ ' $E$, MEADOWLARK'

$547 \approx$ ' MINOR WOODCOCK'

$548=$ ' MOURNING DOVE'

$549=$ ' VULTURE'

55 = 'PRAIRIE CHICKEN

$550=$ 'RED-TAILED HAWK'

551 = ' CARDINAL'

552 = 'MEADOWLARK'
$553=$ ' OWL'.

$554=$ ' COOT

$555=$ 'DOMESTIC CHICKEN'

556 \#'RAPTOR

$557=$ 'RAIL OR COOT'

$56=$ 'WILD TURKEY'

57 ' HAWK'

$571=$ 'SMALL HAWKS'

572 'LARGE HAWKS'

$59=$ 'BIRD LARGE'

$60=$ 'BIRD MEDIUM'

$61=$ 'BIRD SMALL.

$66=$ 'PERCHING BIRD '

$69=$ 'SEE NOTE 7 '

$70=$ 'OPOSSUM'

$700=$ ' INDET RODENT'

701 = 'MUSKRAT

$71=$ ' SHREW'

$710=$ 'EASTERN MOLE'

$72=$ ' BAT'

$73=$ 'ARMADILLO'

$74=$ 'E. COTTONTAIL'

$75=$ ' SWAMP OR JACK RABBIT'

$751=$ ' SWAMP RABBIT'

752 \#'BLK-T JACK RABBIT'

$76=$ ' SQUIRREL

$761=$ 'FOX SQUIRREL'

$762=$ 'GRAY SQUIRREL.

$763=$ 'GROUND SQUIRREL

$764=$ 'FLYING SQUIRREL'

765 ='BLK-T PRAIRIE DOG'

$77=$ ' PLNS POCKET GOPHER .

$777=$ 'RICE RAT

778 = 'HARVEST MOUSE'

$779=$ ' GRASSHOPPER MOUSE

$78=$ ' POCKET MOUSE'

$79=$ 'DEER MOUSE'

$799=$ ' SEE NOTE 8 '

$80=$ ' BEAVER

$800=$ 'SEE NOTE 9 '

81 = ' WOODRAT

$811=$ 'BLACK RAT'

$812=$ ' NORWAY RAT'

$813=$ ' RICE RAT'

$82=$ ' COTTON RAT'

$83=$ ' VOLE

$833=$ ' LEMMING'

$84=$ 'MAMMAL SMALL'

85 = 'DOG/COYOTE'

851 = 'CARNIVORE'

$855=$ ' DOMESTIC DOG '

$856=$ ' COYOTE'

$86=$ 'RACCOON '

$87=$ 'STR IPED SKUNK'

$870=$ ' MUSTELIDS'

$877=$ ' $M I N K$ '

$88=$ 'MAMMAL MEDIUM'

$880=$ 'FOX

$888=$ ' 'GRAY FOX'

$89=$ ' BOBCAT'

$899=$ ' COUGAR'

$90=$ 'BADGER

$900=$ 'DEER OR PRONGHORN'

$901=$ 'DEER SP.

$902=$ 'WAPITI

$903=$ 'DOMESTIC CATTLE'

$904=$ 'DEER OR WAPITI

$91=$ 'BLACK BEAR'

$92='$ DOMESTIC OR FERAL PIG 922 ='PECCARY'

$93=$ ' SHEEP OR GOAT'

936 = ' SHEEP/GOAT/PRONGHORN

$94=$ ' MAMMAL LARGE'

945 " 'MULE DEER'

95. 'WHITE - TAILED DEER'

$96=$ 'PRONGHORN'

$97=$ ' COW/BISON/WAPITI'

$98=$ ' AMER ICAN BISON'

$99=$ ' HORSE'
$999=$ ' CRAYF ISH' ;

IALUE SIDE

$2=\cdot L$

$3=1 \mathrm{~A}$

DE HAS BEEN OUTPUT

ALUE ELEMENंT

$\frac{1}{2}=$ ' CORN CORE

$222=$ 'DENTARY'

$3=$ ' MANDIBLE'

$4=$ ' TOOTH P MX'

$5=$ 'TOOTH P MD'

$6=$ 'TOOTH D MX

$7=$ 'TOOTH D MD'

$8=$ ' TOOTH P MX OR MD'

$9=$ 'TOOTH D MX OR MD '

$10=$ ' STERNUM'

$11=$ ' HYOID

$12=$ 'PETROUS'

$121=$ 'QUADRATE

$13=$ ' JUGAL

$131=$ ' SQUAMOSAL

$14=$ ' $M A X I L L A '$

$15=$ 'CLAVICLE/CLEITHRUM

$16=$ ' CORACOID

$17 \approx$ ' SCAPULA'

$18=$ 'FURCULUM'

19 = 'EGGSHELL'

$20=$ ' HUMERUS'

$21=$ 'ULNA

$22=$ ' RADIUS'

$23=$ 'RADIOULNA

$24=$ ' CAR PAL'

$241=$ ' LUNATE'

$242=$ 'UNCIFORM.

243 = 'TRAPEZOID/MAGNUM '

$244=$ ' PISIFORM

$245=$ ' SCAPHOID'

$246=$ ' CUNE IFORM

$25=$ 'CAR POME TACAR PUS'

$256=$ ' NAVICULAR

$260=$ ' CUBOID

$26=$ 'NASALS'

$27=$ 'TOOTH ?'

$270=$ 'TOOTH MD D/P'

$271=$ ' TOOTH MX D/P'

$28=$ 'CARPAL/TARSAL'

$30=$ 'METACARPAL

$301=$ ' 1 ST METACARPAL'

$302=$ ' 2 ND METACARPAL',

$303=$ ' $3 R D$ METACARPAL',

$304=$ ' 4 TH METACARPAL'

$305=$ ' 5 TH ME TACARPAL'

$31=$ 'PHALANGE ?'

$32=$ 'PHALANGE 1 '

$33=$ ' PHALANGE 2 ',

$34=$ ' PHALANGE 3

$35=$ ' POLLUX/DEW CLAW III'

$351=$ 'DEW CLAW I'

$352=$ 'DEW CLAW II'

$36=$ 'TIBIOTARSUS'

$38=$ ' SESAMOID

$39=$ ' ME TAPODIAL

$40=$ ' ILIUM

$41=$ 'ISCHIUM

$42=$ ' PUBIS'

$43=$ 'ACETABULUM W/ISCHIUM

$44=$ 'ACETABULUM W/PUBIS'

$45=$ 'OS PENIS'

$46=$ 'ACETABULUM W/ILIUM'

$47=$ 'ACETABULUM SOCKET ONLY'

$477=$ ' INNOMINATE'

$48=$ ' FEMUR'

$49=$ 'PATELLA'

$50=$ 'TIBIA.

$51=$ 'FIBULA'

$52=$ 'TIBIOF IBULA'

53 = 'LATERAL. MALLEOLUS' 
$54=$ 'ASTRAGALUS

$55=$ 'CALCANEUM'

56 " 'OTHER TARSALS *

$57=$ 'TARSOMETATARSUS'

58 ' METATARSALS'

$581=$ ' 1 ST METATARSAL.

$582='$ 'ND METATARSAL

$583=3 R D$ METATARSAL

$58 \%=' 5$ TH METATARSAL

$59=$ 'DEW CLAW SPLINT'

$60=$ 'NAVICULOCUBOID

$61=$ 'PROATLAS

$62 n$ 'ATLAS

$63=$ 'AXIS

64 \# ' EPISTROPHUS'

$65=$ ' SECOND VERTEBRA *

$66='$ CERVICAL

$661=' 3 R D$ CERVICAL

$662=$ ' 4 TH CERVICAL.

$663=$ '5TH CERVICAL:

$664=$ '6TH CERVICAL

$665=$ '7TH CERVICAL

$67=$ THORACIC

$68=$ ' LUMBAR

$69=$ 'CAUDAL

$70=$ ' COCCYGEAL:

$71=$ 'PYGOSTYLE'

73 " PENULTIMATE

$73 \approx$ 'ULT IMATE'

75 - 'VERTEBRA

$76 \approx$ 'SACRUM

$77 \approx$ 'UROSTYLE'

$79=$ ' STERNIBRAE '

$80=$ 'RIBS

$81=$ ' LONG BONE NON-MAMMAL'

$82=$ ' LONG BONE MAMMAL
$83=$ ' CRAYF ISH CLAW'

$84=$ ' 'TURTLE INH CLAW'

$85=$ 'TURTLE CARAPACE

$86=$ 'TURTLE PLASTRON

861 : 'HYOPLASTRON'

$862=$ ' HYPOPLASTRON

$863=$ ' EPI PLASTRON'

$864=$ ' XIPHIPLASTRON'

$865=$ 'KERATIN SCUTE'

$866=$ 'PLEURAL'

$867=$ ' ENTOPLASTRON '

$868=$ ' NEURAL

$869=$ ' SUPRAPYGAL

$870=$ 'PYGAL

$871=$ 'PERI PHERAL'

$87=$ 'TURTLE SHELL'

$88=$ 'MAMMAL EXOSKELETON

$888=$ ' LONG BONE

$89=$ 'NUCHAL

$90=$ ' LEPIDOTRRICH'

$91=$ 'AXONOS

$92=$ 'ANAL SPINE'

$93 \approx$ 'PTERYGIOPHORE "

$94=$ 'SPINE I.D. ?

$95=$ 'SCALE'

$96 \approx$ 'OTOLITH

97 " 'PECTORAL SPINE'

$98=$ 'RAY'

$99=$ 'FRAGMENT WITH MODIFICATION

LEMENT HAS BEEN OUTPUT $100=$ 'MISC. ELEMENT';

VALUE ASPECT

$\frac{1}{2}=$ ' COMPLETE'

$2=$ 'PROXIMAL

$3=$ 'DISTAL

$4=$ 'PROXIMAL FRAG"

5: 'DISTAL FRAG'

6 = 'FRAGMENT'

7 n'SHAFT FRAG'

$8 \approx$ 'CONDYLE FRAG"

$9=$ 'SCAPULA NECK'

$10 \mathrm{n}$ 'SEE INVENTORY' -

$11=$ ' INCISOR

$12=' 2$ ND PREMOLAR

$13=\cdot 3 R D$ PREMOLAR

$14=$ ' PREMOLAR ?'

$15=$ ' 1 TT MUR?

$16=, 3 \mathrm{BD} M \mathrm{MAR}$

$17=$ 'MOLAR ?
18 =' TOOTH I. D?

$19=$ 'TOOTH I.D.? FRAG'

$20=$ 'CANINE

$21=$ 'ROOT ONLY

$22=$ 'TOOTH ROW'

$23='$ MOLARS $1-3$ '

$24=$ ' SOCKET INCISOR'

$25=$ ' SOCKET JAW'

$26=$ ' JAW W OUT TEETH

$30=$ ' CENTRUM EPIPHYSIS

$31=$ 'CENTRUM FRAG

$32=$ 'TRANSVERSE PROC.

$33=$ 'VT OR RIB FACET

$34=$ 'NEURAL SPINE

$35=$ 'PHARYNGEAL'

$40=$ 'AXIAL NOTCH.

$41=$ ASCDG RAMUS

$42 \approx$ 'BASAL RAMUS'

$43=$ 'ANT PORTION'

$44=$, POST POR T

$51=$, PROX POST

51

$5=$ PROX POST MED

$53=$ 'PROX ANT LAT

$54=$ "PROX ANT MED.

$55=$ 'PROXIMAL SHAFT'

$56=$ 'CENTRAL SHAFT

$57='$ DISTAL SHAFT

$58=$ 'DIST ANT LAT'

$59=$ 'DIST ANT MED'

$60=$ 'DIST POST LAT'

$61=$ 'DIST POST MED.

$62=$ PROXIMAL EPIPHYSIS

$63=$ 'DISTAL EPIPHYSIS

$64 \approx$ 'PROXIMAL HALF

$65=$ 'DISTAL HALF

$66=$ 'LONG BONE SPLINTER'

$67=$ 'ALL BUT PROX

- ' AROXTAL

$70=$ 'DISTAL

$70=$ 'DISTAL THIRD

$71=$ 'PROX LAT

72: $=$ PROX MED.

$73=$ 'PROX ANT'

$74=$ 'PROX POST

$75=$ 'DIST LAT

$76=$ 'DIST MED

$77=$ 'DIST ANT'

$78=$ 'DIST POST

$81=$ 'INCISOR TIP'

ASPECT HAS BEEN OUTPUT

$91=$ INCISOR FRAG';

VALUE AGE

$\mathbf{1} \approx$ ' ' ' ADULT

$3=$ 'FETAL/NEO-NATAL .

$4=$ ' SMALL FUSED'

$5=$ 'UNFUSED DIAPHYSIS:

$9 \%$ 'UNFUSED EPIPHYSIS'

$19='<1$ YEAR '

$20=1-1,5$ YEARS'

$21=\cdot 2-3,5$ YEARS'

$22=, 4-6,5$ YEARS,

$23=37$ YEARS'

$23=$ ' SL TGHT WEAR'

$25=$ ' SLIGHT WEAR'

$26=$ 'MODERATE WEAR

27 = 'ADVANCED WEAR'

$28=$ 'OPEN ROOTS NO WEAR '

AGE HAS BEEN OUTPUT

$30=$ 'RUGOSE ADULT'

VALUE COND

1. "NOT BURNED"

$2=$ 'WHITE

$3=$ 'BLUE/GRA'Y'

$4=$ 'INTERNAL ONLY'

$5=$ 'RED-BROWN'

$6=$ ' SHINY BLACK'

$7=$ ' CHARRED'

$8=$ 'DIFFERENTIAL'

$9=$ 'PARTLY CALCIFIED

11 ='FLAT BLACK'

$11=$ '

COND HAS BEEN OUTPUT.

$13=$ 'GREEN OR BLLUE' :

$1=$ 'NONE'

$2=$ 'TOOL.

$3=$ ' WORKED PIECE-GROOVED'
$4=$ 'WORKED PIECE-POLISHED AREA

$5=$ 'SLIGHT CUT'

$6=$ 'DEEP CUT'

$7=$ 'RING \& SNAP CUT PREPARED'

$8=$ 'RING \& SNAP CUT COMPLETE'

$9=$ 'BITUMEN PRESENT'

$10=$ 'POSSIBLY WORKED'

$11=$ ' IMPACT DEPRESSION '

$12=$ 'SLICED

$13=$ 'SAWED'

$14=$ 'PITTED

$15=$ " SHINY, POLISHED

$16=$ 'CHARRËD BREAK

$17=$ 'GROUND

18 = 'OCHRE PRESENT'

$19=$ 'CHARRED BREAK AND CUTS'

$20=$ 'SKINNING MARKS

$21=$ 'DISMEMBER ING'

$22=$ 'F ILLETING'

$23=$ 'SEE INVENTORY'

$24=$ 'SPIRAL FRACTURE'

$5=$ 'F LAKEO'

$26=$ 'BATTERED/SMASHED'

$27=\cdot 20$ OR 21,
$28=\cdot 21$ OR 22.

$29=$ 'CHOPPED'

$30=$ 'BEAD

$31=$ 'PREFORM

$34=$ 'SEE NOTE 10 '

MODIF HAS BEEN OUTPUT

$35=$ 'SEE NOTE 11 ; :

VALUE TAPH

$O=$ 'NO EVIDENCE OF WEATHERING *

$3=$ 'PATCHES OF COMPLETE EXFOLIATION

$4=$ 'FIBROUS $W /$ SPLINTERS

$5=$ 'LARGE SPLINTERS, COMPLETE EXFOLIATION'

$6=$ 'GREASY FRESH OBVIOUS INTRUSIVE

$7=$ 'PRESSURE SPLINTERS, UNWEATHERED

$8=$ 'ROOT ETCHED

$9=$ ' STA INED'

$10=$ 'ETCHED AND STAINED'

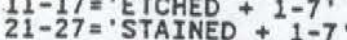

$31-37=$ ' ETCHED AND STAINED + 1-7'

$40=$ ' $G$ NAWED

41-49='GNAWED + $1-9$

$50=$ ' GNAWED + 32'

$52=$ ' GNAWED + 12'

$53=$ ' GNAWED + 13 .

$54=$ ' GNAWED + 23 ,

$55=$ ' GNAWED + 31'

$56=$ ' GNAWED + 65

$57=$ ' GNAWED + 11

$58=$ ' GNAWED + 33.

$59=$ ' GNAWED + 34'

$60=$ 'ROLLED AND WORN'

$61=.60+\frac{1}{2}$.

$63=.60+3$,

$64=.60+7$.

$65=.60+8$.

$85=60+8$.

$67=60+10$.

$68=160+40$

$69=\cdot 60+51$

$70=60+40^{\circ}$

$71=.60+43$

$71=60+44$

$78=$ ' SUN BLEACHED

$78='$ SUN BLEAC
$79=\cdot 60+34$.

$79=' 60+34$
$80=\cdot 60+55$

$88=$ 'CRACKED BROM BURNING'

89 "' COVERED W/ CA-CO3'

$90=$ 'PITTED

$91=$ 'DECORTICATED.

¿ TAPH HAS BEEN OUTPUT

PROC SORT

$92=$ 'HUMIC REACTION'

BY COUNTY'

PROC PRINT

TITLE 'ATTRIBUTE FAUNA

FORMAT CLASS CLASS.

FORMAT TAXON TAXON.;

FORMAT SIDE SIDE.

FORMAT ELEMENT ELEMENT.

FORMAT ASPECT ASPECT, :

F ORMAT AGE AGE.

*FORMAT TAPH TAPH.

* FORMAT COND COND.

- FORMAT MOD MODTF.

- FORMAT COUNTY COUंNंT

BY COUNTY SITE AREA;

ID BAG: 
ATTRIBUTE FAUNA

COUNTY=1 SITE $=479$ AREA =
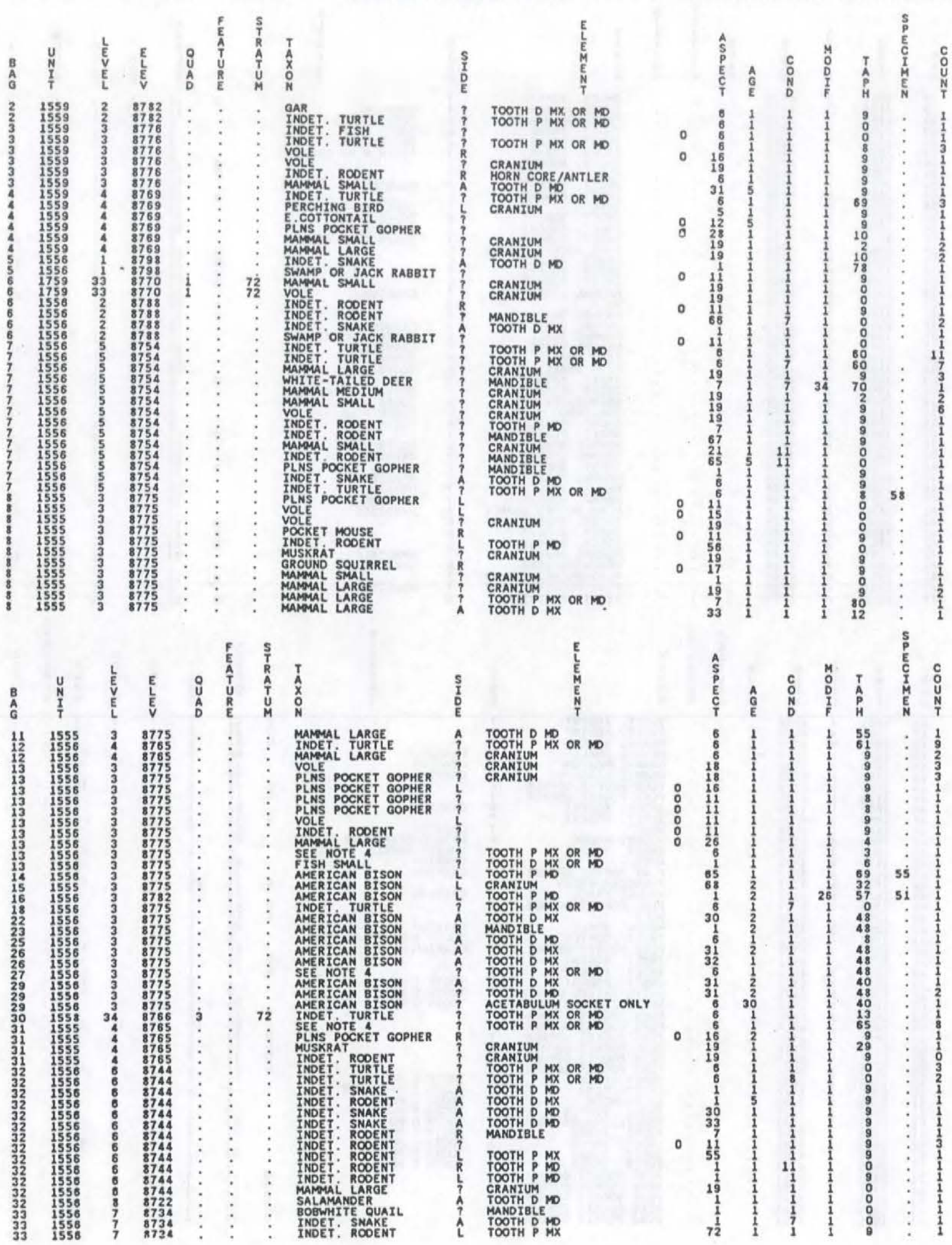
ATTRIBUTE FAUNA
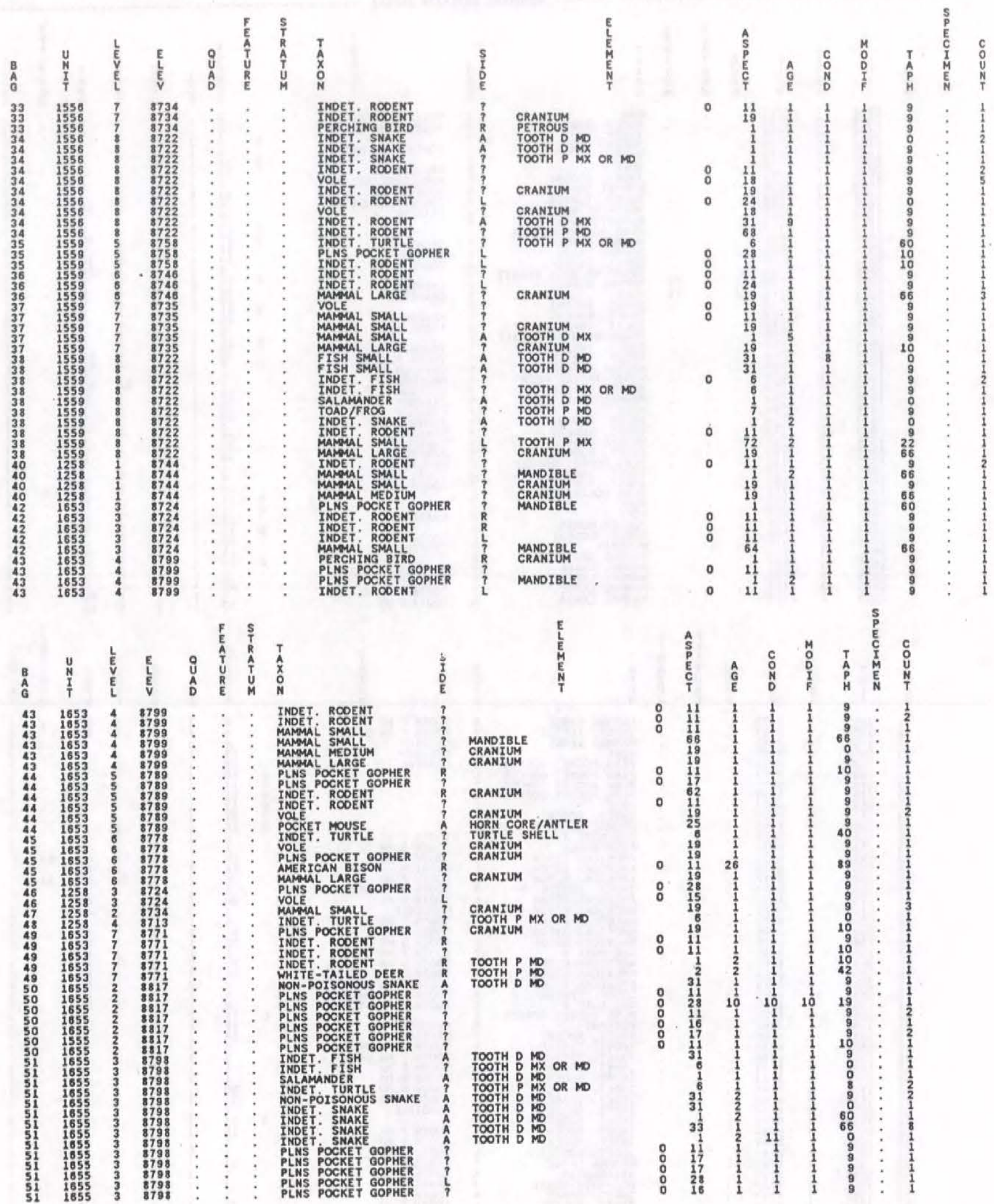
ATTRIBUTE FAUNA

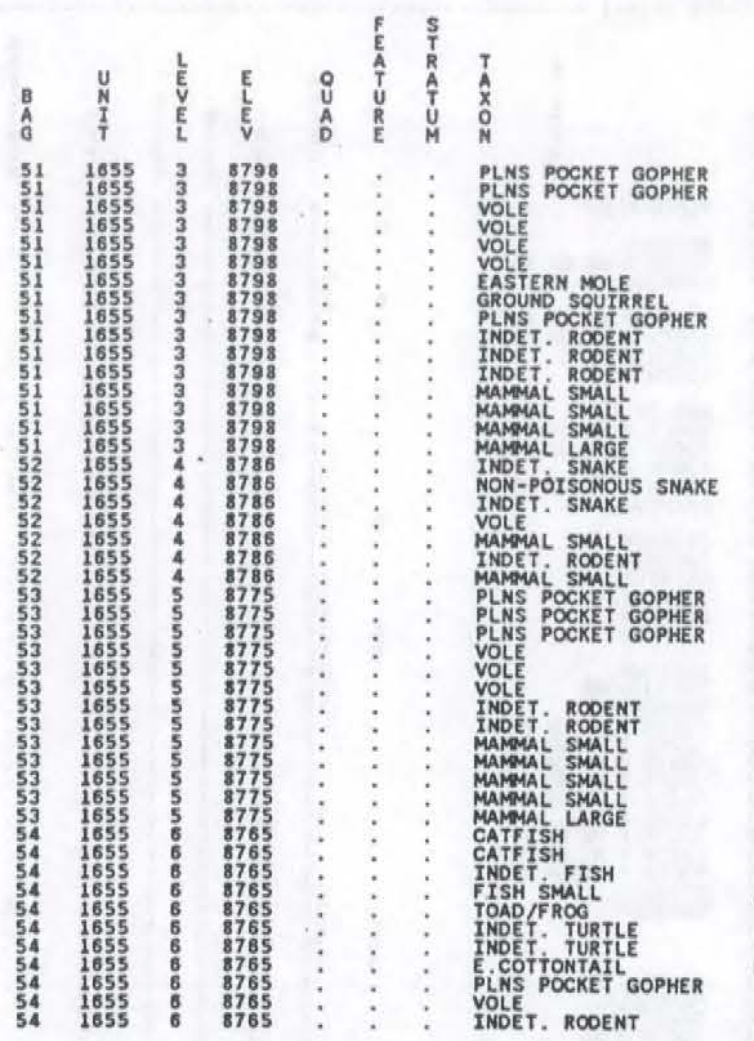

S
I
E
$?$
$?$
R
R
R
?
$?$
$?$
$?$
R
$?$
$?$
$?$
$?$
$?$
A
A
$?$
$?$
?
?
$?$
$?$
$?$
$?$
$?$
$?$
$?$
?
$?$
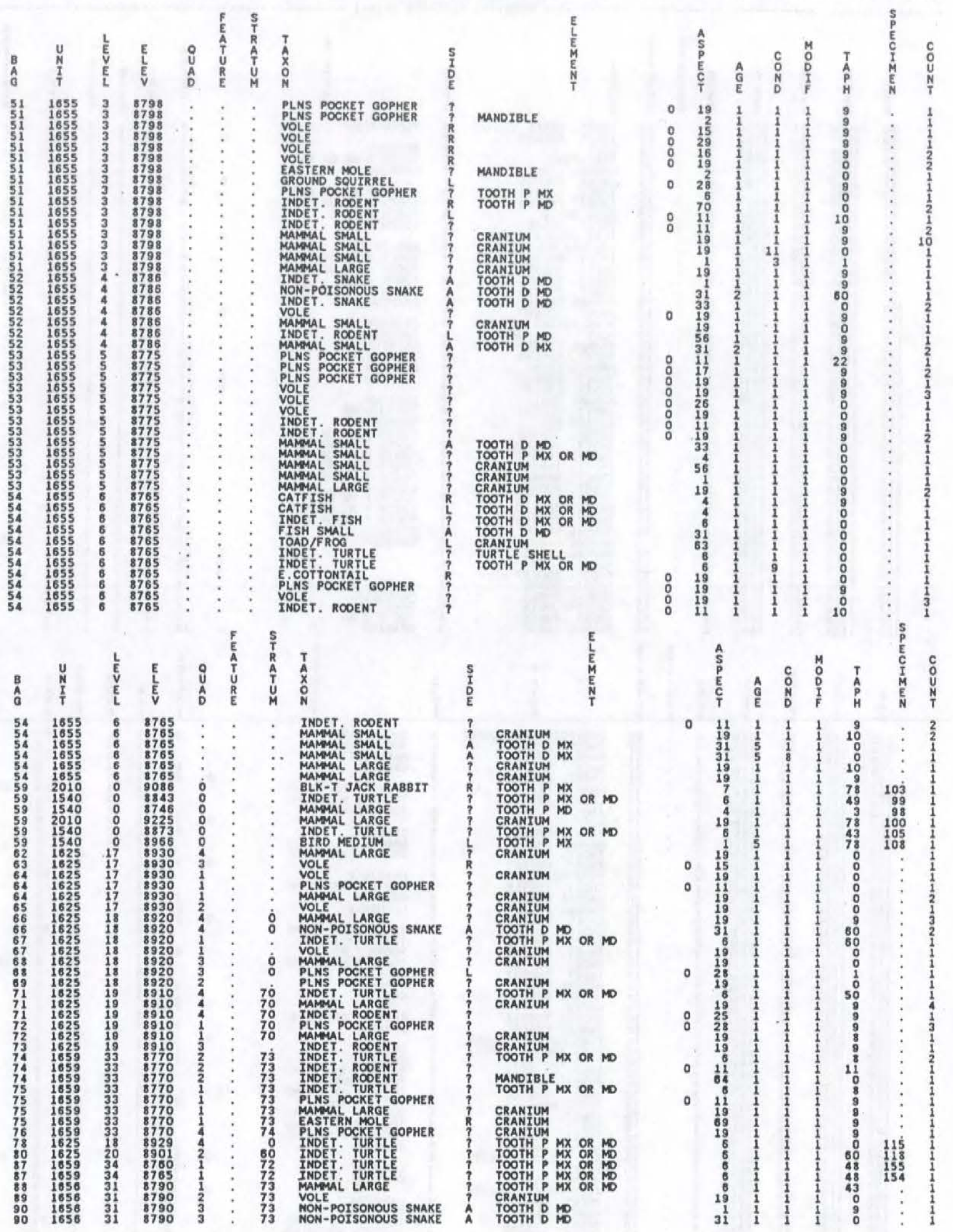
ATTRIBUTE FAUNA

COUNTY=1 SITE=479 AREA=1

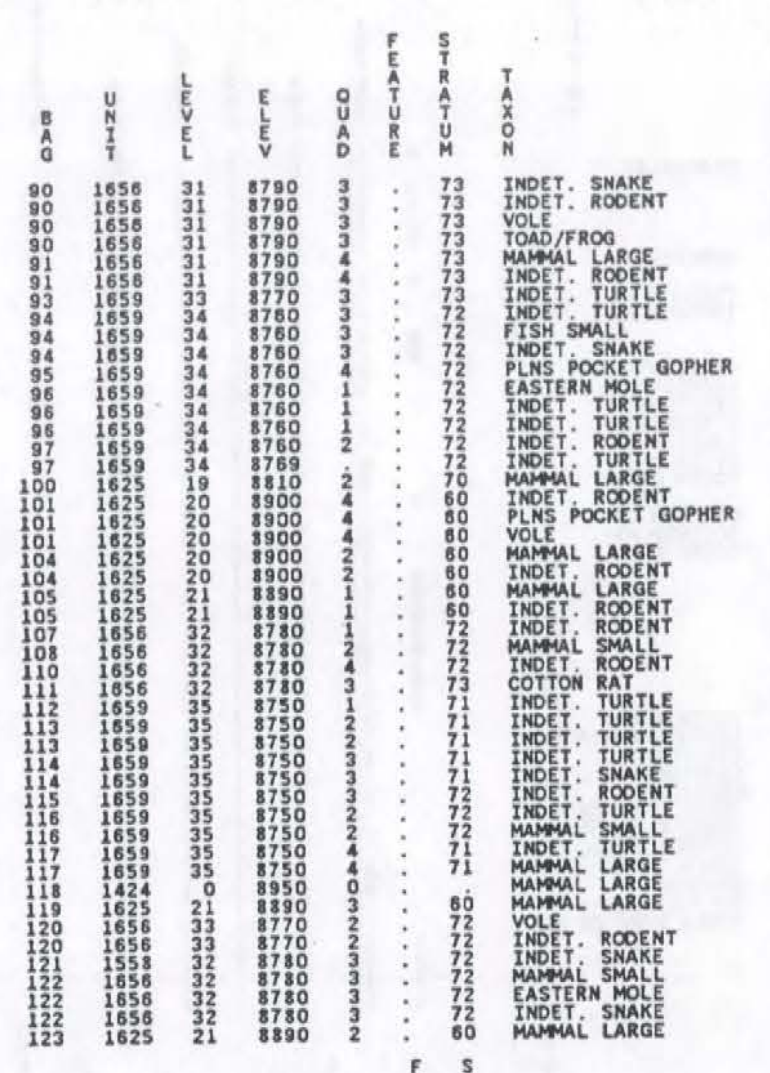

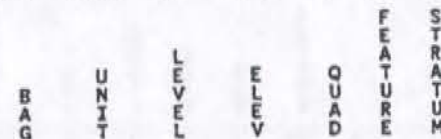

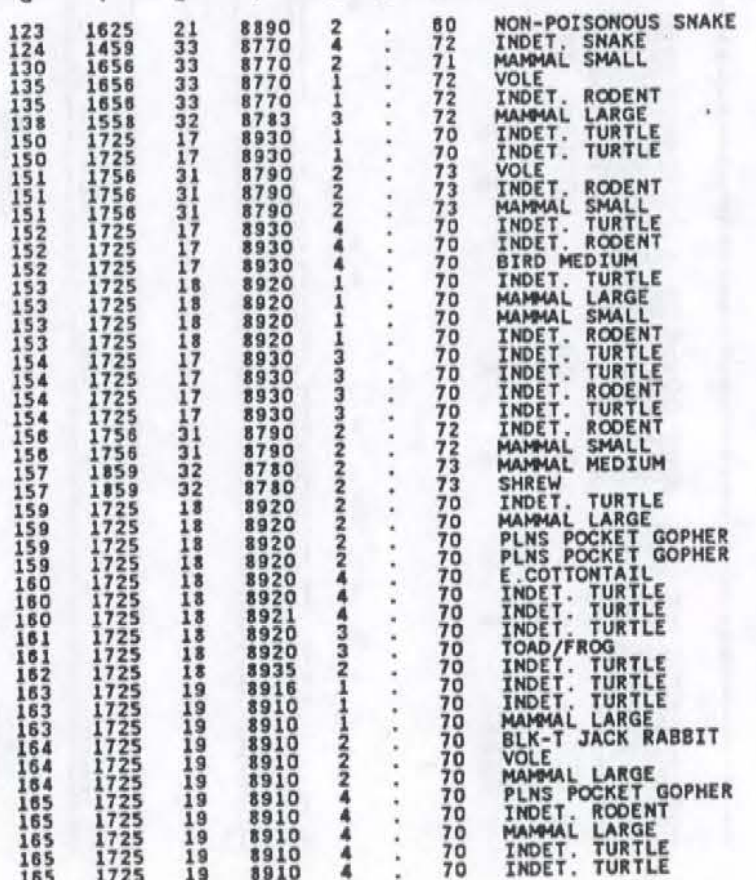

TOOTH D MX

CRANIUM TOOTH P MX OR MD CRANIUM

TOOTH P $M$ TOT OR $\mathrm{OD}$ TOOTH $\mathrm{P}$ MD

MANDIBLE ${ }_{\text {TOOTH P }}$ MX OR MO TOOTH P MX OR MD TOOTH
TOOH $P$ MX
CRANIUM

CRANTUM

CRANIUM

CRANIUM

CRANTUM TOOTH DX

TOOTH P MX OR MO

TOOTH $M X$ OR MO

TOOH P MX

COOTH $P$ MX OR MO

TOOTH P MX OR MD

CRANIUM

TOOTH P MX OR MD

MANDIBLE

TOOTH D ND

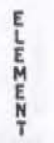

TOOTH D MO

MAND IBLE

TOOTH P MX OR MO

TOOTH D MO

CRANTUM

MANDISLE $M X$ OR MD

MANDIBLE ${ }_{\text {TOOH } P \text { OR MO }}$ CRANTUM

TOOTH P MX OR MO

TOOTH MX

TOTH P MX OR MO

CRANIUM

TOOTH P MX OR MO

chantur

CRANIUM

TOOTH $P$ MX OR MO

TOOTH $P$ M MX OR MD

TOOYH D MO ${ }^{T}$ OR

TOIH P MX

TOOTH P

CRANTUM

CRANIUM

CRANIUM MX OR MO
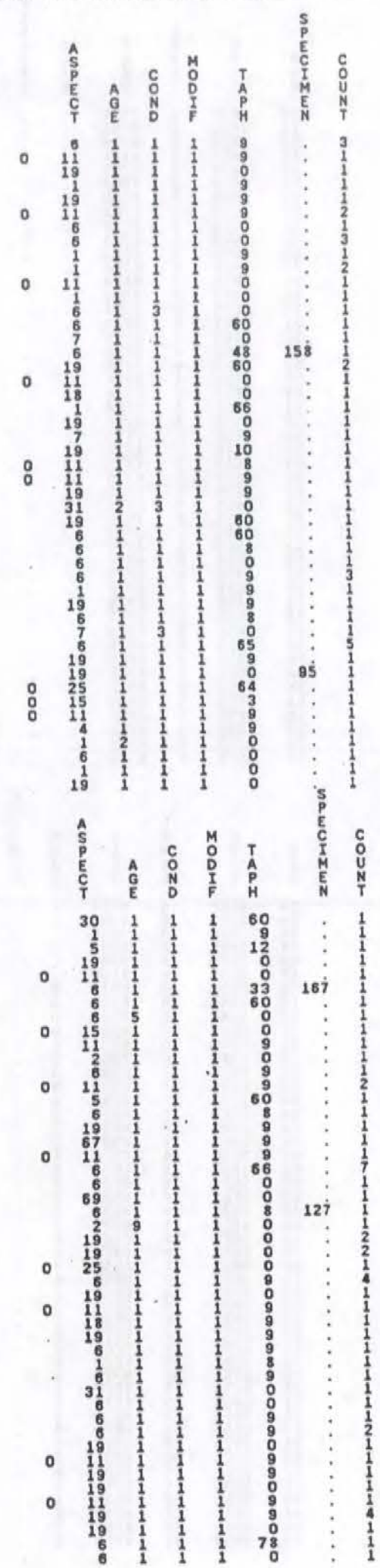
ATTRIBUTE FAUNA
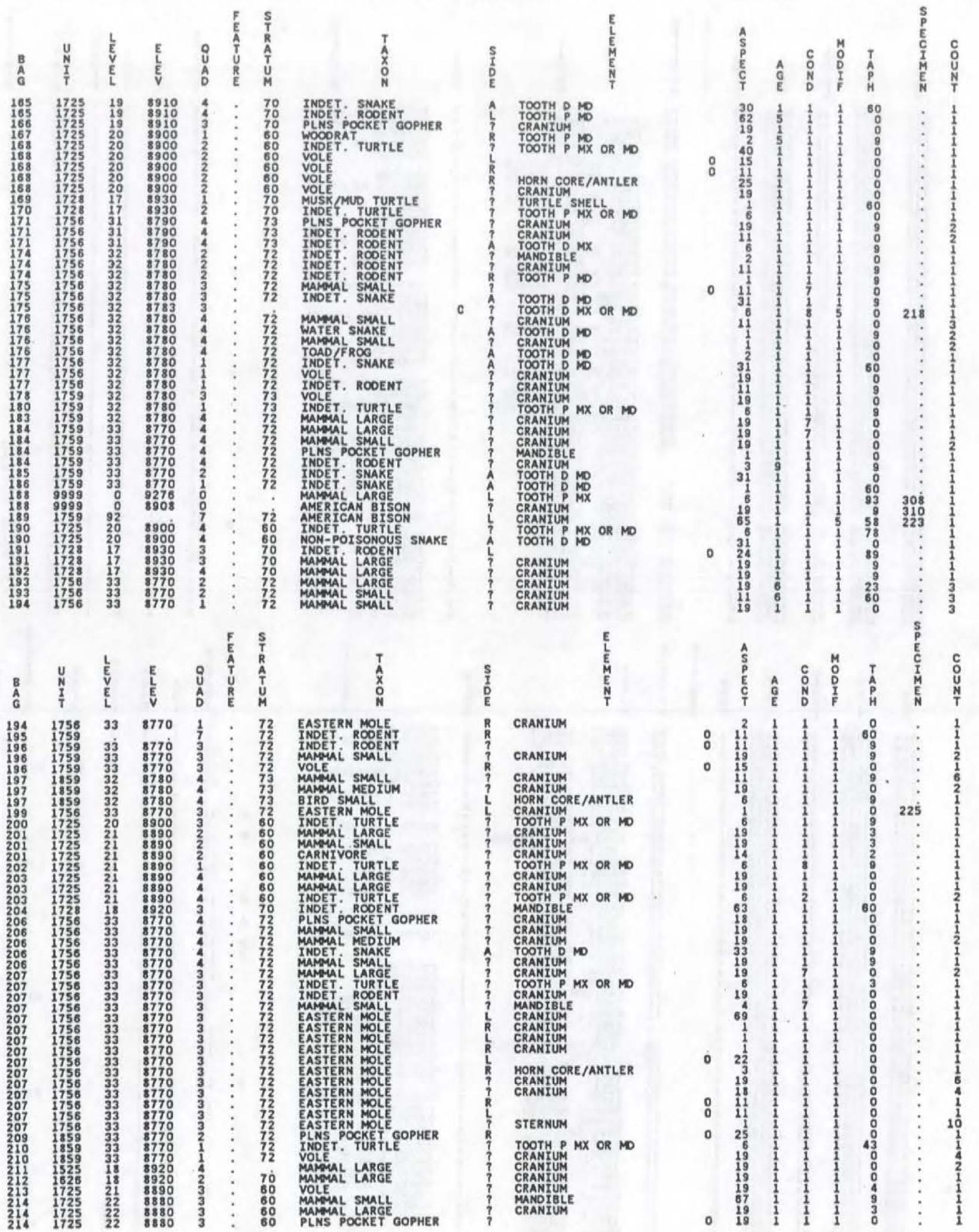
ATTRIBUTE FAUNA

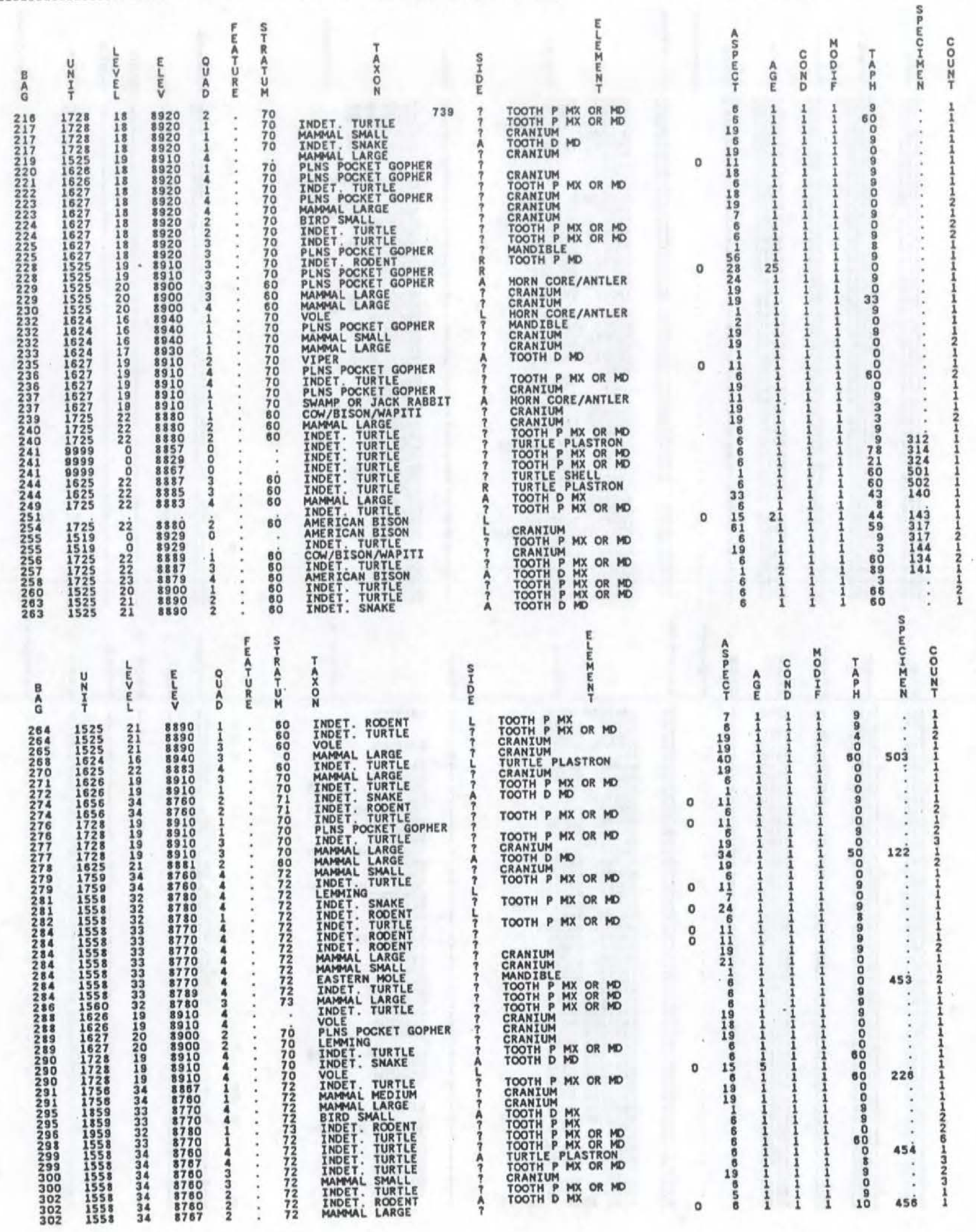


ATTRIBUTE FAUNA
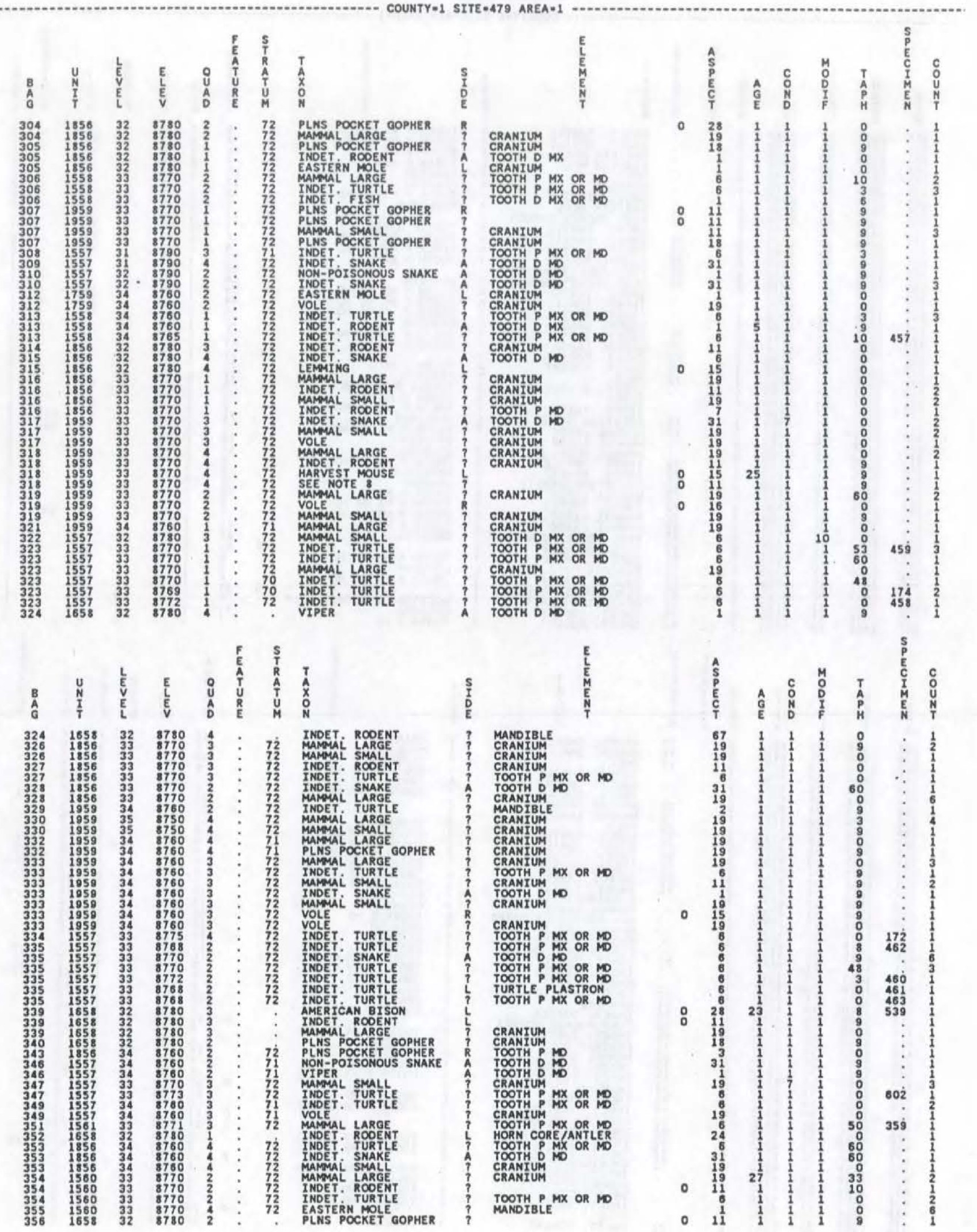

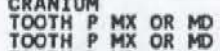

TOOTH DO MO OR MO

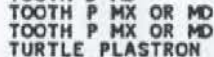

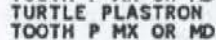

CRANIUM

TOOH P p

ToOnt

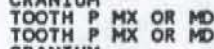

CRAMTUM MX OR MO

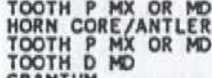

CRAAIUUM

TOOTH P MX OR ND

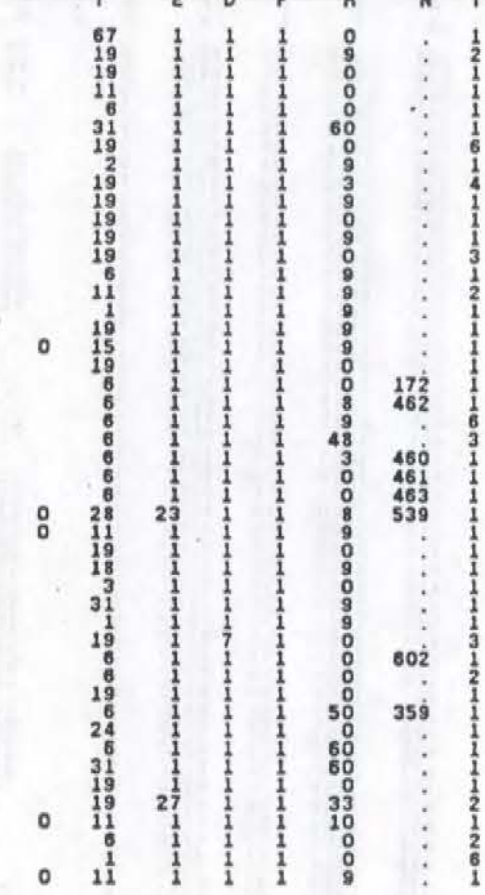


ATTRIBUTE FAUNA

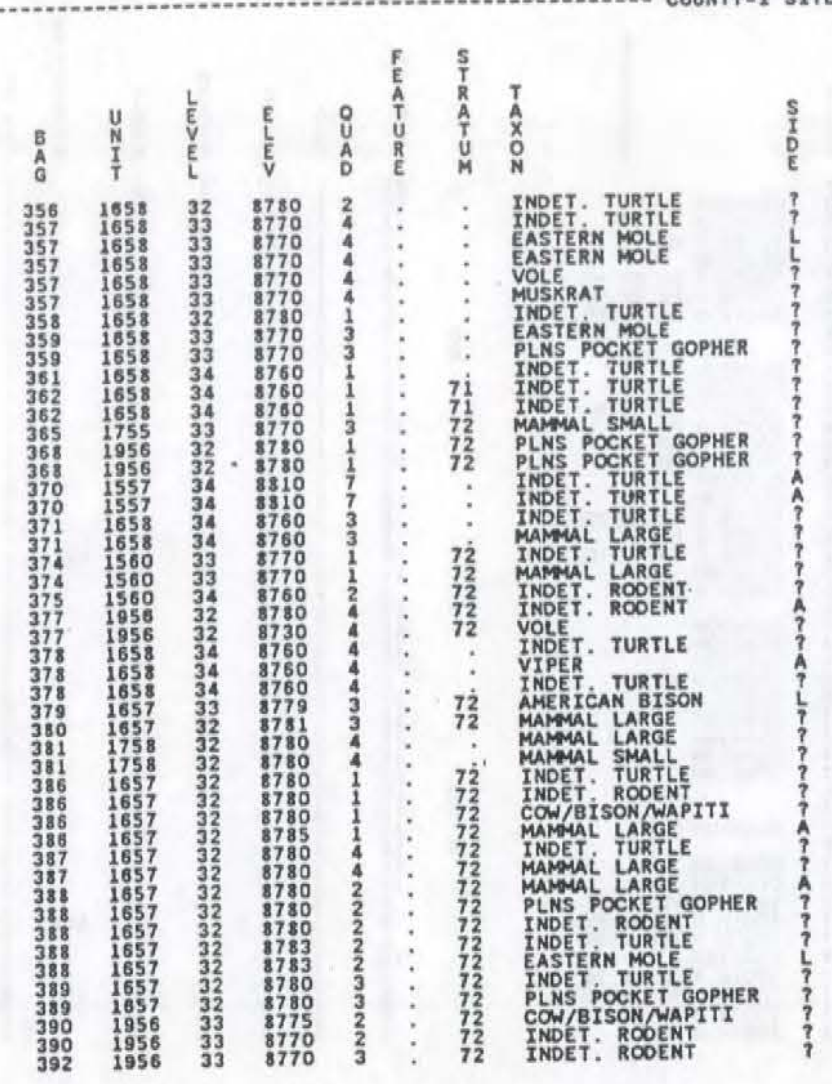

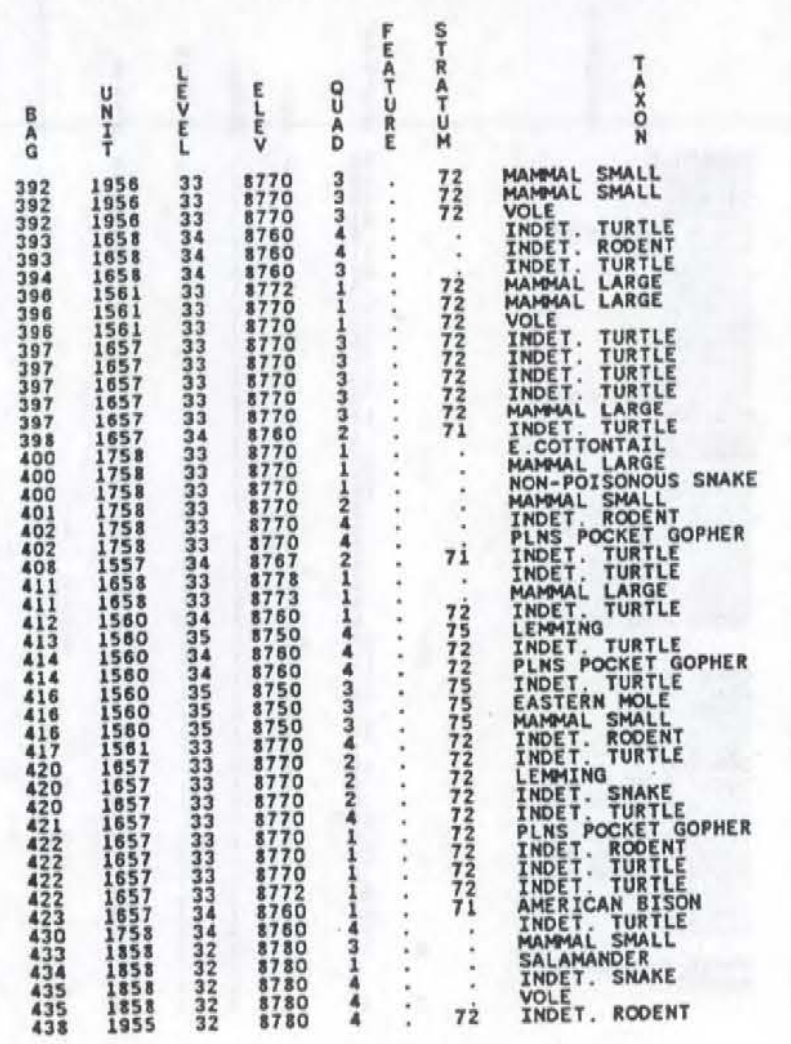

479 AREA $=1$

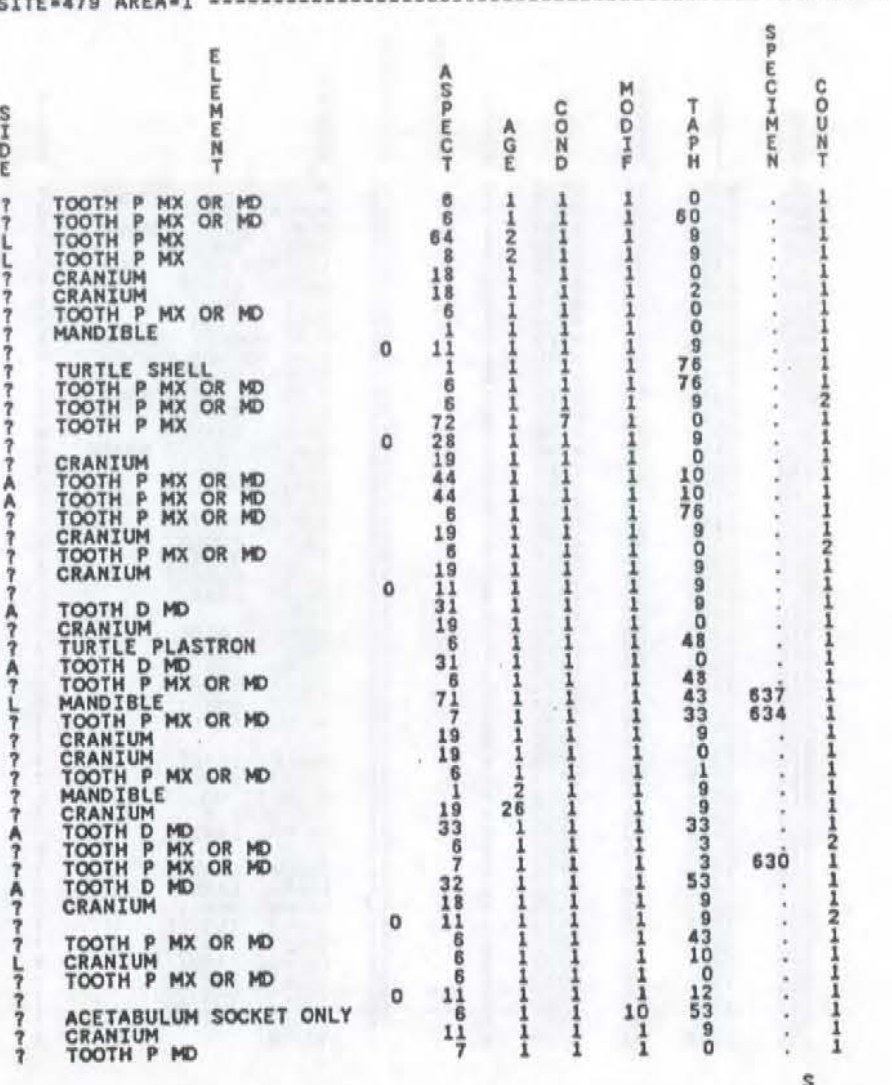

1

CRANYUM

CRANUM $M X$ OR MD TOOTH $P$ P MX OR MO

CRANIUM MX OR ND

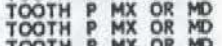

TOOTH

Torit p p

CRANTUM

TOOTH D MO

CRANIUM

CRANIUM

TOOTH P MX OR MD

TOOTH D MD MO NO

TOOTH P MX OR MD

TOOTH P MX OR MO

CRANIUM

TOOTH P MX MR OR MO

TOOTH $P$ MD M OR MO

TOOTH $\mathrm{P} M$ MX OR $\mathrm{MD}$

TOOTH P MX OR MO

TOOHY MD

crantum.

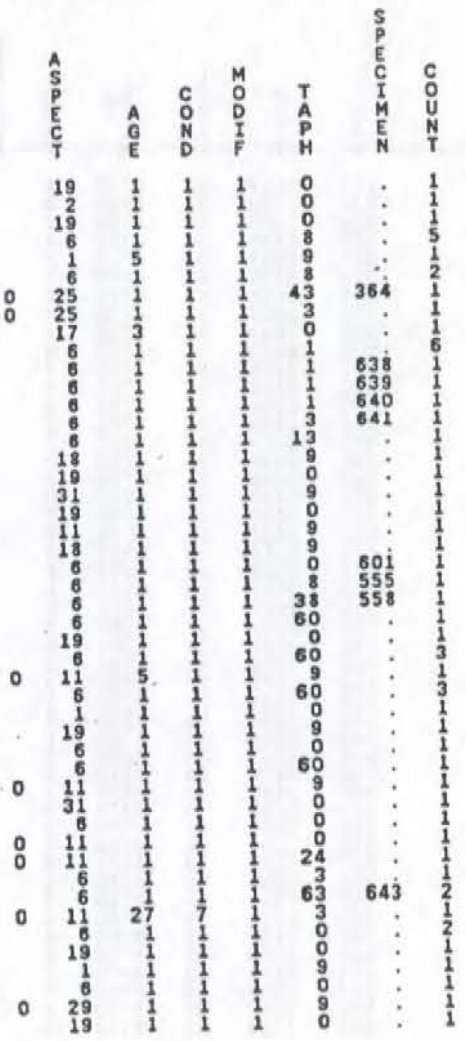


ATTRIBUTE FAUNA

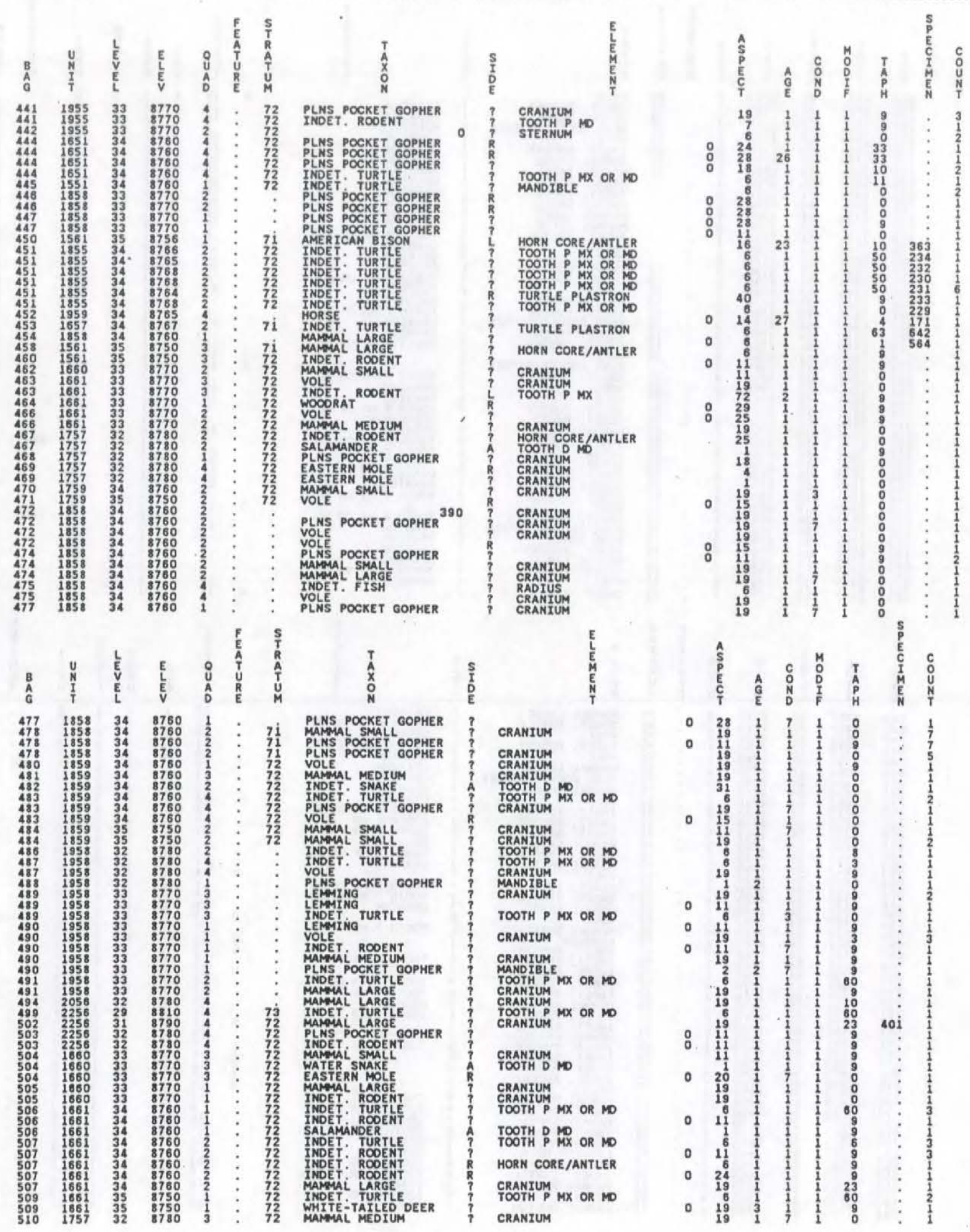


ATTRIBUTE FAUNA
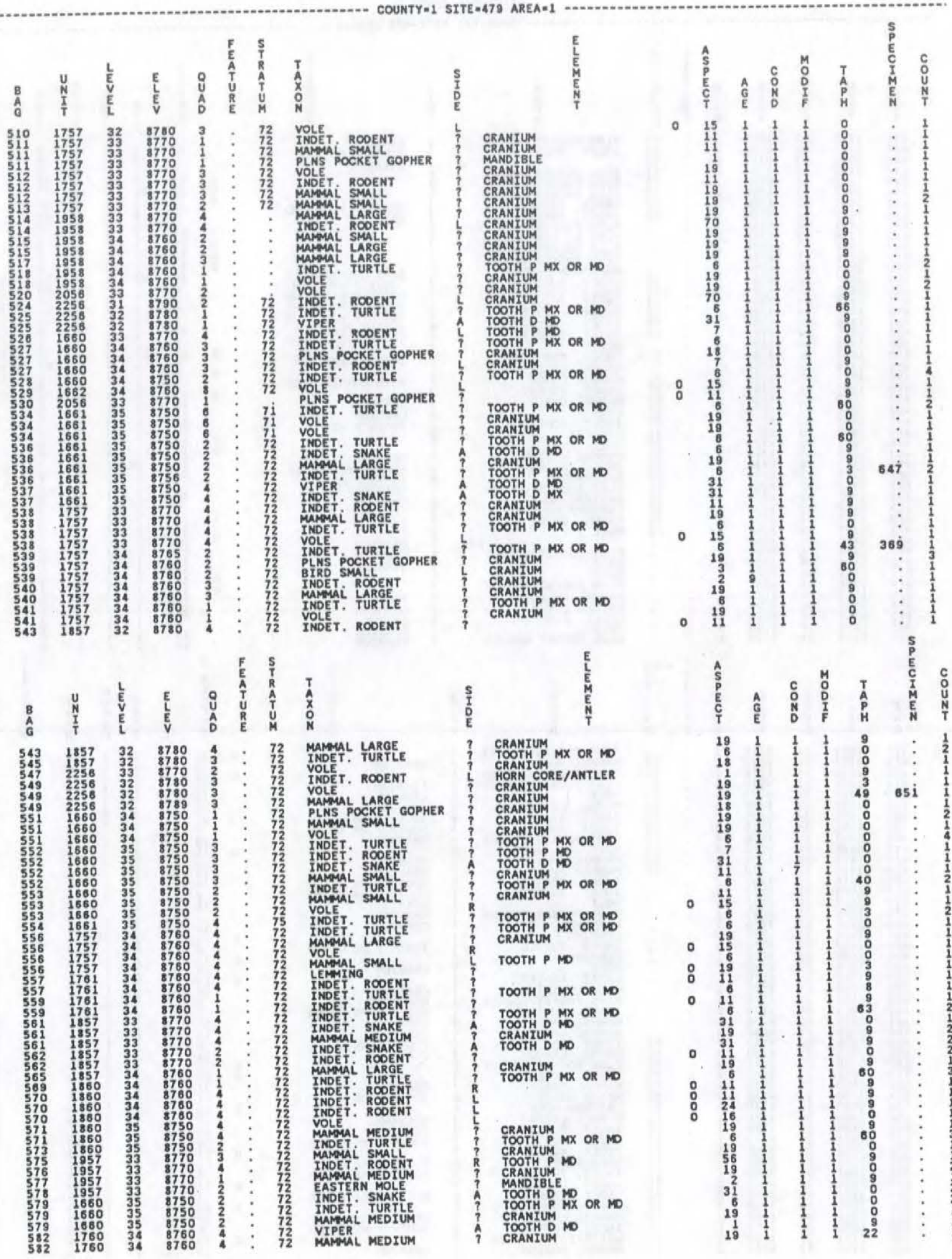
ATTRIBUTE FAUNA

COUNTY=1 SITE-479 AREA =
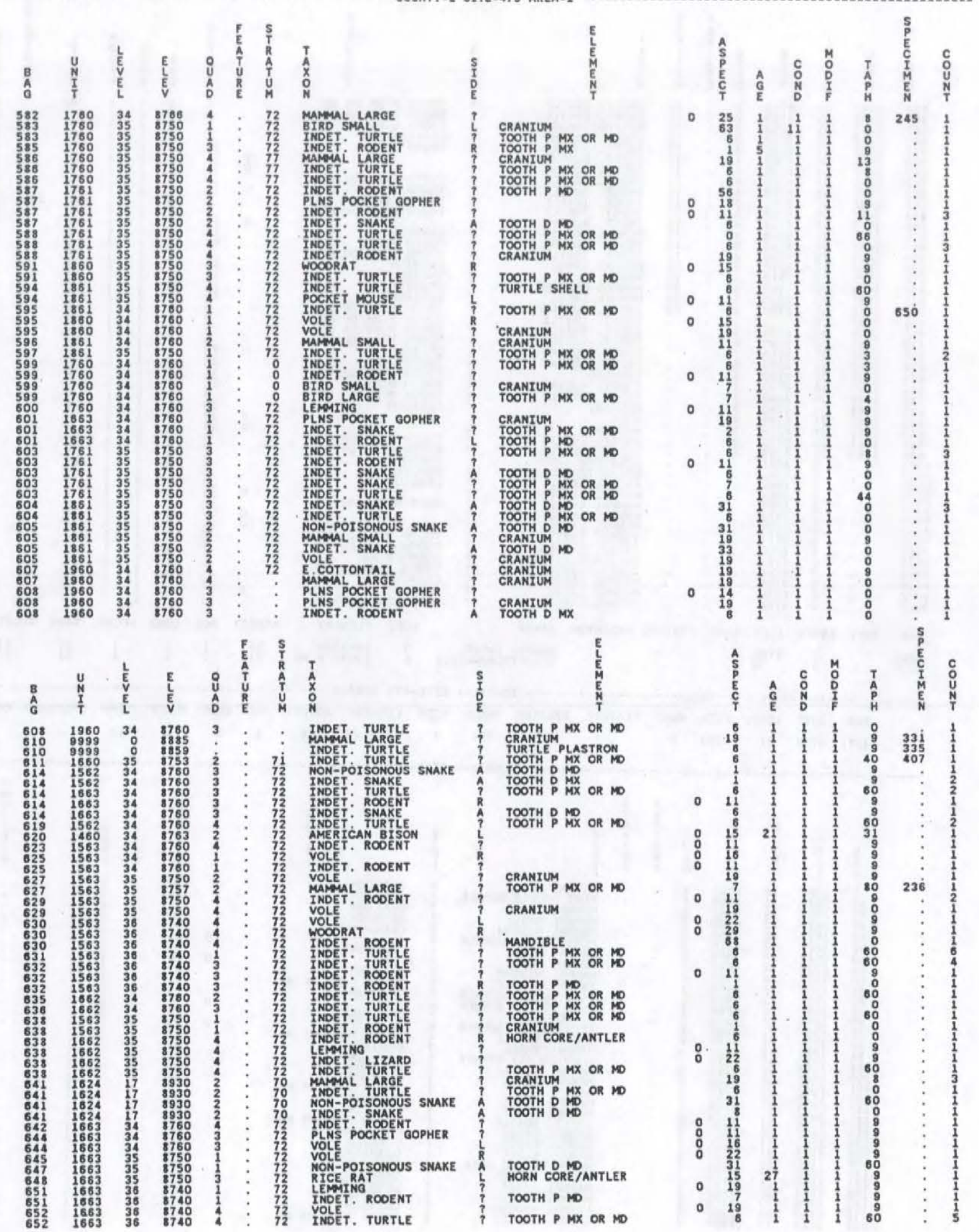
ATTRIBUTE FAUNA

COUNTY=1 SITE=479 AREA=1

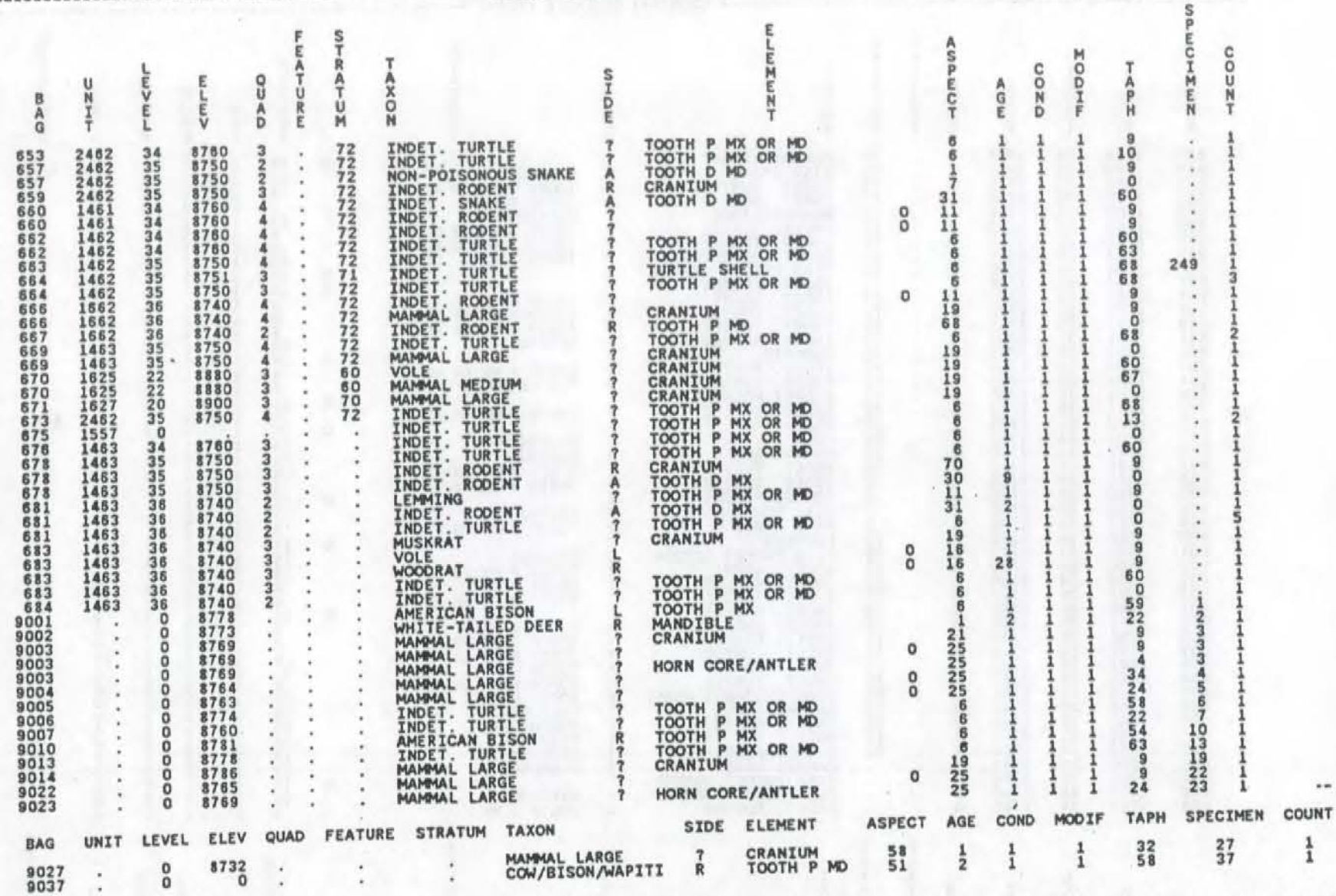

COUNTY=1 SITE $=479$ AREA=2

UNT LEVEL ELEV QUAD FEATURE STRATUM TAXON SIDE ELEMENT ASPECT AGE COND MOOIF TAPH SPECIMEN COUNT

$\begin{array}{llll}2272 & 1733 & 21 & 8898\end{array}$

COUNTY 1 SITE $=479$ AREA = 8
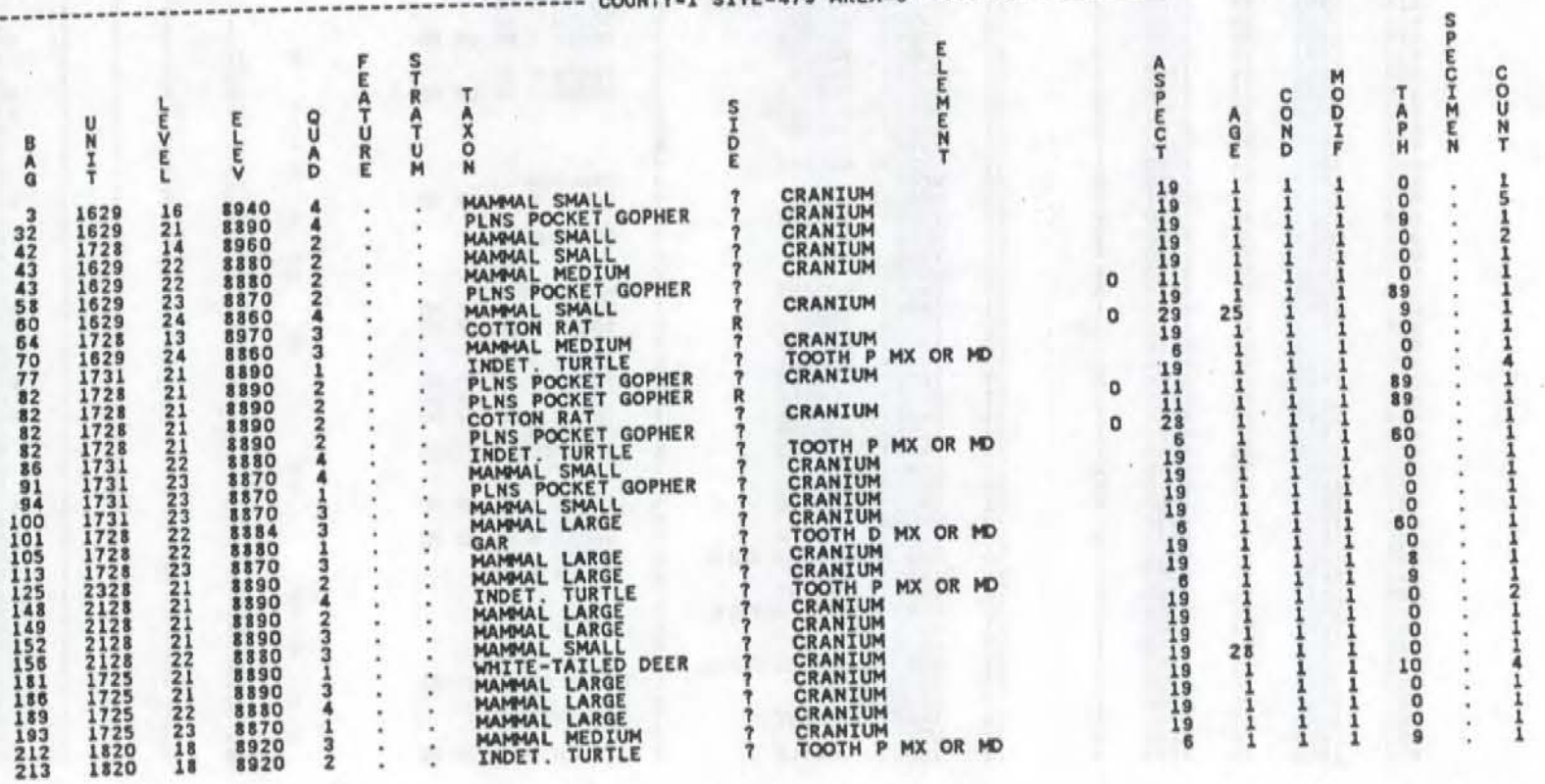
ATTRIBUTE FAUNA

COUNTY=1 SITE=479 AREA=6

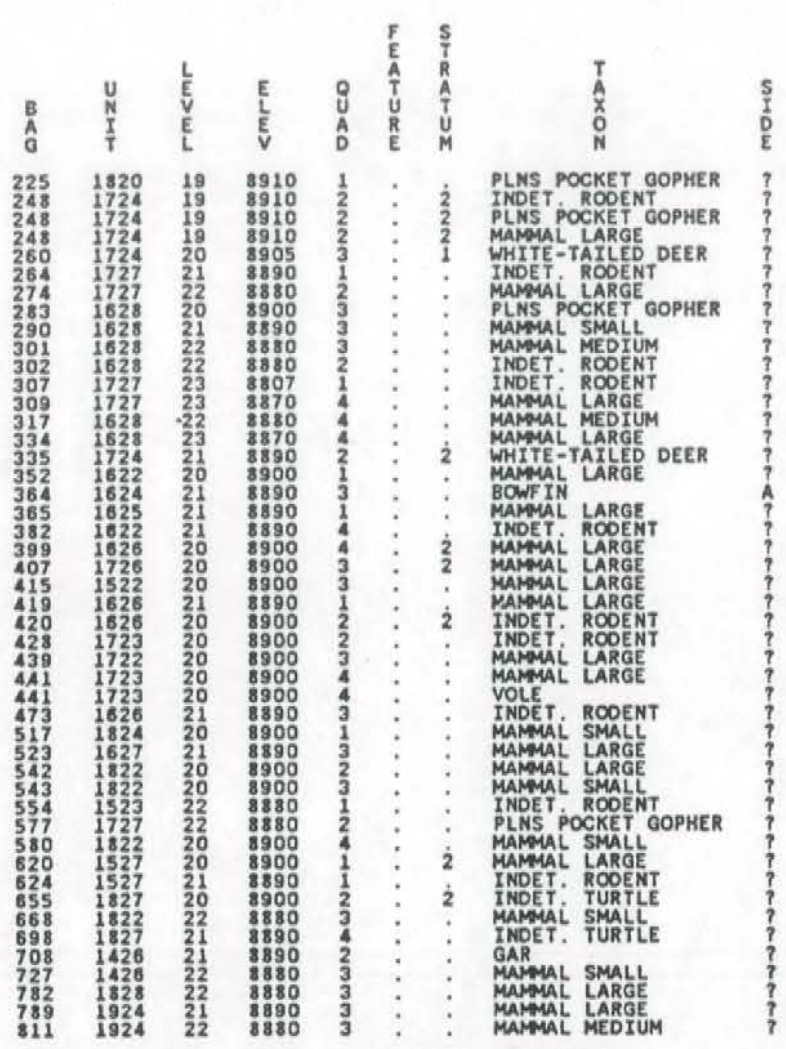

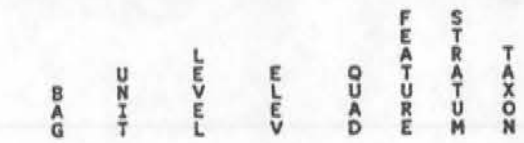

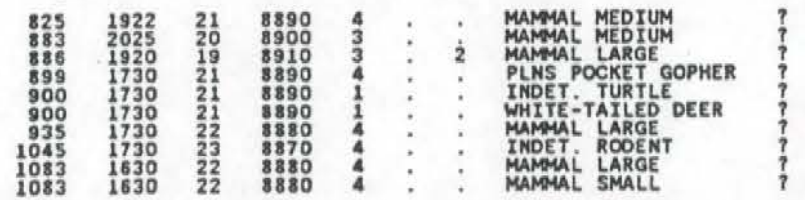

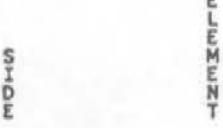

CRANIUM

CRANIUM CRANIUM

CRANTUM

CRANIUM CRANIUM CRANIUM

CRANIUM

CRANIUM TOOTH D MD
CRANIUM

CRANTUM

CRANTUM

CRANIUM

CRANIUM

CRANIUM

CRANIUM

CRANIUM

RANIUM

CRANIUM

CRANIUM

CRANIUM

TOOTH P MX OR MD

CRANIUM MX
TOOTH P MX OR MD
TOOTH D MX OR MD

CRANTUM

CRANIUM

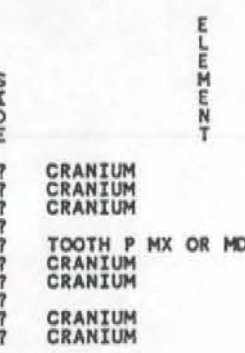

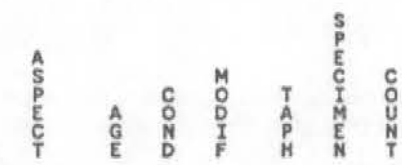

0

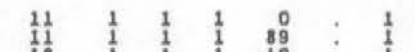

0

0

0

0

0

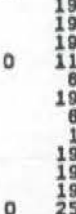

0

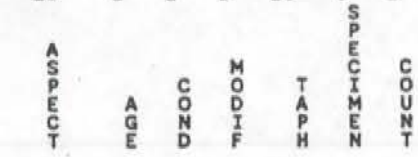

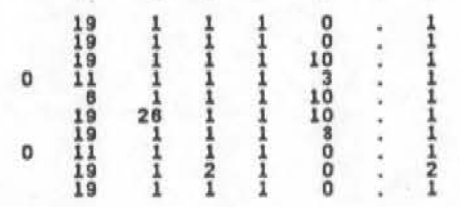




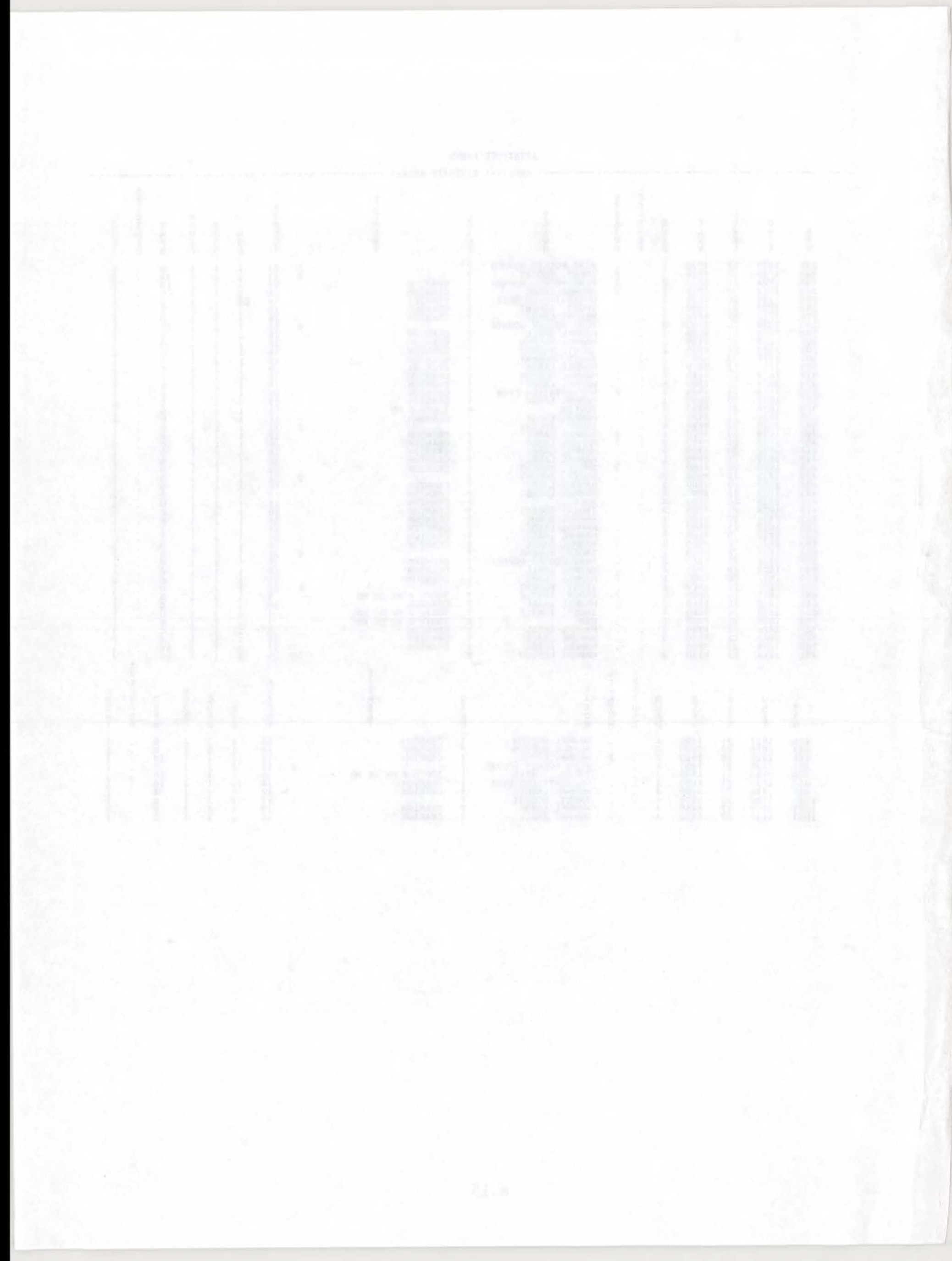

